$5-1998$

\title{
Sebastopol State Historical Park (41GU9), Seguin, Texas: Archeological Excavations, 1978-1988
}

Sandra R. Sauer

Prewitt and Associates, Inc.

Art Black

Prewitt and Associates, Inc.

Cynthia Brandimarte

Prewitt and Associates, Inc.

Follow this and additional works at: https://scholarworks.sfasu.edu/ita

Part of the American Material Culture Commons, Archaeological Anthropology Commons, Environmental Studies Commons, Other American Studies Commons, Other Arts and Humanities Commons, Other History of Art, Architecture, and Archaeology Commons, and the United States History Commons

Tell us how this article helped you.

This Article is brought to you for free and open access by the Center for Regional Heritage Research at SFA ScholarWorks. It has been accepted for inclusion in Index of Texas Archaeology: Open Access Gray Literature from the Lone Star State by an authorized editor of SFA ScholarWorks. For more information, please contact cdsscholarworks@sfasu.edu. 


\section{Sebastopol State Historical Park (41GU9), Seguin, Texas: Archeological}

Excavations, 1978-1988

\section{Creative Commons License}

\section{(c) (1) $\Theta(9$}

This work is licensed under a Creative Commons Attribution-NonCommercial-No Derivative Works 4.0 International License. 
SEBASTOPOL STATE HISTORICAL PARK (41GU9), SEGUIN, TEXAS:

ARCHEOLOGICAL EXCAVATIONS, 1978-1988

by

\author{
Sandra R. Sauer \\ Art Black \\ and \\ Cynthia Brandimarte
}

Principal Investigators: Art Black, Elton R. Prewitt, and Ross C. Fields

REPORTS OF INVESTIGATIONS, NUMBER 111

Prewitt and Associates, Inc.

Consulting Archeologists

Austin, Texas

May 1998

TEXAS ANTIQUITIES COMMITTEE ARCHEOLOGY PERMIT NO. 171 



\section{TABLE OF CONTENTS}

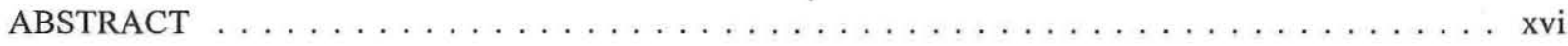

ACKNOWLEDGMENTS $\ldots \ldots \ldots \ldots \ldots \ldots \ldots \ldots \ldots \ldots \ldots \ldots \ldots \ldots \ldots \ldots \ldots$

CHAPTER 1: INTRODUCTION AND HISTORICAL BACKGROUND $\ldots \ldots \ldots \ldots \ldots \ldots \ldots$

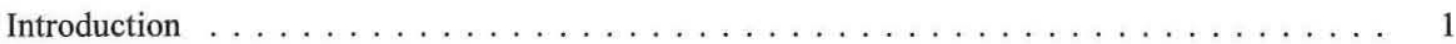

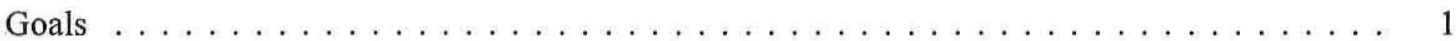

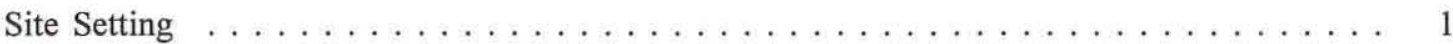

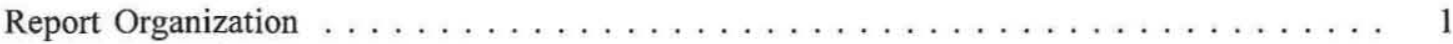

History of Sebastapol During the Zorn Family Occupation $\ldots \ldots \ldots \ldots \ldots \ldots \ldots$

The Zorn Family Prior to the Purchase of Sebastapol . . . . . . . . . . . 3

The Purchase of Sebastapol . . . . . . . . . . . . . . . . . . 11

Life at Sebastopol During the Twentieth Century $\ldots \ldots \ldots \ldots \ldots \ldots$

CHAPTER 2: OBJECTIVES AND METHODS $\ldots \ldots \ldots \ldots \ldots \ldots \ldots \ldots \ldots \ldots \ldots \ldots$

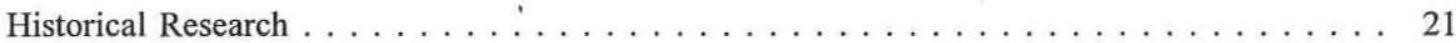

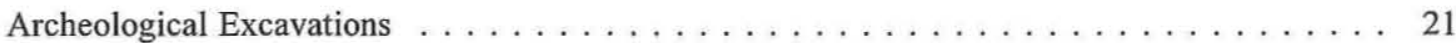

Depositional Characteristics . . . . . . . . . . . . . . . . . 22

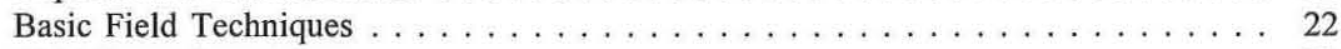

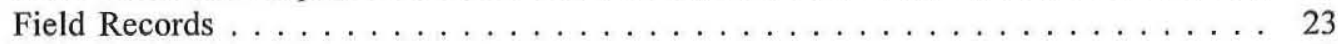

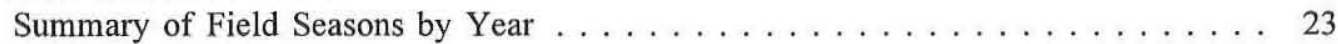

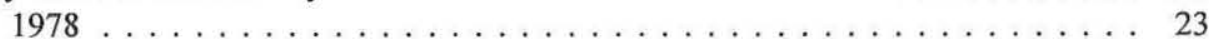

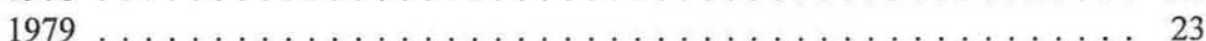

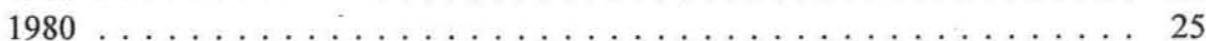

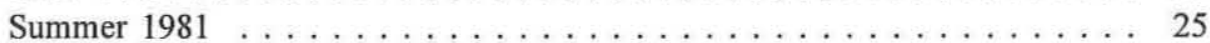

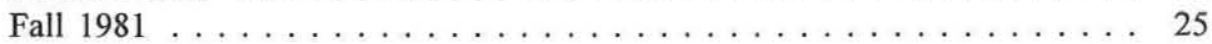

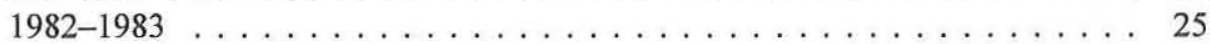

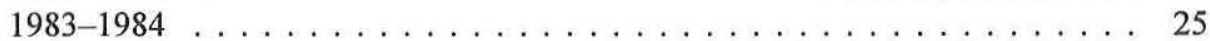

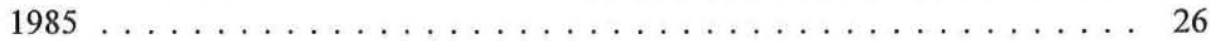

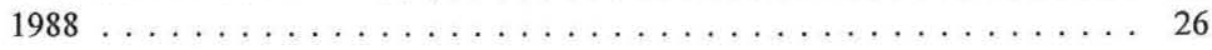

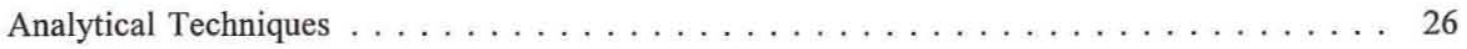

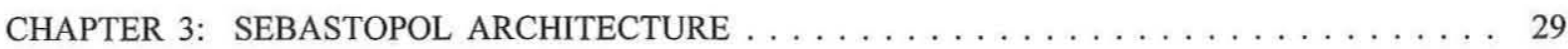

Limecrete Construction in Seguin . . . . . . . . . . . . . . . . . . . . . . 29

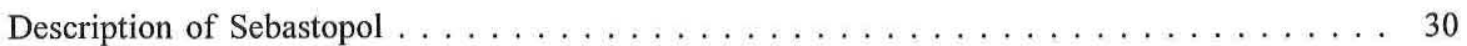

CHAPTER 4: HOUSE AND YARD DEPOSITS $\ldots \ldots \ldots \ldots \ldots \ldots \ldots \ldots \ldots$

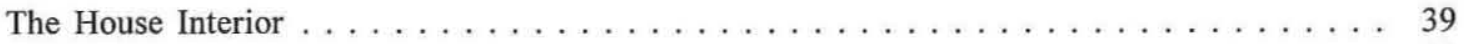

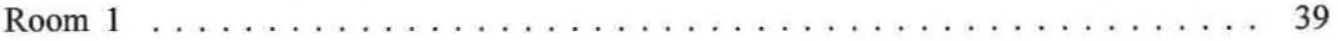

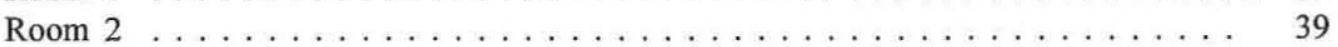

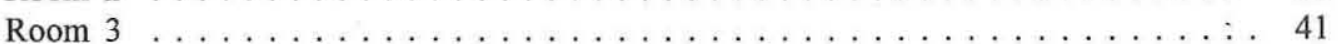

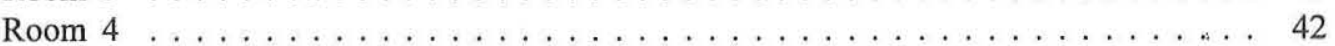

Room 5: The Kitchen . . . . . . . . . . . . . . . . . . . . . . 42

Room 6: The Dining Room . . . . . . . . . . . . . . . . . . . . . . 43

Room 7: The Boys' Room, or the Northeast Room . . . . . . . . . . . . 43

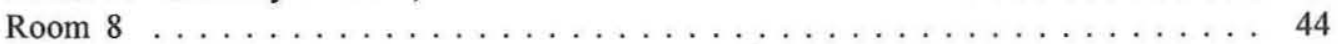




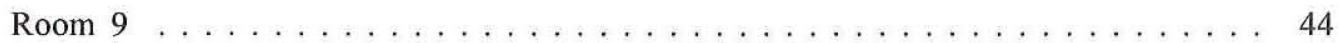

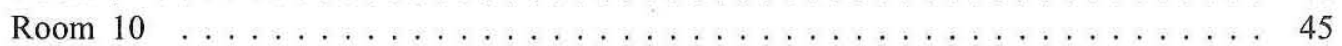

The House Exterior . . . . . . . . . . . . . . . . . . . . . . . . . . . . . . . . . . . 45

General Exterior Features . . . . . . . . . . . . . . . . . . 45

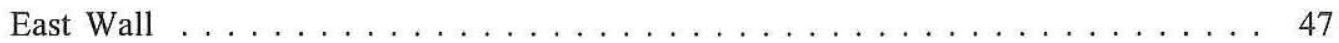

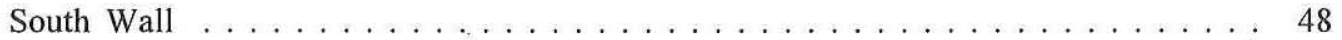

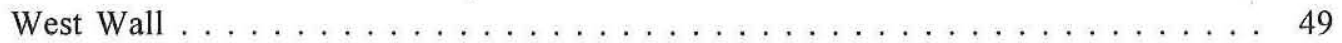

North Wall .................................... 49

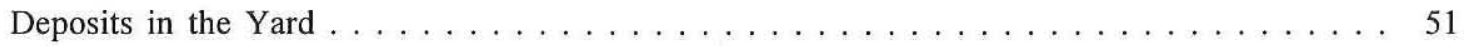

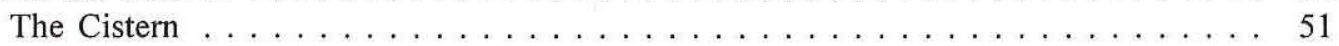

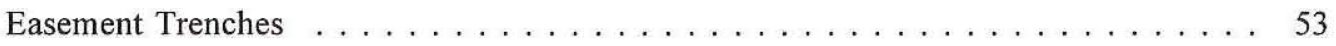

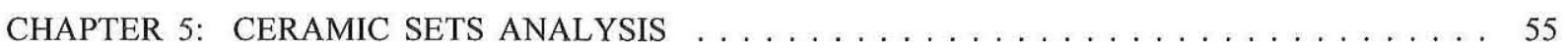

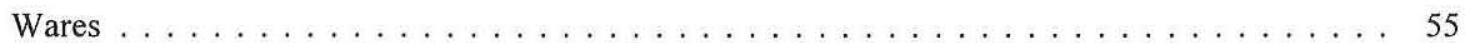

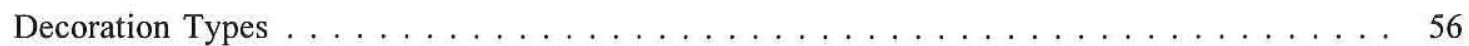

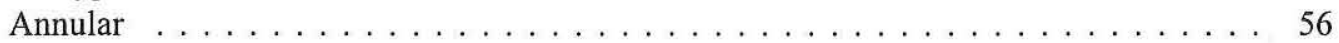

Sponge-Stamped and Spatter $\ldots \ldots \ldots \ldots \ldots \ldots$

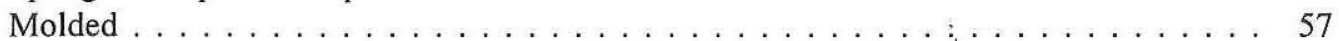

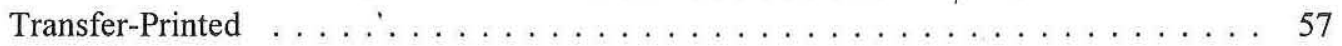

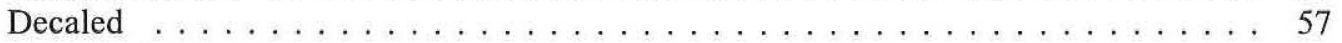

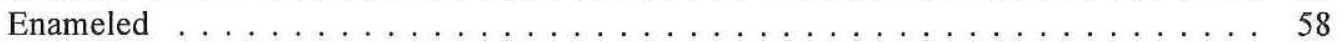

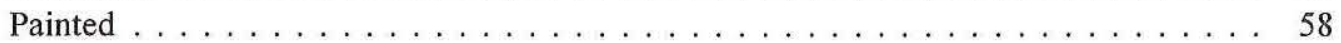

Luster . . . . . . . . . . . . . . . . . . . . . . . . . . . . 58

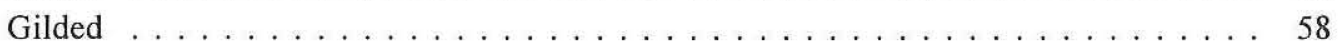

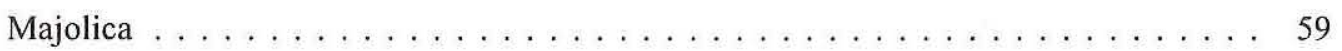

Decorative Styles . . . . . . . . . . . . . . . . . . . . . . . . . 59

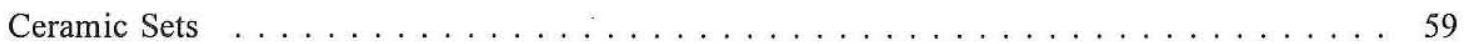

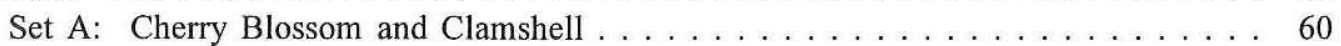

Set B: Lilac Decal . . . . . . . . . . . . . . . . . . . . . . . . 60

Set C: Grass and Flowers Decal . . . . . . . . . . . . . . . . . . 60

Set D: Rose Decal . . . . . . . . . . . . . . . . . . . . . . 62

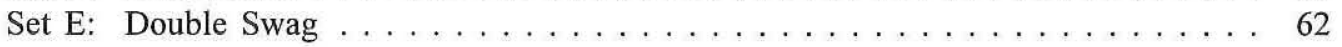

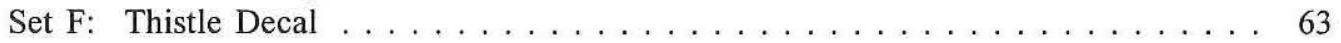

Set G: Fruit Design . . . . . . . . . . . . . . . . . . . . 63

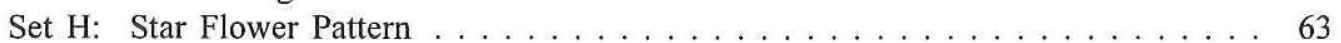

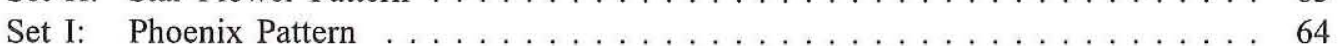

Set J: Rosaline . . . . . . . . . . . . . . . . . . . . . . . . . . . . 64

Set K: Gothic Hawthorn . . . . . . . . . . . . . . . . . . . . . . . . 65

Set L: Molded and Gilded Petals . . . . . . . . . . . . . . . . . . . . . . . . 66

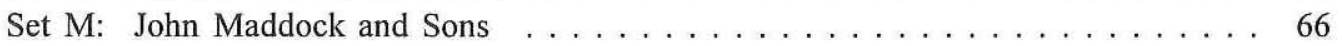

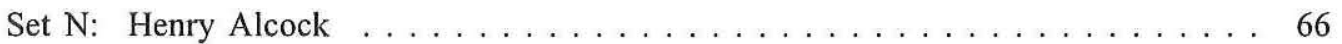

Set $\mathrm{O}:$ Molded and Dimpled ...................... 66

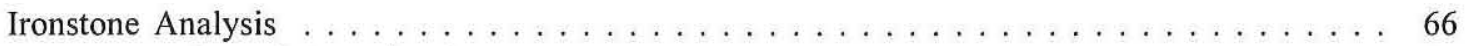

Marks and Associated Patterns . . . . . . . . . . . . . . . . . . . . 69

James Edwards Ironstone China . . . . . . . . . . . . . . . . . 69

J. \& G. Meakin . . . . . . . . . . . . . . . . . . . . . . 70

Pankhurst \& Co. . . . . . . . . . . . . . . . . . . . . . . 70

William Adams \& Sons . . . . . . . . . . . . . . . . . . . . . . . . . 70

J. Wedge Wood . . . . . . . . . . . . . . . . . . . . . . . 71 


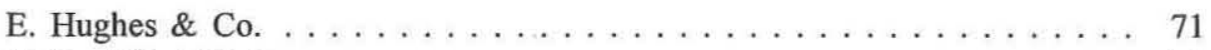

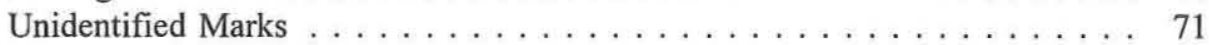

Patterns Not Associated with Marks . . . . . . . . . . . . . . . . . . 72

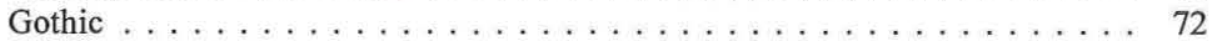

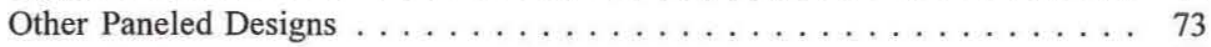

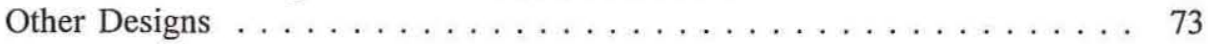

\section{CHAPTER 6: ANALYSIS OF ARTIFACTS FROM THE KITCHEN,}

DINING ROOM, AND ROOM $7 \ldots \ldots \ldots \ldots \ldots \ldots \ldots \ldots \ldots \ldots \ldots$

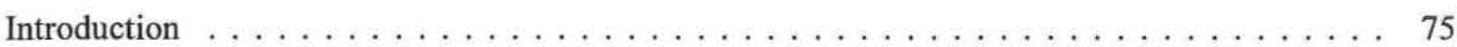

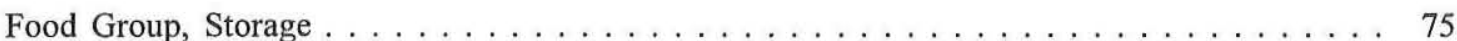

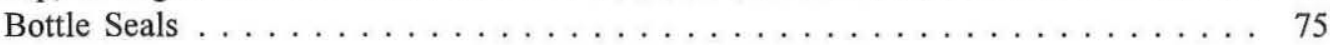

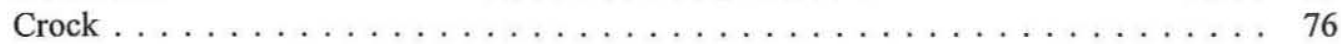

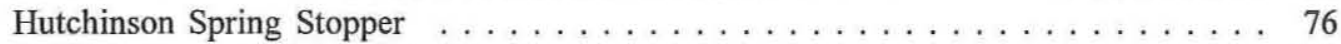

Canning Jars and Related Artifacts . . . . . . . . . . . . . . . . 76

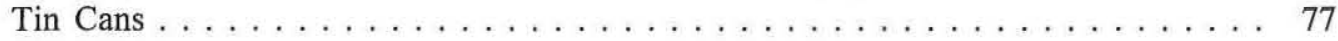

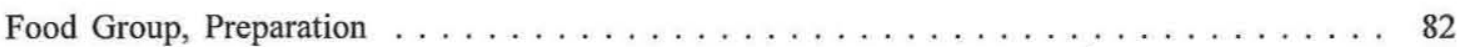

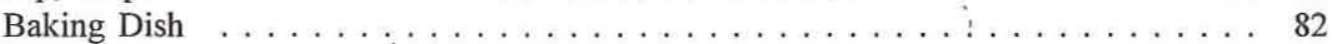

Candy Mold . . . . . . . . . . . . . . . . . . . . . . . . . 82

Mixing Bowls . . . . . . . . . . . . . . . . . . . . 83

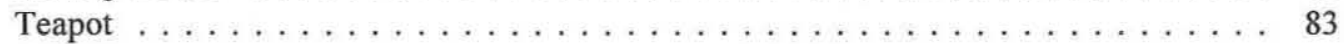

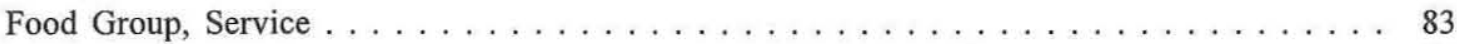

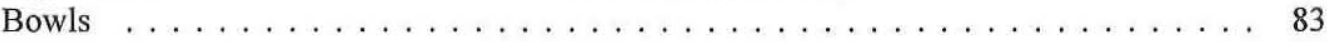

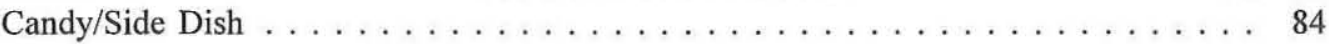

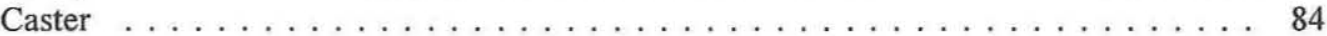

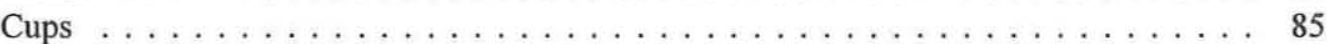

Drainer . . . . . . . . . . . . . . . . . . . . . . . . 87

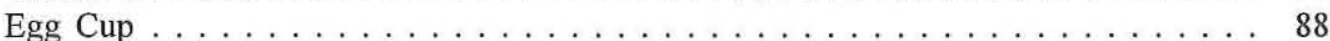

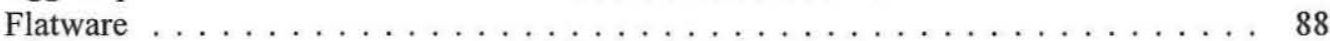

Ladle . . . . . . . . . . . . . . . . . . . . . . . . 88

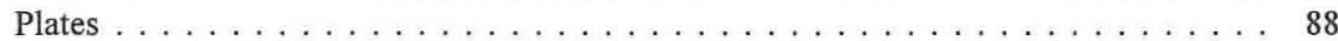

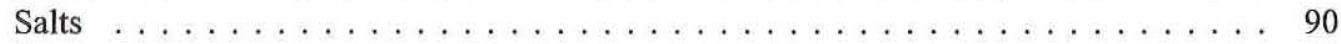

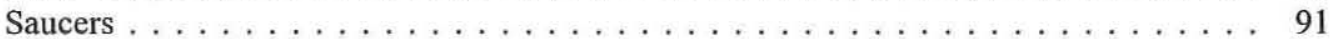

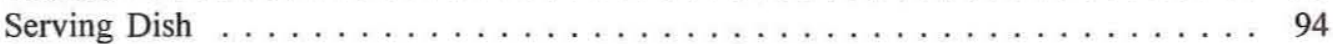

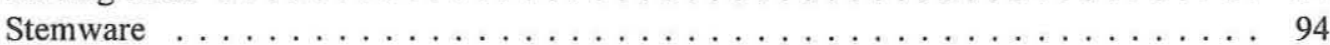

Known Patterns . . . . . . . . . . . . . . . . . . . . . . . . . . 94

Unidentified Patterns . . . . . . . . . . . . . . . . . . . . 95

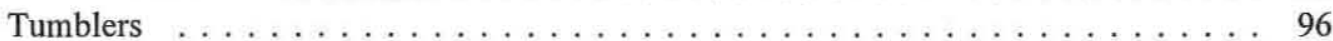

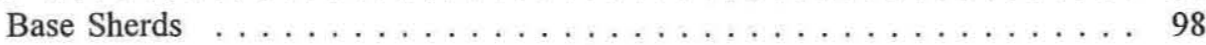

Rim Sherds . . . . . . . . . . . . . . . . . . . . . . . 98

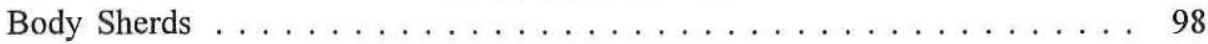

Furniture and Fixtures Group, Furniture Hardware $\ldots \ldots \ldots \ldots \ldots \ldots \ldots$

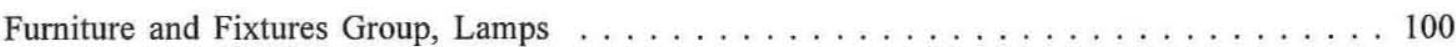

Chimney Rims . . . . . . . . . . . . . . . . . . . . . . . . . . . 100

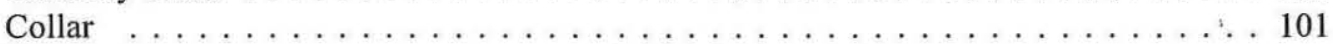

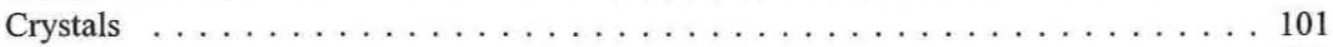

Globes . . . . . . . . . . . . . . . . . . . . . . 101

Furniture and Fixtures Group, Fixtures $\ldots \ldots \ldots \ldots \ldots \ldots \ldots \ldots \ldots \ldots \ldots \ldots \ldots \ldots \ldots$ 


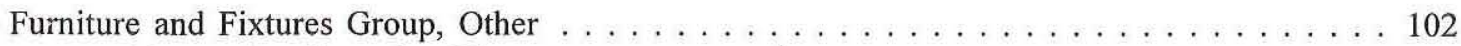

Decorative Ceramics, Plates . . . . . . . . . . . . . . . . . . . . . . . . . . 102

Decorative Ceramics, Unknown Vessels . . . . . . . . . . . . . . . . . . 105

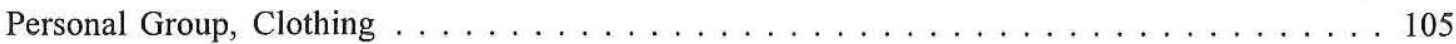

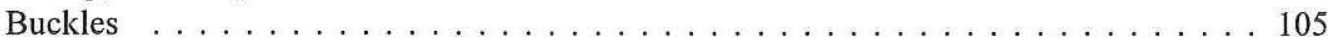

Buttons . . . . . . . . . . . . . . . . . . . . . . . 105

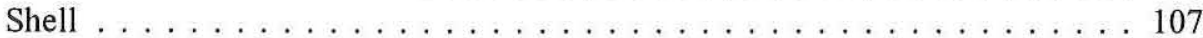

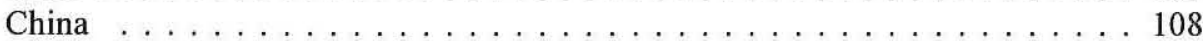

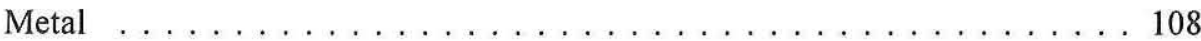

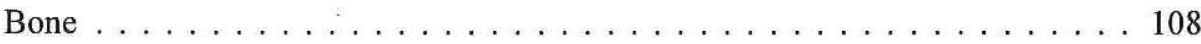

Glass . . . . . . . . . . . . . . . . . . . . . . . . . . . . 109

Composition . . . . . . . . . . . . . . . . . . . . . 109

Plastic . . . . . . . . . . . . . . . . . . . . . . 109

Horn . . . . . . . . . . . . . . . . . . . . . . 109

Hard Rubber . . . . . . . . . . . . . . . . . . . . . . . . . . . . 109

Hard Rubber and Composition . . . . . . . . . . . . . . . . . . . . . . 110

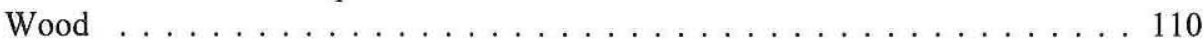

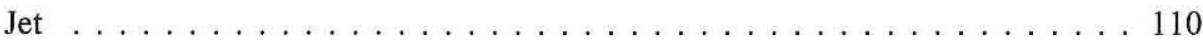

Button Shape . . . . . . . . . . . . . . . . . . . 110

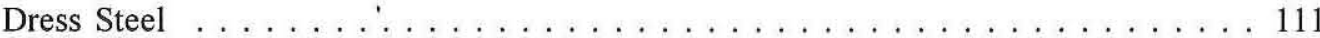

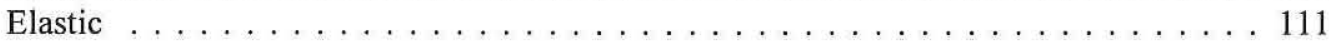

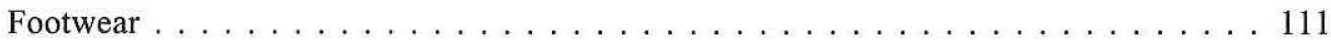

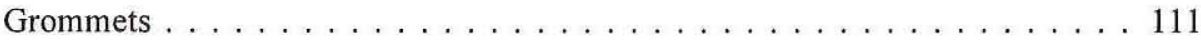

Heels . . . . . . . . . . . . . . . . . . . . . . . 118

Heel Plate . . . . . . . . . . . . . . . . . . . . . . 118

Lace Tips . . . . . . . . . . . . . . . . . . . . . . . . . 120

Shoe Leather . . . . . . . . . . . . . . . . . . . . . . . . . . . 120

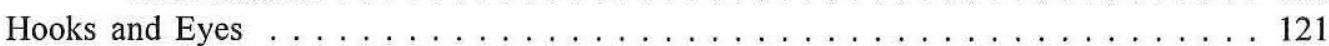

Snaps . . . . . . . . . . . . . . . . . . . . . . . . . 121

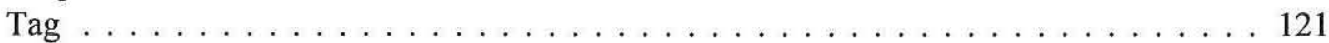

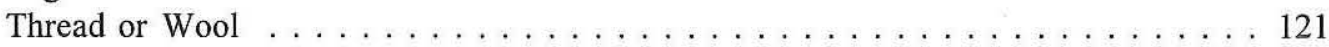

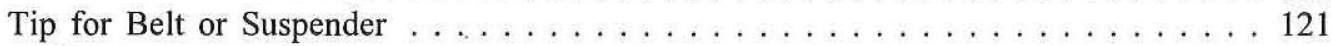

Undergarment Hardware . . . . . . . . . . . . . . . . . . . . . . 121

Washburne Fastener . . . . . . . . . . . . . . . . . . . . . . . . 121

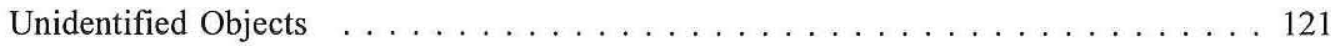

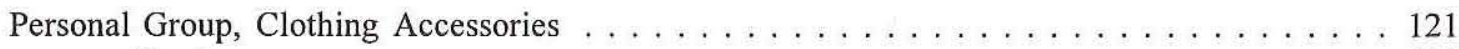

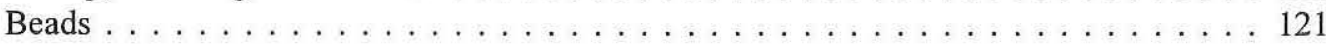

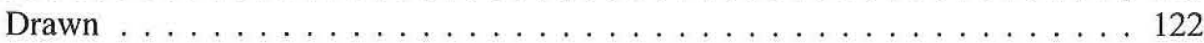

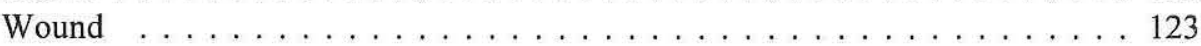

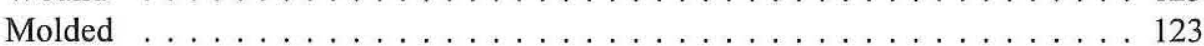

Mandrel Pressed . . . . . . . . . . . . . . . . . . . . . . . . 123

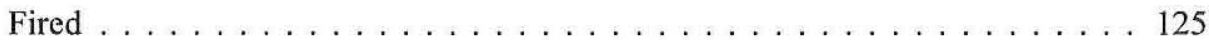

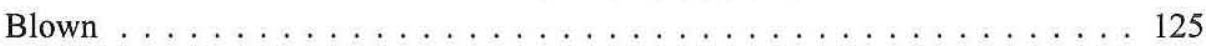

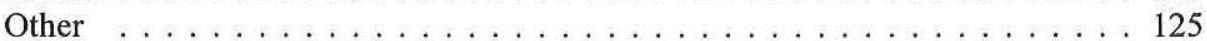

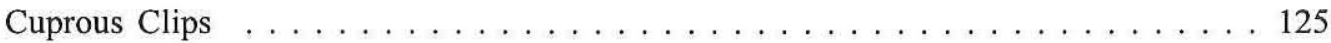

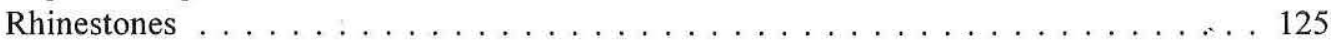

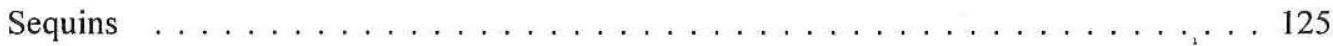

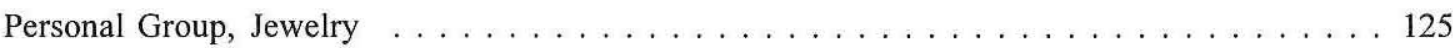

Broaches and Pins . . . . . . . . . . . . . . . . . . . 125

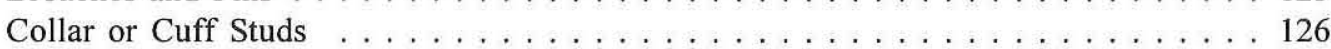

Cuff Links or Collar Buttons $\ldots \ldots \ldots \ldots \ldots \ldots \ldots$ 


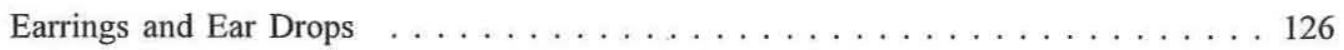

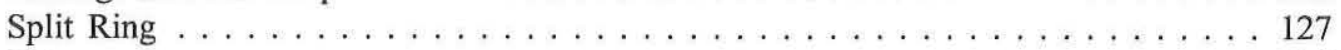

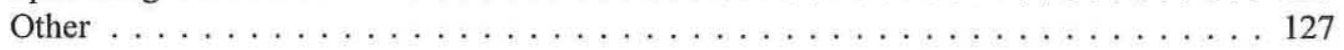

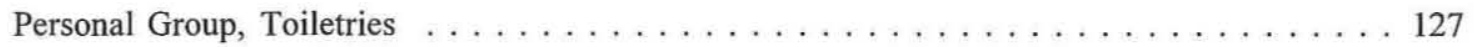

Personal Group, School/Stationery Supplies . . . . . . . . . . . . . . . . . . . 127

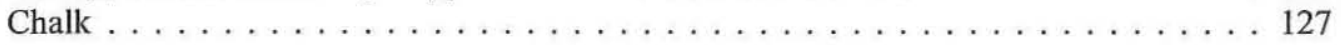

Erasers . . . . . . . . . . . . . . . . . . . . . 127

Mechanical Pencil . . . . . . . . . . . . . . . . . . . . . . . . 127

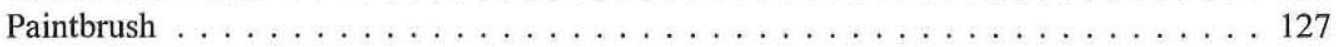

Paper Fasteners . . . . . . . . . . . . . . . . . . . . . . . 127

Pen Parts . . . . . . . . . . . . . . . . . . . . . . 127

Pencil Leads . . . . . . . . . . . . . . . . . . . . . . . . 128

Sealing Wax . . . . . . . . . . . . . . . . . . . . . . 128

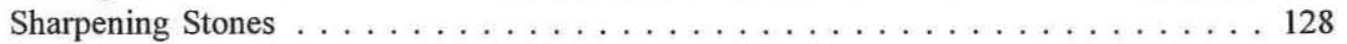

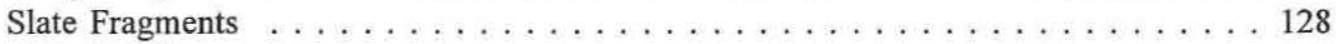

Slate Pencils . . . . . . . . . . . . . . . . . . . . . . . . 128

Wooden Pencils . . . . . . . . . . . . . . . . . . . . . . . . 129

Personal Group, Other . . . . . . . . . . . . . . . . . . . . . . . . . . . . . . . 129

Binoculars or Opera Glasses . . . . . . . . . . . . . . . . . . . . . . . . 129

Buttonhooks . . . . . . . . . . . . . . . . . . . . . . . . . . . . . . . . . . . 129

Coins . . . . . . . . . . . . . . . . . . . . . . . . . . 129

Fan Blades . . . . . . . . . . . . . . . . . . . . . . . . . 129

Key . . . . . . . . . . . . . . . . . . . . . . . . . . . 129

Purse . . . . . . . . . . . . . . . . . . . . . . 130

Rosary . . . . . . . . . . . . . . . . . . . . 130

Spectacle or Eyeglass Lenses . . . . . . . . . . . . . . . . . . 130

Watch and Parts . . . . . . . . . . . . . . . . . . . . . . . 130

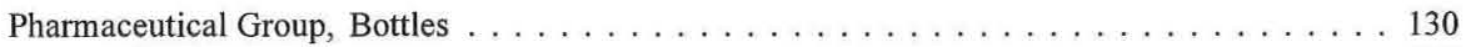

Dr. Harter's Liniment . . . . . . . . . . . . . . . . . . . . . 130

Medicine Vials . . . . . . . . . . . . . . . . . . . . . . 131

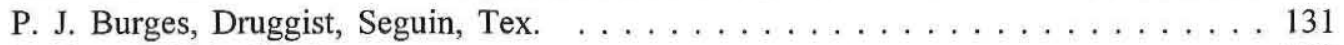

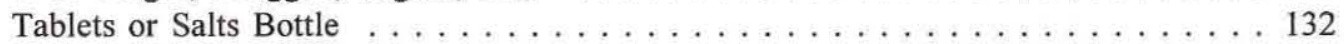

Unidentified Bottles . . . . . . . . . . . . . . . . . . . . . 132

Activity Group, Sewing . . . . . . . . . . . . . . . . . . . . . . . . . . 133

Chalk . . . . . . . . . . . . . . . . . . . . . . . . 133

Pins and Pinheads . . . . . . . . . . . . . . . . . . 133

Safety Pins . . . . . . . . . . . . . . . . . . . 133

Sewing Machine Hardware . . . . . . . . . . . . . . . . . . 133

Singer Sewing Machine Oil Bottle . . . . . . . . . . . . . . . 133

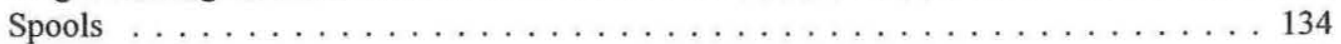

Thimbles . . . . . . . . . . . . . . . . . . . . . . . . . . . 134

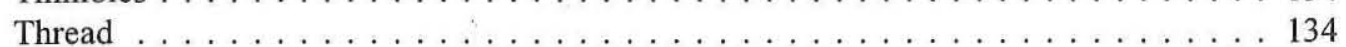

Activity Group, Guns and Ammunition . . . . . . . . . . . . . . . . . 134

Gunflint . . . . . . . . . . . . . . . . . . . . . . . . 134

Lead Pellet . . . . . . . . . . . . . . . . . . . . . . 134

Lead Sprue and Lead Bar . . . . . . . . . . . . . . . . . . . . 134

Percussion Caps . . . . . . . . . . . . . . . . . . . 135

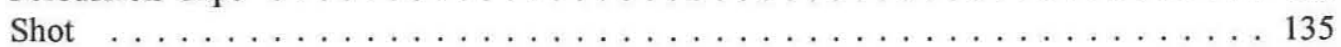

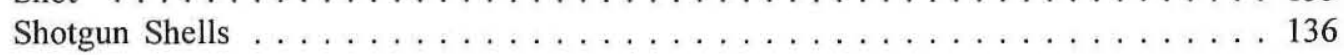


.22 Cartridges . . . . . . . . . . . . . . . . . . . . . 137

Other Cartridges . . . . . . . . . . . . . . . . . . 137

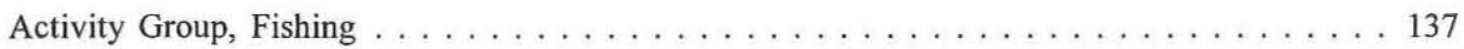

Activity Group, Household . . . . . . . . . . . . . . . . . . 137

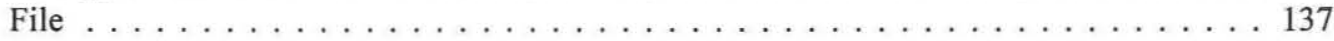

Paintbrush . . . . . . . . . . . . . . . . . . 137

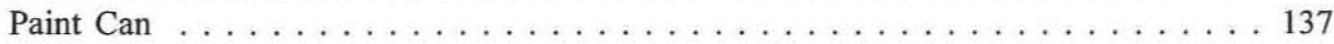

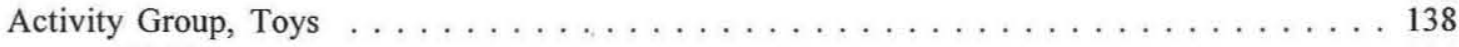

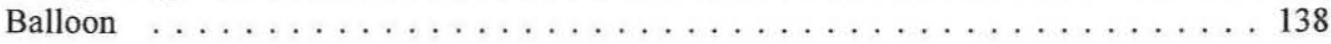

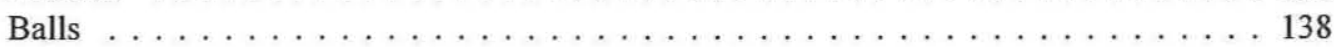

Bottles . . . . . . . . . . . . . . . . . . . . . . 138

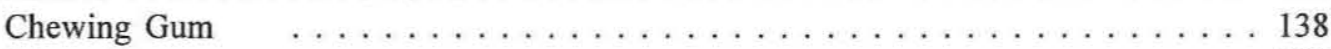

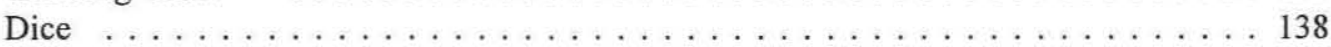

Dolls and Doll Parts . . . . . . . . . . . . . . . . . . . . . 138

Figurines . . . . . . . . . . . . . . . . . . . . . . . . . . . . 139

Harmonicas . . . . . . . . . . . . . . . . . . . . . . . 140

Jacks . . . . . . . . . . . . . . . . . . . . . . . . 140

Marbles . . . . . . . . . . . . . . . . . . . . . . . 140

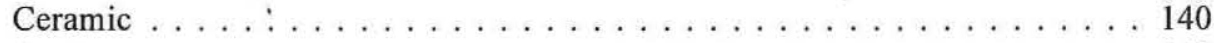

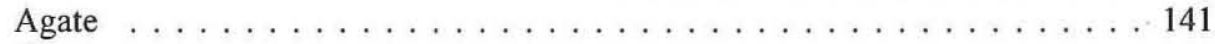

Glass . . . . . . . . . . . . . . . . . . . . . . . . . 141

Tea Sets . . . . . . . . . . . . . . . . . . . . . . . . 142

Tin Whistle . . . . . . . . . . . . . . . . . . . . . . . 143

Wheels . . . . . . . . . . . . . . . . . . . . . . . 143

Activity Group, Farming . . . . . . . . . . . . . . . . . . . . 143

Activity Group, Tobacco Related . . . . . . . . . . . . . . . . . . . . . . . . 143

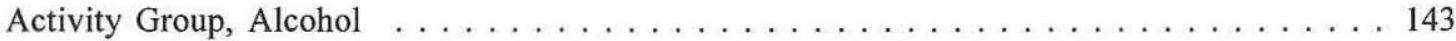

Beer Bottle . . . . . . . . . . . . . . . . . . . . . . 143

Picnic Flasks . . . . . . . . . . . . . . . . . . . . . . 143

Wine Bottle . . . . . . . . . . . . . . . . . . . . . . 143

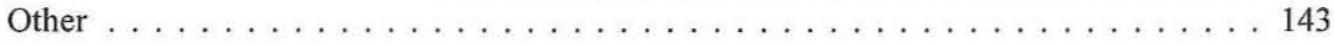

Bone Group . . . . . . . . . . . . . . . . . . . . . 143

Utilities Group, Electrical . . . . . . . . . . . . . . . . . . . . . . . 144

Battery Components . . . . . . . . . . . . . . . . . . . . . . . . . 144

Connectors . . . . . . . . . . . . . . . . . . . . . . . . . 144

Graphite Electrode for an Arc Lamp . . . . . . . . . . . . . . . . . . . . . 144

Insulators . . . . . . . . . . . . . . . . . . . . . . . . . 144

Light Bulb Parts . . . . . . . . . . . . . . . . . . . . . . . . . 144

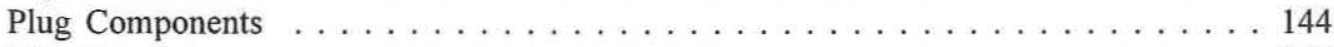

Wire Insulation . . . . . . . . . . . . . . . . . . . 145

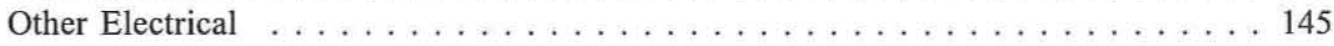

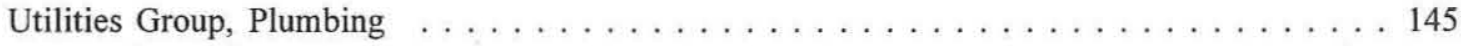

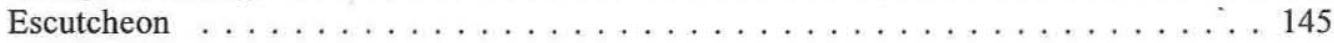

Handle . . . . . . . . . . . . . . . . . . . . . . . . . . 145

Hose Coupling . . . . . . . . . . . . . . . . . . . . . . 145

Other . . . . . . . . . . . . . . . . . . . . . . . . . . . . 145 
Other Group, Miscellaneous . . . . . . . . . . . . . . . . . . . . . . . . 145

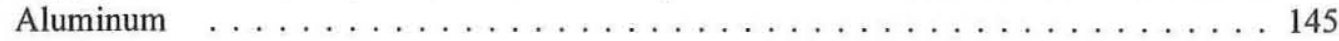

Bottle Caps . . . . . . . . . . . . . . . . . . . . . . . . 146

Bottles . . . . . . . . . . . . . . . . . 146

Brass Bells . . . . . . . . . . . . . . . . . . . . . . 149

Brass Caps . . . . . . . . . . . . . . . . . . . . . . . . 149

Bushing . . . . . . . . . . . . . . . . . . . . . . . . . . . . . . 149

Caps . . . . . . . . . . . . . . . . . . . . . . 149

Chain . . . . . . . . . . . . . . . . . . . . . . . . . . . 149

Christmas Ornament Hanger . . . . . . . . . . . . . . . . . . . . . . . . . 149

Colored Eggshells . . . . . . . . . . . . . . . . . . . . . . . . . . 149

Corks . . . . . . . . . . . . . . . . . . . . . . . . . . . . . 149

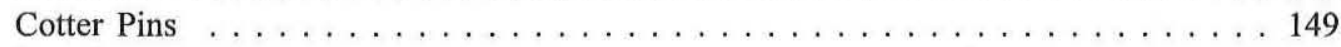

Ferrule . . . . . . . . . . . . . . . . . . . . . . . . . . 149

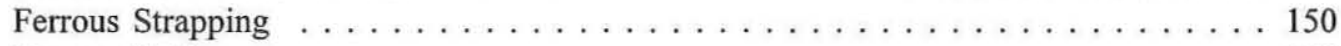

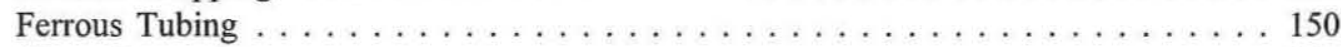

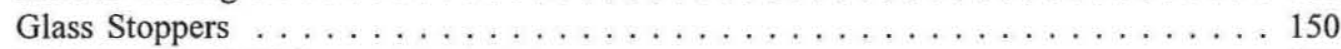

Miniature Golf Club . . . . . . . . . . . . . . . . . . 150

Grommet . . . . . . . . . . . . . . . . . . . . . . 150

Hook . . . . . . . . . . . . . . . . . . . . . 150

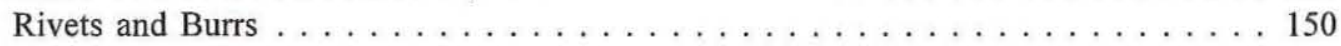

Rubber Stopper . . . . . . . . . . . . . . . . . . . . 150

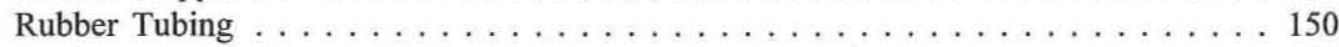

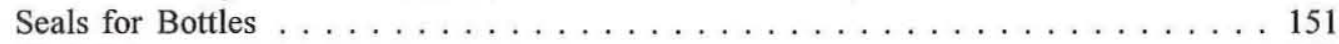

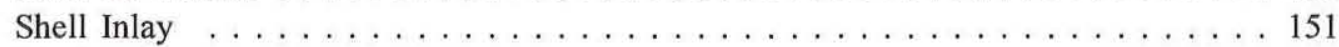

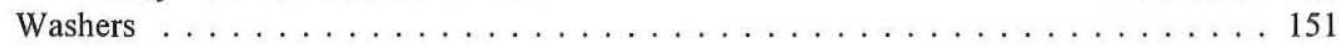

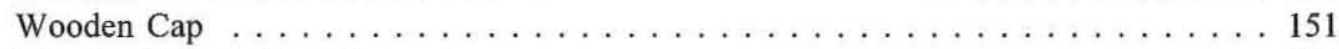

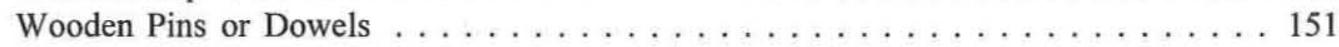

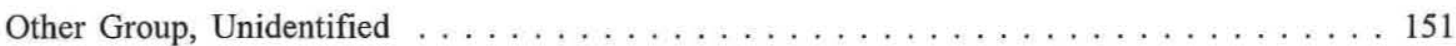

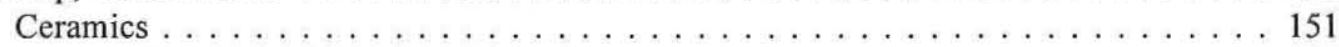

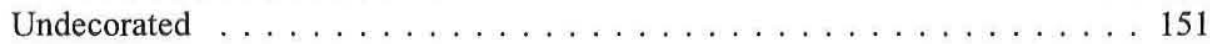

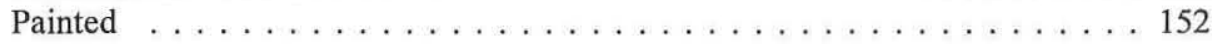

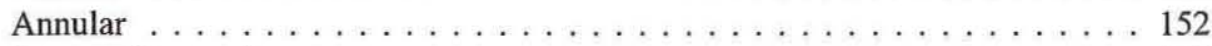

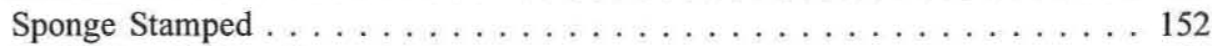

Molded and Glazed . . . . . . . . . . . . . . . . . 152

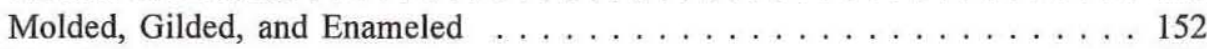

Decaled . . . . . . . . . . . . . . . . . . . . . . . 152

Luster . . . . . . . . . . . . . . . . . . . . . . . . . 152

Transfer Printed and Luster . . . . . . . . . . . . . . . . . . 153

Cuprous Metal . . . . . . . . . . . . . . . . . . . 153

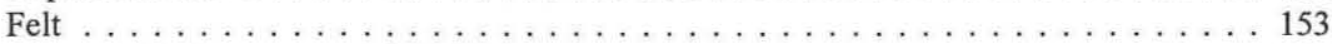

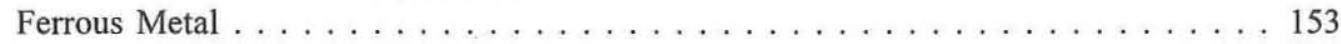

Glass . . . . . . . . . . . . . . . . . . . . . . . . 153

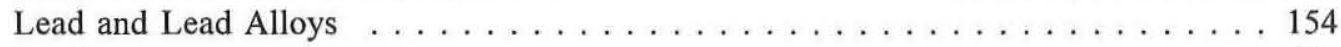

Leather . . . . . . . . . . . . . . . . . . . . . . . . . . . 154

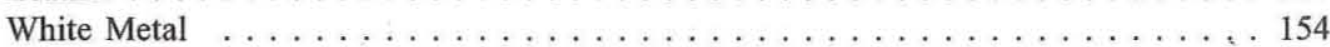

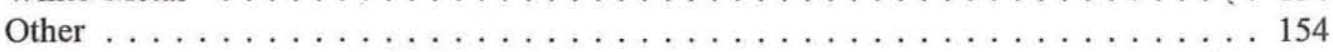

CHAPTER 7: SUMMARY AND CONCLUSIONS $\ldots \ldots \ldots \ldots \ldots \ldots \ldots \ldots \ldots \ldots$

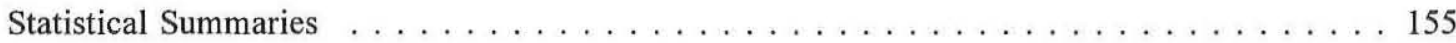

Comparative Room Use . . . . . . . . . . . . . . . . . . . . . . . . . 157 


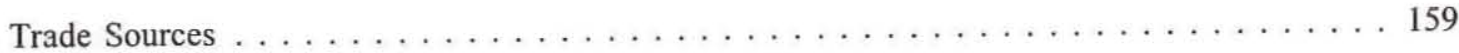

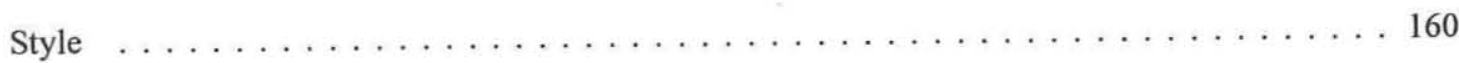

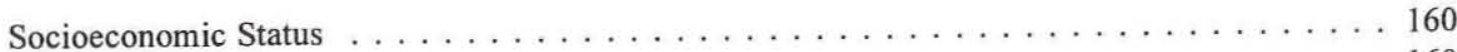

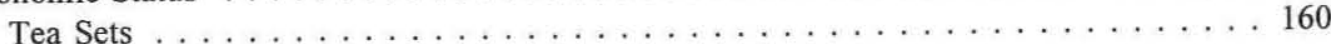

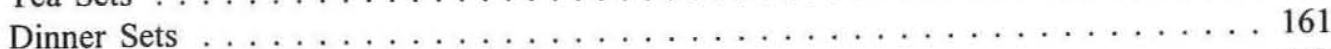

Decorative Household Items . . . . . . . . . . . . . . . . . . . . . 162

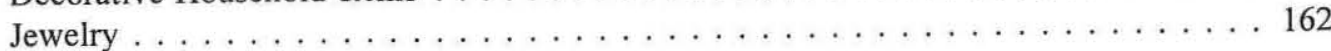

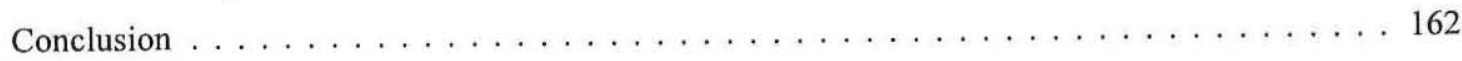

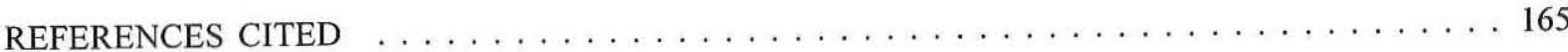

APPENDIX A: The TPWD Classification of All Artifacts from Sebastopol $\ldots \ldots \ldots \ldots \ldots$

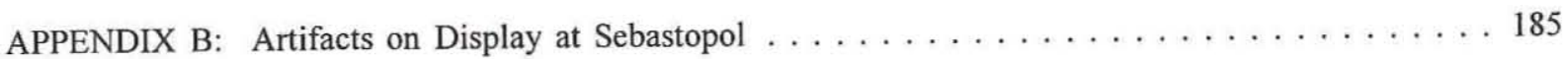




\section{LIST OF FIGURES}

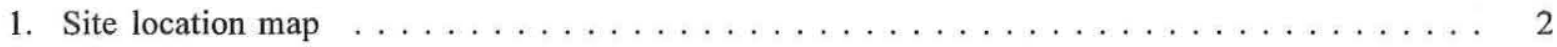

2. Photograph of the Zorn family, taken around $1900 \ldots \ldots \ldots \ldots \ldots \ldots \ldots \ldots$

3. Plat of town lots in Seguin, Texas, showing lots owned by Joseph Zorn Sr.

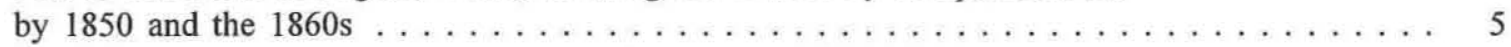

4. 1858 advertisement for Joseph Zorn's store $\ldots \ldots \ldots \ldots \ldots \ldots \ldots \ldots \ldots$

5. Federal pension record dated 1917 documenting Joseph Zorn Jr.'s service in the Civil War . . 10

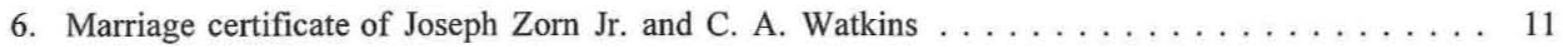

7. Souvenir photograph of Seguin's Guadalupe Lodge No. 109 taken February 11, 1892,

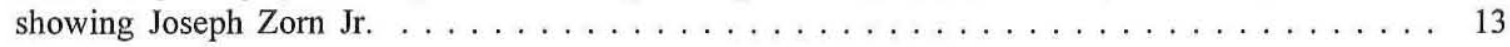

8. 1896 advertisement for Dr. Tegener's dentistry practice $\ldots \ldots \ldots \ldots \ldots \ldots \ldots \ldots \ldots$

9. Photograph of Seguin's turn-of-the-century mule-drawn streetcar $\ldots \ldots \ldots \ldots \ldots$

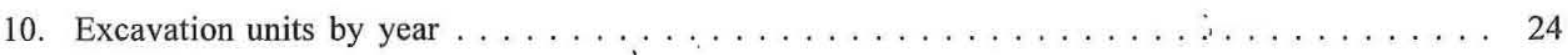

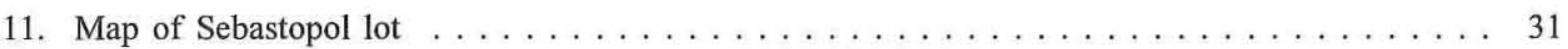

12. The Sebastopol lot as it was during the HABS survey of $1934 \ldots \ldots \ldots \ldots \ldots \ldots \ldots \ldots$

13. Photographs of the south and north faces of the house $\ldots \ldots \ldots \ldots \ldots \ldots \ldots \ldots$

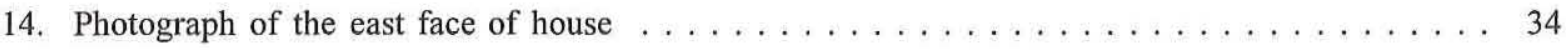

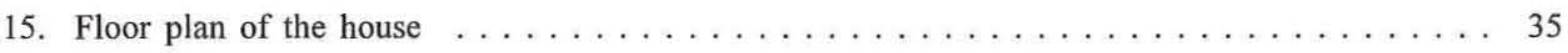

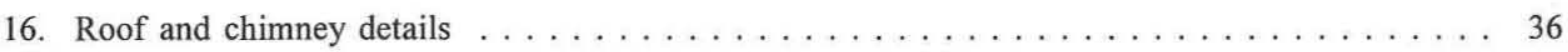

17. 1934 HABS photograph showing imitation brickwork $\ldots \ldots \ldots \ldots \ldots \ldots \ldots$

18. Lower floor plan with excavation units $\ldots \ldots \ldots \ldots \ldots \ldots \ldots \ldots \ldots \ldots \ldots \ldots \ldots \ldots \ldots \ldots$

19. Filled secondary trench along east wall of the house $\ldots \ldots \ldots \ldots \ldots \ldots \ldots \ldots \ldots \ldots$

20. Photographs of excavations along east wall of house $\ldots \ldots \ldots \ldots \ldots \ldots \ldots \ldots$

21. West profile of Unit $8-82$ showing step in bedrock $\ldots \ldots \ldots \ldots \ldots \ldots \ldots \ldots$

22. Photograph of trenches along east wall of the house $\ldots \ldots \ldots \ldots \ldots \ldots \ldots$

23. Excavations along north wall of the house $\ldots \ldots \ldots \ldots \ldots \ldots \ldots \ldots \ldots \ldots \ldots \ldots$

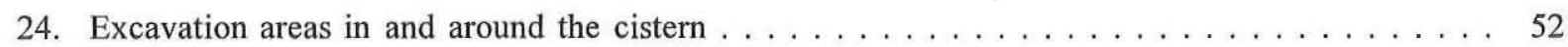

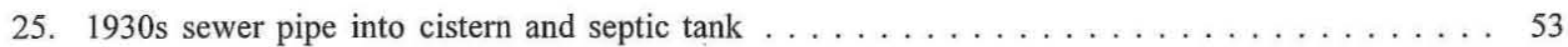

26. Cherry blossom and clamshell cup and saucer $\ldots \ldots \ldots \ldots \ldots \ldots \ldots \ldots \ldots \ldots \ldots \ldots$

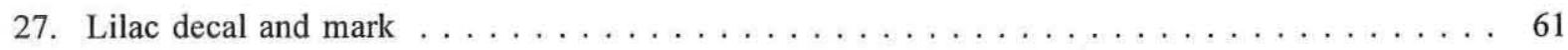

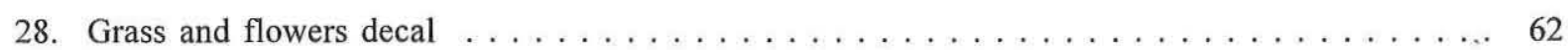

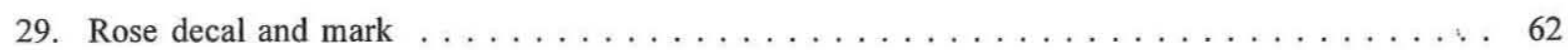

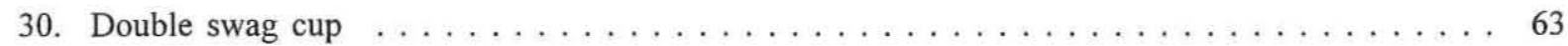

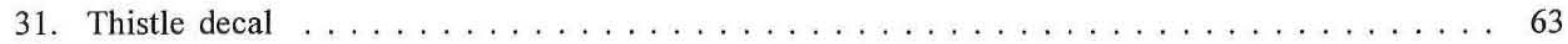

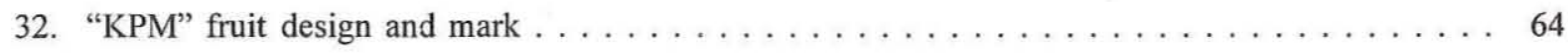




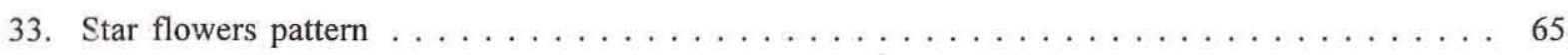

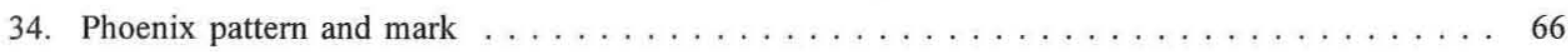

35. Rosaline pattern by Alfred Meakin and mark $\ldots \ldots \ldots \ldots \ldots \ldots \ldots \ldots \ldots \ldots$

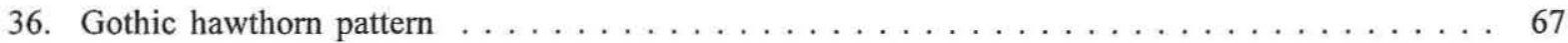

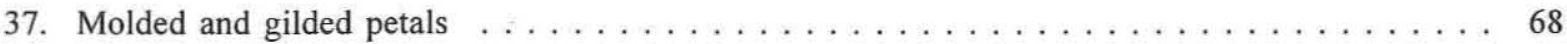

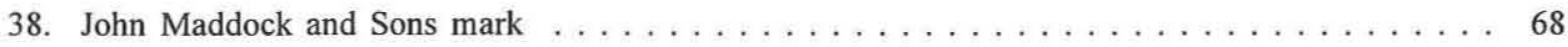

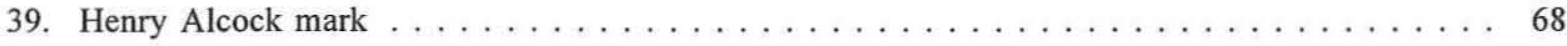

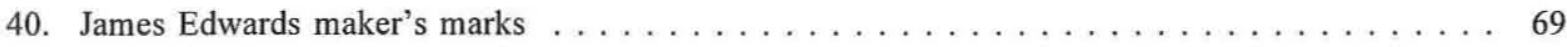

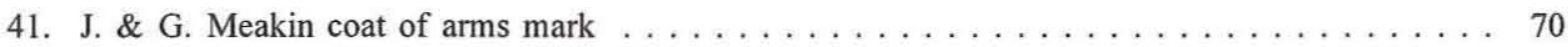

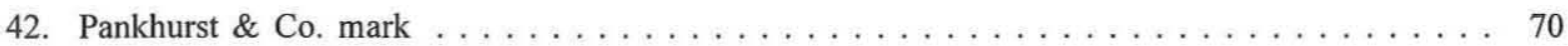

43. William Adams \& Sons mark $\ldots \ldots \ldots \ldots \ldots \ldots \ldots \ldots \ldots \ldots \ldots \ldots \ldots \ldots$

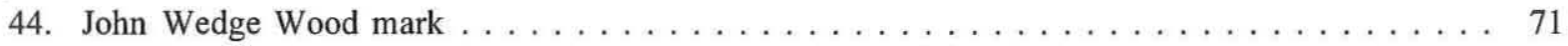

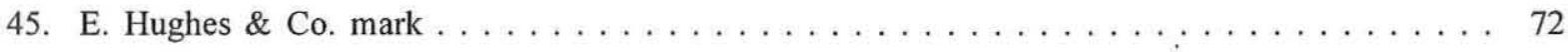

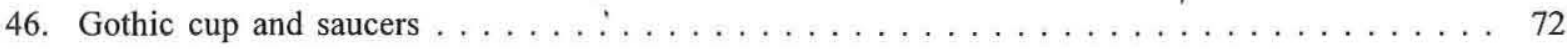

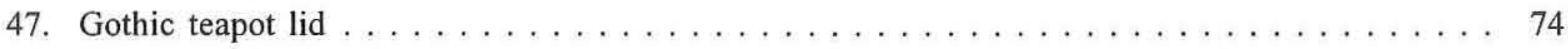

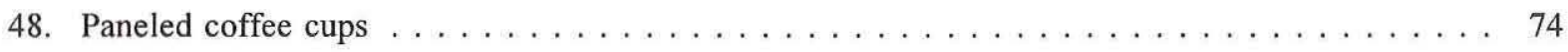

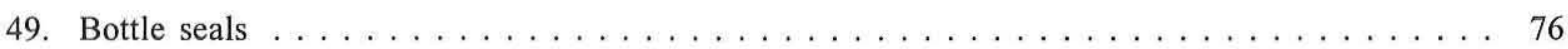

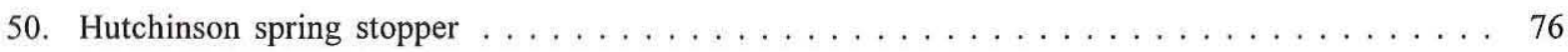

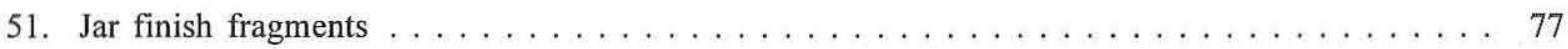

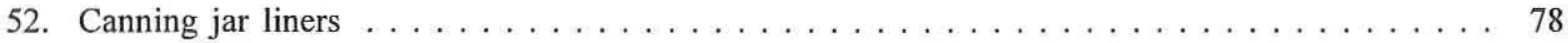

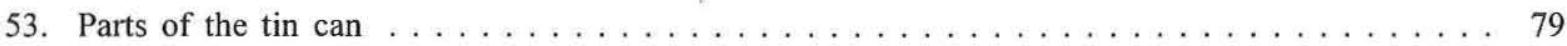

54. Cap with hole and solder shown $\ldots \ldots \ldots \ldots \ldots \ldots \ldots \ldots \ldots \ldots \ldots \ldots$

55. Tin can key-style openers $\ldots \ldots \ldots \ldots \ldots \ldots \ldots \ldots \ldots \ldots \ldots \ldots \ldots \ldots \ldots$

56. Range of cap sizes from hole-in-cap cans $\ldots \ldots \ldots \ldots \ldots \ldots \ldots \ldots \ldots \ldots \ldots$

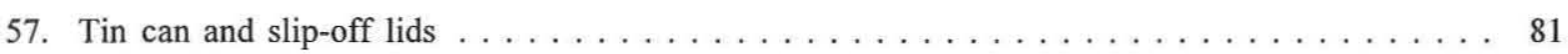

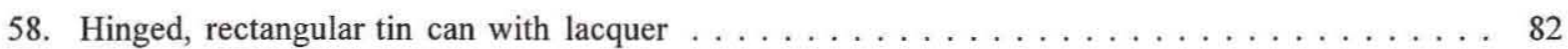

59. Rim sherd of oval serving dish with Rockingham glaze $\ldots \ldots \ldots \ldots \ldots \ldots \ldots \ldots$

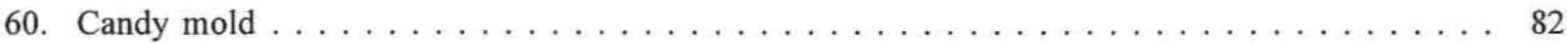

61. Molded yellowware mixing bowl $\operatorname{rim}$ sherd $\ldots \ldots \ldots \ldots \ldots \ldots \ldots \ldots \ldots$

62. Celadonlike bowl $\operatorname{rim}$ sherd $\ldots \ldots \ldots \ldots \ldots \ldots \ldots \ldots \ldots \ldots \ldots \ldots \ldots$

63. Transfer-printed bowl with girl and $\operatorname{dog}$ motif $\ldots \ldots \ldots \ldots \ldots \ldots \ldots$

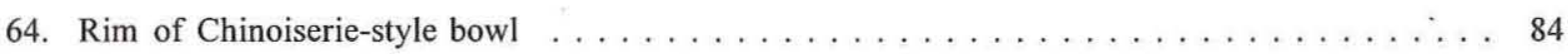

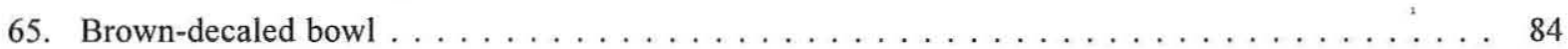

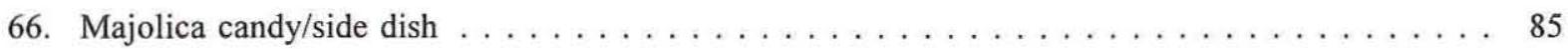

67. Castor molded for a metal stand $\ldots \ldots \ldots \ldots \ldots \ldots \ldots \ldots \ldots \ldots \ldots \ldots \ldots$ 


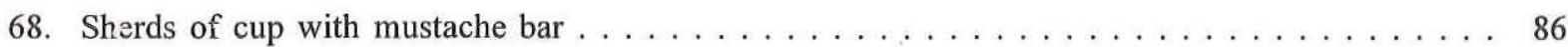

69. Tea leaf luster cup, saucer, and corresponding mark $\ldots \ldots \ldots \ldots \ldots \ldots \ldots \ldots$

70. Transfer-printed drainer $\ldots \ldots \ldots \ldots \ldots \ldots \ldots \ldots \ldots \ldots \ldots \ldots \ldots \ldots$

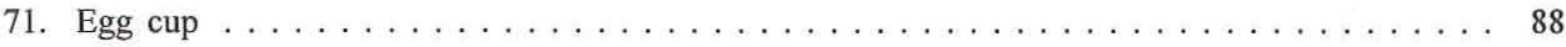

72. Monochrome decal with enameled flowers $\ldots \ldots \ldots \ldots \ldots \ldots \ldots \ldots \ldots$

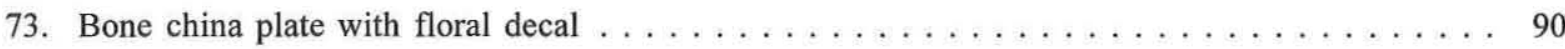

74. Molded, decaled plate with polychrome floral decal and M. Z. Austria mark . . . . . . 91

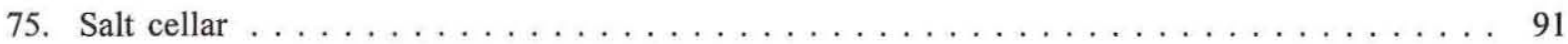

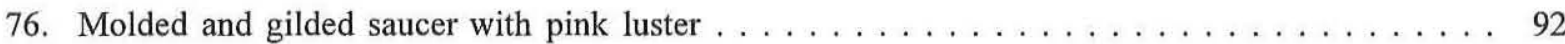

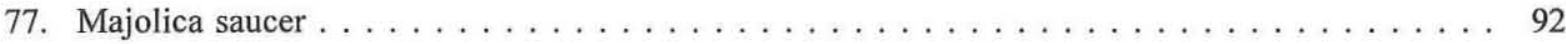

78. Hand-painted Japanese saucer sherds and mark $\ldots \ldots \ldots \ldots \ldots \ldots \ldots \ldots \ldots \ldots$

79. Enameled and gilded saucer with geometric pattern $\ldots \ldots \ldots \ldots \ldots \ldots \ldots \ldots \ldots$

80. Molded, enameled, and gilded saucer $\ldots \ldots \ldots \ldots \ldots \ldots \ldots \ldots \ldots \ldots$

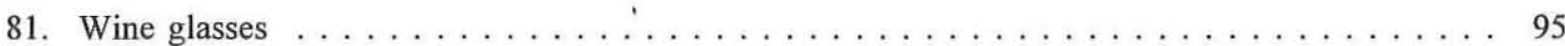

82. Fine cut-and-block press-molded pattern $\ldots \ldots \ldots \ldots \ldots \ldots \ldots \ldots \ldots \ldots \ldots \ldots \ldots \ldots$

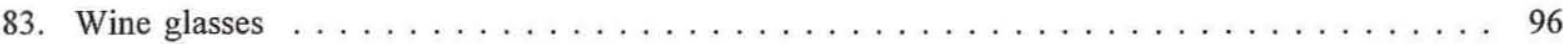

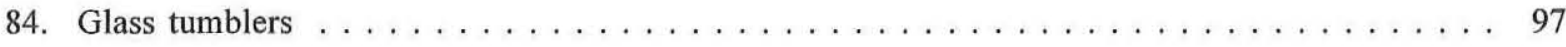

85. Glass tumblers $\ldots \ldots \ldots \ldots \ldots \ldots \ldots \ldots \ldots \ldots \ldots \ldots \ldots \ldots \ldots \ldots$

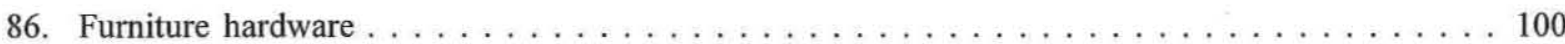

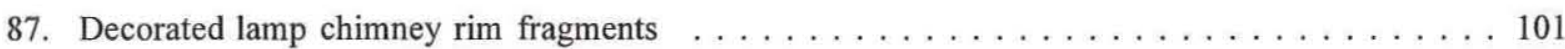

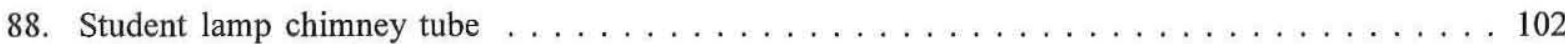

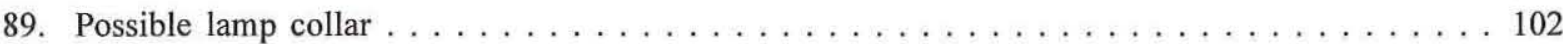

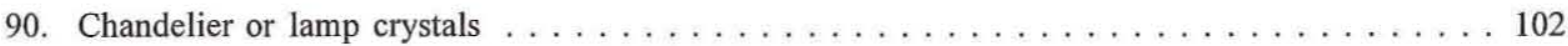

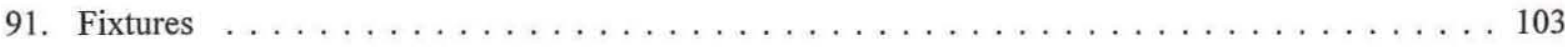

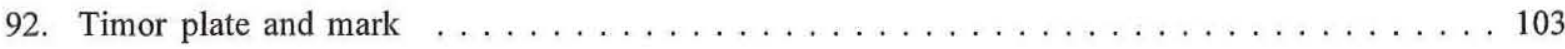

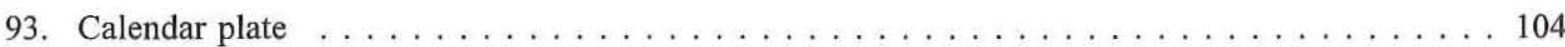

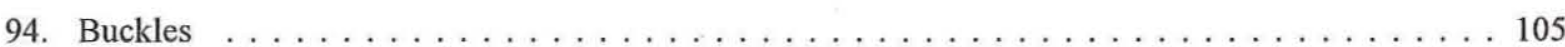

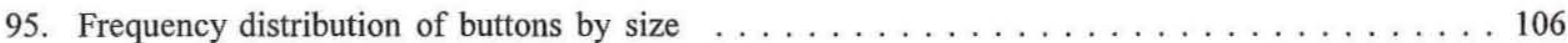

96. Frequency distribution of buttons by material $\ldots \ldots \ldots \ldots \ldots \ldots \ldots \ldots \ldots \ldots \ldots$

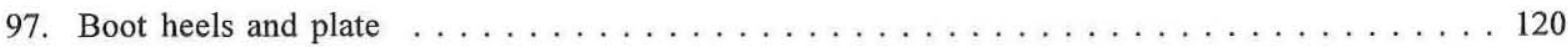

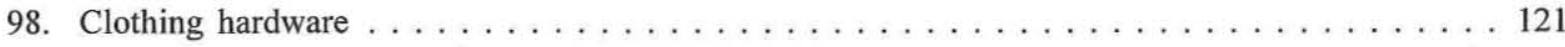

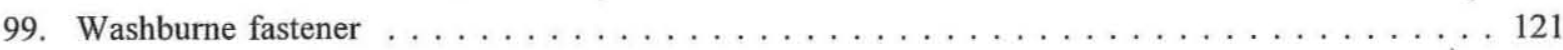

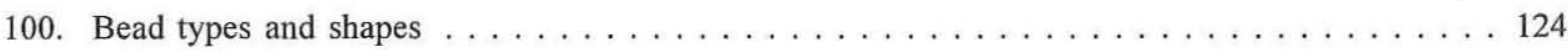

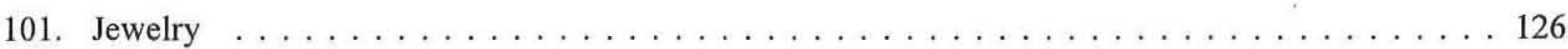

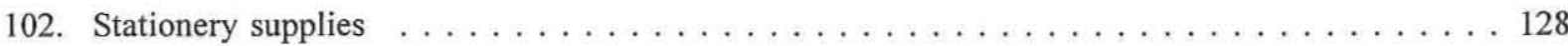


103. Opera glass or binocular lens and eye piece . . . . . . . . . . . . . . . . . 129

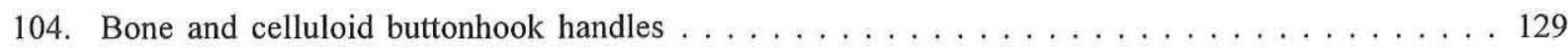

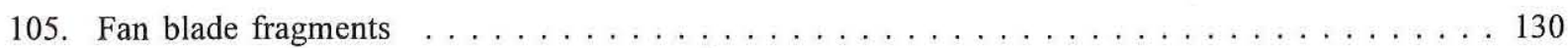

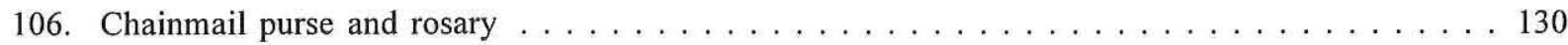

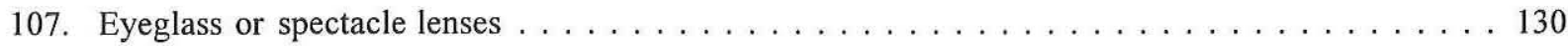

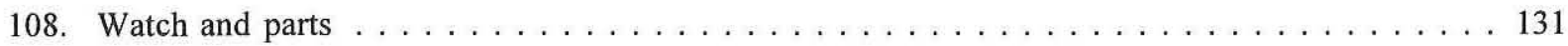

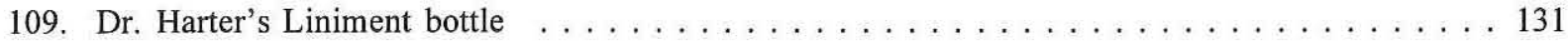

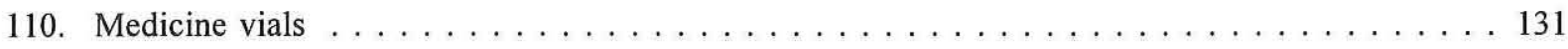

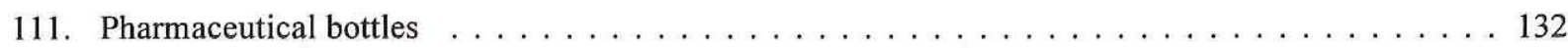

112. Unidentified pharmaceutical bottle with graded measures $\ldots \ldots \ldots \ldots \ldots \ldots \ldots \ldots$

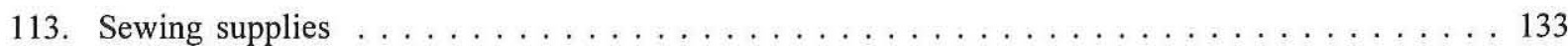

114. Pulley wheel from automatic bobbin winder and

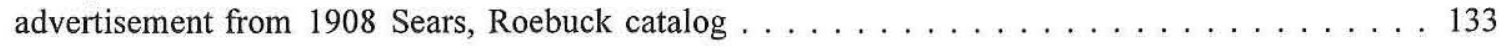

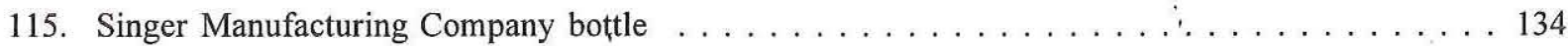

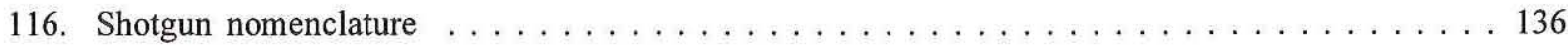

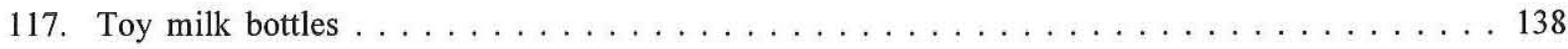

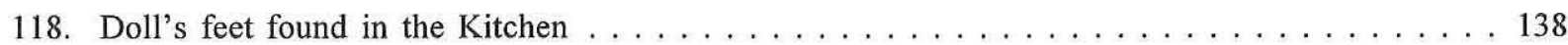

119. African American frozen Charlie doll . . . . . . . . . . . . . . . . . . . . . . . . . . . 139

120. Dolls' crowns . . . . . . . . . . . . . . . . . . . . . . . . . . . . . . . . 139

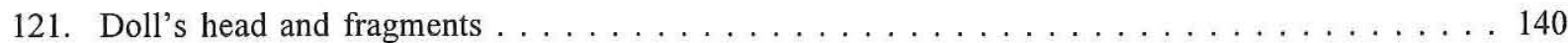

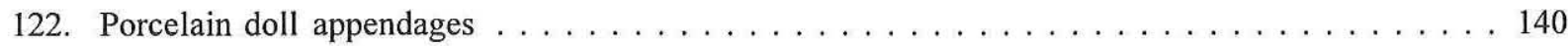

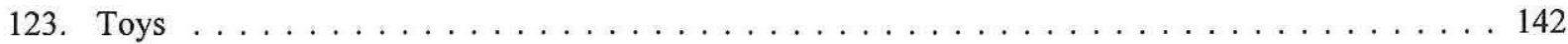

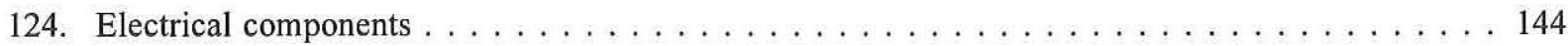

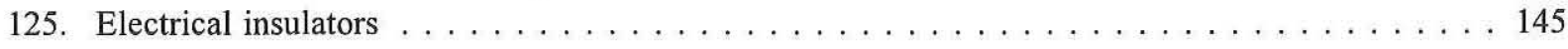

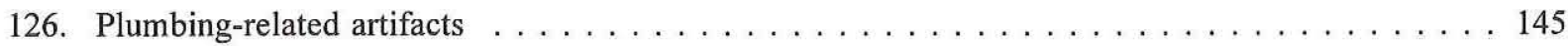

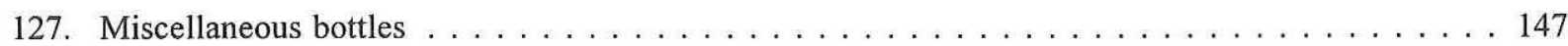

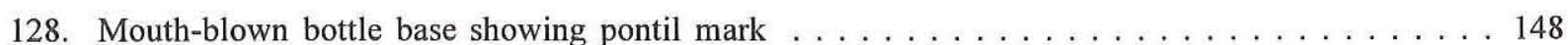

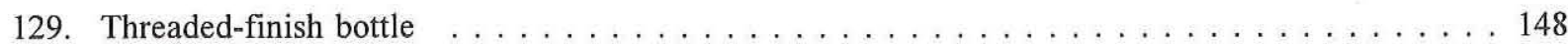

130. Miniature bone golf club, shell inlay, and wooden cap $\ldots \ldots \ldots \ldots \ldots \ldots \ldots \ldots$

131. Majolica hollowware vessel and registration $\operatorname{mark} \ldots \ldots \ldots \ldots \ldots \ldots \ldots \ldots \ldots \ldots \ldots$

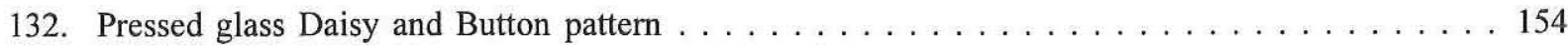

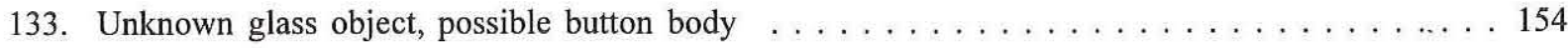

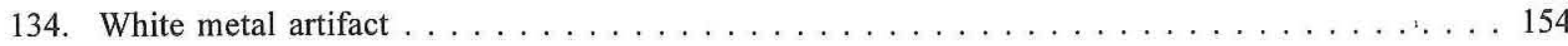




\section{LIST OF TABLES}

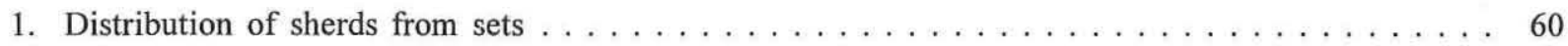

2. Sew-through vs. shanked buttons by material $\ldots \ldots \ldots \ldots \ldots \ldots \ldots \ldots \ldots \ldots \ldots \ldots \ldots \ldots$

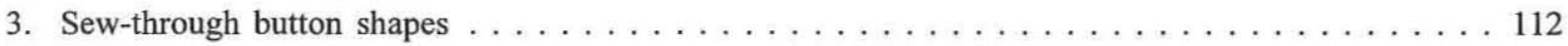

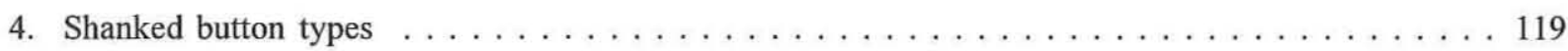

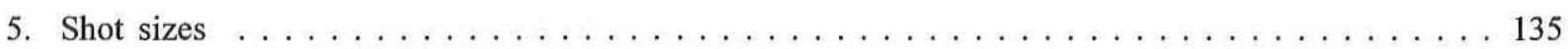

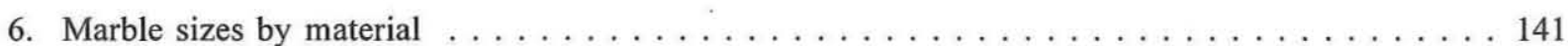

7. Summary of artifacts from the Kitchen, Dining Room, and Room $7 \ldots \ldots \ldots \ldots \ldots$

8. Distribution of artifacts in the Kitchen, Dining Room, and Room $7 \ldots \ldots \ldots \ldots \ldots$ 


\begin{abstract}
The town of Seguin in Guadalupe County, Texas, was known for its numerous limecrete structures. Limecrete structures probably once numbered more than 100; now, the house known as Sebastopol is one of only two still standing. Between 1978 and 1988, archeological excavations were conducted by the Texas Parks and Wildlife Department in and around Sebastopol. The excavations were preparatory to and in conjunction with architectural restoration of the building and development of the site as a State Historical Park.

Archeological excavations were intended to evaluate only those areas impacted by the architectural restoration. Excavation units were placed primarily in and around the building, but also around the cistern and in other yard areas. This report, prepared by Prewitt and Associates, Inc., summarizes the excavation seasons and provides analyses of ceramics from across the site as well as diagnostic artifacts from three rooms in the house. Artifacts range in age from the mid nineteenth century up to modern times and came from as far away as Europe and the Far East. Of 106,586 artifacts recovered by the Texas Parks and Wildlife Department, 4,071 artifacts are discussed here.
\end{abstract}




\section{ACKNOWLEDGMENTS}

Many people from the Texas Parks and Wildlife Department have contributed to this work in numerous ways. Art Black was the principal investigator for the excavations and served a critical role in providing information about work conducted at the site as well as writing parts of Chapters 2 and 4 . Cynthia Brandimarte conducted oral history research into the site during 1981-1982 and wrote the history of the site included in Chapter 1. Peter Maxson also conducted historical research of the site. Jim Bigger was the architect in charge of the restoration project. Jerry Sullivan, an interpretive planner with the Interpretation and Exhibits Branch, wrote and researched the exhibits for the site. Aina Dodge, director of the Archeology Laboratory at the Texas Parks and Wildlife Department, organized the artifact recataloging and was helpful whenever requests were made for information from the lab. Eric Morley spent many hours entering the TPWD catalog information into a database. Many archeologists worked both at the site as field crew and in the lab. In particular, Juliann Pool and Dan Crouch were involved with this project from the fieldwork to reviewing the report. Other field crew included Dana Anthony, Cynthia Banks, Cynthia Brandimarte, Maureen Cavanaugh, Mike Davis, Molly Godwin, John Hart, Terry Holtzapple, Elena Ivy, Chris Jurgens, Vance Langley, Deborah Lebo, Steve Lebo, Mark Lee, George Lewis, Diana "Dino" Lowrey, Mary McCready, Mary Jane McReynolds, David Proctor, Margaret Rochelle, Ted Samsel, Susie Steiglebauer, Kit Taylor, and Melissa Voellinger.

At Prewitt and Associates, Elton Prewitt and Ross Fields served as co-principal investigators for this analysis. Linda Foster, Ross Fields, and Melissa Hennigan edited the text and tables. Karen Gardner provided direction for the pulling of diagnostic artifacts and performed data entry tasks for the artifact analysis. Amy Earls provided vital research which served as a basis for the ceramics chapter. Audra Pineda helped pull

diagnostic artifacts for analysis. Sandra Sauer analyzed the artifacts, wrote most of the report, took the artifact photographs, and drew some of the computer illustrations. Ellen Atha did the hand-drawn artifact illustrations. Sandy Hannum and Brian Wootan were responsible for producing the photographic and illustrative figures. Kerza Prewitt and Scott Richard Schulz drafted the maps. Linda Foster produced the report. 



\section{INTRODUCTION AND HISTORICAL BACKGROUND}

\section{INTRODUCTION}

Sebastopol State Historical Park in Seguin, Texas, is a historic site operated by the Texas Parks and Wildlife Department (TPWD). The structure is an 1850 s Greek Revival residence, historically named Sebastopol, which was purchased and renovated by the Seguin Conservation Society in 1961. This group operated the site until it was purchased by the state in 1976 (TPWD 1983:I:10-11). TPWD has undertaken a structural restoration of the building, including architectural, historical, and archeological investigations, and has developed a historical interpretation program for the building and the site. This report is the analysis and write-up of the archeological component of the restoration project.

Between 1978 and 1988, nine archeological field projects were conducted at Sebastopol (41GU9). During these projects, 10 rooms on the ground floor of the house and areas adjacent to all four exterior walls were either completely or partially excavated. The cistern associated with the house was partially excavated, as were other yard areas. The current research provides a summary of the work conducted during these nine field seasons and an analysis of a sample of the $106,000+$ artifacts recovered.

\section{GOALS}

The goals of this report are fourfold: (1) to summarize the nine seasons of archeological fieldwork conducted between 1978 and 1988; (2) to provide an inventory of artifacts; (3) to examine the pre-1910 ceramic sets found at the site; and (4) to analyze the deposits found in the three finished (plastered and painted, with floors and trimming) lower-floor rooms of the house. The study of the ceramic sets, which contain a wide variety of decoration and ware types, provides a comprehensive look at a late-nineteenth-to-early-twentieth-century central Texas ceramic collection. The study of the three rooms provides insights into the use of those rooms over time.

\section{SITE SETTING}

Sebastopol State Historical Park is located at 704 Zorn Street, Seguin, Guadalupe County, Texas (Figure 1), and is currently open to the public from 9:00 A.M. to 4:00 P.M. Wednesday through Sunday. Sebastopol is located eight blocks west of the courthouse square in a mixed residential and commercial neighborhood, although historically it was primarily a residential area (TPWD 1983:II:45).

Sebastopol is a Greek Revival house constructed of local limecrete. At one time more than 100 limecrete structures probably stood in Seguin (Hauser 1980:58), but due to the nature of the material, only a few still stand. Because it is one of the best surviving examples of early limecrete construction in Seguin, and because Joseph Zorn Jr., the mayor of Seguin from 1890-1910, owned the house for many years, the house is architecturally, technologically, and locally historically significant.

\section{REPORT ORGANIZATION}

This report is designed to provide information about the archeological excavations conducted at Sebastopol and to provide an analysis of the artifacts found during this archeological work. The remainder of this chapter provides a general background of the ownership and use of the site. Chapter 2 describes the methods used in the historical research 


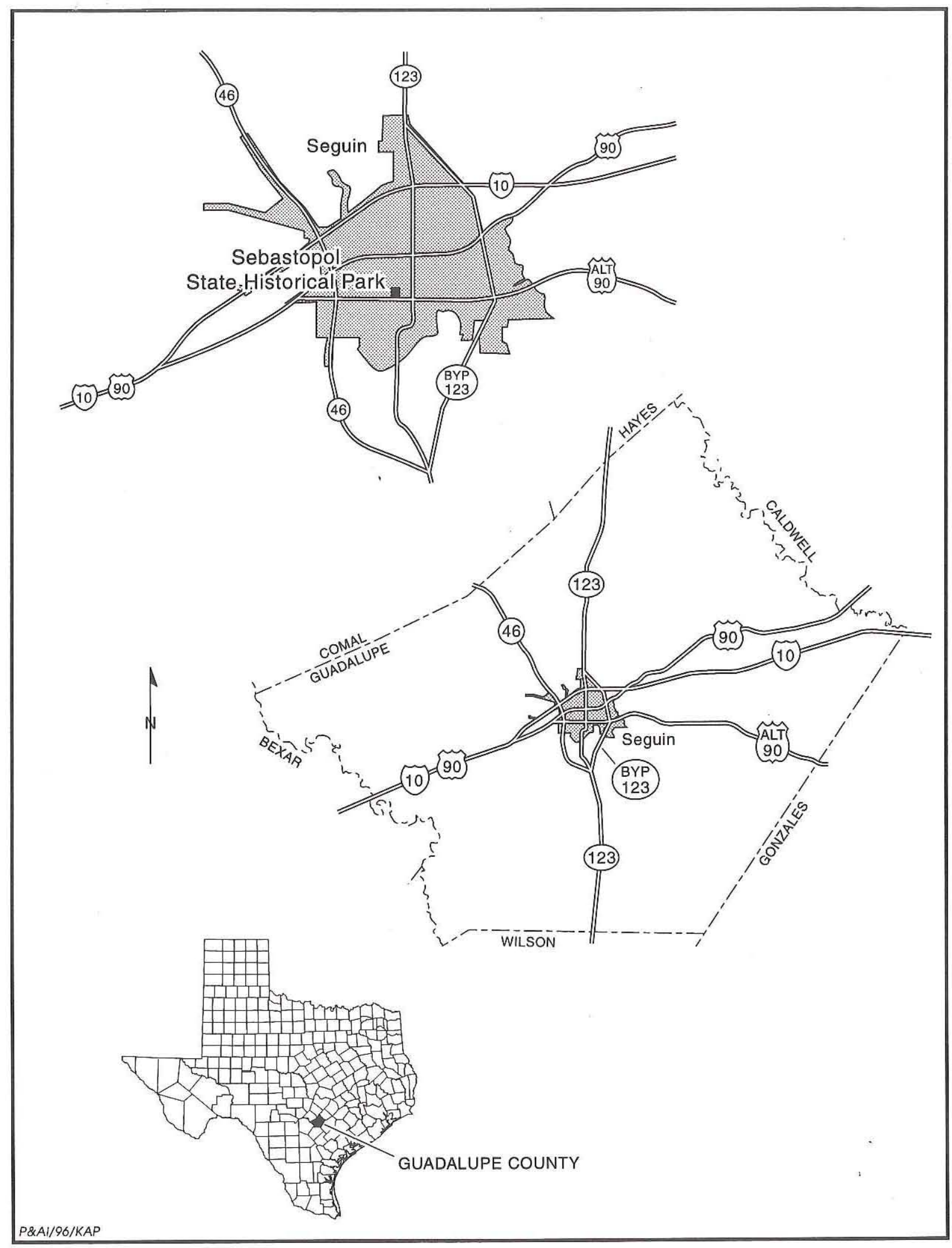

Figure 1. Site location map. 
and fieldwork, with an emphasis on the diversity of techniques used in the different field seasons; it also explains the objectives and methods of the artifact analyses presented in this report. Chapter 3 provides information on the architecture and construction techniques used to build the house. The house and yard deposits are detailed in Chapter 4 to provide the reader with an idea of the stratigraphy and the disturbance present throughout the site. The ceramic sets that predate 1910 are discussed in Chapter 5 before the analysis of selected artifact classes from the Kitchen, Dining Room, and Room 7 in Chapter 6. A comparison of the contents of the finished lower-floor rooms in Chapter 7 helps to better understand the uses of these rooms. Following this comparison, conclusions are presented. The analysis of this varied collection not only offers vital information about Sebastopol but also serves as a catalogue of specific artifact classes for future researchers in historical archeology. Appendix A provides quantitative summaries for all of the artifacts from the site. Appendix B summarizes those artifacts that are on display at Sebastapol and thereby were not available for analysis in this report.

\section{HISTORY OF SEBASTOPOL DURING THE ZORN FAMILY OCCUPATION}

\section{The Zorn Family Prior to the Purchase of Sebastopol}

Since the preponderance of artifacts identified at the site by TPWD archeologists date to the third quarter of the nineteenth century through the midtwentieth century, the agency historian sought to provide a context for these artifacts. The 18751940s era coincides with the occupation of the house by the Joseph Zorn Jr. family (Figure 2). For that reason, the history presented here addresses that family's economic, social, and material environment,

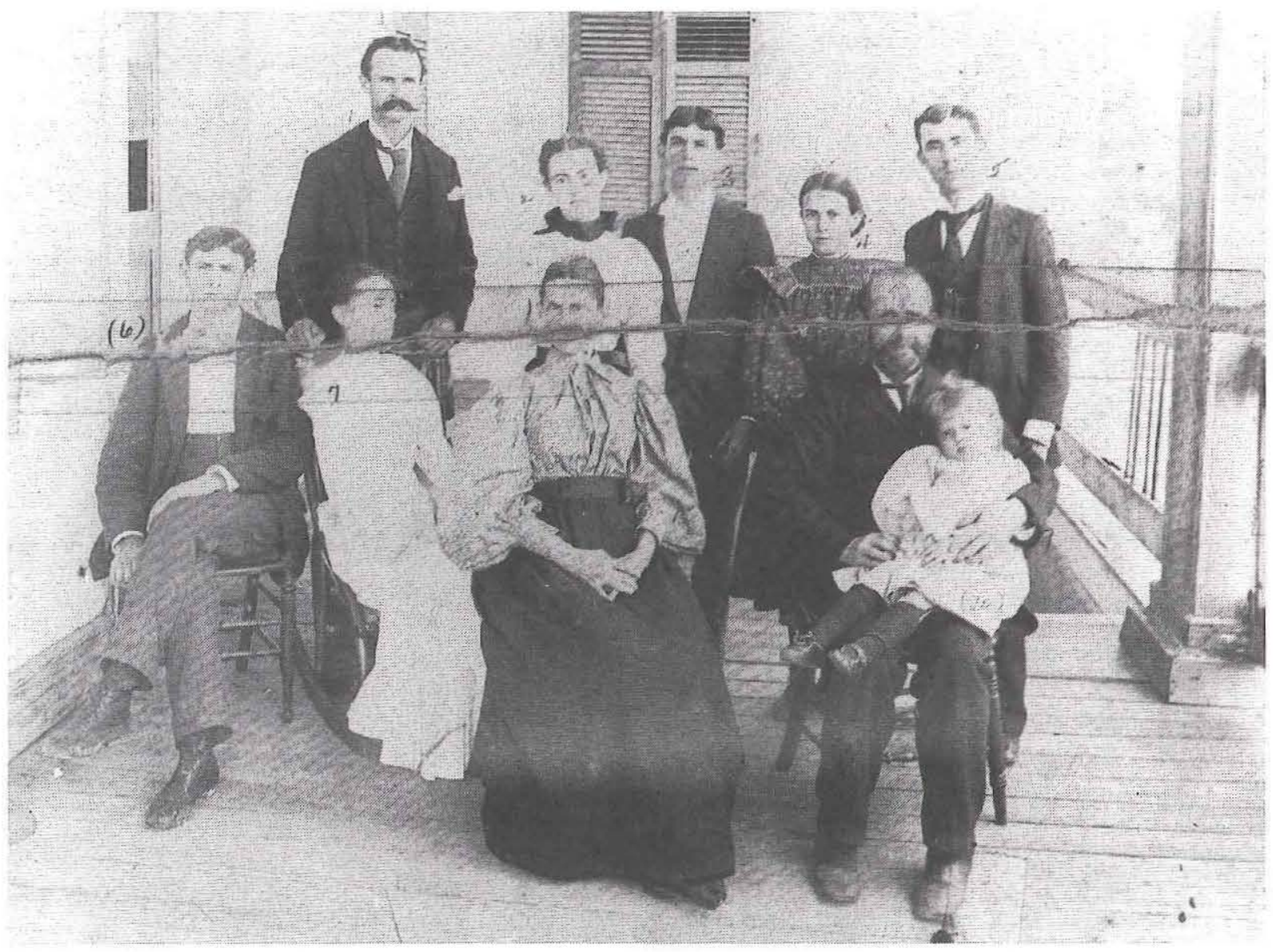

Figure 2. Photograph of the Zorn family, taken around 1900. From left to right, back row: Dr. Tegener, Kate Zorn, Cal Zorn, Nellie Zorn, Joe Zorn III. Front row: Ed Zorn, Theresa Tegener, Nettie Zorn, Joseph Zorn Jr., Hazel Tegener. 
while providing some background to the Zorns' arrival in Guadalupe County at midcentury.

Joseph Zorn Sr. was born in France in approximately 1808 (U.S. Bureau of the Census 1850b). $\mathrm{He}$ is thought to have come from the agriculturally rich French province of Alsace, located on the Zorn River upstream of its intersection with Germany's western border, the Rhine, although naturalization records containing his birthplace and birth date remain unlocated at this time. Family lore places Joseph Zorn in this Alsace-Lorraine area (Tegener 1981a; U.S. Bureau of the Census 1880b).

Although the circumstance and route of Joseph Zorn Sr.'s journey from France to the United States remain undocumented, he likely came by ship to the port of New Orleans sometime in the early 1830s. The birth of three children in Louisiana-Lewis in ca. 1834, Joseph in ca. 1835, and Adaline (birth date not clear, but sometime between 1832 and 1835) indicates that this port may indeed have been his early home (U.S. Bureau of the Census 1850b, 1870, 1880b). Moreover, Hazel Tegener, Zorn's greatgranddaughter, remembered that "he came from New Orleans" (Tegener 1981a). It is likely that by 1840 , however, Joseph Zorn Sr. and his family already had left New Orleans, since his fourth child and the future owner of Sebastopol, Joseph Zorn Jr., was born in Indiana in 1840 (U.S. Bureau of the Census 1860b).

The Zorn surname first appears on the New Orleans census records in 1840 when only the households of Peter Zorn and Florence Zorn are listed (U.S. Bureau of the Census 1840):

Peter Zorn:

1 male, 10 and under 15

Florence Zorn:

3 males, 20 and under 30

3 males, 30 and under 40

4 females, 15 and under 20

It is possible but not probable that Joseph Zorn Sr. may have been one of the three males " 30 and under 40" listed as a member of Florence Zorn's household. However, Joseph's children-one boy and two girls under 10 years of age - and his wife, probably in her twenties, do not fit any of the age categories in either of the two Zorn households in 1840 New Orleans.

Florence Zorn's household appears again on the 1850 census of New Orleans along with that of Lewis Zorn (U.S. Bureau of the Census 1850c). The relationship of Florence and Lewis to Joseph is not known, but it is believed that Peter Zorn was Joseph's brother. By 1850 , Peter and his family had settled at Hermann in Gasconade County, Missouri (U.S. Bureau of the Census 1850a). Peter's nephew, Joseph Jr., first appears as a member of his household.

Peter Zorn, 39, M, tailor, France

Catherine, 27, F, France

Joseph, 9, M, Indiana

Peter, 5, M, Louisiana

William, 1, M, Hermann, Mo.

Meanwhile, Joseph Zorn Sr.'s name surfaces on the Guadalupe County, Texas, census for 1850 (U.S. Bureau of the Census 1850b):

$$
\begin{aligned}
& \text { Joseph Zorn, 42, M, Merchant, } \\
& 1700 \text { [value of his estate], France } \\
& \text { Lewis, 16, M, Clerk, La. } \\
& \text { Josephine,15, F, La. }
\end{aligned}
$$

It is believed that the death of Joseph's wife had caused the temporary separation of the Zorn family members-Joseph Jr. being raised by his uncle in Missouri, Adaline's whereabouts unknown, and Joseph Sr. settling in Seguin, Texas, with his two teenage children.

Although Joseph Zorn Sr. and his two children do not appear in the census until 1850, deed records for Seguin indicate that they lived in the town several years before the census was taken. As early as August 1,1846, Zorn had purchased property in the town. At that time, he paid $\$ 20$ for Lot 4 in Block 29 of what was referred to as Building for Town Lots as opposed to the 12-acre Farming Lots situated away from the center of town (Guadalupe County Deed Record B:11). He followed that purchase with others as he proceeded to acquire choice land in the town. In fact, Zorn negotiated to buy at least 15 parcels of land between his first purchase in 1846 and the early 1860s. During approximately the same period, he sold or divested himself of only one parcel so his acquisitions became sizable (Figure 3). These purchases indicate that Zorn had chosen Seguin as the place where he would make his home, establish his business, and raise his teenage children.

Unfortunately, none of these early deeds specifically mentions a homestead; in fact, it was not until almost 20 years after Zorn bought his first lot that such a reference appeared. On September 18, 1865, Joseph Zorn Sr. bought Lots 1-6 in Block 17 (Guadalupe County Deed Record I:495). This 

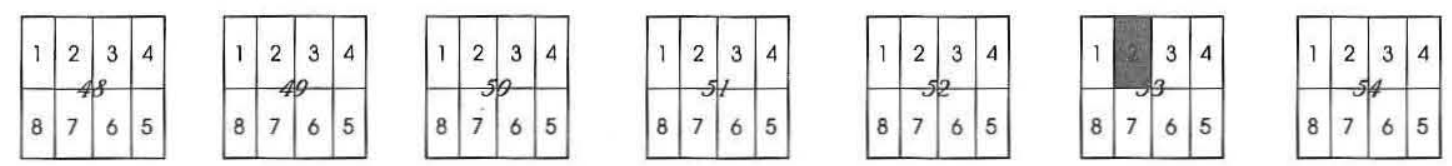

\section{MOUNTAIN}

\begin{tabular}{|l|l|l|l|}
\hline 1 & 2 & 3 & 4 \\
\hline 8 & 4 & 6 & 5 \\
\hline
\end{tabular}
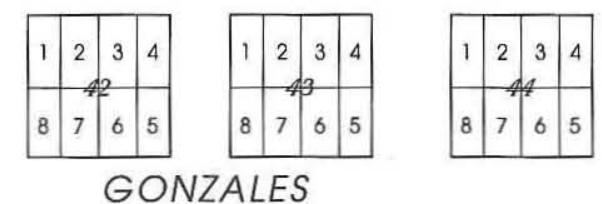

\section{STREET}
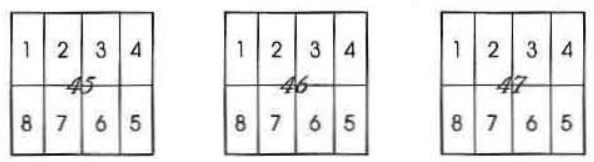

STREET
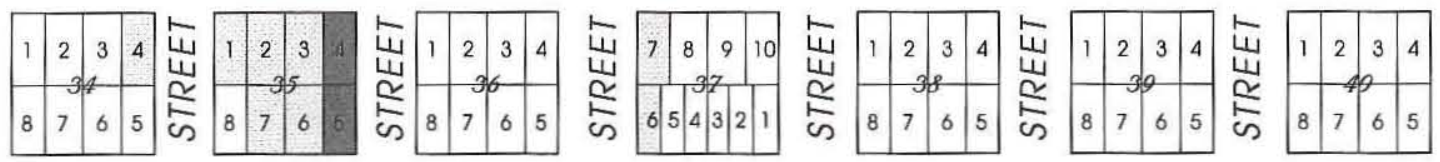

COURT
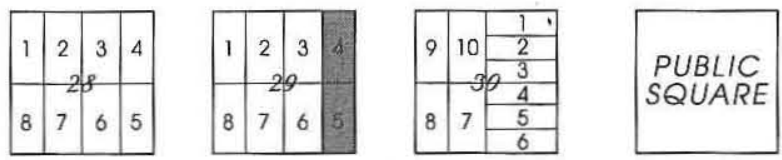

STREET

\section{CENTER}

\begin{tabular}{|l|l|l|l|}
\hline 1 & 2 & 3 & 4 \\
\hline 8 & 7 & 6 & 5 \\
\hline
\end{tabular}

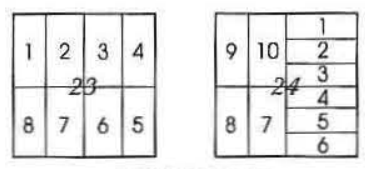

MARKET

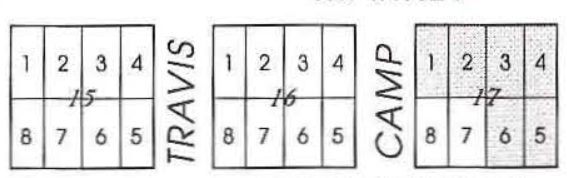

WASHINGTON
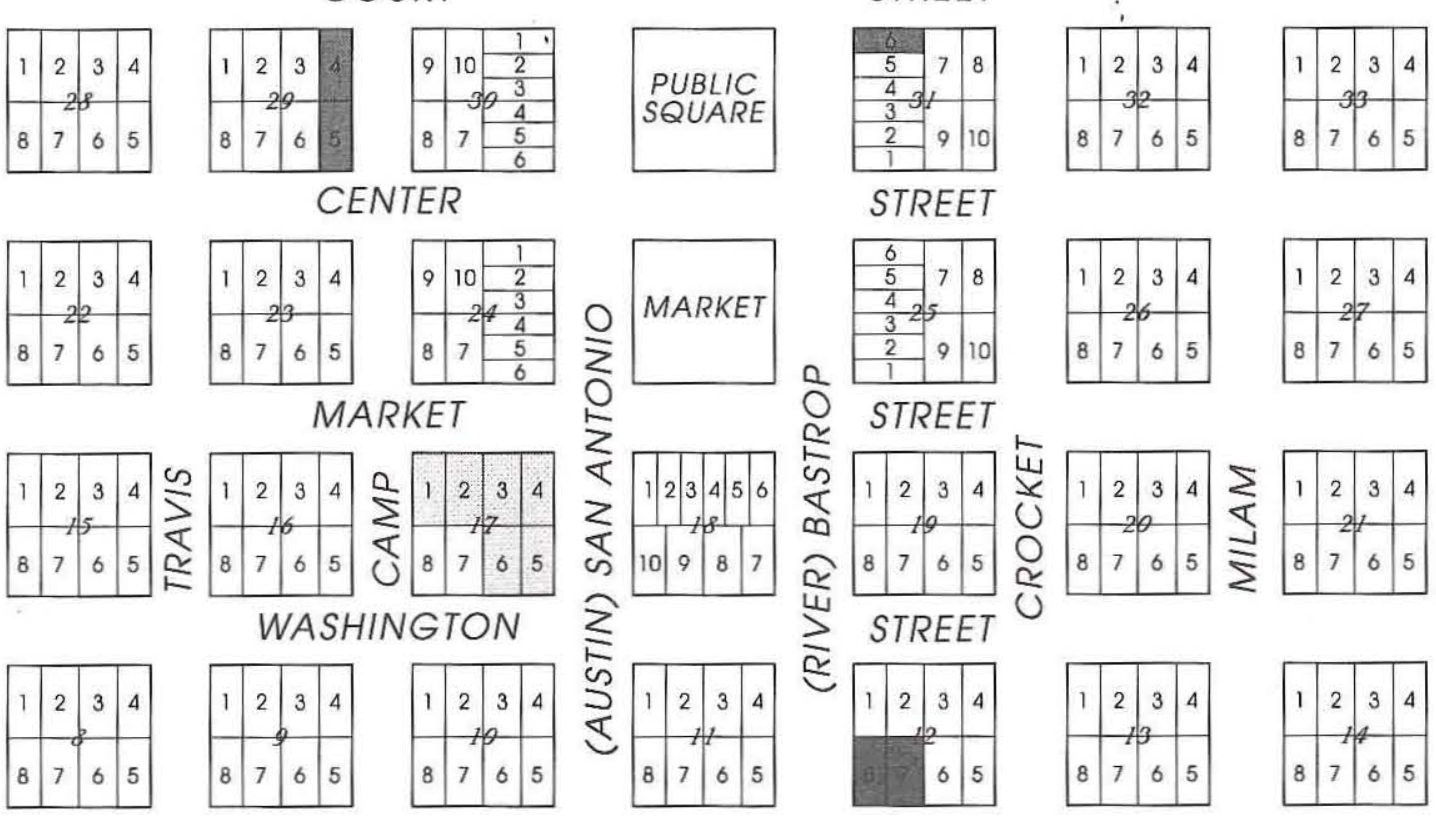

STREET
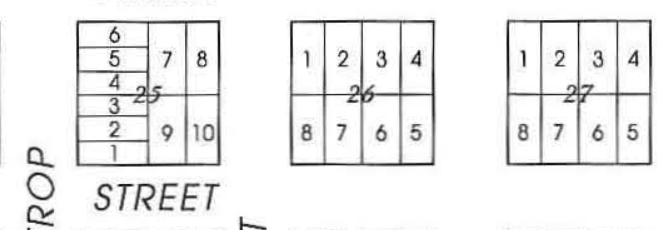

\begin{tabular}{l|l|l|l}
8 & 7 & 6 & 5
\end{tabular}
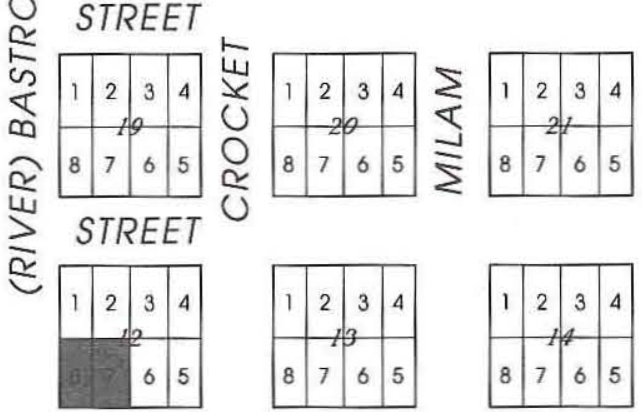

\section{LIVE OAK}

\begin{tabular}{|l|l|l|l|}
\hline 1 & 2 & 3 & 4 \\
\hline 8 & 7 & 6 & 5 \\
\hline
\end{tabular}
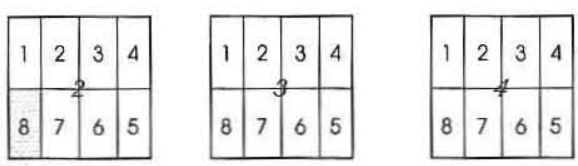

STREET
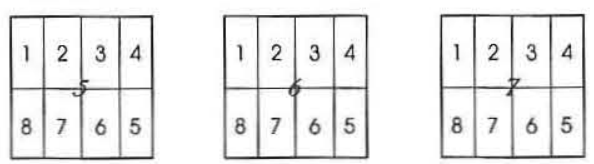

LEGEND

Town Lot acquired by Joseph Zorn Sr. by 1850

Additional Town Lot acquired by Joseph Zorn Sr. by the 1860s

PAI/97/SLH

Figure 3. Plat of town lots in Seguin, Texas, as recorded in the Guadalupe County deed records in 1839, showing lots owned by Joseph Zorn Sr. by 1850 and the 1860 s. 
property, then called "the homestead of J. R. Johnston," became known as "the Homestead Place of . . . Joseph Zorn, Sr." (Guadalupe County Deed Record J:444). Nevertheless, one can speculate that one of Zorn's early land purchases was the site of the family's first Seguin residence. Perhaps, it was the property known as Lot 4 in Block 29, purchased in August 1846, or the land bought in November of 1848 , described as including a lot and a "house" for $\$ 52$, plus the adjacent lot for $\$ 7.50$ (Guadalupe County Deed Record B:485). No known documentation indicates whether Zorn actually used the "house" as his residence, but a later mortgage deed indicates that the structure did house one of his businesses - a Bake Shop (Guadalupe County Deed Record C:534).

With Zorn's rapid accumulation of property during his early years in Seguin, he could have built his residence or residences on any number of lots: perhaps on Lot 5 of Block 29 purchased in May 1847 (Guadalupe County Deed Record B:161), Lot 6 of Block 31 purchased on July 2, 1847 (Guadalupe County Deed Record B:160), or Lot 2 of Block 633 which Zorn purchased on May 1, 1848, for the sum of $\$ 2.14$ (Guadalupe County Deed Record B:354). It is also likely that, when Zorn bought Lots 7 and 8 in Block 12 on December 28, 1849, for $\$ 300$, he acquired along with the land a structure that he may or may not have used as a residence (Guadalupe County Deed Record C:17).

Wherever Zorn and his two children lived in Seguin, he probably owned his residence. Census data from 1850 indicate that the Zorn family had their own home rather than living in a boarding house as Joseph Zorn Jr. did later. Joseph Zorn Sr.'s estate was valued at $\$ 1,700$ in 1850 , which suggests that he had the means to own his residence.

Deed records again are helpful in documenting Zorn's business activity. In February of 1851, he mortgaged Lots 4 and 5 in Block 35 to Andrew J. Beard. These lots are described as ". . . lots number four and five (4 and 5) in Block number thirty five (35) of the inner or building lots of said Town of Seguin and the same now enclosed by a cedar pole fence with my Bake Shop enclosed in the same, and due north of my store on the opposite side of the street from the store" (Guadalupe County Deed Record C:534). Thus Zorn operated a Bake Shop on the northwest corner at the intersection of Court and Camp Streets and owned a store right across the street, on the southwest corner of the same intersection. Since Zorn later bought all but one lot in Block 35, Blocks 29 and 35 may have represented the area not only of his early business activities but also of his home life (Guadalupe County Deed Record G:624, 625).

Newspaper advertisements from the 1850 s show that Zorn's store was a general merchandise type (Seguin Mercury, July 14, 1858) (Figure 4). Not documented in later records, his bake shop may have been a temporary enterprise. Listed as a clerk in 1850 (U.S. Bureau of the Census 1850b), Lewis Zorn probably helped his father with these businesses whose profits supported the family from 1846 until well into the 1860 s.

The Zorn family experienced many changes during the 1850s: Josephine married; her father remarried; Lewis apparently moved from the county while Joseph, and later his sister Adaline and her family, moved to Seguin.' On December 10, 1853, 18-year-old Josephine Zorn married 28-year-old Prussian-born Joseph Wassenich in a Catholic service in New Braunfels (Guadalupe County General Index to Marriages A:76). Wassenich, who listed himself as a farmer on the 1860 census (U.S. Bureau of the Census $1860 \mathrm{~b}$ ), later prospered as a cabinetmaker and furniture importer in Seguin (Taylor and Warren 1975:327). He and his wife had six children: Lewis, Edward, Joseph (traditional Zorn family names), Alice, Rosa Lee, and Frank (U.S. Bureau of the Census 1870).

Less than a month after his daughter's wedding, Joseph Zorn married Theresa Kreusser of Comal County. The ceremony was performed on January 5, 1854, by a Justice of the Peace (Guadalupe County General Index to Marriages A:78). Kreusser, 39 at the time of her marriage to 56-year-old Zorn, had been born in Germany (U.S. Bureau of the Census 1860b) and had one daughter, Wilhemina, from an earlier marriage. Apparently Theresa Kreusser Zorn and her stepson, Joseph Jr., enjoyed an affectionate relationship, for in an 1867 will, she treated with equanimity her daughter and her stepson, and when he later married, his first child was named Theresa (Guadalupe County Probate Record E:556).

By 1860, Joseph's son Lewis disappeared from the census rolls, and by 1870 the elder Zorn's daughter Adaline, her husband George Schmidt, and their five children had appeared (U.S. Bureau of the Census 1860b, 1870).

Although family lore places Joseph Zorn Jr. in 


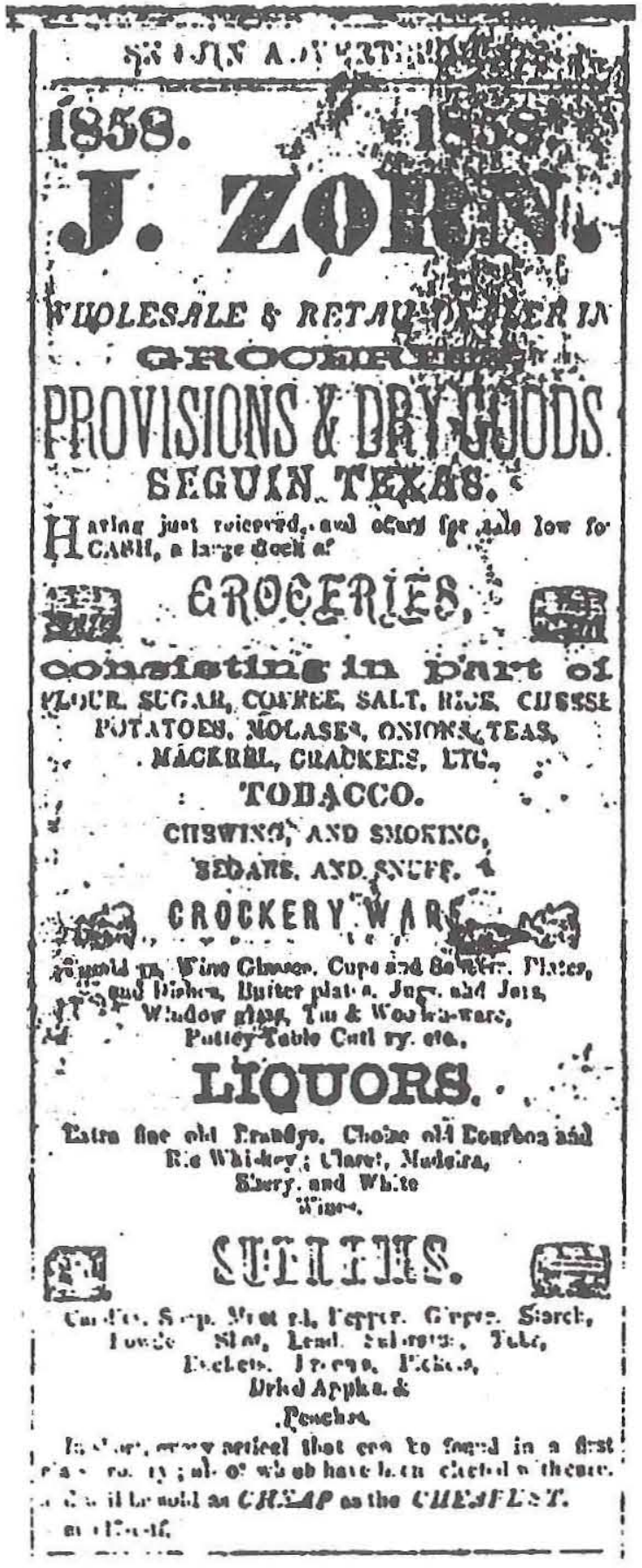

Figure 4. Advertisement in the Seguin Mercury (July 14, 1858) for Joseph Zorn Sr.'s store indicating that it sold groceries, tobacco, crockery ware, liquors, and sundries. 
Seguin by 1850 , no written record documents his presence there until 1858. A list of children ages 6 to 16 and eligible to attend school in Texas was published in 1855 and titled "Texas Scholastics 1854-55" (White 1979). Zorn, who would have been 15 years old at the time of publication, was not included on the list. The first record that documents his presence in Seguin is a civil lawsuit filed against him and his father. Joseph Zorn Sr. and Seguin's future mayor, Joseph Jr., were accused of selling "intoxicating liquor in quantities less than a quart" on February 1, 1858 (Guadalupe County Probate File No. 356). The lawsuit mentions that both men were merchants so it is likely that as a young man, Joseph left his uncle Peter's household in Missouri sometime between 1855 and early 1858 in order to take up his father's occupation in Seguin. Living with his father and stepmother (U.S. Bureau of the Census 1860b), Joseph was naturally taken into the prospering family business.

His new home, new family, and new work no doubt occupied Joseph Zorn Jr. during his first years in Seguin. But in 1861 events arose which captured his attention and that of his contemporaries when news of a civil war filled the pages of the Southern Confederacy, Seguin's newspaper, formerly called The Mercury (Fitzsimon 1938:25).

Zorn enlisted in the "Guadalupe Rangers" on July 20, 1861. Commissioned on September 20, 1861, the Rangers, composed of 85 men and 13 officers, was organized "for active service wherever needed in the state" (Texas State Troops Muster Roll 687). Captain John P. White headed this volunteer cavalry company which was part of the Twenty-fifth Brigade of the Texas Militia (Southern Confederacy, July 19 and 26, 1861). While John Ireland served as the Rangers' first lieutenant, Joseph Zorn became the company's fourth corporal (Texas State Troops Muster Roll 687).

During their brief tenure together, the men of the Guadalupe Rangers probably remained in or near Seguin. It is likely that, after several weeks in a nearby training camp during the summer of 1861, the group functioned as a kind of home guard, protecting trade routes and assuring residents of the town's safety and preparedness (Green 1982). When the company was disbanded soon after its organization, the men joined other commands. Later, Ranger officers John White and John Ireland each organized his own company (Moellering 1938:124).

On March 26, 1862, Joseph Zorn enlisted in
Ireland's Infantry Company, which became Company K of the Eighth Texas Regiment (Kinney 1977: 34033; Texas State Troops Muster Roll 95). Unfortunately, the Eighth Regiment's accomplishments during the war have not been chronicled as have been the more exciting activities of Terry's Texas Brigade or Hood's Texas Brigade. There are, nevertheless, scattered references to the Regiment which at least outline its military activity.

In general, Company $\mathrm{K}$ of the Eighth Texas Regiment served primarily on the Texas coast but also saw action in Louisiana (Wright 1965:104). In July of 1862 , led by Captain W. L. George after Ireland's promotion to lieutenant-colonel, Zorn's company participated in the defense of Corpus Christi (War of the Rebellion IX 1886:624). It is not known exactly what role Joseph Zorn played in these maneuvers. Since it was customary to refer primarily to officers in' official military reports, Zorn, a private at this time, was not singled out.

By the summer of the following year, 1863, Company $\mathrm{K}$ was stationed at Indianola. Many years after the war, a former Indianola residence recalled the names of "Jep Dibrell, John George, three LeGette brothers, Joe Zorn, Goodrich and Douglas" as being in the company. This same witness also documented that most of the men were from Seguin and that some boarded in private homes and even brought their families (Calhoun County Historical Survey Committee 1974:104). The Company apparently saw little action until the end of the year when General Nathaniel P. Banks threatened the Texas coast.

In November of 1863, Banks began his second attack on Texas troops. He seized garrison after garrison along the coast beginning with the island of Brazos de Santiago on November 1, 1863; Brownsville was his next target on November 8 , then Corpus Christi, Aransas Pass, Indianola, and finally Lavaca on December 26, 1863 (Richardson et al. 1981:230). Still stationed at Indianola when Banks began his attack, Company $\mathrm{K}$ was quickly ordered to Fort Esperanza (Calhoun County Historical Survey Committee 1974:104), a Confederate post at Saluria on Matagorda Island (Webb 1952:625). Zorn himself provided an eyewitness account of the events that took place at Fort Esperanza on November 29, 1863:

The federal fleet was outside of the Pass with a number of vessels and for several 
days bombarded the fort, later they landed a large force of men and were about to surround and cut us off from the mainland which forced us to evacuate the fort. As we were infantry we could not bring anything away, all supplies, guns, ammunition, etc., were blown up and destroyed to prevent them falling into the hands of the enemy. We left Esperanza about 12 o'clock at night, passed through Indianola early next morning without stopping until we arrived at Port Lavaca. We remained there but a short time when we were ordered to Galveston [Calhoun County Historical Survey Committee 1974:104105].

It is likely that Zorn and the other men of the Eighth Regiment remained in Galveston until they were needed to defend Texas again from Banks. In the spring of 1864, Banks launched his Red River campaign. Zorn was one of approximately 11,000 men who repulsed Banks's army at Mansfield, Louisiana, on April 8, 1864. The next day, Banks successfully attacked the Confederates at Pleasant Hill, but afterwards retreated across the Mississippi (Richardson et al. 1981:230).

Pension records provide another dimension to Zorn's service to the war effort (Figure 5). These document that in addition to his duty as a combat infantryman, Zorn assumed the extra duty as a member of the Regimental Band. Furthermore, Union records show that Private Joseph Zorn served for an unspecified period of time as a prisoner of war until he was paroled at San Antonio on August 30, 1865.

The Civil War served only as a hiatus in Joseph Zorn Jr.'s early career as a merchant. Upon his return to Seguin, he resumed his father's business, which was advertised in the town's newspapers throughout the 1860s and into the 1870s (The Western Texian, November 4, 1865:4; Guadalupe Times, August 14, 1875:3). The January 19, 1866, issue of The Western Texian announced the arrival of new store items from New Orleans and declared that the "stock has been selected in person and purchased for cash" enabling the Zorns "to sell the very best goods at most reasonable prices."

While none of the advertisements offers an exact location for the store, one does specify that it was located on the west side of the public square
(Guadalupe Times, August 14, 1875:3). This is probably the same store that the family operated in the 1840 s, the one that stood on the southwest corner of the intersection of Court and Camp Streets. Deed records show that the enterprise may have been temporarily expanded to include a second location during the 1860 s. Joseph Zorn Sr. bought Lots 6 and 7 in Block 37, the block north of the public square, along with the "entire stock of goods belonging to said Johnston, McNeely \& Clemons and now in the house situate on said lots together with all the store therewith connected." Zorn paid $\$ 1,500$ cash in March of 1862 and the remaining $\$ 3,500$ five months later (Guadalupe County Deed Record I:265, 266). The Zorns kept the property for only seven years when Joseph Zorn Jr. sold Lot 6 to merchants Baker and Walker for $\$ 2,500$. By the late 1860 s, the family may have operated one store on Lot 7 in Block 37 and another at their original location. But by 1875 , it appears that only one store - that on Lot 4 in Block 29-was being advertised in Seguin papers (Guadalupe Times, August 14, 1875:3).

Sometime during the late 1860 s or early 1870 s, Joseph Zorn Sr. left Seguin. After his wife Theresa died in 1867 (Guadalupe County Probate Record E:556), Zorn sold his homestead (Guadalupe County Deed Record J:38, 40, 41) and his name disappeared from county records. Then 60 years old, Zorn joined his brother and family in Hermann, Missouri, where the elder Zorn became a saloon keeper (U.S. Bureau of the Census 1880a). He had nevertheless left a legacy of service and enterprise to both Seguin and his family. As one of the early settlers of Seguin, he had served the town as a Petit Jury member in 1846 , an alderman in the early 1850 s, and a county commissioner beginning in 1858 (Fitzsimon 1938:15, 18, 23). Moreover, he left his family the property he had accumulated, a solid business, and some stability in the community.

After his father's departure, Joseph Zorn Jr. continued to operate the family business. He listed himself as a merchant in the 1870 census for Guadalupe County and reported the value of his personal property as $\$ 4,000$ and his real property as $\$ 2,500$. Still single in 1870 , Zorn lived, in Jane Rust's boarding house (U.S. Bureau of the Census 1870). On May 10 of the following year, Zorn married Catherine Antoinette Watkins of Seguin (Guadalupe County General Index to Marriages B:278) (Figure 6). The couple had two children- 
sest.

\section{WAR DEPARTMENT.}

THE ADJUTANT GENERAL'S OPFIOE, wasninoron Aprie 10, 1917.

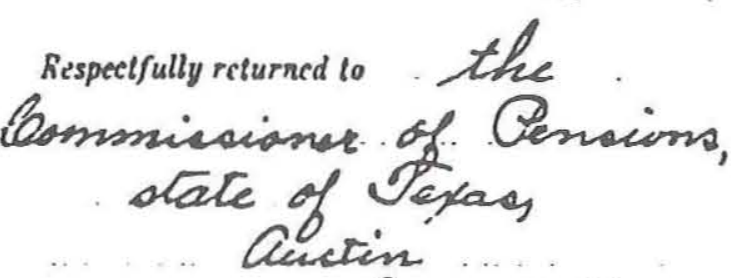

with the information that Goopoh Gorn private, Co. Ot 8 legt teyas. Inf, b.s.t., estietsd "3hasch 26, 1862, cte was transferrad to. the Regil band orec. 1, 1803 , and roll of Fick ofry for gan. Feb. 18\%, hoution file, . chreer him present, a Muscieson. Regimentat Return of \& Pagt Clestar Iuf. fert forns. 1825 . choser him a musician in Baind, absentwith feane 35 doyse from fan. 4 . The Umion presiner of war reends chow him or puriate

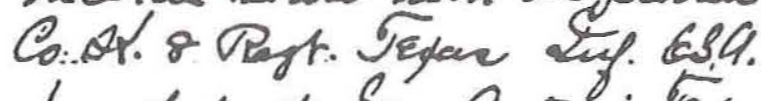
paraked at San Antons, Jylar, Oug. 3c, 1835.

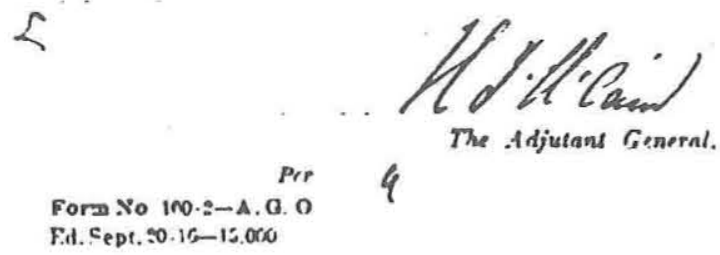

Figure 5. Federal pension record dated 1917 documenting Joseph Zorn Jr.'s service in the Civil War. 


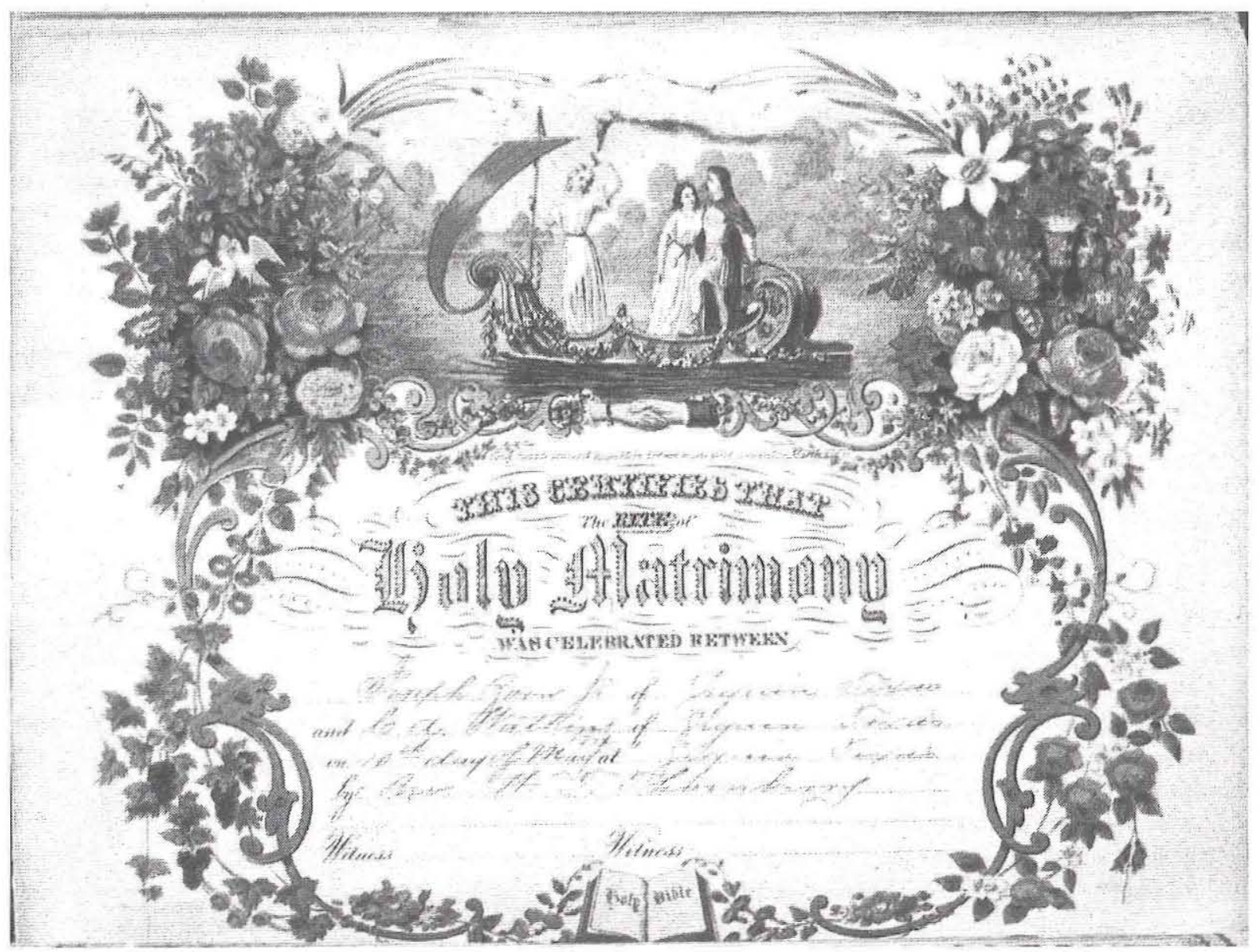

Figure 6. Marriage certificate of Joseph Zorn Jr. and C. A. Watkins in the Zorn family bible; courtesy of Thomas Zorn, Waco, Texas.

Mary Theresa and Kate-before they purchased Sebastopol on March 16, 1874 (Guadalupe County Deed Record M:399; Zorn Family Bible).

\section{The Purchase of Sebastopol}

Joshua Young was responsible for the construction of Sebastopol, which may or may not have been built for his sister, Catharine LeGette. In either case, Mrs. LeGette, a widow, lived in the house with her eight children from the late 1850s until 1874 (Maxson 1978:1-9). Then she sold the home to her son-in-law Joseph Polley for $\$ 1,100$ (Guadalupe County Deed Record M:292-293). In turn, he sold Sebastopol to Joseph Zorn Jr. for the same price two days later (Guadalupe County Deed Record M:339). In selling their home, the LeGettes were, in effect, turning it over to a family friend. Zorn and Jesse LeGette had served together in the
Civil War and had remained close friends (Kinney 1977:34033). Furthermore, Zorn was a witness for the marriages of at least three LeGettes (LeGette Family Papers).

Shortly before and after the Zorns moved into Sebastopol, Joseph sold several parcels of land (Guadalupe County Deed Record M:304, 312, 539; $\mathrm{N}: 136$ ), possibly needing the money from the sales in order to initiate the purchase of Sebastopol. However, soon after he bought the house, his business began to decline, and by the middle of 1875 , he was forced to place in deeds of trust the property that he had recently purchased, plus his store and its inventory. These transactions were designed to secure payments from Zorn for several debts-one for $\$ 600$ to Halff Weiss \& Co. and another for $\$ 1,000$ to Leon Blum of Galveston (Guadalupe County Deed Record B:428, 517).

Zorn was never able to satisfy these creditors 
and by April 1, 1876, declared bankruptcy, "being indebted beyond his ability to pay" (Guadalupe County Deed Record O:92-95). Record of the bankruptcy documents the type of goods that he sold and the names and locations of his suppliers, and it suggests the amount of business Zorn had with each of the firms, to whom he owed most of the $\$ 6,289.56$ total debt. For example, he owed $\$ 78.00$ to the Galveston firm Ralph Levy \& Co., a supplier of cigars and tobacco, and \$27.81 to another Galveston Company, Pierce \& Terry, printers and stationers (Galveston City Directory 1875-1876:192, 229). In order to pay his creditors, Zorn's assets were consolidated. By Texas law, exempt from this procedure was his "household and kitchen furniture" and his homestead, Sebastopol (Guadalupe County Deed Record O:92-95).

While Joseph Zorn Jr. may not have been as successful in business as his father, he was hardly the only Texas merchant to fail. In fact, merchants in the state "frequently went bankrupt through overstocking store goods" (Taylor and Warren 1975:5). This occurred several times in Seguin as the Zorns had purchased stock from ailing firms and then later sold their inventory to the owners of other mercantile businesses (Guadalupe County Deed Record I:265, 266; K:209). Competition from Sequin's four other general merchandise stores, as well as unstable economic conditions during the mid 1870 s, may well have contributed to Zorn's business problems (Fitzsimon 1938:32; Richardson et al. 1981:268).

Zorn appears to have either continued operating his store on a smaller scale or resumed his career as a merchant in the mid 1880s and 1890s. After listing himself as the post warden on the 1880 census, he identified himself as a merchant when his name appeared on a January 22, 1891, list of merchants who advertised in the local column of the Seguin Enterprise. While the 1872 tax rolls show Zorn owning $\$ 4,000$ worth of merchandise, by 1876 his merchandise was valued at $\$ 1,250$, and the following year he owned no goods. Later the 1888 tax rolls indicate that as an "agent," Zorn had merchandise worth $\$ 1,500$; this total declined by the turn of the century. In spite of this continued work as a commercial middle man, there appears to have been a definite shift away from his role as private businessman toward a role as public servant at the time of his store's troubles. He followed in the footsteps of his merchant father, beginning with his arrival in Seguin in the 1850 s until he declared bankruptcy in 1876; he became postmaster in 1877 and served until 1889; the following year, 1890 , Seguin voters made him their mayor, a position he retained until 1910 (Fitzsimon 1938:32, 37). Zorn may have been merchant, postmaster, and saloon keeper all in one since public service positions did not preclude other work. Nevertheless, at the time of his business's decline, it does appear that his household began to rely on his steady income from public service work rather than trust the vagaries of keeping shop during the economically unstable 1870s.

While Zorn was involved in community activities during this time (Figure 7), his life away from work must have focused on his wife, young children, and his home. By 1883, the couple had six children: 11-year-old Mary Theresa, 10-year-old Kate, 8-year-old Joseph, 6-year-old Louis Edward, 4-yearold Calvert, and infant Nellie (Zorn Family Bible). Besides an occasional reference to a social function held at Sebastopol, there is little written documentation of the Zorns' domestic activity during the 1870 s, 1880s, and 1890s (Seguin Times, July 25, 1884:3). Nettie and Joseph's children appear to have left no written record of their life at the home during those years. Surviving grandchildren, however, have been very helpful in reconstructing activities at their grandparents' home.

\section{Life at Sebastopol During the Twentieth Century}

Hazel Tegener (born 1895) has provided the earliest information about the site. Much of the detail that she and her cousin Joseph A. Zorn (born 1901) have supplied about the family and the house during the early years of the twentieth century may well apply to an earlier period. Younger than their cousins, brothers Thomas Zorn and Joseph N. Zorn have provided information about the site dating from approximately 1915 .

It is true that many years have passed since the Zorn grandchildren experienced firsthand the daily routine at their grandparents' home, and that their memories as youngsters may not be factually accurate. In fact, the grandchildren themselves are the first to admit that the structure seemed grander and the ceilings higher than they appear now. Nevertheless, their testimonies, and perhaps those of other frequent visitors to the site, remain one of the few 


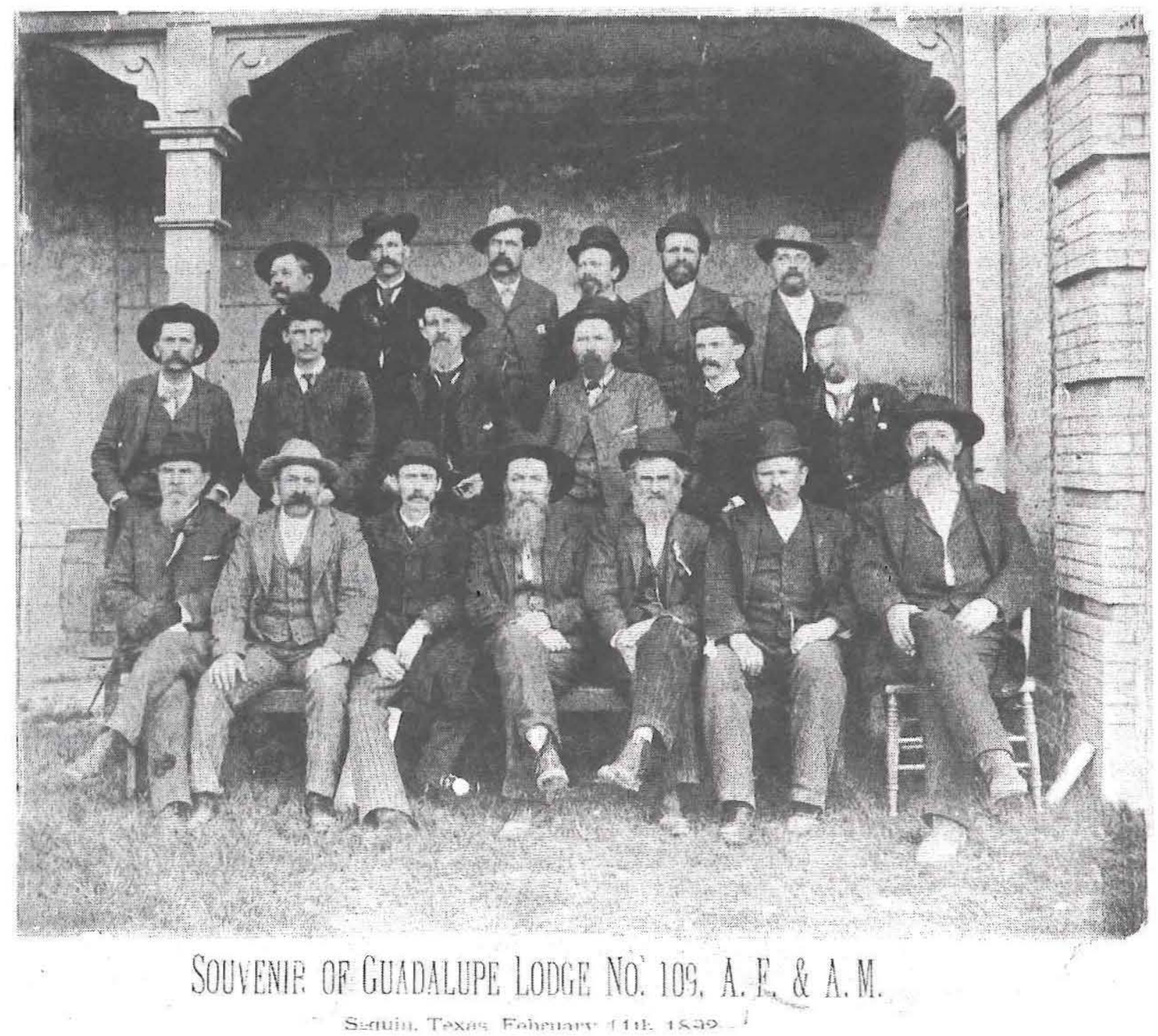

Figure 7. Souvenir photograph of fraternal organization, Seguin's Guadalupe Lodge No. 109, taken February $11,1892$. Joseph Zorn Jr. is pictured in the back row, second from right.

sources concerning domestic life at the Zorn home. And as such, they help to provide a historical context for the material culture found at the site.

Hazel Tegener was the only child of Nettie and Joseph Zorn's oldest child, Theresa, and her husband, Dr. Frederick B. Tegener, a dentist. According to Hazel, her grandfather insisted that she be brought from Mexico where she was born in 1895 to Seguin because "he was tired of not seeing his first grandchild" (Tegener 1981a). So when Hazel was 3 or 4 years old, she and her parents arrived for a visit at the Zorn home and remained there for approximately the next 10 years.

Thus, from approximately 1896 until 1908,
Dr. Tegener worked as a Seguin dentist and he and his family were part of the Zorn household (Figure 8). They occupied the west room of the upper story while Nettie and Joseph used the adjoining room as their bedroom. The unmarried Zorn daughters, Kate and Nell, shared the upper floor east room and their three brothers slept in the room below (Tegener 1981c).

Employees of the Zorn family were responsible for much of the work required to operate and maintain this household of 10 . At least one of the grandchildren recalled the names of several African American employees who worked at SebastopolUncle Ephraim, Aunt Ruth, and Aunt Cilla. 
18

\section{DR. F B. TEGENER,
*Resident Dentist. \\ Oold Crows and Plate Worls S Specialty. \\ Ones fn Kirodiom Bellding. \\ MEOUIN, TFXAB.}

Artbur May Directory Co."

Figure 8. Advertisement in the Homeseeker's Guide to Seguin and Guadalupe County, Texas (Arthur May Directory Co. 1896) for Dr. Frederick B. Tegener's dentistry practice.

Hazel Tegener remembered being told that Uncle Ephraim returned to Seguin with Joseph Zorn from Galveston where Zorn had been during the Civil War. Ephraim apparently functioned at first as Zorn's personal "body servant" and later as the family's general helper as well as caretaker of its house and grounds. Hazel recalled that her "grandfather built him a little cottage out in the back where one of those houses are now under a big oak tree. And Columbus, his son, was born there," although his mother soon left the family (Tegener 1981a).

Unlike Uncle Ephraim, Aunt Ruth and Aunt Cilla did not live on the site. Instead they lived nearby in an African American community called Weniger Hill located approximately one-half mile northwest of the Zorn home. Aunt Ruth helped the Zorn family when they entertained guests, but her primary chore was to do the family's wash (Tegener 1981b). On Mondays she and her daughter Rose came to the bathhouse or washroom located on the north side of the house and accessible from the kitchen exit (Tegener 1981a, 1981b). Zorn family members bathed in the small one-room frame building furnished simply with a bathtub and a chair (Tegener 1981a; W. Zorn 1981). Ruth and Rose did the washing outside, probably on the west side of the bathhouse. Only a bench, three tubs, and a "huge black iron pot" used for boiling the clothes assisted them in their work (Tegener 1981a; J. N. Zorn 1981). After Aunt Ruth and Rose had hung the wash out to dry, Idella Simmons came on Tuesdays to do the ironing (Tegener 1981a). Ruth often brought along her son George, who might do some chores for Joseph Zorn or play with the mayor's visiting grandson, Joe (Tegener 1981a; compare to J. A. Zorn 1981).
Probably the most beloved servant was Aunt Cilla whose loyalty to Mrs. Zorn and her family became legend. When granted her freedom after the Civil War, Cilla reportedly preferred to remain with Nettie (Tegener 1981a; J. A. Zorn 1981). Later when Mrs. Zorn had contracted yellow fever during a trip to New Orleans, Cilla was recalled to have risked her own health in order to care for her longtime mistress and friend. "They were just like sisters together," Hazel recalled (Tegener 1981a).

Also legend was Cilla's skill as a cook. Although "she absolutely could cook anything," her specialties included sweet potato pone, donuts, hominy, and broiled steaks (Tegener 1981a). Each year in preparation for the Christmas holidays, Cilla began the day after Thanksgiving to bake mincemeat and at least six fruit cakes which she stored in the pantry chest along with "every known preserve and pickle" (Tegener 1981a)., From mustang grapes that she and Joseph Zorn gathered, Cilla concocted a tasty green grape pie (Tegener 1981a). Having tasted Cilla's cooking at the Zorn home, railroad superintendents who were friends of the mayor regularly stopped at Seguin on their trips from San Antonio to Houston just to pick up some of Cilla's famed nut bread (Tegener 1981a).

Hazel remembered that each morning Cilla prepared a formal breakfast for the family. Joe Zorn always demanded polite conversation, neat dress, good manners, and plenty of food at all meals (Tegener 1981a; J. A. Zorn 1981). After breakfast, Zorn went to town while Nettie planned the evening meal with Cilla. Then Nettie got together with friends to talk about church activities or to quilt at the house. In the meantime, Cilla cleaned up after breakfast and returned to her home. Nettie always took a nap in the afternoon before dressing for the evening: "she'd dress in another dress and be real fresh and nice in the evening." After a formal dinner in the dining room, the family sat out on the porch during the warm weather and "Gramps would reminisce about something or else we'd all talk" (Tegener 1981a).

All in all, Hazel and Joe remembered a good life at Sebastopol during the early decades of this century-days spared of adult concerns. Hazel recalled Saturday picnics with girlfriends under the tree on the house's east side, special birthday presents, Christmas celebrations, parties and games with school friends, a favorite peach tree, and eating watermelon over by the gravel pit (Tegener 1981a). Joe's summer vacations at his grandparents' home 
included riding in Seguin's mule-drawn streetcar (Figure 9), hunting with Uncle Cal, sleeping out on the west porch, and going to the circus. Their only chore was to churn buttermilk for a grandmother whose only fault was that her homemade bread was not as good as baker's bread. Disappointments were rare during those days. Joe did recall one time, however, when his impressive catch of 14 field larks, while being kept cool overnight outside the west door, was eaten by rats which were plentiful around Sebastopol. And he did not forget another time when his grandfather scolded Hazel and him for substituting pebbles for the jelly beans that Zorn was going to give Joe's younger cousins, Bill and Joe Norman (J. A. Zorn 1981).

In addition to Nettie's church friends, Hazel's schoolmates, and the Zorn grandsons, Sebastopol entertained politicians, judges, and businessmen. Especially during Joseph Zorn's term as mayor from 1890 until 1910, the house welcomed VIPs from both the community and the state. Hazel recalls that the guests frequently were invited to dine with the entire family downstairs or were entertained upstairs in the parlor or living room (Tegener 1981a; Maxson 1978:18).

While Zorn's term as Seguin mayor probably marked Sebastopol's social heyday, it may have also marked the structure's optimum physical appearance. Although no photographic documentation survives that confirms this, Zorn apparently did have both the means to hire employees to care for his family and the motivation as mayor to maintain the home. One can further speculate that the house gained prominence not only because it was the mayor's house but also because of its imposing character. Heading west from town on Court Street, the structure loomed over 4 acres of pastureland and grounds that were free of tract houses, convenience stores, a gymnasium, and a Dairy Queen. The property was enclosed on the east, north, and west by a 4-ft-high whitewashed horizontal plank fence and on the south by a fence with two gates: a small one for foot traffic and a larger wooden gate for vehicles. On the south side, a picket fence with a center gate extended south approximately $50 \mathrm{ft}$ from the southeast and southwest corners of the house to enclose Nettie Zorn's flower garden and a gravel walk. Outbuildings included a carriage house west of the house, a barn to the northwest, and an outhouse northwest of the barn. Several horses and cows that Zorn kept were confined to the pastureland west of the house and outbuildings. On the north side, a wire fence enclosed the orchard and vegetable garden behind the bathhouse (Tegener 1981c).

Recollections of the Zorns' older grandchildren help somewhat in trying to recreate the appearance of the house interior at the turn of the century. The grandchild most familiar with the site, Hazel Tegener, offered much information about room use, furnishings, furniture placement, and decorative objects (Tegener 1981c). Hazel and Joe remembered several items that were located in prominent places in the house or that were themselves impressive. Both recalled the mantel clock in the dining room framed by four decorative plates. The dining room itself was impressive with its beaded wood wainscotting and its plate rail displaying Mrs. Zorn's unusually rich collection of ceramics. The decorative plates and a pair of matching vases that adorned either side of the mantel clock in the parlor were reported to be purchases made by Joseph Zorn Jr. in New Orleans where he, sometimes accompanied by his wife, had shopped for items to stock his merchandise store. Hazel and Joe referred to a more utilitarian object-the Buckgarland stove-located in the southwest corner of their grandmother's kitchen. For Hazel, the "Buckgarland Range" recalls memories of Aunt Cilla melting butter and broiling steaks on the stove lid; and Joe remembers Uncle Cal cooking freshly picked mustang grapes on the stove and putting the juice in bottles that later exploded (Tegener 1981a; J. A. Zorn 1981).

Compared with the 1920 s and later, the years at the turn of the century appear to have been banquet years for the Zorn family. They enjoyed the comforts of accumulated possessions and the company of their family representing three generations. Furthermore, Nettie and Joseph, both still very active in the community, brought a degree of community focus to their family and home.

Younger grandchildren, Bill and Joe Norman Zorn, sons of Mr. and Mrs. Edward Zorn, have supplied information about their family and the site dating from the middle to late 1910s. Born in 1911, Bill Zorn remembers visiting his grandparents each summer during late July and early August. Sometimes accompanied by their parents, Bill and his younger brother Joe rode the train from Del Rio to Seguin where they stayed about 2 weeks. These visits were temporarily halted in 1926 when Joe was injured in an accident but were resumed in the 1930s (W. Zorn 1981). 


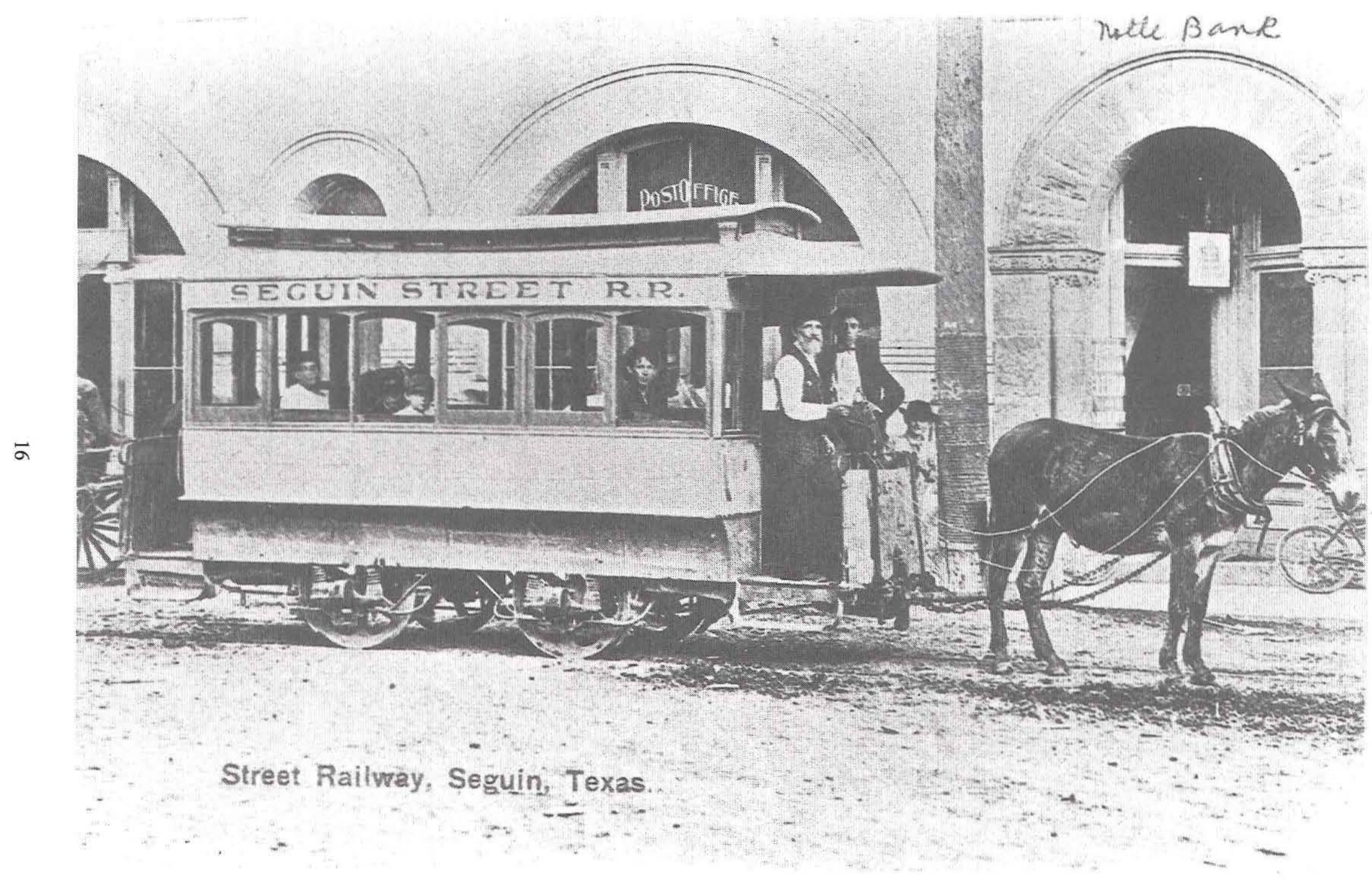

Figure 9. Seguin's turn-of-the-century mule-drawn streetcar photographed near the courthouse square. 
By the 1910s, the 10-member Zorn household of 1900 was considerably reduced. Edward was living in Del Rio; Joe Zorn III was a lawyer in Beaumont; Nell had moved to Waco and Kate spent time there as well as in Del Rio until she returned to Seguin and married; Theresa and her family had their own home near her parents (Tegener 1981a). Only Calvert, a widower, remained with his parents. He occupied the west room upstairs, and Nettie and Joseph continued to use the middle room as their bedroom. During their visits, Bill and Joe stayed in the east room adjacent to their grandparents' or on cots on the west side of the porch (W. Zorn 1981).

Neither Bill nor Joe remembered Zorn employees who were so important during the earlier period. These younger grandchildren did not recall Uncle Ephraim's house being on the site or Aunt Ruth doing the family wash or Aunt Cilla's cooking (J. N. Zorn 1981; W. Zorn 1981). Bill remembered that his grandmother, rather than employees, did the work at the Zorn home: "She did all the work to my knowledge. She didn't have anybody come to help her" (W. Zorn 1981). Nettie also cooked most of their meals. Bill particularly recalled her homemade egg noodles that she put out on a board and placed on the cistern to dry. "My grandmother was a fantastic cook," he declared (W. Zorn 1981). On the other hand, Joe remembered that she may have had a black woman to help her with the cooking. He says that "granny did very little of the work" (J. N. Zorn 1981). It is likely that Joe was recalling a later period during the 1930 s when his grandmother was unable to cook and do housework. Prior to Mrs. Zorn's death in 1937, Mary Ibarra cooked breakfast for her and Cal (Ibarra 1981). Nevertheless, during the late 1910 s, it is plausible that the deaths of long-time family employees, a small household, and reduced circumstances of the elder Zorns might account for the lack of domestic help.

In his late seventies, Joseph Zorn did not stay at home during his grandsons' visits. Instead, he went to town "every morning about daylight o'clock" (W. Zorn 1981). At first as manager of the telephone company he went to his office, and later he went to town to visit with friends (J. N. Zorn 1981). Even though the "cantankerous old booger" was not around the house much, Bill remembered that " $[t]$ here was never any doubt about who was boss in that house." Zorn impressed his grandson as a "stern" old gentleman who was "very, very set in his ways" (W. Zorn 1981).

Their grandfather was no longer a young man or public official, and Bill and Joe did not remember the parties or dinners of the earlier period. Nettie Zorn did occasionally entertain her church friends at the house. But, in general, it was just the Zorn family members who dined together and gathered informally after supper on the porch to talk (J. N. Zorn 1981).

During the days, Bill and Joe played alone at their grandparents, sometimes fishing for crawdads in Walnut Creek or climbing the oak tree on the northwest side of the house. Like their older cousins, they remembered riding Seguin's muledrawn streetcar from the railroad depot to the courthouse square and churning butter for their grandmother out on the old cistern wall (W. Zorn 1981). Their favorite pastime involved taking the old buggy out of the shed barn northwest of the house, dragging it up the hill, and riding it back down again (J. N. Zorn 1981; W. Zorn 1981). Play was interrupted only when they accompanied their grandmother to Methodist Church services or when they visited their uncle, Dr. Tegener, for the annual dental check-up (J. N. Zorn 1981).

Uncle Cal, who was "just like a kid," sometimes took them squirrel hunting and fishing on the Guadalupe River where they caught catfish and perch (J. N. Zorn 1981; W. Zorn 1981). Occasionally $\mathrm{Cal}$ took his nephews on excursions in his Model-T to Kingsbury and Luling where he collected 10-15 cents/week premiums for a life insurance company. Or he would take them to town where they would visit and buy a watermelon off one of the farmers' trucks parked around the courthouse (J. N. Zorn 1981; W. Zorn 1981). Bill remembered Cal as "the best uncle . . that a fella ever had" (W. Zorn 1981).

Unfortunately, details about the interior appearance of the house eluded Bill and Joe who were preoccupied with spending their summer vacations outdoors. Either as young boys they did not notice, or now as older men they cannot recall much information about furnishings or interior architectural details, only that the parlor was "not too heavily furnished." Joe remembered just a few items that his grandparents had in their home-a mantel clock and a china cabinet, both in the dining room, and "an old wood cook stove" in the kitchen (J. N. Zorn 1981).

Like their older cousin, Bill and Joe remembered Nettie's flower garden on the south of the 
house, the barn and outhouse northwest of the house, and the bathhouse and fenced garden between the house and Walnut Creek. But they did not recall a carriage house or an employee's house on the property (J. N. Zorn 1981). Neither of the Zorns' younger grandsons could describe the boundary fences, but they were familiar with a circular driveway where Cal parked his car. Like Hazel and Joe A., Bill and Joe N. roamed the original 4-acre site- to the pastureland on the west, north down by the creek, and east over to the gravel pit. One of their most vivid recollections, however, involved the yard south of the house. In April 1923, the Edward Zorn family came to Seguin to attend Joseph Zorn's funeral. The grandsons remember being awakened by the popping sound of bluebonnets as they "throw their seeds." That field of bluebonnets was "the most beautiful thing you ever saw," Bill recalled (W. Zorn 1981).

After Joseph Zorn's death, the condition of the house and grounds continued a decline that probably began in the late 1910s. In 1917, at 77 years of age, Joseph Zorn applied for his Confederate pension. On a small income and at their age, maintenance of the site may have become difficult for the elder Zorns with no employees and only Calvert to help. Between the time that Hazel and Joe A. first saw the site and the time Bill and Joe N. saw it, outbuildings had been removed or, more likely, had fallen down. Ephraim's house was no longer standing. Also gone was the carriage house where the Zorns kept the surrey, their primary means of transportation (J. A. Zorn 1981). The surrey became instead a toy for Bill and Joe N. and was stored in the barn. Meanwhile, Cal's Model-T Ford carved out a semicircular driveway in front of the house. The dwelling itself had become so dilapidated that 7 years after Joseph Zorn's death, a 1930 Sanborn map delineates Sebastopol's outline and describes the construction material as "adobe" under which is written "old" (Sanborn Fire Insurance Maps 1930).

It is impossible to document conclusively based upon oral history sources alone, but it appears that the 20-year period from 1910 until 1930 was a particularly pivotal time, not only for the Zorn home but also for the family itself. Joe A. and especially Hazel seem to have witnessed a busier, more convivial household. They knew their grandparents when Nettie and Joe were younger, more active, and more influential than when Bill and Joe N. knew them. Notwithstanding tendencies to romanticize the past,
Hazel did live at Sebastopol before family members began to leave, seeking their futures and livelihoods in other areas of the state, when they were without the base of a family business in Seguin. On the other hand, Bill and Joe's experience at the site began when the site was occupied only by their grandparents and Uncle Cal.

After a brief hiatus because of Joe's accident, the Zorns continued to travel from Del Rio to Seguin, visiting the family home on a regular basis until Nettie Zorn's death in 1937. Calvert lived alone in the house after his mother's death, supporting himself by painting and repairing other people's homes. Nettie and Joseph's other children remained settled in other parts of the state-Joseph in Beaumont, Nell in Waco, and Kate living at times with her sister in Waco or in Del Rio with Edward. The Zorns oldest daughter Theresa and her husband died in 1937 and 1938,' respectively (Zorn Family Bible).

In 1941, single and for the most part selfsupporting, Kate and Nell were responsible for selling the west 1.8 acres of the original 4 acres (Guadalupe County District Court Cause A-1291). The two sisters probably stayed in the home for short periods of time during the late 1940s and early 1950s. Kate often went to Seguin to care for her sick brother and she frequently enlisted Nell's help (T. Zorn 1981). One long-time Seguin resident remembers that one or both of the Zorn sisters worked as a seamstress(es) at a Seguin department store and that both may have lived for a brief time in a boarding house on the south side of West Court Street. In any case, Sebastopol housed not only $\mathrm{Cal}$ and his two sisters, at least on a temporary basis, but also renters. According to Joe Zorn, the upstairs was divided into apartments when $\mathrm{Cal}$ and Kate lived there (J. N. Zorn 1981).

After Cal's death in 1952, the Ibarra family rented the house for \$16-\$18 a month from Hazel Tegener who then owned the property. Mrs. Mary Ibarra's association with the house had begun long ago in the 1930s when, as a girl of 12 , she cooked breakfast for $\mathrm{Cal}$ and his mother for 30 cents a week. Perpetuating two of the earlier myths about the house, Calvert Zorn entertained Mary Ibarra with the story about how Sebastopol's room was designed to hold water in case of Indian attack and the story about the tunnel which stretched from the house to Walnut Creek. Not entirely derivative, however, Cal created a new and fanciful tale about a jail that was 
situated underneath the parlor of the house (Ibarra 1981).

When Sebastopol became the Ibarras' residence in the 1950s, the large family occupied both levels of the structure. Later, they used only the second story when climbing the stairs became burdensome for Mrs. Ibarra. At that point the family used the east room as their kitchen and dining room. The southeast corner of the parlor had been partitioned off as a living room, but Mary Ibarra's sister-in-law slept there during visits to help with the children. Two Ibarra children were born in the west room upstairs. During the summer, the family slept on the east side of the porch; Mr. and Mrs. Ibarra usually slept in the parlor during the summer and in the middle room during the winter, using only the fireplace in that room. Located in the west doorway area between the parlor and the middle room was a bathroom with toilet facilities and a bathtub that the family used instead of the bathhouse which still stood in the 1950s (Ibarra 1981).

Mrs. Ibarra remembered that, 50 years ago when she worked at the house, it was "real pretty" and contained "old furniture." Later when she moved there with her family, Kate Zorn Whittaker gave her some of the family dishes and what Mrs. Ibarra described as an antique metal china cabinet. Unfortunately, the family left these items behind when they moved in the late 1950s, and Mary Ibarra speculated that vandals destroyed them (Ibarra 1981).

Most of the Zorn heirlooms went to the daughters after Nettie's death. When Theresa Zorn Tegener died soon after her mother, her inheritance went to Hazel. She, in turn, sold many of these objects to the Texas Parks and Wildlife Department who returned them to Sebastopol. What happened to those items that Kate inherited is more of a mystery. Mrs. Thomas Zorn believes that Kate sold or gave most of them to one of her friends in Waco. Mr. and Mrs. Tom Zorn inherited Nellie's possessions-a substantial collection of ceramics and several pieces of furniture from the house which have been photographed and documented by TPWD staff.

Like other late nineteenth and early twentieth century objects located beneath the ground, the furnishings suggest that the Zorns were a middleclass family who perhaps had better-than-average access to available goods. Their role as merchants and an early family connection in New Orleans no doubt affected the range of the Zorn possessions. But even without these advantages, the Zorns and their material world offer insights into dominant middle-class culture and a valuable case study of American consumerism in turn-of-the-century Texas (Chapters 5 and 6). 



\section{OBJECTIVES AND METHODS}

The Historic Sites and Structures Act of 1967 was instituted to protect and preserve the heritage of the state for the benefit of the people of Texas (TPWD 1983:II:2). Following this mandate, the historic house of Sebastopol was purchased by TPWD in 1976. Sebastopol is one of the last standing, largely unmodified limecrete buildings in Seguin and, as such, is architecturally significant. Possibly more than 100 limecrete buildings built between 1842 and 1860 once stood in this community (Hauser 1980:58). The site also is historically significant locally as the home of Joseph Zorn, the city's mayor from 1890 to 1910 . After purchase by the state, the building was to be opened to the public as a historic site, but growing evidence of structural problems postponed its opening until solutions could be found (TPWD 1983:II:7).

The main goal of TPWD's Preservation Plan and Program for Sebastopol was "to protect and maintain Sebastopol House State Historic Structure ... in an economical and efficient manner consistent with the standards and objectives of the Texas Parks and Wildlife Department" (TPWD 1983:II:10). Architectural investigations were initiated to study ongoing deterioration and recover data necessary for the restoration of the building. During this work, potential archeological deposits were encountered, at which time an archeologist was assigned to assess the significance of these deposits (Art Black, personal communication 1995; TPWD 1983:II:93). The archeological deposits revealed in the 1978 testing were found to contain data significant to the restoration and interpretation of the building. It was recommended that further excavations be undertaken.

Between 1978 and 1988, excavations at Sebastopol were conducted to aid in the architectural research and restoration efforts. These archeological projects also were designed to mitigate disturbance to remaining deposits, leading to the complete excavation of those areas that planning indicated would be destroyed, altered, or disturbed during the restoration. Tests in other' locations were for interpretive and identification purposes. All other undisturbed areas were left untouched for their preservation and for possible use by future archeologists (TPWD 1983:II:93).

\section{HISTORICAL RESEARCH}

The historical research used in this report was conducted prior to the involvement of Prewitt and Associates. During 1981, Cynthia Brandimarte conducted numerous tape-recorded interviews with descendants and associates of the Zorn family. These were transcribed in 1986, at which time Brandimarte wrote a narrative on the property and its history of occupation based on these interviews and other primary historical sources. The TPWD Preservation Plan includes an earlier historical narrative written with several primary and secondary sources (TPWD 1983:II:14-28). No primary historical research was conducted by Prewitt and Associates. Instead, Brandimarte authored a new historical narrative concerning the occupation by the Zorn family, using the results of the earlier research.

\section{ARCHEOLOGICAL EXCAVATIONS}

The archeological work at Sebastopol occurred over a 10-year period between 1978 and 1988 . During this time, many areas differing in the nature of their deposits were excavated. These ranged from deep, wide easement trenches near the creek to shallow units under the floorboards in the house. 
Testing or excavation of these areas was approached on a situational basis, with archeological techniques modified or adapted to the nature of the deposits. Consequently, the following descriptions of techniques are general.

Areas were selected for excavation if they were due to be disturbed during the architectural study and subsequent restoration of the house. The majority of the excavations occurred within and around the lower floor of the house, investigating deposits accumulated below finished (wooden) floors, into dirt floors, and around the perimeter of the house.

In many cases, entire areas of deposits were excavated to restore air spaces, replace architectural features, and adaptively reuse some rooms as work and storage areas. In addition to the house-related excavation areas, a portion of the cistern west of the house was excavated to its bottom over several field seasons, trenches to the north of the house were excavatedduring a Seguin-sponsored rechannelization of Walnut Branch Creek, and the outbuildings on the property were investigated with test units.

\section{Depositional Characteristics}

Accumulated archeological deposits at Sebastopol proved to be one of the most unique and complicating aspects of excavation at this site. This complexity resulted from the origin of the deposit matrix. Unlike most archeological situations where the matrix of the deposits is usually from surrounding soils, deposits at Sebastopol derived primarily from decomposed plaster and limecrete. This was particularly the case for the interior deposits, although deposition around the immediate exterior of the house was certainly influenced by these materials. As described in Chapter 3, limecrete is basically composed of gravel cast in a lime matrix. The origin of the gravel used in the construction of Sebastopol is the native beds of conglomerate bedrock upon which the house was constructed. Oral history indicates that a large gravel pit, now filled, lay to the east of Sebastopol on an adjacent property. This pit was probably the source of the gravel for the house, although some material was probably used from the cut made into the hillside during preparation of the site for construction of the house. This bedrock conglomerate is itself remarkably similar to limecrete in composition, being gravel set in a matrix of limestone. In fact, this similarity is so strong that, during the excavations, the distinction was at times lost when clearing crumbled or decomposed limecrete from original bedrock surfaces, resulting in actual removal of bedrock as perceived deposit.

Several other aspects of the origin of deposits at Sebastopol complicated its excavation and quite often led to differential recognition of stratigraphy by different excavators. This was particularly the case where deposits derived from varying mixtures of decomposed plaster, limecrete, dark-colored native soils, and possibly ash from the fireplaces. Differing proportions of these elements could result in a patchwork of coloration, even within a recognized single layer of deposit. Additionally, the size and proportion of gravels would change also within a single natural level. When excavated, these changes often gave the appearance of sublevels, resulting in the excavators' decisions to divide a single level into several components. An aspect of this situation was the repeated observation that stratigraphy observed in profile often did not appear to correlate well to stratigraphy observed while excavating. Unfortunately, Munsell soil color charts were not available to the excavators during the seasons of work at this site, and soil color distinctions were recognized and reported using terminology unique to the individual excavator. This has had the unfortunate result of increasing the perceived complexity of the deposits, making it harder to correlate field records between individual excavators.

\section{Basic Field Techniques}

Generally, initial units in each area were set up and excavated in arbitrary 0.2-ft levels. As basic stratigraphic levels were recognized, units were excavated with trowel and brush in natural levels. In most units, natural levels were found to contain two or three different types of soil deposits (see Depositional Characteristics above). Depths were measured from a room or unit datum related to the primary datum and were recorded either below datum, below ground surface, or above sea level. Materials excavated were screened through $1 / 4$-inch mesh, with some deposits put through $1 / 8$-inch and sometimes $1 / 16$ inch mesh. On occasion, materials from selected areas were water screened and bagged for later analysis in the lab. Time and funding constraints prohibited analysis of these samples; however, they remain curated for future study. Measurements were 
made with an engineer's scale, utilizing feet and tenths of feet. Units within the house were laid out in relation to room size. Each room was measured and divided into standard 3- or 4-ft-square units depending on room dimensions. Since most of the room dimensions could not be perfectly divided into standard units, several units from most rooms were of nonstandard size or irregular shape. One exception to this pattern was the dining room where much of the deposits beneath the wooden floors had accumulated between the floor joists. Consequently, the joists were utilized as natural east-west grid lines and these sections of deposits were then divided into 3 - $\mathrm{ft}$ sections. Units on the exterior of the house were generally $4 \times 4 \mathrm{ft}$, placed adjacent to the house and located by measurement from the corners of the building. The easement trenches for the creek stabilization were recorded in $3-\mathrm{x}-10-\mathrm{ft}$ units.

\section{Field Records}

Field records were kept by individual excavators during each field season. Other documentation included drawings of plan views and profiles, as well as black-and-white and color photographs. Written logs recorded the information for each photograph and slide.

Analysis for this report was started in 1995, some 17 years after the first archeological work was conducted at the site and 7 years since the last archeology was done. During this time, analysis of data and artifacts was begun and set aside many times as TPWD staff was directed to projects of higher priority. As a result of this time lag, staff changes, the disbanding of the Historic Sites and Restoration Branch of TPWD, and several reorganizations of the TPWD archeology laboratory, certain sets of field notes and photographs could not be located and were not available for this study. Included in these are the records for the 1983-1984 field season. Excavations during this season concentrated on the cistern, and the lack of original field notes forced reliance upon incidental and secondary records such as personal photographs and slides. The same situation occurs with the notes for the 1988 field season, which concentrated around the southeast corner of the house, Rooms 3, 8, and 9.

\section{Summary of Field Seasons by Year}

Excavations were conducted over nine field projects between 1978 and 1988 (Figure 10). These include 1978, 1979, 1980, summer 1981, fall 1981, $1982-1983,1983-1984,1985$, and 1988. Below is a listing of the areas excavated each season.

\section{8}

In 1977 Jim Bigger, TPWD architect assigned to the project, recognized a concentration of cultural materials while studying architectural features in the Dining Room and realized that archeological investigations should accompany the architectural study. Subsequent to this, staff archeologist Art Black was assigned to the project (Art Black, personal communication 1995).

During the first season of archeological work in May 1978, two test units were excavated next to the exterior of the house. One unit was located adjacent to each of the west and east outer walls, and each was located from 10 to $13 \mathrm{ft}$ back from the front (south) corners of the house (see Figure 10). Archeological excavations began in July 1978, with Art Black acting as the project director. During this season, the first work was conducted on the cistern. A 6-x-6-ft excavation unit was positioned in the area of the cistern.

Excavations were conducted in the northeast room of the lower floor, designated as Room 7 . The room was laid out in sixteen $3-\mathrm{x}-3 \mathrm{ft}$ units and four $2-x-3 \mathrm{ft}$ units along the northern wall. The four units excavated lay against the south wall and were numbered 7-1 to 7-4 from west to east.

The Kitchen was laid out in nine 4-x-4-ft units, all excavated during the 1978 season and numbered 5-1 to 5-9 east to west beginning with the southwest corner unit.

\section{9}

Excavations resumed during December 1979 with the Dining Room as the main focus of the project. The Dining Room was divided into units using the floor joists as east-west gridlines and dividing the resulting rows into 3 - $\mathrm{ft}$ sections (see Figure 10). The units were lettered $\mathrm{A}$ to $\mathrm{I}$ from north to south and numbered 1 to 6 from, east to west. The units excavated in this season were $\mathrm{A} 2$; $\mathrm{B} 1-\mathrm{B} 3 ; \mathrm{C} 1-\mathrm{C} 3, \mathrm{C} 5$, and $\mathrm{C} 6$; D1, D2, D4, and D6; El-E6; F3-F6; G2 and G3; H2 and H5; I2, I5, and I6. An additional unit was located under the stairs which led to the landing at the southeast corner of 


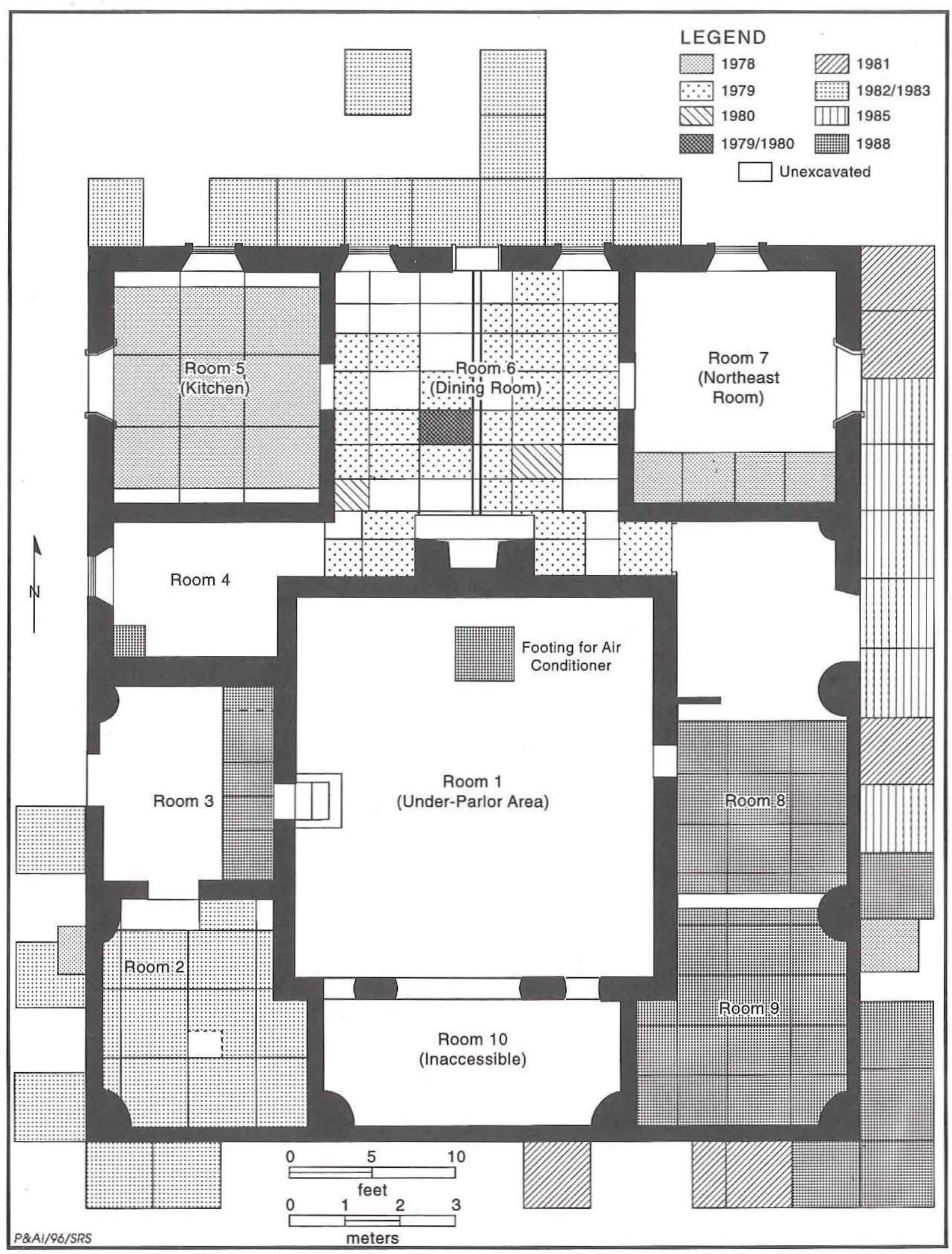

Figure 10. Excavation units by year. 
the Dining Room. A backhoe trench at the north end of the site also was monitored during this month.

\section{0}

In February 1980, rechannelization of Walnut Branch was begun by the city of Seguin. A special archeological project lasting 10 days was funded to test the affected area. Walnut Branch cuts across the north boundary of the Sebastopol property (see Figure 11). Two trenches were located on the south bank within the area of the creek to be widened. One $80-\mathrm{ft}$ trench ran east-west and was bisected by the 16 - $\mathrm{ft}$ north-south trench between 20 and $23 \mathrm{ft}$ from the east end of the longer trench.

\section{Summer 1981}

During July 1981, a special project was undertaken by archeological staff in support of the structural study of the building. The interior plaster was removed from all rooms in the house. Many architectural attributes of the house noted in Chapter 3 were revealed during this project.

\section{Fall 1981}

During the fall of 1981, six excavation units were placed along the east and south walls of the house. Originally designated as units 1 through 6 , they were later assigned the labels 81-1 through 81-6. All units were adjacent to the exterior walls of the house and were excavated by arbitrary $0.2-\mathrm{ft}$ levels, and all units were $4 \times 4 \mathrm{ft}$ except for Unit 81-6 which was 4 x $2 \mathrm{ft}$. Units 81-1, 81-2, and 81-5 were located on the east wall, the others on the south (see Figure 10).

\section{$1982-1983$}

The first task of the 1982-1983 field season was to clear debris from the pre-Civil War floor in the Dining Room. This was done to study the damage to the compacted floor from various activities and water since its exposure in 1979 . The majority of the work during this season was in the form of new excavations on both the exterior and interior of the house. Exterior excavation units were numbered 1-82 to $16-82$, and most were placed adjacent to the north, south, and west exterior walls (see Figure 10). All 16 were 4-x-4-ft units and were excavated in natural levels. Units 2-82, 3-82, and 13-82 were extended into the yard to the north of the house in search of further limecrete piers.

The cistern was also partly excavated during this field season. The 1978 unit in the east/northeast side of the cistern fill was re-excavated and a 4-x-4 $\mathrm{ft}$ test unit was placed in the fill. After these were excavated to between 3.5 and $4.0 \mathrm{ft}$, a backhoe was brought in to remove the top $4 \mathrm{ft}$ of fill. At this depth was found the top of a fine brown loam stratum. Once a large portion of the cistern was exposed at this level, three more $4-\mathrm{x}-4 \mathrm{ft}$ units were excavated down another ca. $2 \mathrm{ft}$ into the cistern. Because of time constraints, the brown loamy soil in the first test unit was dug out without being screened. In this same unit, a test hole was excavated with shovels and a posthole auger to about $10 \mathrm{ft}$. Test unit 2 was excavated to about $6 \mathrm{ft}$ below the original ground surface, and unit 3 was excavated to about $5 \mathrm{ft}$ (see Figure $25 b$ ).

Excavations in the interior of the house were limited to Room 2 in the southwest corner of the lower floor. The room was blocked out in 4-x-4-ft sections (see Figure 10), leaving a 1.2-ft-wide strip of floor along the west wall that was divided into three units, while along the north wall a strip $1.16 \mathrm{ft}$ wide was divided into units. This room was riddled with rodent holes and disturbance.

\section{$1983-1984$}

Excavations lasting from December 1983 until February 1984 concentrated on the cistern. Backfill from previous excavations was removed in an area covering approximately $16 \times 20 \mathrm{ft}$. Within this large cleared area, a smaller area about $10 \times 10 \mathrm{ft}$ was dug down further. As excavations became deeper in the cistern, the excavation area became smaller. The smallest excavation area was a unit placed on the south or southeast wall of the cistern and dug down along that wall to somewhere between 13 and $15 \mathrm{ft}$ (see Figure 25c). At the bottom of the unit, the dimensions were roughly $4 \times 2.5 \mathrm{ft}$.

Fourteen levels were excavated below : a layer of refuse from the 1960s restoration. Some of the natural levels were further subdivided to take account of differences in the sediments encountered during excavation. Layers of ash in the deposit indicate use of the cistern as a dump. 


\section{5}

Excavations continued on the east wall of the house between April 2 and 26, 1985. Six excavation units were placed adjacent to the east wall of the house. These units were located toward the north half of the wall and were placed between the units excavated in 1981. Units were designated as 85-1 to 85-6. Unit 81-2 was re-excavated as a control and to orient the 1985 season's units.

\section{8}

This last season of work lasted intermittently from June 20 until September 12, 1988. Units excavated during this field season include five exterior units around the southeast corner of the house, 30 units within Rooms 8 and 9, and four units within Room 3. When the plumbing was changed in Room 4, artifacts were collected. In October 1988 there was an investigation into the Dining Room fireplace. Units on the exterior of the house were numbered $88-1$ to $88-5$, and those inside were numbered by room and then unit (9-1 to 9-18, $8-1$ to $8-12$, and $3-1$ to $3-4$ ). Units were excavated in natural levels. One unit was placed in the underparlor area where the air conditioner was to be located, and a sample unit was collected in the Room 10 area.

\section{ANALYTICAL TECHNIQUES}

The long history of occupation, the extent of disturbance, missing field records, and the very large collection of over 106,000 artifacts presented a dilemma when it came to devising a plan for how to analyze and present the materials recovered from the site. The strategy chosen consists of three main tasks. It was derived from consultation with TPWD staff (especially Art Black) and Texas Historical Commission personnel about the best possible use of the Sebastopol data.

The first task stemmed from the need to document the large artifact collection so that the data would be easily accessible to future researchers. This process consisted of reproducing the existing artifact inventory, as recorded by TPWD laboratory personnel. The cataloging system used for this purpose was a TPWD-modified version of one designed specifically for nineteenth-century historic artifacts by Roderick Sprague (Sprague 1981). This classification summarizes functional artifact types in easily read tables, and these are presented for Sebastopol in Appendix A.

The second and third tasks, which arose because of the unusually rich and varied nature of the artifact assemblage, focused on analyzing and describing two subsets of the collection in detail. One subset consists of diagnostic artifact classes from the three northernmost lower-floor rooms, chosen to provide insights into the activities of the families that lived in the house. Artifacts related to structural architecture were excluded from this part of the analysis because the architecture of the house was already well understood and the artifacts quantified. Other classes of modern and nondiagnostic artifacts from the lower-floor rooms also were excluded because they could provide little useful information; these classes include undecorated lamp chimney glass, unidentifiable artifacts, matchsticks, nondiagnostic glass, flat glass, and modern plastic. These classes are quantified in Appendix A.

The second subset consists of the part of the ceramic collection clearly associated with the LeGette and Zorn occupations. The objective of this analysis is to provide a visual and written description of ceramic variability from this time. Ceramics made after 1910 were excluded from this analysis to ensure that none of the analyzed materials were deposited by later occupants. Ceramics postdating the LeGette and Zorn occupations could have been deposited either by boarders who resided at the house in the 1940s, or by individuals who used the structure after it was purchased by the Seguin Conservation Society in 1961. For ceramics manufactured in the decades before the 1940s, it can be difficult to know whether their use was associated with the LeGette and Zorn occupations or with later occupations. This difficulty arises because of the potential for time lag between when a ceramic vessel was manufactured and when it was deposited in the archeological record. For example, a study comparing 12 late-nineteenth- and early-twentieth-century sites in Washington state documented an average time lag of 21 to 23.5 years between manufacture and discard (Adams and Gaw 1977:228). To ensure that all of the ceramics analyzed were associated with the earlier occupation of the structure, then, a manufacture date of 1910 was selected as the cutoff date for this analysis.

To further ensure that later materials are excluded, the ceramic analysis focuses on ceramic 
sets (those patterns represented by three or more vessels). This should eliminate any teacup and saucer sets or odd ceramic pieces brought to the site at a later date by boarders or the Seguin Conservation Society. Exceptions to this include one set that is represented by only two pieces; this set is included due to its documented age of 1851-1866. This set has the highest likelihood of having belonged to the LeGettes.

In the late 1970 s and early 1980 s, after the excavation of the kitchen and dining rooms, TPWD archeological staff had begun analyses of several artifact groups from those excavations. Ceramics were the primary focus of this initial phase of analysis, with all main groupings of ceramics and distinct sets or patterns of china being identified and dated. Similar studies were begun on temporally diagnostic groups of glassware, children's toys, a variety of household items including a concentration of straight pins found in the dining room, and selected types of food remains. With subsequent seasons of materials coming into the TPWD archeological laboratory, newly recovered artifacts from these categories were separated from individual lots after processing for inclusion in the ongoing analyses. As these studies were repeatedly set aside for projects of higher priority, many of them were never completed nor were materials from all seasons of excavation incorporated. After the dismantling of the Historic Sites and Restoration Branch of TPWD in the early 1990s, the newly created Cultural Resources Program contracted with Prewitt and Associates to undertake a report covering the various excavations and to complete the analysis of the artifact collection from Sebastopol. In 1995, records and artifact collections were transferred to Prewitt and Associates' facilities for study.

Artifacts from all of the excavation seasons had been cleaned and resorted by the TPWD archeological lab during the months prior to the transferral to Prewitt and Associates. After the transfer, those artifacts selected for analysis were pulled from their lot bags and placed in ziplock plastic bags. Also put into the plastic bags were tags made of acid-free paper and enclosed in a plastic sheath identifying the Prewitt and Associates project number, lot number, provenience of the artifact, type of artifact, and number of artifacts in the bag. An acid-free tag within a plastic sheath also was put into the lot bags in exchange for the pulled artifact identifying how many and what types of artifacts were pulled. This ensures that a physical record exists of each artifact pulled in every lot bag.

All diagnostic ceramics and those larger than $4 \mathrm{~cm}$ at their widest point were removed from their lot bags. These include ceramics recovered not only from the lower rooms of the house, but those from all excavation areas. A ceramic sherd was considered diagnostic if it had a recognizable pattern or was a recognizable portion of a vessel. Especially with the porcelain, smaller sherds were kept if they showed a distinct or unique design. After these ceramics were separated, they were further sorted into paste and decoration type and then analyzed to determine which pieces belonged together in sets. Some sherds that were not from sets or the lower rooms but that showed signs of being particularly old were set aside during this preliminary analysis.

Before the work by ;Prewitt and Associates began, a number of ceramic sherds and vessels had been separated out by TPWD personnel. Prewitt and Associates began the analysis of these ceramic pieces before the other artifacts were pulled. During this analysis, every sherd was analyzed, and each vessel was given a number. Any design represented by more than one vessel was assigned a set number. After this initial analysis was finished, it became clear that these previously pulled sherds represented about one-quarter of all ceramics recovered from the site, and that the analysis procedures would have to be changed to deal with the remainder of the collection. For simplicity and consistency, the described sets have been renumbered and are represented by capital letters.

After the sets were separated out from the other ceramics, their designs and makers' marks were studied to determine their age. No sets were found that could not be dated to a specific time period. Each set was sorted into the minimum number of vessels, and the number of sherds was counted. All ceramic sherds from the Kitchen, Dining Room, and Room 7 that did not belong to pre-1910 sets were kept separate and included in the analysis of the lower-room materials.

Glass fragments from the lower three rooms were separated in much the same manner as the ceramic sherds. Any glass fragment that was diagnostic, showing mold seams or identifiable to vessel, was selected for analysis. Iron fragments were collected only if they were diagnostic (i.e., had a recognizable seam or edge which could be identifiable). Unidentifiable corroded fragments of iron 
were not separated. Unidentified but potentially identifiable fragments were separated and recorded as such. All recognizable toys, stationery supplies, buttons, beads, and other diagnostic classes of artifacts were separated regardless of size. Modern plastics, such as candy wrappers and straws, are not described here.

For each class of artifact chosen for study, a list of attributes required for analysis was created, and recording sheets were created from these lists.
These attributes were given code numbers for computer entry. In this way, every important attribute for every selected artifact is recorded as a code on a sheet of paper and in a computer data base. The data base was used to sort and quantify the selected artifacts. The selected artifacts are also described in writing in Chapters 5 and 6, and examples are illustrated. When possible the manufacturer, location of manufacture, and dates of manufacture are supplied with the descriptions. 


\section{SEBASTOPOL ARCHITECTURE}

Most of this chapter is summarized from the 1983 TPWD Preservation Plan, which was based on historical research, on-site observations, interviews, architectural investigations, and archeological research. An additional important source of information is Hauser's 1980 Master of Architecture thesis on limecrete construction in Seguin.

\section{LIMECRETE CONSTRUCTION IN SEGUIN}

Concrete construction has been used since Roman times, often as a response to construction material availability. Brick construction demands a high skill level, so where lumber is rare, concrete construction is sometimes utilized. Concrete is generally defined as a combination of water, mineral aggregates, and a binding medium blended in specific proportions, which hardens into a stonelike mass (TPWD 1983:II:29).

Several kinds of concrete have been used for construction in the past. Different combinations known as cob, pisé, and tabby all have been used in house construction; the limecrete used to build Sebastopol is closely related to these early forms (Hauser 1980:3; TPWD 1983:II:29). Limecrete, or gravel wall construction, is a concrete formula in which local lime was used as the bonding agent in combination with water and gravel. Different limecrete formulas were used for a variety of construction projects in mid-nineteenth-century Seguin. "Cisterns, walls, outbuildings, houses, stores, churches and even the county courthouse were all constructed of concrete" (TPWD 1983: II:39). A few limecrete houses, rubble, and the ruins of limecrete walls are still visible in areas throughout Seguin.
Concrete house walls were poured into wooden molds in layers, a new layer being poured when the last one had dried enough to support the weight of the next. The shape of the molds was maintained using long, removable iron tie bolts to keep the boards together and wooden spreaders (which remained in the wall) to keep the boards apart. The wall's layers were as high as the width of the boards of the wooden forms, varying from 8 to 16 inches, and the walls were about $1 \mathrm{ft}$ thick. As the walls grew taller, scaffolding was necessary to transport the limecrete to the top of the walls. In this way, the house was built from the ground up.

The use of limecrete construction in Seguin during the 1840 s, 1850 s, and 1860 s was facilitated by a number of factors. The most important was the availability of resources: timber grew along the Guadalupe River and its tributaries, providing the lumber necessary for forms and wooden structural attributes; alluvial gravel deposits were plentiful; and limestone bedrock exposures were common in the area (Hauser 1980:54). The normal supply of construction-quality walnut from Indianola was strained, which meant a lack of good lumber from which to build entire houses (Hauser 1980:59).

The number of people needed to build a concrete house ranged from three to seven or more, but expertise was not necessary for the majority of the crew. Before the Civil War, slave labor was available to use during construction, which provided the numbers needed at a low cost (Hauser 19.80:53). The resources available, combined with the slave labor and the influx of German craftsmen into a wealthy, booming area, created a situation where limecrete construction became popular (TPWD 1983: II:35). Encouraging this popularity was Dr. John Park, who experimented with limecrete construction 
and understood the materials in the Seguin area (Hauser 1980:53-58). Because of these favorable conditions, "Seguin contains the largest known concentration of these early concrete buildings in the United States, with possibly as many as 100 existing at one time" (Hauser 1980:60).

\section{DESCRIPTION OF SEBASTOPOL}

Sebastopol is located on a roughly rectangular lot, 2.2 acres in size (Figure 11). Streets border the property to the west and south, while East Walnut Branch creates part of the northern border. A community and county center is located adjacent to the property on the east, separated from the historical park by a wire fence. This fence was erected to prevent impacts on the historical park by activities in the community center, which included people walking over the lawn and parking their cars on the southeast corner of the Sebastopol lot. Mostly clear of vegetation, the Sebastopol site has open vistas in all directions except to the north where large trees obscure the view. Other smaller trees are scattered to the east and west of the house, with a pair of western red cedar trees to the south bordering the walkway to the building. Most of the 2.2 acres is grassy lawn which from the south slopes east to west, the slope increasing more toward the creek as it reaches the house. It is likely that the site originally was mostly exposed bedrock without the lawn to the south, with trees growing mostly near the creek (Art Black, personal communication 1995). A cistern was located directly to the west of the house. The cistern apparently was not completed since no lining was evident which would have sealed the porous bedrock. Based on the results of the TPWD excavations, it seems to have been used as a septic tank or cesspool in the 1930 s as well as a refuse dump during the restoration of the house in the 1960s.

The earliest architectural information on the house and the site comes from the Historic American Buildings Survey (HABS) of 1933-1934, which made detailed recordings of the architecture and the site layout. The site plans show a slightly larger lot than the one now used by the park (Figure 12). At least two fences and possibly a perimeter fence are shown. The perimeter is marked with a broken line; although it is not defined as a fence, a gate is labeled in the southwest corner of the property indicating a fence on at least the south border. One of the other two fences runs out from the house parallel to the south wall, starting at the southwest and southeast corners of the building and stretching to the east and west property perimeters. The other fence outlines a plot in the northeast corner of the property, delineating a garden or stock pen (TPWD 1983:II:47). Descendants of the Zorns remember fences, both picket and wire, at the site, but not the details of their layout. Also shown on the HABS plans are two outbuildings, labeled "new outbuilding" and "shed." The grandchildren remember an outhouse in the general location of the shed near the northwest corner of the property and the new outbuilding, just to the north of the house, as the location of the bath or wash house.

Other features at the site are remembered in the oral histories. A driveway, created by Cal Zorn's Model T Ford, ran from the southwest corner of the property toward the house. A carriage house, a barn, and a small residence for Ephraim, one of the family's employees, were located to the west of the house. The barn and small residence were located west of the current property line. Altering the layout of the property from the earliest site plans, East Walnut Branch was widened and reinforced in 1980 , cutting into the north edge of the property.

Sebastopol is a rectangular house located north of center on its rectangular lot, which is oriented approximately to the points of the compass and stretches approximately $430 \mathrm{ft}$ on the north-south axis by $225 \mathrm{ft}$ on the east-west (see Figure 11) (TPWD 1986). The house was cut into the slope where the plain begins to descend down to East Walnut Branch. Because of this, the house presents a slightly elevated, one-story facade on its south side (Figure 13a) and a two-story facade on its north (Figure 13b). The building was built in a Greek Revival style which "was the dominant style of American Domestic architecture during the interval from about 1830 to 1850 (to 1860 in the Gulf Coast states)" (McAlester and McAlester 1990:182). The largest numbers of Greek Revival buildings occur in areas with the highest growth rates during this time period (McAlester and McAlester 1990:182). The Greek Revival style in the early nineteenth century was spurred on by archeological investigations at the time which emphasized Greece as the mother of Rome and shifted architectural interests from Roman to Greek (McAlester and McAlester 1990:182-183). Sebastopol does have a templelike quality whe viewed from 


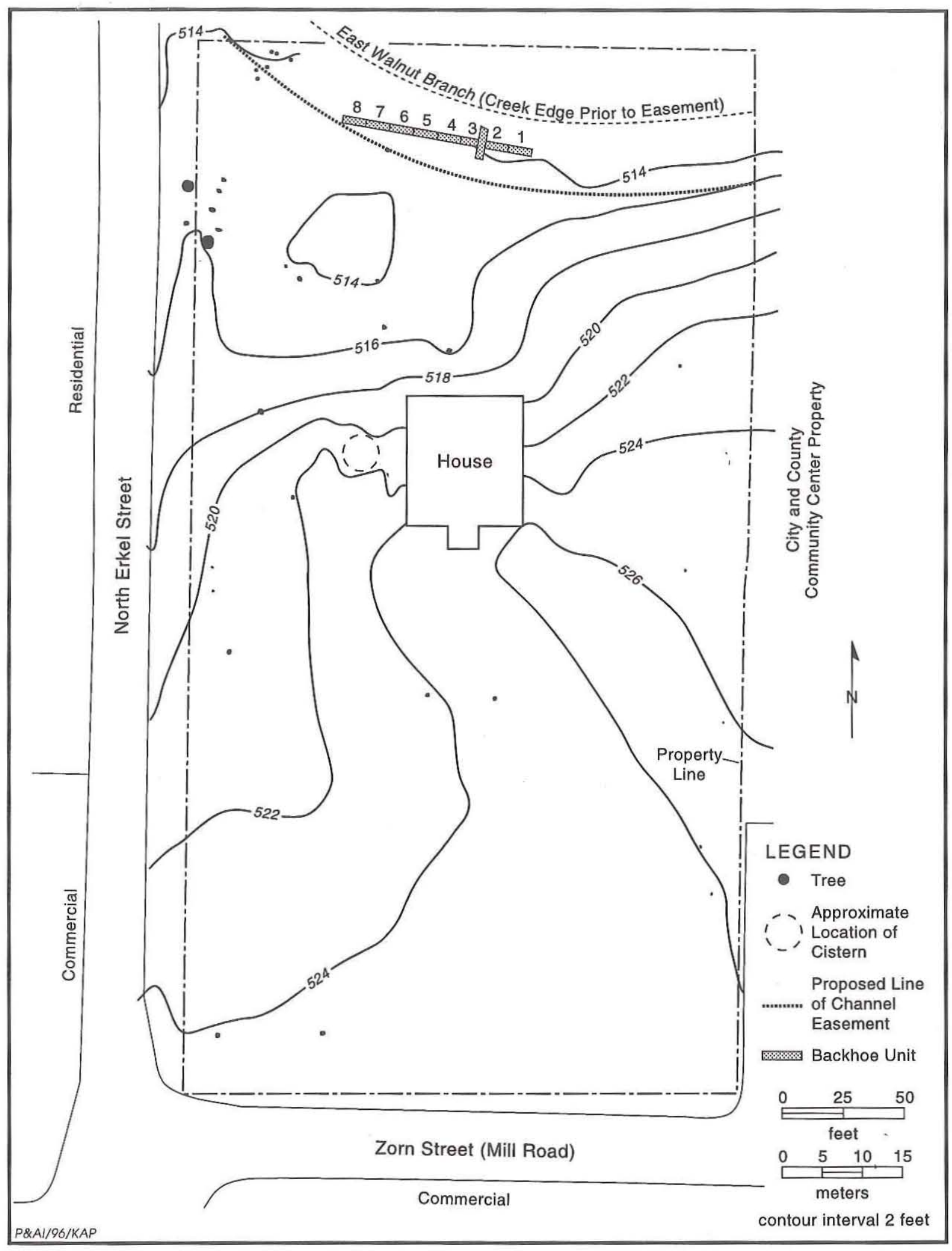

Figure 11. Map of the Sebastopol lot. 


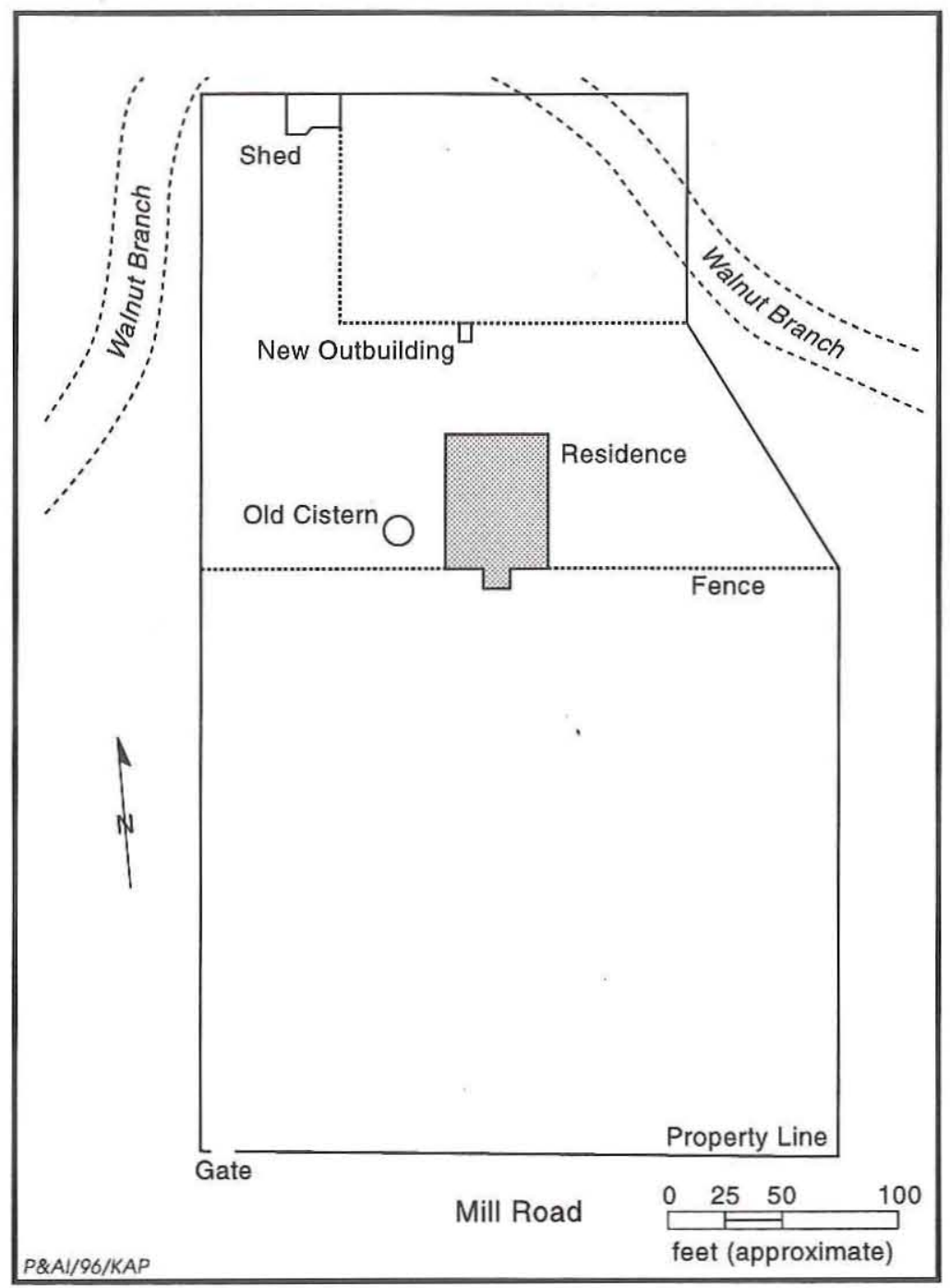

Figure 12. The Sebastopol lot as it was during the HABS survey of 1934 . was the walkway.

The house contains a total of 12 rooms. One storage area and one unused area are also present on the first floor (Figure 15). Most of the rooms are either plastered and painted white with dark wood trim or unfinished in the case of the front lower-floor rooms. The upper floor has a Tshaped floor plan, having three bedrooms across the top of the $T$ and the parlor as the stem, with a U-shaped gallery surrounding the parlor. The lower floor follows the T-shape as well, except with the under-gallery area being made of walled-in rooms. A stairwell goes from the inside downstairs to the east gallery on the upper floor.

The northern facade is symmetrical with a central door at ground level flanked by two windows on either side. Each of these windows is replicated in the upper floor, directly above. Architectural and archeological investigations discovered that another door was formed above the ground-floor door during the construction of the house. In addition, a limecrete pier was found just to the west of the ground-floor door. The upper door was filled in while the house was being built and no other piers were found, leading to the conclusion that the plans for the house were altered during construction. It is possible that an upper-floor balcony was to be placed in the upper bedroom with a columned, twostory portico around both the upper and lower doors. Greek Revival architecture in Texas during this time period is replete with houses that have the same facade as the north face of Sebastopol. This facade is most often seen on the front of the houses, though, not on the back. Often, these facades are also embellished with a portico or larger, full-length veranda or gallery. It is possible that what is now the back of the house was originally intended to be the front. This would have provided a much more imposing entryway into the house, created the impression of a larger interior, and suited the 


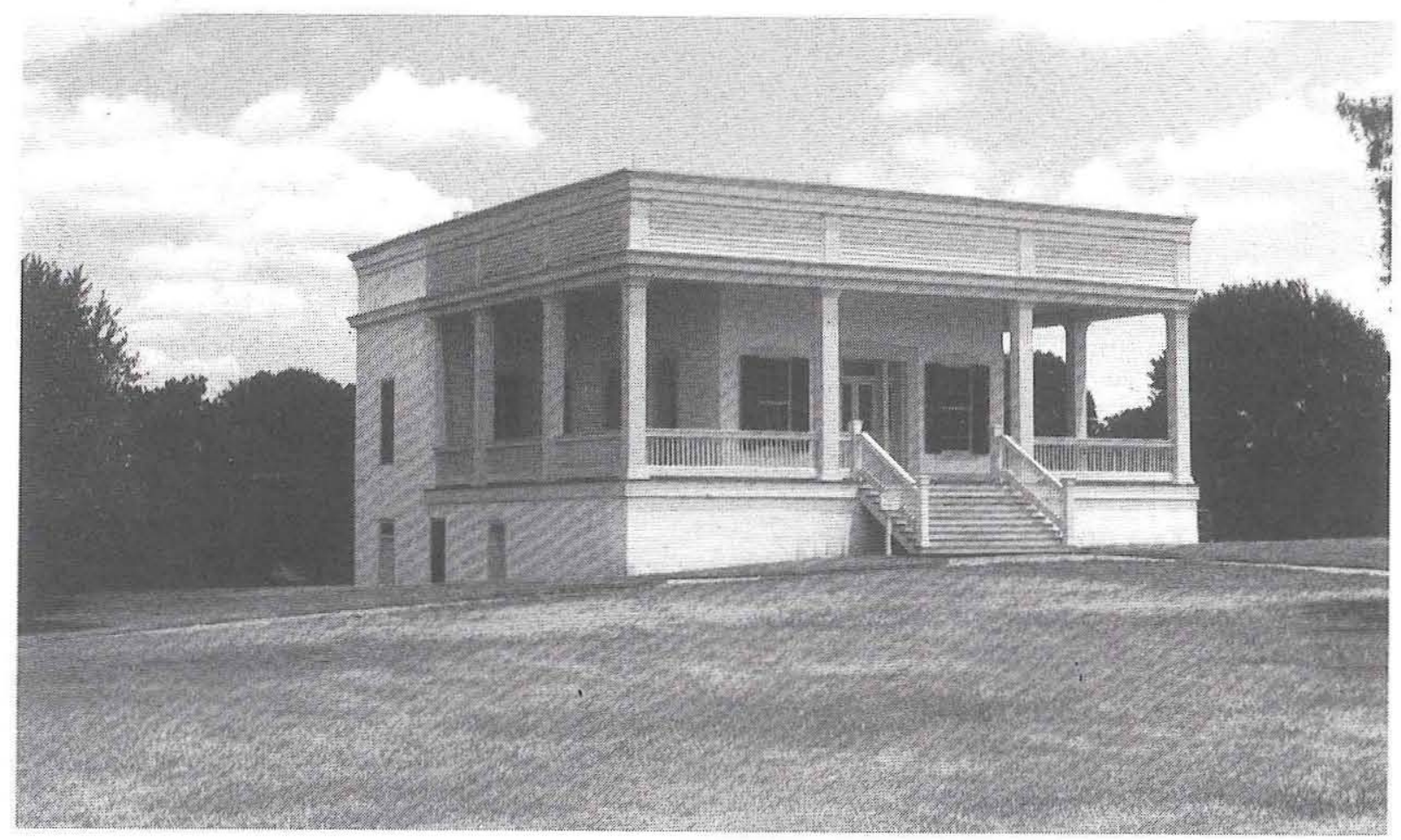

a

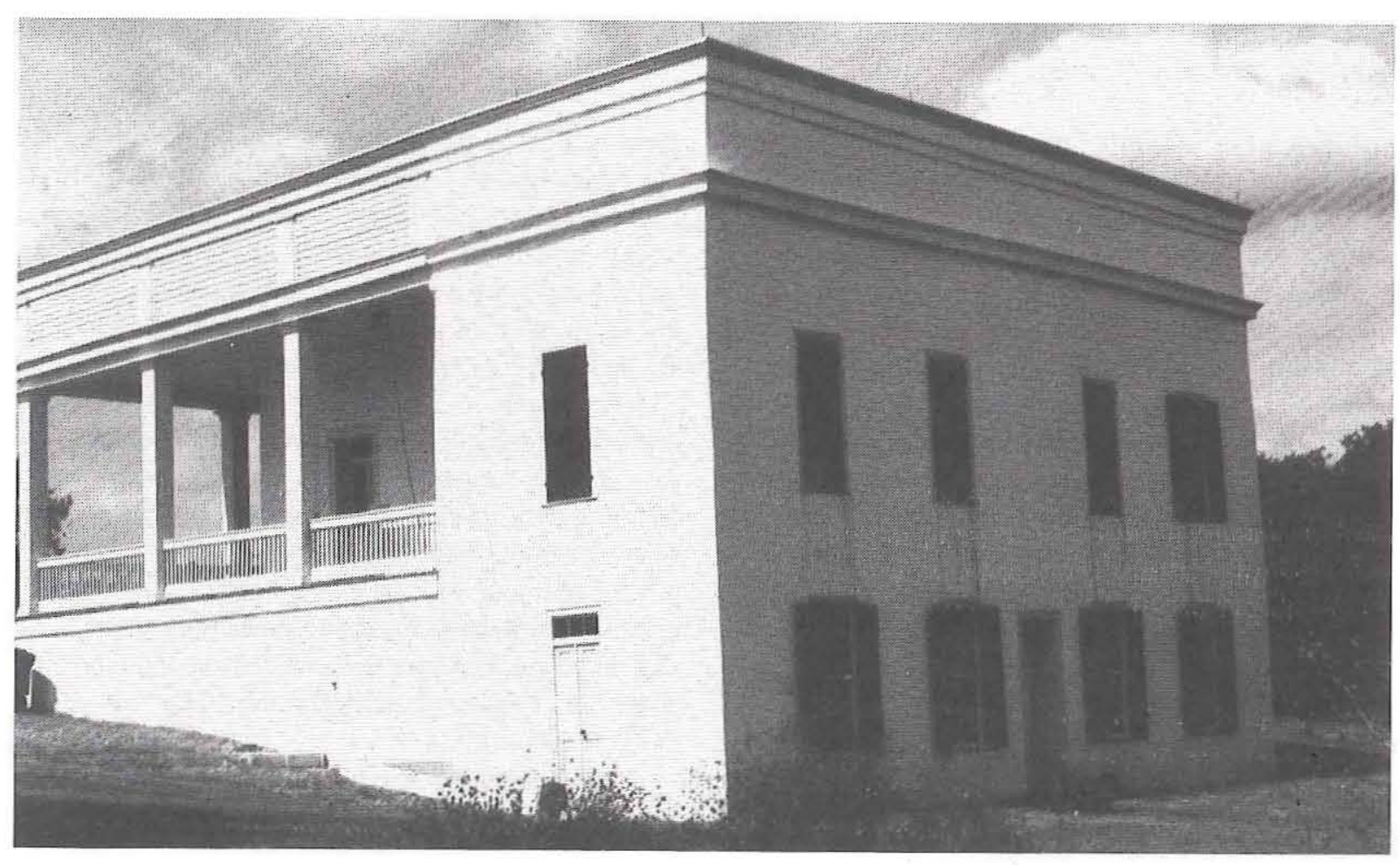

b

Figure 13. South $(a)$ and north $(b)$ faces of the house. 


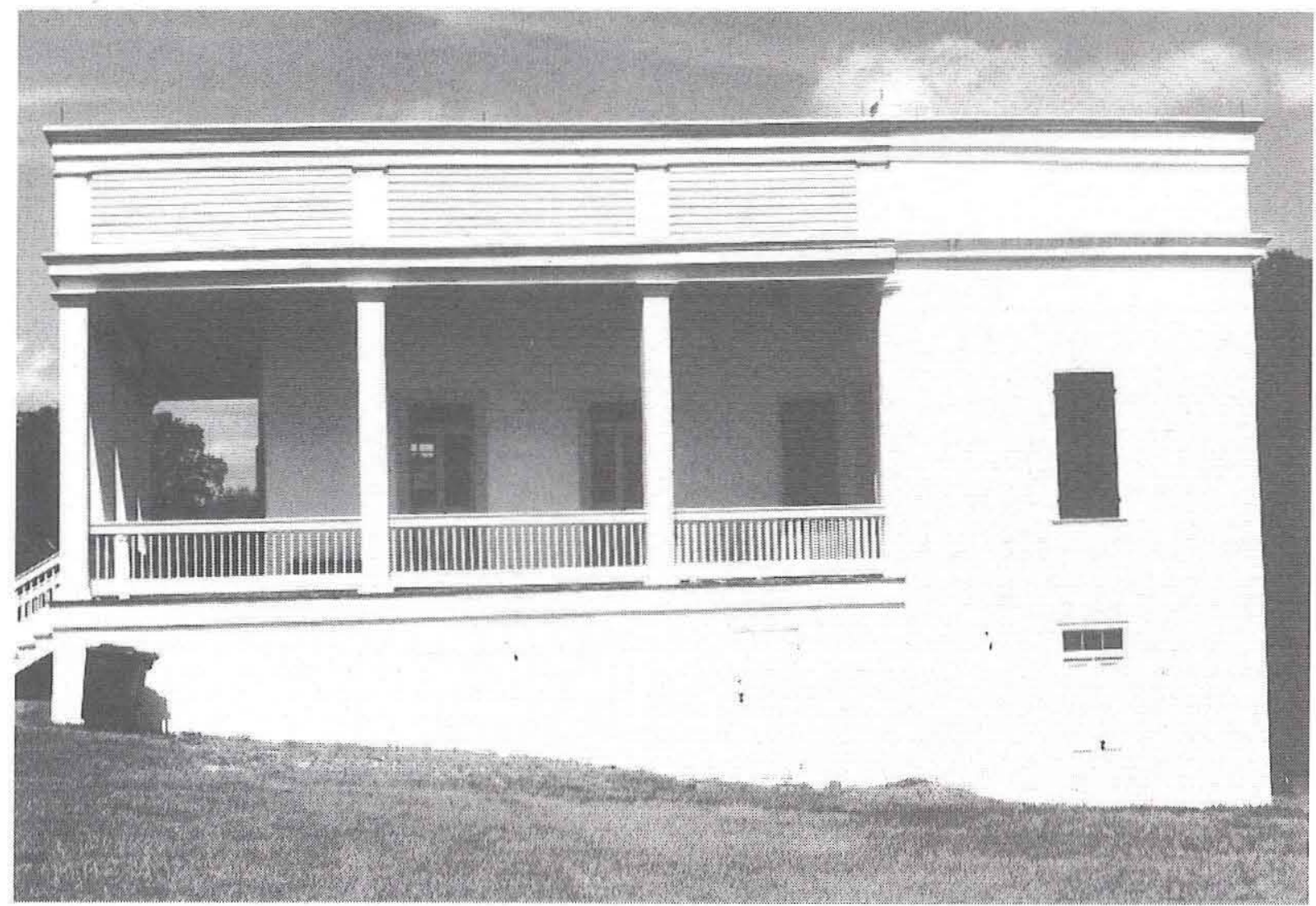

Figure 14. East face of house.

architectural styles of the time more than the current entryway. The original plans for the house have not survived, so we may never know what the original intentions were for the north face of the house.

The two rooms flanking the main lower-floor room, or dining room, both have full-sized doors to the outside. In fact, all of the rooms in the house originally had doors to the outside, with the exception of the master bedroom, which would have had a door and a balcony had the elaboration of the northern facade continued. The under-parlor area, only partially excavated and used for storage, also had no door to the outside due to its central location. Easy access to the outside and a lack of interior connection between upper and lower floors leads to the impression that a good deal of time was spent in the outdoors and that there was less distinction between inside and outside with this house than we are used to today. This impression is strengthened by the remembrances of the grandchildren who recall long summer evenings talking and sleeping in the gallery.

The roof of the house was designed to give the appearance of a flat roof while providing the draining capability of a sloped roof. A hipped roof is surrounded by a half gable, creating a rectangular trough around the roof, $8 \mathrm{ft}$ in from front and back and $10 \mathrm{ft}$ from the sides. In profile, the roof takes the shape of a W (Figure 16a). The trough was drained by pipes on the west, north, and east sides which ran out to the exterior of the walls. The drain pipes stuck out from the walls under the substantial entablature far enough to drain away from the delicate concrete. The drainage system has since been modified with the drain running into the ground through one of the pillars. The wooden entablature disguises this odd-shaped roof, and where the limecrete $\mathrm{T}$ meets the wooden entablature, the shape is continued through limecrete moldings (TPWD 1983:II:53).

The limecrete chimney serving the master bedroom, parlor, and dining room fireplaces is visible protruding above the entablature in the HABS drawings, as is the western flue which served the kitchen stove (Figure 16b). A flue was built into the eastern side of the house as well, but it was 


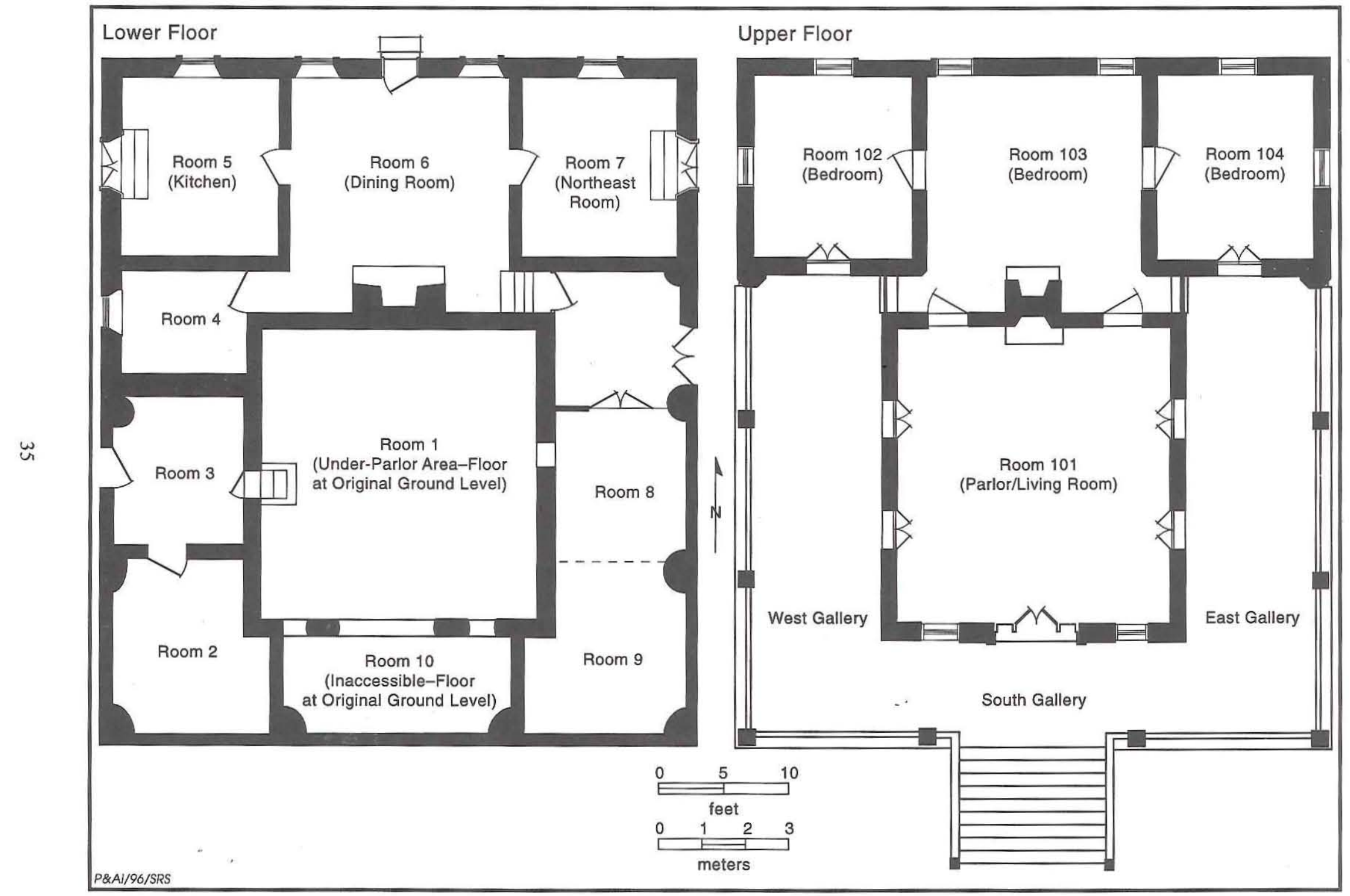

Figure 15. Floor plan of the house. 


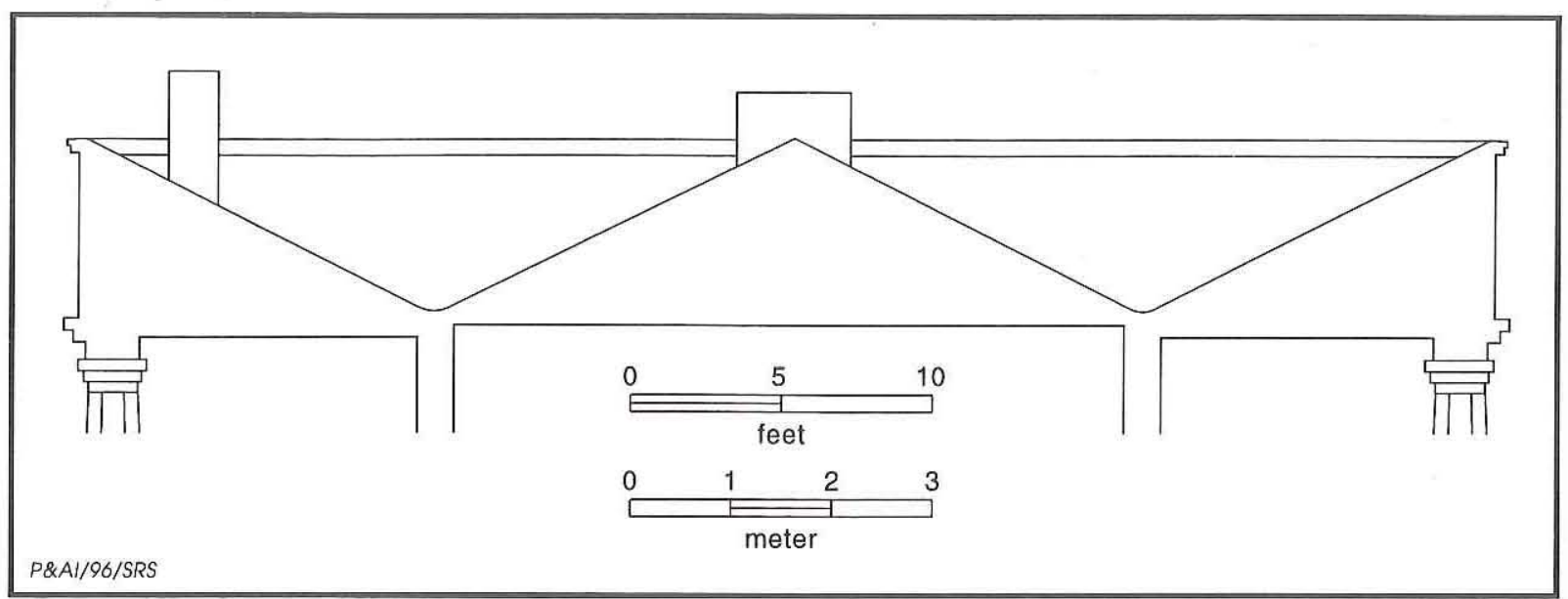

a

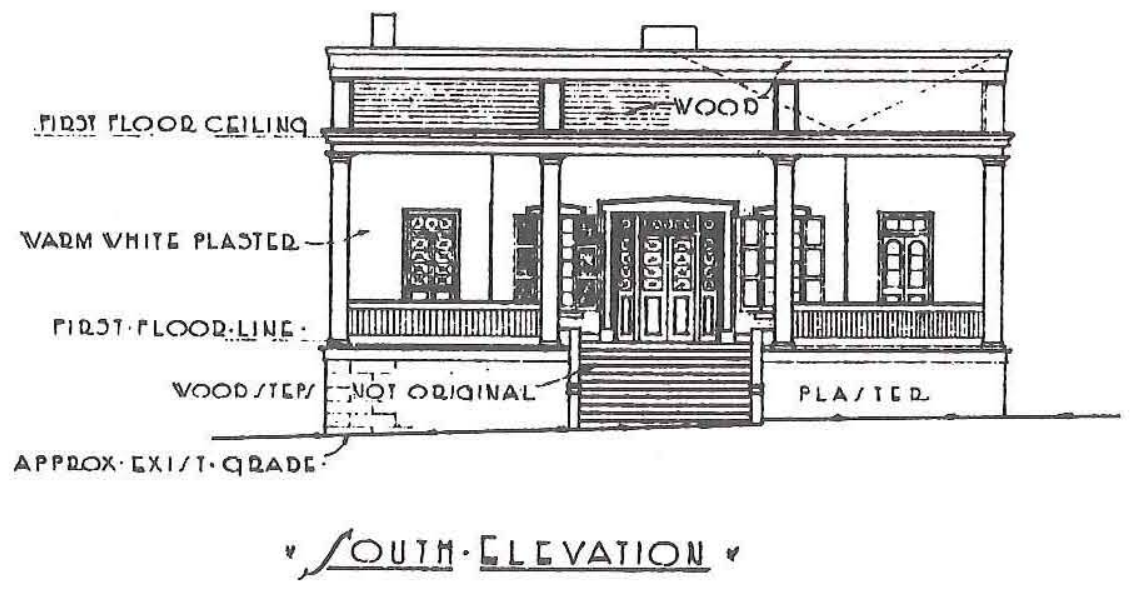

b

Figure 16. Roof and chimney details. (a) Roof cross section; (b) 1934 HABS drawings showing the chimney above the roof level.

never used (it is missing the soot staining of the western one) and is not seen in the HABS illustrations (TPWD 1983:II:53-55).

There are eight rooms in the lower floor, numbered 2 to 9 starting in the southwest corner and moving clockwise (see Figure 15). The house is symmetrically designed with only the under-gallery areas being asymmetrical between the west and east sides of the lower floor. The under-parlor area was designated as Room 1 although it was not a habitable space, its floor being at original grade with about $5 \frac{1}{2} \mathrm{ft}$ of headroom at its northern end. The area under the front porch was completely blocked off from the rest of the house as well as the exterior, and it was designated Room 10. Four of the rooms, numbers 4 through 7 , were finished. The original uses of the rooms are not known at this time, but their use during the Zorn occupancy is. Room 4 was the pantry, Room 5 was the kitchen, Room 6 was the dining room, and Room 7 was used as a bedroom and later probably for storage. During the LeGette occupancy, it is thought that Room 5 was used as a bedroom and Room 6 was the dining room and kitchen combined. There is some evidence that the dining room originally had a dirt floor which was covered over at the end of the LeGette occupancy; limecrete ledges and a central limecrete beam were added after the original construction to support the wooden floor. Antebellum houses in the South often had a detached kitchen to 
"remove unwanted heat" (Jordan 1978:138-139). It is likely that, even if never built, the house was designed around having a separate kitchen. This would explain the relatively small fireplace in the dining room.

The use of the other four under-gallery areas during the Zorn occupancy is unknown. It has been postulated that, at that time, these rooms were used only for storage (TPWD 1983:II:57) due to a lack of windows, their unfinished walls, and earthen floors. Early in the history of the house, however, these lower-floor rooms had a more complex use. Archeological investigations have revealed the original existence of doors and windows in all of these rooms. There is evidence of continuous deposits within and without the doors, meaning the openings were filled some time after the construction of the house began. The filling of these doors and windows could have occurred part way into construction or 20 years after the house was built. At this time, there is not enough evidence to confirm either statement. As mentioned earlier, there was a walkway dug around the house to access these rooms, and exterior steps are found at the southwest and southeast corners of the house (Art Black, personal communication 1995; TPWD 1983:II:59, 96-97). This archeological evidence indicates that these rooms were intended to be used as more than simply storage spaces. Rooms 2 and 3 are adjoining rooms located in the southwest corner of the lower floor. The rest of the lower floor (with the exception of the under-parlor area) is not accessible through Rooms 2 or 3 . It was common on plantations during the antebellum era to provide accommodation for guest or chance travelers. To protect the family's privacy, these rooms were constructed within the house but with no doors that would open into it (Silverthorne 1986:182). This is a possible explanation for the presence of these two rooms at Sebastopol.

Rooms 8 and 9 were once separated by a wall corresponding to the wall between Rooms 2 and 3 , making the lower floor roughly symmetrical (TPWD 1983:II:59). That wall is now gone, and Room 9 is split in two with a partition. Room 8 is the one under-gallery room that is connected to the finished rooms, and it is the only lower-floor room that has access to the upper floor through the staircase. It is believed that the staircase is not original to the LeGette period, but that the Zorns installed it at a later time (TPWD 1983:II:59). This would mean that, when the house was constructed, there was no connection between the upstairs and the downstairs, and that to get from upstairs to down, one would have to go out onto the gallery, down the front stairs, and around the side of the house.

The area under the front section of the gallery, Room 10 , is a mystery in regards to its use. It was connected to the under-parlor area by three openings, a central rectangular window flanked by two smaller openings, and it was connected to Room 9 by a small portal which was added in the twentieth century. All three of the portals in the under-parlor area had walnut grilles set into them.

The orientation and construction of Sebastopol provided comfort during both the hot summers and the moderate winters of Seguin. The wrap-around gallery facing south was placed to funnel southeastern breezes as well as propide at least partial shade for all but one of the upper-floor rooms. That room is the master bedroom which has a completely northern exposure and probably remained fairly cool. A large number of openings in each room plus ceiling heights better than $13 \mathrm{ft}$ provide cross ventilation for the rooms. Only two windows are unshaded on the upper floor (TPWD 1983:II:66). The lower floor, having mostly a northern exposure, being partially dug into the ground, and having doors and windows aligned for ventilation, would have remained cool throughout the year (TPWD 1983:II:66). The biggest contributor to climate control in the house would have been the thick limecrete walls ranging from 12 to 16 inches in width, which contain heat in the winter and keep it out in the summer.

It appears that Sebastopol was constructed in two phases. First, the T-shaped portion of the house was poured, and then the under-gallery area was completed. The materials for the house were probably collected locally (a gravel pit was located to the east of the house), and some of the materials may have come from the excavation for the house foundations. These excavations were extended approximately $4 \mathrm{ft}$ from the edge of the house to provide the walkway access to the under-gallery rooms (TPWD 1983:II:68).

For the construction of Sebastopol, evidence suggests that form boards were 1 inch thick and varied in width and length. The tie bolts used were $1 / 2$ inch in diameter. The spreaders were mostly walnut. Form boards and tie bolts were reusable, while the spreaders remained in the walls and are 
still visible in some areas of the house (TPWD 1983:II:69).

Oral accounts of the exterior of the house record it as white with darker shutters. All of the grandchildren who visited Sebastopol remember it this way. The HABS survey from 1934 points to an interesting variation away from this solid white exterior. At the time of the survey, the plastered portions of the Sebastopol house were not white but were covered in a "subdued maroon with warm white marking to imitate stone joining" (Historic
American Buildings Survey 1934:2, house exterior sketches) (see Figure 16b). The blocks of pigmented plaster are recorded in the sketches and visible on the black-and-white photographs from the time (Figure 17). Apparently, the pigmenting of concrete or plaster in an ashlar style was a new development after the Civil War (TPWD 1983:II:31). After the Greek Revival style had become passé, the alteration of the exterior surface of the house may have been an attempt to modernize the building. The date of this exterior work is not known.

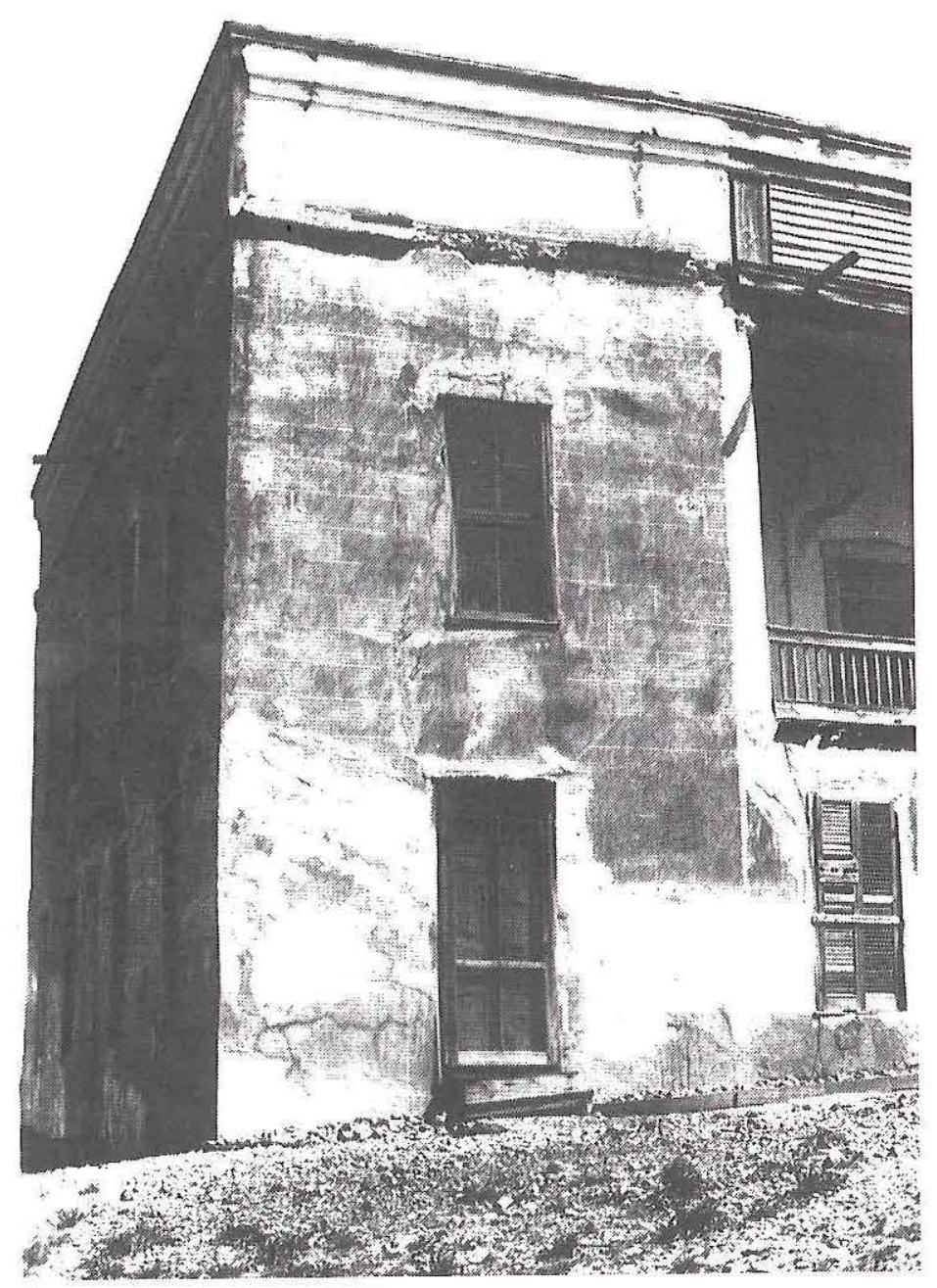

Figure 17. 1934 HABS photograph showing immitation brickwork. 


\section{HOUSE AND YARD DEPOSITS}

This chapter summarizes data recovered from each excavated room or feature. The primary focus is to provide an overview of stratigraphy and feature formation. Artifact analysis is presented in Chapters 5 and 6.

Room numbers, 1 through 10 in a general clockwise distribution, were assigned by the project architect (Figure 18). The following review of room excavations follows this numbering scheme with discussion of the exterior of the house, including the cistern, the easement trenches, and miscellaneous areas, following in turn. Each room or area is described as a single narrative, even when excavated over multiple field seasons.

\section{THE HOUSE INTERIOR}

A general trend can be seen in the stratigraphy throughout the excavations of the house. A layer of limecrete spill from the construction of the building is commonly found on top of the bedrock gravels. These gravels represent the surface formed when the topsoil and upper layers of bedrock were removed to first begin wall construction. In unfinished rooms, this limecrete spill has been mixed with the gravel surface by foot traffic, forming a compacted floor. In finished rooms with installed wooden floors, a deposit of dust, decomposed limecrete, and plaster has accumulated under the wooden floors, completely filling the subfloor airspaces in some areas. Debris from the 1960s restoration is often found on and mixed into the top of this deposit. In the case of the unfinished areas below the porch, layers of decayed wood fragments (described below) are probably also related to the restoration efforts of the Seguin Conservation Society in the 1960s. In general, the excavated rooms in the house all exhibit this pattern of three basic strata. The exception is Room 1 where traces of original soil grade could be identified below the construction layers and still overlying original bedrock..

\section{Room 1}

Room 1 is the lower floor area located directly under the parlor (see Figures 15 and 18). The room measures approximately $21.5 \times 22.5 \mathrm{ft}$ with an undulating floor resulting in a ceiling height of between 5 and $6 \mathrm{ft}$. During the 1988 field season one unit was excavated in three levels at the proposed location for the heating/air-conditioning unit.

In the sequence of house construction, the rooms surrounding Room 1 were excavated and then the walls of Room 1 were cast in place. The original soil and bedrock grade within Room 1 was not removed and served as the floor surface for the under-parlor area. Additional fill was deposited in the room during construction, particularly around the interior periphery resulting in a deposit sequence of gravel mixed into loose powdery soils overlying remnants of the original soil grade which in turn overlay bedrock.

The only original entry to Room 1 was through a doorway in the center of the west wall, entering from under-gallery Room 3. Tradition holds that Room 1 was used as a storage area, and this is supported by the unfinished and unleveled floor as well as its being the driest and coolest area within the house (TPWD 1983:II:57).

\section{Room 2}

Room 2 is located in the southwest corner of the lower floor and measures $13.5 \times 13.1 \mathrm{ft}$ with a 


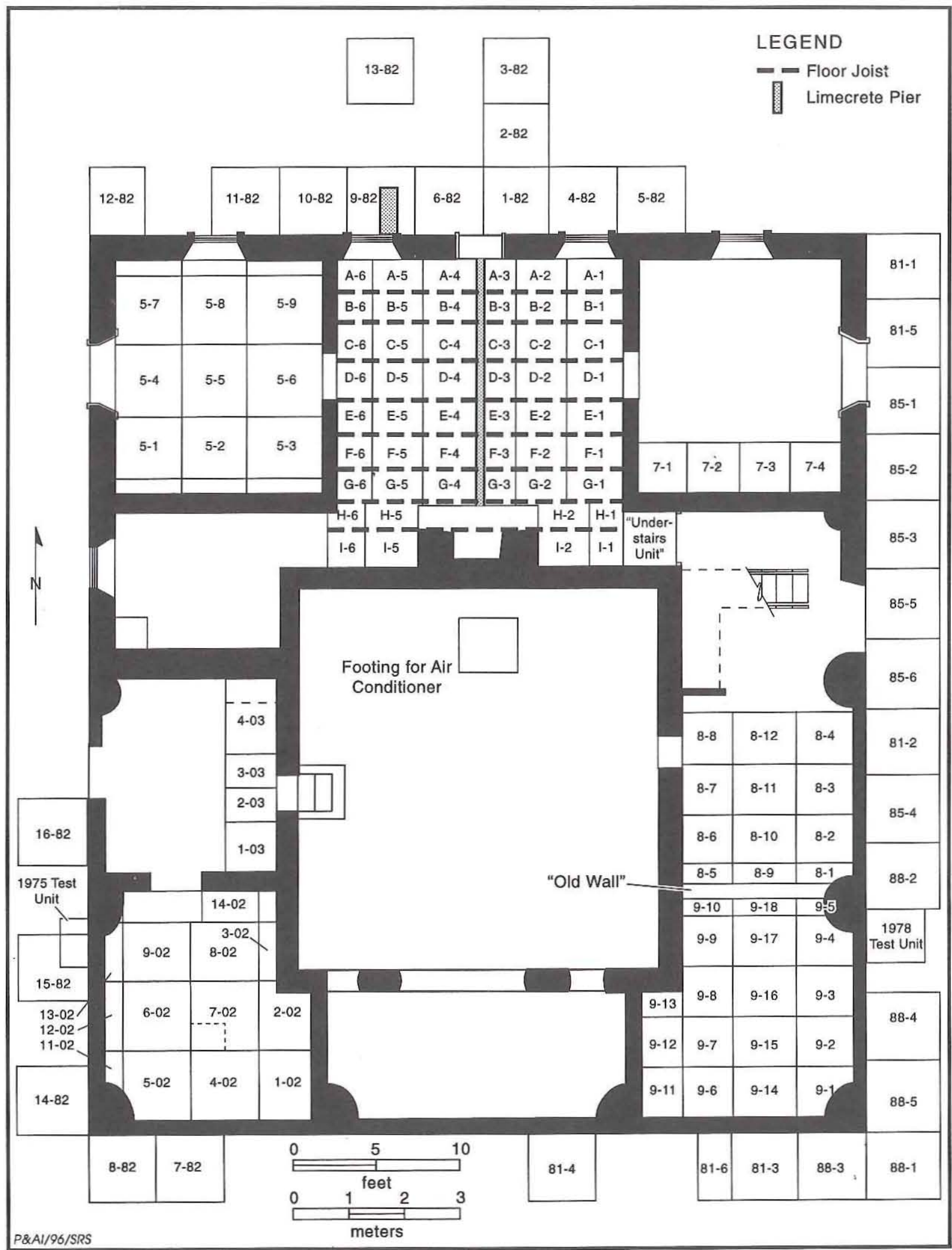

Figure 18. Lower floor plan with excavation units. 
ceiling height of approximately $8 \mathrm{ft}$. There are two approximately 1 -ft-wide, quarter-round limecrete buttresses in the northwest and southwest corners of the room. These buttresses were placed to assist the walls in supporting the joists for the gallery. Room 2 is L-shaped and overlaps two sides of the southwest corner of Room 1 (see Figures 15 and 18).

In addition to the one doorway in the north wall allowing entry from Room 3, there were two external doorways planned during construction, located in the south and west walls. The doorways were filled with limecrete either during construction or later, as part of some level of renovation during the late LeGette occupation or, more likely, the early Zorn occupation. The incorporation of these additional doorways during construction indicates an original intention to use this area as an activity/ living area. The interior was never finished with plaster or wooden floors, and with the sealing of the doorways, the room probably came to be used more for storage. This has been the case during recent years when this room was used for the storage of maintenance equipment and materials.

Because of the room's potential use for interpretation of building construction, the entire floor was excavated (TPWD 1983:II:96) revealing a generally consistent stratigraphy across the room. Recent debris from building repairs was removed from the top of Level 1 and discarded prior to excavation. Three distinct soil levels were found by the excavators. The first, Level 1 , was a mix of gravel, plaster, and sandy soil which became thinner and more compact toward the center of the room and thicker along the walls. Architecturally related artifacts such as plaster, wire and cut nails, and window glass, as well as bottles, were found in this level. These artifacts seemed to concentrate in the lower part of the level. The second level, 2A, was described as being very thin (absent in some units), silty, and discolored a reddish brown from rotting wood. It contained few artifacts. Level 2B was a darker gray-brown sandy loam with some gravel which contained glass, cut nails, ceramics, and some rotted wood. A fourth level, Level 3, was noted in most of the units below Level 2B. This level was defined as a soft, ashy-gray soil with some gravel and possible powdered plaster, probably from deterioration or erosion of the walls during construction and the early decades of the house's existence. Deposits were generally 0.2 to $0.3 \mathrm{ft}$ deep on top of an original packed surface similar to that in the
Dining Room (TPWD 1983:II:96).

The large amount of wood residue in Level 2A can be accounted for by one of two possible scenarios. The first and most likely is that, during the reconstruction of the gallery above, a substantial amount of debris such as wood shavings was deposited on the floor of this room (TPWD 1983:II:96). The artifact inventory charts indicate that 1,341 nails (36 percent of the assemblage from the room, 67 percent of which were cut nails) were found in Room 2, an indication that much of the debris was likely due to a replacement of the gallery deck. The second, less likely explanation is that the wood residue resulted from use of the room for storing firewood.

A compacted surface was observed at the bottom of Level 2 in Units 4-02 and 5-02 adjacent to the sealed doorway in the south wall. This floor surface, which fans into the room from the doorway, indicates use of the door as an entrance into the room before the doorway was sealed. A lip of limecrete extended horizontally at $0.25 \mathrm{ft}$ above the ground surface along the entire west wall of Unit 12-02. This limecrete lip may have originally been intended for the placement of a wooden floor that was never installed. Although a filled door is in the west wall, no compacted floor or other indications of door use along this wall were noted.

\section{Room 3}

Room 3 is located midway on the west side of the lower floor, north of Room 2 (see Figures 15 and 18). It measures approximately $10 \times 11.5 \mathrm{ft}$ with a ceiling height of $8.5 \mathrm{ft}$. One limecrete buttress supporting the gallery joists is located in the northwest corner of the room. This room has an external door in its west wall and two internal doors, one in the south wall leading into Room 2, and the other in the east wall leading into Room 1, the under-parlor area. Room 3 is known to have been used for storage and also as a restroom from the late 1930 s to the 1970 s.

Four units, field designated 1-03 to $4-03$, were excavated along the east wall in Room 3. Beginning with Unit $1-03$, a $3-\mathrm{x}-3-\mathrm{ft}$ unit located in the southeast corner, Units 2-03 and 3-03 were located in front of the door in the east wall, and both were $3 \times 2 \mathrm{ft}$. Unit 4-03 was north of Unit 3-03 in an area disturbed by the installation and later demolition of a concrete slab for the restroom facilities. After 
the removal of the first level, the remainder of the unit was divided into north and south halves due to a perceived color change.

Units in Room 3 were excavated through three levels. Level 1 was a loose, mixed, gray powdery fill, being subject to the room's use as a modern workshop area. In the area of Unit 4, Level 1 contained debris from the recent concrete removal. Level 2 was similar to Level 1 although more compact, and Level 3 was a dark brown soil in contact with bedrock.

Two features, 1 and 2, were found in this room. The first in Unit 2-03 and the other in Unit 4-03 were both shallow and amorphous with no distinguishing characteristics to identify their origin or purpose.

\section{Room 4}

Room 4 is located north of Room 3 and south of Room 5 (see Figures 15 and 18). Historically known to be the pantry, presumably with shelves lining the walls, this room was converted into a restroom during the stewardship of the Seguin Conservation Society. The room measures approximately $10 \times 8.25 \mathrm{ft}$ with a ceiling height of $10.5 \mathrm{ft}$. Entrance is by a door at the northeast corner, entering from the southwest corner of the Dining Room (Room 6). A window is located in the west wall. Modification of the room into a restroom required the laying of a concrete floor; therefore, no excavation was undertaken in this room. However, during the TPWD restoration project of the structure, the toilet in the southwest corner of the room was removed, and a small portion of the concrete floor below it was torn out to replace the wastewater lines. Subfloor deposits visible in the resulting hole were found to have been completely disturbed by the placement of the original wastewater lines. A limited assortment of materials resulting from various occupations and renovations was collected from the disturbed fill.

\section{Room 5: The Kitchen}

Room 5, located in the northwest corner of the ground floor (see Figures 15 and 18), was traditionally used as a kitchen. The room is $12 \times 14 \mathrm{ft}$ with a ceiling height of $10.5 \mathrm{ft}$. There are two doors leading into this room, an exterior doorway in the center of the west wall and one central in the east wall exiting into the Dining Room. A window is located in the center of the north wall, and two limecrete joist-bearing ledges run the length of the north and south walls.

Early in the architectural study of the room, several floorboards had been removed allowing inspection of subfloor deposits. Accumulated deposits had completely filled most of the subfloor area to the bottoms of the floor joists and to the bottom of the flooring between some of the joists. Removal of the deposits was necessary to restore air circulation around the woodwork to prevent or hinder decay (TPWD 1983:II:93). Bricks used as joist supports and visible in debris between the floor joists were of the same variety as those used elsewhere in the 1960s restoration by the Seguin Conservation Society to replace missing masonry around various window and door openings. This and the type of lumber used in the flooring indicated that the floor was a replacement laid during the 1960 s renovation. Later study of the floor joists, hewn from cedar logs, suggested that they too were not original to the room and may have been reused from another historic structure. The relative newness of the flooring, the quantity and composition of deposits, and the distribution and size of artifacts further indicated that flooring was largely or completely missing during the later years of private ownership. Although no dates for this condition can be absolutely assigned, oral history suggests that this condition existed during most of the 1950s and may have originated earlier. Excavations of the entire floor area were conducted in 1978.

Numerous ceramics were found in the fill below the floor. The majority of these are believed to have been deposited when the floor was in this poor condition, probably during the 1950 s. It is likely that the deposits were disturbed and mixed due to foot traffic and other uses of the room during this time.

Although disturbed during years of exposure after the original wooden flooring deteriorated, and later during the rehabilitation of the building by the Seguin Conservation Society, the stratigraphy below the floor and surface deposits in the Kitchen seemed to be divided into two general strata. Surface debris primarily consisting of reconstruction materials was coarse screened for nonarchitectural artifacts and discarded prior to excavation.

The upper stratum (Level 1) was a fine, gray, powdery layer mixed with sand and artifacts such as 
nails, window glass, wood, ceramics, toys, and other items. Level 1 appeared to have been relatively recent in origin containing a mixture of reconstruction debris mixed with materials from later occupation of the house. The next stratum (Level 2) was a darker, denser, gray-brown dirt mixed with fine gravel and sand. Level 2 is the earlier deposit made up of the debris that fell through the floor and later garbage deposited when there was no floor, or at least when parts of it were missing. It is likely that most of the sediment and many of the larger artifacts in Level 2 were deposited during the midtwentieth century, with the smaller, more-fragmented pieces from the lowest elevations dating as early as the LeGette/Young period (1854-1874). Again, the division between the two levels was not always distinct due to mixing. Below Level 2 bare bedrock was uncovered in most areas of the room, although limecrete spill from the original casting of the walls was noted in some locations. The walls 'of this room were dug deeply into the bedrock, whereas in Room 7 the walls sit on the bedrock surface.

A large number of ceramic vessel sherds $(1,530)$ were recovered from the Kitchen. Many of these are large pieces and can be reconstructed into whole or partial vessels. These larger sherds may be the result of one deposit episode later in the history of the house, quite possibly after the death of the last Zorn occupant in 1952. The ceramics were distributed both vertically and horizontally throughout the Kitchen.

\section{Room 6: The Dining Room}

Room 6, also known as the Dining Room, is located centrally in the north section of the lower floor. The room is $17.35 \times 18 \mathrm{ft}$ in size with a ceiling height of $10.5 \mathrm{ft}$. Five doors lead into this room: one in each of the south corners leading to Rooms 4 and 8; one in each of the east and west walls leading into Room 7 and Room 5 (the Kitchen), and one door central in the north wall leading to the back yard. A fireplace is central in the south wall and is the only fireplace on the lower floor. Two windows flank the exterior door in the north wall. This room is known to have been used as a dining room during the Zorn occupation, but it may have been used originally as a kitchen by the LeGette family.

The room was gridded into excavation units using the in-place floor joists. These lay approximately $2 \mathrm{ft}$ apart and ran from east to west. From the north wall, the areas between the joists were lettered A to I. Beginning at the east wall, each of the rows was divided into $3-\mathrm{ft}$ units, numbered 1 through 6. Because of the dimensions of the room, this resulted in Units A-6 to G-6 being $2.35 \mathrm{ft}$ in length. The irregularly shaped areas between the fireplace and the southwest and southeast doorways were given designations relative to their positions adjacent to the main floor area (see Figure 18). An area in the southeast corner of the room and under steps leading up to the door to Room 8 was later excavated when the steps were removed for architectural study. In total, at least 33 of 54 units were excavated: A-2, B-1 through B-3, C-1 through C-6 (excluding unit C-4), D-1 through D-6 (excluding D-5), E-1 though E-6, F-2 through F-6, G-2, G-3, G-6, H-2, H-5, I-2, I-5, I-6, and the "under the stairs" unit. Twelve units were noted as being unexcavated, and another 9, are undifferentiated.

The stratigraphy in this room seems to follow the same three-level pattern as the Kitchen. A white to ash-colored layer caps the deposits, with a more gravelly, darker fill below. In most cases, the excavators divided this second level in two, noting that the lower part tended to contain more small pea-sized gravels and become darker gray. The biggest difference in this room is the existence of a hard-packed floor which seems to replace the construction debris level seen in the kitchen and other lower-floor rooms. This hard-packed floor was created early in the life of the house before the wooden floor was installed, and it is likely the only feature excavated that can be attributed to the LeGette occupation period. Several excavators stated that the fill lifted easily from the compact floor level.

With the installation of the wooden floor, limecrete ledges were poured to support the wood joists. Three ledges were poured, two running north-south along the east and west walls and one running north-south from the exterior door to the center of the fireplace. These ledges were formed in trenches approximately $0.4 \mathrm{ft}$ deep and cut through the compacted floor surface. The central ledge or beam lay under the west end of the row 3 units reducing their length by as much as a foot.

\section{Room 7: The Boys' Room, or the Northeast Room}

Room 7 is similar to Room 5 in its shape and orientation. Located in the northeast corner of the 
lower floor (see Figures 15 and 18), this room is $12.5 \times 14 \mathrm{ft}$ with a ceiling height of $10.5 \mathrm{ft}$. A window is located central on the north wall, an exterior door leads out through the east wall, and an interior door leads to the Dining Room through the west wall. In this room, the walls of the house are sitting directly on top of bedrock (TPWD 1983:II: 95).

After the floorboards and joists were removed for architectural study, excavation units were positioned only along the south wall. Investigations were halted in this room after the excavation of the four units revealed the thinness of the deposits and a general scarcity of materials (TPWD 1983:II:95). Indeed, "[t]he presence of a [relatively] thick soil and artifact deposit, located outside the east exterior doorway to this room . . . indicates that much of the accumulated fill in this room was dug out during the 1961 rehabilitation by the Seguin Conservation Society" (TPWD 1983:II:95). One major point of difference in comparison to Room 5 is the absence of cast-in-place limecrete joist-support ledges. Rather, six large pieces of bedrock were placed along the north and south walls to support the floor joists.

Stratigraphy in this room was found to be particularly localized. The similarities of bedrock and limecrete, the subtleties of deposits, and the various periods of disturbance had resulted in stratigraphic sequences that were not continuous or consistently recognized. However, a very generalized sequence can be observed reflecting the basic two to three primary levels of bedrock or compact floor surface, varying amounts of fill, and a cap of modern construction debris. One item of note is the observation by one of the excavators that the bedrock fragments supporting the floor joists appeared to rest on Level 2. Since the project architect believed that the joists were original to the room, the placement of the joist supports on or in Level 2 suggests that wooden flooring may have been a late, perhaps Zorn period, addition to the room.

\section{Room 8}

Room 8 is located under the gallery on the east side of the house (see Figures 15 and 18). It is directly south of Room 7 and north of Room 9 . The southern extent of the room is defined by the footing of an old wall which originally separated this room from Room 9. A door was present in this wall and is still indicated by the sill in the wall base fragment. Four semicircular, floor-to-ceiling limecrete buttresses supporting the gallery joists and identical to those in Room 2 are located along the east wall of Rooms 8 and 9 . The buttresses are evenly spaced, dividing the wall in Rooms 8 and 9 into three sections. Room 8 is approximately $10 \times 23.5 \mathrm{ft}$ in size with a ceiling height of $8.5 \mathrm{ft}$. This is the only lower-floor room to be connected to the upper floor by a staircase; it leads from the north end of Room 8 to the gallery above. The north half of the room has an exterior door in its east wall and an interior door in its northwest corner which leads to Room 6, the Dining Room. An exterior door was once present in the southern section of the east wall in Room 8; this has been filled with limecrete.

The north half of Room 8 has a cement floor and therefore was not excavated. The south half of the room was gridded into nine units measuring $3 \times 3 \mathrm{ft}$, with the remaining area divided into three smaller units (approximately $1.3 \times 3 \mathrm{ft}$ ) against the old wall that separated Rooms 8 and 9, similar to the wall dividing Rooms 2 and 3 (see Figure 18).

Stratigraphy in this room seems to have been similar to that in Room 2 . Room 8 deposits were generally split into three levels. Level 1, as in the rest of the rooms, was composed of the loose surface materials created mostly during the reconstruction of the house in the 1960s. The top of Level 2 was marked by fill stained red from the wood fragments present within it. In some cases, this lay on a second component, a hard gravelly level, possibly debris from later limecrete construction. In other areas, a third part to Level 2 was a thin dark soil above Level 3, which is the house construction debris level. Not all of these distinctions were evident in all units, but this seems to have been the trend throughout the room. Later units excavated, Units 8-10 through 8-12, were split into finer levels, but the distinction between the three primary levels was still evident.

\section{Room 9}

Room 9 is located in the southeast corner of the lower floor of the house (see Figures 15 and 18). The room dimensions are $11.5 \times 13 \mathrm{ft}$ with a ceiling height of $8.5 \mathrm{ft}$. Two floor-to-ceiling limecrete piers are located in this room. Rooms 8 and 9 were excavated in conjunction with each other. 
The room was divided into twelve 3-x-3-ft units, with three smaller units in the southwest corner and three across the north wall.

The stratigraphy followed the findings in Room 8 , with Level 1 being the surface level, Level 2 being a darker and more compact matrix with a woody component on top, and Level 3 being a plaster/concrete layer sitting on top of the bedrock. Ash lenses were found in the levels, often recorded as just below the woody layer in Level 2 or just above Level 3. Some of the excavators split these three levels into as many as six strata, but most of the units were excavated in three levels and similar stratigraphic patterns were seen throughout the room.

An ash pit filled with burned corn cob fragments and burned wood was found in Units 9-15 and 9-16. This indicates that either a fire was built in the floor of the house or ash was deposited there from elsewhere. Although an unlikely location for a firepit or hearth, the size was small enough to have offered little danger to nearby woodwork such as the ceiling or porch decking.

Also found in this room were postholes. At least two postholes were found in Units 9-17 and 9-18. These features may have once held the bases of temporary supports for the porch flooring above.

\section{Room 10}

Room 10 is the area under the south gallery between Rooms 2 and 9 (see Figures 15 and 18). This area was originally blocked off from the rest of the under-gallery area, although a grilled or barred opening occurred in the wall separating this area from Room 1, the under-parlor. A small entrance hole previously dug through a sidewall currently leads into this space. The room is approximately $17.5 \times 7.25 \mathrm{ft}$ in size with a ceiling height of 5.5 to $7 \mathrm{ft}$ (the floor slopes down toward the north).

No excavations were undertaken in this room. Surface collections were made which included fragments of glass Christmas ornaments, probably from decoration storage by the Seguin Conservation Society.

\section{THE HOUSE EXTERIOR}

Excavations over five field seasons were conducted adjacent to all exterior walls. Descriptions of these excavations follow a discussion of general exterior features.

\section{General Exterior Features}

Deposits around the exterior of the house are dominated by gravel-filled soils. The bedrock in the area consists of bedded layers of a lime and gravel conglomerate of varying strength. Due to the similar makeup of limecrete and the bedrock, it was at times difficult for excavators to distinguish the two. In at least one instance on the east side of the house, a field worker excavated through covering deposits and into the bedrock surface of a subgrade walkway and, in the same area, worked through deposits of decomposed limecrete and into the actual limecrete wall surfaces (Art Black, personal communication 1995).

Probably the most unique features found in excavations around the exterior of the house were two sections of walkway along the east and west walls, which turned the southeast and southwest corners to continue along the south wall to approximately $8 \mathrm{ft}$ from the two corners. Since the house sits upon a slope, the walkways originally began at or near ground surface close to the north corners of the house. As the walkways moved south along the east and west walls, the walking surfaces became progressively deeper. Near the southeast corner, accumulated deposits above the walkway were almost $4 \mathrm{ft}$ deep.

Brief test excavations in 1978 revealed the depth of deposits, the base of the porch perimeter wall, a sealed doorway in that wall, and a secondary trench dug into the fill of the walkway (Figure 19a and $b$ ). Additional test units dug along the east wall in 1981 identified the nature of the walkway, and the bedded nature of its fill and determined its width at just over $4 \mathrm{ft}$. Excavations in 1985 and 1988 completed the excavation of the east walkway.

The removal of the walkway fill and inspection of the interior surfaces of the porch perimeter wall revealed a series of sealed openings in that wall, as discussed in the previous narration for Rooms 8 and 9. With the recognition of the exterior walkway, it became obvious that, as originally planned, the areas beneath the porch were designed to be used on a regular basis and not as simple storage-areas. Additionally, the exterior access suggests that the rooms were designed for individual access, possibly as living areas for slaves or servants. However, the unfinished interior wall surfaces, the exterior openings sealed with cast limecrete (a material that fell into disuse by the early 1870 s), and the dating of 


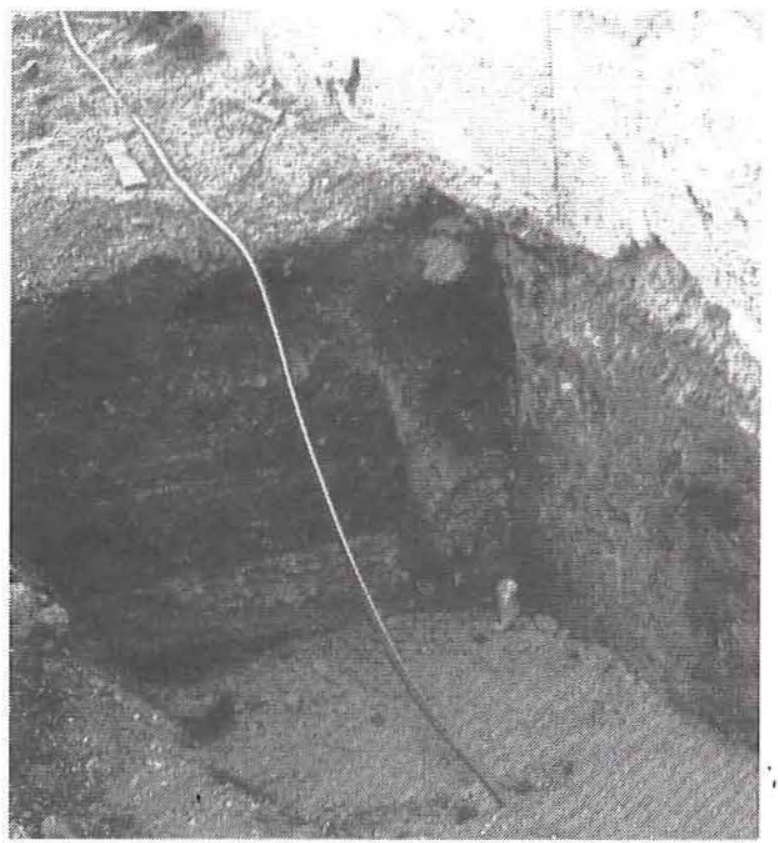

a

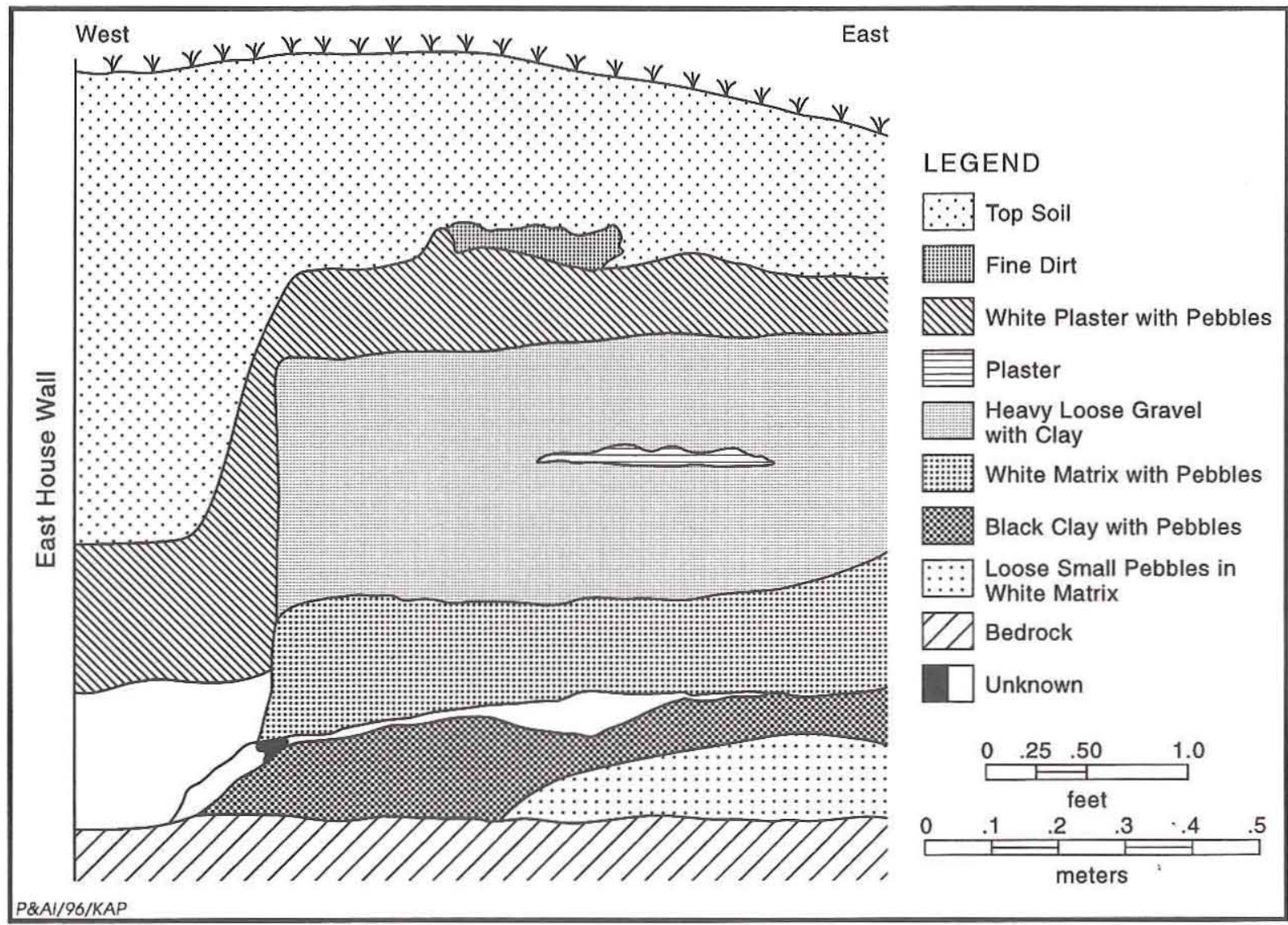

b

Figure 19. Filled secondary trench along east wall of the house. (a) Photograph showing south wall of Unit 88-4; (b) profile drawing of north wall in Unit 81-5. 
artifacts from the primary walkway deposits suggest that not only were these rooms never used for their original purposes, but that the exterior doorways were probably sealed during the early decades of the building's existence, possibly even during the latter stages of construction.

The artifacts found in the lower levels of the walkway fill, as well as the fill of the secondary trench, all support a nineteenth-century date. These include large sherds (one $12.5 \times 9 \mathrm{~cm}$ ) of a molded, octagonal, ironstone serving dish with matching plate fragments. Based on their decoration, these sherds most likely date to $1850-1870$ (Miller 1991:9). Also found in this unit in the trench were other artifacts, none of which refute an 1850-1870 date. Trench artifacts include large fragments of flat glass, metal strapping, pieces from a highly patinated champagne bottle, over 100 fragments of cut nails, shoe grommets, a wood screw, and a screw-in hook (the latter two were available by 1865 [Howard 1989:96; Russell and Erwin 1865:126, 155]). Many of these artifacts are large, which would be expected only in an undisturbed context where trampling and other activities could not break them into smaller sherds.

Recognition of the filled secondary trench (see Figure $19 a$ and $b$ ) in front of one of the sealed openings suggested that the trench was excavated into the walkway fill to make room for the plank forms used in sealing the door opening. However, excavations in 1985 and 1988 revealed that the secondary trench was continuous along most of the east wall. This negated its previously suggested purpose, as a continuous trench would have been unnecessary for the simple filling of the spaced door openings. A subsequent interpretation of the secondary trench helped to explain additional features associated with the porch perimeter wall. The exterior walkways fell into disuse after the sealing of the door openings and began to fill with accumulated deposit. At some point after the walkway was largely filled, the secondary trench was dug into the walkway fill to the base of the porch perimeter wall, possibly to determine the integrity of the wall base. The addition of buttresses to the interior wall corners of the porch perimeter wall supports this interpretation. The fact that these buttresses were built of mortared pieces of bedrock indicates that their construction dates to the final quarter of the nineteenth century after cast limecrete was no longer utilized for construction. Further, a limecrete buttress built up beside the southern portion of the east wall (Figure 20a) suggests that structural load problems with the porch perimeter wall may have been recognized early in the history of the house.

Excavations in the area of the west wall and the west section of the south wall area revealed evidence of a corresponding walkway. This evidence includes a step cut into the walkway surface and the edge of the walkway cut into the bedrock (Figure 21).

Although there are alternative interpretations for the features found around the walls of Sebastopol, the only one that addresses all known data may be summarized as follows. At some point early in the history of the house, possibly during the latter phases of construction, the decision was made that the doors that were to service Rooms 2, 8, and 9 should be sealed. This could have corresponded with the decision to fill in; the door in the master bedroom and abandon the construction of a balcony or finished porch on what is now the back of the house (see Chapter 3). With the change in building plan, the walkway was no longer needed and began to fill by natural deposition. After the walkway was largely filled, for some reason a trench was dug into the walkway fill to reveal the base of the wall. One possible explanation for this trench is that the integrity of the walls was in question, also explaining the interior buttressing.

\section{East Wall}

The east wall excavation units are those directly beside the east wall of the house (see Figure 18). Unit 88-1 at the southeast corner of the house is included in the south wall descriptions. Excavations of the east wall units were conducted in 1978, 1981, 1985, and 1988.

Two doors currently exit to the outside along the east wall of the house. These doors are located at approximately 7-10 ft and 24-26 ft south of the northeast corner. Two filled exterior doors are located in the area of Rooms 8 and 9 of the east wall. All of the units along this wall were $4 \times 4 \mathrm{ft}$ except for the 1978 test which was a 3-x-3-ft unit. The primary discoveries of these excavations, the filled walkway and sealed doorways, are discussed in the narrative preceding this section.

After clearing the bedrock walkway surface, a shallow channel was observed paralleling the wall approximately $1 \mathrm{ft}$ east of the secondary trench. This channel was observed primarily in Units 81-1 


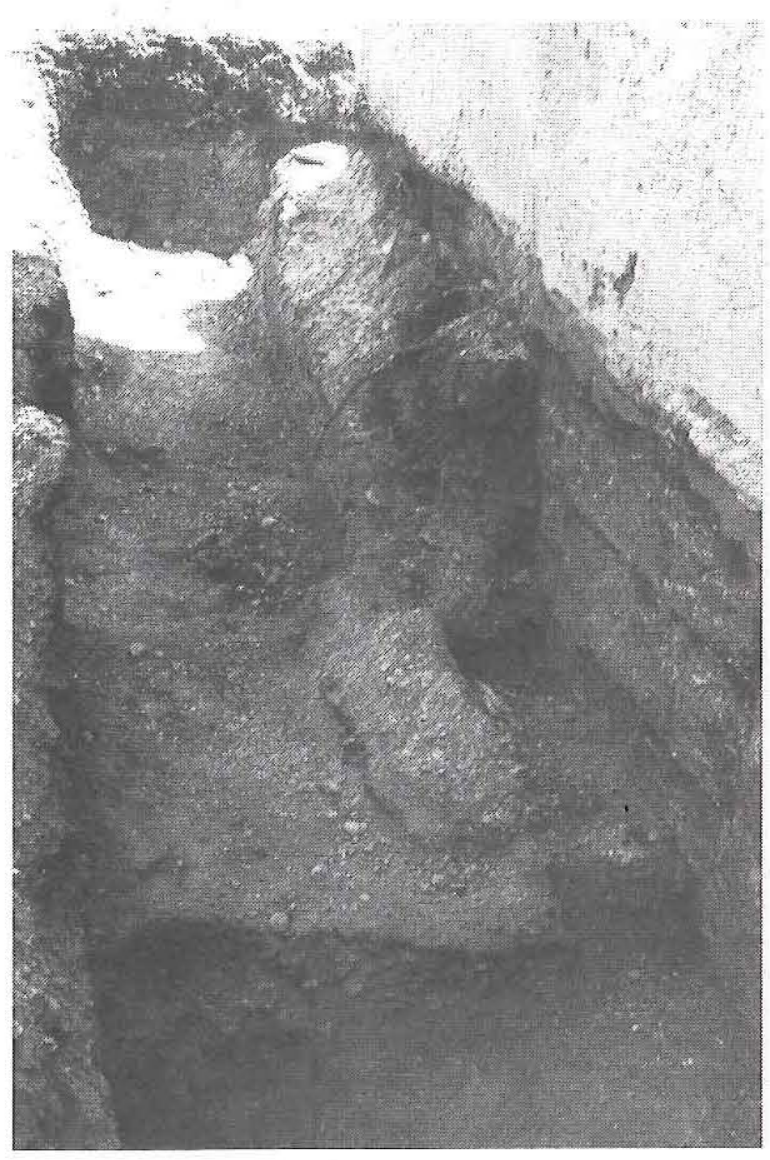

a

Figure 20. Excavations along east wall of the house.

and $81-5$ (Figure 22). There is no documentary evidence to suggest the purpose for this feature, although simple drainage control is possible. The only diagnostic artifact from the feature is a rim sherd from an earthenware cup, approximately 2.5 inches in diameter. The piece has a blue transferprint pattern with a flower and bird and appears to be from a teacup. Due to the lack of a string rim and the sparseness of the pattern, the piece appears to date to 1875-1890 (Amy Earls, personal communication 1995).

\section{South Wall}

Seven units were excavated along the south wall (see Figure 18). From west to east, these are 8-82, 7-82, 81-4, 81-6, 81-3, 88-3, and 88-1. Unit $88-1$ is not directly adjacent to the south wall but is at the very southeastern corner of the house.

The walkways from the east and west walls

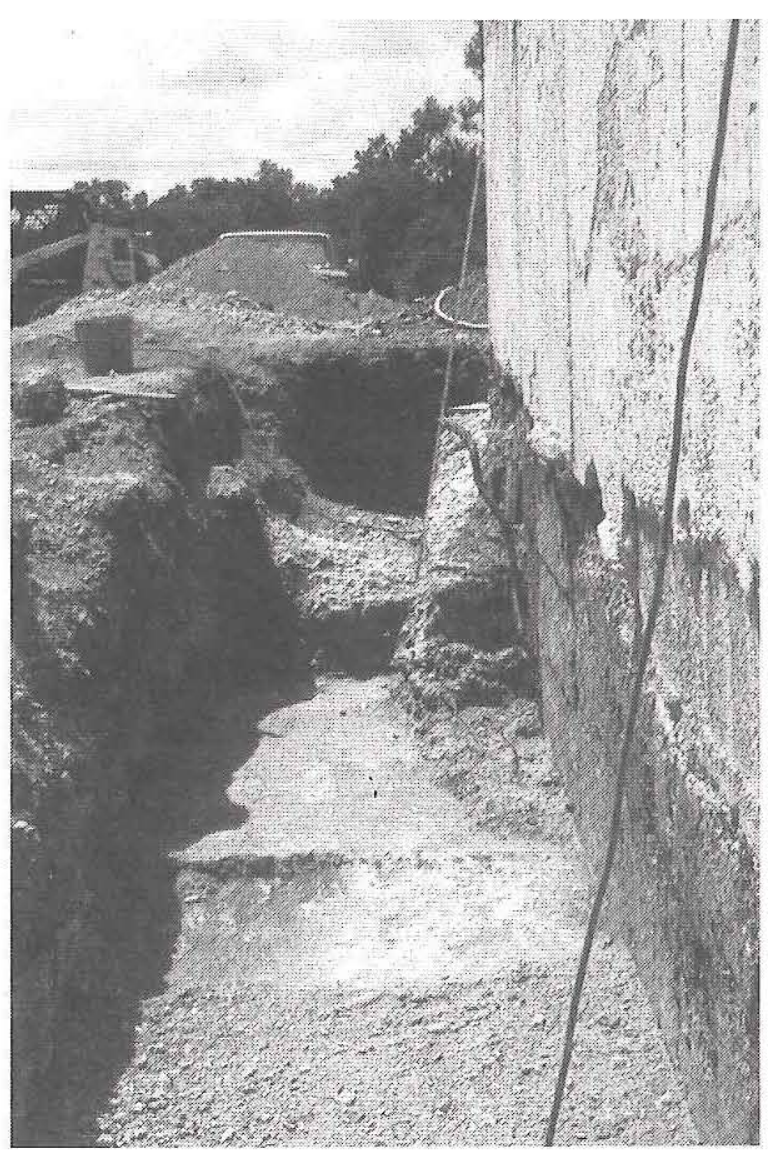

b

(a) Detail of limecrete buttress; (b) detail of walkway.

terminated approximately $8 \mathrm{ft}$ in from the two corners of the south wall. A 1-ft-high step leading up to the south door in Room 2 was carved into the bedrock walkway surface approximately $1 \mathrm{ft}$ east of the southwest corner of the house. A corresponding step at the southeast corner was not identified, but a similar step may have been present adjacent to the east wall near the corner.

In the higher levels 'along the south wall, evidence of gardening was noted. Two large pits over $1.5 \mathrm{ft}$ wide, up to $2 \mathrm{ft}$ deep, and filled with topsoil were found in Unit 81-3. These pits are attributed to activities of the Garden Club, which used the house and grounds after the purchase of the house in 1961 by the Seguin Conservation Society. The wall buttress visible on the east wall extends around the southeast corner into this unit, and a step in the wall was visible in Unit 81-4. Signs of a trench next to the wall were visible in Level 3 of Unit 7-82 and in Level 3 of Unit 81-4. 


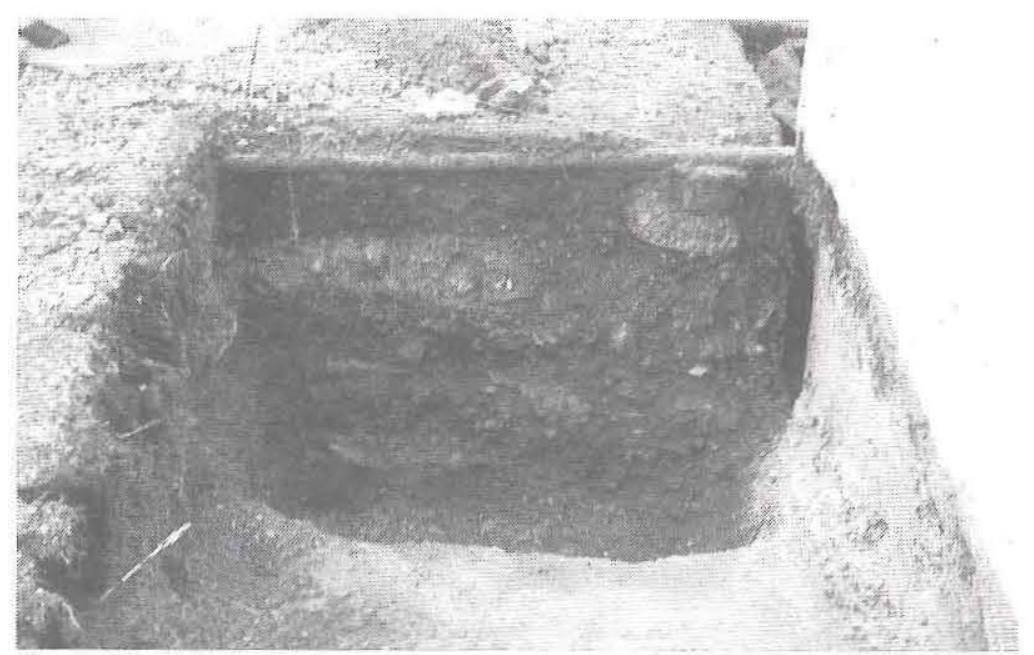

Figure 21. West profile of Unit 8-82 showing step in bedrock.

The primary features noted along the north wall were a trench and a short limecrete pier. Unlike the trench along the east wall, the trench along the north wall was between $2 \mathrm{ft}$ wide (in Unit 11-82) and $3 \mathrm{ft}$ wide (in Unit 1-82) at the bottom of Level 1. The bottom of the trench in Unit 11-82 was $0.9-1 \mathrm{ft}$ wide and cut $0.25 \mathrm{ft}$ into the bedrock (Figure 23a). This trench could have been a builder's trench in which soil and loose bedrock gravels were removed to expose a stable construction surface. A subgrade walkway was not evident in this area and would not have been necessary due to the

\section{West Wall}

Four units were excavated along the west side of the house (see Figure 18). From north to south, they are 16-82, the 1978 test unit, 15-82, and 14-82. Unit 15-82 overlapped the 1978 test unit. Unit 16-82 was placed on the south edge of the door leading into Room 3, Unit 15-82 was $4 \mathrm{ft}$ south of Unit 16-82, and Unit 14-82 was $4 \mathrm{ft}$ farther south at the south end of the west wall. All the 1982 units measured $4 \times 4 \mathrm{ft}$; the 1978 unit was $3 \times 1.5 \mathrm{ft}$ in size. The western wall was subject to more disturbance from plumbing than the east wall, with pipes running along the house wall in Units 15-82 and 14-82. Additionally, the area along the west wall was reported to have been used as a driveway as well as for pedestrian access to the rear of the house and was consequently subject to continuous disturbance.

When the house was fully restored in 1988, after the archeological excavations were complete, the entire area $4 \mathrm{ft}$ out from the house on all of the walls was excavated into bedrock for the purpose of laying a French drain.

\section{North Wall}

Excavation units along the north wall include Units $1-82$ to $6-82$ and $9-82$ to $13-82$. All except Units $2-82,3-82$, and 13-82 were adjacent to the wall. These other units were placed farther north (see Figure 18). The easternmost end of the north wall was not excavated. relative shallowness of the deposits.

A limecrete pier was found in Unit 9-82 (Figure 23b). It is approximately $1 \mathrm{ft}$ wide and $3 \mathrm{ft}$

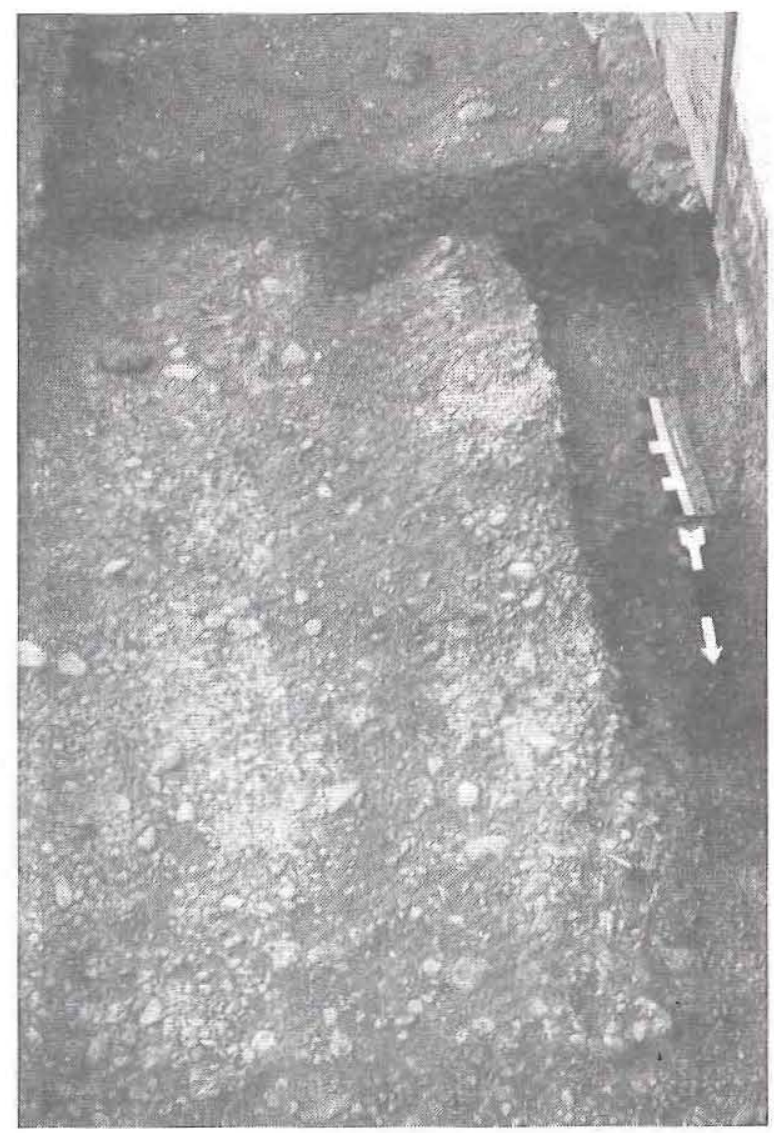

Figure 22. Trenches along east wall of the house; shallow channel is in center of photo, east of secondary trench. 


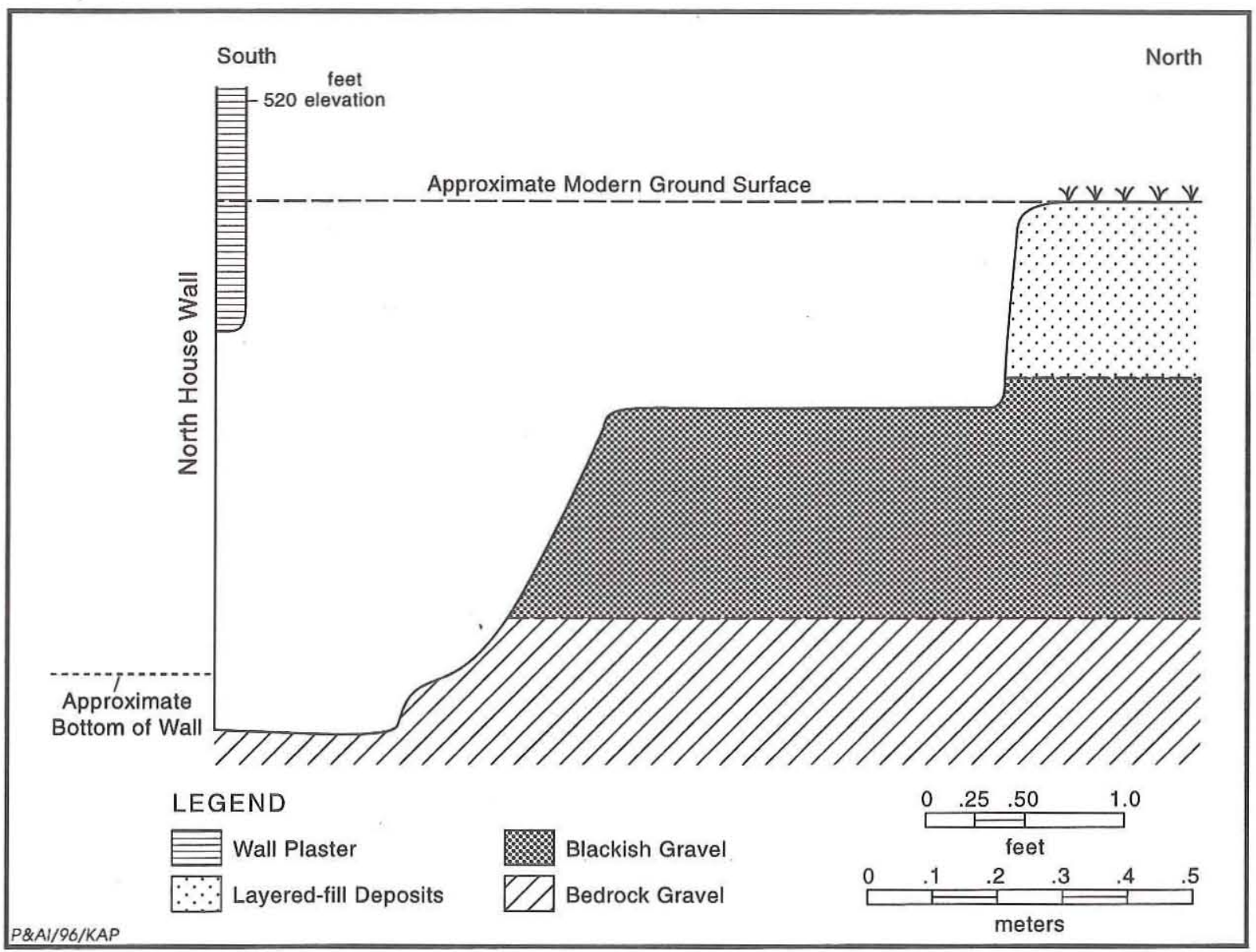

a

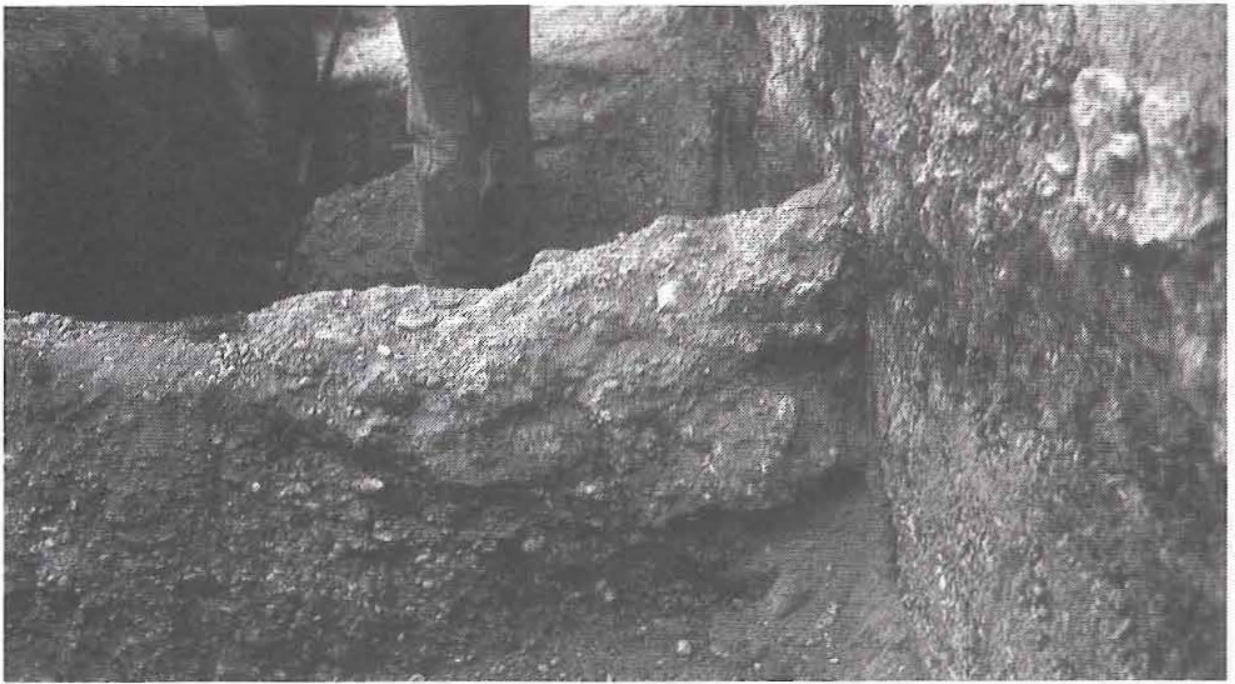

b

Figure 23. Excavations along north wall of the house. (a) Profile of trench; $(b)$ limecrete pier found in Unit 9-82. 
long, exiending perpendicular from the north wall. The pier was located approximately $3.5 \mathrm{ft}$ west of the door leading into the Dining Room. A corresponding pier was not located east of the doorway. It is believed that the pier was poured with the intention of placing at least one other corresponding pier on the east side of the door. These are believed to have been designed to support a porch or gallery above the door for the second-floor master bedroom exterior door. This second floor exterior doorway was discovered during the removal of all interior wall plaster during the 1981 field season. This doorway had been sealed with limecrete, suggesting that it occurred during the latter stages of house construction, possibly at the same time that the doorways in the porch perimeter wall were sealed.

\section{DEPOSITS IN THE YARD ,}

\section{The Cistern}

The cistern, originally a large cylindrical hole excavated into the bedrock, is located to the west of the house (see Figure 11). Intended as a water storage facility, the cistern was never completed and it came to be used as a periodic dumping site. Excavations took place over three seasons: 1978, 1982-1983, and 1983-1984. Unfortunately, primary field records for this feature are among those that can no longer be located.

The exact diameter of the cistern is not known, but extrapolation based upon remaining records suggests a diameter of around $15 \mathrm{ft}$ and a depth between 13 and $15 \mathrm{ft}$. The excavation unit and backhoe excavation locations suggested in Figure 24 are extrapolated from secondary records and photographs and are considered to be only approximate.

During the 1978 season, a 6-x-6-ft unit was positioned near the center of the cistern (Figure $24 a$ ). At a depth of $4-5 \mathrm{ft}$ below present ground surface, an old ground surface was encountered. Based upon materials lying on that surface, it was recognized that the upper 4 to $5 \mathrm{ft}$ of fill was of recent origin and probably occurred during the renovation of Sebastopol by the Seguin Conservation Society. Within the eastern edge of this unit, the opening to a septic tank was uncovered. Inquiry of local residents indicated that this feature was built in the 1930s. The excavation was extended to further explore the tank and associated previous ground surface. The top of the tank was bell shaped, made out of laid bricks, and extended to a depth of at least $9 \mathrm{ft} 4$ inches. At $4 \mathrm{ft}$ below its opening, the tank was $2 \mathrm{ft} 10$ inches in diameter with the lower portion of the feature filled with old boards and other architectural debris. The opening of the tank was surrounded by bricks, and at this level a 6-inch sewer pipe led into the tank from the house (Figure 25). This pipe no longer was connected to the house, but extrapolation of the path leads to Room 3 which oral history had indicated to be the location of the first toilet facility installed during the late 1930s. A backhoe was utilized during the last days of the 1978 fieldwork to attempt removal of the modern fill; however, time limits forced refill before the goals of the excavation could be realized.

In 1982-1983, two excavation units were dug in the northwest and southwest corners of the cistern adjacent to remnants of the bedrock rim of the cistern. Subsequent to this a backhoe was again used to remove the recent fill from the upper portions of the cistern. Three 4-x-4-ft excavation units were dug after the backhoe clearing of the cistern (Figure 24b). Near the end of the field season, a posthole auger was used to test below a thick layer of rubble associated with the $1960 \mathrm{~s}$ restoration of the house. This test was excavated down to approximately $10 \mathrm{ft}$ below the ground surface. The ceramics found in the lower levels of the test matched some of those found in the Kitchen.

The 1983-1984 season concentrated around a deep excavation of the cistern. The area cleared in the previous seasons was maintained, and new excavations began at this level. A unit was begun against the south wall of the cistern where no previous units had been excavated (Figure 24c). This unit was excavated to the bottom of the cistern, which was located at $15-16 \mathrm{ft}$ below present ground surface. With increasing depth, excavation walls were sloped and stepped to prevent collapse of the unstable side walls. The many levels of fill in the cistern largely consisted of gravels mixed with soil, crumbled limecrete or bedrock, and ash; these were of various grades of stability. With increased depth the unit became increasingly smaller so only an area of approximately $4 \times 2 \mathrm{ft}$ at the bottom of the cistern was exposed. This surface was similar to that of bedrock which had been exposed as walking surfaces for a period of time.

A large amount of debris removed from the house during the 1960 s restoration of Sebastopol was 


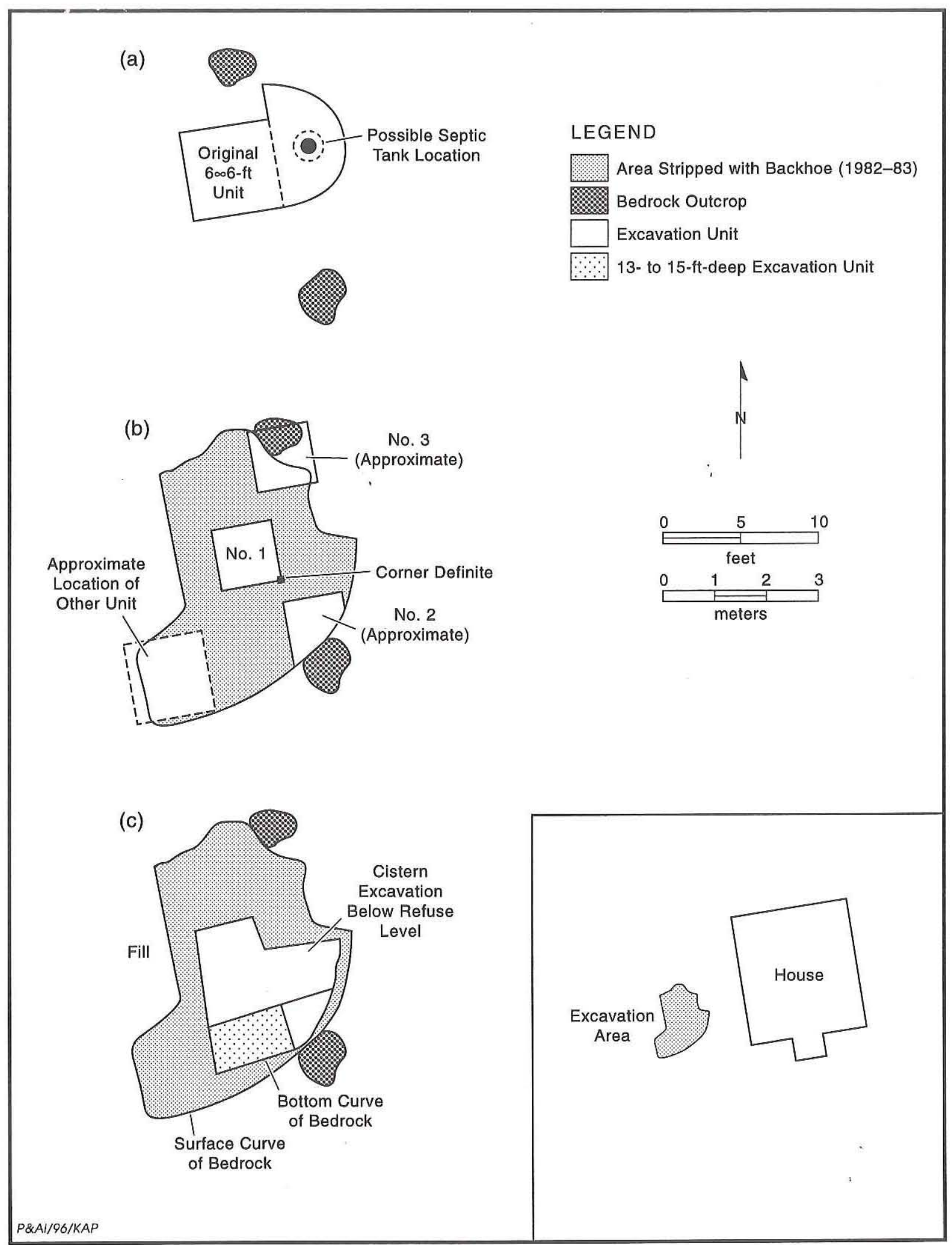

Figure 24. Excavation areas in and around the cistern. (a) 1978 excavations; (b) 1982-1983 excavations; (c) 1983-1984 excavations. 


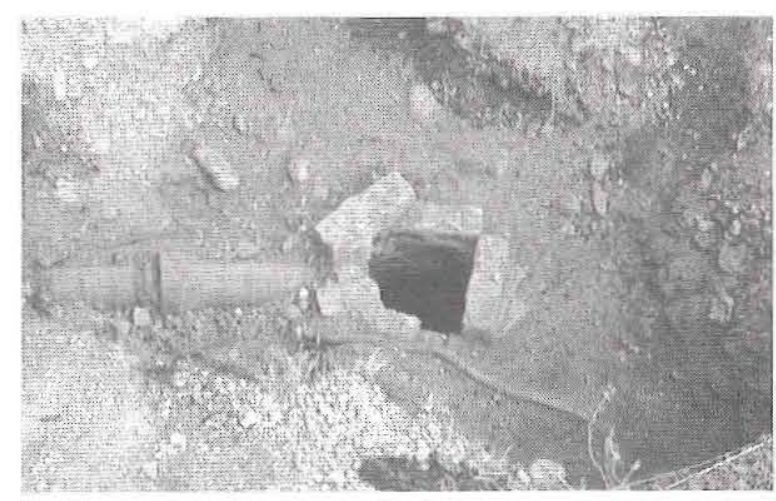

Figure 25. 1930s sewer pipe into cistern and septic tank.

dumped into the cistern. A level consisting primarily of architectural wood was located and excavated directly beneath the $4-5 \mathrm{ft}$ of recent fill. Door hardware was found with this wood, as were moldings and other household wood artifacts (Art Black, personal communication 1995). It is believed that during the renovations in the early 1960 s a great deal of damaged woodwork in the house was torn out and replaced. The discarded wood seems to have been deposited in the cistern and accounts for most if not all of the missing original doors and interior trim.

\section{Easement Trenches}

During the summer of 1980, the City of Seguin widened the bed of Walnut Branch, just to the north of Sebastopol, during construction associated with a flood control project. Specially funded archeological investigations were conducted during this construction in an agreement between the City of Seguin and TPWD. Two trenches were excavated in the area of the creek. One, running east-west, was $80 \mathrm{ft}$ long and $3 \mathrm{ft}$ wide (see Figure 11); the other, running north-south, was approximately $15 \mathrm{ft}$ long and $3 \mathrm{ft}$ wide. The east-west trench was divided into eight units, each $10 \mathrm{ft}$ long and numbered from east to west. Units $1,3,5,6$, and 8 were excavated. All of the north-south trench was excavated. The deposits consisted of varying levels of mixed soils and gravels. Since the soils were considered noncultural, the excavations were conducted using picks and shovels, and no screening of the sediments was done. Those artifacts seen during excavation were the only ones collected. A total of 197 artifacts were recovered from these excavation trenches, most of which were modern. 



\section{CERAMIIC SETS ANALYSIS}

Nearly 5,000 ceramic sherds have been recovered from the site. These represent a diverse collection of ceramic artifacts (primarily tableware) ranging from the LeGette period up to the 1940s. Due to the size of the ceramic collection and time constraints during analysis, only those decorated white earthenwares and porcelains that predate 1910 are analyzed and described in detail here. By restricting the age of the ceramics to pre-1910, the possibility of including ceramics deposited after the LeGette and Zorn occupations is reduced. An average time lag of 22 years has been suggested between the making of a ceramic vessel and its deposition in the archeological record (Adams and Gaw 1977). Using this time lag as a loose guideline, the 1910 date potentially eliminates ceramics used at the house after the 1930s or 1940s. Since Cal Zorn probably did not buy fancy ceramic sets after the death of his mother, any sets brought to the house after the 1930 s likely are not related to the Zorn family.

The study of only sets allows us to focus on those items that were used regularly as tablewares rather than cup and saucer sets or other odd pieces that were used in a more limited fashion, including as decoration throughout the house. During this time, many people-especially those living in remote areas-appear not to have been concerned with using matching sets of ceramics (Majewski and O'Brien 1987:179). At Sebastopol, however, there is ample evidence that sets were considered important. The remains of at least 15 matching sets are represented here. Of the 4,886 ceramic sherds excavated across the site, 687 are analyzed in this chapter. At least 99 vessels are represented by these sherds. This chapter provides a description of the different ware types and decoration styles before providing detailed descriptions and illustrations of the sets recovered at Sebastopol.

\section{WARES}

Late-nineteenth-century ceramic assemblages tend to be extremely complex due to the large number of different ceramic types from that period (Majewski and O'Brien 1987:129). The Sebastopol collection contains most of the ceramic types available after the mid nineteenth century-from ironstone to bone china-with varying decorations from molding to decals. The majority of the collection consists of decorated white-bodied tablewares, although stoneware is present as well.

The term "ironstone" is used inconsistently in the ceramics literature. Miller (1991:10) suggests that ironstone or white granite is a hard whitebodied ware that is often vitrified or semivitrified and that was the dominant type in use from the 1850 s until the 1890s. Majewski and O'Brien (1987:120) suggest, however, that the first type of ironstone was a fine, dense earthenware which competed well with oriental porcelain. By the mid nineteenth century, a heavier, unvitrified, less expensive ware (still called ironstone) had been developed by the Staffordshire potters for the frontier markets in Canada and the United States. Wetherbee (1985:15) has a listing of all the names that have been included under the term "ironstone." They include "ironstone," "granite china," "stone china," "granite," "white granite," "stone ware," "pearl china," and many others. Miller prefers' that the term "ironstone" be used only to describe "Mason's Patent Ironstone China" (Miller 1991). Using the term in this way would deny the fact that potters, collectors, and archeologists alike have used the term 
in a much broader context for over a century. The "ironstone" found at Sebastopol is the later, heavier type of ironstone produced in Staffordshire for export. Several producers are represented in the collection, with the most common being James Edwards and Sons.

Between 1870 and 1880, heavy-bodied, undecorated, or unmolded ironstones declined in popularity while lighter weight, molded whitewares with moredelicate floral or abstract decorations were preferred (Majewski and O'Brien 1987:114-115, 120, 123124). This shift is seen in the Sebastopol collections, which contain both the early, heavily molded ironstone and the floral transfer-printed and, later, decaled white earthenwares and porcelains.

The refined earthenware sets from Sebastopol tend to come from the Staffordshire potteries of England. One noted exception to this is a large set, highly represented in the collections, which was made in Trenton, New Jersey, by Burroughs and Mountford Company.

Porcelain is a vitreous and translucent whitebodied ware of which there are basically two kinds: hardpaste and softpaste. Bone china is considered a variety of softpaste porcelain, although it has properties intermediate between hardpaste and softpaste (Majewski and O'Brien 1987:126). Bone china is fired at a lower temperature than hardpaste porcelain, which means it can be decorated with a wider range of colors (Miller 1991:11). This type of softpaste porcelain is highly translucent and may show conchoidal fractures along breaks. If the glaze is crazed, the ware will stain. Hardpaste porcelains were made in China, Japan, and continental Europe and have a thick and glassy glaze (Majewski and O'Brien 1987:127). In separating the Sebastopol collection into hardpaste porcelain and bone china, an ultraviolet light was used; hardpaste porcelain shows up a magenta color under the light, while bone china shows up white or with a slightly pink hue. Only a few small sherds of hardpaste porcelain were found at Sebastopol, but these display the hand-painted, blue-hued decoration of Chinese porcelain. Also made of hardpaste porcelain are many of the dolls' heads excavated from the site.

Bone china sources identified at Sebastopol are Austria, Germany, Japan, and possibly France. Only two sets from Germany are represented, both likely dating after 1895. No porcelains from Great Britain were identified, which is curious given Majewski and O'Brien's (1987:129) conclusion that Great
Britain was the largest exporter of porcelain in the late nineteenth century.

Most porcelain vessels were decorated, with overglaze decoration being the most common technique on European porcelain before about 1880 . Cobalt, one of the sole colors able to withstand the high firing temperatures, dominated the underglaze decorations on porcelain (Majewski and O'Brien 1987:128).

\section{DECORATION TYPES}

\section{Annular}

Annular, otherwise known as dipped, banded, or slip banded, is the term used to describe hollow vessels with horizontal bands of colored slip. Annular vessels can have other decorations added such as mocha (dendritic designs), hand-painted swirls, and others. Most annular-decorated earthenware was produced in England between the late eighteenth century and the early twentieth century as an inexpensive ware for both local use and export (Majewski and O'Brien 1987:163), although some were made in the United States from at least the 1870 s to the 1920s (Ketchum 1987:48). In the United States, mocha on cream-colored ware reached its greatest popularity between 1795 and 1835 (Miller 1991:6). On yellowware, though, mocha was common only in the last half of the nineteenth century (Miller 1991:6). Colors on dipped wares are usually earth tones, such as brown, gray, ocher yellow, olive, rust, and tan; but blue is also sometimes seen (Miller 1991:6-7).

\section{Sponge-Stamped and Spatter}

Sponge-stamped designs generally are composed of repeated elements. These elements were created by applying the color with a sponge cut to create a design. The manufacturing process was invented in 1845 (Robacker and Robacker 1978:80), and price lists are available from 1848 until 1871 (Miller 1991:6). This decoration type was produced by British potteries throughout the nineteenth century (Majewski and O'Brien 1987:161). For their period, sponge-decorated wares were the least expensive decorated vessels available.

Spatter decorations were produced from the 1820 s to the 1860 s. Paint or powder was spattered or sprinkled on a piece to get an inconsistent spat- 
tered pattern. Majewski and O'Brien (1987:161163) group sponge and spatter decorations together because the terms are often, misleadingly, used interchangeably by collectors and archeologists.

\section{Molded}

Relief-molded decoration became popular on ironstone beginning about 1840 and continuing until well past 1900. Molded decoration from 1840 to 1870 included hexagonal and octagonal vessel forms with panels, ribs, and scallop shapes often included. Postbellum patterns included narrow ribbing over much of the vessel with naturalistic border motifs. In the early $1870 \mathrm{~s}$, the two primary shapes were plain, flowing curvilinear forms with minimal decoration and rectangular forms. Completely undecorated ironstones also became popular during this period. By 1890 , relief decoration had shifted to curvilinear delicate floral and abstract motifs consistent with the Art Nouveau movement on finer wares. By this time the traditional heavy ironstone was produced only as hotel and toilet wares, and relief molding was combined with decals, hand painting, and gilding. Many of the lighter, morevitreous wares were marketed as semiporcelain, no doubt in an effort to compete with the influx of translucent hardpaste porcelains being manufactured in Germany, Austria, and Bavaria. American-made ironstone began to compete with the British product after the Civil War. Many American-made vessels were plain and unmarked, with minimal relief decoration (Majewski and O'Brien 1987:154-155, 157).

\section{Transfer-Printed}

Transfer prints can be recognized by their underglaze, stippled appearance. In producing a transfer print, strong nonabsorbent tissue paper was impressed with an inked design from an engraved copper plate. The inked side of the paper was then applied to an unfired ceramic body and rubbed to exchange the ink. The piece was dipped in glaze and fired after the design was applied. A two-stage bat printing process was also used but was not as common. At least three sources explain in detail the steps of the transfer-printing process (Copeland 1982; Hughes 1961; Wyman 1980).

The very earliest transfer prints (1750-1780) were applied over the glaze, but after the 1780 s, all transfer prints on earthenware bodies were underglaze. Underglaze printing rarely was used on bone china because underglaze colors other than blue could not withstand the extreme firing temperatures required for these highly vitreous wares (Majewski and O'Brien 1987:128). Flow-printed designs were popular from 1835 until about World War I. Those designs from the late nineteenth and early twentieth centuries are distinctive due to their delicate molding and gilding (Majewski 1994b). Multicolored transfer prints requiring separate color applications and firings appeared about 1840 , and a method where blue, red, and yellow could be fixed from a single application in one firing was invented in 1848 . Brown and green were added to the combination in 1852. Printed ceramics with hand-painted detail date from as early as 1840 to ca. 1860 (Majewski and O'Brien 1987:143). Compared to decal designs, transfer-printed decorations' do not have sharp lines (Majewski and O'Brien 1987:146).

The demand for printed wares increased in the early 1870 s, and many Japanese-style patterns printed in brown on an ivory-tinted body were introduced during this period. Late-nineteenth-century prints have monochrome floral motifs around the rim or occasionally over the entire vessel, and they are often found in combination with molded and gilded designs and occasionally with hand-painted detail. Through time, printed designs became less complex and tended to occupy less of the vessel surface. As decals became less expensive in the early twentieth century, they generally replaced printed designs (Majewski and O'Brien 1987:142-143, 145-146; Miller 1991:7, 9).

There are good reference sources which provide the data needed to identify and source certain transfer-print designs (Pollan et al. 1996; Williams 1987; Williams and Weber 1986). Because designs were commonly pirated and duplicated, however, if the border and center patterns are not both present, a pattern identification can only be tentative (Pollan et al. 1996).

\section{Decaled}

This assemblage, like many othẹ latenineteenth-century and later assemblages, contains many decal-decorated ceramics. Decals are designs that were printed on film or paper and applied to the ceramic surface (Majewski and O'Brien 1987: 146). Decal decoration can be distinguished from 
transfer prints by several attributes: it is applied overglaze, maintains sharp lines and fine stipples, can have shading within the colors, and uses bright, clear, natural colors. A slight relief may be felt at the edges of a decal. Since decals usually are applied overglaze, the decal must be hardened-on in a decorating kiln (Majewski and O'Brien 1987:146).

Monochrome decals are engraved on a copper plate; this technology is older than lithography or photolithography, which were required to create polychrome decals (Majewski 1994b; Majewski and O'Brien 1987:128, 146-147). Monochrome decals with enameled fill were in use by 1885 (Majewski and OBrien 1987:147). Toward the end of the nineteenth century, floral decoration again became popular; decals were well suited to this task.

Decal decoration was used primarily on imported porcelains before 1900 (Majewski and O'Brien 1987:147). After the turn of the century, decal-decorated ceramics became more affordable than printed ceramics, and up to at least 1950, decals were still the most popular decoration types on dinnerware (Taylor 1950, quoted in Majewski and O'Brien 1987:147). The American ceramics industry was supplied with decals mostly by German and French firms until the 1930s, when Americanmade decals became available (Majewski and O'Brien 1987:147).

There is no necessary one-to-one correspondence between manufacturer and decal pattern, as decal producers sold to many ceramics manufacturers. Decals, therefore, are difficult to source. They are also difficult to date except for the relative dates of monochrome and polychrome decals. Dating a decaled vessel can sometimes be achieved by a backmark, however, and also by any other decoration techniques used on the vessel.

\section{Enameled}

Enameled decoration is painted over the glaze. A wider range of colors is available for enameled decoration, which, unlike underglaze painting, does not have to withstand the high temperature of the glost or glazing oven (Miller 1991:7). Enamel painting also produces a sharper image because the colors do not melt into the glaze. Because overglaze decoration requires an additional firing in the hardening-on oven, this type was more expensive than underglaze painted wares. The disadvantages of this decoration type are that the color can be worn away during use (Miller 1991:7).

\section{Painted}

Unlike enameled pieces, which could be painted anytime after the ceramic was fired, underglaze painted decoration was part of the factory system. During the 1870 s, large painted floral polychrome motifs resurged in popularity on table and tea wares (Miller 1991:8).

\section{Luster}

Lusterware is pottery that has a metallic cast to its decoration. It was popular in the nineteenth century and was produced in large quantities by British potters (Gibson 1993:3). Luster colors in shading and stenciling were popular in the nineteenth and early twentieth centuries. Sherds with luster decoration are common on nineteenth-century sites, often occurring on tea wares. Platinum oxide and gold were used to produce luster in its many varieties. The stencil process in reverse is termed "resist decoration." This decoration type commonly is used in combination with luster (Majewski and O'Brien 1987:164).

The copper tea leaf luster color of a "luster band" set made by Meakin is described in a Sears, Roebuck and Company (1897:681) catalog as "a heavy luster band and a flower sprig in luster which resembles gold very closely but will not wash off as gold is apt to do." This catalog indicates the availability of this pattern decorated underglaze until the turn of the century. Majewski and O'Brien (1987:160) describe the original tea leaf luster pattern introduced in the $1850 \mathrm{~s}$ as an overglaze decoration on semivitreous ironstone. Initially, the design outline was printed in dark green, black, or purple on the vessel surface before glazing and firing, after which the copper or gold luster was applied by hand. Thin luster bands often were added. This overglaze gilt often wore off during use (Wetherbee 1985:150). From approximately 1880 to 1900 , the perfected underglaze variety of the tea leaf pattern was extremely popular (Majewski and O'Brien 1987:160).

\section{Gilded}

Gilding is probably the most common decorative technique in the Sebastopol assemblage. Single 
or multiple gold stripes around the borders were used to decorate sets of white-bodied wares with many vessel forms. The very bright gold gilding postdates 1860 (Majewski and O'Brien 1987:161).

\section{Majolica}

Bold, multicolored glazes on somewhat coarse, buff-colored earthenware were popular in America and England during the last half of the nineteenth century. These wares were reminiscent of the tinglazed majolicas made in Italy, Spain, and Mexico after which they were named. American-made majolica was decorated with low-relief patterns of molded leaves, shells, seaweed, or complex Orientallike designs. The most popular colors were pink, green, turquoise, and light blue that were applied underglaze (Denker and Denker 1982:134; Godden 1991:xxv).

English majolica was introduced by Minton around 1850 and was painted by their leading artists. This early attempt was made to emulate the Italian maiolica, which was an earthenware coated with an opaque white glaze or slip with a design painted on it. Within a few years, the term "majolica" was used to describe all Victorian earthenwares decorated with semitranslucent glazes (Godden 1991:xxv-xxvi; Snyder and Bockol 1994:6). Majolica was most popular through the $1890 \mathrm{~s}$, and some continued to be made up until World War I (Snyder and Bockol 1994:49).

\section{DECORATIVE STYLES}

The following discussion of late-nineteenth-and early-twentieth-century decorative styles on English and American ceramics is summarized from Majewski (1994b). A few vessels in the assemblage are decorated in patterns possibly based on the Aesthetic Movement of the 1870s-1880s. Japanese-influenced designs exhibited at the Philadelphia Centennial in 1876 stimulated a widespread interest in Japanese art in the United States. Japanese or pseudo-Japanese motifs included sprays of cherry blossoms, sparrows, diaper patterns, fan shapes, or sunflowers placed asymmetrically. Ceramics were decorated in this style using several techniques, including underglaze transfer printing in muted greens and browns and also in red, black, blue, and blue-black; overglaze enameling, occasionally as accents; gilding; and luster. Transfer printing was revived as part of this movement, and the use of subdued colors was a reaction to the bright, harsh colors of the mid nineteenth century. Turquoise and other bright overglaze colors were used on porcelains, and pastels were used on Victorian majolicas (Majewski 1994a:5).

Art Nouveau-influenced patterns are common in the Sebastopol assemblage. This 1890s-ca. 1910 style employs curvilinear elements and is typified by natural forms. Common motifs were stylized plant forms and scrolls. Major decorative techniques include enameling and painting, aerography, matte glazes, decals, gilding, and luster. Aerography, a technique developed at Rookwood Pottery in 1884, involves application of color with an atomizer to produce blending and shading of colors, and it was used to apply background color on inexpensive porcelains and earthenware. "By the 1890 s, Japanese style was no longer popular in ceramics, but asymmetrical placement of transfer-printed floral sprays continued as did use of muted hues and restrained handpainted color accents and gilding" (Majewski 1994a:6). Flow blue printing experienced renewed popularity on thin-bodied wares with relief molding. Vessels with printed Chinoiserie patterns often had painted or enameled luster accents and other light-color washes (Majewski 1994a:6), as is seen in the Timor pattern plate in the assemblage. Art Nouveau motifs were very popular with amateur china painters.

The Art Deco style, dating from the 1910s until the 1930 s, consisted of regular and abstract patterns. This style is uncommon in the Sebastopol assemblage. In this style, motifs such as plants were repeated, rather than being flowing or asymmetrical. Patterns in the 1920s were dynamic and diverse, while those of the 1930s were more restrained and symmetrical. Decorative techniques included painting and enameling, decals, the use of bright or primary colors, stenciling, aerography, colored glazes, and luster. Decals were especially popular in the 1920 s and 1930 s.

\section{CERAMIC SETS}

In total, 15 ceramic sets (Sets A-O) were identified in the Sebastopol collection. Within these sets, a minimum of 99 vessels are represented by 687 sherds (Table 1). The majority of these sherds, 525 , were excavated from beneath the floor of the Kitchen, while 118 were excavated from the cistern. 


\begin{tabular}{|c|c|c|c|c|c|c|c|c|c|c|c|c|c|c|c|c|}
\hline \multicolumn{17}{|c|}{$\begin{array}{c}\text { TABLE } 1 \\
\text { DISTRIBUTION OF SHERDS FROM SETS }\end{array}$} \\
\hline Sets & A & B & $\mathrm{C}$ & D & $\mathrm{E}$ & $\mathrm{F}$ & G & $\mathrm{H}$ & I & $\mathrm{J}$ & $\mathrm{K}$ & $\mathrm{L}$ & M & $\mathrm{N}$ & $\mathrm{O}$ & $\begin{array}{l}\text { Total } \\
\text { by Area }\end{array}$ \\
\hline $\begin{array}{l}\text { Room } 5 \\
\text { Room } 6 \\
\text { Room } 7 \\
\text { Room } 8 \\
\text { Cistern } \\
\text { East Wall } \\
\text { South Wall } \\
\text { No Provenience }\end{array}$ & 73 & 1 & $\begin{array}{r}16 \\
3\end{array}$ & 60 & $\begin{array}{l}4 \\
4\end{array}$ & 7 & 3 & $\begin{array}{l}10 \\
16\end{array}$ & $\begin{array}{r}8 \\
2 \\
32 \\
4 \\
1 \\
1\end{array}$ & 6 & $\begin{array}{l}4 \\
1 \\
2 \\
2\end{array}$ & 50 & 46 & 19 & 5 & $\begin{array}{r}534 \\
7 \\
3 \\
2 \\
118 \\
6 \\
1 \\
25\end{array}$ \\
\hline Total by Set & 75 & 60 & 85 & 66 & 9 & 19 & 35 & 128 & 48 & 9 & 9 & 56 & 56 & 19 & 13 & 687 \\
\hline MNI per Set & 6 & 8 & 10 & 11 & 3 & 5 & 4 & 20 & 7 & 4 & 2 & 6 & 6 & 3 & 4 & 99 \\
\hline
\end{tabular}

Some of the sets are represented by sherds from both the cistern and the Kitchen, and when crossmends are seen between the two areas, this is stated. This connection between the Kitchen and the cistern is evidence of Kitchen waste being deposited in the cistern. When measurable, the diameter and height of the vessels are recorded.

\section{Set A: Cherry Blossom and Clamshell}

Count: 75 sherds representing at least 6 vessels

Vessel Types: 3 cups $(9.5 \mathrm{~cm}$ in diameter, $7.6 \mathrm{~cm}$ high), and 3 saucers $(16.4 \mathrm{~cm}$ in diameter) Paste: Bone china

Description: The pattern found on these pieces consists of molded clamshell swags at the rim with a scalloped edge (Figure 26). The swags were air brushed in two colors, and gilding was applied around the edge. A monochrome decal of cherry blossoms is incorporated on the bodies of the pieces. Gilding and molding are present around the cup depression in the saucer and around the footring on the cup. The cup handle is gilded on one side. Color combinations include peach and purple-blue swags with a cherry red decal, pink and yellow swags with a blue decal, and salmon and green swags with a purple decal. Seventy-three sherds are from the Kitchen, and two are from the cistern. This represents a formal tea set, most likely reserved for afternoon teas.

\section{Set B: Lilac Decal}

Count: 60 sherds representing a minimum of 8 vessels

Vessel Types: 4 bowls (13.2 $\mathrm{cm}$ in diameter), 1 cup, 1 plate (approximately $21.4 \mathrm{~cm}$ in diameter), 1 saucer (15.1 cm in diameter), and 1 other

Paste: Bone china

Description: The pattern consists of either a green and purple, green and pink, or green, orange, and purple decal of lilac leaves, branches, and blooms (Figure 27). The maker's mark is green printed with "Austria" over a Prussian double-headed eagle and "MZ" below it. An orange enameled " 87 " is also present on the base of at least one vessel. The maker is Moritz Zdekauer of Altrohlau, Bohemia, producers of earthenware and porcelain from 1884 until 1909 (Kovel and Kovel 1986:94). The inclusion of "AUSTRIA" indicates a probable post-1891 date (Godden 1991:11). Nine sherds are from the cistern, 50 are from the Kitchen, and 1 sherd has no provenience recorded.

\section{Set C: Grass and Flowers Decal}

Count: 85 sherds representing a minimum of 10 vessels

Vessel Types: 1 compote, 2 cups $(7.6 \mathrm{~cm}$ in diameter), 2 plates (18.9 $\mathrm{cm}$ in diameter), 3 saucers (13.9 $\mathrm{cm}$ in diameter), $1 \mathrm{small}$ bowl, and 1 other

Paste: Bone china

Description: The pattern on this set varies from vessel to vessel. Each decal is outlined in orange and is a combination of flowers and grass (Figure 28). The decals are enameled over in blue, pink, and green (two shades of each). There is gilding on the edges 


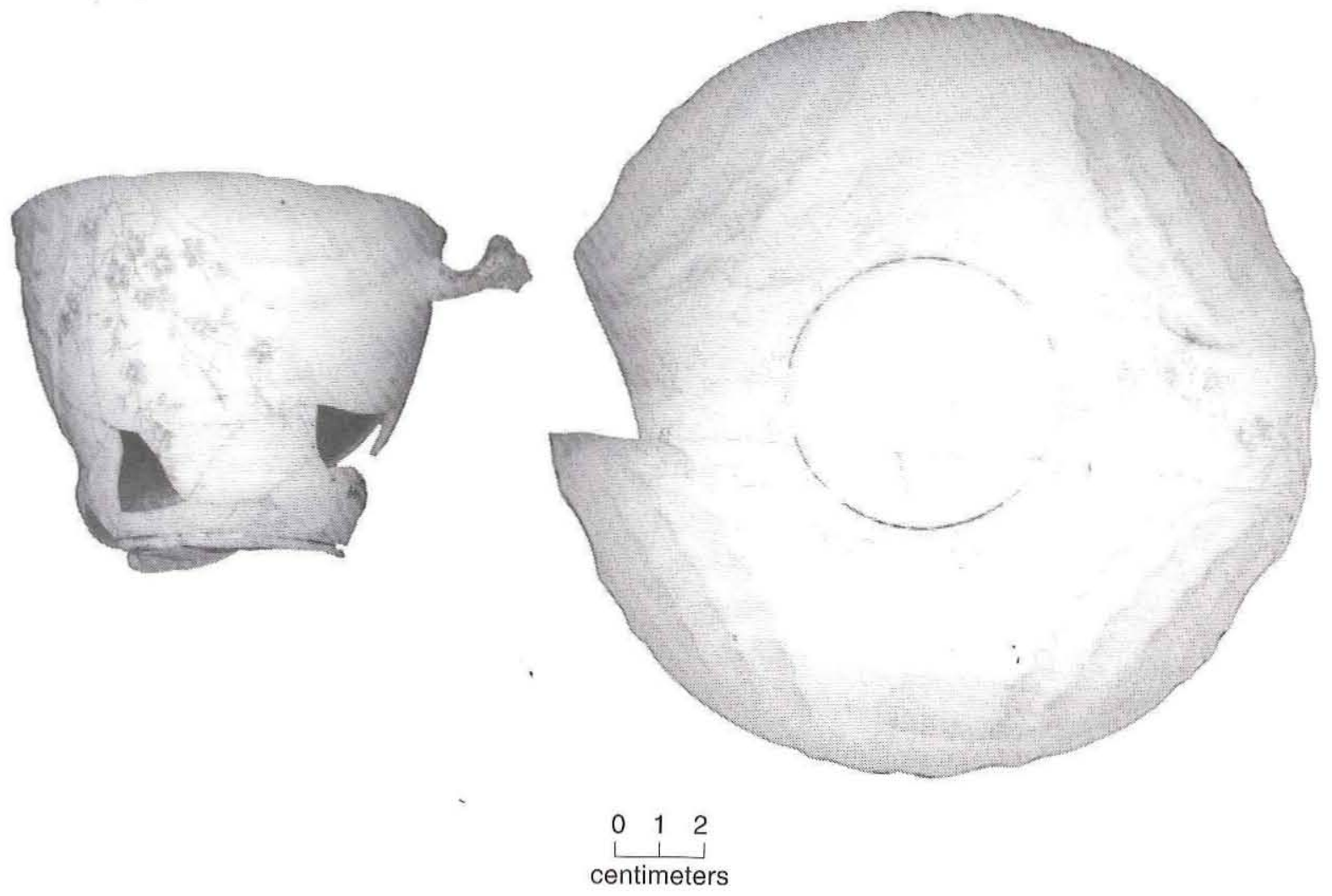

Figure 26. Cherry blossom and clamshell cup and saucer.
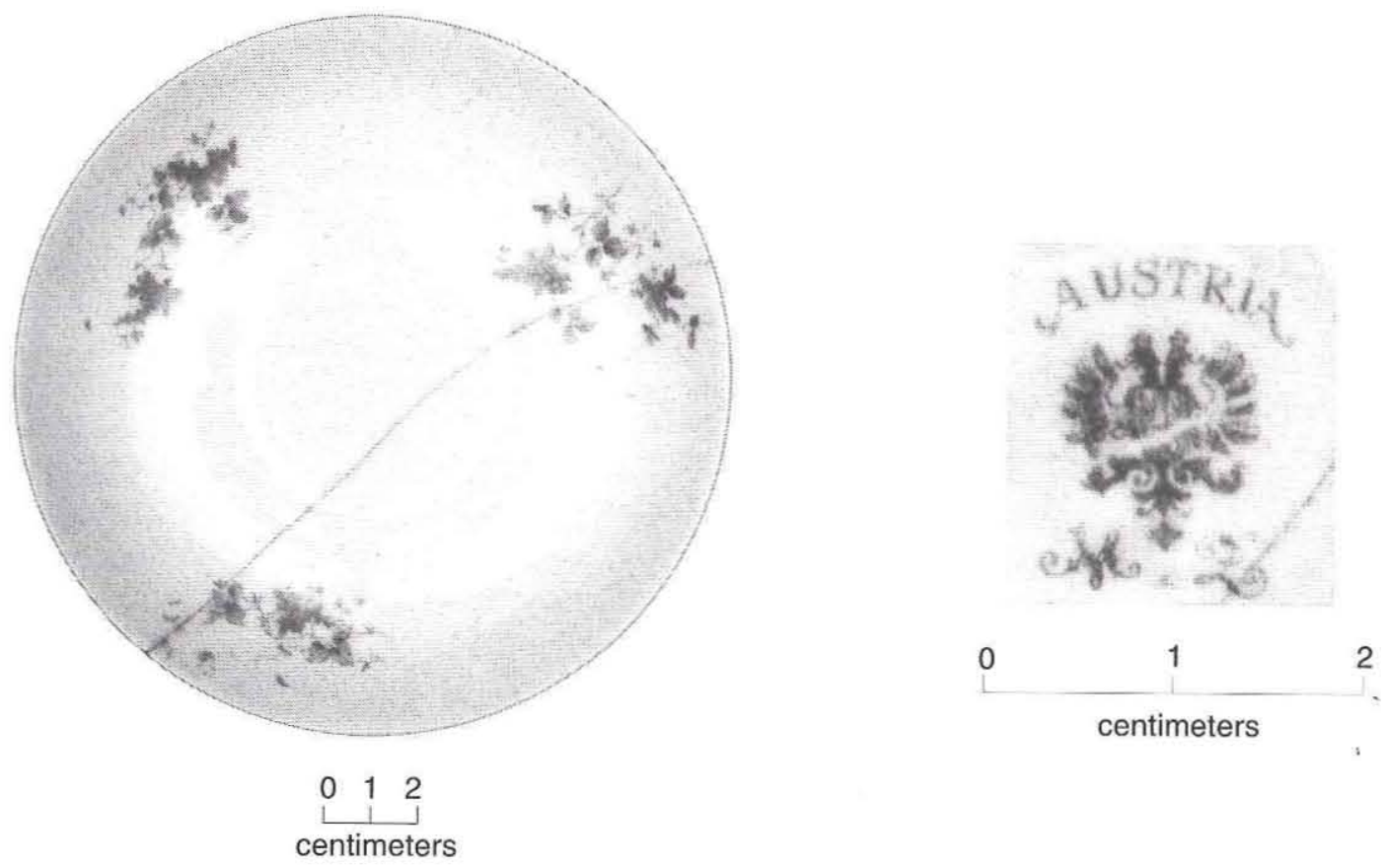

Figure 27. Lilac decal and mark. 


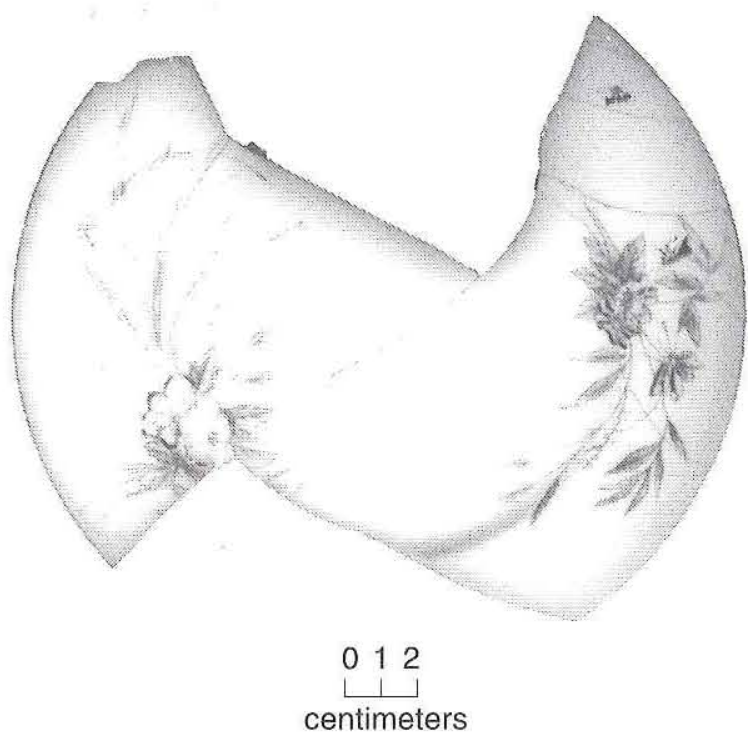

Figure 28. Grass and flowers decal.

of each piece. The maker's mark is printed in green: "D \& Co." This mark is similar to that used by R. Delinieres \& Co. of Limoges, France, makers of porcelain from 1879 to 1900 (Kovel and Kovel 1986:170). The mark lacks a country of origin, indicating a pre-1891 date. In 1891, the McKinley Tariff Act went into effect, requiring the country name on each piece of china imported to the United States (Godden 1991:11). Sixteen sherds were recovered in the cistern, 2 in the Dining Room, and 64 in the Kitchen; three have no provenience recorded.

\section{Set D: Rose Decal}

Count: 66 sherds representing a minimum of 11 vessels

Vessel Types: 1 bowl, 2 cups, 4 saucers $(14.5 \mathrm{~cm}$ in diameter), and 4 small plates $(17.6 \mathrm{~cm}$ in diameter)

Paste: Bone china

Description: This set has a double scalloped edge, the outer of which is feathered with gilding. The cup ring on the saucer is outlined with a thin stripe of gilding. The decal decoration consists of shaded pink or purple roses with yellow to green stems and leaves (Figure 29). The green printed maker's mark consists of "KPM" with a vertical line above the "P." An encircled "MADE IN GERMANY" backmark is printed in orange ink. On some pieces, "1869" has been enameled. The maker may have been the Carl Krister Porcelain Manufac-

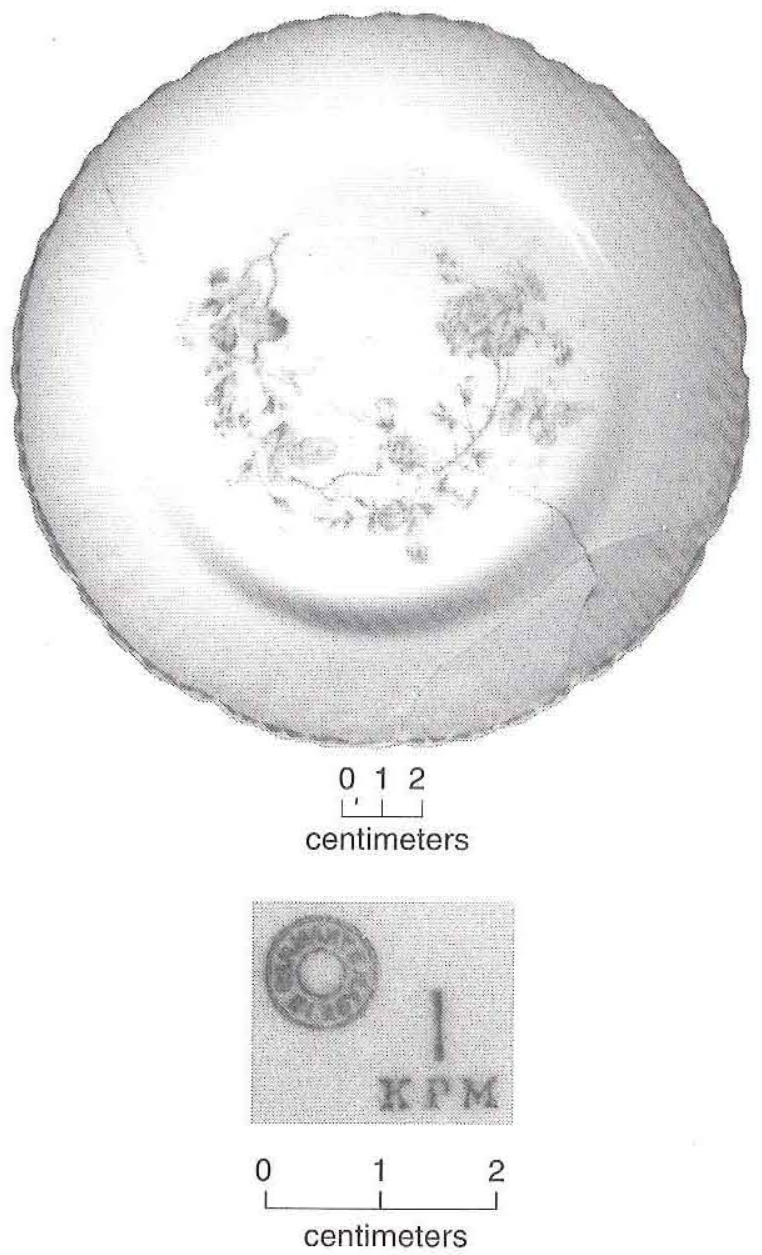

Figure 29. Rose decal and mark.

tory, Waldenburg, Silesia, Germany, made after 1885 (Kovel and Kovel 1986:183). The mark on these pieces is similar to one produced by this manufactory but is lacking periods after the letters (Cushion and Honey 1980:93; Kovel and Kovel 1986:183). The "Made in Germany" mark indicates either a post-1887 date (Kovel and Kovel 1986:231) or a post-1891 date (Godden 1991:11). Six sherds were recovered from the cistern and 60 from the Kitchen. This may have been a tea set.

\section{Set $\mathbb{E}$ : Double Swag}

Count: 9 sherds representing a minimum of 3 vessels

Vessel Types: 3 cups $(8.8 \mathrm{~cm}$ in diameter, $6.3 \mathrm{~cm}$ high)

Paste: Ironstone 
Description: This set of cups is ribbed at the base and part way up the body from the base. A double molded ribbed swag decorates the base just above the footring (Figure 30). One sherd was recovered from the cistern, 4 from the Dining Room, and 4 from the Kitchen.

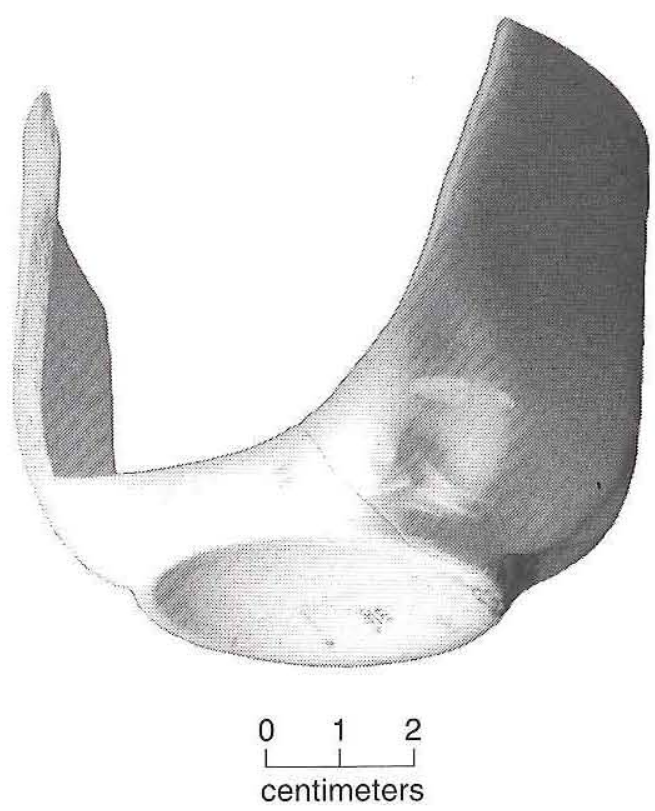

Figure 30. Double swag cup.

\section{Set F: Thistle Decal}

Count: 19 sherds representing a minimum of 5 vessels

Vessel Types: 2 saucers $(15.1 \mathrm{~cm}$ in diameter), 2 cups $(9.5 \mathrm{~cm}$ in diameter), and 1 plate

Paste: Refined earthenware

Description: The decal on this set is a pink, white, and green thistle which repeats around the vessels (Figure 31). The saucer and plate are molded around the rim, and all pieces have gilding on the rim. A very small portion of a green-blue printed mark is present but unidentifiable. Seven sherds were found in the cistern and 12 in the Kitchen. The teacup has a flared rim. The plate, cup, and saucer are all gilded around the rim.

\section{Set G: Fruit Design}

Count: 35 sherds representing a minimum of 4 vessels

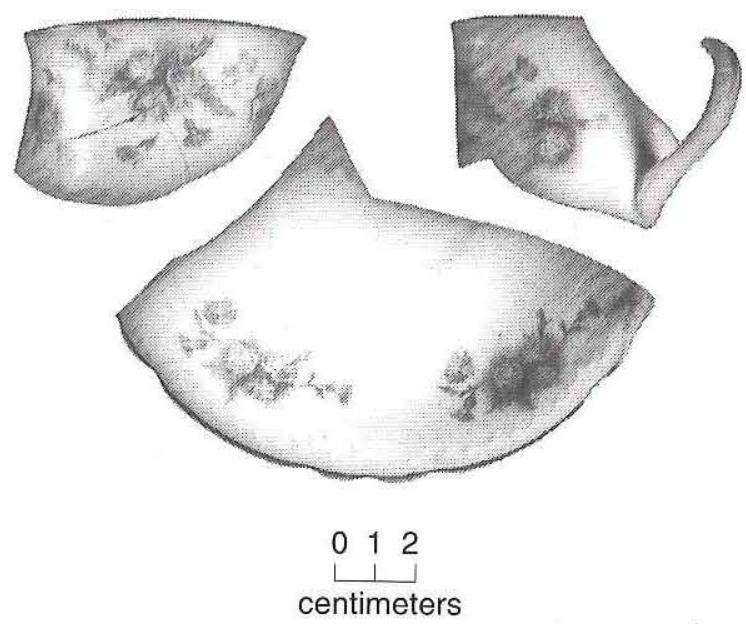

Figure 31. Thistle decal.

Vessel Types: 1 cup, 2 large plates $(20.2 \mathrm{~cm}$ in diameter), and 1 small plate $(16.4 \mathrm{~cm}$ in diameter); an additional vessel, a soup bowl or plate, is on display at Sebastopol.

Paste: Bone china

Description: These pieces are gilt around a scalloped edge. Below the edge is a $1.6-\mathrm{cm}$-wide enameled band in either pink, blue, or purple, outlined in black. Two more lines of gilding run below this enameled band. The centers of the plates have enameled, polychrome fruit designs (Figure 32). The cup fragment has gilding on the edge abutting an enameled purple band which has an uneven lower edge bordered by an enameled, dark maroon line. The mark is a green-printed "KPM" with a vertical line above. As with Set D, the maker may have been the Carl Krister Porcelain Manufactory (post1885) (Kovel and Kovel 1986:183). Because no country of origin is incorporated in the mark, these pieces most likely date between 1885 and 1891 . Nine sherds were found in the cistern and 23 in the Kitchen; no provenience was recorded for 3 sherds. Another vessel from this set is on display at Sebastopol State Historic Park. This piece is a soup bowl or plate 6.5 inches in diameter.

\section{Set H: Star Flower Pattern}

Count: 128 sherds representing a minimum of 20 vessels

Vessel Types: 1 butter pat, 1 cup or bell $(6.9 \mathrm{~cm}$ in diameter), 2 demitasse cups $(6.3 \mathrm{~cm}$ in diameter, $5.0 \mathrm{~cm}$ tall), 1 dish cover, 1 large hollow 


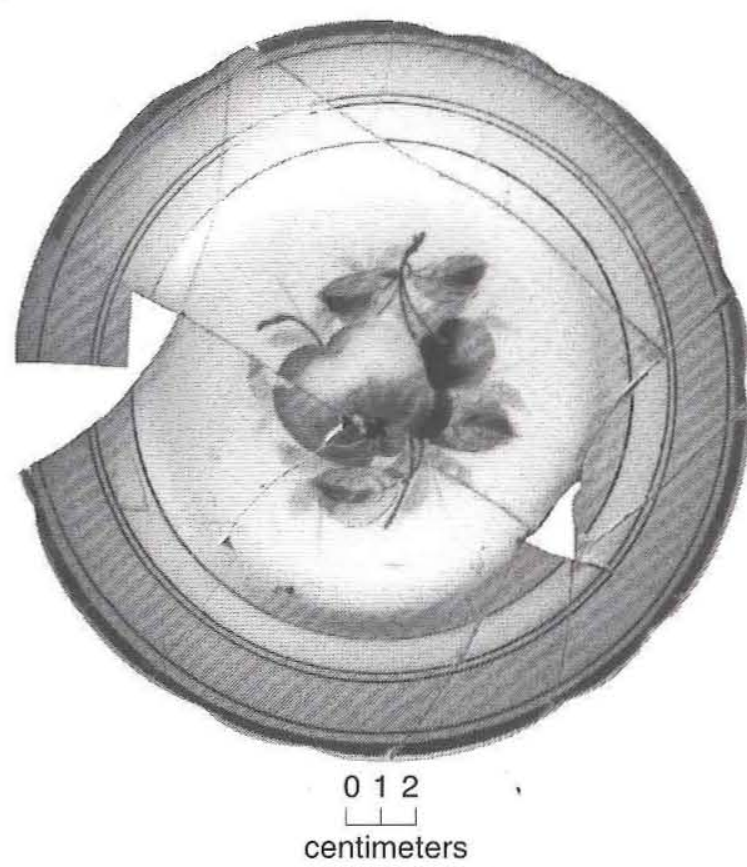

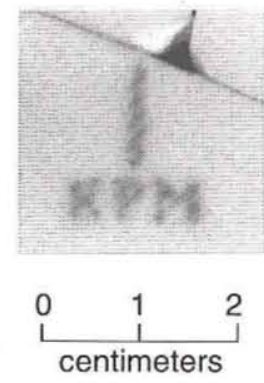

Paste: Bone china

Description: This pattern is a transfer print with phoenix birds and flowers. There are three birds repeating around each piece, and an edge pattern is present (Figure 34). The printed base mark only says "MADE IN JAPAN," making it a post-1887 pattern, and most likely from the twentieth century (Kovel and Kovel 1986:231). The pattern, used for over 100 years, is known as "Flying Phoenix," "Flying Turkey," and "Ho-o," and is still being produced (Banks 1983:149). Thirty-two sherds were recovered from the cistern, 8 from the Kitchen, 2 from Room 7, 4 from along the east exterior wall, and 1 from along the south exterior wall; 1 sherd no longer maintains its provenience. The Japanese style was most popular from the late 1870 s through the 1880s (Majewski 1994a:5), although Kovel and Kovel (1986:229) give a possible date of 1921 for the earliest use of the word "Japan" as part of a mark.

\section{Set J: Rosaline}

\section{Set I: Phoenix Pattern}

Count: 48 sherds representing a minimum of 7 vessels

Vessel Types: 2 bowls ( $13.2 \mathrm{~cm}$ in diameter), 2 cups $(8.8 \mathrm{~cm}$ in diameter), and 3 saucers
Count: 9 sherds representing a minimum of 2 vessels

Vessel Types: 1 cup ( $6.9 \mathrm{~cm}$ in diameter), and 1 saucer (13.9 cm in diameter); another cup and saucer set is on display at Sebastopol. 

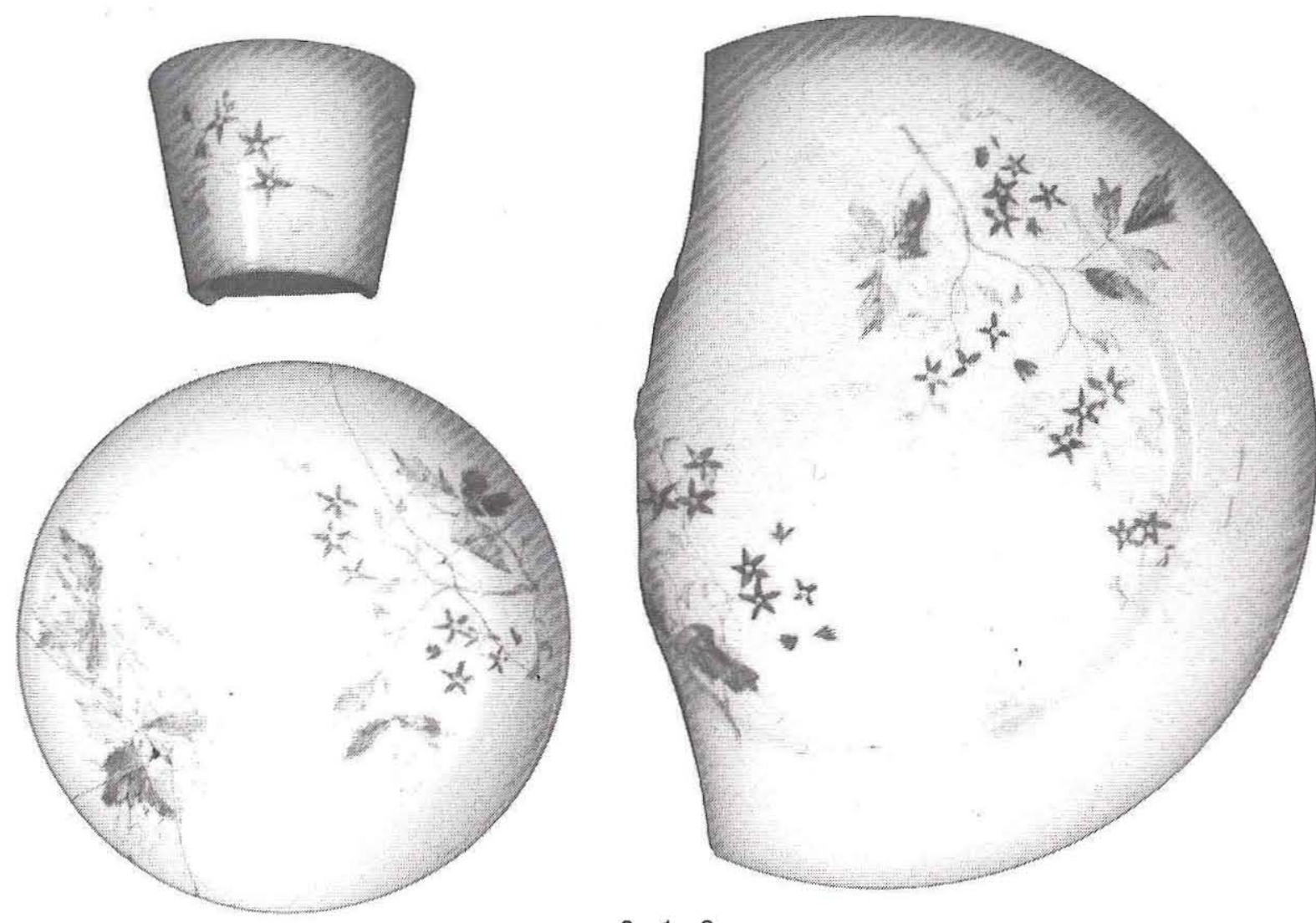

$\begin{array}{lll}0 & 1 & 2\end{array}$

centimeters

Figure 33. Star flowers pattern.

Paste: Refined earthenware

Description: These pieces are decorated with a brown transfer print of flowers and leaves and a rim with a fan and triangle motif (Figure 35). Over the print, flowers are painted blue with red centers. Some of the leaves are painted yellow. The enameling was done underglaze. The mark is printed: "PARISIAN GRANITE/ROSALINE PATTERN/ ALFRED MEAKIN/ENGLAND/4" all under a crown. Alfred Meakin was a Staffordshire potter in business in Tunstall from 1875. This mark, lacking "Ltd" after the name, indicates a pre-1897 date, while the presence of "England" indicates a post1891 date (Godden 1991:425-426). The brown transfer print with enamel indicates a date of 1870 to 1900 (Majewski 1994a:5). Three sherds were recovered from the cistern and six from the Kitchen.

\section{Set K: Gothic Hawthorn}

Count: 9 sherds representing a minimum of 2 vessels

Vessel Types: 1 cup and 1 saucer (included in the sets due to the potential age of the pieces)

Paste: Ironstone

Description: This set is covered in a repetitive blue transfer-print design of small circular white reserves filled with hawthorn blossoms and separated by seaweed (Figure 36). No mark is visible, but a known maker of this pattern was Livesley Powell \& Co. (Williams and Weber 1986:28), a Staffordshire pottery from Old Hall Lane and Miles Bank, Hanley, England. The company was in business from 1851 to 1866 and subsequently became Powell and Bishop (Godden 1991:392). Four sherds were 

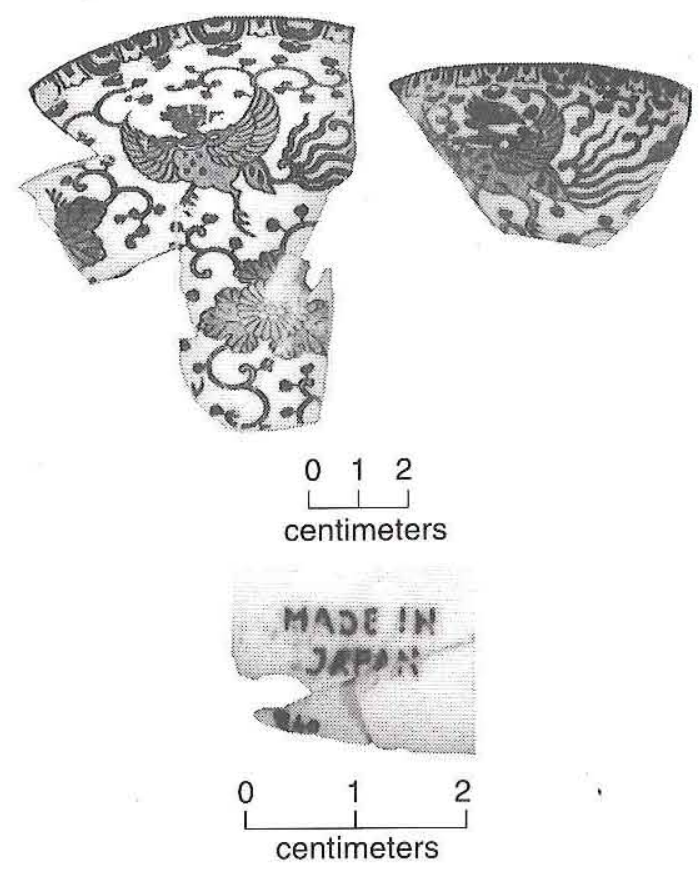

Figure 34. Phoenix pattern and mark.

found in the Kitchen, one in Room 7, two along the east wall, and two in Room 8.

\section{Set L: Molded and Gilded Petals}

Count: 56 sherds representing a minimum of 6 vessels

Vessel Types: 1 bowl (13.2 $\mathrm{cm}$ in diameter), 2 cups $(8.8 \mathrm{~cm}$ in diameter), 2 plates $(18.9 \mathrm{~cm}$ in diameter), and 1 saucer $(15.1 \mathrm{~cm}$ in diameter)

Paste: Bone china

Description: The cups of this set are ribbed, while the bowl, plates, and saucer are molded like petals with scalloped edges (Figure 37). A wide band of gilding runs around the rim over a narrow band. Gold rings decorate the center of at least the plates and saucer. The footrings of the cups are encircled with gilding. The mark on the saucer is an orange-enameled "14," while one on a plate is a teal-enameled "7." Five sherds were excavated from the cistern and 50 from the Kitchen; 1 no longer maintains its provenience.

\section{Set M: John Maddock and Sons}

Count: 56 sherds representing a minimum of
6 vessels

Vessel Types: 2 bowls $(17.0 \mathrm{~cm}$ in diameter), 2 plates $(20.2 \mathrm{~cm}$ in diameter), and 2 unknown vessels

Paste: Refined earthenware

Description: This set is not decorated, but the glaze pooled a slightly blue-green color. The mark is a crown and scepter on a pillow over "TRADE MARK/ROYAL SEMI.PORCELAIN/JOHN MADDOCK \& SONS/ENGLAND" (Figure 38). The maker is John Maddock and Sons, a Staffordshire potter from Newcastle Street and Dale Hall, Burslem, England. The mark dates to ca. 1906 or later (Godden 1991:406). Ten sherds were excavated from the cistern and 46 from the Kitchen.

\section{Set N: Henry Alcock}

Count: 19 sherds representing a minimum of 3 vessels

Vessel Types: 3 saucers $(12.6 \mathrm{~cm}$ in diameter)

Paste: Refined earthenware

Description: This set is not decorated, only covered in a clear glaze. The mark is Henry Alcock \& Co. from Cobridge, England; it incorporates a British Royal Arms and the word "SEMI-PORCELAIN" (Figure 39). The mark (Godden 1991:27) dates 1880-1910, although inclusion of "England" and lack of "Ltd." indicate a date range of 18911899. All 19 sherds were recovered in the Kitchen.

\section{Set O: Molded and Dimpled}

Count: 13 sherds representing a minimum of 4 vessels

Vessel Types: 3 small bowls $(13.9 \mathrm{~cm}$ in diameter) and 1 large oval bowl

Paste: Refined earthenware

Description: The pieces are lightly molded on a shallow marly with gilding around the rim and the inside base. There is no mark on any of these pieces. Eight sherds were recovered from the cistern and five from the Kitchen.

\section{IRONSTONE ANALYSIS}

Within the Sebastopol ceramics, the ironstone group, consisting of 229 sherds representing at least 

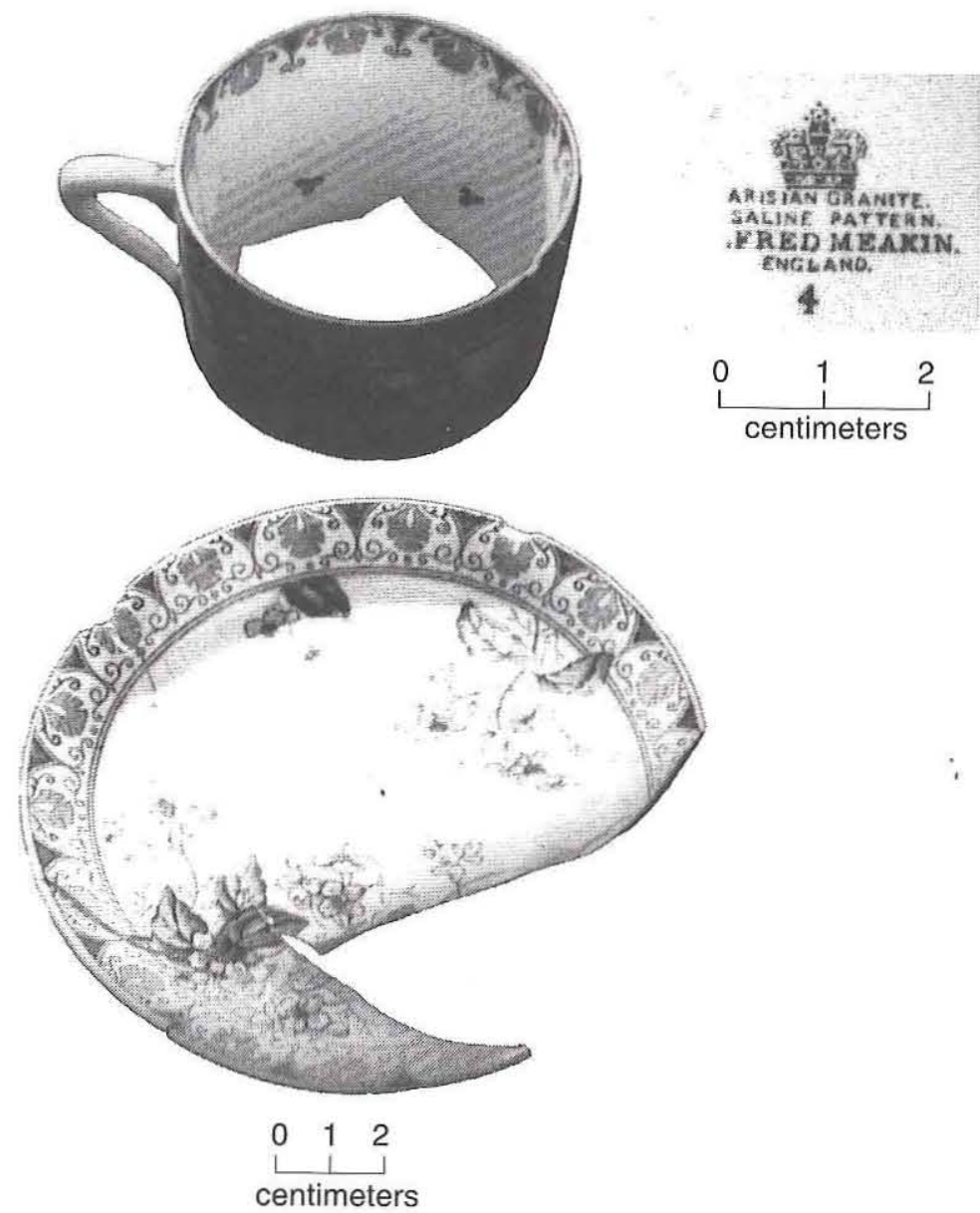

Figure 35. Rosaline pattern by Alfred Meakin and mark; photo of the pieces on display at Sebastopol.
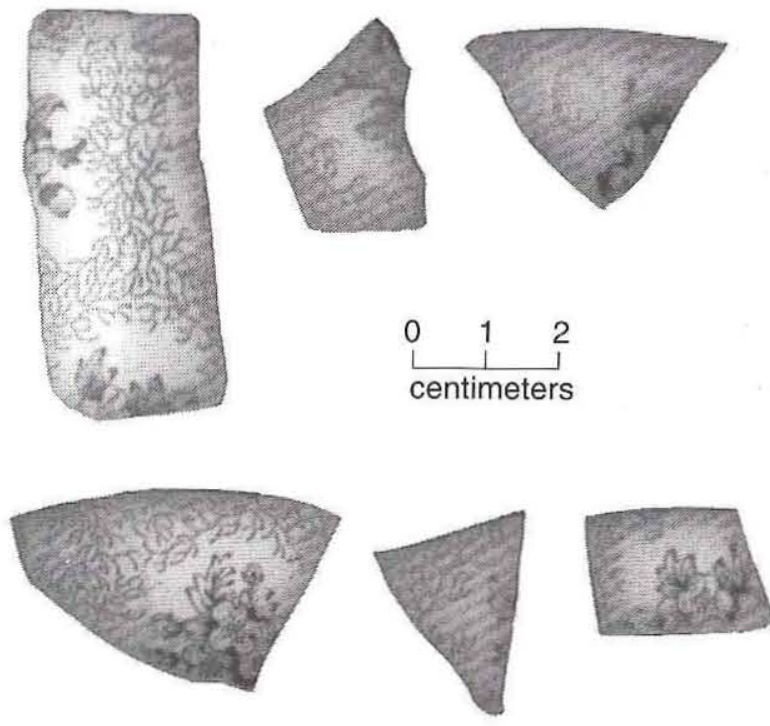

Figure 36. Gothic hawthorn pattern. 

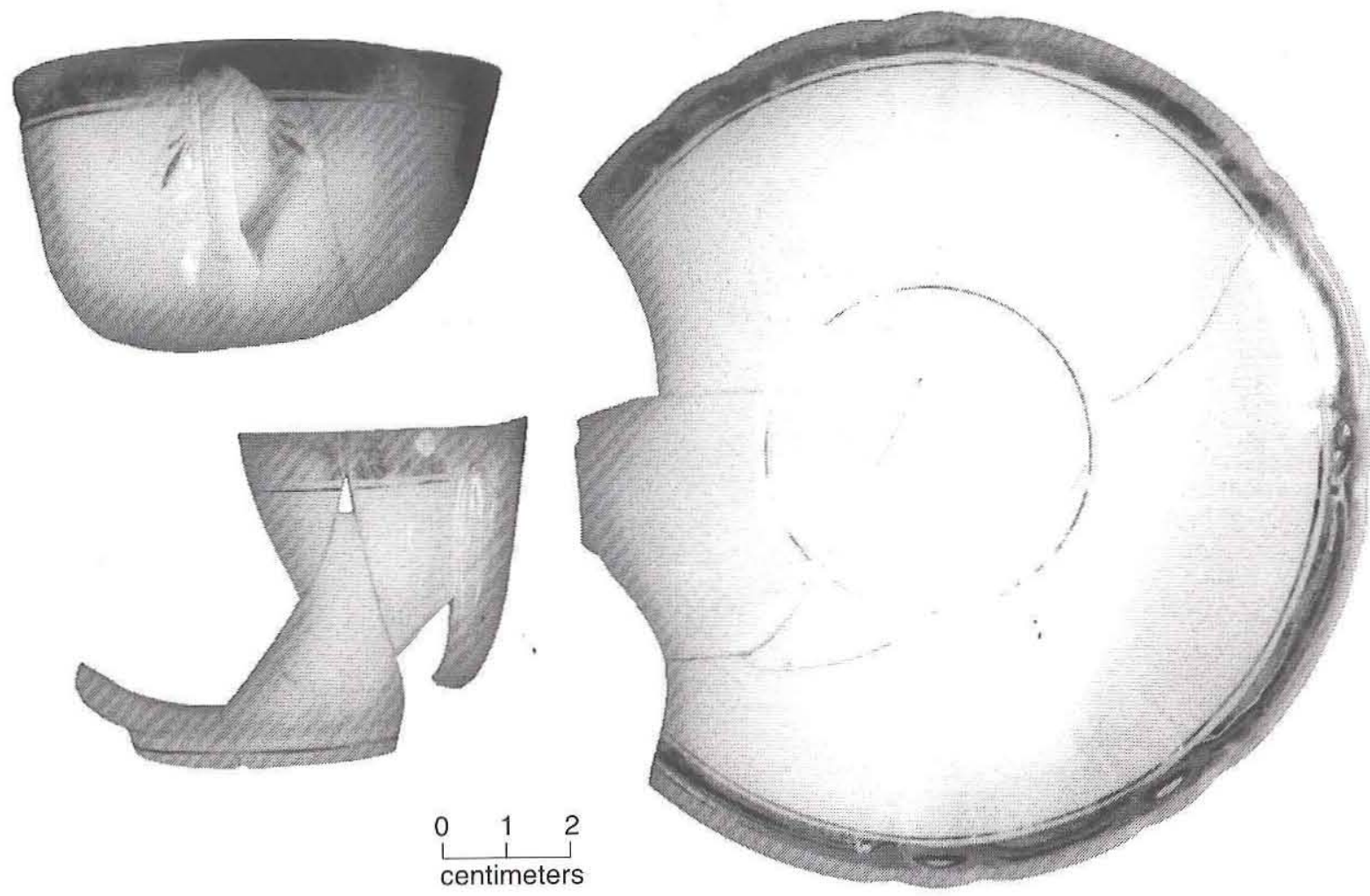

Figure 37. Molded and gilded petals.
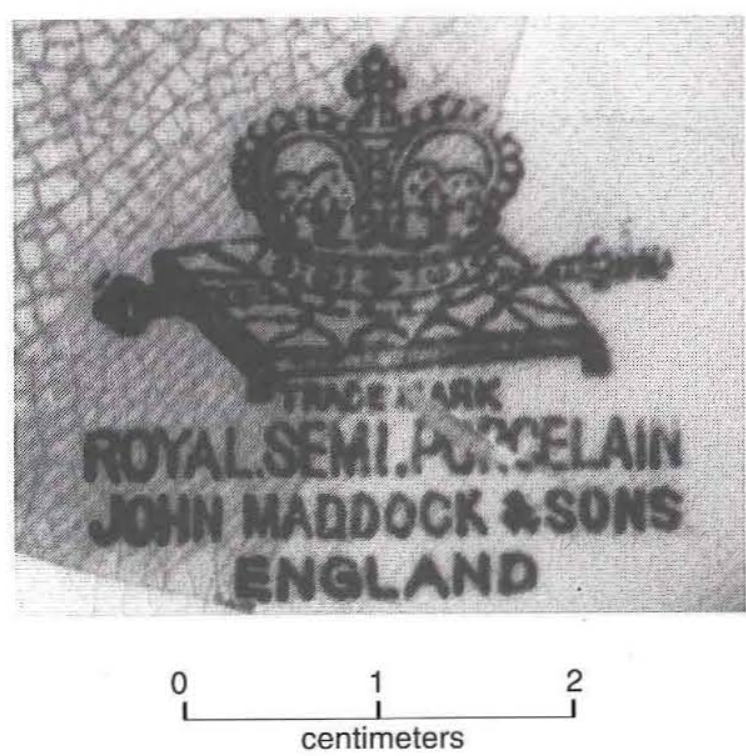

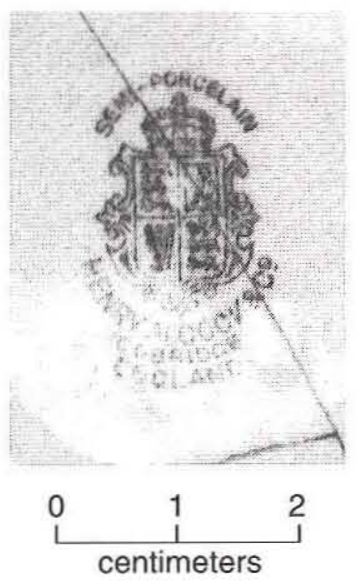

Figure 39. Henry Alcock mark.

Figure 38. John Maddock and Sons mark. 
50 vessels, has proved more difficult to separate into sets. Unlike the transfer-printed, decaled, and enameled pieces, the white ironstone does not have easily recognizable, consistent patterns between pieces of the same set. Due to the vessels' differing shapes, the saucer, cup, plate, and large vessels of the same set all may have different molded patterns; this makes it difficult to recognize sets without a suitable type collection. Few references are available for white ironstone, and many of those were written with the collector in mind. They show unique pieces from sets but do not show the variation within sets and often do not show details. Because of these complications, a variation in method was necessary with the white ironstone.

Fourteen different makers' marks were found on ironstone sherds. From these sherds, a minimum of 21 vessels was identified to maker. Unfortunately, the basal sherds with the marks generally cannot be matched with specific patterns, again making the identification of sets difficult. Some of these potters are recognized as makers of white ironstone in the literature, and some marks incorporate the word "ironstone." Those marks that definitely came from a piece of white ironstone are discussed here.

All vessels that can be identified as white ironstone are described in as much detail as possible and are grouped by decoration as much as possible. By discussing all of the makers of ironstone as well as all the identifiable patterns, a larger number of pieces can be discussed than for the other ceramic sets. This prevents missing the description of a set due to the inability to recognize it.

A piece was identified as white ironstone if it was from a white-bodied, heavily molded vessel with no other decoration, or if the mark identified it as being ironstone. Most pieces have a crazed, pooled glaze with either a gray or blue tint. Other vessels were included if the molded pattern could be recognized as one used by the ironstone makers even if the glaze was more consistent. Two handle sherds with blue enamel were included due to their characteristic shape and glaze. Molded white ironstone is particularly interesting at this site, as many of the pieces can be dated to the LeGette period.

\section{Marks and Associated Patterns}

\section{James Edwards Ironstone China}

James Edwards was a Staffordshire pottery in business from 1842 to 1851 when they became
James Edwards \& Son (Godden 1991:230; Wetherbee 1985:21). Of the Staffordshire potters, Edwards probably designed and made a larger variety of patterns than any other pottery in the 1840s (Wetherbee 1985:34).

There are 14 sherds of a printed royal coat of arms mark identifiable as James Edwards (Figure 40a). With these 14 sherds, a minimum of 6 vessels is represented. To add to the printed marks, there are 6 sherds associated with the impressed name "James Edwards" (Figure 40b). A minimum of 3 marks is represented in these 6 sherds. There is no evidence for whether the printed and impressed marks are from the same vessels. These sherds may represent at least two sets by Edwards, or they may be from a single set with an impressed and printed mark on each piece. Edwards is known to have made, amongst many others, the Gothic pattern (Wetherbee 1985:35), of. which there are several pieces in this collection. 'However, none of these sherds could be cross-mended with a specific mark.
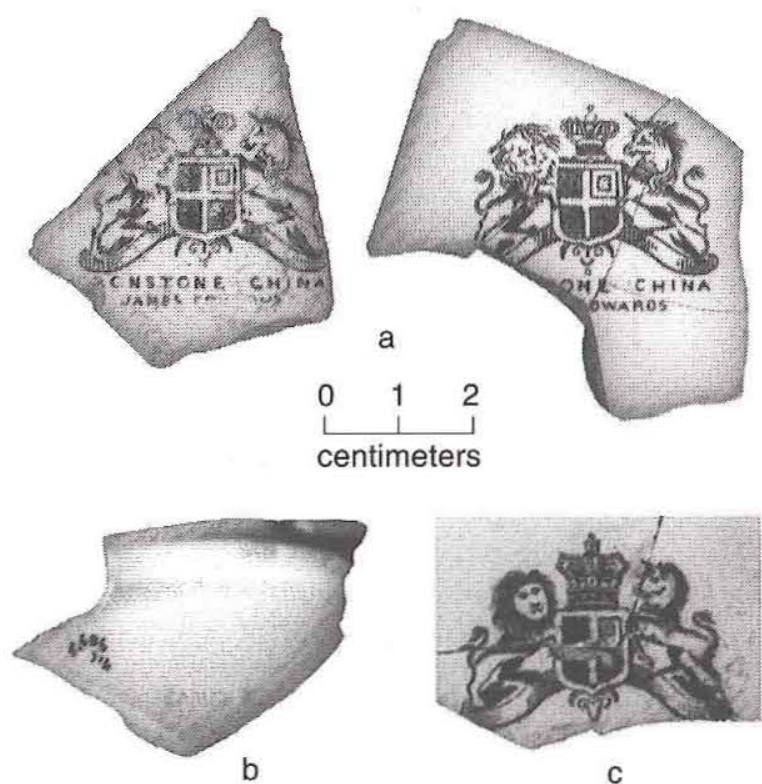

C

Figure 40. James Edwards maker's marks. (a) Printed marks; $(b)$ impressed mark; $(c)$ variation of printed mark.

Another mark, strikingly similar to that above (see Figure 40a), is found on the base of at least 2 ironstone saucers represented by 12 sherds (Figure $40 \mathrm{c}$ ). The heads of both the lion and the unicorn have been modified from that above, as has the crown on top of the shield in the coat of arms, but the shield, the ribbon below the shield, and the 
bodies of the two animals are the same. Due to the more-refined nature of the ware, it is assumed that this mark dates after the other. There is no name on this second mark, so it is not known if this was James Edwards or James Edwards \& Sons. The pattern on these pieces appears to match the "Curved Gothic" shown in a photograph of a cup in Wetherbee (1985:8).

Of the Edwards pieces, eight were recovered from Room 2, nine from the Kitchen, one from the cistern, one each from Rooms 8 and 9, five from along the west wall, two from along the south wall, four from along the east wall, and one from along the north wall.

\section{J. \& G. Meakin}

J. \& G. Meakin has been in operation in Hanley, Staffordshire, since 1851 (Godden 1991: 427). The mark is a royal coat of arms with "IRONSTONE CHINA" above the arms and "J. \& G. MEAKIN/HANLEY/ENGLAND" below the arms (Figure 41). The mark represented here postdates 1890 (Godden 1991:427). Thirty-one undecorated ceramic sherds are associated with this mark, with a minimum vessel count of two: one saucer and one unidentified vessel. All sherds but one were recovered from the Kitchen; the other was found in the cistern.

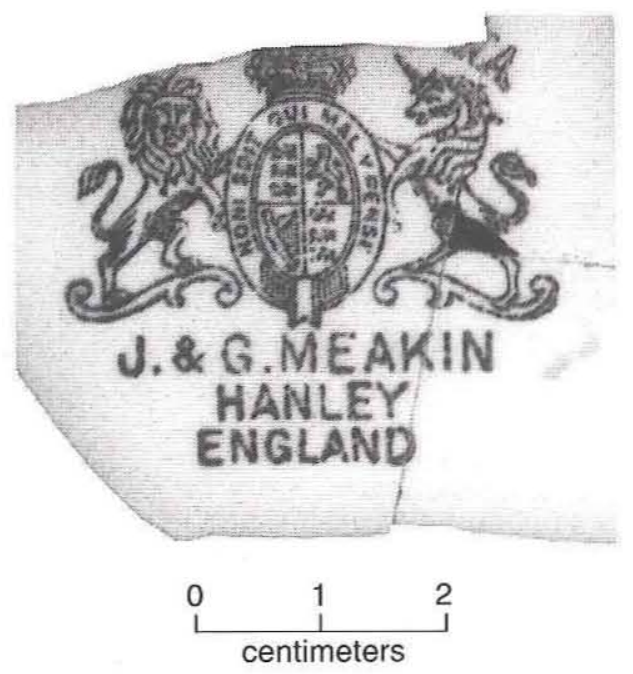

Figure 41. J. \& G. Meakin coat of arms mark.

Pankhurst \& Co.

Pankhurst \& Co. was in operation in Hanley, Staffordshire, from 1850 to 1882 ; "\& Co." was added after 1852 (Godden 1991:481). The mark in this collection is a royal coat of arms with "PANKHURST \& CO." above the coat of arms, "IRONSTONE" printed within the arms, and "CHINA" printed below (Figure 42). The single mark was found on 6 cross-mending sherds which also cross-mend with 15 sherds of a plate made in the "Curved Gothic" design. This style was also made by James Edwards (Wetherbee 1985:36). Eight of the sherds are from along the south wall of the house, and 13 are from the east wall.

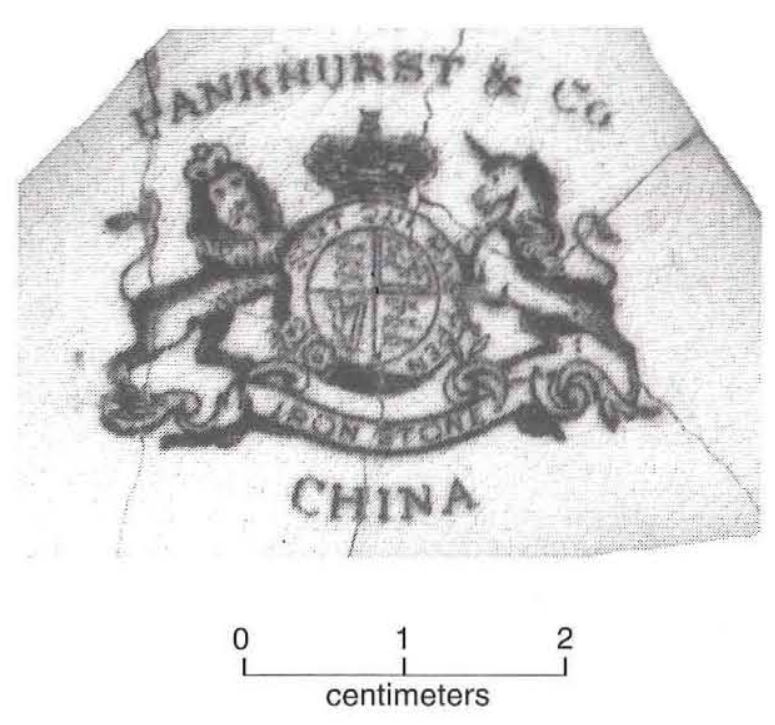

Figure 42. Pankhurst \& Co. mark.

\section{William Adams \& Sons}

A William Adams \& Sons mark found on two cross-mending ceramic sherds at the site is an American eagle crest with "SUPERIO . ..." above the eagle, "WHITE GRANITE" in the ribbon below the eagle, and "W. ADAMS \& . . ." below the crest. The same mark, only smaller, was found on vessel 151, a toothbrush box found in Unit 85-2 on the east wall of the house, with the complete mark shown on the base where the "\& SONS" below the eagle is clear. Because the latter mark is identical but more complete, it is the one illustrated in Figure 43, even though these pieces are not technically included in this analysis. Two sherds represent a minimum vessel count of one (not including the toothbrush box). One sherd was recovered from Room 9, and the other is from Room 8.

William Adams \& Sons (potters) Ltd. was in business in Tunstall, Staffordshire, from 1769 to the 


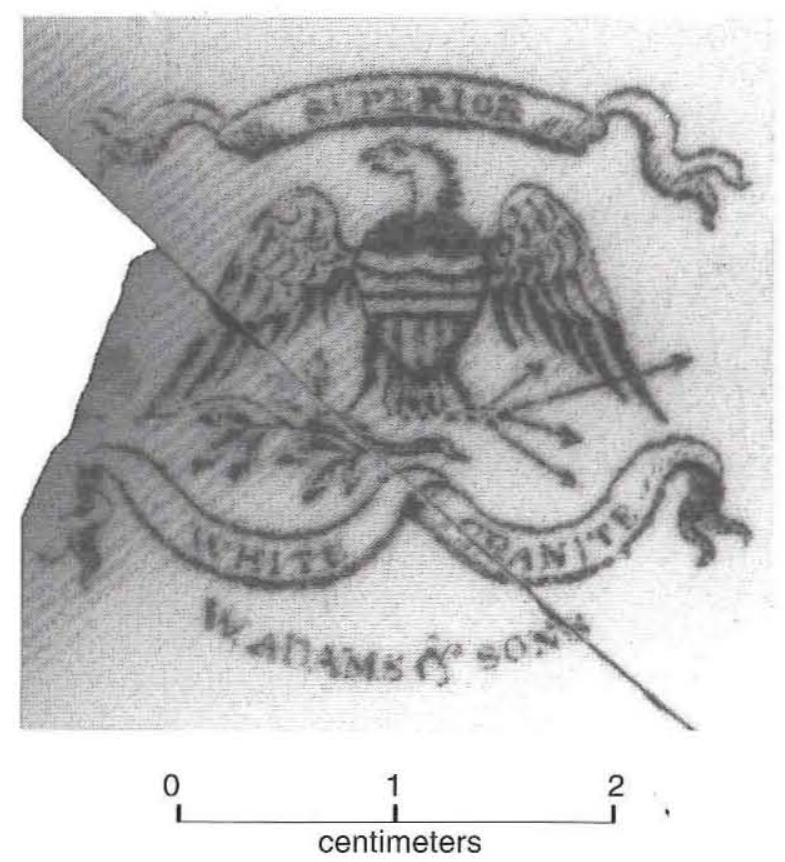

Figure 43. William Adams \& Sons mark.

present and is part of the Wedgwood group (Godden 1991; Kovel and Kovel 1986:266). Godden (1991:21) indicates that the use of "W. Adams \& Sons" occurred from 1819 to 1864 , although his wording is not entirely clear. The mark found on the pieces at this site is not represented in the literature, but the use of "\& Sons" and the lack of "England" indicate its use during the mid nineteenth century.

\section{J. Wedge Wood}

A printed mark of a ribbon tied in a knot with "IRONSTONE CHINA/J. WEDGWOOD" written on the ribbon and "PEARL" written in the loop of the ribbon is dated from 1841 to 1860 (Wetherbee 1985:20) (Figure 44). This mark is one used by a John Wedge Wood (not the famous Josiah Wedgwood) who was in business first in Burslem (1841-1844) and then Tunstall (1845-1860) (Godden 1991:687). Two sherds with this mark make up a minimum vessel count of one. One sherd was excavated from Room 2, while the other has the rather dubious provenience of "under north door." The exact door is not specified.

\section{E. Hughes \& Co.}

One sherd was found with a partial impressed diamond mark. At the top of the diamond is "VI"

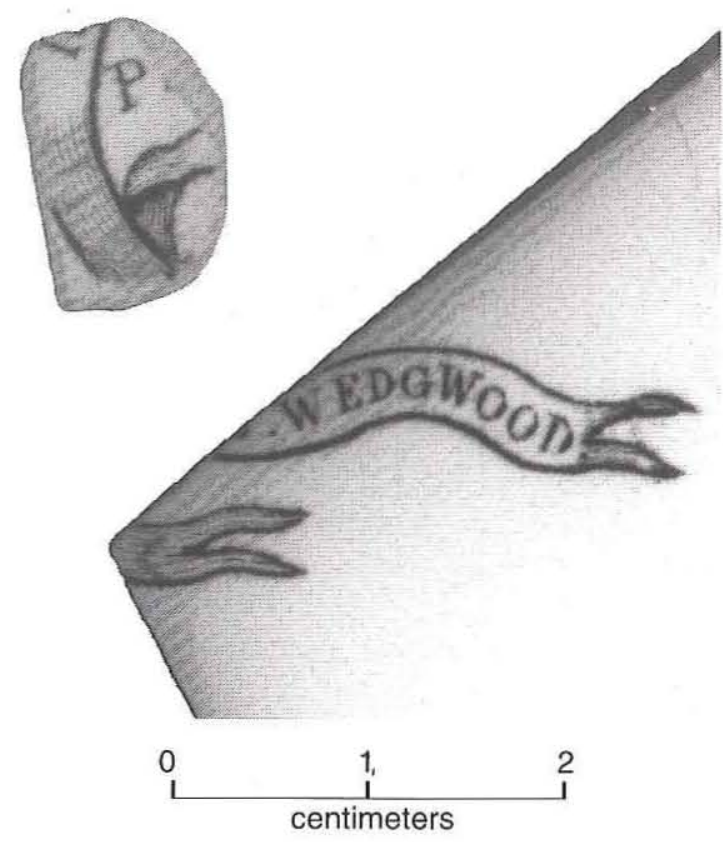

Figure 44. John Wedge Wood mark.

within a circle. Below this is a "P" within a half circle (Figure 45). On the left side of the diamond is a partial number with a " 2 . . ." showing. The right side and bottom of the mark are obliterated. Within the diamond, "E. HUG . . /GRANI . .." is impressed. Elijah Hughes \& Co. was in operation in Cobridge from 1853 to 1867 , during which time they used an impressed mark (Godden 1991:338). The numbers and letters used in this mark do not all correspond with the standard listing of years, months, and wares (Godden 1991:527; Kovel and Kovel 1986:238-239). The Roman numeral "VI" in the circle at the top of the diamond would normally be an "IV" on any earthenware or porcelain vessel (Godden 1991:526). The "P" in a half circle below the roman numeral would indicate 1851 , before Hughes was in business. Seemingly, Hughes used his own system of codes. The practice of using private marks to date wares was not uncommon (Godden 1991:12). The one sherd with the mark leads to a minimum vessel count of one. This sherd was excavated in Room 8.

\section{Unidentified Marks}

Seven additional unidentified marks are present on 39 sherds. Half of an impressed royal coat of arms mark is present on a saucer base. No maker's name is visible, and no design pattern can be 


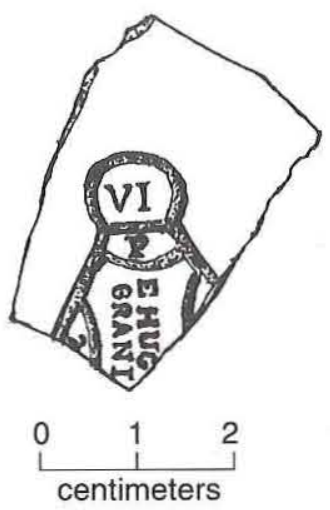

Figure 45. E. Hughes \& Co. mark.

discerned. This sherd was excavated from along the east wall of the house. Half of a printed royal coat of arms mark is present on another base sherd. No maker's name is visible, and neither the vessel type nor design pattern can be discerned. The ribbon below the unicorn has "MON" written on it. This sherd was uncovered in the cistern. The basal sherd of a saucer is impressed with a partial mark. Framed in a scrolled rectangle are the letters “. . . ONSTONE /. . . HINA /. . ST \& Co." This sherd was excavated from Room 9. Another basal sherd is impressed with "EN . . ." above the corner of a rectangle or square. This sherd was also excavated from Room 9. Two sherds of a large undecorated platter were found in the cistern. The platter had an impressed mark on its base, but the mark is not readable. One basal sherd excavated from the cistern has a " 57 " impressed into it. Vessel 149 is a saucer with no decoration and an unidentified mark. The mark is a royal coat of arms with ". . . STONE CHINA" above the arms and "C.P." below. Thirty sherds excavated from the Kitchen make up the saucer.

\section{Patterns Not Associated with Marks}

\section{Gothic}

The Gothic pattern was made by many potters in various forms. The basic shape is paneled octagonal with slightly flared rims and pedestaled bases on the larger hollow forms. Among the Gothic patterns are different variations, including the Curved Gothic, Gothic Cameo, Bordered Gothic, and Gothic Rose (Wetherbee 1985). Several pieces in the collection match examples of the Gothic pieces represented in Wetherbee's (1985) photographs. Others appear to be similar in form and design but are not absolutely identified as such.

Minimally, one saucer (7 sherds) and four cups (24 sherds) were identified as possibly of the Gothic pattern. The profile of a cup was reconstructed from base to rim, and no evidence of a handle is present (Figure 46a). Only rim sherds of the saucer were found. Another saucer pattern was found on seven sherds, representing two saucers, which appears to be a different Gothic pattern than the first saucer (Figure $46 b, c$ ). As mentioned above, the 21 sherds of a "Curved Gothic"-pattern plate recovered at the site were made by Pankhurst \& Co. Also mentioned above, 12 sherds of a minimum of two saucers were found that seem to match cups of the Curved Gothic design (Wetherbee 1985:8). These saucers were probably made by James Edwards.
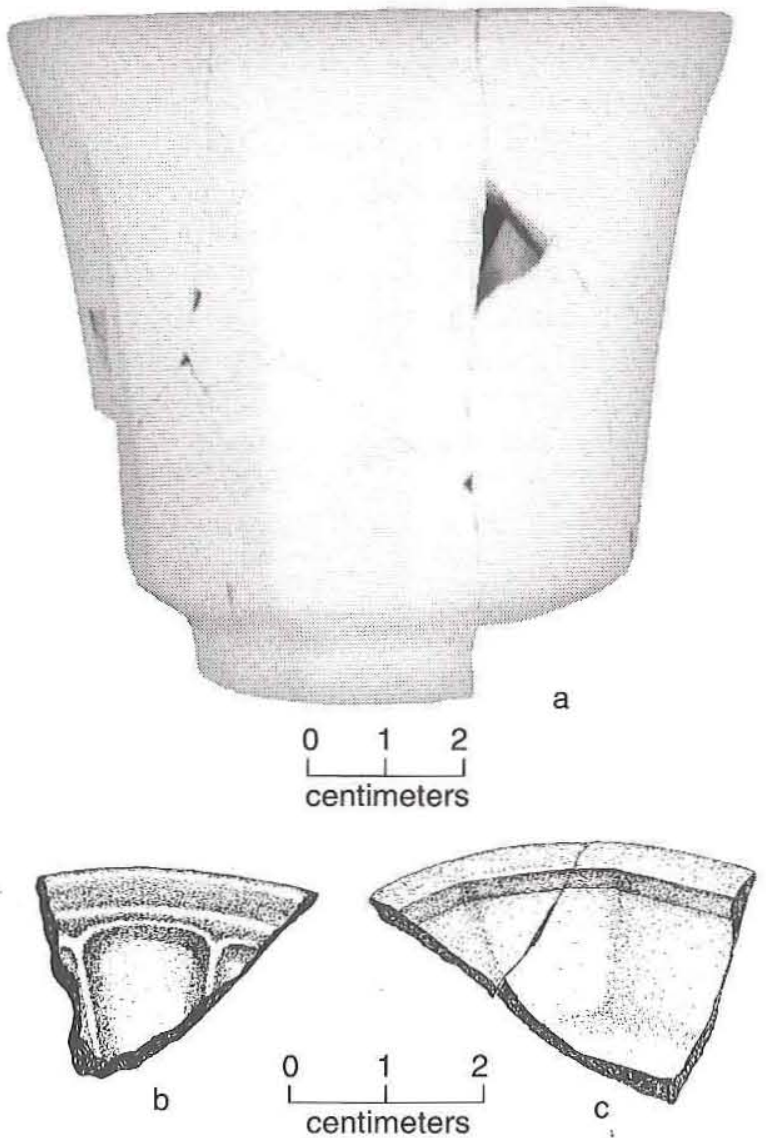

Figure 46. Gothic cup and saucers.

Several pieces of larger hollowwares of the Gothic pattern were found at the site. Seven sherds 
of two covered soup tureens are present, as is one sherd of a tureen lid and three sherds of a tureen base with the pedestal and part of the body intact (Wetherbee 1985:34-35). All of these tureen sherds match a photograph of a tureen of John Alcock design illustrated in Wetherbee (1985:35). Many makers were producing these pieces at this time, though, and a James Edwards sugar bowl also illustrated in Wetherbee (1985:34) has a base identi$\mathrm{cal}$ in design to these tureens.

An open serving dish, lacking a lid rim, was found in 11 sherds. This dish is similar to the tureens but has a molded pattern on the inside of the bowl. A minimum of two lids for sugar bowls, teapots, coffee pots, hot beverage pots, or similar vessels were recovered. One sherd is the base of a lid and could be of the Curved Gothic design. The other three sherds come from one lid of a Gothic design identical to that illustrated in Wetherbee (1985:35) on a John Alcock teapot lid (Figure 47). Two base sherds of slightly differing Gothic designs also were recovered. These sherds appear to be from a teapot or other such unpedestaled vessel. Two handle sherds that appear to be of a Gothic design also were recovered.

\section{Other Paneled Designs}

Eight sherds of at least two coffee cups paneled with 10 or 12 sides and molded around the rim were recovered (Figure $48 a$ ). Two large pieces of the rim where a handle may have attached are missing from one cup, as is the body in the areas where the bottom of a handle would have attached. Five sherds were recovered from along the east wall, and three are from the Dining Room.

Two cup rim sherds of a different paneled design with a rim molding and a definite handle were recovered (Figure 48b). The two sherds represent two different cups. One was found along the south wall of the house, the other along the east wall.

Eight sherds of other unidentified paneled cups were recovered from the site, and these could represent five separate vessels. One sherd each was found along the south wall of the house, in the cistern, and in Room 8. Five more sherds were excavated along the east wall.

\section{Other Designs}

Two fragments from an unidentified scalloped plate were excavated from Room 9. Two fragments from a plate with possibly an Adam's Scallop design (Wetherbee 1985:42) were found in Room 8, and one fragment was found along the east wall. Six sherds cross-mend to form part of a ribbed, handled cup. These sherds were all excavated from the Kitchen. Two ironstone sherds, one from the Kitchen and one from the Dining Room, both appear to be from larger serving dishes. Another sherd from the Kitchen may be a body sherd from a cup. One ironstone basal sherd, unidentifiable to vessel type, was excavated from Room 7. 


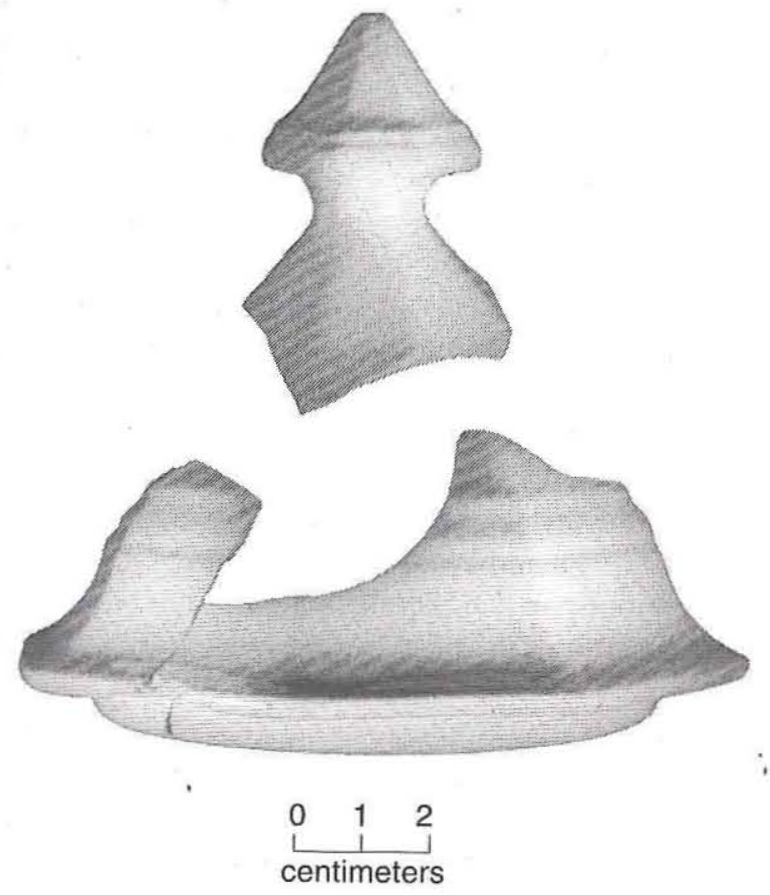

Figure 47. Gothic teapot lid.
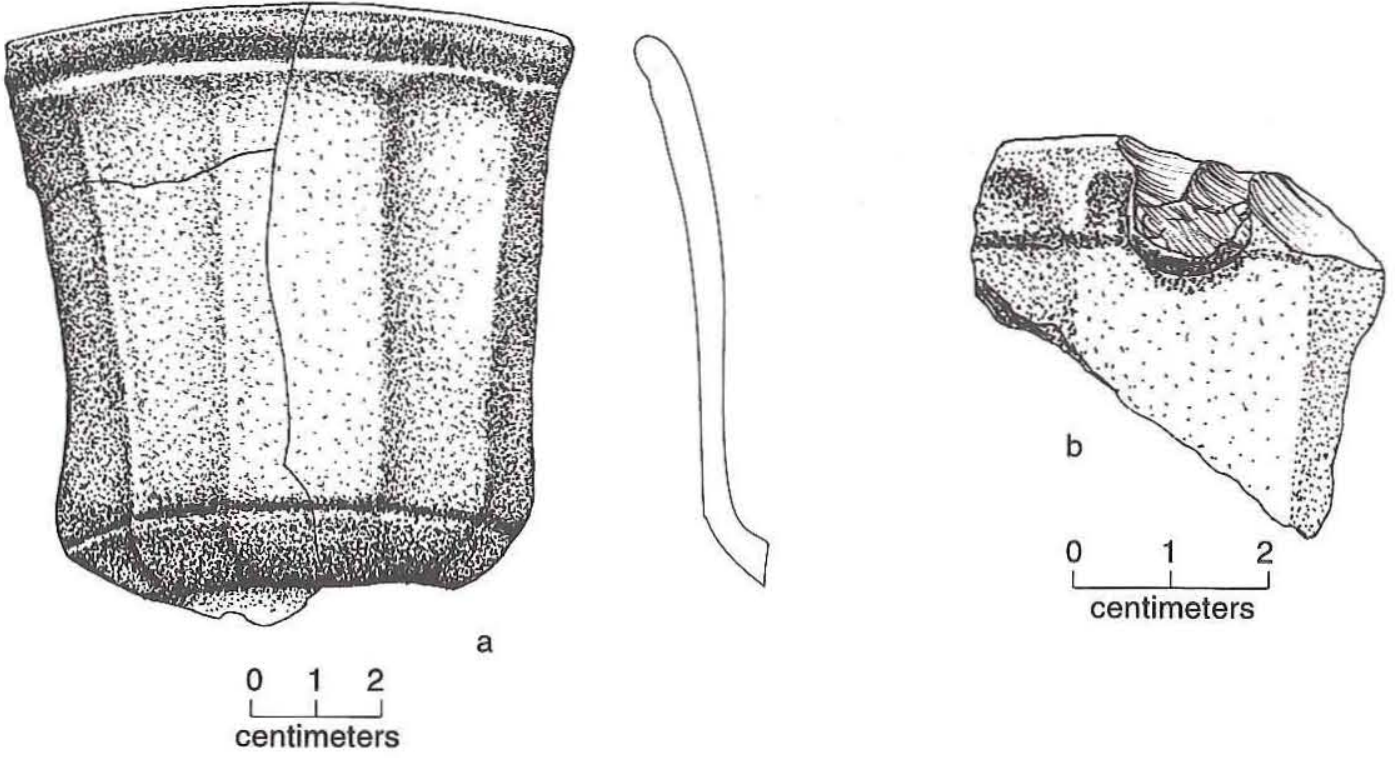

Figure 48. Paneled coffee cup (a) and rim sherd with molding (b). 


\section{ANALYSIS OF ARTIFACTS FROM THE KITCHIEN, DINING ROOM, AND ROOM 7}

\section{INTRODUCTION}

This chapter provides descriptions of diagnostic artifact classes found in the Kitchen, the Dining Room, and Room 7. The artifacts are organized by group and class. Within the classes, artifacts are listed alphabetically by type. Group definitions are loosely based on Stanley South's (1977:95-96) pattern recognition groups, as modified to suit this site. Groups include Food, Furniture and Fixtures, Personal, Pharmaceutical Bottles, Activity, Recreation, Bone, Utilities, and Other. Within the Food group and Service class, some types are broken down further by decoration. Within the Other group, the Miscellaneous class includes identified artifacts with several possible functions, while the Unidentified class includes artifacts that are potentially identifiable but that were not identified through the process of the research. Architectural artifacts, as previously mentioned, are not included here.

In most cases, the minimum numbers of items represented by artifact fragments or sherds are included, as well as the number of fragments found. The minimum number of items (MNI) is a more reliable indicator of the number of objects than fragment count, as some items can be highly fragmented while others can be whole or broken into only a few fragments. Minimum number was based on cross-mending sherds and the decoration, shape, and color of vessels. For some of the artifact types or classes, a detailed explanation of history and manufacturing methods is provided. Those artifacts found in quantity have more-detailed information than those of limited numbers.

A number of artifacts are on display at Sebastopol and were not available for this analysis. They include five bottles, three toys, four marbles, one slate pencil, one spoon, one fork, several buttons, and some ceramics. The ceramics are discussed in the context of their sets (see Chapter 5).

\section{FOOD GROUP, STORAGE}

\section{Bottle Seals}

Seals were common on bottles of all kinds, including mustard, ketchup, pickled food, milk, and alcohol. Only the identifiable seals are discussed here. Other seals are discussed under Other Group, Miscellaneous.

One lead bottle seal has a coat of arms mark embossed in the center with writing embossed around it: ". . . SSE \& BLACKWELL/. . . ORS TO HER MAJESTY/. . . O SQUARE/LONDON" (Figure 49a). This seal was make by Crosse \& Blackwell from London, England, a company started in 1830 (Toulouse 1971:113). Historically, Crosse \& Blackwell produced food products such as chowchow (Wilson 1981:89) and mustard (Toulouse 1970:68) among other goods. Toulouse (1970:68) indicates that Crosse \& Blackwell products were widely used, even in the western mining camps. This seal was found in the Kitchen.

One seal from a McIlheny Tabasco Sauce bottle was excavated from the Kitchen (Figure 49b). Mcllheny is a company located on Avery Island, Louisiana, which has been producing hot sauces since just after the Civil War (Orser and Babson 1990:107).

The remains of two cardboard milk bottle seals were excavated from the Kitchen. One, highly fragmented and representing only about one-third of the seal, has the writing ". . . ND DAI. . . . . XAS." The other, representing over half the seal, 


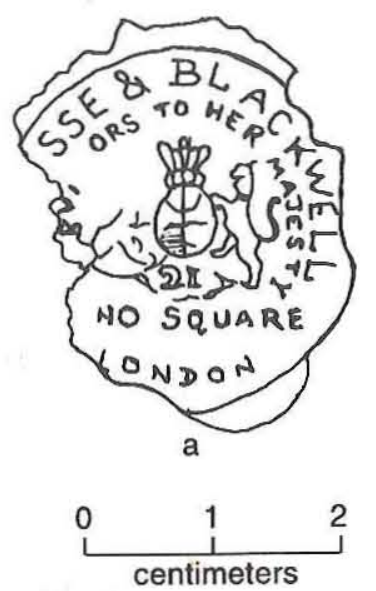

Figure 49. Bottle seals. McIlheny Tabasco Sauce.

has ". . . END DAIRY/. . . ECKER. . . TOR" visible. Both seals are from the same' brand of milk.

\section{Crock}

An undecorated stoneware crock lid was found in the northeast quadrant of the Kitchen. About one-third of this $17.8-\mathrm{cm}$-diameter lid is present in one sherd. An undecorated stoneware crock body sherd was also excavated from the Kitchen. This sherd has horizontal striations on its interior surface indicating that it was thrown on a wheel. It also appears to be $17.8 \mathrm{~cm}$ in diameter and may be part of the same vessel as the lid sherd. It is possible that these were from another vessel type such as a slop jar or a churn.

\section{Hutchinson Spring Stopper}

One Hutchinson spring stopper wire was found in the Kitchen. The Hutchinson's Patent Spring Soda Bottle Stopper was patented in 1879 in the United States. This stopper is a heavy-gauge wire with a rubber gasket attached to one end. The wire is looped and bent in such a way as to protrude from the mouth of the bottle (Figure 50). The pressure of the carbonated beverage in the bottle keeps the seal in place until a sharp blow to the top of the wire breaks the seal. The spring stopper could be reused until the gasket wore out. Used well into the twentieth century, the spring stopper eventually gave way to the crown closure (Jones and Sullivan 1989:162).

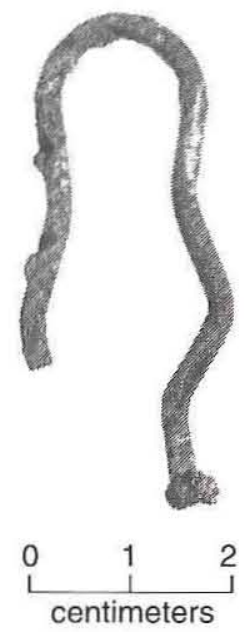

Figure 50. Hutchinson spring stopper (1879-twentieth century).

\section{Canning Jars and Related Artifacts}

One Griffen gasket or canning jar seal was found in the Dining Room. This type of seal had a thumb tab with which to grasp it (White 1978:6162).

Fragments of two jars were excavated from the Dining Room. One is a finish fragment which would have been used with a zinc seal or screw-on cap (Figure 51a). The other is a finish and body fragment from a jar which sealed with a liner and spring clip (Figure 51b) (Jones and Sullivan 1989: 166). Both are of colorless glass. Two other jar fragments found in the Kitchen are made of glass with a pale blue tint. Both have embossing on them and may have come from the same jar, although they do not cross-mend. One fragment has "NO" or "ON" embossed on it, and the other is embossed with what appears to be the curve of an "S."

Canning jar liners are a single part of a complex closure. They were usually sandwiched between a metal cap and a rubber seal to protect the food from the metallic taste imparted by the metal lid. Liners with a Lightning-type closure were used with no metal cap, only a seal. The glass liner, developed in the United States, was available by 1869 (Jones and Sullivan 1989:160, 165). The remains of five liners were excavated: four from the Kitchen and one from the Dining Room. The liner found in the Dining Room is the type used with a Lightning closure (Figure 52a). This type of closure was available for fruit jars by 1877 (Jones and Sullivan 1989:167). This liner is of colorless 


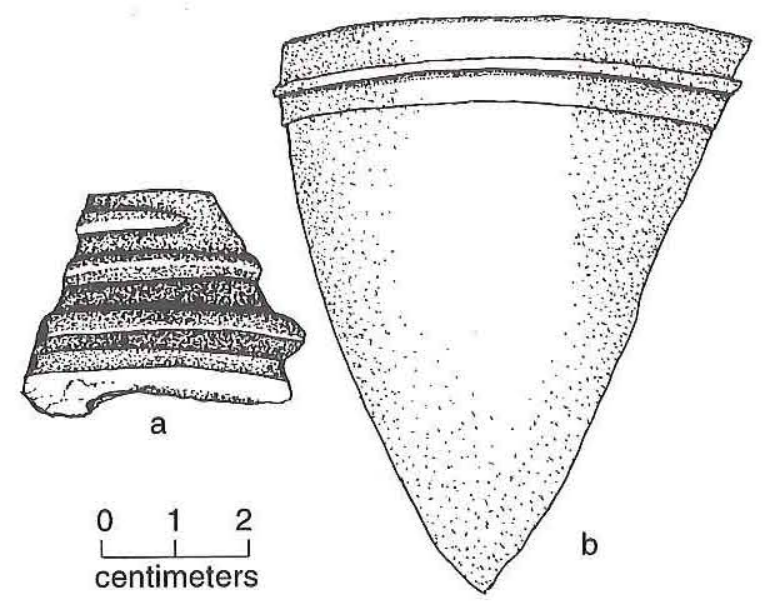

Figure 51. Jar finish fragments. (a) Finish fragment used with a zinc seal or screw-on cap; $(b)$ finish sealed with a liner and spring clip.

glass and is complete. Another complete liner was found in the Kitchen; it is made of milk glass and would have been used in conjunction with a metal lid, not a zinc closure, since the top of the liner is not marked in any way (Figure $52 b$ ). A complete but broken liner was excavated from the Kitchen. It has a lip which would have overlapped the finish of the canning jar. The top of the liner is embossed with an intricate design and the words: "H. J. HEINZ Co./PITTSBURGH, PA." (established 1869). On the design, the wording "KEYSTONE PICKLING \& PRESERVING WORKS" is embossed (Figure 52c). The keystone was used by Heinz in various designs from ca. 1876 to 1880 (Toulouse 1971:237). This piece is made of colorless glass and would have been held securely onto a jar with a zinc screw band (Jones and Sullivan 1989:165). A fragment of another milk glass liner from the Kitchen would overlap the finish and be held in place with a zinc screw band. Visible embossing on top of the liner is "... RK PAT'D. . ." (Figure $52 d$ ). The last fragment of a liner from the Kitchen is also made of milk glass. It has some embossing on the bottom which reads ". . LY/. . TS." This was probably used in conjunction with a lid as opposed to a zinc seal (Figure 52e).

\section{Tin Cans}

Most of the ferric (iron-based) metal excavated at Sebastopol was highly corroded and friable. The tin cans are not an exception, and because of this it is difficult to identify which small pieces of iron were once tin canisters. While over 1,000 pieces of tin cans were originally identified in the TPWD classification as coming from the Kitchen, not all of these are necessarily from tin cans. Only those diagnostic pieces that could definitely be identified as a tin can part are included here. These include metal fragments with seams, joints, and shapes belonging to tin cans (Figure 53). Thirteen tin can sherds unidentifiable to type were recovered from the Dining Room, and the rest of the 182 diagnostic fragments were recovered from the Kitchen. A minimum of 35 cans was found here.

Nonhermetically sealed tin canisters were used as early as 1796 . Methods for preserving food in hermetically sealed cans, however, took some time to perfect; by 1810 , experiments were being conducted to preserve food in tin cans. The earliest tin canisters were made by hand. A rectangle of tin plate was cut and rolled to form the body, with the sides being plumb or lapped and soldered to create a seam. Two round disks were cut for the ends; they were either flush or were crimped by hand at the edges to be soldered to the body. By 1847 , a machine was invented that automatically flanged the ends of the can. A hole was usually left in one end of the can to allow it to be filled. After filling, this hole was covered with a cap which was soldered in place. This type of can is known as the hole-andcap can (Rock 1984:99).

The hole-in-cap can was developed around 1820 . The hole-in-cap can simply incorporated a vent hole to release pressure. It was a great improvement because it prevented cans from exploding; the pressure of heating and reheating the cans during the canning process had often caused cans to burst. The vent hole was sealed by placing a drop of solder on it after the first heating of the can (Rock 1984:99). This process leaves a distinctive mark on the top of the tin can (Figure 54); even when corroded, preservation differences can be seen where the solder was, and a sharp hole protrudes on the interior. Sometimes a round or rectangular tin-plated "chip" is found in association with this hole. The chip was placed on top of the food to keep the hole from being clogged when the pressure in the can was increased due to heating (O'Bannon 1983:179).

Hole-in-top is the name given to evàporated milk cans which have a small (less than. $1 / 8$ inch) filler hole in one end. This filler hole acted in the same fashion as the larger hole in a hole-in-cap can, but this smaller hole was sealed only with a drop of solder. Adding confusion to this definition are those 

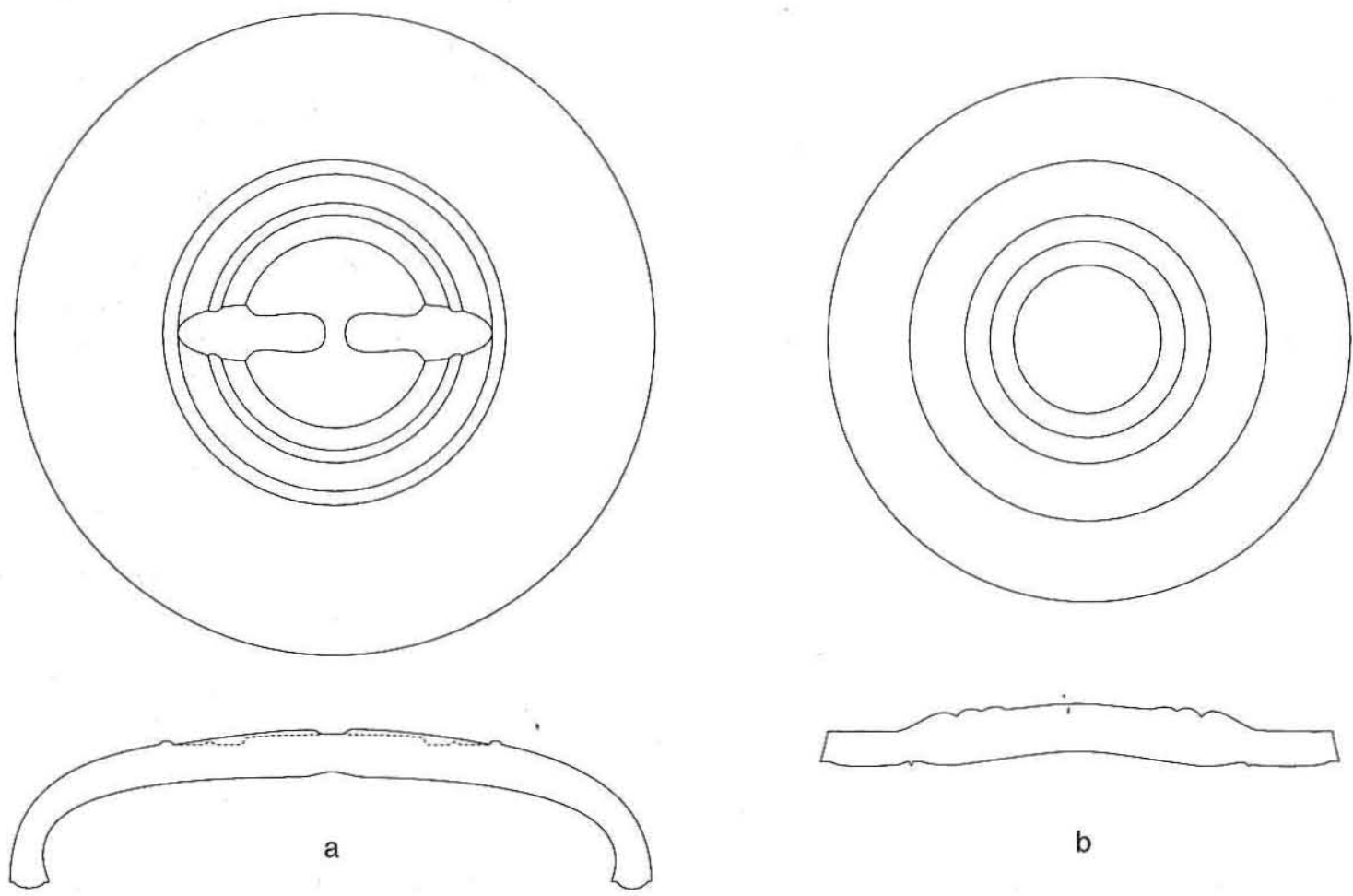

b
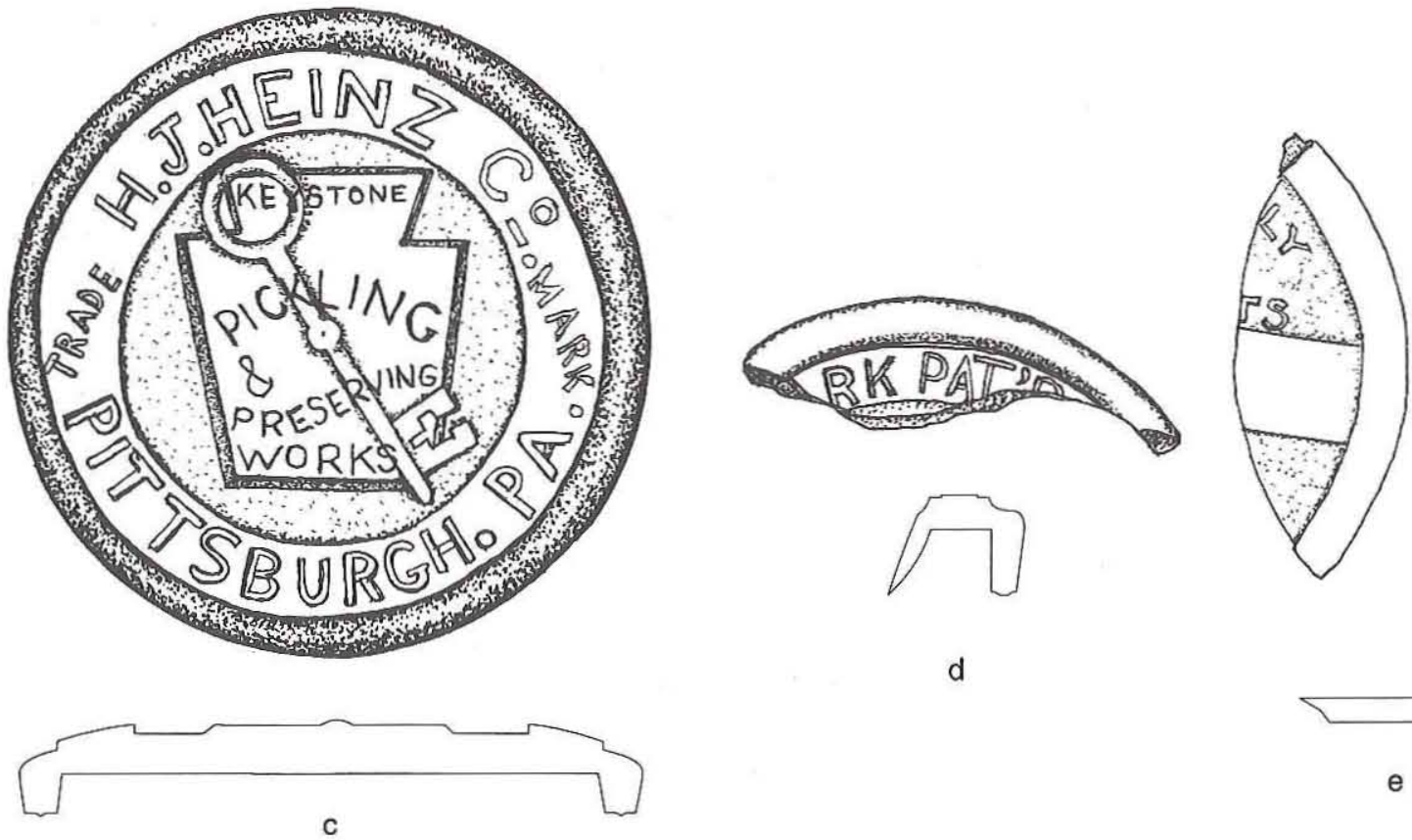

d

Figure 52. Canning jar liners. (a) Lightning style liner; $(b)$ milk glass liner, for use with metal lid; (c) Heinz liner, for use with zinc screw band; $(d)$ milk glass liner, for use with zinc screw band; $(e)$ milk glass liner, for use with metal lid. 


\section{CAN TYPES}

Hole-in-Cap Tin Can (ca. 1820- early twentieth century)

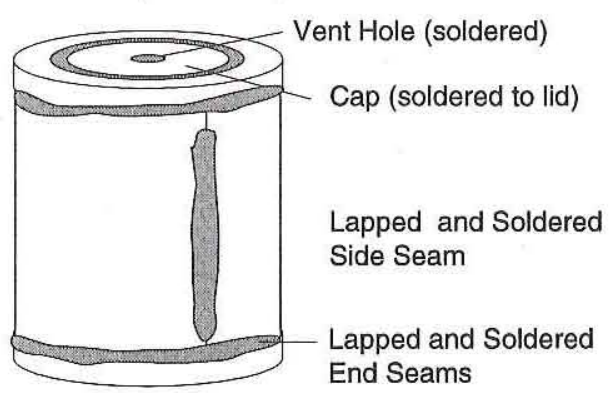

Hole-in-Top Can

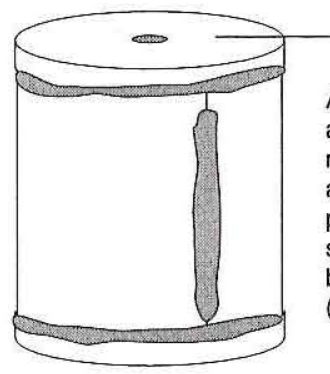

Note: no cap

Although Rock (1984) gives a date of post 1900 for evaporated milk cans of this type, there is no available information for possible previous manufacture. Meat and salmon cans of this variety have been found in a 1903-1906 context (Sauer 1995).
Hole-and-Cap Tin Can (ca. 1810-1820)

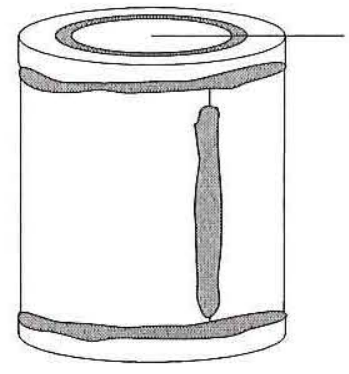

Note: no vent hole

The forerunner of the hole-incap can, the hole-and-cap can, was short lived as the pressure of heating often caused the cans to explode.
Sanitary Can (ca. 1904)

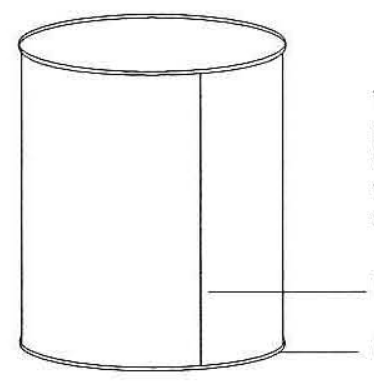

The sanitary can was perfected by 1904 , but this type of can was being produced by the Max Ams Machine Company as early as 1898 (Rock 1984:101)

Interlocking Side Seam

Crimped End Seam

\section{SIDE SEAMS}

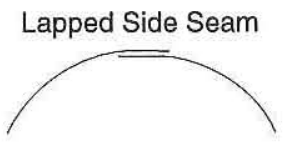

Double Internal<smiles>C[Hg]C</smiles>

Interlocking Side Seams (invented 1888)

HOLE-IN-CAP END

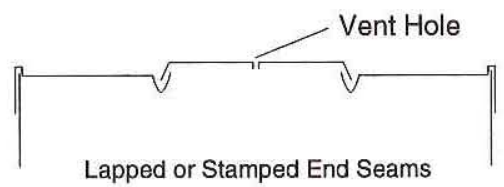

P\&AI/96/srs

\section{INTERIOR OF CAN END}

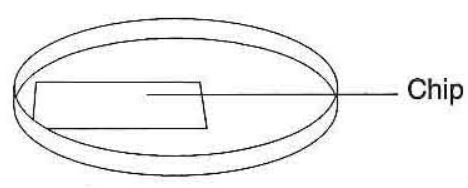

Metal chips were sometimes placed on top of canned food before the lid was soldered into place. The chip prevented the boiling food from clogging the vent hole (O'Bannon 1983:179).

\section{END SEAMS}

Lapped (earliest) or Stamped (1847) End Seams

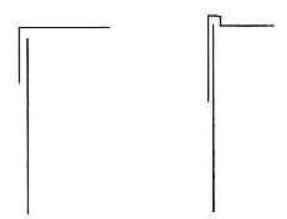

A drop press was invented in 1847 which would convert flat disks into vertically flanged caps.
Crimped End Seam (invented 1897)

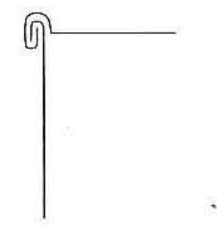

The crimped end seam was the pivotal technology which facilitated the development of the sanitary can.

Figure 53. Parts of the tin can. 


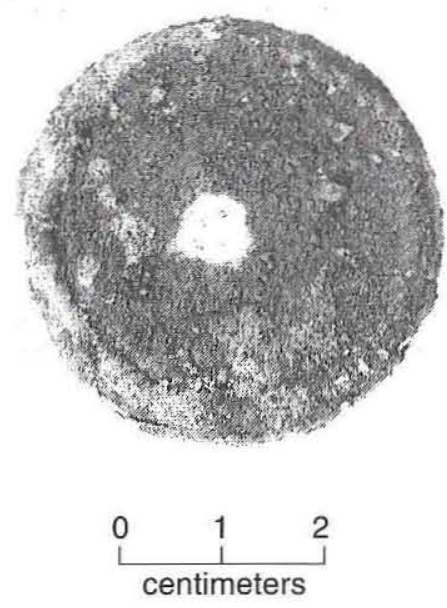

Figure 54. Cap with hole and solder shown.

cans that have no filler hole, but have one or two vent holes punched into the top (including salmon cans from the Northwest Coast) or the side (meat cans) (Sauer 1995). Rock (1984:105) classifies these as "open-top" cans. However, when using this term to indicate this type of can, specifying the presence of a vent hole is necessary since open-top cans do not necessarily have vent holes. The literature is not clear on the terminology, and some authors use holein-cap, hole-and-cap, and hole-in-top interchangeably (Rock 1984:100); however, they are used as specifically defined terms here because of their utility and specificity.

The side seams on tin cans changed over the years. The first type of seam was simply plumb (the two edges butted against each other) or lapped (one edge of the tin overlapping another) with the two edges being soldered together on both the interior and exterior of the can. In 1888, a machine for making locking or double seams was patented (see Figure 53). This type of side seam was made by bending both edges of the tin plate, hooking them together, and then flattening them. The locked seam created a much stronger can which was less likely to swell or leak when heated. Locked seams are defined as internal or external (with the folds inside or outside, respectively). In 1897, the technology for creating locked end seams was patented (see Figure 53). The combination of the double side seam, the crimped end seals, and automatically applied sealing compound produced a "solderless can" by the end of the nineteenth century. This type of can became known as the "sanitary can" because no lead solder could contaminate the food.
It was in mass production by 1904 and is the type still used today (Rock 1984:105). The key-opened can was first patented in 1864 . However, it was not widely used until Edwin Norton of Chicago, Illinois, started using it in 1895 . Keys were used on meat cans, fish cans, tapered cans, and coffee cans (Ritchie and Bedford 1985:100; Rock 1981:14, 1984:101; Sauer 1995:98). Four keys from such cans were recovered from the Kitchen (Figure 55).

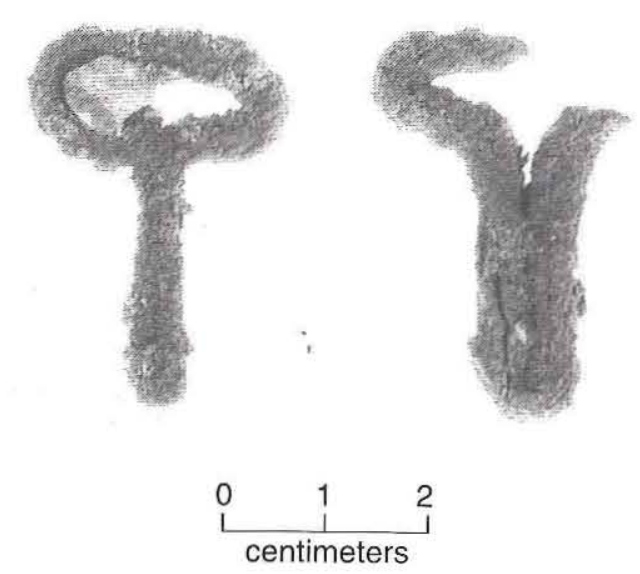

Figure 55. Tin can key-style openers (patented in 1864, most after 1895).

The remains of 12 caps, in 24 sherds, from hole-in-cap cans were found. Only one of these caps is still soldered to the end of the can. Other end fragments from hole-in-cap cans are present, but these were not used to determine the MNI since the caps could have belonged to the same cans as the ends. The caps vary in diameter from 2.8 to $6.5 \mathrm{~cm}$ (Figure 56). The end pieces from the hole-in-cap cans number 29 and range in diameter from 9 to $14 \mathrm{~cm}$. Visible end seams on all of the hole-in-cap cans are lapped. All of the identifiable hole-in-cap cans are round.

Two ferrous metal screw caps represented by three fragments were found in the Kitchen. These could have been used on metal or glass containers. Both appear to be from continuous-thread containers and are knurled around the top (i.e., they have embossed vertical lines used to improve friction). One has a depressed circle in the top of the lid. Both lids are about $4.5 \mathrm{~cm}$ in diameter. One has a height of about $2 \mathrm{~cm}$, the other about $1.5 \mathrm{~cm}$. Because of the knurling, which was not used much prior to 1906, and because the bases are not rolled, which was common after 1920 , it is likely that these 

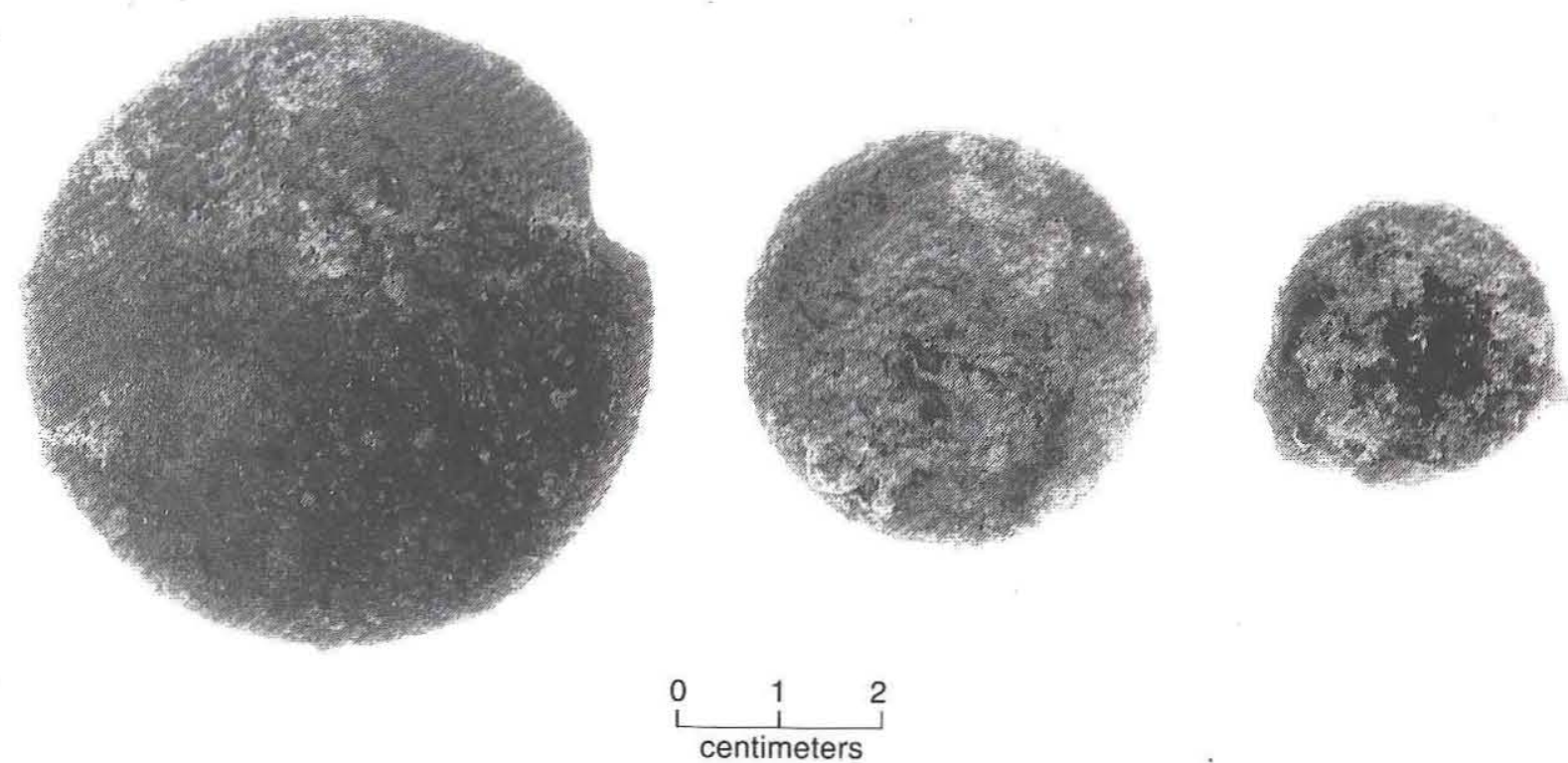

Figure 56. Range of cap sizes from hole-in-cap cans.

caps date between 1906 to 1920 (Bender 1986:46).

Ten whole and fragmented slip-off can ends were recovered in 20 fragments (Figure 57). Measurable diameters on four of these are $3.4,4.2,5.5$ and $6.2 \mathrm{~cm}$. This is the type of can used for dry goods which did not need to be hermetically sealed, such as baking soda. One can body of this type with a diameter of $5.4 \mathrm{~cm}$ was recovered from the Kitchen. This complete can had a bottom end seam that was lapped. No embossing is present on any of these lids or on the can.
Five fragments of one rectangular can, 3.75 by $6.25 \mathrm{~cm}$, were found in the Kitchen. At least one end of this can had a clinched end seam. Six fragments of another rectangular can were also found in the Kitchen. This can had a slip-off lid and a bottom end seam that was clinched. Four fragments of another rectangular can were recovered from the Kitchen. This can had a hinged lid which was decorated with molding and what appears to be lacquer (Figure 58). Two other sherds from the Kitchen appear to be from a rectangular tin can.
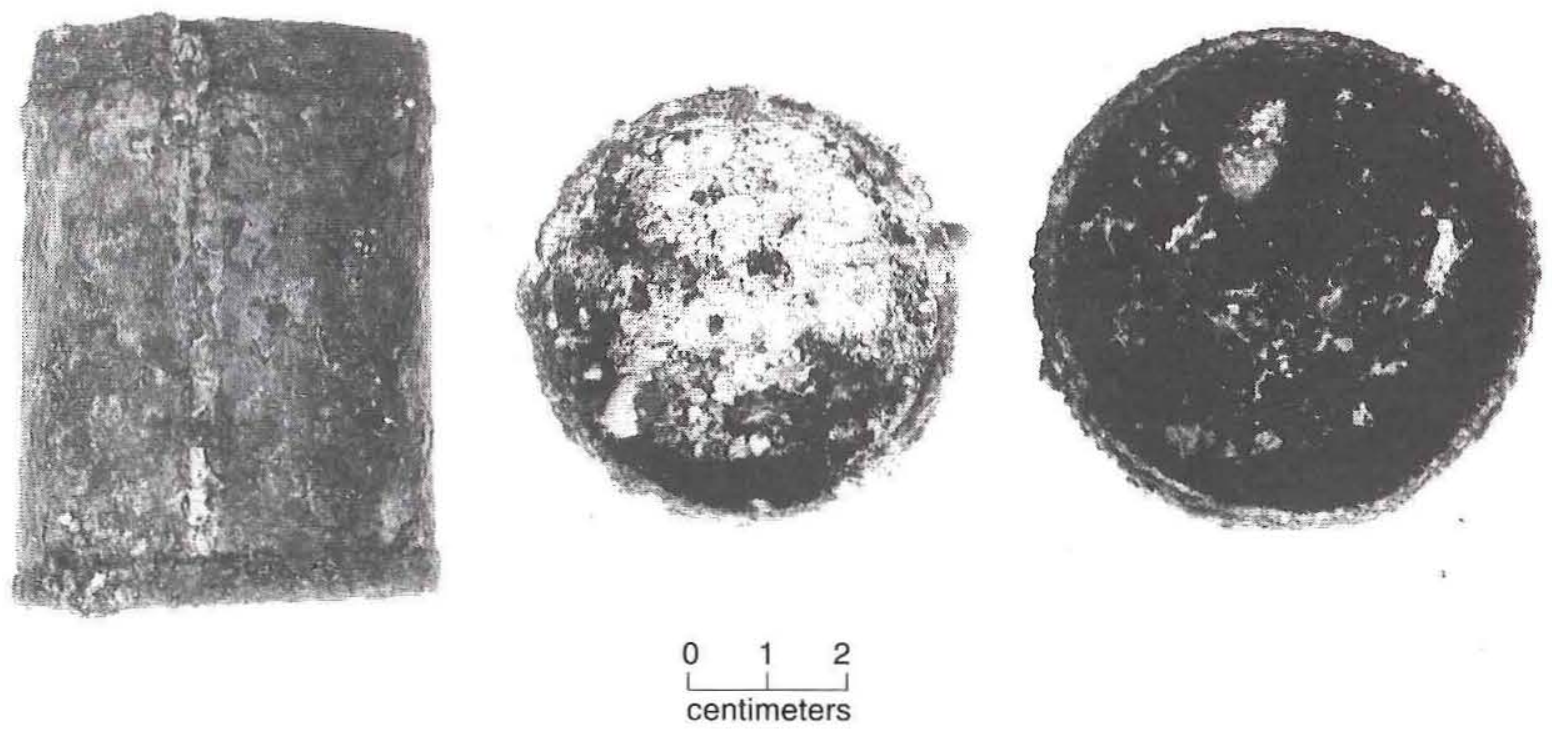

Figure 57. Tin can and slip-off lids. 


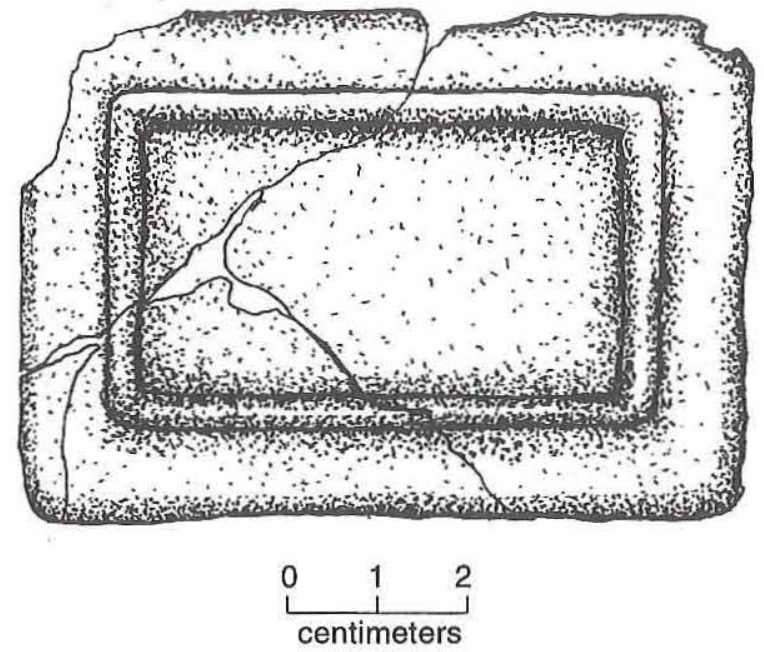

Figure 58. Hinged, rectangular tin can lid with lacquer.

A minimum of nine other cylindrical cans with lapped end seams, all of which may have been part of the hole-in-cap cans mentioned above, were found. In total, there are 70 sherds from this type of can that either have part of the end seam visible or were found in good association with end seam fragments. These cans range in diameter from 3 to $16.5 \mathrm{~cm}$.

One fragment of a cylindrical can with a clinched end seam was excavated from the Kitchen, and one large can with clinched end seams and a lapped side seam was found in 10 fragments in the Dining Room. The latter is highly corroded, and neither of the ends is present to tell if it was a holein-cap can.

Two ferrous fragments with flaring rims were found in the Kitchen. It is not evident what kind of can or vessel these sherds represent. Three can sherds from the Dining Room have unidentifiable manufacturing techniques.

\section{FOOD GROUP, PREPARATION}

\section{Baking Dish}

Thirteen base, side, and rim sherds of an oval baking dish were recovered from the Kitchen. This dish has a yellowware paste and is decorated in the Rockingham style (Figure 59). Aside from the glaze, no other decoration is present. Rockingham was originally made in England around 1785 (Brewer 1996:10). Oval baking dishes were made

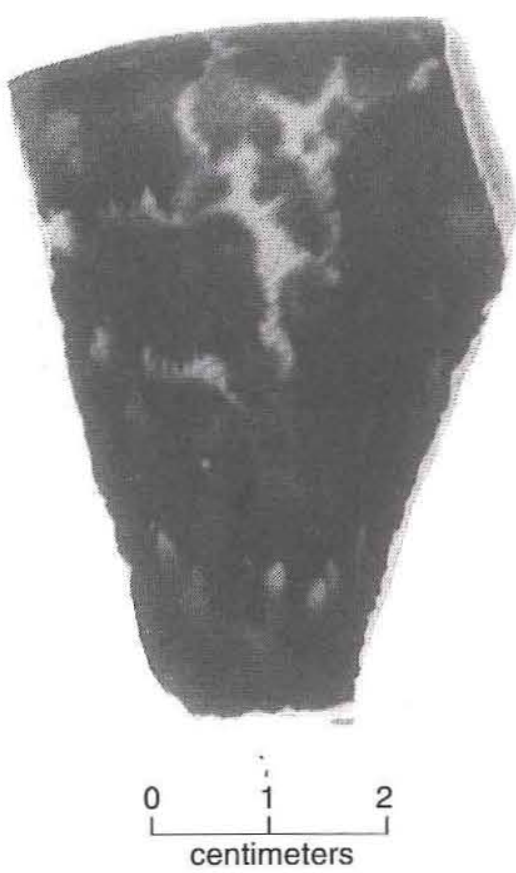

Figure 59. Rim sherd of oval serving dish with Rockingham glaze.

by most companies that produced Rockingham and were in production well into the first quarter of this century (Brewer 1996:72).

\section{Candy Mold}

A ferrous metal candy mold was found in the Kitchen (Figure 60). This piece is round with scalloped sides and is $4.5 \mathrm{~cm}$ at its widest diameter.

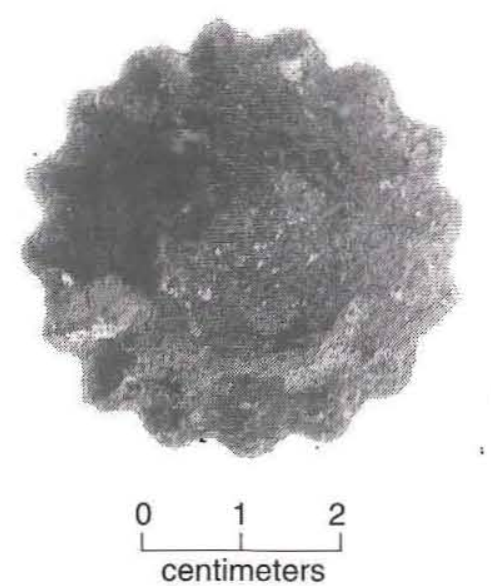

Figure 60. Candy mold. 


\section{Mixing Bowls}

Six sherds of a molded yellowware mixing bowl were found in the Kitchen. A small portion of the rim is present, but little of the body is shown. The rim is thick and is molded in bands; scalloping starts where the rim meets the body (Figure 61). From the rim sherd, it appears that the diameter of the bowl was between 33 and $35.5 \mathrm{~cm}$. Molded yellowware bowls were less common than wheel turned and were made in diameters from 12.7 to $35.5 \mathrm{~cm}$. Yellowware bowls were made from the 1830s until World War II (Ketchum 1987:31).
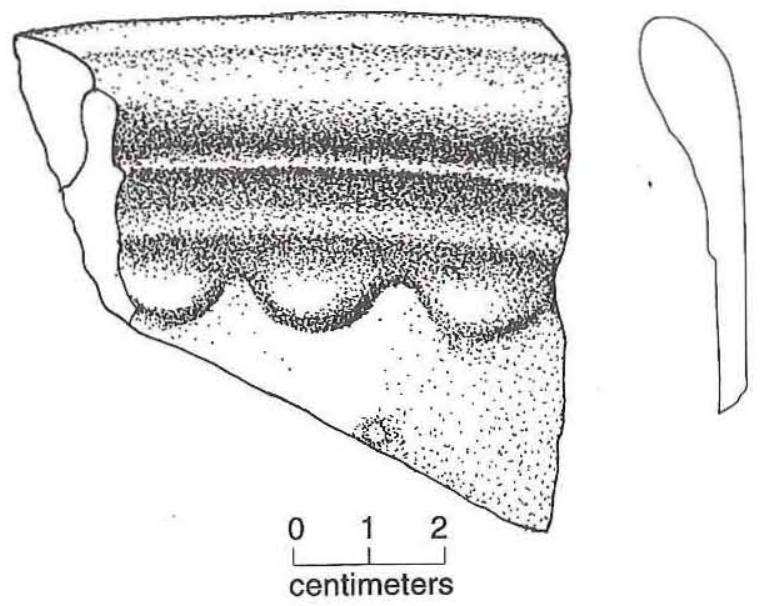

Figure 61. Molded yellowware mixing bowl rim sherd.

One body sherd from a wheel-turned yellowware bowl was excavated from the Kitchen. It is banded with two white stripes bordering one brown stripe. Brown and white were the predominant colors used for banding on yellowware mixing bowls (Ketchum 1987:31).

\section{Teapot}

Five sherds of a brown luster teapot were recovered in the Kitchen. Pieces of the spout and strainer are present. The color of this vessel is typical of a "Brown Betty" teapot, a common style even today. The paste is an off-white-colored earthenware.

\section{FOOD GROUP, SERVICE}

\section{Bowls}

Two thick, undecorated white earthenware bowl sherds (one rim and one body) were excavated from the Kitchen and could be from the same vessel. The rim sherd indicates a bowl diameter of approximately $16.5 \mathrm{~cm}$.

One bone china bowl rim sherd with gilding only was recovered from the Kitchen. This bowl appears to have been $15.2 \mathrm{~cm}$ in diameter.

One hollowware, bone china vessel rim sherd, probably from a bowl, has a light-green-tinted glaze resembling celadon and was found in the Kitchen (Figure 62). Both the interior and exterior were painted with simple fine-line curvilinear strokes producing a very simple fish scale-type pattern. The strokes resemble Chinese calligraphy and, in combination with the celadon color, give the effect of an Oriental design. A small portion of the rim was folded out to the exterior, creating a scallop or possible pour spout.

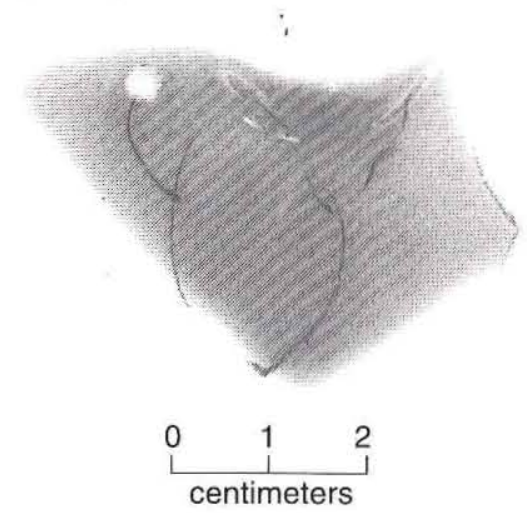

Figure 62. Celadonlike bowl rim sherd.

A small white earthenware bowl with a red transfer print, which is over two-thirds complete in 13 sherds, was excavated from the Kitchen (Figure 63). The diameter of the bowl is $11.4 \mathrm{~cm}$. The central scene pictures a girl wearing a hat with her arm around a dog. The maker cannot be identified, but it incorporates the word "England" which usually denotes a date after 1880 (Majewski and O'Brien 1987:167).

A 10.2-cm-diameter bone china rice or tea bowl, represented by two large rim sherds, is decorated with a Chinoiserie-style garden decal enameled with light green, dark green, and orange (Figure 64). Decorative elements include trees, shrubbery, and a bridge or pathway. Complex geometric and floral elements are present at the rim, which is enameled in dark green. These sherds were found in the Kitchen. The copper plate or lithograph stone used to create this decal was finely and deeply incised, 


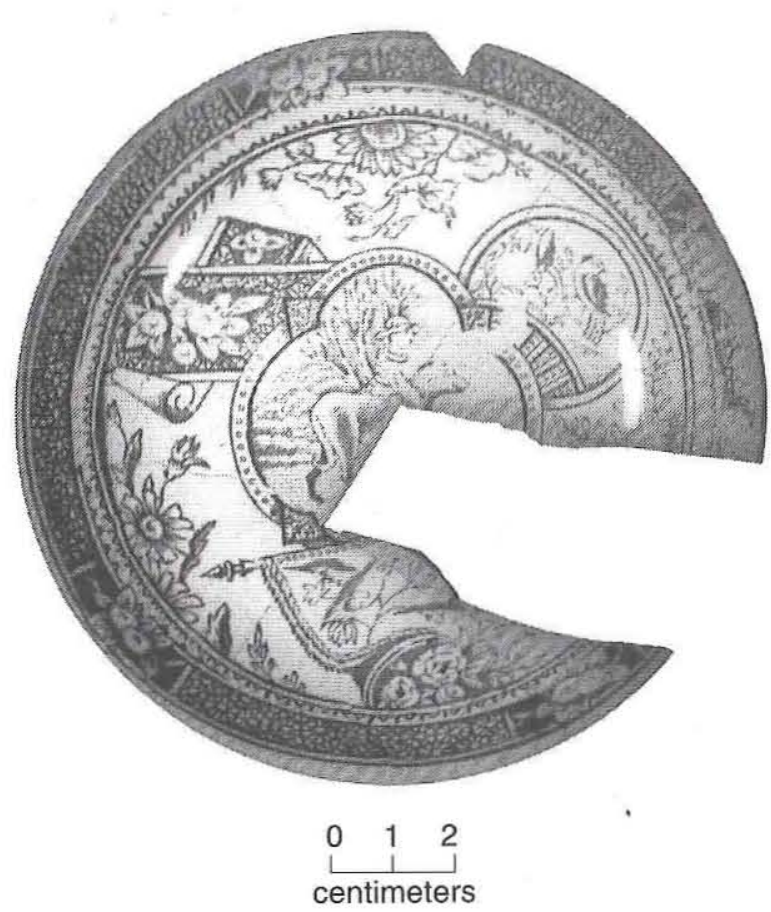

Figure 63. Transfer-printed bowl with girl and dog motif, post-1880.

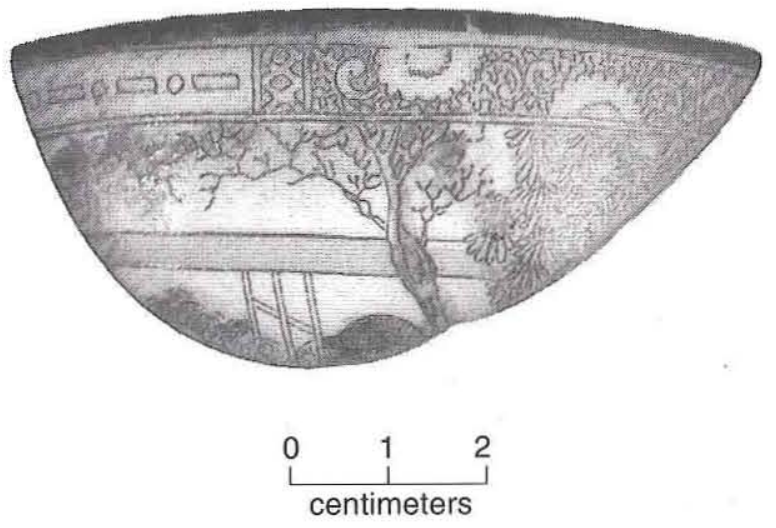

Figure 64. Rim of Chinoiserie-style bowl.

producing a detailed line design in which the red ink has high relief. An orange band below the rim appears to have been inked during the decal process. Unlike most decals, which provide fine degrees of shading, the shading on this pattern is created by hand tinting with greens and orange. The outline of this pattern is similar to transfer printing in its complexity of pattern and lack of shading, but its fine detail and overglaze application indicate that it is a decal. The decoration on this bowl may be an example of the popularity of Chinoiserie styles in the 1890s (Majewski 1994a:6).

A shallow white earthenware bowl with a diameter of approximately $15 \mathrm{~cm}$ is represented by three marly sherds recovered from the Kitchen. This vessel is decorated with a stripe of gilding below the rim, very light relief molding in a scallop or scroll form below the gilding, and a finely detailed floral decal extending below the molding. The decal consists of bright green leaves and a row of four flowers - pink roses on either end, and white flowers in the center. This design repeats at least once around the vessel based on the few sherds recovered. The rim is scalloped.

A medium-height, 16.5-cm-diameter fluted bone china bowl decorated with a brown decal was excavated from the Kitchen (Figure 65). Brown and gray flowers or seed pods, stems, leaves, and an orange flower were enameled over the decal. Only one-third of the bowl, primarily the side, is present in two sherds, so little of the pattern is known. The scalloped rim edge is gilded with gold.

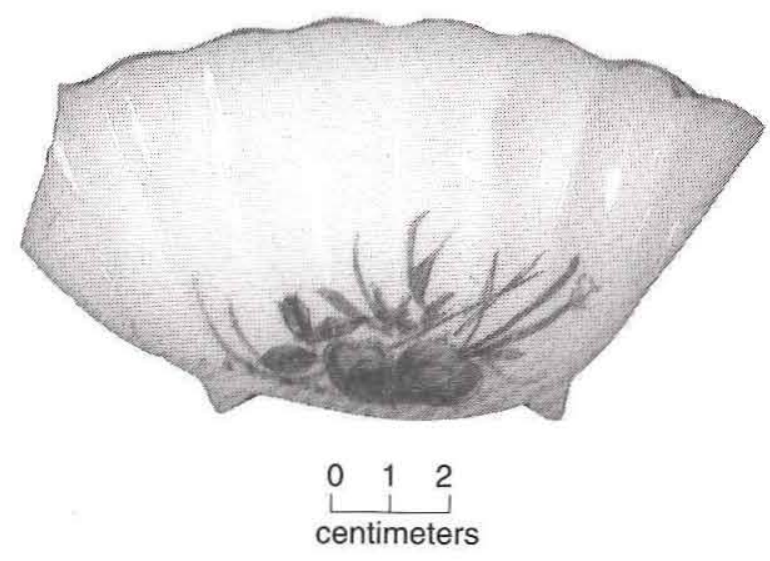

Figure 65. Brown-decaled bowl.

\section{Candy/Side Dish}

Twenty-three sherds of three majolica candy or side dishes were found in the Kitchen. These dishes are $12.7 \mathrm{~cm}$ in diameter and stood $2.5 \mathrm{~cm}$ tall. Each dish is molded with a basketweave pattern with a veined leaf in the center (Figure 66). The colors on these pieces range from brown in the center fading to green just around the leaf. The rims are tinted a mustard yellow.

\section{Caster}

One glass caster was found in the Kitchen (Figure 67). This piece, which was likely a pepper 


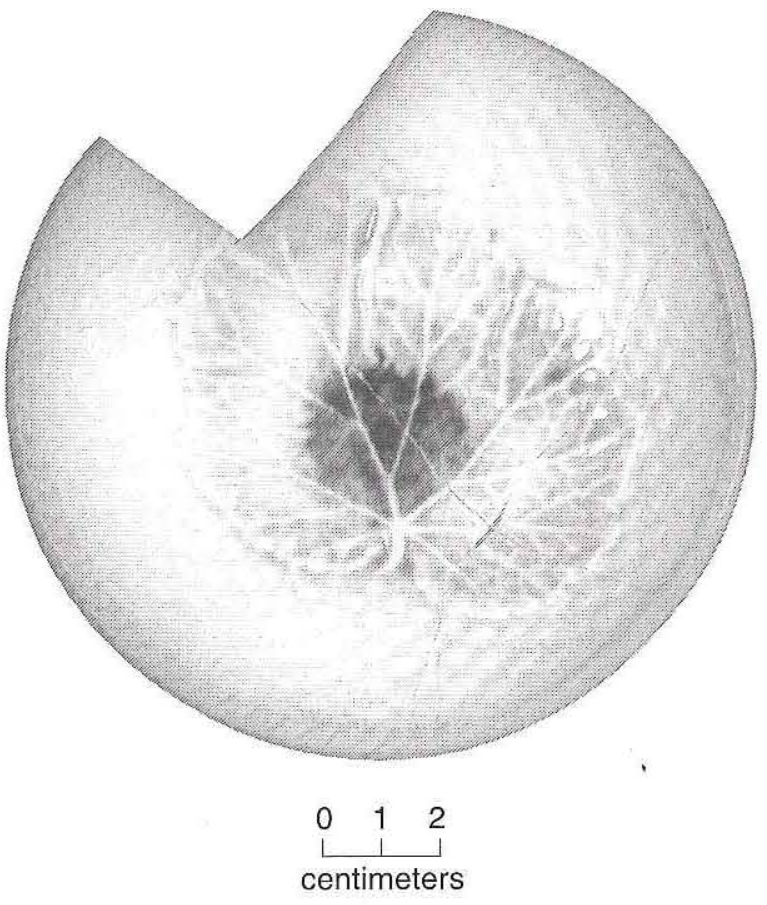

Figure 66. Majolica candy/side dish.

shaker or mustard bottle, is molded to fit into a metal stand, a feature common on mid-nineteenthand early-twentieth-century casters and cruets (Jones and Sullivan 1989:133). The caster stands $7 \mathrm{~cm}$ tall and has a maximum width of $2.9 \mathrm{~cm}$. This piece is similar to one made by the Sandwich Glass Co. and described as a toy mustard caster (Barlow and Kaiser 1987:Photo 3358).

\section{Cups}

An undecorated white earthenware cup, $8.3 \mathrm{~cm}$ in diameter, is represented by two large rim sherds forming one-quarter of the vessel. These two sherds were found in the Kitchen. No handle is present. Fourteen sherds representing three-quarters of a handled white earthenware cup, $8.9 \mathrm{~cm}$ in diameter, were found in the Kitchen. The glaze has a gray tint, and the cup would have stood $7.6 \mathrm{~cm}$ high. An undecorated white earthenware rim sherd from a cup or mug was excavated from the Dining Room, as was a single undecorated cup body sherd. Two white earthenware cup handle fragments, one cup body sherd and a cup base sherd were excavated from the Kitchen. The base sherd has what looks like a " 22 " enameled in red on it.

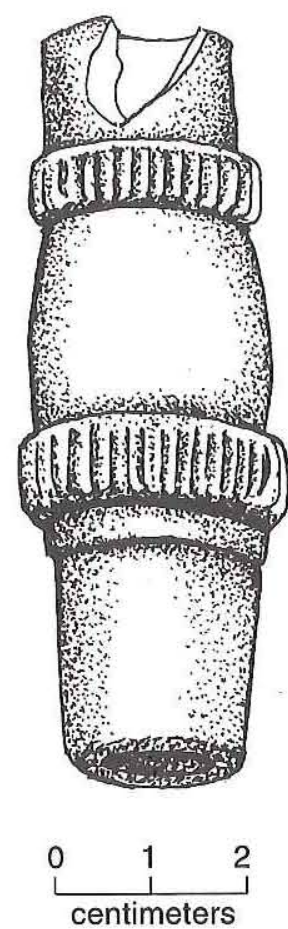

Figure 67. Caster molded for a metal stand.

One sherd, approximately one-half of an undecorated demitasse bone china cup, was excavated from the Kitchen. No handle is present. The cup was $5.7 \mathrm{~cm}$ in diameter and stood $5 \mathrm{~cm}$ tall. The remains of two undecorated bone china cups, both $9.5 \mathrm{~cm}$ in diameter and standing $5 \mathrm{~cm}$ tall, were recovered from the Kitchen. Approximately threequarters of one (12 sherds) and only one-half of the base of the other (1 sherd) are present. Nineteen sherds from another undecorated bone china cup were also found in the Kitchen. This cup was $7.6 \mathrm{~cm}$ in diameter and $7 \mathrm{~cm}$ tall. Approximately two-thirds of the cup is present. An illegible twocharacter mark is present on the base. A rim sherd, body sherd, basal sherd, and handle sherd, all undecorated bone china, were recovered from the Kitchen. These were not related to any of the other recognized vessels.

Two bone china cup bases with a stripe of gilding above the footring were excavated from the Kitchen. Imprinted on the base of each cup are the initials "G.D." A gilded tea cup handle was excavated from the Kitchen.

Ten sherds from a molded white earthenware cup were excavated from the Kitchen. The cup was approximately $8.9 \mathrm{~cm}$ in diameter and stood about 
$5.7 \mathrm{~cm}$ high. A low-relief molded swag outline occurs directly above the exterior of the footring; the remainder of the cup is undecorated. Approximately one-third of the cup, including a section from the rim to the base, is present. One molded bone china cup handle sherd also was excavated from the Kitchen.

Two molded and gilded bone china cup handles of the same design were recovered. One was found in the Kitchen, the other in Room 7. Three other different bone china cup handles are represented by five sherds excavated from the Kitchen.

A tiny portion of the rim of a handled, enameled, bone china cup is present in seven sherds. Its floral pattern consists of enameled blue and pink flowers with light and dark green and brown leaves. The handle is painted dark matte green and highlighted with thick outlines and bosslike dots of offwhite paint. A thick stripe above the base also is painted dark green with a central off-white stripe. The dots are scattered randomly between floral designs, and clusters of six larger dots painted dark green also are present. These sherds were excavated from the Kitchen.

A sherd from an enameled bone china cup with a floral design was also excavated from the Kitchen. The decoration on this rim sherd consists of a floral design with orange flowers and green stems and leaves dipping below a 1.3-cm-wide band of yellow below the rim outlined with dark brown stripes and a gold gilded stripe. Very little of the portion of the floral design within the yellow field is present. A body and handle sherd of a bone china tea cup was recovered from the Dining Room. This piece has an air-brushed pink tint, dating it to after 1884 (Majewski 1994b).

An enameled cup with gilding is represented by three bone china sherds from the Kitchen. The small portion of the floral design present is outlined in black and has brown leaves. An area of orange ground behind this design appears to have been applied with an atomizer based on the subtle shading of the color. This aerographic technique was developed in 1884 (Majewski 1994b). The rim edge is gilded.

A handled bone china cup with mustache bar, enameled in blue and gold, was excavated from the Kitchen (Figure 68). The cup is less than onequarter complete in five sherds and has a diameter of approximately $8.9 \mathrm{~cm}$. Gold and blue stripes outline a band of flowers near the handle and also

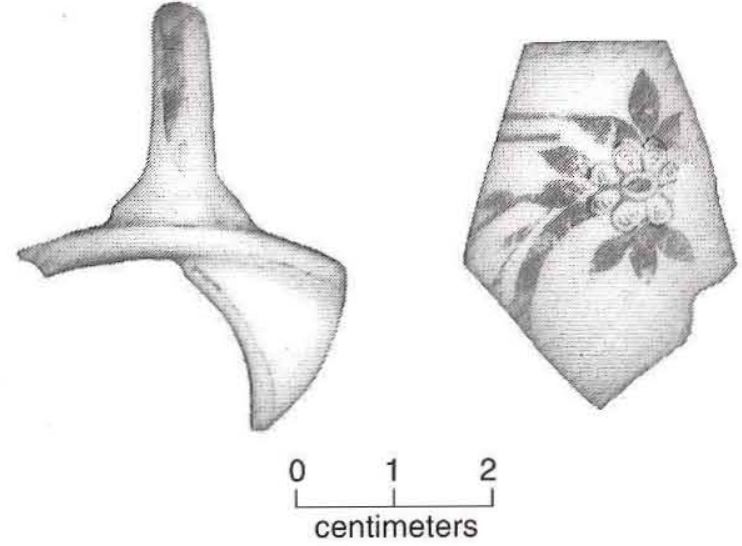

Figure 68. Sherds of cup with mustache bar.

occur above the footring. Very little of the floral decoration is present, but one rim sherd shows relatively broad stems and leaves, the latter slightly overlapping an eight-petaled blue flower with a gold center. The leaves above the flower extend above the framing gold and blue stripes nearly to the stripe of gold along the rim edge. Below the flower is a hand-enameled light blue ground probably applied with a stencil, leaving unpainted leaf elements. A body sherd from this cup has three to four parallel stripes crosscut obliquely by four sets of fine parallel stripes. A stripe of gilding runs along the interior edge of the mustache bar and along the outside of the handle. Mustache bars were offered as options with three different imported gilded china (porcelain) coffee cups in the 1895 Montgomery Ward \& Company catalog.

The remains of a bone china cup molded in a diamond pattern and painted pink were excavated from the Kitchen. The color is unevenly applied and may have been intentionally spattered or sprayed lightly with an atomizer. Only three body sherds are present.

A fluted bone china cup with enamel luster and gilding, represented by three separate rim, handle, and body sherds, was excavated from the Kitchen. The curvilinear flutes are enameled with pink luster, which also laps onto the lower edge of the handle. The rim edge is gilded, and pink luster- extends down the exterior below the rim for an unknown distance before the fluting begins. One side of the handle is gilded.

One-half of a bone china demitasse cup, represented by 10 sherds, was found in the Kitchen. The exterior of the cup is molded in a foliate pattern and 
is enameled; the interior is hand enameled in light green with a gilded, scalloped rim edge. The handle has gilded bands framing a row of four dots on its upper curve. The sherds indicate that the cup had a $5 \mathrm{~cm}$ diameter and was $5 \mathrm{~cm}$ high. A second, identical handle was also found in the Kitchen.

The remains of a handled, white earthenware cup are decorated on one side with a copper luster tea leaf pattern and matching bands below the rim on the interior and exterior (Figure 69). The pattern appears to have been painted underglaze and then enameled overglaze. An oval, pink luster tally mark is present on the base. This cup probably matches the saucer with the same design. The cup was $8.25 \mathrm{~cm}$ in diameter and $7.6 \mathrm{~cm}$ tall. The base does not have a projecting footring but is slightly concave. The 11 fragments of this cup are from all portions of the vessel and were excavated from the Kitchen.

One white earthenware cup rim sherd has two fragmentary portions of a polychrome floral decal. The one sherd was excavated from the Kitchen.

A bone china cup, with approximately one-third of the rim represented by two sherds, was excavated from the Kitchen. This $9.5-\mathrm{cm}$-diameter vessel has a gold decal with shamrocks and stems in a $1-\mathrm{cm}-$ wide band along the exterior rim. Tiny four-petaled flowers form framing triangles spaced at $1.25-\mathrm{cm}$ intervals alternating between the rim and the lower edge of the decoration.

The remains of a white earthenware cup, represented by only three rim sherds, were excavated from the Kitchen. This cup is decorated with a brown floral decal consisting of fine dendritic foliage behind gilded flowers. The rim also was gilded, but most of this gilding has worn off. The cup was $8.9 \mathrm{~cm}$ in diameter.

\section{Drainer}

Part of a white earthenware drainer was excavated in seven sherds from the Kitchen (Figure 70). This drainer fragment has six $0.5-\mathrm{cm}$ drain holes and a $1.9-\mathrm{cm}$ hole at one corner at what would have been the center of the drainer. The decoration is transfer printed with branches and leaves in flow

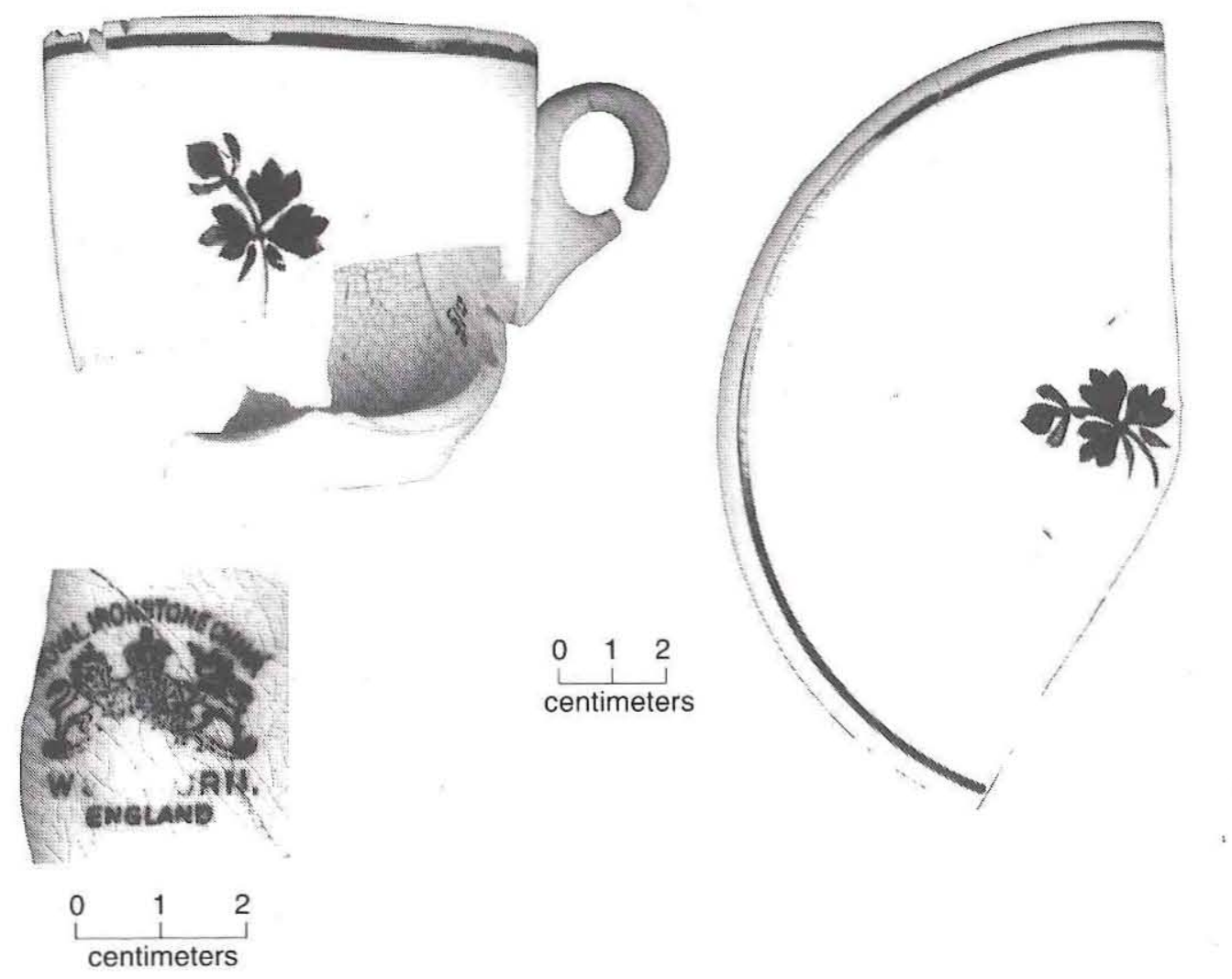

Figure 69. Tea leaf luster cup, saucer, and corresponding mark. 


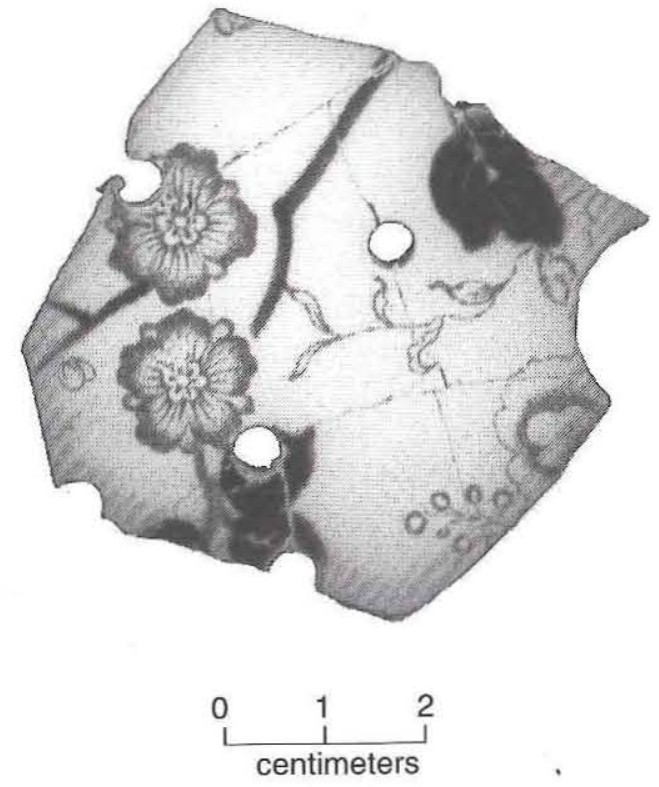

Figure 70. Transfer-printed drainer.

blue and flowers and smaller stems and leaves in red. Many vessel types would have a drainer similar to this, including soap dishes (Ketchum 1987:76), butter dishes (Williams 1987:227), and colanders (Ketchum 1987:85).

\section{Egg Cup}

The remains of at least two identical undecorated bone china egg cups were recovered (Figure 71). Five sherds were excavated from the Kitchen deposits, and one sherd was excavated from the Dining Room; this latter sherd cross-mends with one from the Kitchen. The bowl of the egg cup has a diameter of $5 \mathrm{~cm}$.

\section{Flatware}

Four fragments of three one-piece bone handles were recovered. Two were found in the Kitchen and one in the Dining Room. All are of a size and shape to suggest that they were handles from flatware. In addition, two two-piece bone handles were found in the Kitchen and two were found in the Dining Room.

Two ferrous handles, apparently from flatware, were found in the Kitchen; two more were found in the Dining Room. Two fragments of one ferrous knife blade and three pieces of two ferrous knife

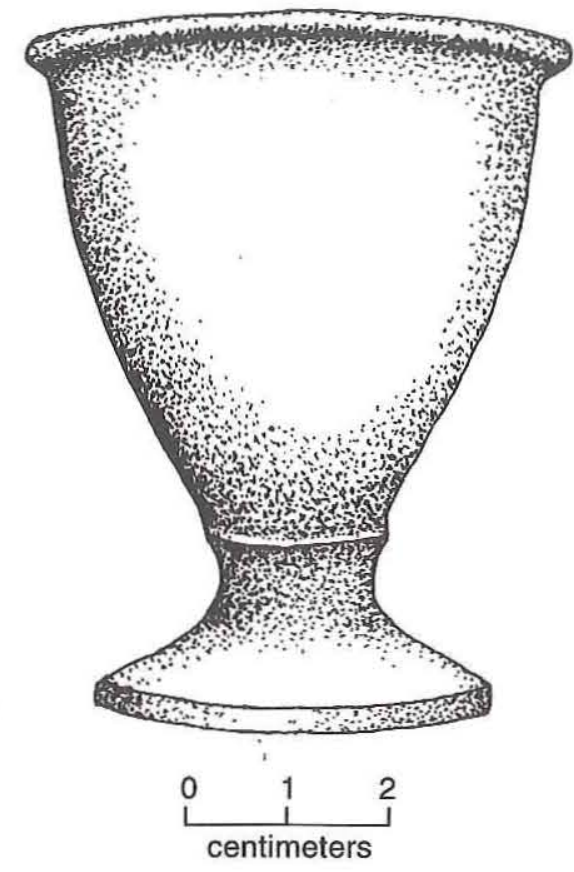

Figure 71. Egg cup.

tangs were recovered from the Kitchen.

One silver teaspoon was excavated from the Kitchen deposits. This spoon has a mark on the back which incorporates "MEXICAN SILVER." The only reference to a mark using "Mexican Silver" indicates Thomas Ellin \& Co., Silvester Works, Arundel St., Sheffield, which was in operation from 1892 to 1919. The company produced cutlery and edge tools (Woodhead 1987:70). A second spoon, this one appearing to be silver plated, was excavated from the Dining Room. This is a serving spoon and it has no marks.

\section{Ladle}

An iron vessel, possibly a ladle, was found in 19 pieces in the Dining Room fireplace. The vessel consists of an inwardly rolled lip, straight sides, and a flat bottom. Only about half of the vessel is present.

\section{Plates}

Two rim sherds and one base sherd representing less than one-quarter of an undecorated white earthenware plate were excavated from the Kitchen. The plate was $17.8 \mathrm{~cm}$ in diameter. Also recovered 
were seven rim sherds from undecorated earthenware plates. Three of these are from the Kitchen, and the other four are from the Dining Room.

Eighteen sherds from an undecorated bone china plate were excavated from the Kitchen. This plate is nearly complete and has a diameter of $19 \mathrm{~cm}$. Two matching plates with whiter glazes and wider marlys than the last were excavated in 25 sherds from the Kitchen. Each has a reinforcing ring on the underside of the marly break, and they are $19 \mathrm{~cm}$ in diameter. One of these plates is nearly complete with two sherds, and approximately threequarters of the other is present, represented by 23 sherds. Another bone china plate with a marly similar to these last two was excavated in four sherds from the Kitchen. This plate differs from the other vessels in that it has a grayer glaze and no reinforcing ring on the underside of the marly break. Approximately one-third of this plate is present.

One earthenware plate rim sherd with only gilding around the rim was excavated from the Kitchen. The paste is off-white or slightly cream colored. The remains of two bone china plates, each gilded with an upper wide and lower narrow stripe of gold were excavated from the Kitchen. One is represented by three small rim sherds and was approximately $16.5 \mathrm{~cm}$ in diameter. The other is a complete, $19-\mathrm{cm}$-diameter plate that was found in two sherds.

A bone china plate fragment with a gilded rim and enameled blue ground was excavated from the Kitchen. The remains of two other enameled and gilded bone china plates also were found there; both have gilding on the scalloped rim edge and paired wide and narrow gilded stripes at the brink. Between the gilding, the entire marly is enameled in pink. The ragged edges may indicate hand enameling. The decoration on the rim of each vessel is similar, although the rim band is a darker pink on one. It is possible that these vessels are from the same set. The plate with the darker band was excavated in five sherds, the other was found in eight sherds. Both plates are represented by only a small portion of the marly.

A bone china plate decorated with a brown floral decal is represented by a single rim sherd. No lot number is present on the sherd, so its provenience is not known. The rim is gilded with a stripe of gold. The rim border consists of alternating four-petaled florets and beads on a blue ground above a string of overlapping scallops. The small portion of the floral decal on the marly has light green and yellow leaves and pink and blue flowers.

Two sherds of different white earthenware dinner plates, decorated with a finely detailed brown decal originating at the lightly scalloped rim and trailing over the rim, were excavated from the Kitchen (Figure 72). Different stylized flower clusters are enameled with pink and blue. One plate has a diameter of $24 \mathrm{~cm}$; the other is too small to measure. These sherds are good examples of the early monochrome decals.

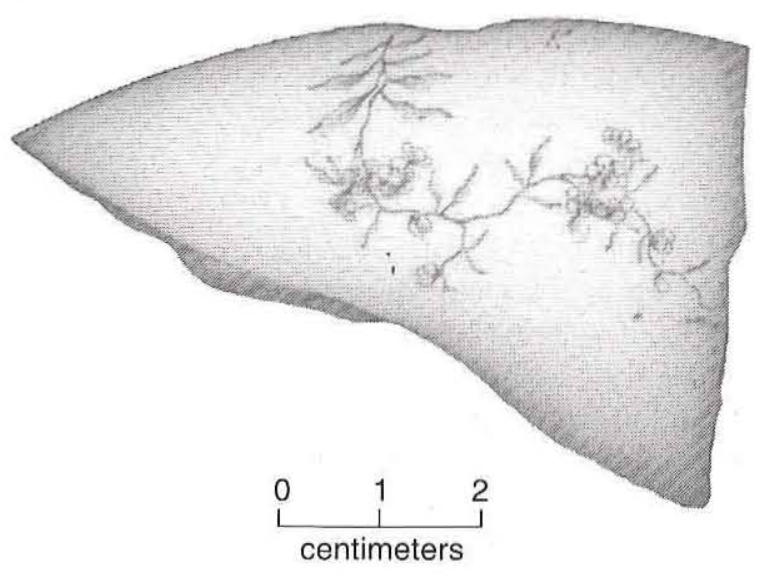

Figure 72. Monochrome decal with enameled flowers. This is an example of early decals.

A white earthenware plate with a polychrome floral decal, enamel, and gilding is represented by two marly sherds from the Kitchen. Less than onequarter of the vessel is present, so most of the pattern is unknown. One decorative element is a large rosebud in pink, brown, green, and yellow. The rim was decorated in light green with an atomizer based on the subtle fading of the color away from the rim. This aerographic technique was developed in 1884 (Majewski 1994b). A stripe of gilding is present below the unscalloped rim. The diameter of this plate was $18.4 \mathrm{~cm}$.

Fourteen sherds from a molded white earthenware plate with a polychrome rose decal were found in the Kitchen. This plate is represented by large rim sherds and small body sherds and appears to have been approximately $20.3 \mathrm{~cm}$ in diameter. The decal has pink, blue, and yellow flowers with green and brown leaves and branches. This decal matches the one on a saucer from the collection.

A molded bone china plate with a floral decal is represented by seven rim sherds from the Kitchen. 
This plate is decorated with very light molded relief that would be virtually invisible on a moreopaque body. The molding appears to consist of clamshell-type scallops between plain scallops, and this molding is reflected in the rim scalloping. The finely detailed decal has large flowers and some leaves outlined in brown, with the remainder of the design of green leaves and pink and yellow flowers not outlined. The plate was approximately $20 \mathrm{~cm}$ in diameter.

A bone china plate with a decal, molding, and gilding was excavated from the Kitchen in 11 sherds (Figure 73). This 19.7-cmdiameter, nearly complete plate is decorated with elaborate molding covering the entire marly, a stripe of gilding below the rim, and six alternating large and small decal flower clusters around the outer half of the center with an additional small flower in the center. The molded marly consists of large scallops $6.4 \mathrm{~cm}$ wide accented along the inside of the curve with

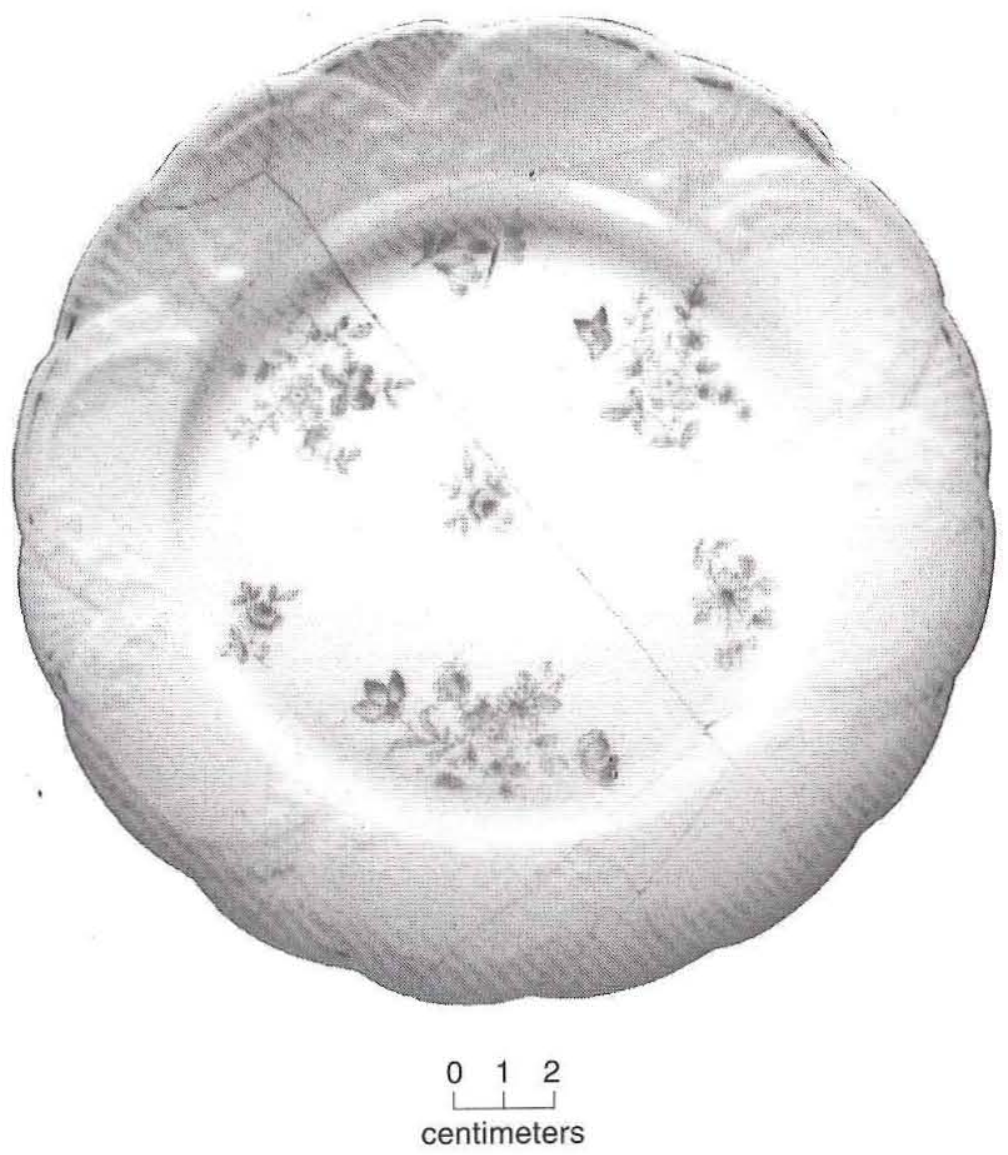

Figure 73. Bone china plate with floral decal. molded foliate motifs. Between each large scallop is a segmented, clamshell-like scallop. The two scallop types combine to create a broadly scalloped rim. The decal consists of a floral design outlined in orange. The orange, pink, and blue flowers and green leaves were enameled within the orange decal outline. All of the flower clusters are slightly different decals.

Another bone china plate with a decal, molding, and gilding is from the Kitchen. This plate, represented by five rim and marly sherds, is decorated with a band of gilding at the rim. Underneath and extending below the gilding is delicate molding in the form of a 5-cm-wide scroll above a line of five bosses. The scalloped rim parallels this molding. The decal is outlined in pink and consists of a cluster of pink flowers with green leaves, but little of the pattern is present. The plate was $20.3 \mathrm{~cm}$ in diameter. An additional, nearly complete plate with this pattern is on display at Sebastopol State Historical Park (Figure 74). This plate has pink flowers placed in at least four clusters around the rim, with

two of those clusters trailing down into the center. The center of the plate has a small cluster with two flowers. The green printed back mark, based on catalog information, is "M.Z./[Prussian doubleheaded eagle]/AUSTRIA." This mark was used by Moritz Zdekauer of Altrohlau, Bohemia, producers of earthenware and porcelain, from 1884 until 1909 (Kovel and Kovel 1986:94j).

\section{Salts}

Two halves of one glass salt cellar were excavated from the Kitchen. This salt holder was hexagonal and faceted, stood $2.3 \mathrm{~cm}$ tall, and was $4.6 \mathrm{~cm}$ at its widest point (Figure 75), A sixpointed star was impressed on the bottom of the piece. M'Kee and Brothers advertised this style of salt cellar in their 1871 catalog (M'Kee \& Bros. 1981:180), but this is a very simple style which was, no doubt, made by many companies. 

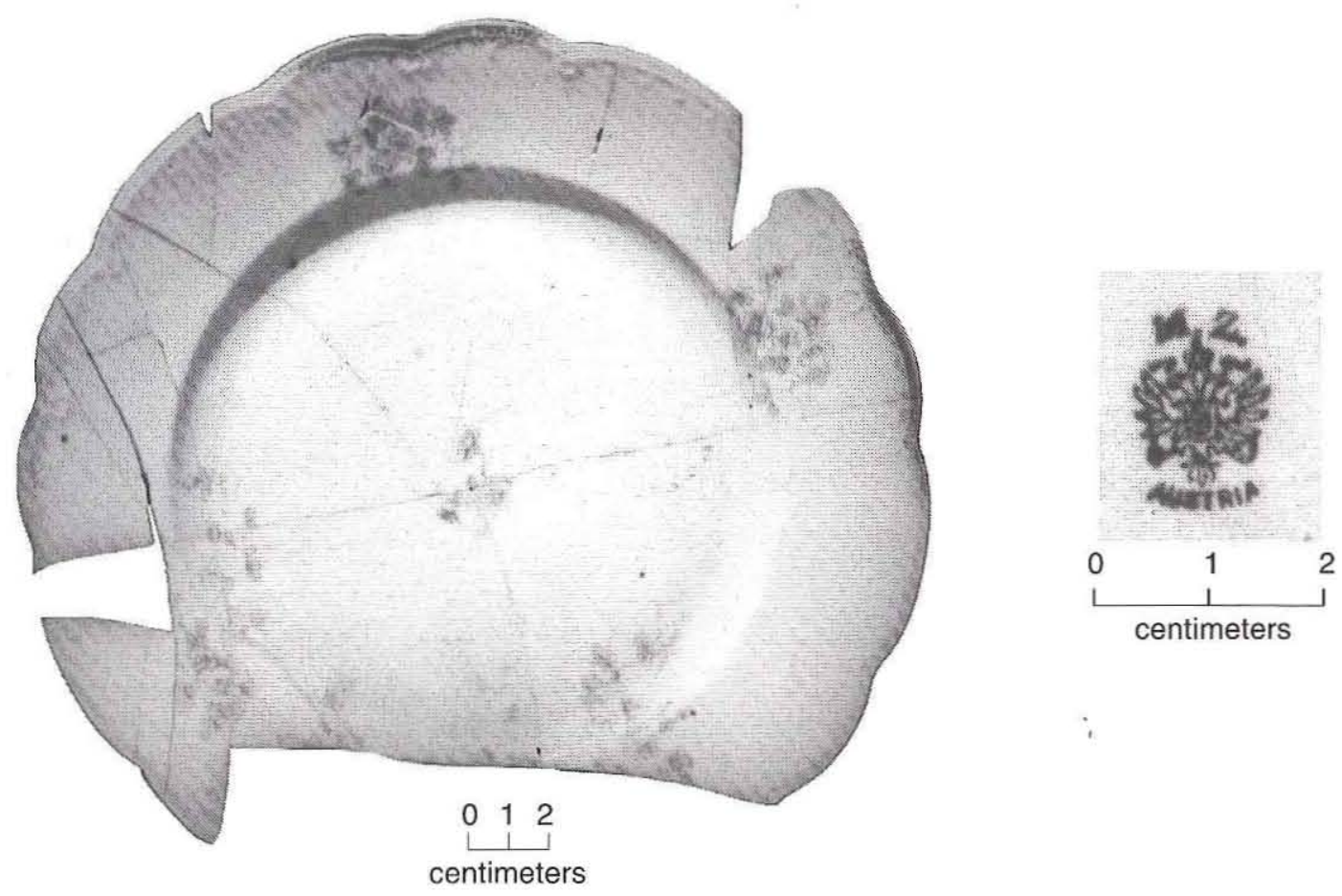

Figure 74. Molded, decaled plate with polychrome floral decal and M.Z. Austria mark (1884-1909).

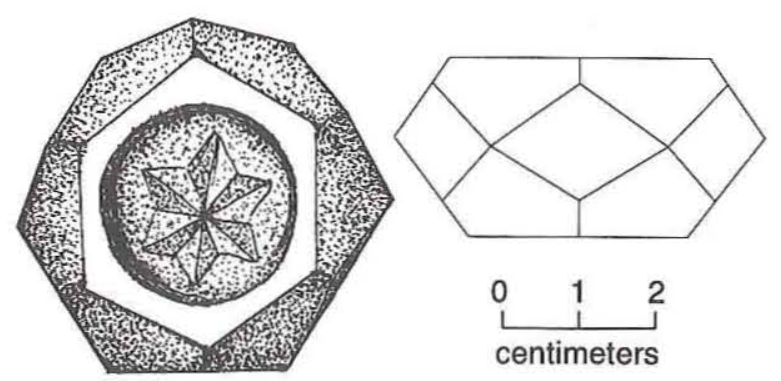

Figure 75. Salt cellar.

\section{Saucers}

A minimum of three undecorated bone china saucers were excavated from the Kitchen. One sherd represents about one-third of a $10.8-\mathrm{cm}-$ diameter demitasse saucer. Sixteen sherds make up approximately one-third of a $15.25-\mathrm{cm}$-diameter saucer. Two rim sherds represent the third undecorated saucer.

Two gilded white earthenware saucers, each $15.25 \mathrm{~cm}$ in diameter, have a gilded stripe below the rim. Eight rim sherds were found in the Kitchen.

A single rim sherd from a gilded, molded, and airbrushed bone china saucer was excavated from the
Kitchen. The airbrushing is a pale yellow, and the gilding follows the pattern of the molding. The diameter of the piece was approximately $15.25 \mathrm{~cm}$. This piece postdates 1884 (Majewski 1994b).

Five sherds from the Kitchen cross-mend to form a nearly complete bone china saucer (Figure 76). The edge of this $15.25-\mathrm{cm}$-diameter saucer is decorated with molded shell-like curvilinear ribs and bosses covered with pink luster. The scalloped rim edge is gilded, and the cup ring is outlined with a circle of gilding. The molded and painted edge is reminiscent of nineteenth-century shell-edged decoration, but the gilding and the modern vessel form (shallow with a cup ring and molded ring inside the footring on the base) indicate a turn-of-the-century to early-twentieth-century form.

One majolica saucer, $16 \mathrm{~cm}$ in diameter, was found in seven sherds in the Kitchen. This piece has a complicated molded pattern with a stylized flower design in the cup ring and geometric designs surrounding this in panels. A molded flower pattern encircles the saucer over the geometric patterns (Figure 77). The colors include brown in the cup ring and blue and black in the geometric panels. The black and brown colors have a luster quality. 


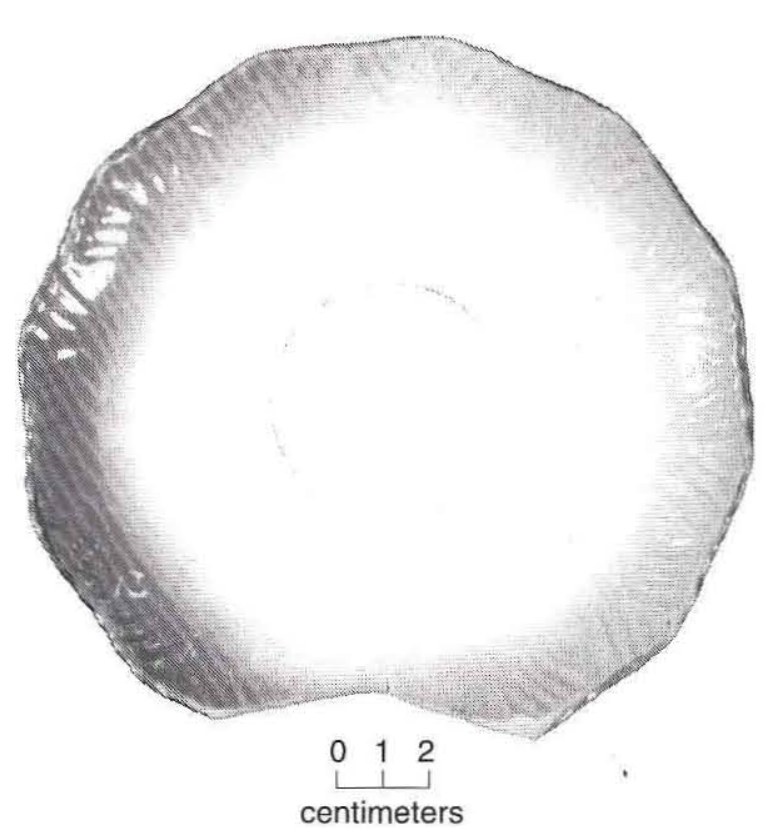

Figure 76. Molded and gilded saucer with pink luster (post-1884).

The flowers are a purplish red with blue-green stems. The colors were applied underglaze but appear to melt into the glaze, causing the edges of the colors to blend. Deep yellow enhances the rim of the saucer. Embossed on the base is "... WOOD," and enameled on the base is "3282" and a "u," all in deep red. This saucer was made by Wedgwood. This firm produced majolica wares from 1862 into the first quarter of the twentieth century (Snyder and Bockol 1994:113-115).

A bone china saucer, approximately one-half complete in 23 sherds from the Kitchen, has a floral and arch pattern around the rim (Figure 78). Pink and orange flowers with green and blue leaves are enameled on a white field. In between floral pairs, double gilded stripes frame a solid yellow band $1.5 \mathrm{~cm}$ wide enameled by hand and outlined with brown stripes. A gilded arch is enameled near one of the floral pairs. The overall appearance is a pastel watercolor effect. The diameter of this saucer is approximately $14 \mathrm{~cm}$. The mark incorporates the words "HAND PAINTED" and "MADE IN JAPAN" and likely dates to the twentieth century (Godden 1991:11).

Another bone china saucer, which is one-third complete, is similar to the last but probably not from the same set based on the differing decoration technique. It shares the same yellow band framed

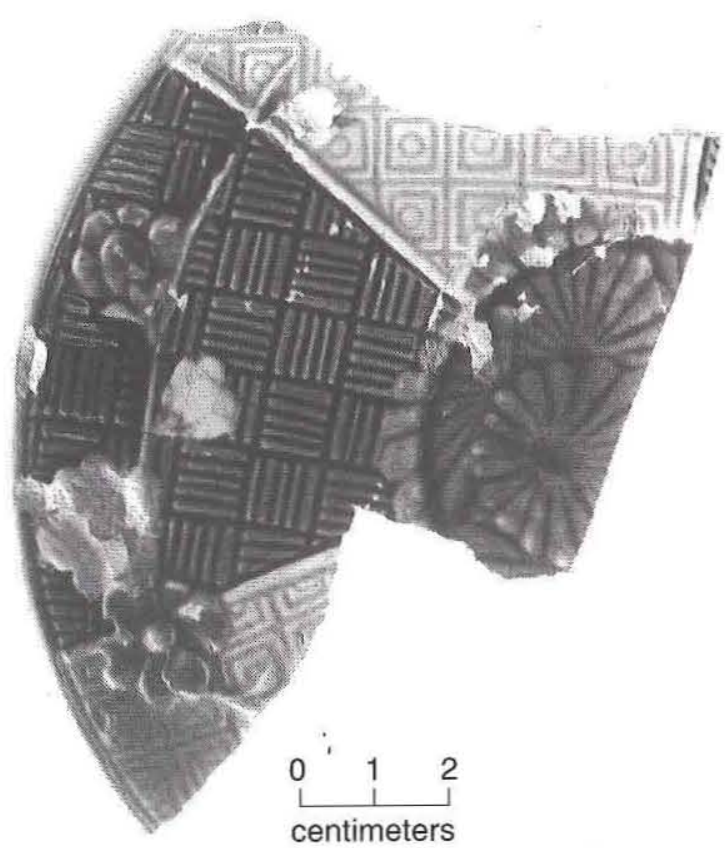

Figure 77. Majolica saucer.

by finer brown stripes and gilding below the rim, but there is no gilding below the yellow. The yellow band has straight, crisp edges, and the color is evenly applied, indicating that a stencil was used, perhaps with an atomizer. The flowers and leaves are outlined with brown enamel and are a different hue from the other dish. Part of what appears to be the same mark as that on the previous vessel is visible on this piece. Five sherds make up what remains of this 14-cm-diameter saucer from the Kitchen.

A third enameled and gilded bone china saucer, which is two-thirds complete, is decorated with a geometric pattern reminiscent of a Greek key pattern (Figure 79). The rectilinear pattern enameled in black occurs in a $1.25-\mathrm{cm}$-wide band on a plain white field bordered on each side by a $0.64-\mathrm{cm}$-wide enameled blue band outlined in black. There is gilding below the rim, at the interior edge of the brim decoration, and outlining the cup ring. This saucer was found in eight sherds in the Kitchen and was $16 \mathrm{~cm}$ in diameter. A gilded, handwritten " 2133 " is the only maker's mark.

Six sherds of a $14.5-\mathrm{cm}$-diameter white earthenware saucer are from the Kitchen (see Figure 69). The decoration was a copper luster tea leaf pattern in the center and matching band below the rim. The rim band appears to have been painted under- 


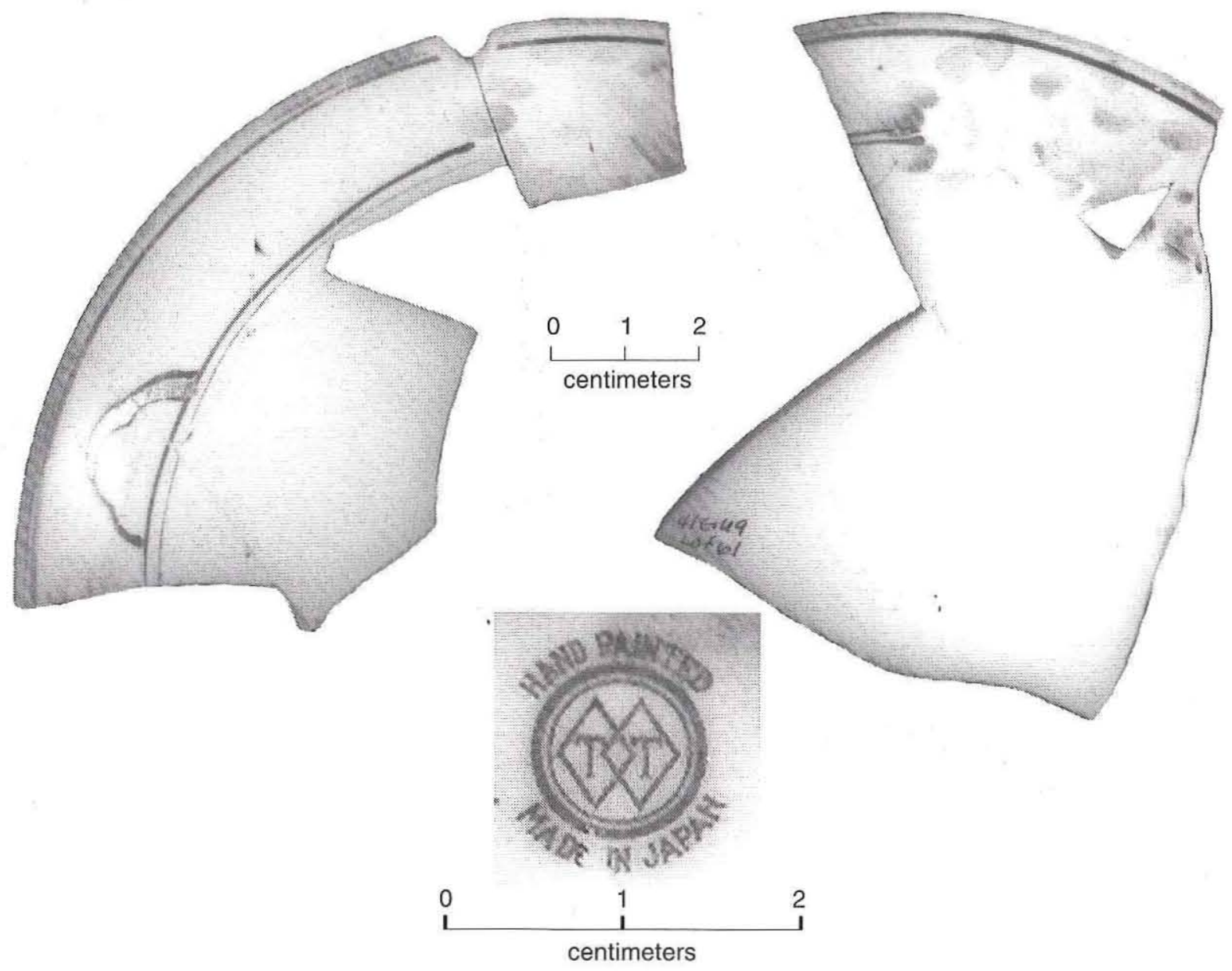

Figure 78. Hand-painted Japanese saucer sherds and mark.

glaze and then enameled overglaze. The saucer probably matches the tea leaf cup. The tea leaf pattern was introduced in the 1850 s and was most popular between 1880 and 1900 (Majewski and O'Brien 1987:160). The maker of this piece is likely W. \& E. Corn of Burslem and Longport, in business from ca. 1864 to 1904 (Godden 1991:175). After 1891, "England" was added to marks to comply with the American McKinley Tariff Act of 1891 (Godden 1991:11). The Sears, Roebuck and Company (1897:681, No. 9603) catalog indicates availability of this pattern until the turn of the century, although the Sears' manufacturer is Meakin.

A bone china saucer, one-third of which is present in seven sherds, has a double row of shell molding, the first beginning approximately $1.25 \mathrm{~cm}$ below the rim and the other around the molded cup ring (Figure 80). Approximately one-third of the saucer is present, so some elements of the pattern are unknown. The marly is enameled with alternating designs. The larger design is a pink and yellow nasturtium or poppy-type flower with dark and light green and yellow stem and leaves and a shadow effect created with light blue enamel. The smaller design is a violet or pansy-type flower surrounded by pink and yellow buds and light and dark green leaves; the central flower in each of these clusters varies from purple to red to orange in the fragments represented. The floral cluster in the center of the saucer appears similar to the violet or pansy motif but larger and more complex. The molded scroll and scalloped rim has a wide band of gilding. These sherds are from the Kitchen and indicate that the vessel's diameter is approximately $15.25 \mathrm{~cm}$.

One rim sherd of a white earthenware saucer molded with secondary scallops and vertical hatching was excavated from the Kitchen. The saucer had an iridescent rose decal. The design has pink roses 


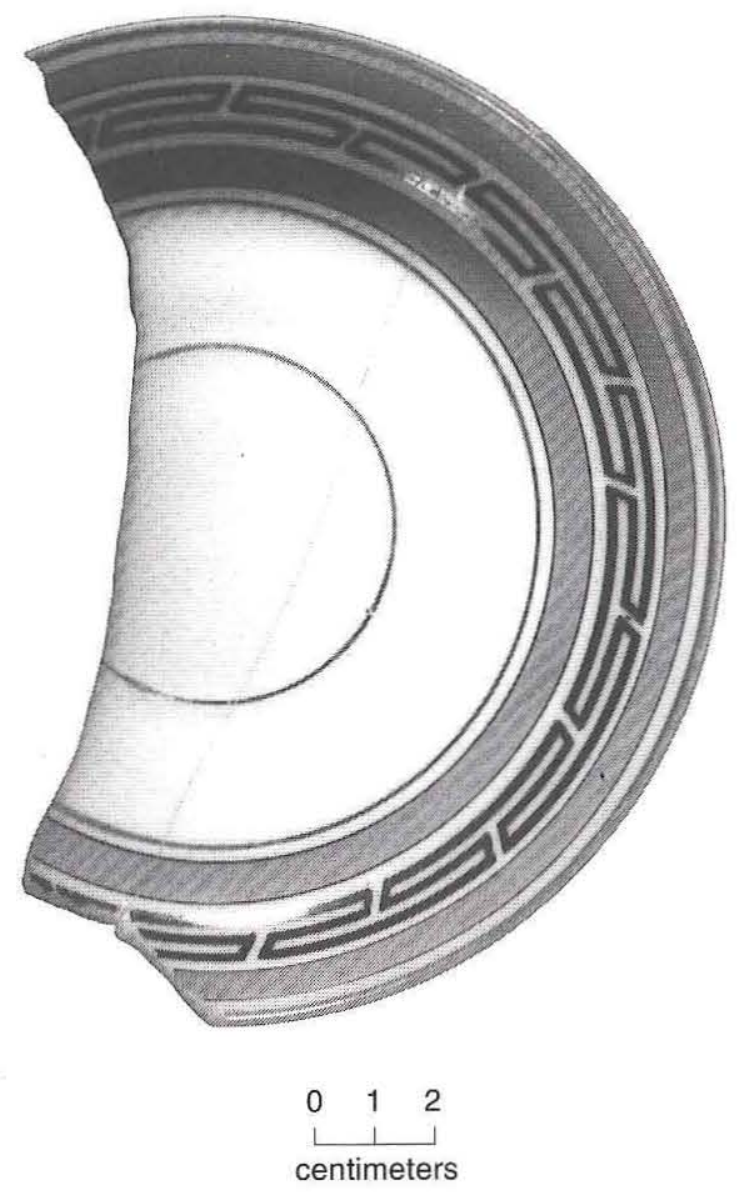

Figure 79. Enameled and gilded saucer with geometric pattern.

with blue and yellow shading, light green leaves, and red-over-green stems and leaf detailing. Also present are flowers with pink coloring over blue, producing an iridescent effect. This same decal is present on a plate.

One bone china saucer was found with the same shamrock decal on the rim as the matching cup but, in addition, has fine low-relief molding that is difficult to identify because of the fine decal. Approximately one-quarter of the rim is present in nine small sherds from the Kitchen, and the diameter of the vessel was approximately $11.4 \mathrm{~cm}$.

Another bone china saucer represented by three marly sherds only is decorated with very low relief molding visible on the translucent porcelain. Beneath the scrolls below the rim are clamshell scallops, and the decal design is trailed over the marly up to the rim. The small but not very finely executed design consists of yellow and green leaves

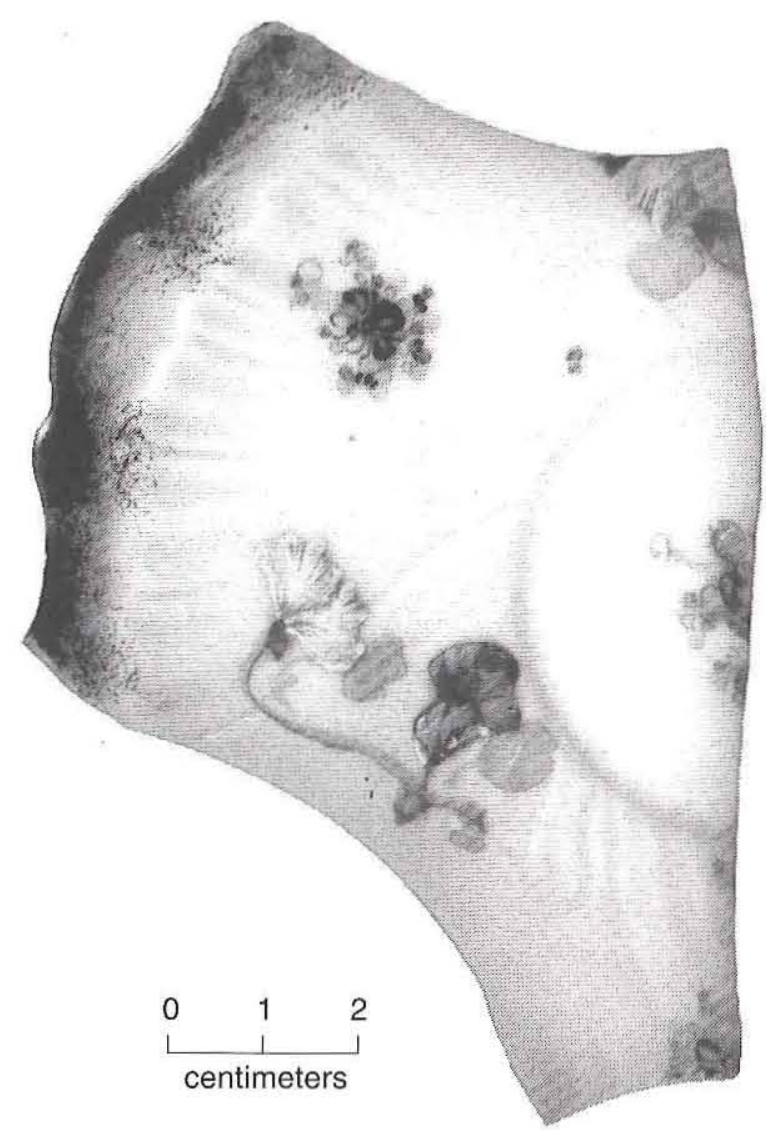

Figure 80. Molded, enameled, and gilded saucer.

and orange and yellow flowers. The saucer appears to have been $15.25 \mathrm{~cm}$ in diameter and is from the Kitchen.

\section{Serving Dish}

Four glass sherds from the lid of a large serving dish were recovered in the Kitchen. The lid was made of colorless glass.

\section{Stemware}

The term "stemware" is used to describe those tableware vessels with a stem, such as wine glasses, goblets, spoon holders, and celery vases. A minimum of 14 individual vessels is represented.

\section{Known Patterns}

Eight fragments of two wine glasses of the Ashburton pattern were found in the Kitchen (Figure $81 a$ ). The vessels were made of pressed lead or 

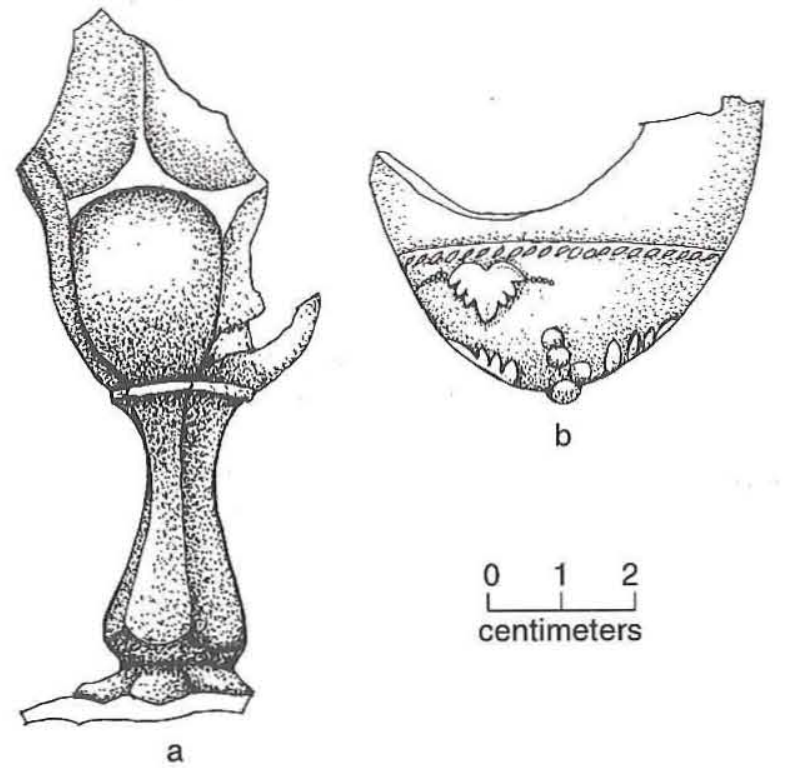

Figure 81. Wine glasses. (a) Ashburton pattern; (b) Currant pattern (patented 1871).

flint glass which fluoresces under ultraviolet light. The diameter of the base is $5.25 \mathrm{~cm}$. Only parts of the base, stem, and body are present. The rim is not discernible from the remains found, but mold seams are present indicating a two-part mold. The Ashburton pattern was issued by many companies as early as 1848 , as late as post-1891, and in reproductions in the 1960s and 1970s. The pieces found at Sebastopol are heavy and brilliant, a quality common to the earlier productions (Jenks and Luna 1990:26).

One rim and body fragment from a wine glass of the Currant pattern was recovered from the Kitchen (Figure $81 \mathrm{~b}$ ). This piece of pressed glass shows part of the pattern that was patented by Mary B. Campbell in 1871. It is known that Campbell, Jones \& Co. of Pittsburgh, Pennsylvania, produced this pattern, but variations in vessel shapes indicate more than one manufacturer (Jenks and Luna 1990:141).

Ten body and rim sherds of two large goblets press molded in the fine cut-and-block pattern were excavated from the Kitchen (Figure 82). These goblets were $9.5 \mathrm{~cm}$ in diameter. The blocks of the pattern were painted pink on one goblet, and blue on the other. Jenks and Luna (1990:209) specify that two sizes of goblet were made in this pattern: men's and lady's. The lady's goblet was smaller than the man's, although no dimensions are given. The first issue of this pattern was in 1890 , and it

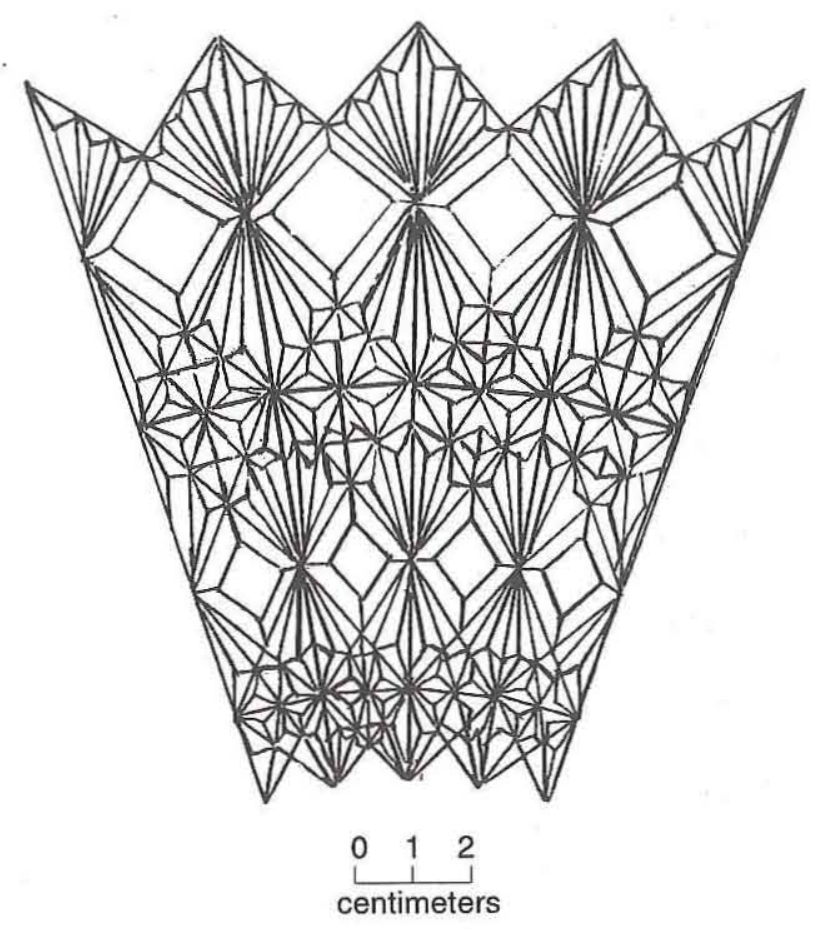

Figure 82. Fine cut-and-block press-molded pattern.

has been reproduced as recently as 1969 .

\section{Unidentified Patterns}

One sherd of a stemware vessel was excavated from the Kitchen. This piece is the joint between the base and stem. No mold seam is present and the glass fluoresces under ultraviolet light, indicating that it contains lead. Three sherds of stemware bases with a diameter of $7 \mathrm{~cm}$ were excavated from the Kitchen. One base, $7.5 \mathrm{~cm}$ in diameter, with a stem fragment still attached, was excavated from the Dining Room. This base has three mold seams indicating a three-piece mold. This piece also has a hexagonal stem. A minimum of two goblets with recognizable but unidentified bowls and $8-\mathrm{cm}$ base diameters were excavated from the Kitchen in 20 sherds. The goblets are made of a heavy glass which is undecorated except for an embossed ring which encircles the base of the bowl above the stem. The glass does not fluoresce.

Two 8-cm-diameter bases which may match those above were also excavated from the Kitchen. Four other 8-cm-diameter base fragments representing a minimum of two vessels were excavated from the Kitchen. These could match any number of styles, including the one discussed above. Five 
fragments of 9-cm-diameter bases, two with clear mold seams, were recovered from the Kitchen. These fragments represent a minimum of two vessels. Three fragments of the bowl of an optic-molded vessel, possibly a spoon holder, were found in the Kitchen. It has wide ribs running up the interior of the bowl, and appears to have been footed.

Two undecorated, yet different, goblet bowls were excavated from the Kitchen. The following were also found in the Kitchen: seven fragments of at least three pressedglass wine glass bowls which have no decoration except mold seams (Figure 83a); a wine glass bowl fragment with fluting extending about a third of the way up the bowl from the stem and with mold seams similar to those in Figure $83 a$, indicating that it was press molded (Figure 83b); a pressmolded wine glass bowl fragment with three single grain sheaves running up the side of the glass (Figure $83 c$ ); and eight fragments of an etched wine glass bowl made from lead glass that fluoresces under ultraviolet light (Figure 83d).

\section{Tumblers}
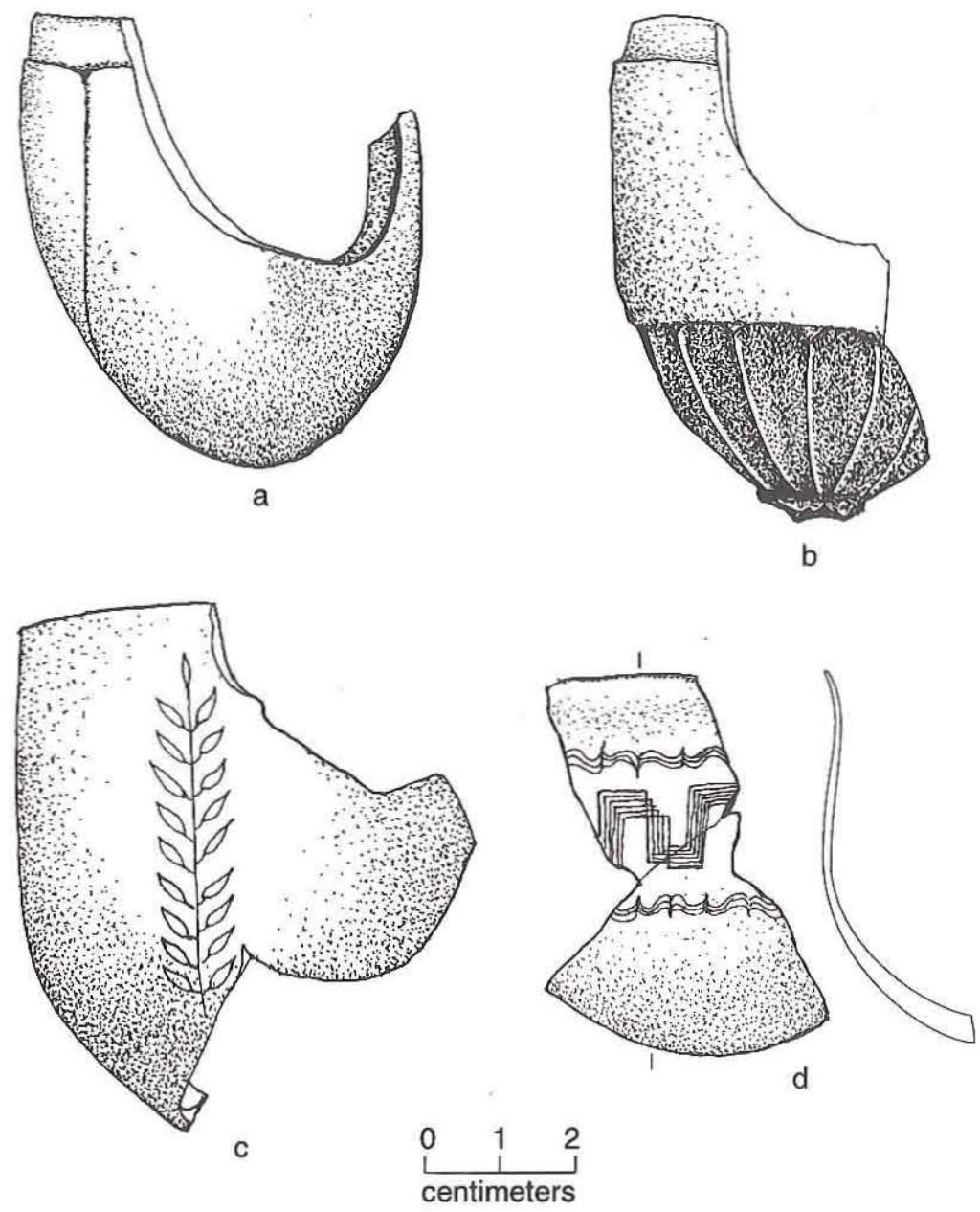

Figure 83. Wine glasses. (a) Undecorated, press-molded wine glass bowl with seams; $(b)$ press-molded, fluted wine glass fragment; $(c)$ unidentified press-molded pattern of grain sheaves; $(d)$ pattern on etched lead wine glass fragments and profile.
A minimum of 35 tumblers are represented in the Sebastopol collections by 182 glass sherds. Twelve tumblers with recognizable patterns are present. Pattern No. 1 is represented by one body sherd with fluted bottom found in the Kitchen. The diameter of this piece is unknown. A similar style is illustrated in the Sears and Roebuck catalog of 1897 (1897:686). Pattern No. 2 occurs on an opticmolded tumbler which stands $7.1 \mathrm{~cm}$ tall and was excavated from the Kitchen in seven sherds. The pattern texture is present on the interior of this glass (Figure 84a). This tumbler has a base diameter of $5 \mathrm{~cm}$ and a rim diameter of $6.5 \mathrm{~cm}$. Pattern No. 3 occurs on a pressed-glass rim sherd from the Kitchen (Figure 84b). This piece has a rim diameter of $5 \mathrm{~cm}$. Pattern No. 4 occurs on a contact-molded tumbler with a diameter of $9 \mathrm{~cm}$ recovered in 17 sherds from the Kitchen (Figure 84c). This pattern is advertised in the 1897 Sears and Roebuck catalog as a blown tumbler (1897:686). One rim sherd of a contact-molded tumbler displaying Pattern No. 5 was found in Room 7 (Figure 84d). This tumbler was octagonal in shape and had a diameter of $7.5 \mathrm{~cm}$. Pattern No. 6 is represented by one basal sherd with a starburst on the base and diagonal flutes molded on the interior (Figure 84e). This tumbler had a basal diameter of $4.5 \mathrm{~cm}$, and was found in the Dining Room. Pattern No. 7 is seen on fourteen sherds of an optic-molded tumbler with molding on the exterior, interior, and base (Figure $84 f$ ). This tumbler is $9.5 \mathrm{~cm}$ tall; it has a rim diameter of $7 \mathrm{~cm}$ and a basal diameter of $6 \mathrm{~cm}$. 

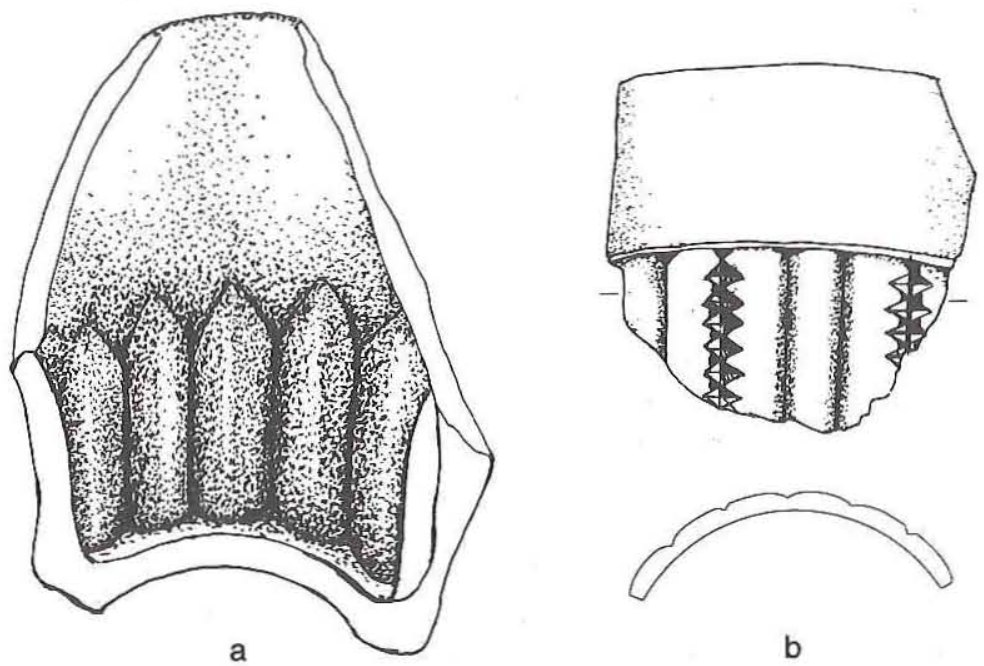

b
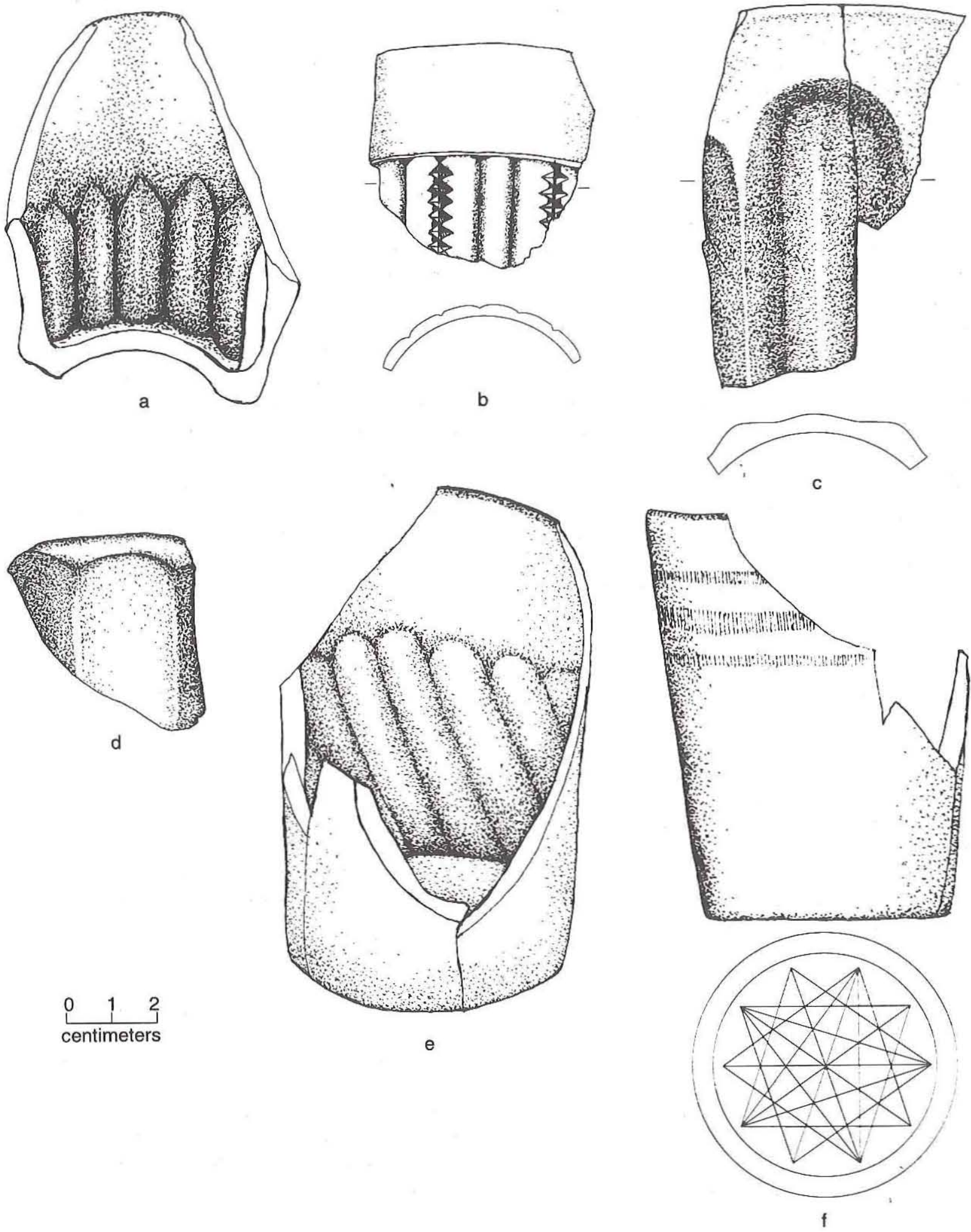

Figure 84. Glass tumblers. (a) Pattern No. 2, optic molded: (b) Pattern No. 3. press molded: (c) Pattern No. 4. contact molded; $(d)$ Pattern No. 5, octagonal, contact molded; $(e)$ Pattern No. 6. starburst base: (f) Pattern No. 7. optic-molded tumbler and base. 
The base is molded in a geometric, 10-pointed star pattern. All sherds are from the Kitchen. Nineteen sherds of an optic-molded tumbler were found in the Kitchen, and one sherd was found in the Dining Room. This tumbler is decorated with Pattern No. 8 , consisting of knurls molded on its interior surface (Figure $85 a$ ). The glass is thick, with a height of $9.5 \mathrm{~cm}$, a rim diameter of $7.5 \mathrm{~cm}$, and a basal diameter of $5.75 \mathrm{~cm}$. Twelve sherds of a very thin bodied tumbler were found in the Kitchen. Pattern No. 9 on this tumbler appears to be an appliqué of some sort, although the intention was to imitate etching. Where the pattern meets itself, a crooked seam can be seen (Figure $85 b$ ). This tumbler has a rim diameter of $7 \mathrm{~cm}$, and the glass fluoresces under ultraviolet light, indicating lead glass. Three sherds of another thin-bodied tumbler were found in the Kitchen. Pattern No. 10 on this piece is an ivy (Figure 85c), and like Pattern No. 9, imitates an etched pattern although it is raised above the glass. These pieces are also made of lead glass and fluoresce under ultraviolet light. Twenty-seven sherds of a blue tumbler representing Pattern No. 11 were found in the Kitchen. Molded teardrops are present on the inside of the vessel indicating optic molding (Figure $85 d$ ). This tumbler has a rim diameter of $7 \mathrm{~cm}$ and a base diameter of $6 \mathrm{~cm}$. It fluoresces yellow under ultraviolet light, which may indicate uranium in the glass. Thirteen sherds of a pink tumbler were found in the Kitchen. Similar to Pattern No. 11, Pattern No. 12 has teardrops molded on the interior of the tumbler. Unlike the previous pattern, though, the interior and exterior base have relief in the form of a starburst (Figure 85e). The pink color is achieved through "flashing," or a thin layer of pink glass applied to the interior of colorless glass (Vose 1989:70). This tumbler has a base diameter of $6.5 \mathrm{~cm}$. The glass fluoresces white under ultraviolet light, indicating lead content.

\section{Base Sherds}

One base sherd from an octagonal tumbler was found in the Dining Room. Fifteen sherds of a tumbler with a base diameter of $6.25 \mathrm{~cm}$ and a pattern of stripes around the body were found in the Kitchen, as were 11 sherds of four undecorated tumbler bases. Of the latter four, one has a base diameter of $4.5 \mathrm{~cm}$, one has a base diameter of $6 \mathrm{~cm}$, and two have base diameters of $6.25 \mathrm{~cm}$. Three of the glasses have no visible mold seams but, due to their symmetrical nature and glossy finishes, appear to have been molded. The other tumbler has a reversed " 1 " pressed into its interior base, indicating that the tumbler was press molded.

\section{Rim Sherds}

Two sherds from a 5.5 -cm-diameter pressmolded tumbler were recovered from the Kitchen. This tumbler has a ring with knurling below; the ring runs around the vessel just under the rim. The vessel may have been a jelly tumbler with a lid (Sears, Roebuck and Co. 1897:686). Also found in the Kitchen were the following: 1 rim sherd from a 6-cm-diameter tumbler made of thick glass; 3 sherds of a 7 -cm-diameter tumbler; 3 sherds of different undecorated tumblers with rim diameters of $7.5 \mathrm{~cm} ; 2$ cross-mending sherds of a tumbler $7.5 \mathrm{~cm}$ in diameter which have stems and leaves etched into them; 12 sherds of six different undecorated tumblers with rim diameters of $8 \mathrm{~cm} ; 3$ sherds from three different undecorated tumblers with diameters of $8.5 \mathrm{~cm}$; and 5 sherds from three different undecorated tumblers with diameters of $9 \mathrm{~cm}$. The Dining Room yielded $1 \mathrm{rim}$ sherd of a 7-cm-diameter tumbler.

\section{Body Sherds}

Five tumbler body sherds were excavated. Four are from the Kitchen, and one is from the Dining Room.

\section{FURNITURE AND FIXTURES GROUP, FURNITURE HARDWARE}

Included in this class are not only furniture and fixture hardware, but also lamps and decorative knick-knacks that were part of the visible decor even if their function is not clear. One "long wrought pivot" furniture caster was found in Room 7 (Figure $86 a$ ). This type of caster was available as early as 1865 (Russell and Erwin 1865:159). One cuprous escutcheon with a keyhole was found in the Kitchen in three pieces. The escutcheon is diamond shaped and was secured with two rivets (Figure 86b). The rivets are less than $2 \mathrm{~cm}$ in length, leading to the assumption that this escutcheon was on a drawer or cupboard door. This piece is approximately $6.5 \mathrm{~cm}$ long and $3 \mathrm{~cm}$ tall.

One marble fragment, polished flat on three 


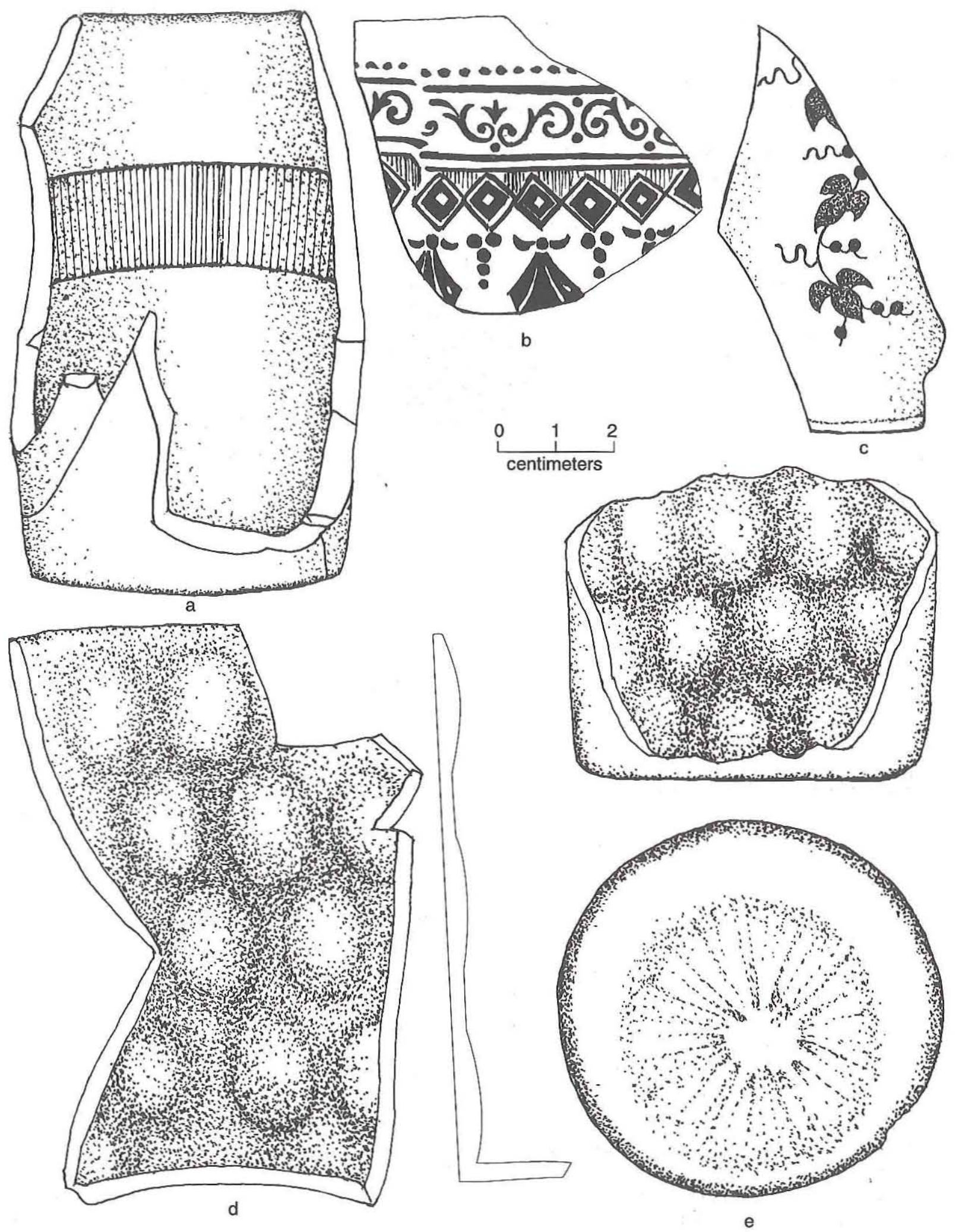

Figure 85. Glass tumblers. (a) Pattern No. 8, optic molded with knurls; (b) Pattern No. 9, appliquéd, thin bodied, geometric pattern; (c) Pattern No. 10, appliquéd, thin bodied, ivy pattern; $(d)$ Pattern No. 11, optic-molded teardrops in blue; (e) Pattern No. 12, optic-molded teardrops and starburst in pink. 
faces, was found in the Dining Room. Marks on one of the sides look like cut marks from a knife. This honey-colored stone, $2.1 \mathrm{~cm}$ thick, could have been part of a counter or table top. Five pieces of mica were recovered from the Kitchen. The largest fragment is $7 \mathrm{~cm}$ long and $3.5 \mathrm{~mm}$ thick. A common use for mica was as windows in stoves (see Sears, Roebuck and Co. 1902:n.p.), although it could be used for wall windows and electrical insulation (Random House 1978:565). Two cuprous plates from the same piece of furniture were found in three pieces in the Kitchen. These plates were molded to fit between a round hole and a right-angle corner. Each has a small hole through which it would have been attached to the furniture by a nail (Figure $86 c$ ). These
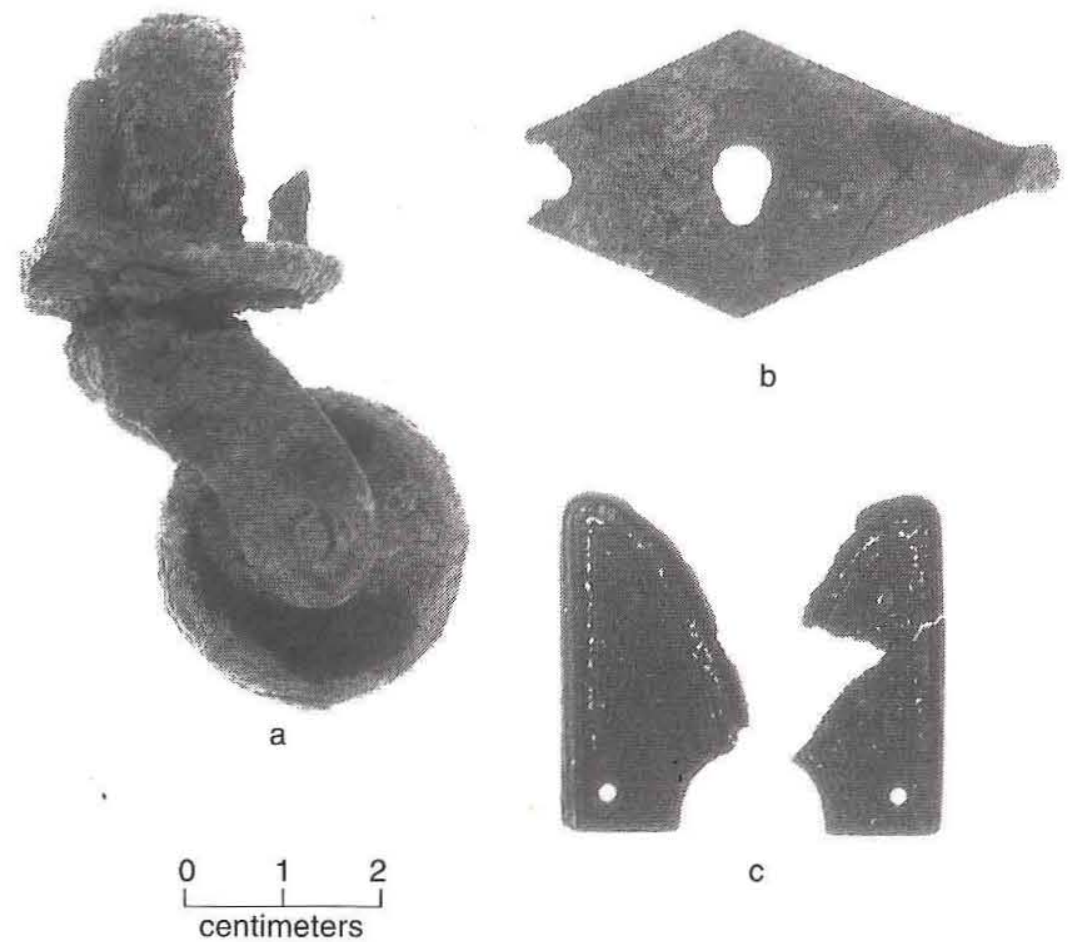

b
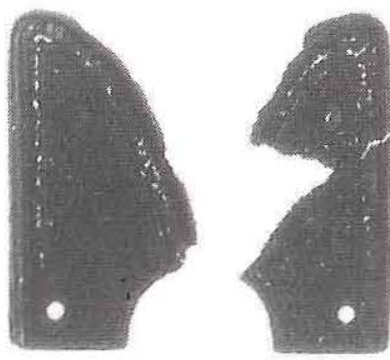

C

Figure 86. Furniture hardware. (c) cuprous plates. plates look as if they would have been used on a small box or fancy cupboard, as they are intricately molded.

\section{FURNITURE AND FIXTURES GROUP, LAMPS}

\section{Chimney Rims}

Decorated upper rims on lamp chimneys were popular from the 1870s onward and are easily identified, while undecorated rims are often falsely identified as tumblers or other tableware. Lamp chimney body shape can be indicative of age, but shape is often difficult to determine from small fragments. Because of the large number of lamp chimney body fragments found and the limitations of lamp chimneys for diagnostic purposes, only the decorated upper rims of lamp chimneys are discussed in any detail here (with one noted exception).

Lamp chimneys generally did not appear in significant quantities on archeological sites until after the widespread use of kerosene fuel and burners designed for use with chimneys. Kerosene was used almost universally by 1864 in North America
(Woodhead et al. 1984:58).

None of the decorated lamp chimney rims found at Sebastopol fluoresce under ultraviolet light, although some lamp chimney body sherds do, indicating lead content in the glass. Soda-lime glass was invented in 1864, and crimped rims became popular in the 1870s. These three facts combine to indicate that the lead chimney glass sherds most likely are older than the nonlead sherds (Woodhead et al. 1984:61, 62). Thus, undecorated lead glass lamp chimneys were used at the site earlier than the 1870 s, but because the rims were not decorated, they are not represented in this section.

Originally lamp rims were decorated by hand, but machines were invented in 1877 and 1883 that would crimp and bead the rims of lamp chimneys (Woodhead et al. 1984:62). Differentiating which rims were produced by hand and which were made by machine can be difficult, and because of this the distinction is not made here.

In total, 7,960 sherds from the Kitchen, Dining Room, and Room 7 were identified as lamp chimney glass. Only 11 of these are decorated rim sherds, 10 from the Kitchen and 1 from the Dining Room. Ten of the 11 sherds are crimped while 1 is deco- 
rated with a beaded design (Figure 87). Each sherd is slightly different in thickness and width of crimps, indicating that each came from a different lamp chimney. One of the rim sherds has enough of the chimney body attached to see that the rim flared out. Flared rims were common in the late nineteenth century (Woodhead et al. 1984:61).

Also found in the Kitchen was a long, narrow chimney tube, probably the upper part of a student lamp chimney (Figure 88). The student lamp was a revival of the Argand type of burner and was developed in the 1870s (Woodhead et al. 1984:59).

\section{Collar}

One possible lamp collar was found in the Kitchen (Figure 89). This piece is made of cuprous metal and has threads around a central hole. The collar is the metal bracket that clamps onto the body of the lamp and onto which the burner is fastened. The wick passes through the collar into the body of the lamp.

\section{Crystals}

The remains of eight lamp or chandelier crystals were found in the Kitchen in 10 sherds (Figure 90). Five of the crystals are small and would have hung off the bottom of a lamp or chandelier. The other

three are long and would have hung off the small crystals. A small and large crystal together are called a "prism" (Jennings and Gottfried 1993:226). All of the crystals are made of leaded glass. Unlike the utilitarian globes and chimneys, the crystals were likely still made of lead glass after the development of soda-lime glass because of its brilliant characteristics. One of the lead crystals also has a slight amethyst color.

\section{Globes}

Twenty-one sherds of a lighting fixture globe were excavated from the Kitchen. This glass fluoresces under ultraviolet light, indicating lead glass. The globe is made of colorless glass and appears to be undecorated except for a flaring rim. It also appears to have been hand blown and likely predates the 1870 s because of its lead content.

Another colorless, undecorated globe is represented by two sherds from the Kitchen. The base of this globe has a smaller diameter than the first, and it also fluoresces under ultraviolet light. The base seems to have been roughly cut or broken off.

\section{FURNITURE AND FIXTURES GROUP, FIXTURES}

Nine artifacts are in this class. Three are blind
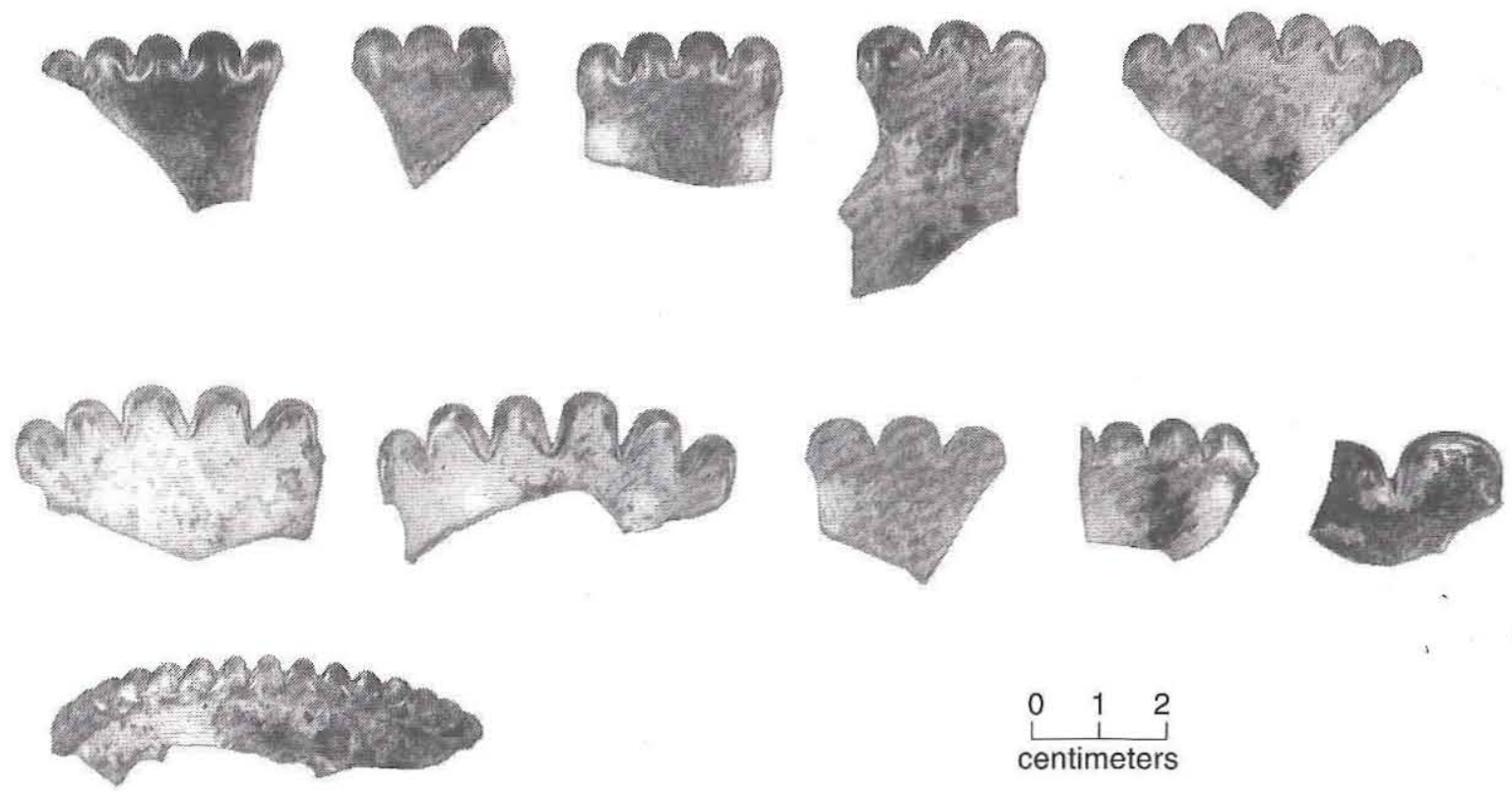

Figure 87. Decorated lamp chimney rim fragments. All are crimped except for the bottom left, which is beaded. 

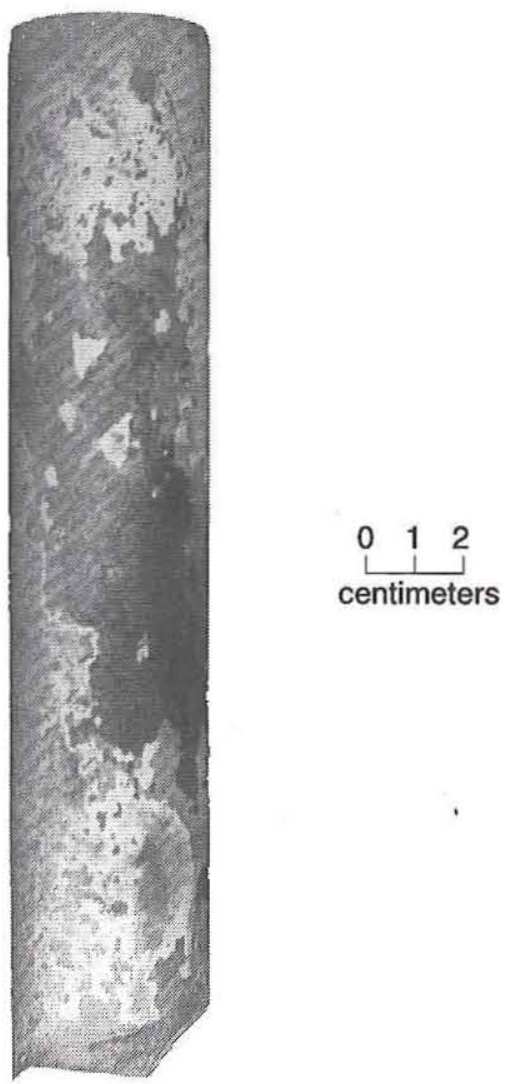

Figure 88. Student lamp chimney tube.

brackets, of the type for spring-wound blinds, found in the Kitchen and Dining Room (Figure 91a); all three are made of ferrous metal. One other ferrous metal bracket was found in the Kitchen. It has a long body, but one end is missing. One doorknob rose was found in the Kitchen. It is made of ferrous metal and has two holes for attaching to the door with screws (Figure 91b). A doorknob rose is a round plate which attaches to the door and through which the spindle enters into the door from the doorknob. One hook made of ferrous metal was found in the Kitchen. This piece is very corroded and broken into three pieces, but it has one hole in the center of a diamond-shaped escutcheon. One polished, round, wooden knob broken into three pieces was found in the Kitchen. Another wooden knob or handle as

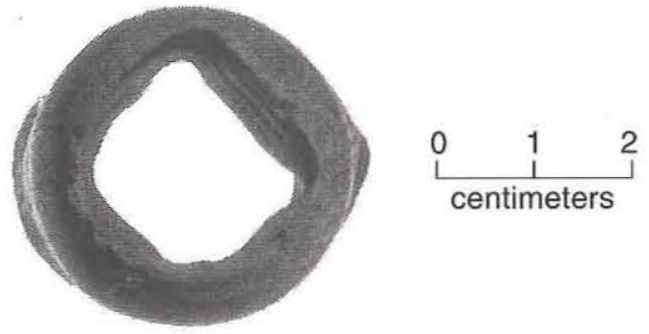

Figure 89. Possible lamp collar.

found in the Dining Room. This second knob is rectangular and made of unfinished wood; it was attached with a single screw which is still embedded in the knob. The final item is a glass fragment that includes the bulb and part of the shaft of a thermometer; it was found in the Dining Room.

\section{FURNITURE AND FIXTURES GROUP, OTHER}

\section{Decorative Ceramics, Plates}

Four sherds of a flow-printed white earthenware plate with a Chinoiserie-style Timor pattern in enamel and enameled luster was found in the Kitchen (Figure 92). The plate is $17.8 \mathrm{~cm}$ in diameter and has a mark with an impressed "N3," a printed "TIMOR/V \& B," and an enameled tally mark. This nearly complete plate is printed in blue with a Chinoiserie-style pattern in the central scene and on the marly (the print is a slightly flow blue). The print was enameled in polychrome with a rust color (also along the unscalloped rim), orange,
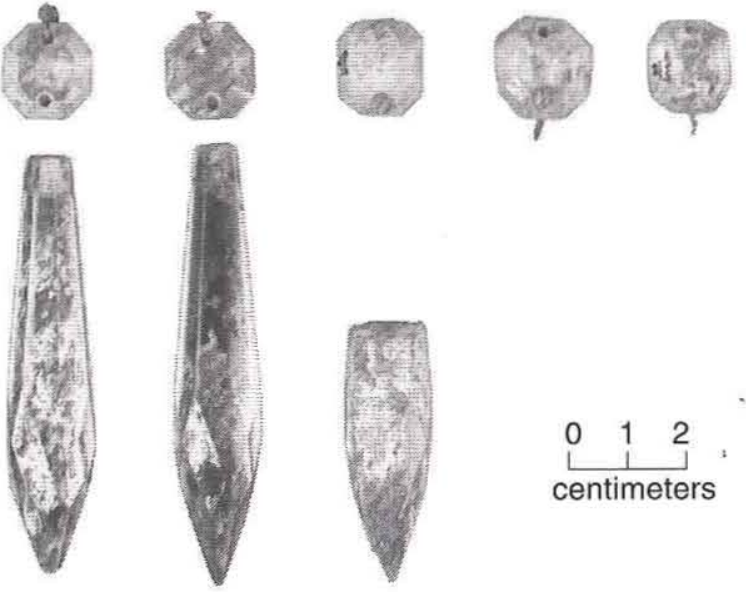

Figure 90. Chandelier or lamp crystals. 


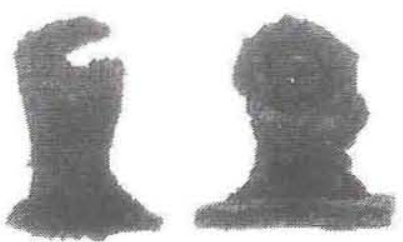

a

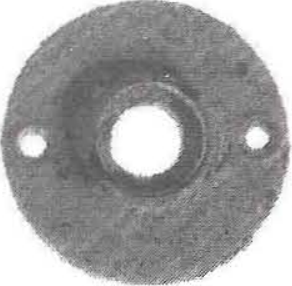

b

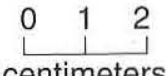

Figure 91. Fixtures. (a) Blind brackets; $(b)$ doorknob rose.

yellow, two shades of light green, blue, and a salmon-colored luster. Williams (1987:572) classifies this as a polychrome Chinoiserie pattern with luster. An example on a tea tile made by Villeroy \& Boch, Germany, is illustrated in Williams (1987:592). The Sebastopol example, also probably made by Villeroy \& Boch, differs slightly from the illustration in details of leaves and flowers, but has the full central scene.

Timor is an island in the East Indies; the Dutch arrived there shortly after 1613 in search of trade
(Williams 1995:53). The Timor patterns made in Germany, Holland, and France were related to the Willow pattern derived from Chinese Canton patterns. In the central scene, an Oriental princess stands in a garden holding a wand, fan, or scroll. A young man crouches on a roof above the garden, where his boots already are on the ground, before leaping down to join her. A pointed pagoda with a pennant is behind a lattice fence in the background. This pattern dates approximately 1870-1880 (Williams 1987:572). The V \& B mark beneath the pattern name (see Figure 92) resembles the initials portion of a mark used by Villeroy \& Boch of Mettlach, Germany, on earthenware, figurines, and tiles ca. 1860 (Kovel and Kovel 1986:71b), although the mark border is strikingly different. The same pattern by a different potter dates to ca. 1875 (Williams 1995:53), and Chinoiserie made a resurgence in popularity in 1890 (Majewski 1994a:6). However, from this V \& B mark, the plate appears to date to the earlier period.

No evidence of use wear with table implements is evident on this plate, but the paint on the bottom edge of the rim and marly are worn differently than the rest of the rim; the painted decoration on the
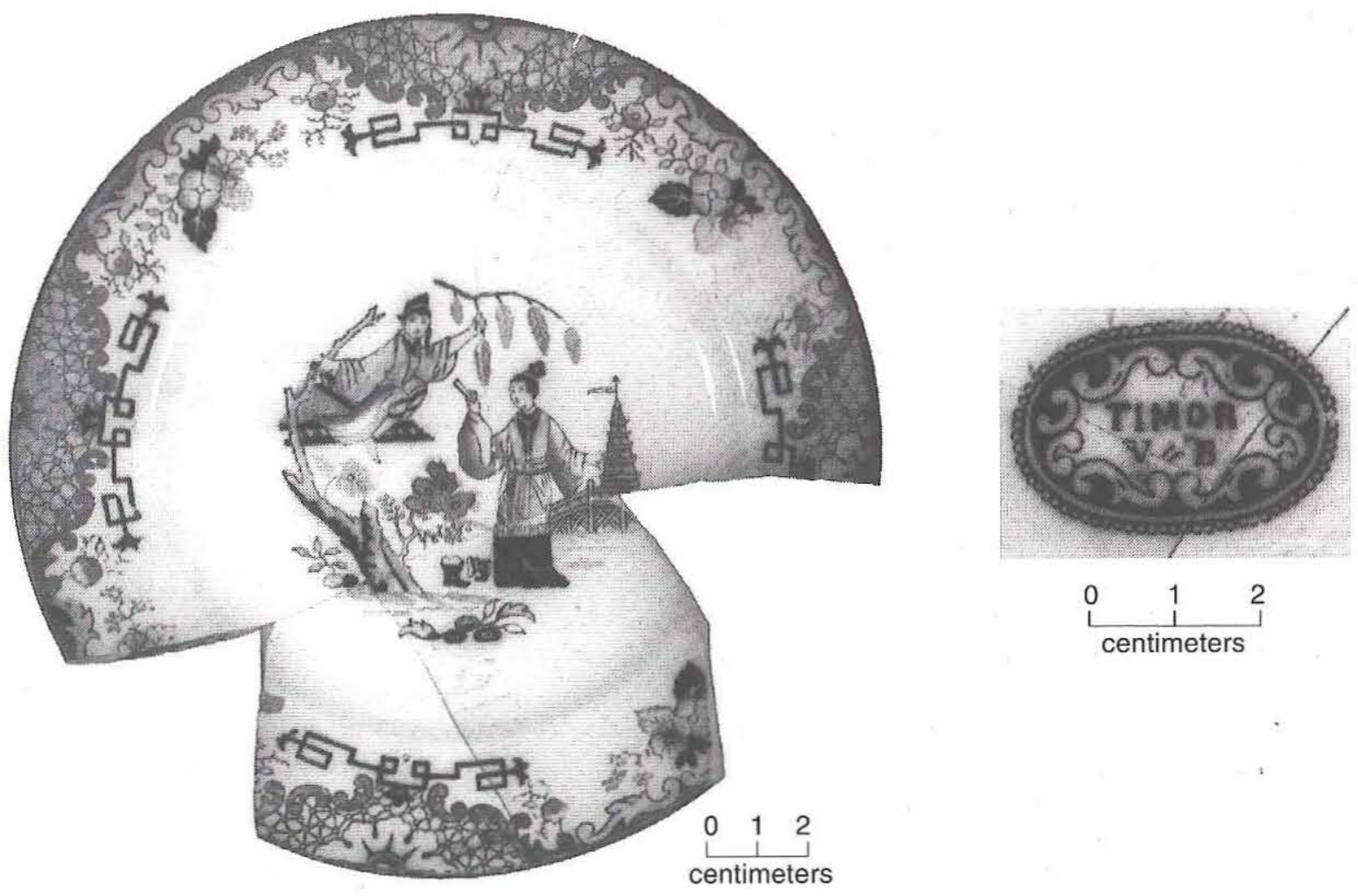

Figure 92. Timor plate and mark. 
bottom portion of the marly is completely worn off in an area $4 \times 1.5 \mathrm{~cm}$. These two factors combine to indicate that this plate was decorative and displayed standing on its rim and leaning against a wall, such as on a plate rail (Griffiths 1978:74).

A fluted bone china plate with all-over enamel and gilding was found in the Kitchen in 21 sherds. The vessel is $16.5 \mathrm{~cm}$ in diameter and has a greenprinted mark with "S\&S" over " $L$ " with a horizontal line separating the two. This small plate is decorated with an enameled floral pattern on a blue background. Less than half of the vessel is present. The design consists of variegated light and dark pink and yellow flowers; aqua, light and dark green, and purple leaves; purple stems and berries; and an orange element, probably a flower. The scalloped rim edge is gilded. Although brush strokes are visible on the floral elements, indicating that they were painted by hand, the blue background color is even and appears to have been applied by aerography. An atomizer was used to apply ground colors on low-priced porcelains and earthenwares; aerography was developed by L. A. Fry at the Rookwood Pottery in 1884 (Majewski 1994b). A stencil probably was used since the pink, yellow, and light green floral elements were enameled on a white ground, not over the blue. The edges of many of the elements are dark where the two colors of enamel overlap. Other elements, such as pink stems and berries and green leaves, were enameled in their entirety over the blue, causing them to appear purple. The enamel has worn off along some of the ridges between flutes.

Another bone china plate similar to the one above in shape, but with a pink background, was found in the Kitchen. This small fluted plate is decorated with a floral enamel pattern on a pink ground and gilding around the rim. This vessel is represented by only 10 sherds, mostly from the rim. The only remnants of the enameled floral elements are dark green leaves and part of a yellow flower.

A white earthenware plate, $21 \mathrm{~cm}$ in diameter with a calendar decal, was found in the Kitchen in two sherds (Figure 93). The form of this plate is unusual in that it lacks a break between the marly and the center. Less than one-third of the plate is present. The visible decoration incorporates a scenic view surrounded by large ivy leaves and small blue flowers. The three calendar pages in the right foreground, on top of a large ivy leaf, are June and July above December. The first calendar plate in

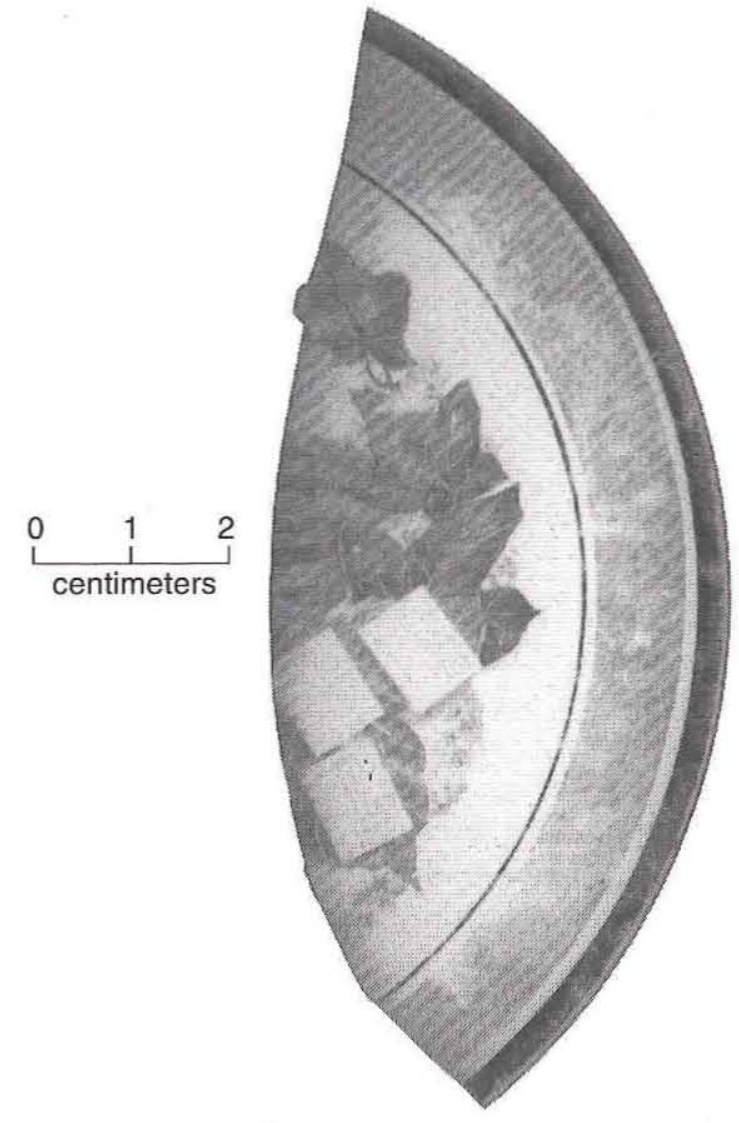

Figure 93. Calendar plate.

the United States was made in 1906. A few earlier examples were made in England (Kovel and Kovel 1986:257). June 1 was a Tuesday in the year represented by this calendar. Years in the first half of the twentieth century in which this occurred were $1909,1915,1920,1926,1937,1943$, and 1948. A $1.25-\mathrm{cm}$-wide enameled rim of aqua outlines the plate with a wide stripe of gilding below the edge and a narrow stripe of gilding below the aqua band. Use-wear marks on the body indicate its use as a serving vessel, but due to its decoration, it is presumed that its first and intended use was as a decoration.

Three other plate rim sherds found in the Kitchen appear to be similar to the above calendar plate based on the rim decoration. These sherds have the same wide stripe of gold gilding below the edge and the narrow stripe of gilding below the rim band, but the 1.25 -cm-wide enameled rim band on these pieces is light green, not aqua. Differential preservation could account for the difference in color, since the above calendar plate appears very 
worn; thus, these sherds could actually be part of the same plate.

A rim sherd from a bone china plate was found in the Kitchen. This piece appears to have had a gray background, possibly painted clouds. Molding around the rim is accented by heavy gilding. From this small portion, the appearance is of a scene painted onto a decorative plate.

\section{Decorative Ceramics, Unknown Vessels}

Two sherds of bone china with a thick cobalt glaze and gilded stripes were found in the Kitchen. The rim of this vessel was scalloped, but its shape is not discernible. A small bone china vessel with a scalloped rim and a footed base was found in the Dining Room in three sherds. This vessel was fluted up the sides and had blue enamel applied to the bottom half of the sides with an atomizer. Gilding is present on the inner portion of the rim. One sherd of a bone china vessel made of a lattice pattern was found in the Kitchen. This piece was footed and has a corner that indicates an octagonal shape. The base and sides of this object had holes throughout.

\section{PERSONAL GROUP, CLOTHING}

\section{Buckles}

Eight buckles were recovered. One is a harness-style buckle, made of ferrous metal, from Room 7 (Figure 94a). This type of buckle was used on harnesses, belts, and other articles, but its presence in Room 7 suggests a clothing utility. Two slide buckles were found in the Kitchen, one in the Dining Room, and one in Room 7 (Figure 94b-e). Two buckles that look like vest or pants buckles were excavated, one from the Kitchen and one from the Dining Room (Figure 94f, g). One other small buckle was excavated from the Kitchen (Figure 94h).

\section{Buttons}

Before the zipper was invented, buttons were the primary means of fastening clothing. Shoes, underwear, and gloves, as well as shirts, coats, dresses, pants, and other items, all incorporated buttons as fasteners, while dress coat and uniform sleeves often used buttons solely as decoration. Because of their

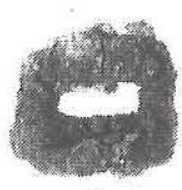

a
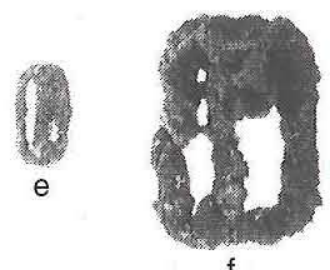

f

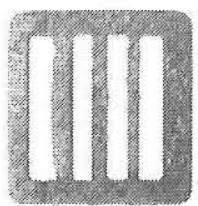

b
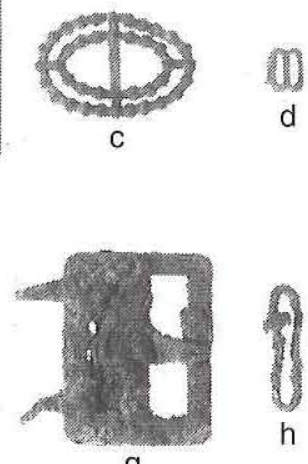

g

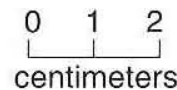

Figure 94. Buckles. (a) Harness; $(b-e)$ slide; $(f-g)$ vest; (h) other.

varied uses, buttons often appear in large quantities in late-nineteenth-century sites.

In total, 326 buttons were recovered from the Kitchen, Dining Room, and Room 7. Of these, $201 \frac{1}{2}$ were found in the Kitchen, $95 \frac{1}{2}$ in the Dining Room, 24 in Room 7, and 5 had no provenience (this total includes 5 jeans studs, which are not technically buttons but served a similar function). Over 30 different shapes in 16 materials were found. Although the age of many of these buttons is not determinable, the assemblage is varied and provides a type collection for button materials, sizes, and shapes. The purpose of this section is to describe these artifacts and provide a typology that can be used by other researchers. This is accomplished by discussing three main attributes: size, material, and shape. A fourth attribute-decoration-tends to be the defining characteristic for the collector, but for the archeologist this is not practical since most buttons found in archeological contexts are not decorated. Most of the buttons found at Sebastopol are simple and undecorated. Some of the most complicated designs seen on the small collection of decorated specimens are on the molded black glass buttons. These were intended for fancy dresses and coats. One of the black glass buttons is decorated with a mottled pattern.

Possibly the most important factor in determining a button's function is its size. Obviously, a tiny trimming button is not going to be chosen to fasten an overcoat, and a 1.5-inch-diameter button will not be used to fasten a dainty glove. 
Buttons were commonly measured in lines or lignes, each line being 1/40 of an inch (Luscomb 1992:121). Luscomb (1992:121) notes that it was manufacturers and wholesalers who used the line measurements and that dressmakers seldom even knew what a line was. This is not supported by the fact that Sears, Roebuck and Company used line terminology in selling their buttons to the general public at the turn of the century.

From the classifications in the Sears, Roebuck and Co. catalogs from 1897, 1902, and 1908, the following size ranges can be determined. Standardsized shirt buttons were a 16 -line size, while small shirt buttons were 12 line. Trimming buttons (those used on shirtwaists, collars, ties, and other small items) ranged between 10 and 16 lines. Those buttons defined as "dress" ranged anywhere from 18 to 30 lines in size, although in one entry, some dress buttons are listed at sizes from 12 to 20 lines.
Vest buttons were generally around 24 or 25 lines. Coat buttons ranged from 30 to 40 lines, and overcoat buttons were the largest at 43 lines or over. These are not hard and fast uses for each button size, but they gives an indication that the smaller buttons (from 10 to 16 lines) were generally used on undergarments and shirts, the medium sizes (from 18 to 30 lines) were used on dresses, shirts, and vests, and the largest buttons (from 30 to 60 lines) were used on coats and overcoats. Pants buttons are advertised by Sears as coming in small, fly, or suspender sizes. No line sizes are associated with these button types.

At Sebastopol, a total of 150 of the buttons are in the 13- to 17-line sizes (Figure 95). There are 70 buttons between the 21- and 24-line sizes, and 36 buttons between the 26- and 30-line sizes. The largest concentration of button sizes reflects shirts and undergarments, while the less-represented groups

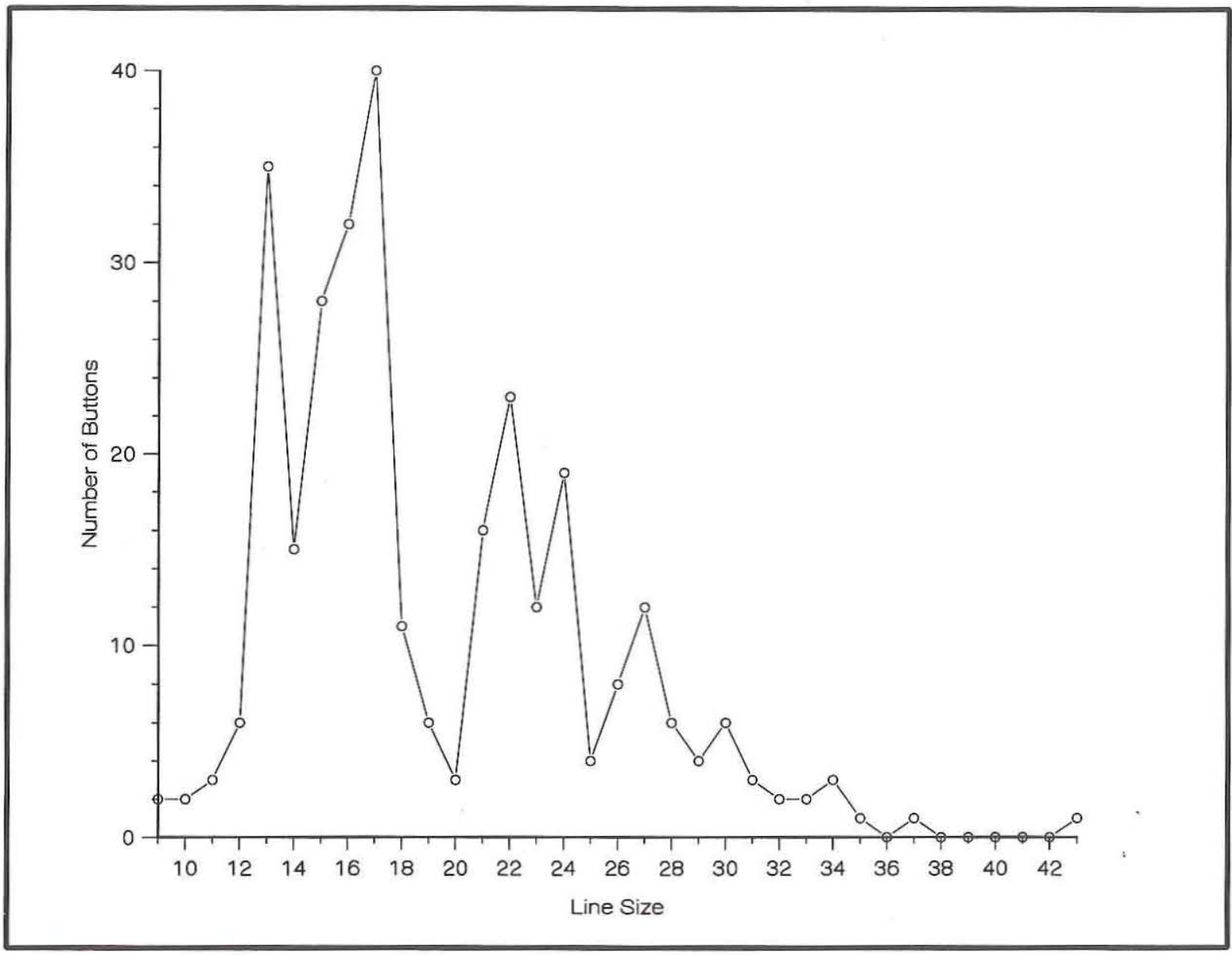

Figure 95. Frequency distribution of buttons by size. 
are from vests, dresses, and other such garments. This type of distribution should be seen in any household, because undergarments and shirts had more buttons on them than other articles of clothing. The lower numbers of coat and overcoat buttons likely reflect the warm climate and the smaller numbers of buttons on these types of garments.

\section{Shell}

The most common button material found at Sebastopol is shell or pearl (Figure 96). Although Kelso (1971) uses the terms "shell" and "pearl" to identify materials with differing refraction qualities, this distinction tends not to be made in the archeological literature and is not made here; the terms "shell" and "pearl" are used interchangeably to describe any button made from freshwater or saltwater mollusks. White shell is the most common of the pearl buttons, making up 31.6 percent of the total button assemblage (103 buttons), while black (or dusky-hued) shell makes up 1.2 percent of the assemblage (4 buttons) and unidentifiable shell makes up 2.5 percent of the assemblage ( 8 buttons). The unidentifiable shell is burned, discolored, or fragmented in such a way that the original color is not determinable. Both white and black shell buttons can be cut from the same shell, although more often they come from different shells.

Saltwater shells were fished from Australia and other areas such as Gambia, the Touamotu and Fiji Islands, the Philippines, Indonesia, and Tahiti (Kelso 1971:4-5; Schiff 1979:36). White shells also came from the Red Sea and the Persian Gulf (Kelso 1971:7). Many of the freshwater shells were mussels fished from the Mississippi River (Claassen 1994). It is the nacre, or pearly lining (sometimes called mother-of-pearl), on the inside of the shells

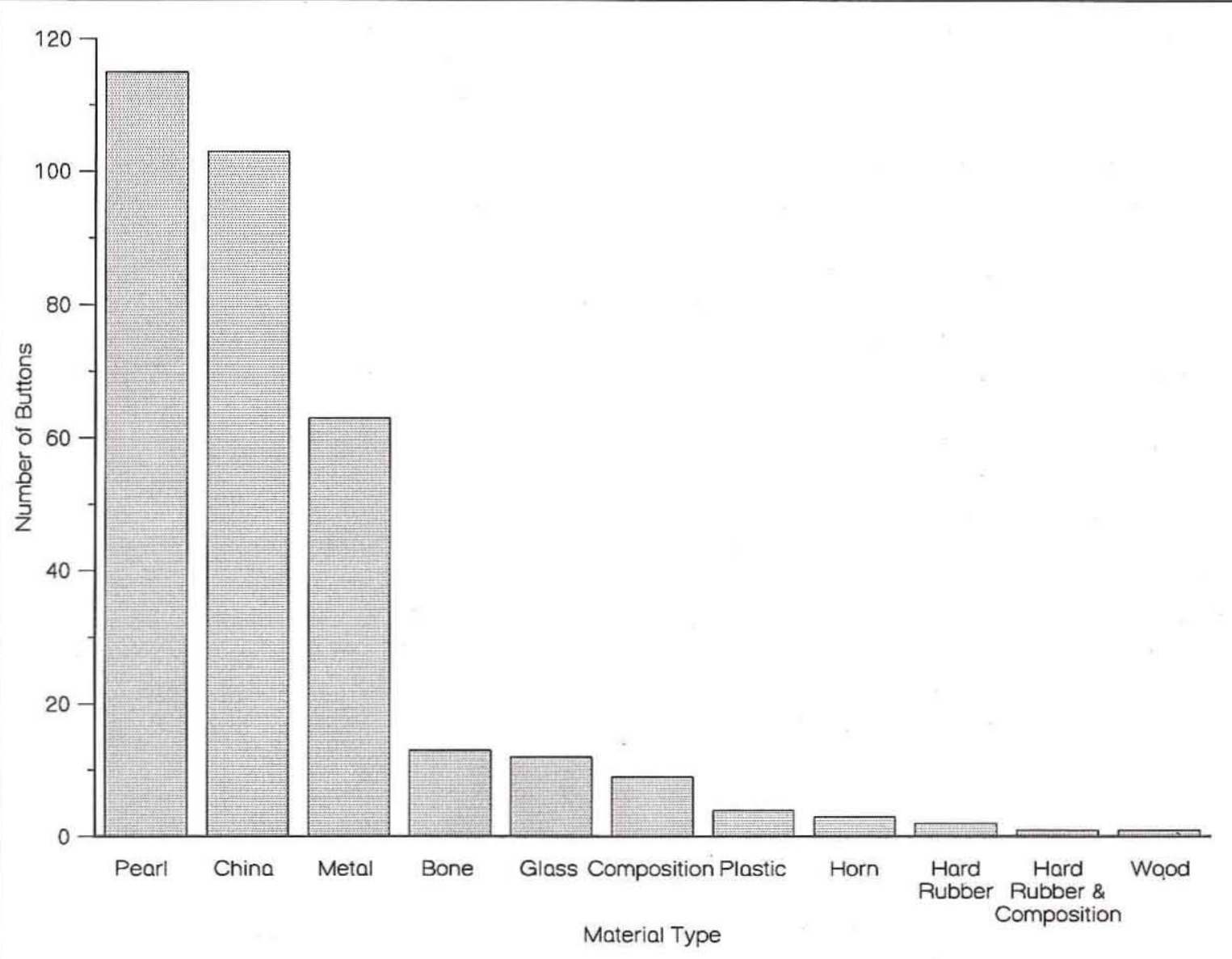

Figure 96. Frequency distribution of buttons by material. 
that provides the lustrous sheen and lends the name "pearl" to these buttons. Nacre ranges from almost pure white through tones of yellow and brown to gray and almost black (Kelso 1971:4). The nonshiny "bark" of the shell can sometimes be found on the back of a pearl button.

Pearl button blanks were cut by tube saws. Blanks would be ground and tumbled to smooth the edges, and one side would be ground flat to create the back of the button. Holes were then drilled and the design was created. Sorting and dying occurred after drilling. Buttons would be boxed for sale to clothing manufacturers or sewn onto cards (carded) for retail (Claassen 1994). Although pearl buttons have been made since the eighteenth century, their predominant use was during the period from 1898 to 1930 (Claassen 1994:80).

\section{China}

Porcelain, or "china" as it is referred to in the literature, is the second most plentiful button material. A total of 103 china buttons (or 31.6 percent of the assemblage) was found in the finished rooms of the lower floor.

China buttons, sometimes referred to as "Prosser buttons," were invented by Richard Prosser. His process, patented in 1840 in England, incorporated compressing a fine porcelaneous powder in a steel die to about one-quarter its bulk and then firing (Albert and Adams 1970:4). Being mold made, these buttons were very regular in shape. China buttons were most often white but could be decorated with transfer-print patterns in the same manner as ceramic vessels. They could also be colored, have painted rims, or be decorated with stencils. The regularity in shape and design and the number of buttons that could be made in this manner all promoted the sale of china buttons (Albert and Adams 1970:4).

Prosser, with the aid of Minton's, an English porcelain works that bought a part interest in the patent, produced small china buttons for less than 6 years (Albert and Adams 1970:5). Felix Bapterosse of France made small china buttons using a wet process that incorporated milk as a binding agent and with which he used plaster of Paris molds (Albert and Adams 1970:10). Using his wet process, Bapterosse produced the buttons at half the cost of the British-made buttons. By the $1850 \mathrm{~s}$, the French dominated the small china button industry, lasting into the early twentieth century (Pool 1991:7).

China buttons are often mistaken for milk glass buttons in the archeological literature. It has been suggested that these materials can be distinguished, as china buttons generally have indentations on the base around the sew-through holes while milk glass buttons do not (Storm 1976:118). The indentations may be made from setting the china buttons on sand during the firing process (this is speculation since a reference to this process has not been found).

China buttons were advertised as "Agate" buttons in the Sears catalogs as well as in "Cole's Encyclopedia of Dry Goods." This encyclopedia also noted that the china buttons made in France were more translucent due to a higher grade of feldspar in the porcelain paste (Pool 1991:7).

\section{Metal}

Metal buttons found at Sebastopol were made of brass, ferrous metal, brass and ferrous metal, brass and cloth, ferrous metal and cloth, white metal, and unknown metal and cloth. In total, there are 63 metal buttons (19.3 percent of the button assemblage). Some of the brass or ferrous buttons with shanks likely were cloth covered, even though no sign of the cloth remains. However, some were sew-through buttons similar in shape to pearl and china buttons. The two buttons made of white metal are likely pewter but could be lead or zinc. The material is very soft, and the area between the holes on one has been stretched from use.

\section{Bone}

Thirteen bone buttons were found (4 percent of the button assemblage). Bone has been used to make buttons for at least the last three centuries (Luscomb 1992:25). Cattle bones were most extensively used, although bison bones also were used when they were available. The bone was boiled to remove the meat and to soften it, and then it was cut and laid out in slabs. Disks were then cut from the bone slabs, shaped on a lathe, and often further carved or molded (Pool 1991:5).

Bone was used in several ways in the making of buttons. A disk of bone with a center hole could be covered in fabric to create a shankless button. Likewise, a disk of bone with a single hole with a metal shank added could have a thin piece of sheet 
brass molded over it (Pool 1991:2). Bone could also be the sole material used and could be cut or molded to create different shapes. A plain bone button was strictly utilitarian and would be used on articles such as undergarments or trousers (Luscomb 1992:25), whereas carved bone buttons were often very fancy and used on more-decorative garments.

\section{Glass}

Twelve glass buttons make up 3.7 percent of the button collection; six of these are black glass. Glass buttons were popular from the 1840 s until World War II, when plastic became the material of choice (Hourart 1977:55; Luscomb 1992:80). Black glass (often falsely called "jet" in imitation of the more expensive material) buttons were most fashionable at the end of the Victorian era through the Edwardian era and were made in largest quantities between 1880 and 1910 (Schiff 1979:24).

\section{Composition}

Nine composition buttons (2.8 percent of the button assemblage) were found. Composition is a term used to describe buttons made from some of the earliest organic plastics. Composition buttons were first produced in 1875 by Isaac Smith of New York. These buttons were molded into their forms and were generally either sew-throughs or selfshanks (Pool 1991:9). Composition buttons generally show flecks of different-colored materials and may include pieces of shell or bone. The composition buttons at Sebastopol tend to be decayed, although some are in good condition; their state of decay seems to depend on what they are made of. "Composition" refers only to buttons made before 1925. After 1925, all synthetic buttons are included under the name "plastic" because it is difficult to determine the specific materials of which they are made (Brown 1942, as referred to in Pool 1991:9).

\section{Plastic}

Hard rubber could be considered the first natural plastic to be used in the button industry (described below). A synthetic plastic called Parkesin (made from castor oil and chloroform) was introduced in 1865. Fast on the heels of Parkesin was celluloid (nitro-cellulose and camphor), invented in 1869 to imitate ivory. Bakelite, the first synthetic polymer, was introduced in 1909 and greatly expanded the plastics industry. Modern, nonflammable plastics replaced the earlier celluloid in 1945 (Pool 1991:9). At Sebastopol, only four modern plastic buttons (1.2 percent of the button assemblage) were recovered.

\section{Horn}

Three horn buttons ( 0.9 percent of the assemblage) were found in the lower-floor rooms. These are similar in appearance to shell buttons but have a more polished surface and different microscopic qualities. Without a comparative collection and microscopic examination, it is difficult to distinguish the two. These horn buttons were cut from natural horn slabs, not molded from processed horn. Although horn buttons were often dyed black (Luscomb 1992:98), the ones found at Sebastopol maintain their natural cream color.

The 1897 Sears, Roebuck and Co. catalog advertised "Imitation Pearl Buttons" made of polished horn. The cost difference between horn and pearl was significant, with a dozen 24-line horn buttons costing $\$ 0.06$ and a dozen 24-line white pearl buttons costing $\$ 0.20$. It appears that the residents of Sebastopol overwhelmingly used the more expensive shell buttons.

Pool (1991:6) suggests that horn buttons are absent from the archeological record because of their susceptibility to bug and worm damage. This could explain why there are so few horn buttons at Sebastopol, but because there is no sign of decay and little damage to the horn buttons recovered, this seems not to be the case. It would appear that horn was simply not the preferred material for buttons or that it was not available at Sebastopol. Horn buttons may decay more rapidly than shell, but they also may be misidentified more often in analysis.

\section{Hard Rubber}

The process of vulcanizing rubber (combining rubber with sulphur and heating) was patented in 1843 by Charles Goodyear (Friedel 1995:22). Vulcanization caused the rubber to harden to a consistency like plastic. The process was improved and the patent updated by his son, Nelson, in 1851 (Pool 1991:8). Most hard rubber buttons have backmarks, and the two found at Sebastopol are no exception. Both of these are embossed with "N.R.Co./Goodyear's P=T.1851." The abbreviation 
"N.R.Co." belonged to the Novelty Rubber Company of New York and New Brunswick, New Jersey (Pool 1991:9). Pool (1991:8) states: "The Goodyear patent expired in 1870; buttons made by the Novelty Rubber Company . . . without an 1851 patent date are assumed to have been made after that expiration date." This suggests that the buttons with 1851 embossed may date between 1851 and 1870 . Of all the hard rubber producers, the Novelty Rubber Company made the greatest variety of rubber buttons (Pool 1991:8). Most rubber buttons are black, but the two found at Sebastopol are dark brown.

\section{Hard Rubber and Composition}

One button is made of a combination of both hard rubber and composition materials.

\section{Wood}

One wooden disk with a central hole was found. This disk is assumed to be the base of a metal button or the body for a fabric button (Pool 1991:2).

\section{$J e t$}

True jet is a compact black coal that was highly polished and used for making beads, jewelry, and buttons (Random House 1978:487). From the 1820s until the end of the nineteenth century, jet was the only material from which mourning jewelry was made. Luscomb (1992:111) states that jet buttons are very rare but that glass buttons were called "jet" because of their color. Gere (1993:522) notes that by the 1860 s and 1870 s jet was extensively used for trimming and embroidering the elaborate dresses of the period but does not specifically mention buttons. Jet and glass can look very similar, especially if the glass is deteriorating with a patina, but black glass is heavier and glossier than true jet. There are two or three buttons in the Sebastopol collection that may be jet, but because they are more probably glass they are included in the glass category.

\section{Button Shape}

Shape is the most varied attribute of this collection, although it may not be as telling as size in determining the type of article on which a button was used. The first distinction between shapes in the typology used here is whether a button is sewthrough or shanked (Table 2). A sew-through button has holes through which thread is drawn to fasten it to clothing. A shanked button has some kind of shank device, either molded into the body of the button or added to it, through which the thread is run.

Sew-through buttons can have from one to six holes. The Sebastopol collection $(n=248)$ contains specimens with one, two, three, four, and five holes. Sew-through buttons come in a variety of materials, shapes, and sizes. It is neither practical nor useful to discuss shape without the context of material and size. What a button was made of determined to some extent the types of shapes that could be made, and size equally limited shape. General shape names such as "geometric," "mound," "ball," or "disk" are broad terms which describe the overall shape of a button but do' not provide enough detail for a useful discussion of shape. The classification used here remedies this by providing illustrations of more-specific and common button shapes and showing the variation between materials (Table 3 ).

The Sears, Roebuck and Co. catalogs illustrate the difficulty of developing a coherent typology for buttons. The buttons in these works are classified sometimes by size or shape, but usually by material. In trying to be consistent with the terminology of the times, it is impossible to fit a typical archeological typology based solely on shape into the Sears definitions. The biggest difficulty in describing an assemblage by shape comes with the pearl buttons. It would seem that there were as many unique shapes and designs as there were factories that produced pearl buttons.

When possible, Table 3 uses traditional terms for shape, although in some cases collectors' terms are used. In some instances, shape names are taken from a discussion of one material type and applied to others with similar form. In other cases, new names are used to describe a shape not previously defined. Sources for the shape names are Adams (1967), Claassen (1994), Kelso (1971), Lamm et al. (1970), Pool (1991), and Ryan (1986). Because of the lack of stratigraphy at Sebastopol, it is.impossible to give dates to these buttons from the archeological context alone. It is hoped that researchers in the future will study button preference through time and that this classification will aid in that study.

The shanked buttons from Sebastopol $(n=59)$ display loop shanks, self shanks, pad shanks, and 
TABLE 2

SEW-THROUGH VS. SHANKED BUTTONS BY MATERIAL

\begin{tabular}{|c|c|c|c|c|c|}
\hline Material & Sew-through & Shank & Jean Stud & Unknown & Totals \\
\hline China & 95 & 9 & - & _- & 104 \\
\hline White Pearl & 97 & 6 & - & - & 103 \\
\hline Black Pearl & 3 & 1 & - & - & 4 \\
\hline Bone & 13 & - & - & - & 13 \\
\hline Wood & 1 & - & - & - & 1 \\
\hline Cuprous & 2 & 10 & 1 & 5 & 18 \\
\hline Cuprous and ferrous & 5 & 4 & 1 & 1 & 11 \\
\hline Ferrous & 5 & 3 & 2 & 7 & 17 \\
\hline Composition & 7 & 2 & - & - & 9 \\
\hline White metal & 2 & - & - & - & 2 \\
\hline Hard rubber & 2 & - & - & - & 2 \\
\hline Glass & 1 & 5 & - & - & 6 \\
\hline Plastic & 3 & 1 & - & - & 4 \\
\hline Black glass & - & 5 & - & - & 5 \\
\hline Unidentified pearl & 7 & 1 & - & - & 8 \\
\hline Hard rubber and & & . & & 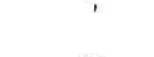 & \\
\hline composition & 1 & - & - & - & 1 \\
\hline Cuprous and cloth & 1 & - & 1 & 1 & 3 \\
\hline Ferrous and cloth & - & 11 & - & - & 11 \\
\hline Metal and cloth & - & 1 & - & - & 1 \\
\hline Horn & 3 & - & - & - & 3 \\
\hline Totals & 248 & 59 & 5 & 14 & 326 \\
\hline
\end{tabular}

one pin shank. A loop shank is a separate loop of metal that is glued, molded, or hooked into the base of the button. The self shank is molded as part of the body of the button. A pad shank is made from a pad of fabric protruding through a hole in the back of the button. The pad of fabric is the part through which the thread fastens the button to the clothing. A pin shank is a metal pin through the body of the button with a loop on the bottom. Classification of shanked buttons in this collection is simpler than for the sew-through buttons (Table 4). There are far fewer shanked buttons. Most are flat or mounded, but in many cases (especially with the self shanks), the shank is an integral part of the shape. Because of this, it is more fitting to classify these buttons by the type of shank than by body shape.

\section{Dress Steel}

One fragment of a dress steel or corset stay was found in the Dining Room. It appears to be made of either early plastic or hard rubber (see Figure 98g). Dress steels were made of celluloid by 1885 (Friedel 1983:76-77).

\section{Elastic}

Three fragments of elastic thread were excavated from the Dining Room.

\section{Footwear}

Due to poor leather preservation, a large sample of identifiable footware was not found. The shoe parts that survived are 19 metal grommets, 5 thick heels, 1 heel plate, 24 cuprous lace tips, and 4 pieces of sole leather.

\section{Grommets}

Seven shoe grommets were found in the Kitchen, 10 in the Dining Room, and 1 in Room 7. All are made of brass. One other grommet with a shoe lace hook attached was found in the Kitchen. This is the type of grommet that would have been 
TABLE 3

SEW-THROUGH BUTTON SHAPES

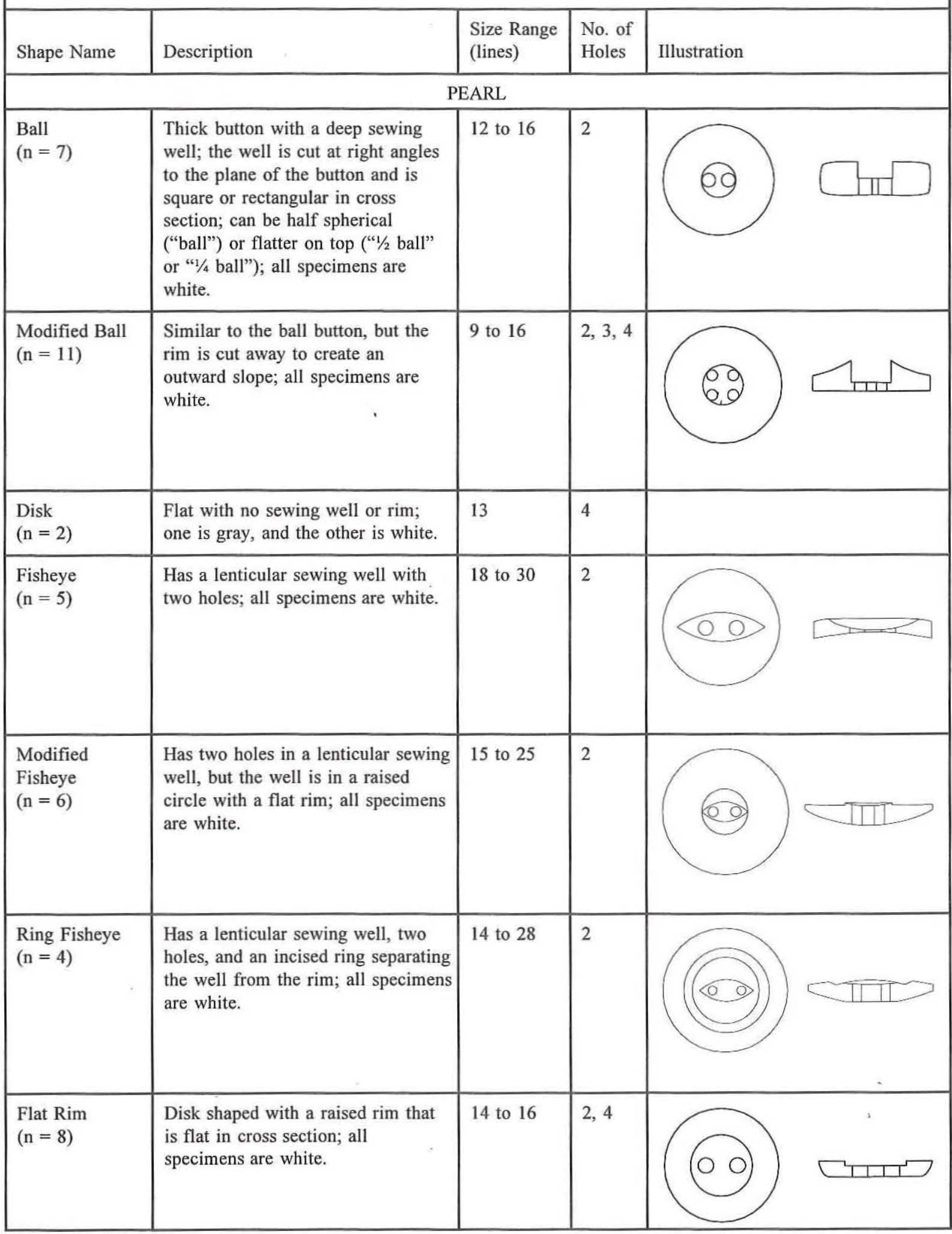




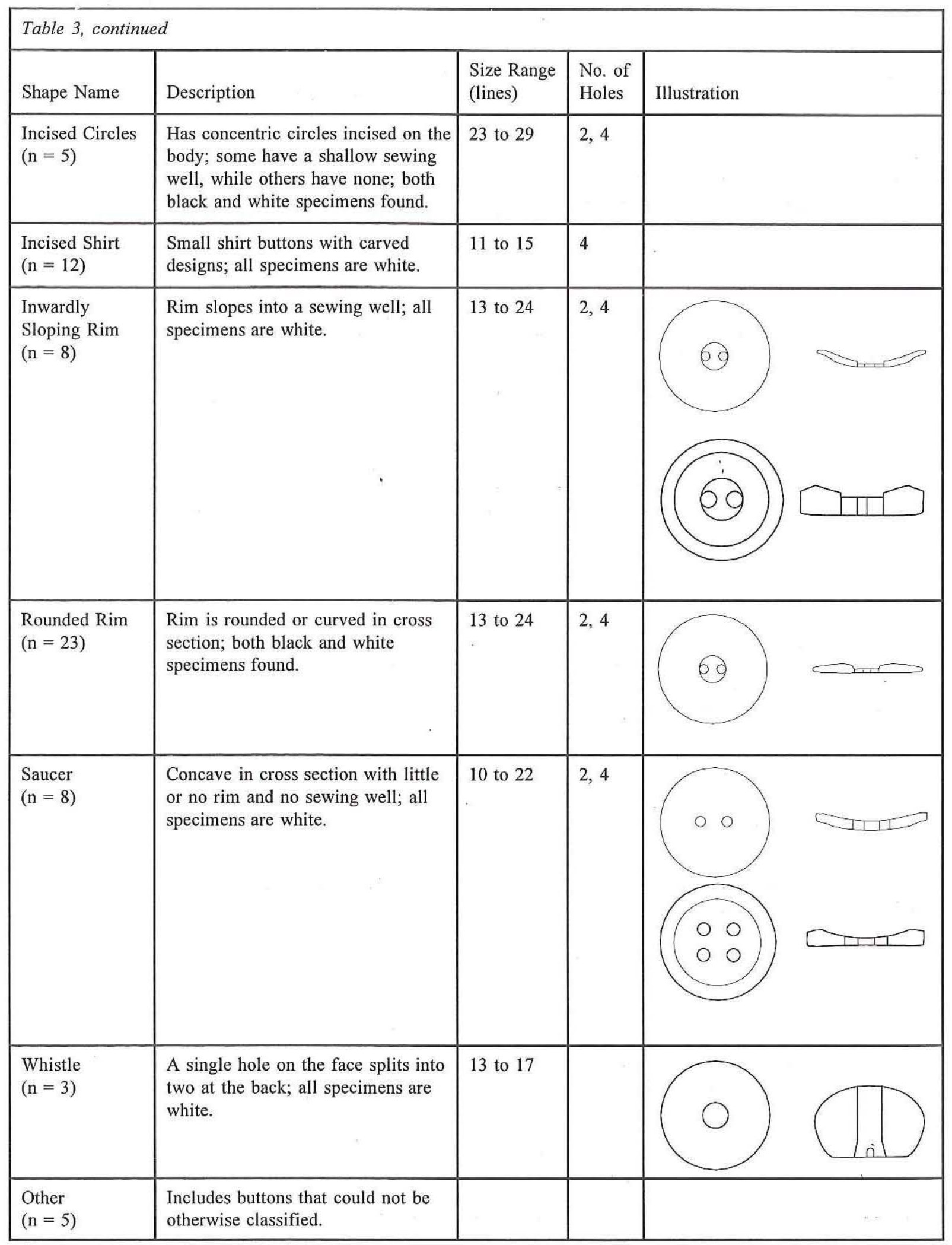


Table 3, continued

\begin{tabular}{|l|l|l|l|l|}
\hline Shape Name & Description & $\begin{array}{l}\text { Size Range } \\
\text { (lines) }\end{array}$ & $\begin{array}{l}\text { No. of } \\
\text { Holes }\end{array}$ & Illustration \\
\hline
\end{tabular}

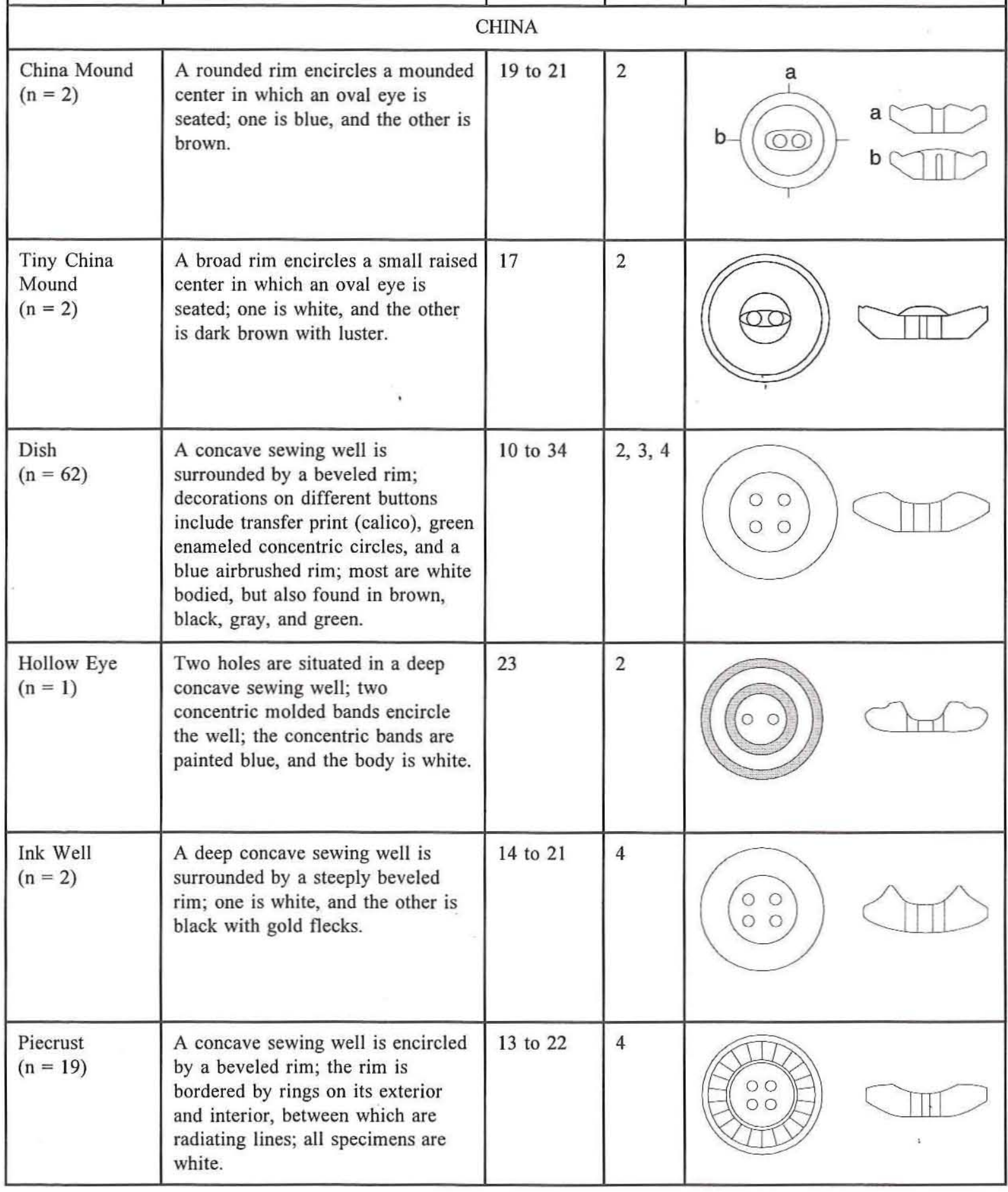




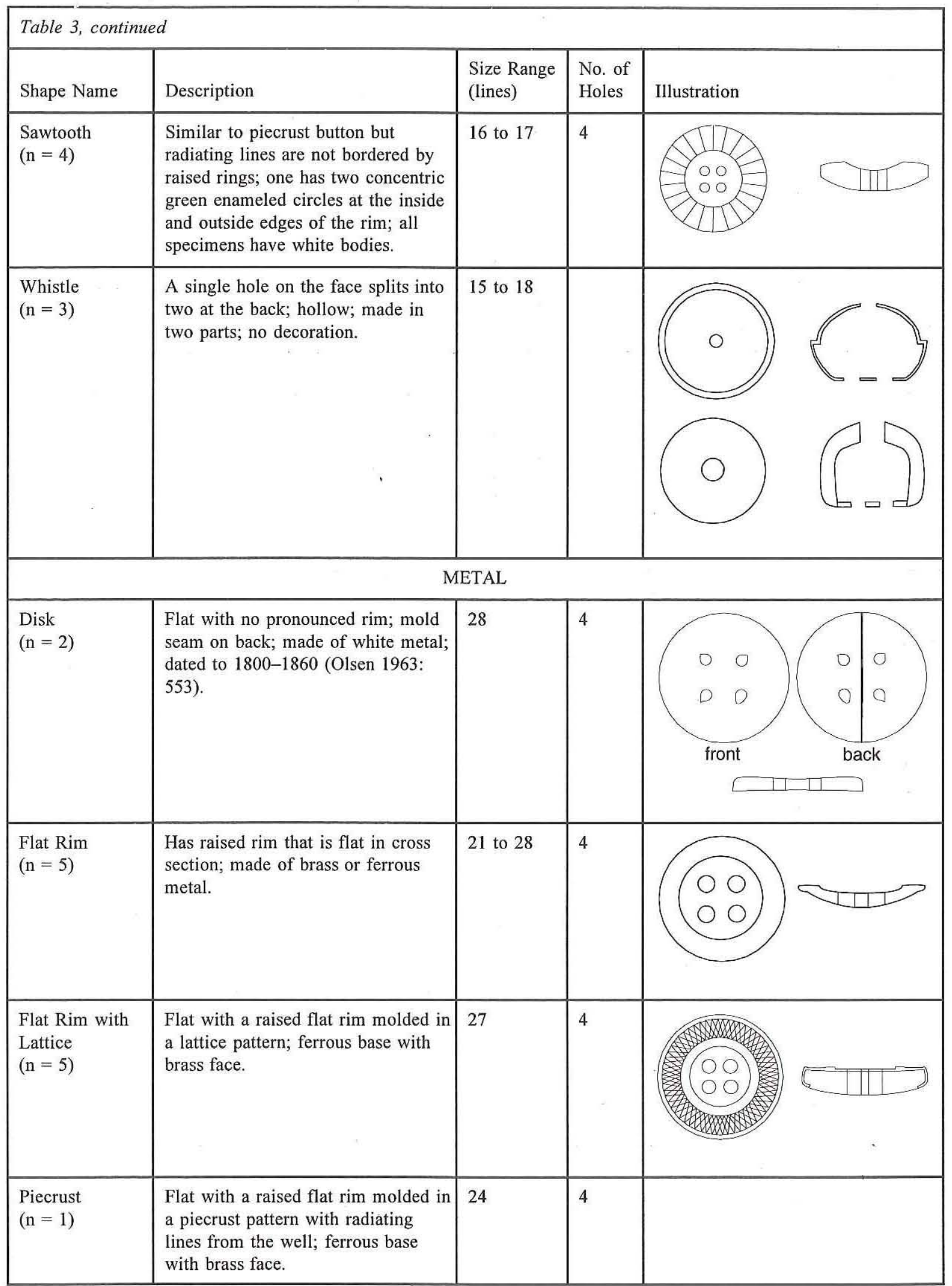




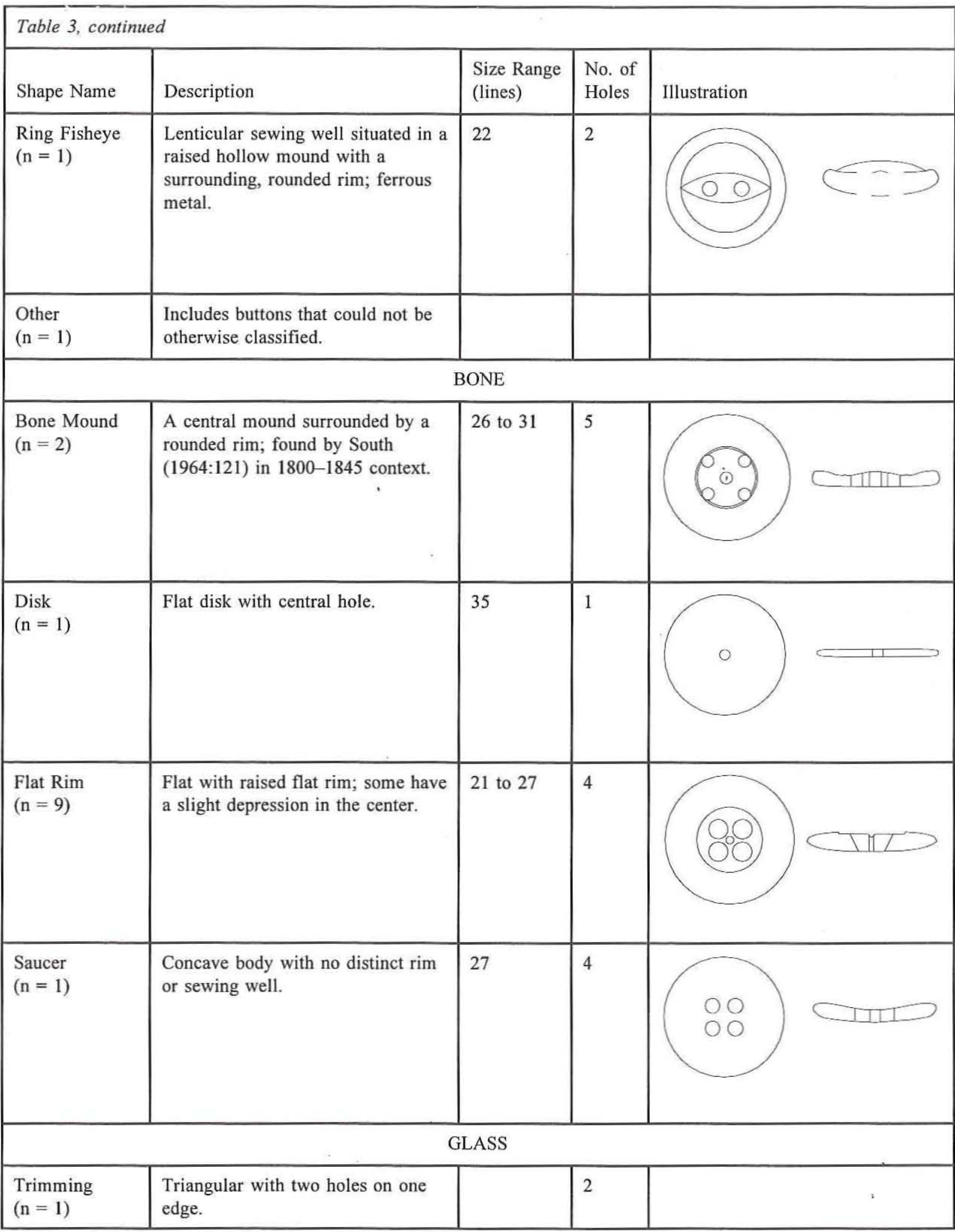




\begin{tabular}{|c|c|c|c|c|c|}
\hline \multicolumn{6}{|c|}{ Table 3, continued } \\
\hline Shape Name & Description & $\begin{array}{l}\text { Size Range } \\
\text { (lines) }\end{array}$ & $\begin{array}{l}\text { No. of } \\
\text { Holes }\end{array}$ & Illustration & \\
\hline \multicolumn{6}{|c|}{ COMPOSITION } \\
\hline $\begin{array}{l}\text { Realistic } \\
(\mathrm{n}=3)\end{array}$ & $\begin{array}{l}\text { Molded to represent an object, in } \\
\text { this case a clamshell. }\end{array}$ & 30 & 2 & & \\
\hline $\begin{array}{l}\text { Whistle } \\
(\mathrm{n}=1)\end{array}$ & $\begin{array}{l}\text { One hole on the face branches to } \\
\text { two on the back; has a rim around } \\
\text { the edge; gray with marbled black, } \\
\text { ivory, and blue. }\end{array}$ & 26 & & & \\
\hline $\begin{array}{l}\text { Other } \\
(\mathrm{n}=3)\end{array}$ & $\begin{array}{l}\text { Includes buttons that could not be } \\
\text { otherwise classified. }\end{array}$ & & 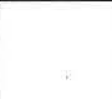 & & \\
\hline \multicolumn{6}{|c|}{ PLASTIC } \\
\hline $\begin{array}{l}\text { China Mound } \\
(\mathrm{n}=1)\end{array}$ & $\begin{array}{l}\text { A rounded rim encircles a mounded } \\
\text { center in which an oval eye is } \\
\text { seated; blue. }\end{array}$ & 19 & 2 & & \\
\hline $\begin{array}{l}\text { Fisheye } \\
(\mathrm{n}=1)\end{array}$ & $\begin{array}{l}\text { Has a lenticular sewing well with } \\
\text { two holes; buff colored. }\end{array}$ & 22 & 2 & & \\
\hline $\begin{array}{l}\text { Saucer } \\
(\mathrm{n}=1)\end{array}$ & $\begin{array}{l}\text { Concave in cross section with little } \\
\text { or no rim and no sewing well; pink } \\
\text { and molded. }\end{array}$ & 43 & 2 or 4 & & DIII \\
\hline \multicolumn{6}{|c|}{ HORN } \\
\hline $\begin{array}{l}\text { Rounded Rim } \\
(\mathrm{n}=2)\end{array}$ & $\begin{array}{l}\text { Rim is rounded or curved in cross } \\
\text { section. }\end{array}$ & 23,24 & 4 & & \\
\hline
\end{tabular}




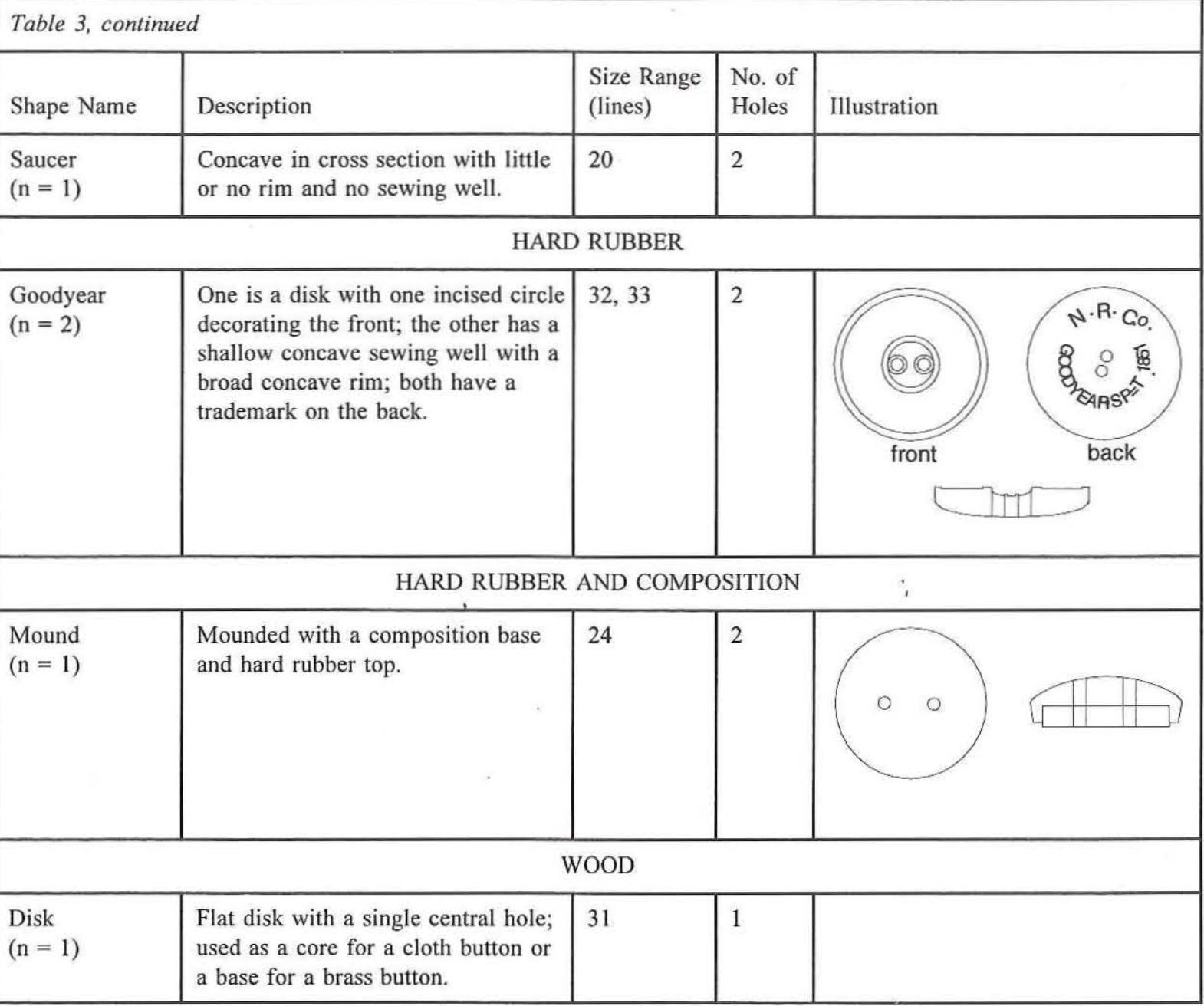

on the upper portion of the eyelet row into which the shoelace would hook.

\section{Heels}

Two matching rubber heels were found in the Kitchen. These have inserts of what appears to be wood on their bases (Figure 97a). A small indentation the same shape as the heel is present in the center of the upper surface. Five holes are present in each heel through which they would have been attached to the shoes. These heels have wear on opposite margins indicating that they could have been part of the same pair of shoes. The all-rubber heel did not appear until 1895. At this time, the rubber heel was hard, heavy, and attached with screws (Anderson 1968:59); the Sebastopol specimens are not inconsistent with this description.

The sole of one heel was found in the Dining
Room. The material has not been identified, but it is very hard and inflexible. Corroded iron nails are still present in the heel (Figure 97b). One leather heel from a woman's high-heeled boot or shoe was found in the Kitchen (Figure 97c). Wear is seen on the lower left margin of this heel indicating a possible right shoe. This piece is $3 \mathrm{~cm}$ wide and was secured with brass nails. The most telling shoerelated artifact is a leather boot heel and lift found embedded in a wall of the Dining Room. Its location dates this shoe to the house's construction period (1854 to 1856). The heel is rounded and has wooden pegs which attached the heel lift to the sole, as well as cuprous nails which bind the laminae of the heel together (Figure 97d).

\section{Heel Plate}

One brass heel plate was found in the Kitchen. 


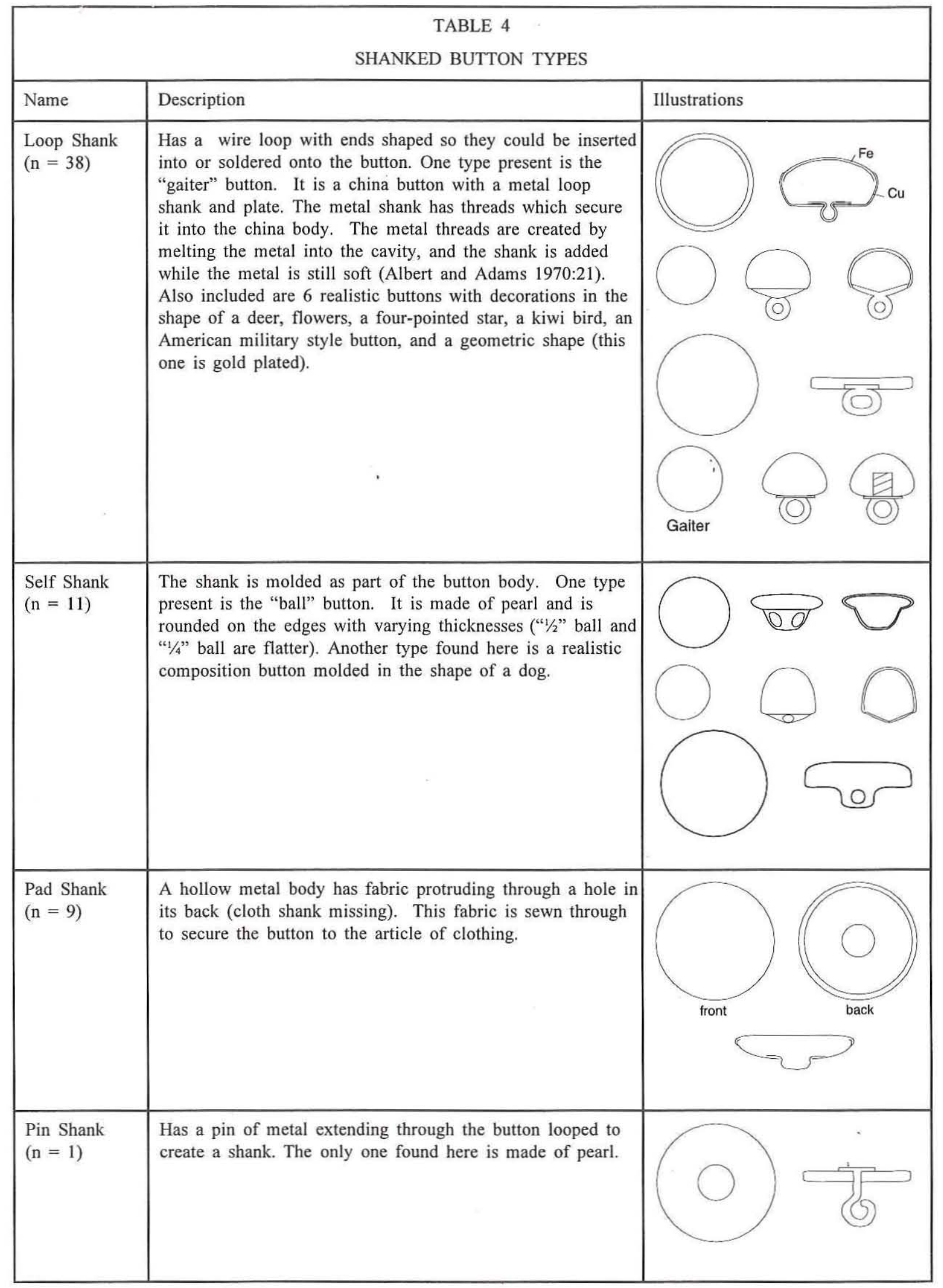




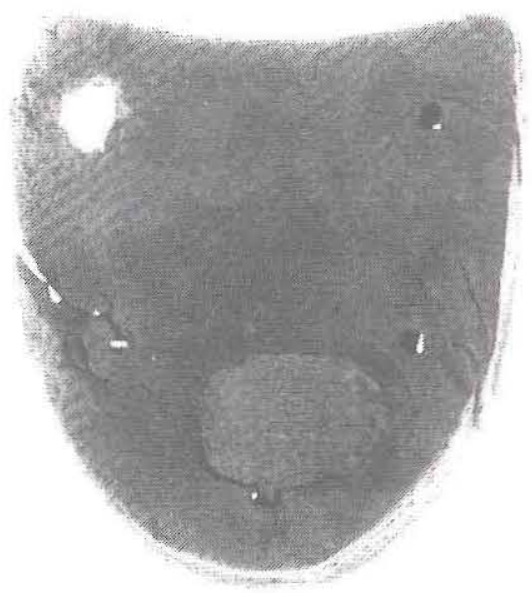

a

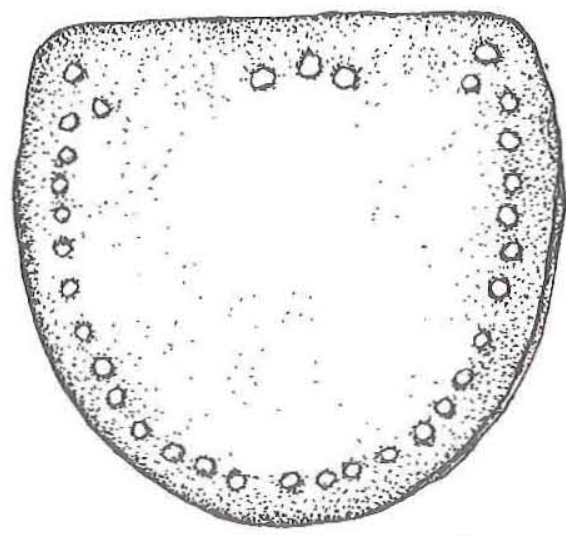

d
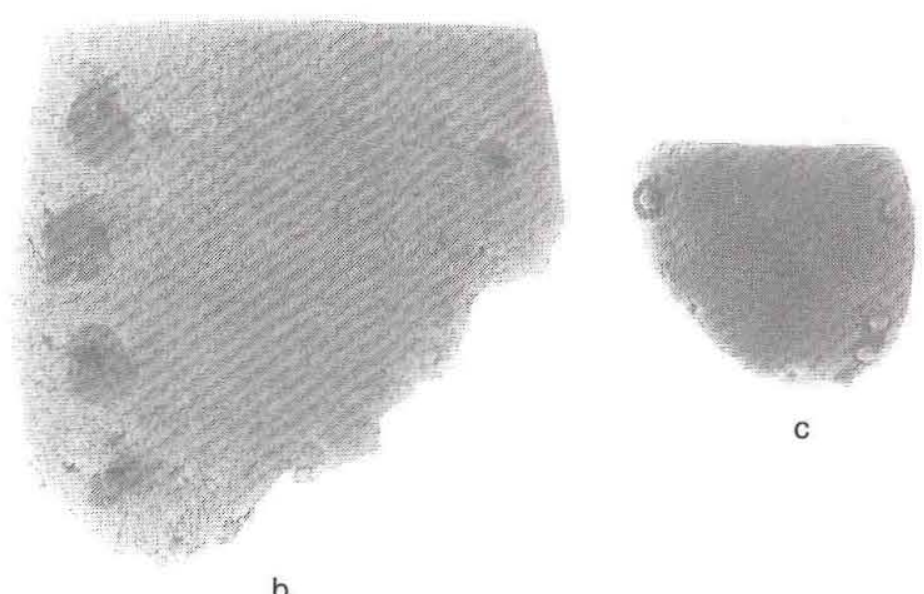

c
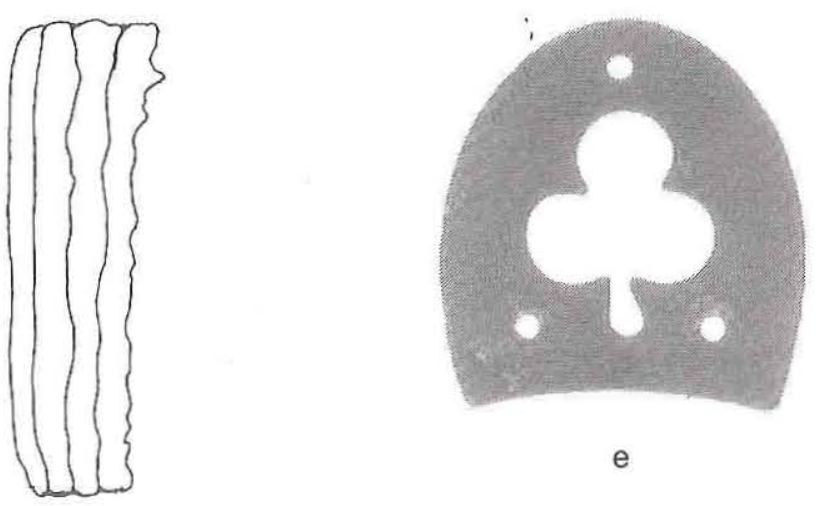

e

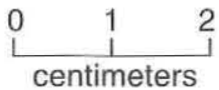

Figure 97. Boot heels and plate. (a) Rubber boot heels (post-1895); $(b)$ heel of unidentified material; $(c)$ leather heel from woman's high-heeled boot or shoe; $(d)$ leather heel found in Dining Room wall (1854-1856); $(e)$ brass heel plate (Civil War era).

It has a trefoil carved out of it and three holes through which it would have been attached to a heel (Figure 97e). This piece was plated with a silvercolored metal which has worn off the lower surface from use. This style of heel plate is known to have been used on the heels of the boots of Civil War soldiers (Lord 1995:87).

\section{Lace Tips}

Twelve brass shoe lace tips were found, 4 in the
Kitchen and 8 in the Dining Room. All of these pieces appear to have been wrapped around the ends of shoe laces, and three still have the fabric inside.

\section{Shoe Leather}

Four leather sole fragments were found in the Kitchen. At least two were sewn, and all four have holes where sewing occurred or pegs were inserted. Two fragments look like insole parts. Other leather fragments were found, but none could be positively 
identified as shoe leather.

\section{Hooks and Eyes}

Thirty-three hooks and eyes were excavated in 40 fragments. Two were found in Room 7, 21 were found in the Dining Room and 10 were found in the Kitchen. Some were made from flat wire, and some were made with round wire. It appears that the flatwire hooks and eyes were more crude in their shaping, and they may be older than the round-wire ones.

\section{Snaps}

Three snaps were found in the Dining Room, and six were found in Room 7. Five of the snaps from Room 7 are attached to one piece of knit fabric.

\section{Tag}

One cardboard tag, like those found on modern jeans, was found in the Dining Room.

\section{Thread or Wool}

Nine thread or wool fragments were excavated from the Dining Room. These appear to be heavy thread like that used in weaving or fine knitting, not fine sewing threads.

\section{Tip for Belt or Suspender}

One white metal tip for a belt or suspender strap was found in the Dining Room (Figure 98a).

\section{Undergarment Hardware}

Five artifacts are included under this heading, all from the Kitchen. One is a corset busk eye (Ing and Hart 1982:163) (Figure 98b). The second is a garter hook loop with a slide buckle at the top (Figure 98c). The third is a clasp, like that used on a garter belt or hose supporter (Figure 98d); it is made of a cuprous metal (most likely brass), and both the loop and the hook are present. The other two pieces of hardware consist of an undecorated slide buckle with a hook attached (Figure 98e), which is similar to the hook on a man's garter (Sears, Roebuck and Co. 1902:970), and a decorated slide buckle with an eye through which a hook would have fastened (Figure 98f).

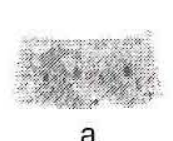

a

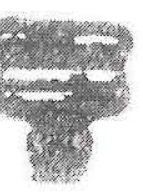

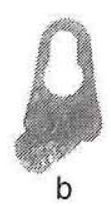
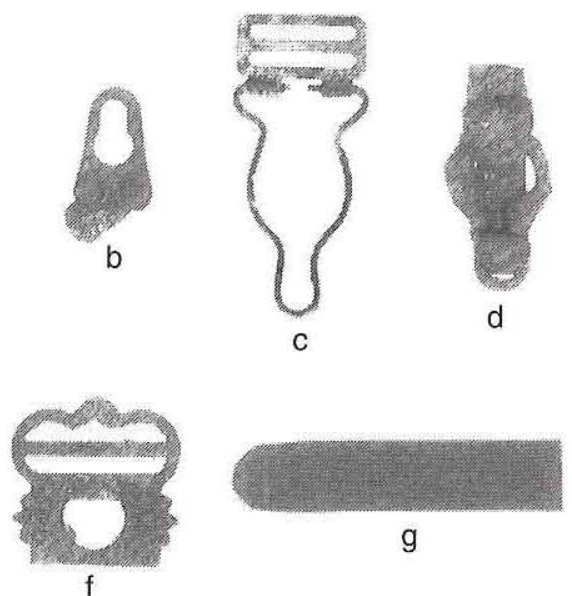

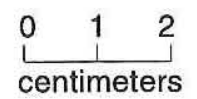

Figure 98. Clothing hardware. (a) Belt tip; (b) corset busk eye; $(c)$ garter hook loop; $(d)$ hose clasp; $(e)$ garter hook; $(f)$ slide buckle; $(g)$ corset stay.

\section{Washburne Fastener}

The Sears, Roebuck and Co. 1902 catalog (1902:940) advertises at least three products by the Washburne Company which all seem to have fastened in the same manner. One item, which looks like the illustration of the Washburne scarf fastener, was found in the Kitchen (Figure 99).

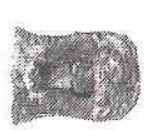

a

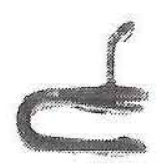

b

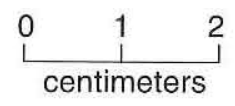

Figure 99. Washburne fastener. (a) Top view; $(b)$ side view.

\section{Unidentified Objects}

Three unidentified cuprous objects were included in this group because of similarities to the items here.

\section{PERSONAL GROUP, CLOTHING ACCESSORIES}

\section{Beads}

Beads are found at nearly every historic site in 
North America. The books and articles written about beads by historical archeologists tend to concentrate on early trade beads, with very little information intended specifically for the historical archeologist studying late-nineteenth- and earlytwentieth-century sites. Collector's books, on the other hand, tend to focus on unusual beads and the decorative objects made from beads. Roderick Sprague (1985) wrote an article intended specifically for the historical archeologist employing terms used in bead analysis up to that time. Because Sprague synthesizes several works and recent historical archeological literature does not contain much additional information, this study relies on Sprague's article for terms and definitions. Presented here are the general principles of bead manufacture, rather than an exhaustive look at how all beads are made.

The beads found at Sebastopol likely came to the site in the form of already-produced decorations such as necklaces, bead trimming, and the like. The Sears catalogues from both 1897 and 1902 illustrate black-beaded trimmings which appear to be made of beads of both the "seed" and "cracked-off" variety (see below) (Sears, Roebuck and Co. 1897:319, 1902:930). These trimmings also incorporate "jet spangles" which are the shape of sequins. It is less likely, but possible, that the women at the house bought unstrung beads and strung them in a decorative manner themselves.

The first level of classification used with this collection is method of manufacture. The beads are then further separated using shape, material, size, color, and decoration. Prior to mechanization, there were generally four ways to produce a glass bead; the glass could be drawn, wound, molded, or blown. Some terms denoting shape were derived from standard terms in the literature (Kidd and Kidd 1970; Spector 1976; Sprague 1985), while other terms were selected because they best describe the shape. Color is described in subjective terms, not using Munsell charts or any other standard measures.

\section{Drawn}

The most common type of bead found at most archeological sites is the drawn bead (Sprague 1985:87); this holds true at Sebastopol, where 68 drawn beads were excavated. Drawn beads were made by a glass blower taking a gather of glass on the end of a blowpipe and blowing air into the gather. Another glass worker would attach a pipe or rod to the opposite side of the glass gather, and the two men would run in opposite directions, creating a long cane of glass with a hole in the center. If the beads were to have a faceted cross section, the gather would be shaped before it was drawn into a cane. These canes would be sold to the bead manufacturers who would break the canes into small bead-sized pieces. For those classified here as "cracked-off," this was the end of the process. However, some drawn beads were further finished by reheating in an oven to produce softer, rounded edges. When this is done, the holes are preserved by filling them with ashes and sand. The very smallest beads, or "seed beads" as they are known, were made in this manner. An explanation of this process is provided in Lardner (1832:182-183). Other finishing techniques include rubbing individual beads with a cloth and finishing with emery paste or sawdust (Sprague 1985:90). Beads would be sorted by size in a series of sieves and then sold either by count or weight (sometimes called "count" or "pound" beads, respectively).

The general shape of a drawn bead would be created as the gather was blown on the blowpipe. By either rolling on the marver or by blowing the gather into a mold (a less documented method), the gather would have a shape that would be maintained even as the tube was drawn out. The proportion of the hole in the bead would be the same as the hole blown into the gather by the glassmaker (Sprague 1985). If bubbles are found as inclusions in drawn beads, they run lengthwise along the bead, parallel to the hole. Drawn beads are further classified here by shape, not decoration as is traditionally done. The reason for this is the decorations and color layers of the Sebastopol beads are not as differentiated as are the shapes.

Drawn beads are often called embroidery beads; the smallest (0-2 $\mathrm{mm}$ in diameter) are called "seed beads," and the larger (3-5 $\mathrm{mm}$ in diameter) have been given the name "pony beads" (Sprague 1985: 91). However, there is a gap in this classification system between 2 and $3 \mathrm{~mm}$ diameter. For the Sebastopol collection, the term "seed" is used to describe those reheated beads that are less than $3 \mathrm{~mm}$ in diameter and rounded at the edges. The larger, finished and rounded beads are called "rounded" (3-5 $\mathrm{mm}$ in diameter). Unfinished tubedrawn beads that were simply broken into lengths are called "cracked-off." Other, larger tube-drawn beads or small finished tube-drawn beads with a 
generally tubular shape are called "tubular" (Figure 100).

All but one of the 29 cracked-off beads came from the Dining Room. The one other was found in the Kitchen. Each of these beads has a thick patina, but they appear to have been made of a black, dark blue, or dark green glass. All 12 seed beads were recovered from the Dining Room. They were made from white, black, brown, green, clear, and red glass. Fifteen rounded beads were found in the Dining Room, one was found in Room 7, and two were found in the Kitchen. All but one are made from black glass; the other is made of translucent white glass. Four larger (6 to $16 \mathrm{~mm}$ long) tube-drawn, or tubular, beads were found. Three are from the Dining Room, and one from the Kitchen. Two are hexagonal and faceted, one is hexagonal, and one is round with no facets. Three tiny tube beads (all under $3 \mathrm{~mm}$ in diameter and length) were found in the Dining Room, and one is from an unknown provenience, although it likely is from the Dining Room since it was excavated in 1979. A medium-sized (about $3 \mathrm{~mm}$ in diameter) faceted tubular bead was found in the Dining Room.

\section{Wound}

Typically, wound beads are the second most common type recovered archeologically (Sprague 1985:93). This was not the case at Sebastopol, where only seven wound beads were found. Here, there is an equal number of molded and wound beads and a larger number of mandrel-pressed beads (included by Sprague with the molded beads). It is possible that, during this later time period, mechanization contributed to a higher proportion of molded beads.

Wound beads were made by either winding a softened cane of glass around a wire or bamboo reed until the desired size was achieved or pouring molten glass around a rotated wire or bamboo reed (Sprague 1985:93). The wire or reed would be coated in a clay slip or some other material to prevent the glass from sticking; this material can often be seen inside the holes of wound beads. If air inclusions are found in wound beads, they are oriented around the hole.

Five beads that could be positively identified as wound were found. Three of the wound beads are from the Dining Room, one is from the Kitchen, and one is from Room 7. Two of the beads appear to have been made of aqua glass, and two were made of black glass. One of the black glass beads is doughnut shaped, meaning that it has a narrow body and a large hole (see Figure 100). One of the wound beads is made of colorless glass and is spherical.

A sixth bead with characteristics of a wirewound bead was excavated from the Dining Room. This small blue bead is about $4 \mathrm{~mm}$ long and has two holes. A wire still remains in one of these holes. Although not fitting with the process of winding glass around a single wire, this bead is included in this category because a scar on one end is like that created on a wound bead.

One white bead about $3 \mathrm{~mm}$ in diameter was found in the Dining Room. It is painted with a white luster and has the typical scars of a wirewound bead encircling its hole.

\section{Molded}

Molded beads are shaped in a mold. To prepare the glass for the mold, the glass is drawn, wound, folded, or blown (Sprague 1985:95). Molded beads may have a mold seam, but some may have no distinctive marks at all. Faceted beads that are very uniform, round beads that are perfectly spherical, and other symmetrical beads can usually be called molded. Asymmetrical beads can be called molded if made in a specific form (e.g., zoomorphic).

Three spherical molded beads were excavated from the Kitchen. Two are made of plastic; one is green, the other baby blue. The third molded bead is white glass with a very polished surface; a rosary was also found at the site, and this bead matches the rosary beads (see Figure 106b). Two faceted, molded beads were found, one in the Kitchen and the other in the Dining Room; one is white, and the other a pale yellow. One molded, faceted, black glass bead was excavated from the Dining Room. It is flat, has two holes, and is only faceted on one face. One last molded bead was excavated from the Dining Room; it has an odd, roughly triangular shape and is made of an orange-colored glass.

\section{Mandrel Pressed}

One type that Sprague (1985:19) includes in the molded category is "mandrel pressed." These beads have a tapered hole with a bulb of percussion 


\section{BEAD TYPES}

Wire Wound Bead Characteristics

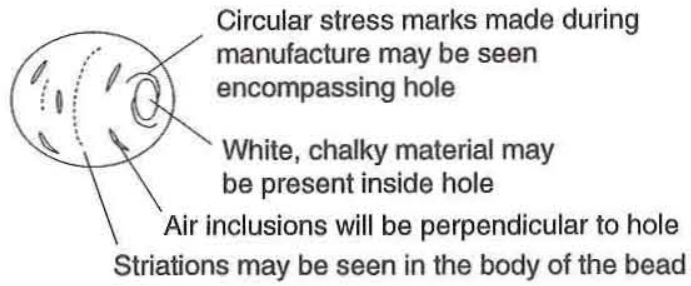

Molded Bead Characteristics

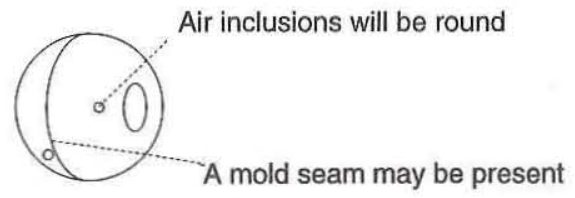

A molded bead will be symmetrical or the shape will be very uniform
Tube Drawn Bead Characteristics

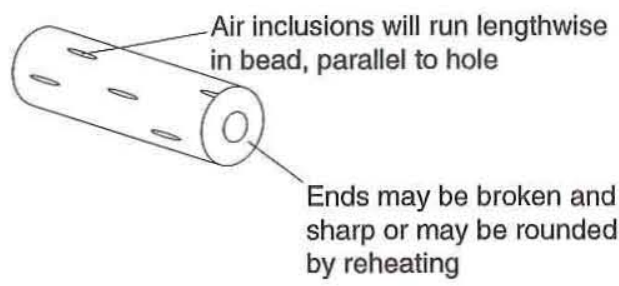

Blown Bead Characteristics

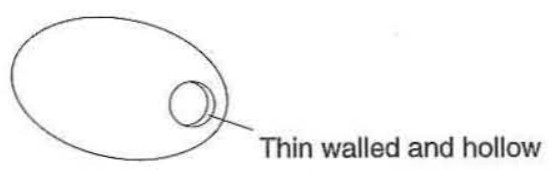

Blown beads are rare on archeological sites due to their fragility

\section{BEAD SHAPES}
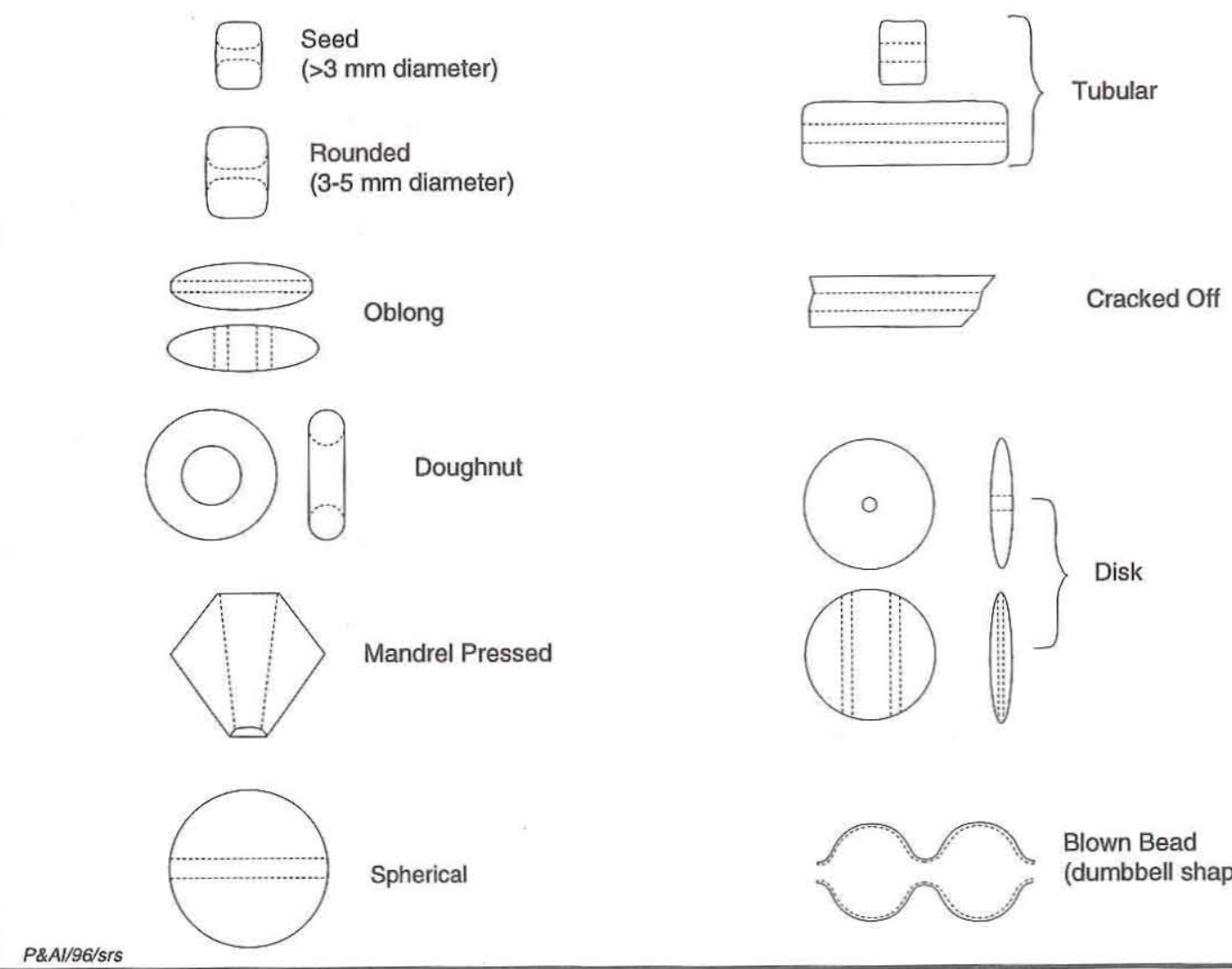

Figure 100. Bead types and shapes. 
around the smaller end and are unevenly faceted. For the Sebastopol collection, the mandrel-pressed beads are given their own classification, as they appear to have been made in a different manner than most of the molded beads.

Remains of eight colorless mandrel-pressed beads were found. All eight are from the Dining Room, and all appear to be 6 to $7 \mathrm{~mm}$ in diameter. These beads fluoresce under an ultraviolet light, suggesting that they are made from lead glass. One intact mandrel-pressed bead was found in the Dining Room. It is larger, having a diameter of $11 \mathrm{~mm}$, and is made of black glass. This bead is corroding badly.

\section{Fired}

Sprague uses the term "fired beads" for one of his types. These are made from compressed granular material that is fired like a ceramic. Sprague created this classification because fired beads can either be molded or shaped by hand and therefore do not fit comfortably into the molded category. The Sebastopol collection contains two fired porcelain beads which appear to have been made in the same manner as china buttons. Around one end of the perforation, these beads have the same pocked surface seen on the back of the porcelain buttons; they have been called "Prosser beads" after the man who patented the process (Sprague 1985:97). Sprague notes that the holes in Prosser beads are tapered, but this is not the case with the Sebastopol beads, which have cylindrical holes. The beads are slightly lopsided, likely from the cooling process. It is believed that the pockmarks on the back of Prosser buttons are created by the buttons being placed on sand to cool. If this is the case, and if the beads were treated in the same manner, then they may have been slightly elastic when taken out of the mold, perhaps settling slightly to produce a lopsided appearance. A clear mold seam can be seen on each of the beads. One of these fired beads was found in the Dining Room, and the other is from the Kitchen.

\section{Blown}

One blown bead was recovered from the Dining Room. It has two bulbs with a narrow spot in the middle creating a dumbbell shape. The intention may have been for this type of bead to be broken in two. A tube of glass would be heated in sections which would be blown to create bubbles in the tube. The tube would then be broken between the bubbles to create the beads. This is one way to create blown bubbles, but other methods have been suggested (Sprague 1985:97).

\section{Other}

One small clay bead was found in the Dining Room. It is small enough to be considered a seed bead, but it is not glass. Another larger clay bead, about $4 \mathrm{~mm}$ in diameter, was excavated from the Dining Room. One small, flat wooden bead was found in the Dining Room. One spherical, lusterdecorated bead was excavated from the Dining Room; it is lopsided and may have been wire spun or molded.

\section{Cuprous Clips}

Two cuprous clips were excavated from the Dining Room. These consist of a round disk with two pointed arms which come out from the sides of the disk and were folded to the back. It appears that these clips were used to fasten decorations, such as rhinestones and the like, to cloth; the rhinestones or other decorations would have been glued to the disk.

\section{Rhinestones}

Two rhinestones were excavated from the Dining Room. One is blue and the other is colorless.

\section{Sequins}

Seven sequins were excavated in the Dining Room. All are plastic. One sequin is $2 \mathrm{~cm}$ in diameter with a hole near the edge of the body. The others are about $6 \mathrm{~mm}$ in diameter with a central hole.

\section{PERSONAL GROUP, JEWELRY}

\section{Broaches and Pins}

The face of a stick pin or tie tack was found in the Kitchen (Figure 101a). This piece has a ceramic center with what appears to be a blue flower painted on it and a cuprous border with flowers and 


\section{Split Ring}

One gold split ring was found in the Kitchen. The use of this item is not known.

\section{Other}

What appears to have been a barrette was excavated from the Kitchen. This piece is cuprous scrollwork on a wide cuprous backing (Figure 101j). The part that would have attached the item is no longer present. A piece of gold chain, four links long, was recovered in the Dining Room. An odd cuprous bauble was found in the Kitchen; it is made of three circles connected to each other, with each consecutively larger (Figure 101k). A cuprous pendant was also found in the Kitchen. It was decorated, although it is no longer identifiable, and appears to have had some sort of lacquered finish. This pendant is in poor condition and is broken into several pieces.

\section{PERSONAL GROUP, TOILETRIES}

Thirty-one comb fragments are in this class. Nine are made of modern plastic, 17 are made of hard rubber, and 5 are made of bone or wood. Three fragments are from Room 7, 10 are from the Kitchen, 16 are from the Dining Room, and 2 are of unknown provenience. A minimum of 8 plastic combs are represented in green, blue, yellow, pink, and clear. At least 6 hard rubber combs are represented in dark brown and brownish red, and a minimum of 3 bone or wood combs are present.

\section{PERSONAL GROUP, SCHOOL/STATIONERY SUPPLIES}

Hazel Tegener, one of the Zorns' grandchildren who lived at the house, remembers her mother having a little blackboard with which she would sometimes teach the children in the living room. The material culture indicates that some schoolwork was done at the Sebastopol house, including work with white chalk. Whether the mothers were teaching their children at home or homework was being done in the Dining Room and Kitchen cannot be distinguished through the archeological record, but the conclusion can be made that at least one of these activities took place. Other items such as fancy pen holders, sealing wax, and paper fasteners indicate that household business matters were also conducted in the lower rooms of the house.

\section{Chalk}

Two small white chalk fragments were found in the Kitchen.

\section{Erasers}

Two used white rubber erasers of the type that slides onto the end of a wooden pencil were excavated from the Kitchen.

\section{Mechanical Pencil}

One corroding piece of cuprous metal appears to be part of a screw-type mechanical pencil. This piece came from the Dining Room.

\section{Paintbrush}

Part of a small paintbrush was excavated from the Kitchen. It includes the cuprous ferrule that held the bristles onto the shaft. Also included is part of the wooden shaft.

\section{Paper Fasteners}

Two rectangular-headed prong paper fasteners were found in the Kitchen (Figure 102a).

\section{Pen Parts}

Two mother-of-pearl pen shafts were excavated, one from the Kitchen and one from the Dining Room (Figure 102b). In the Sears 1902 and 1909 catalogs, these short pen shafts are called "slide holders," while longer versions are considered "desk holders." Both of these slide holders are shown in a Sears advertisement (Sears, Roebuck and Co. 1902:97, 1909:97). One cuprous pen cap with a diameter of 0.42 inch was excavated from the Dining Room; it was likely from a fountain pen. Also from the Dining Room is one pen nib holder, i.e., that part of a nib pen that holds the nib and is clinched to the shaft. One corroded ferrous pen nib was excavated from Room 7 , and what appears to be part of another ferrous pen nib was excavated from the Dining Room. 

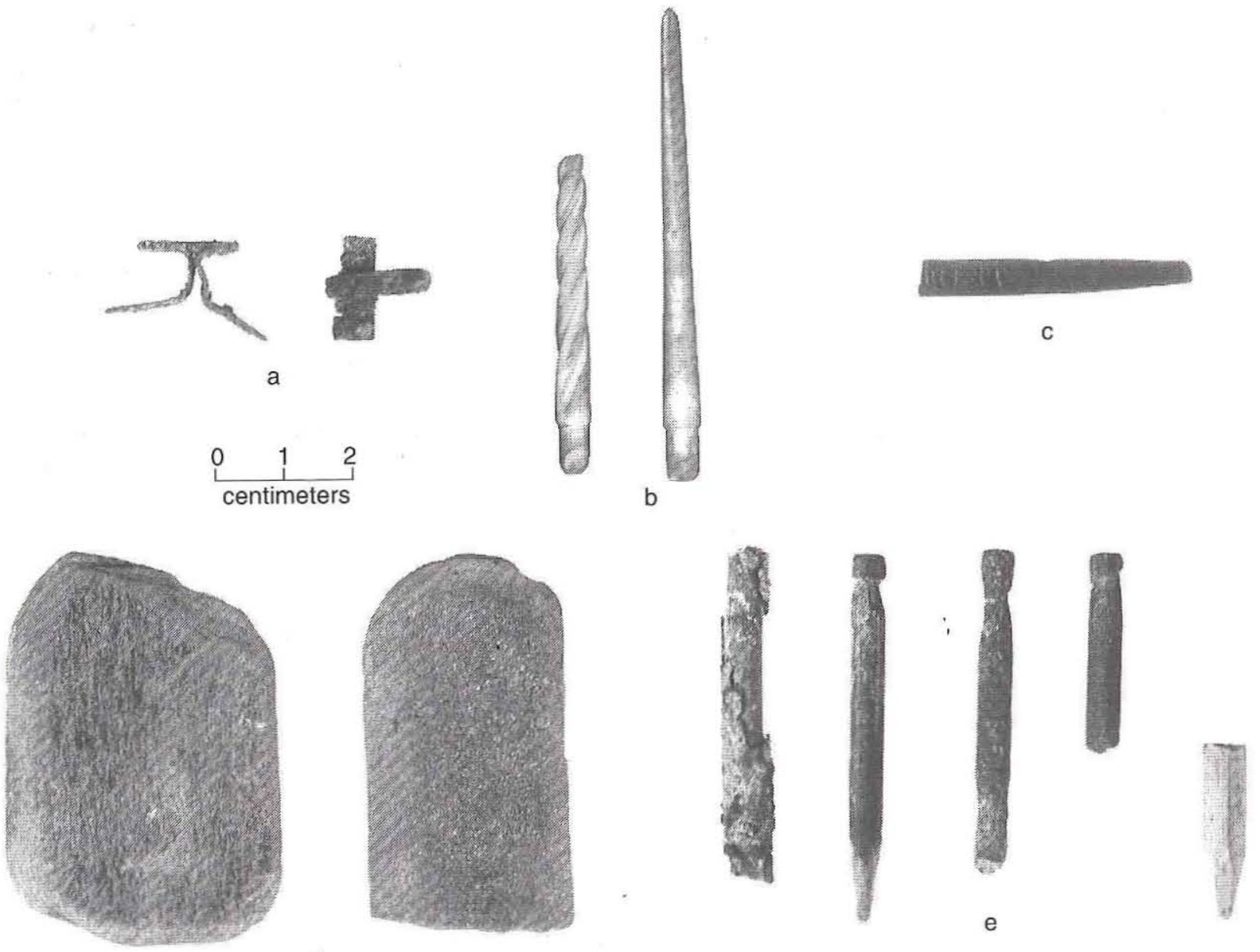

d

Figure 102. Stationery supplies. (a) Paper fasteners; $(b)$ pearl slide holders; $(c)$ sealing wax; $(d)$ sharpening stones; $(e)$ slate pencils.

\section{Pencil Leads}

Twenty-six fragments of gray pencil leads were recovered. These pencil leads would have been found in wooden pencils or used in mechanical pencils. Two are from Room 7, 10 are from the Kitchen deposits, and 14 are from the Dining Room. Nine fragments are square in cross section, but most are round.

\section{Sealing Wax}

A piece of black sealing wax was found in the Kitchen (Figure 102c). Embossed on the side is “. . . RIS No 1."

\section{Sharpening Stones}

Two stones found in the Kitchen have the remains of either lead or graphite (Figure 102d). Both stones are flat; one is about $6 \times 4 \mathrm{~cm}$, and the other is $5.5 \times 3 \mathrm{~cm}$. It appears that these stones were used as pencil sharpeners.

\section{Slate Fragments}

Thirteen slate fragments were recovered, 1 in Room 7, 7 in the Kitchen, and 5 in the Dining Room. These most likely represent slate boards, which were commonly used for schoolwork. The larger pieces show the remnants of writing on both sides.

\section{Slate Pencils}

Forty-four fragments of 39 slate pencils were recovered. Nine are from the Dining Room, and the 
other 35 are from the Kitchen. They could have been used to write on slate boards. These pencils could be used in a holder, and one such corroded cuprous holder was found around a slate pencil fragment. Nubs on the ends of three slate pencils suggest that they were kept in holders (Figure 102e). One fragment of a slate pencil is triangular in cross section, while the others are round.

\section{Wooden Pencils}

The remains of 12 wooden pencils were recovered in 18 fragments. These include wooden shafts, leads embedded in wood, erasers, and copper eraser ferrules. Ten are from the Kitchen, and 8 were found in the Dining Room.

\section{PERSONAL GROUP, OTHER \\ Binoculars or Opera Glasses}

A large lens from a pair of binoculars or opera glasses was excavated from the Kitchen. The lens is still within its brass bracket. An eyepiece from binoculars or opera glasses was also excavated from the Kitchen (Figure 103).
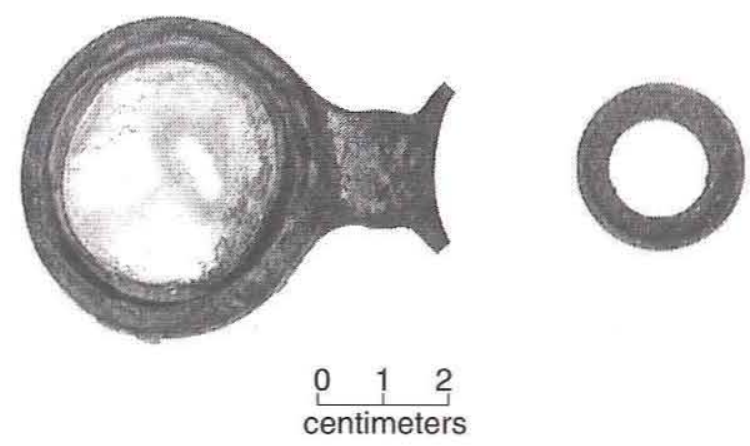

Figure 103. Opera glass or binocular lens and eyepiece.

\section{Buttonhooks}

One bone handle with part of a ferrous shaft was excavated from the Kitchen (Figure 104a). This handle and shaft are likely from a buttonhook. Although it is also possible that they belonged to part of a manicure set, the plain nature of the handle suggests a more common function. A celluloid handle, which appears to have belonged to a buttonhook, was also found in the Kitchen (Figure 104b). A very similar handle made of celluloid is seen in

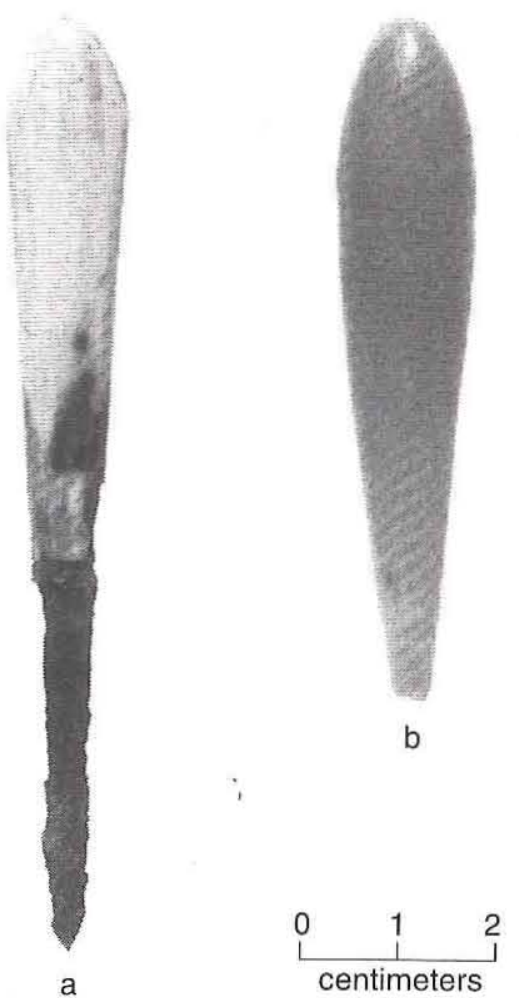

Figure 104. Bone $(a)$ and celluloid $(b)$ buttonhook handles.

Mace's Collector's Guide to Victoriana (1991:128).

\section{Coins}

Seven coins were excavated from the Kitchen. These include three Indian Head pennies dated 1880, 1897, and 1906; an 1874 shield-type nickel; a 1902 Liberty Head nickel with a Denver mint mark; a 1920 Winged Liberty Head or "Mercury"-type dime; and a highly corroded Seated Liberty dime dating 1860-1891 (Yeoman 1976). No coins were found in the Dining Room or in Room 7.

\section{Fan Blades}

Three fragments of a hand-held fan were found in the Kitchen, and one was found in the Dining Room. These blade fragments are made of thin bone with a design that resembles fish lined up nose to tail (Figure 105).

\section{Key} Kitchen

One cuprous skeleton key was found in the 

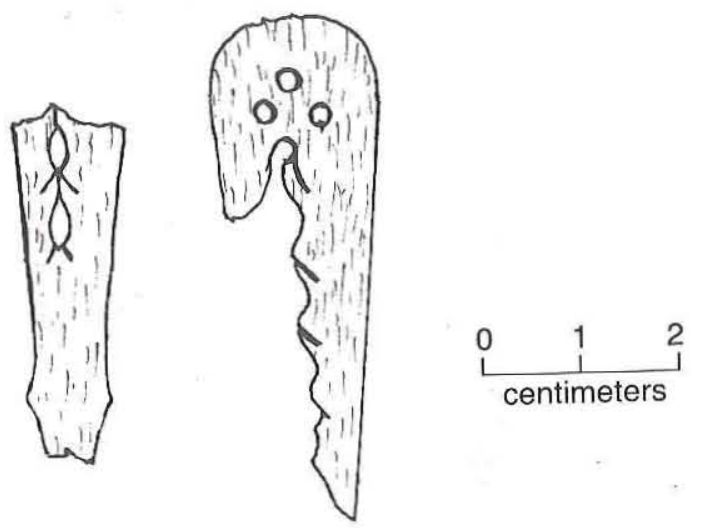

Figure 105. Fan blade fragments.

\section{Purse}

One small $(3.8 \times 3.8 \mathrm{~cm})$ chain mail purse was excavated from the Dining Room (Figure 106a). The mesh part of the purse appears to have been gold plated over brass, while the frame was gold plated but on a different metal. A chain was attached to the top of the purse. This type of purse was used on a chatelaine (Mace 1991:148), which was popular in the Victorian era.

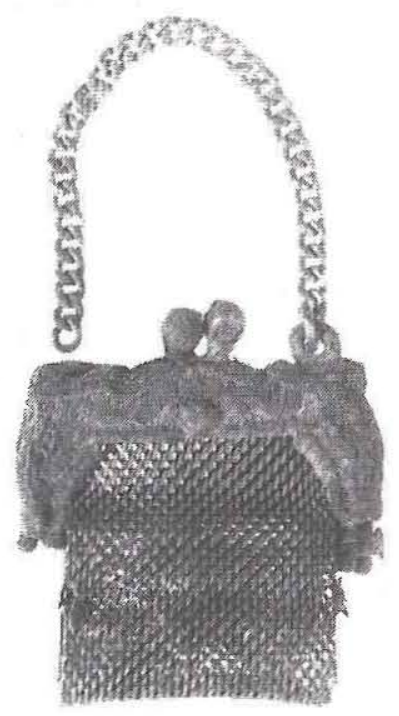

a

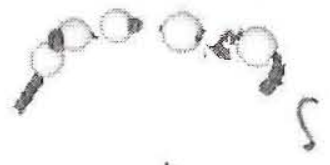

b

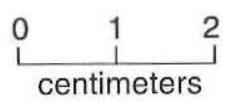

Figure 106. Chain mail purse $(a)$ and rosary $(b)$.

\section{Rosary}

The remains of a rosary were excavated from the Kitchen (Figure 106b). Five molded white glass beads are connected by a cuprous chain. Another bead, likely from this rosary, was found in the
Kitchen and is described above. A similar rosary was found at the Carrington-Covert House in Austin, Texas (Roberson 1974:121).

\section{Spectacle or Eyeglass Lenses}

The Sears catalog of 1897 separates spectacles and eyeglasses; spectacles had arms to hook over or behind ears, and eyeglasses were either pinched on the nose or held in place on a rod. Two lenses from either spectacles or eyeglasses were found (Figure 107). One, from the Dining Room, is flat and made of clear glass. No vision correction would have been gained by using this lens. It is also possible that this piece of glass is from a frame or pendant, but the edges are beveled like an eyeglass or spectacle lens. The other lens, from the Kitchen, is concave, has a small amount of the ferrous rim still attached,; and is tinted gray, apparently coming from a pair of sunglasses.
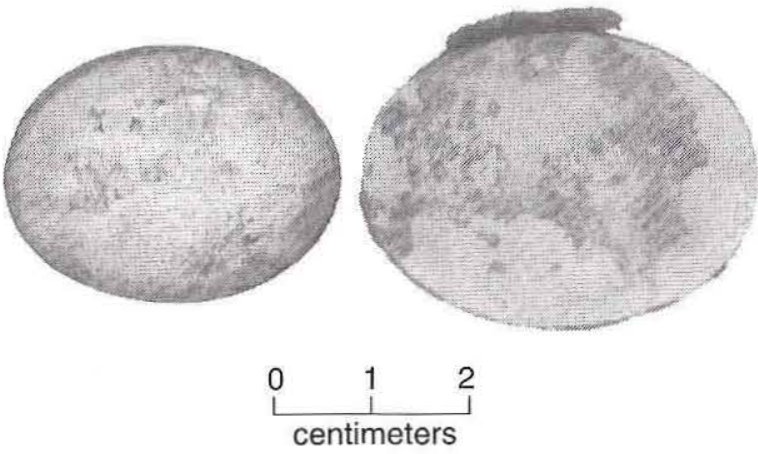

Figure 107. Eyeglass or spectacle lenses.

\section{Watch and Parts}

Five pieces of a pocketwatch and watch chain were found in the Kitchen (Figure 108). Included are a watch cover, the watch body, a spring, and part of a watch chain. The exterior of the watch is brass, and the interior appears to have been ferrous. The chain is cuprous, probably brass, and is of a rope design. No decorations or identifying marks are present.

\section{PHARMACEUTICAL GROUP, . BOTTLES}

\section{Dr. Harter's Liniment}

One bottle found in the Kitchen is embossed with "DR. HARTER'S" on one side and "L . . . NT" 


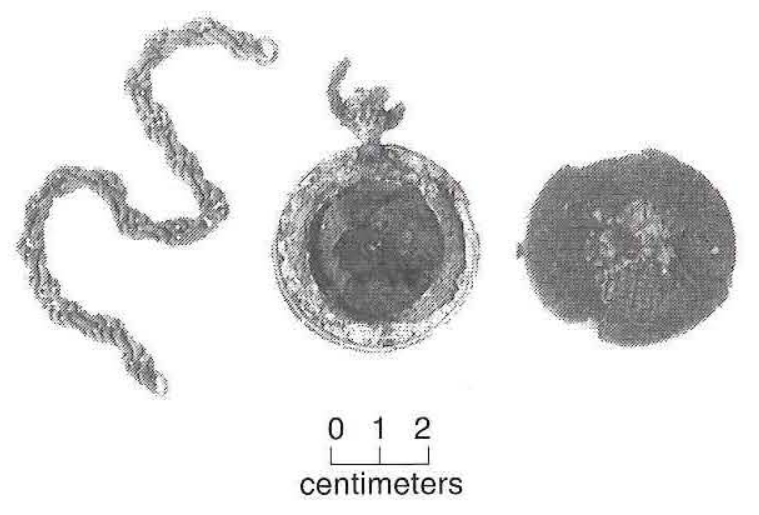

Figure 108. Watch and parts.

on the other. Fike (1987) describes Harter's Elixir of Wild Cherry, Iron Tonic, Lung Balm, Soothing Drops, and Wild Cherry Bitters; however, there is no mention of Harter's Liniment. Milton G. Harter established his business in 1855 in St. Louis, Missouri (Fike 1987:20, 35). He died in 1890, at which time the sales operation moved to Dayton, Ohio (Fike 1987:35). Fike does not mention how long Harter's name was used on bottles.

The Harter's bottle found here is pale green and mold blown. It was manufactured in a three-piece cup-bottom mold and has a flattened side finish. The bottle stands $11.4 \mathrm{~cm}$ tall and is $4.3 \times 2.6 \mathrm{~cm}$ with a rectangular cross section and chamfered corners (Figure 109).

\section{Medicine Vials}

The remains of three small vials were found. One is from the Dining Room, and the other two are from the Kitchen. Two are mold blown and made of pale green glass; the manufacture method is not determinable for the other, which is made of a colorless glass (Figure 110).

\section{P. J. Burges, Druggist, Seguin, Tex.}

Two bottles from druggist P. J. Burges were excavated from the Kitchen. The backs of both bottles are oval in cross section, while the fronts have half-hexagon cross sections. "P.J. BURGES/DRUGGIST/SEGUIN, TEX" is embossed on the front of each bottle. Both bottles have a prescription finish and were blown by hand in a three-piece cup-bottom mold (Figure 111a).

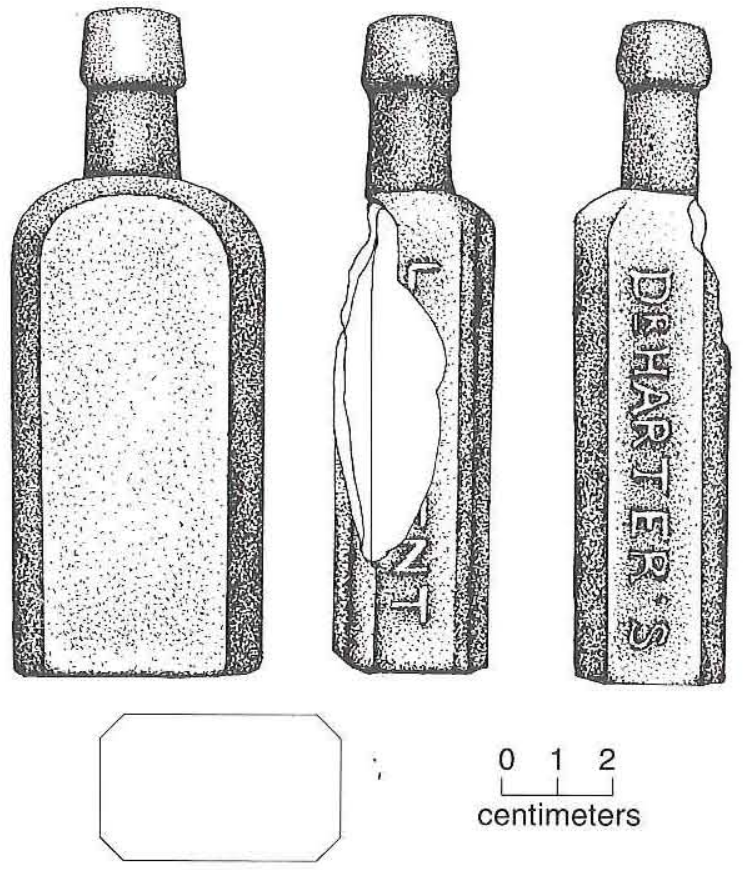

Figure 109. Dr. Harter's Liniment bottle.

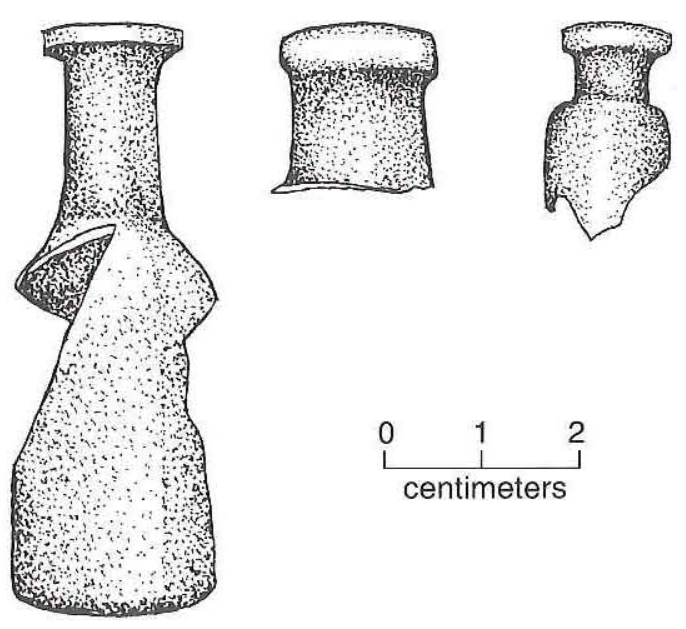

Figure 110. Medicine vials.

The smaller bottle is nearly complete and stands $9.0 \mathrm{~cm}$ tall with body dimensions of $3.6 \times 2.3 \mathrm{~cm}$. The larger of the two is represented by seven sherds, including about half of the body, the base, and the neck and finish. The height of this bottle cannot be determined, but the body dimensions are $5.1 \times 3.2 \mathrm{~cm}$. On the base is embossed "M/PAT'D MAY 15 88/D. F. \& CO." Toulouse mentions that "D F \& Co/M" was found on the base of a bottle 

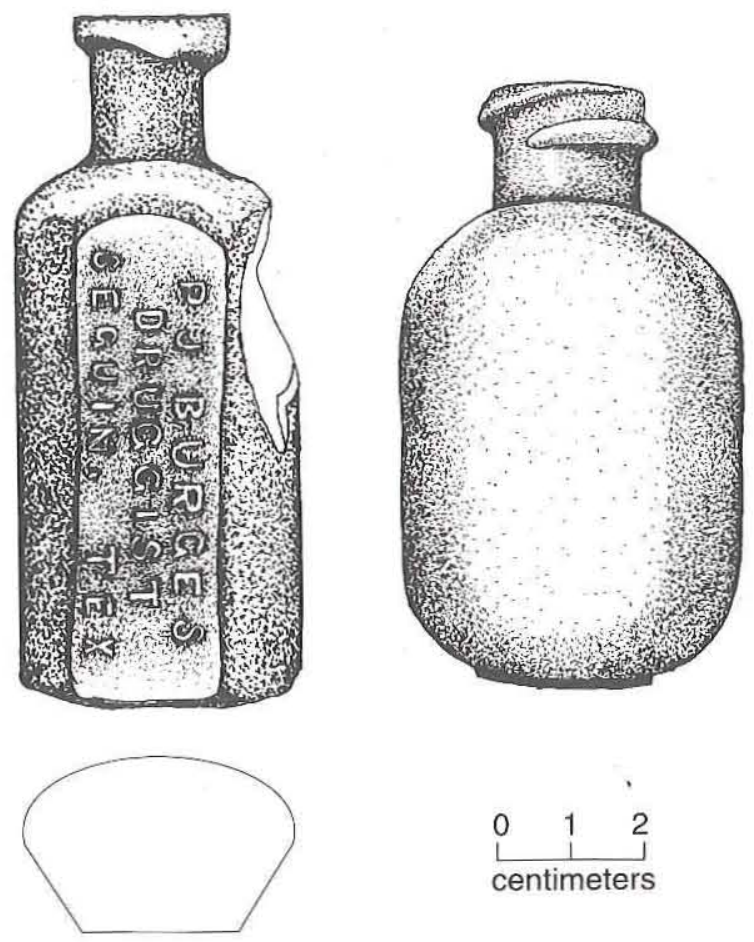

Figure 111. Pharmaceutical bottles. (a) P. J. Burges bottle and cross section; $(b)$ tablets or salts bottle.

labeled "F.M. Heath, Druggist, Riverside, Calif." and "Pat May 15, '88" on one side. Toulouse suggests a date of 1890 to 1900 for that bottle based on the manufacturing technique (Toulouse 1971:160).

\section{Tablets or Salts Bottle}

One squat, oval bottle was found in the Kitchen. The shape of this bottle was one of the most common used for tablets or salts (Fike 1987:15). The bottle stands $7.7 \mathrm{~cm}$ tall, is $4.5 \mathrm{~cm}$ across and $2.6 \mathrm{~cm}$ front to back, and has a screw top (Figure 111b).

This bottle appears to be mold blown; although the mold seams reach to the top of the finish, the rim is rough suggesting a burst-off type of mold. This style of mold seems to date to the second half of the nineteenth century and possibly into the twentieth century (Jones and Sullivan 1989:41). A mark on the base reads " $323 . "$

\section{Unidentified Bottles}

One colorless pharmaceutical bottle, unidentifiable to maker or vender, was excavated from the
Kitchen. This particular bottle shape is identified by Fike (1987:14) as having been manufactured exclusively for prescription use (Figure 112). The bottle stands $9.4 \mathrm{~cm}$ tall and has a prescription finish. In cross section, the shape is a Philadelphia Oval, with body dimensions of $3.5 \times 2.1 \mathrm{~cm}$. The bottle is embossed with graded measures on both sides in cubic centimeters ("cc") and ounces. The bottle was mold blown in a three-piece cup-bottom mold. On the base is a mark reading "usona." This mark has not been identified.
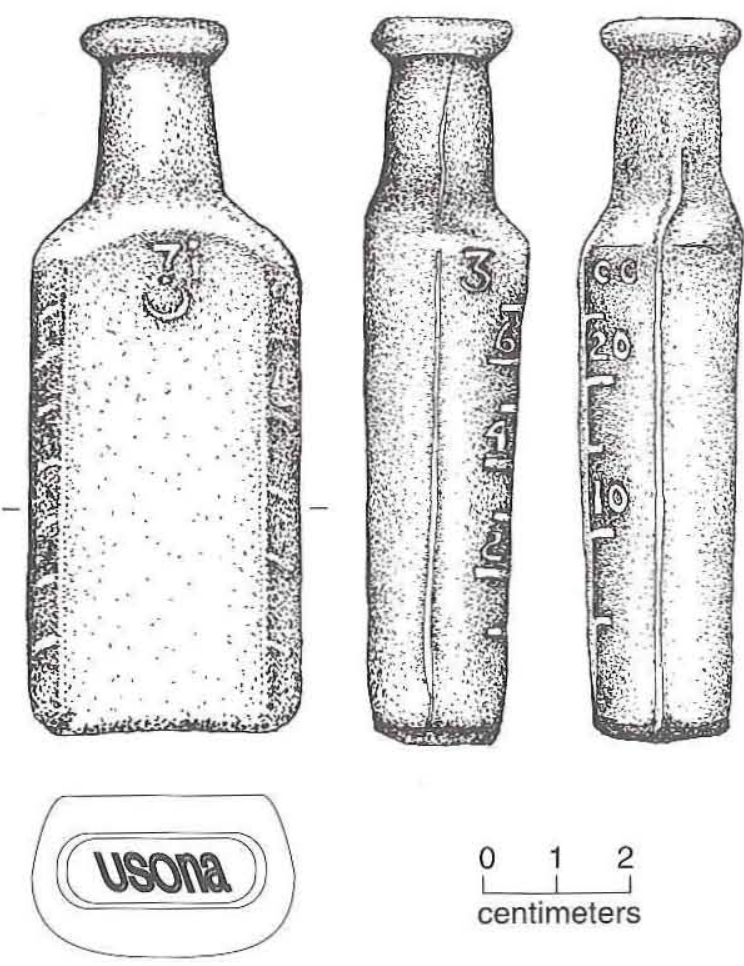

Figure 112. Unidentified pharmaceutical bottle with graded measures.

One glass fragment from the Kitchen has part of a paper label still attached. This label is not readable, but the words "Take" and "Peppermint" are visible. The sherd is from a flat-sided bottle and has a pale green hue. Another glass fragment from a flat-sided bottle was found in the Kitchen. This sherd is pale blue in color, has chamfered corners, and has the embossed letters "... ME . ..." on the side. 'Residue from a paper label is present around the corner. A pale green fragment from another flat-sided bottle was recovered in the Kitchen. This piece has "LON" embossed on its side. A colorless stopper, finish, and 
neck were recovered in several pieces from the Kitchen. This finish and stopper are seen on a "Qt. Tincture" bottle in the M'Kee catalogues from 1871 and 1868 (M'Kee and Brothers 1981:136, 179). On this basis, it might be considered a chemical bottle (Wilson 1981:59). This stopper and finish appear to be from a mold-blown bottle. One colorless bottle, mold blown in a three-piece cup-bottom mold, was excavated in the Dining Room. This bottle is round in cross section with a flanged lip. The height of this piece is $11.2 \mathrm{~cm}$, and its diameter is approximately $4 \mathrm{~cm}$. Wilson (1981:110) identifies this shape of bottle as "round prescription."

\section{ACTIVITY GROUP, SEWING}

\section{Chalk}

Two fragments of blue tailor's chalk were found, one in the Kitchen and the other in the Dining Room.

\section{Pins and Pinheads}

Six glass pinheads, one with the pin attached, were excavated, three from the Kitchen and three from the Dining Room. Four of the glass heads are white, and the other two are dark blue or black (Figure 113a).

\section{Safety Pins}

The remains of at least three safety pins were found. One spring part was found in the Dining Room and two in the Kitchen. The single safety pin head is from an unknown provenience (Figure 113b).

\section{Sewing Machine Hardware}

One cuprous object that appears to be part of an automatic bobbin winder was found in the Dining Room (Figure 114). This object shape is seen in advertisements from the 1908 Sears catalog (Sears, Roebuck and Co. 1908:41, 45, 46, 53). This piece is the pulley wheel which comes in contact with the belt on the machine to spin the bobbin (Sears, Roebuck and Co. 1908:53).

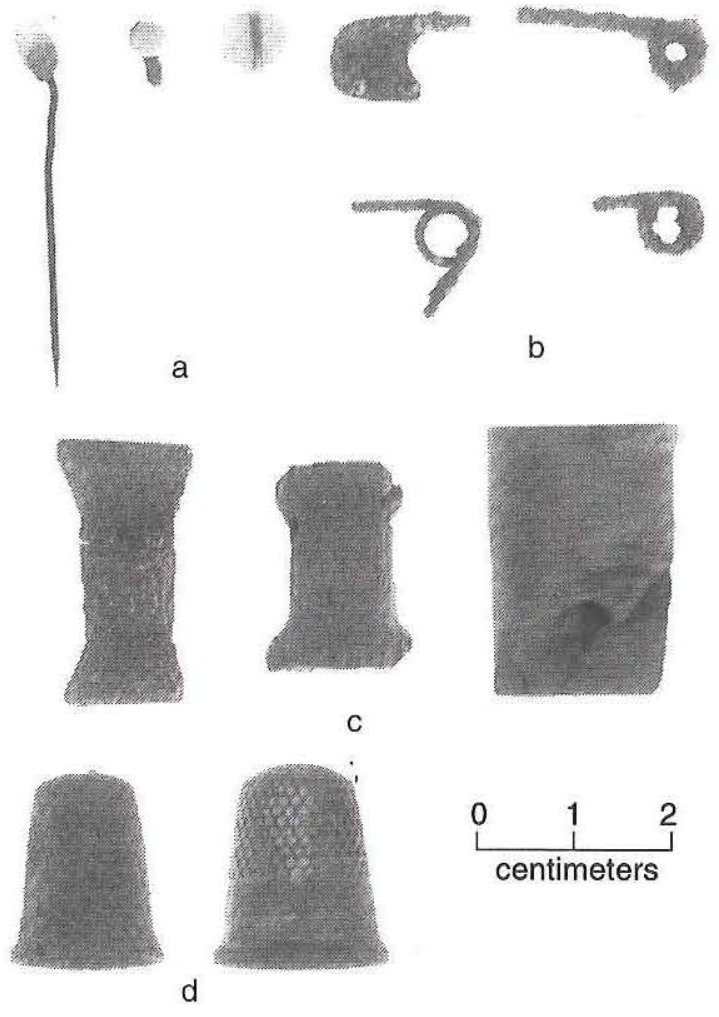

Figure 113. Sewing supplies. (a) Pin and pinheads; $(b)$ safety pins; (c) spools; (d) thimbles.

\section{Singer Sewing Machine Oil Bottle}

One colorless bottle from the Singer Manufacturing Company was recovered from the Kitchen. The Singer company's logo is embossed on the front panel (Figure 115). It is likely that this bottle contained

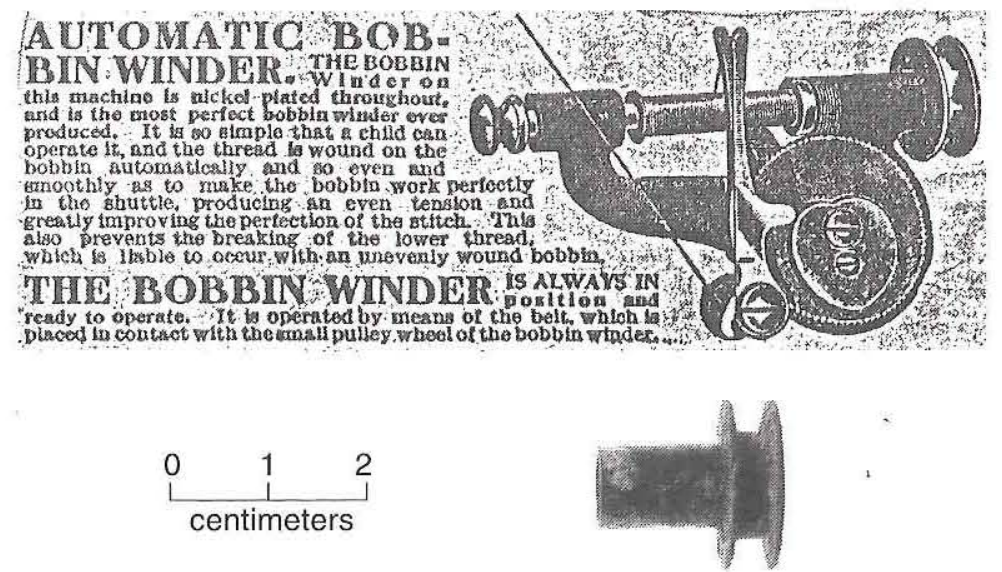

Figure 114. Pulley wheel from automatic bobbin winder and advertisement from 1908 Sears, Roebuck catalog. 


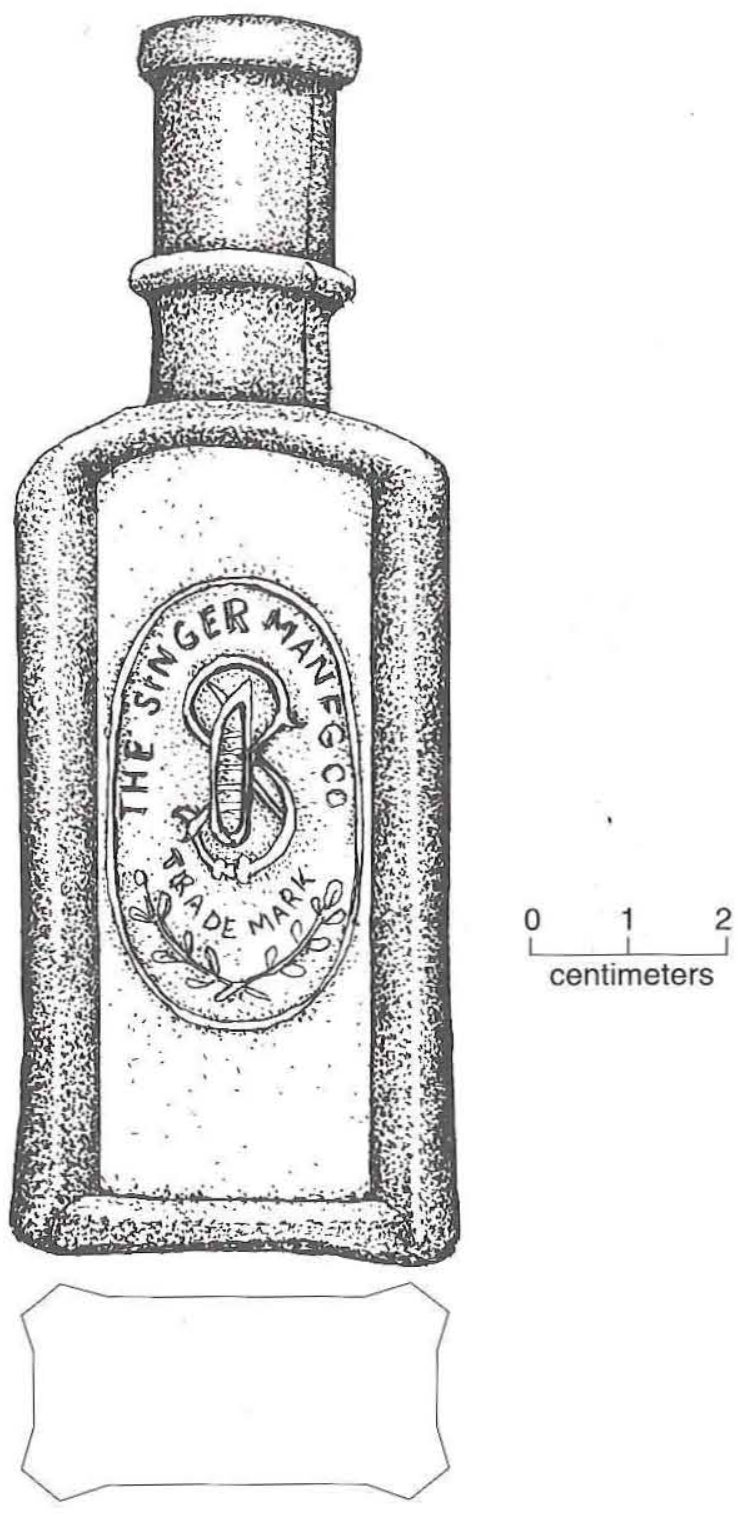

Figure 115. Singer Manufacturing Company bottle.

sewing machine oil. An identical bottle is on display at Sebastopol.

\section{Spools}

Six sherds of three wooden thread spools were found in the Dining Room (Figure 113c).

\section{Thimbles}

Two thimbles were found in the northwest corner of the Dining Room. Both are made of a cuprous metal (Figure 113d).

\section{Thread}

One tangled bundle of loose off-white sewing thread was excavated in the Dining Room.

\section{ACTIVITY GROUP, GUNS AND AMIMUNITION}

It is assumed that all of the items in this class represent either hunting or sporting, rather than defensive, activities. The large number of percussion caps in the collection indicates that a percussion lock gun was used at Sebastopol. The lead sprue and the two pieces of shot with mold seams indicate that bullets or shot were molded at the house. The large quantity of shot in the lower rooms indicates hunting for food, the consumption of game, and the loading of shotgun shells or muzzle-loading shotguns. Ten-, twelve- and sixteen-gauge'shotguns were all used at the Sebastopol site. The one gunflint indicates the presence of a flintlock gun at the site, probably in the early years of the occupation.

\section{Gunflint}

One 24.9-x-18.4-mm, honey-colored French gunflint was recovered from the Kitchen (Kenmotsu 1991:201; Witthoft 1966). The flint likely represents an early part of the occupation at Sebastopol. The flint is square on its striking platform and round on its other end. It looks like it was used, but not extensively.

\section{Lead Pellet}

One lead pellet, used as ammunition in a pellet gun, was found in the Dining Room.

\section{Lead Sprue and Lead Bar}

One clue that bullets and lead shot were molded in the lower rooms at Sebastopol is the sprue left over from the melting and pouring process. Five pieces of sprue were excavated from the Kitchen and Dining Room. The small quantity of shot in the Kitchen, combined with the presence of sprue, likely indicates the reloading of shot, as opposed to the eating of large quantities of wild game.

A partially flattened lead bar, probably flattened to be cut and melted, was excavated from the Dining Room. This bar has ". . LL" embossed on its side. 


\section{Percussion Caps}

Twenty-one percussion caps were found. Two are from Room 7, 5 are from the Kitchen, and the remaining 14 are from the Dining Room. Nine of the caps appear to have been fired; one unfired cap has the headstamp "SB." Single- and double-barrel muzzle-loading percussion shotguns were popular into the early twentieth century due to the low cost of the ammunition (Barnes 1993:383).

\section{Shot}

The term "shot" applies to both shot used as multiple projectiles from shotguns and lead balls used as single projectiles fired from earlier firearms. All of the lead balls collected from the lower three rooms at Sebastopol are discussed here under this heading.

Shot is made by dropping molten lead in a shot tower into a vat of water. The size of the shot is determined by the size of the sieve through which the lead is poured (Traister 1994:301). Not all of the shot found in the lower three rooms at Sebastopol were dropped, however; at least one number 1 buck- shot shows the remnants of a mold seam, and one of the larger .38-caliber bullets was clearly made in a two-part mold.

According to Traister (1994:301) and Barnes (1993:398), shot is given a numerical designation based on diameter. The largest, number 1 shot, is .16 inch in diameter; the smallest, number 12 shot, is .05 inch in diameter. An air rifle shot is .175 inch in diameter, a BB has a diameter of .18 inch, and a BBB has a diameter of .19 inch. Buckshot is larger and is numbered from No. 4 Buck through No. 000 Buck. The largest, No. 000, has a .36-inch diameter and the smallest, No. 4, a .24-inch diameter (Table 5) (Barnes 1993:386).

In total, the lower three rooms yielded 135 balls of shot ranging from .09 inch in diameter (size 8) to .38 inch (probably bullets). Forty-three pieces of number 2 shot, 26 pieces of number 4 shot, 20 pieces of number 3 shot, 8 pieces of number 6 shot, 5 pieces each of number 1 and number 5 shot, and smaller quantities of everything from number 8 shot up to number 0 buckshot were found. In addition, 10 pieces of shot are so corroded they are not measurable. Two are .38 caliber, and these are probably

\begin{tabular}{|c|c|c|c|c|c|c|c|}
\hline \multicolumn{8}{|c|}{$\begin{array}{c}\text { TABLE } 5 \\
\text { SHOT SIZES }\end{array}$} \\
\hline \multicolumn{4}{|c|}{ Shot Number } & \multicolumn{4}{|c|}{ Buckshot Number } \\
\hline Shot No. & $\begin{array}{l}\text { Diameter } \\
\text { (inches) }\end{array}$ & $\begin{array}{l}\text { Diameter } \\
(\mathrm{mm})\end{array}$ & $\begin{array}{l}\text { Number to } \\
\text { the oz. }\end{array}$ & $\begin{array}{c}\text { Buckshot } \\
\text { No. }\end{array}$ & $\begin{array}{c}\text { Diameter } \\
\text { (inches) }\end{array}$ & $\begin{array}{c}\text { Diameter } \\
(\mathrm{mm})\end{array}$ & $\begin{array}{c}\text { Number to } \\
\text { the } 1 \mathrm{~b} \text {. }\end{array}$ \\
\hline 9 & .080 & 2.03 & 585 & 4 & .24 & 6.10 & 340 \\
\hline 8.5 & .085 & 2.16 & * & 3 & .25 & 6.35 & 300 \\
\hline 8 & .090 & 2.29 & 410 & 2 & .27 & 6.68 & * \\
\hline 7.5 & .095 & 2.41 & 350 & 1 & .30 & 7.62 & 175 \\
\hline 6 & .110 & 2.79 & 225 & 0 & .32 & 8.13 & 145 \\
\hline 5 & .120 & 3.05 & 170 & 00 & .33 & 8.38 & 130 \\
\hline 4 & .130 & 3.30 & 135 & 000 & .36 & 9.14 & * \\
\hline 3 & .140 & 3.56 & * & & & & \\
\hline 2 & .150 & 3.81 & 90 & & & & \\
\hline 1 & .160 & 4.06 & * & & & & \\
\hline Air Rifle & .175 & * & 55 & & & & \\
\hline BB & .18 & 4.57 & 50 & & & & \\
\hline BBB & 19 & 4.83 & * & & & & - \\
\hline $\mathrm{T}$ & .2 & 5.08 & * & & & & 1 \\
\hline $\mathrm{F}$ & .22 & 5.59 & * & & & & \\
\hline \multicolumn{8}{|c|}{ *Information not available } \\
\hline Bas & 993 & & & & & & \\
\hline
\end{tabular}


bullets. The larger buckshot were probably used to hunt deer or deer-sized animals.

The largest quantity of shot, 95 pieces, is from the Dining Room. Twenty each were found in the Kitchen and in Room 7. The fact that only onequarter of Room 7 was excavated suggests that shot was much more common there than in the Kitchen, indicating that shot was loaded in Room 7. The presence of this traditionally male exercise supports the theory that Room 7 was a boy's bedroom. The large number of shot in the Dining Room could be attributable to loading shotguns or cartridges or to eating meat killed with shot (spitting the shot out while eating the meat). The small number of shot in the Kitchen suggests that such activities were not as common there.

Aside from lead shot, five unmeasurable pieces made of ferrous metal were excavated from the Dining Room. These may have been steel, shot, but may also have been rusted ball bearings or something similar. The presence of lead shot most likely represents two activities. The first is the reloading of shells. It was common to reload shotgun shells by hand to reduce the price of ammunition. It is probable that this activity occurred in all three rooms. The other activity is the eating of wild game. If shot was used to kill the game for meals, it would need to be separated from the meat. This would most often happen while the food was being eaten in the Dining Room. The large number of shot, 95 pieces, found in the Dining Room supports this theory.

\section{Shotgun Shells}

In total, 12 shotgun shells were recovered. Two are from Room 7, one is from the Dining Room, and nine are from the Kitchen. One shell is so corroded that no headstamp can be seen. Two others are very corroded, but some clues to their origin can be ascertained.

Two of the shells have full brass tubes, and two were brass and paper shells with an extended brass head reaching 1 inch up the tube, known as "high brass." The latter two were made by Winchester. The other eight have shorter brass heads (low brass) and had paper tubes (Figure 116). Five of the shells are 10-gauge, three are 12-gauge, two are 16-gauge, one is either 10- or 12-gauge, and the last is too corroded to tell. The "No." designation on the shells denotes the gauge, but this is not visible on some. In these cases, size was used to determine the gauge

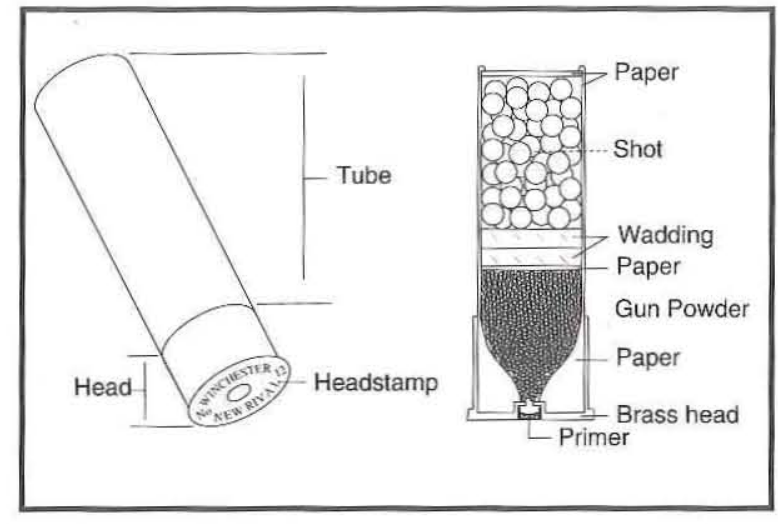

Figure 116. Shotgun nomenclature.

(10-gauge having a head diameter of approximately .9 inch, 12-gauge having a head diameter of approximately .85 inch, and 16-gauge having a head diameter of about .8 inch). Because these diameters are very close and each shell differs somewhat, comparisons between unlabeled and labeled shells were also used to determine gauge. Breechloading shotguns were available as early as the late 1840 s, but the likelihood that anyone at Sebastopol owned one that early is slim.

Four shells have headstamps from the Union Metallic Cartridge Company, which was incorporated in Bridgeport, Connecticut, in 1867. This parent company merged with Remington in 1912, and after that date the headstamp changed to "REM-UMC" (Flayderman 1980:140; other sources say this change occurred in 1910 or 1916 , but 1912 is used more consistently). One shell has the stamp "U.M.C.Co/ No. 10/NEW CLUB," and another highly corroded shell appears to have the same markings. A third shell has the corroded headstamp "U.M.C.Co/No. ... /BLAC . . . LU ... A"; this is a 10 -gauge shell. A fourth shell is marked "U.M.C.Co . . No. 12 ... CLUB." All four of these shells had a paper cartridge with a short brass head.

Two paper shells are from the Remington ArmsUnion Metallic Cartridge Company. One has a headstamp of "REMINGTON U.M.C./No. 16/NITRO CLUB." The other is corroded but has a headstamp most likely reading "REM U.M.C./No. . . . /SHUR SHOT." This second shell was likely a 10 - or 12 gauge.

A highly corroded fully brass cartridge from the Kitchen has a headstamp that is not readable, but one section has ". . . PORT CON. ..." This could also be a U.M.C. or REM-U.M.C. cartridge since these 
companies were based in Bridgeport, Connecticut. This is most likely a 10-gauge shell.

One shell has the mark "W.R.A.Co./No. . . . I RIVAL" of the Winchester Repeating Arms Company. This is likely a 12-gauge shell. The New Haven Arms Company, of New Haven, Connecticut, changed its name in 1866 to the Winchester Repeating Arms Company. From that time until about 1940, the initials "W.R.A.Co." were used to identify some of their products (White and Munhall 1977:156). The Rival was available for many years as a primed empty but was changed to a black-powder load in 1894 when the Winchester Leader was announced (Vinson 1968:91). One Winchester Leader shell was found in the Kitchen. The head of this shell extended about 1 inch up the tube. Part of the headstamp is visible: ". . . INCHESTER . . . / . . EADER." The size of the shell indicates a 10-gauge. Two Winchester New Rival paper and brass shells were found. One is a 12gauge with a head that extended 1 inch up the tube, and the other is a 16-gauge. Both of these shells are unfired.

\section{.22 Cartridges}

Eight .22-caliber short rimfire cartridges were excavated from the Kitchen, and one came from the Dining Room. All nine had been fired. One is corroded and no headstamp can be discerned, while another has an impressed mark that is no longer readable. The other seven have impressed headstamps. Three have a "P" headstamp. This particular "P" was used by the Peters Cartridge Company from 1895 to 1934 when it was incorporated as part of the Remington Arms Company (Barber 1987:64, 83, 197). Two cartridges have a "US" headstamp. This mark was used by the United States Cartridge Company which produced rimfire cartridges from 1869 to 1936. The "US" headstamp was likely used between 1875 and 1936 (Barber 1987:40). One cartridge has a "U" headstamp. It was made by the Union Metallic Cartridge Company after 1885, the Remington ArmsUnion Metallic Cartridge Company, Inc., between 1912 and 1934/1935, or the Remington Arms Company, Inc., between 1934/1935 and the present (Flayderman 1980:140; Barber [1987:48] gives dates of 1916 to 1920 for REM-UMC, and several sources are contradictory on the year of this transition). One cartridge has only a small impressed "H." This stamp was used by the Winchester Repeating Arms Company after 1895 and continued to be used after the purchase of that company by Western Cartridge Company in 1931. The two companies combined to create Winchester/Western (Barber 1987).

Two .22-caliber long or long rifle rimfire cartridges were found, one each in the Kitchen and Dining Room. One has not been fired. One has a " $U$ " headstamp, and the other has a small " $\mathrm{H}$ " headstamp.

\section{Other Cartridges}

One unidentified cartridge was excavated from the Kitchen. Only the head remains of this used center-fire cartridge with a head diameter of 0.50 inch.

A cartridge with the headstamp " $F \ldots 6 \ldots 88$ " was found in the Kitchen. It was made by the Frankford Arsenal, an American government company. The " 6 " and " 88 " indicate that the cartridge was made in June 1888 (White and Munhall 1977:72). The diameter of the head is $0.60 \mathrm{inch}$, and the caliber is between 0.41 and 0.45 . The top of the casing appears to have been cut, and a hole has been punched in the cartridge at 0.45 inch up from the head. This center-fire cartridge has been fired.

\section{ACTIVITY GROUP, FISHING}

One fishhook, $8.5 \mathrm{~cm}$ long, was found in Room 7. It is made of ferrous metal.

\section{ACTIVITY GROUP, HOUSEHOLD}

\section{File}

Part of a very corroded file was found in the Dining Room. It is made of ferrous metal.

\section{Paintbrush}

Over 300 paintbrush bristles were recovered from the Dining Room. These bristles are $7.5 \mathrm{~cm}$ long and appear to come from a large paintbrush. The bristles are synthetic with remnants of green and white paint; they are modern and probably relate to the restoration of the house.

\section{Paint Can}

Two fragments of a paint can lid were found in Room 7. This is the style of lid that needs to be 
pried out from the end of the can and can be securely closed by forcing it back into place. This particular type of can was developed in 1895 (Ritchie and Bedford 1985:102).

\section{ACTIVITY GROUP, TOYS}

\section{Balloon}

Six fragments of a red rubber balloon were found in the Dining Room.

\section{Balls}

Three fragments of a rubber ball were found in the Dining Room. The ball appears to have been tan or chalk colored and was approximately $4.5 \mathrm{~cm}$ in diameter. Hollow rubber bat balls are advertised in the Sears, Roebuck 1902 catalog (Sears, Roebuck and Co. 1902:915). These balls were white and were made in several sizes, $4.75 \mathrm{~cm}$ diameter being size 20 . A small brown ball was found in the Kitchen. It is made of plastic or hard rubber and is $1.9 \mathrm{~cm}$ in diameter. This ball has a weight incorporated into its interior so that it wobbles when it rolls. Incised lines decorate one hemisphere.

\section{Bottles}

Three small colorless glass bottles that appear to be toy milk bottles were found in the Kitchen (Figure 117). They were mold blown in a three-piece cupbottom mold and stand $7.0 \mathrm{~cm}$ tall with a diameter of $1.8 \mathrm{~cm}$. One is currently on display at Sebastopol.

\section{Chewing Gum}

One piece of green-colored chewing gum was found in the Dining Room.

\section{Dice}

Two dice were found in the Kitchen. Both are made of bone; one is $0.8 \mathrm{~cm}$ square on a side, the other is $1.2 \mathrm{~cm}$. The smaller die has a flower embossed into the side with six dots.

\section{Dolls and Doll Parts}

Porcelain dolls enjoyed enormous popularity from the mid-nineteenth century up until World War I (Tosa 1987:20). They were popular toys for children,

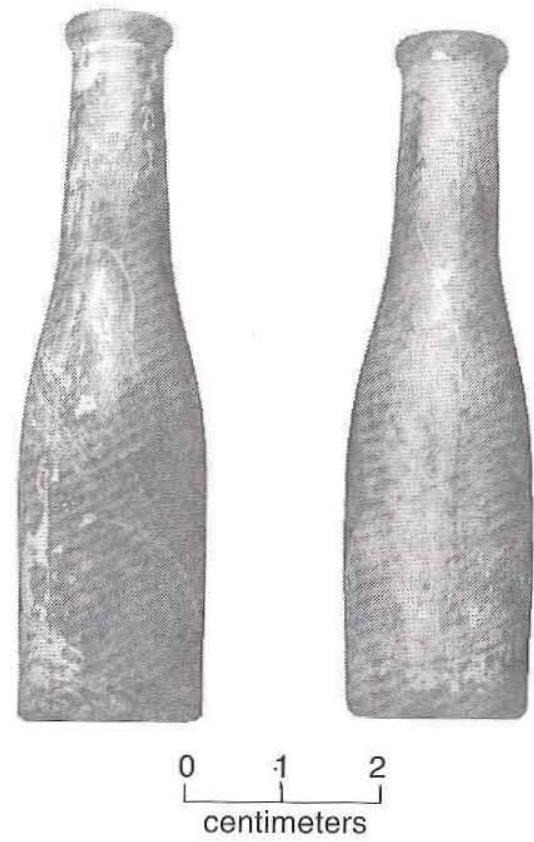

Figure 117. Toy milk bottles.

and they accurately reflect the styles of the times in which they were made (Tosa 1987:22), making them a sometimes useful archeological artifact.

Six dolls' feet were found in the Kitchen (Figure 118). Each foot has a different shoe, meaning that each represents a different doll. The largest shoe is hollow porcelain and has a flat heel, while the rest are solid with a high heel.
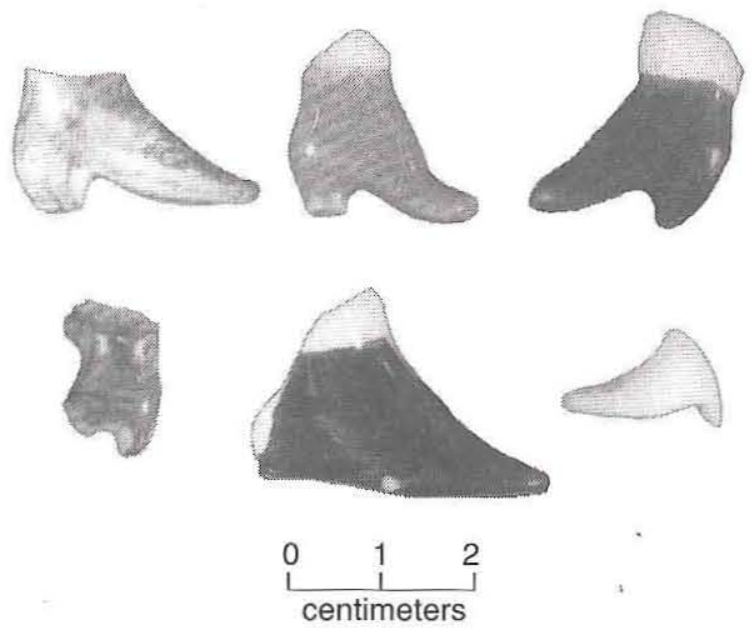

Figure 118. Dolls' feet found in the Kitchen.

One blue glass eye was found in the Dining 
Room. The first patent for a glass doll's eye was taken out in 1855 by Claude-Joseph Blampoix, a Parisian doll maker (Tosa 1987:27). Glass eyes were often found in bisque dolls' heads, but they were not usually found in glazed porcelain heads (Coleman 1968:219).

One "frozen Charlie" doll was found in the Kitchen (Figure 119). Solid porcelain dolls with no moving pieces were commonly called "frozen Charlottes," "frozen Charlies," or "bathing dolls"; they were common from 1850 until World War I (Foulke 1995:84; Tosa 1987:150). This specimen is unique in that it represents a Negro child. The cheeks and lips are tinted yellow and red, and the eyes have white spots for pupils. No reference to a black frozen Charlie doll was found during this analysis, although reference to a black baby doll dating ca. 1850-1860 was found (Tosa 1987:120). The doll from Sebastopol is one of the only racespecific artifacts found which could be interpreted as being indicative of the African American workers at the site.

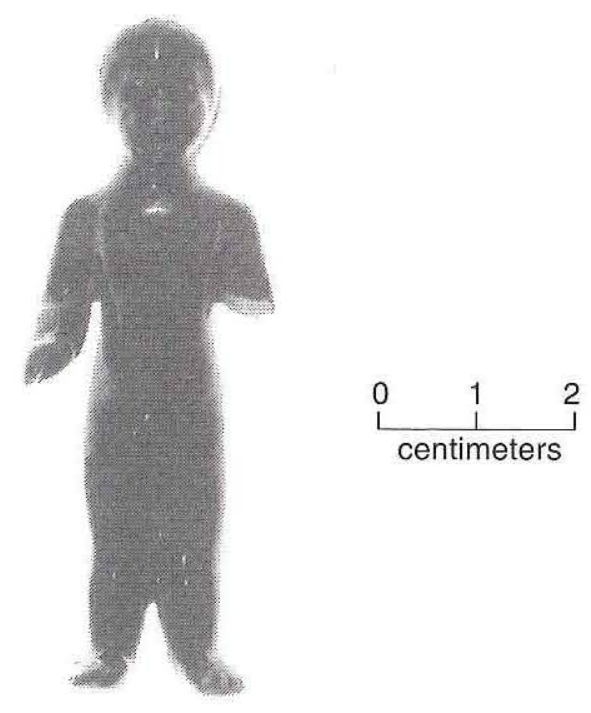

Figure 119. African American frozen Charlie doll.

One doll's crown was found in the Kitchen. It is made of cuprous metal and has decorative crosses around its rim (Figure 120a). Another possible doll crown was also found in the Kitchen. It is made of porcelain and is gilded (Figure 120b). Holes are present around the object which, if actually a crown, could have been used to sew it onto the doll's head.

Four pieces of a glazed porcelain doll's head

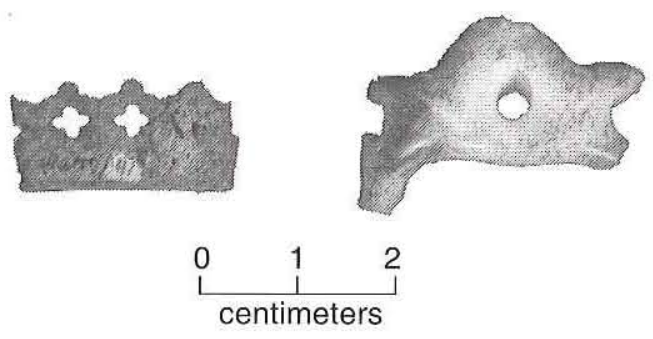

Figure 120. Dolls' crowns.

were recovered in the Kitchen. This doll had dark hair and blue eyes with pink cheeks and brown eyebrows (Figure 121a). Four other sherds (two bisque and two glazed porcelain) from similar dolls were found in the Dining Room (Figure 121b-e). All four of these sherds have brown, curly hair. These eight sherds are from dolls that would have had cloth or leather bodies with the hair molded as part of the head. The head would have been attached to the body along the bodice where holes are present to sew through. This type of doll's head was common from the 1850 s to World War I, being distinguished primarily by hairstyle and clothes. None of the sherds is large enough to determine hairstyle. One complete bisque doll's head was found in the Kitchen. This is a small head $(2.3 \mathrm{~cm}$ tall) with an open hole in the top into which a cork or piece of wax with hair attached would have been plugged. It has blue eyes, pink cheeks, brown eyebrows, red lips, and a " 36 " carved into the back of the head (Figure 121f).

Shoulder or bodice sherds from a porcelain doll were also recovered, three in the Kitchen and two in the Dining Room. These sherds have holes where the body would have been sewn together with the head. A completely straight arm from an adult doll was found in the Kitchen (Figure 122a). This arm is $7 \mathrm{~cm}$ long and matches that found on an 18451850 doll (Tosa 1987:134). A smaller porcelain arm, less than $2 \mathrm{~cm}$ in length, was also found in the Kitchen (Figure 122b). It appears to be from a small frozen Charlotte. A small porcelain leg approximately $2.5 \mathrm{~cm}$ long was found in the Dining Room (Figure 122c); it also could be from a frozen Charlotte.

\section{Figurines}

Five sherds, all from the Kitchen, appear to be parts of figurines. One is porcelain and may be part 


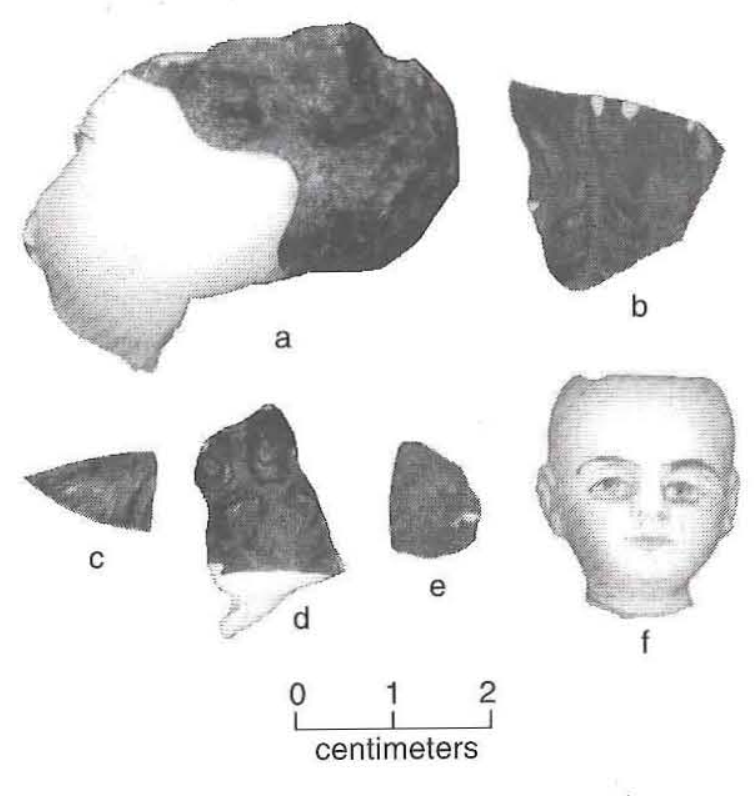

Figure 121. Dolls' head and fragments.

of a foot, and one sherd appears to have been a pink flower with a green leaf. The other three sherds are dark pink, green, and pink.

\section{Harmonicas}

Two harmonica reed plates were found in the Kitchen. Both are made of cuprous metal.

\section{Jacks}

One ferrous metal jack was found in the Kitchen.

\section{Marbles}

Marbles have been made from several materials over the past three centuries, with clay, porcelain, glass, and stone being the most common. Marbles were sold by material and size. The distinction between sizes comes from the game "Marbles," in which the player uses a larger "shooter" to knock smaller marbles out of a circle. When sorting marbles, it is difficult to simply divide them into small and large sizes because there is a continual grade from small through large. Thus, Table 6 lists the sizes of marbles sorted by material. Marbles also had other uses. Chinese Checkers, solitaire games, a mosaic art set, the game "carpet bowls," and even election ballots (white for one vote, black

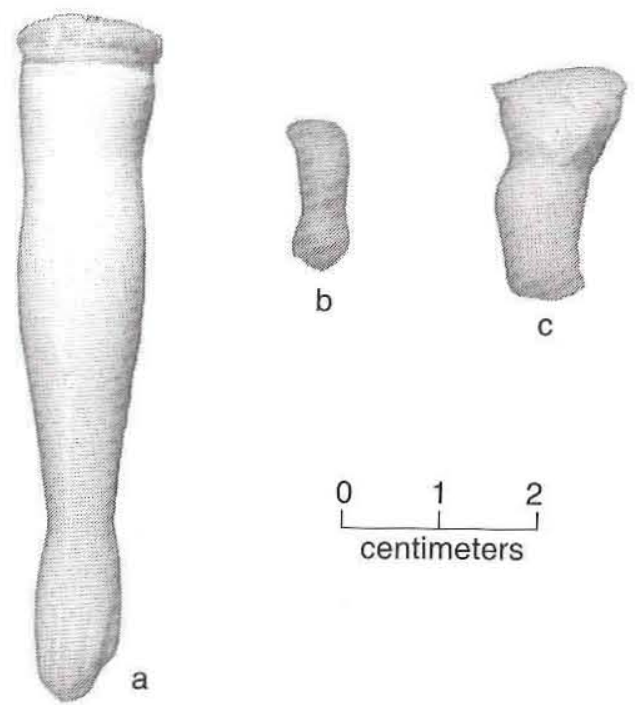

Figure 122. Porcelain doll 'appendages.

for another) were and still are alternate uses for marbles (Grist 1993).

Marbles alone may not provide tight dates for an archeological site, but broad date ranges can be determined, and more importantly, social activities and economic details of the children's lives can be ascertained. By comparing the numbers of undecorated, less expensive clay marbles and the more expensive glass and agate marbles, the relative amounts of money spent on the children's toys can be gauged. As detailed below, 16 handmade glass marbles were excavated from the lower three rooms at Sebastopol, while 25 ceramic marbles and only 1 agate marble were found. It would appear that Sebastopol is typical in the numbers and types of marbles in that there are more of the less expensive marbles. Machine-made glass marbles were found only in the Dining Room. This suggests that in the later years children did not play marbles in the Kitchen; with the earlier marbles there is a more equal distribution between the Kitchen and the Dining Room.

\section{Ceramic}

In the literature, there is confusion between the terms "clay," "china," and "porcelain." The sources referenced for this research do not clarify this problem, and because of this, the Sebastopol marble analysis does not distinguish between marbles of these materials unless the marble is broken or 


\begin{tabular}{|c|c|c|c|c|c|c|c|c|c|}
\hline \multicolumn{10}{|c|}{ TABLE 6} \\
\hline Material & $9 / 16$ & $5 / 8$ & $3 / 4$ & $7 / 8$ & 1 & $13 / 16$ & Odd Size & Broken & Totals \\
\hline Agate & - & - & - & 1 & - & - & - & - & 1 \\
Clay & 9 & 6 & 9 & 3 & - & - & 1 & 1 & 29 \\
Glass & 1 & 14 & 4 & 2 & 1 & 1 & 3 & - & 26 \\
Porcelain & 1 & - & - & - & - & - & - & - & 1 \\
\hline
\end{tabular}

otherwise obviously of a certain paste. The types are described by body color, decoration type, and presence/absence of glaze.

Clay marbles, until the introduction of machinemade glass marbles, were the least expensive and, therefore, the most common type (Randall 1979:9). Unglazed clay marbles were made by rolling or molding the clay into balls and then firing them. If a marble was to be glazed, the glaze would be applied before the marble was fired. After the first firing, a decoration could be painted over the glaze, and the marble would be fired a second time. Some clay marbles were glazed, but many were not. Although there were companies that made only marbles, many of the earlier ones were made as a side business by dinnerware manufacturers (Grist 1993:6).

The only marble from Sebastopol that can definitely be called "porcelain" is one brown and yellow Bennington-style marble from the Dining Room fireplace. Benningtons were glazed with a dark (blue, brown, or green) spotty glaze and mimicked the glazes used by a Bennington porcelain factory in Vermont. This style of marble was also made in Germany (Grist 1993:6, 36; Randall 1979:13).

Four marbles from the Kitchen have a colored paste, as do four from the Dining Room. One of the Dining Room marbles is broken and appears to have been made from a reddish brown earthenware. All of the paste colors are earth tones, ranging from orange to nearly black. None of these colored clay marbles is glazed, but three (two from the Kitchen and one from the Dining Room) seem to have been painted at one time, with only small portions of the paint still present. The paints were black, blue, and white with one color painted on each marble.

Fourteen undecorated, white-bodied marbles were excavated from the Kitchen. Only two came from the Dining Room, and one was found in Room
7. It is possible that some of these white marbles may have been decorated or painted at one time but that the decorations wore off.

Three ceramic marbles have a white paste, painted decoration, and no glaze. All were found in the Kitchen. One is decorated with a blue swirl, one with dark concentric and crossing circles, and the third with red and blue concentric and crossing circles. One glazed ceramic marble with a mottled blue and white design was excavated from the Dining Room. This type is called a "Line Crockery" or a "Jasper" (Grist 1993:40).

\section{Agate}

Agates were made out of stones (agate, carnelian, marble, onyx, and tiger-eyes) that were chipped and shaped against a grinder. These spheres have minute facets; in general, the older the agate, the more noticeable the facets. Agates without facets are newer and machine made (Grist 1993:6-7). Confusing the issue are reproductions made from glass to resemble agate marbles. It can be difficult to distinguish between machine-made glass marbles and modern machine-ground agates. Many of the later mechanized companies even incorporated the word "Agate" into their title. For instance, two of the biggest makers of machine-made glass marbles were the Akro Agate Company and the Christensen Agate Company (Grist 1993).

Only one true agate marble was found. This "aggie" is from the Dining Room. It has a dark milky appearance with orange-brown inclusions and small white marks. Facets can be seen on the surface where the shaping of the stone took place.

\section{Glass}

By 1846 , glass marbles were commonly produced in Germany, and they continue to be made in 
many countries today (Randall 1979:7). Handmade marbles were primarily imported from Germany, but they were also produced in the United States from 1880 to 1882 and 1897 to 1902 (Randall 1979:15). The oldest handmade marbles have two pontil marks, while, according to Grist (1993), during the "transition period" of $1880-1915$ when the machinery to produce marbles was being perfected, handmade marbles had a single pontil. All of the early types of marbles, including handmade glass and clay, began to disappear from stores after World War I, being replaced by the less expensive machine-made glass marbles. By the mid to late 1930s, machinemade glass marbles were the only type sold in any quantity (Randall 1979:18).

The most common handmade glass marbles are those with a translucent swirled center and a transparent body. These swirls can be of several colors, styles, and combinations, and often an outer swirl of thinner glass threads or ribbons adds to the decoration. The inner core can be a lattice, ribbon, divided, or solid core (twisted). Because the patterns used to decorate glass marbles prior to the twentieth century did not change over time, decoration type and color are of little utility in dating glass marbles of this period (Randall 1979:1). Styles changed after the turn of the century with the advent of the marble-making machine. Twentieth-century machine-made glass marbles are more variable over time with certain styles.

Four handmade glass marbles were excavated from the Dining Room. These include two marbles large enough to definitely be called shooters (both 1 inch or larger in diameter). Five handmade glass marbles were excavated from the Kitchen; all are under 1 inch in diameter. All of the handmade glass marbles are highly patinated, and the interiors of most are difficult to determine. Of those that can be seen, the interior decoration is a swirl design of some type. There are no solid-colored handmade marbles. All specimens have two pontil marks. Another marble from the Dining Room, possibly handmade, looks like a "Slag" (also called "Horizontal Swirl"), believed to be among the first Americanmade glass marbles (Grist 1993:34). It does not have a pontil mark, but rather, the glass appears to have been folded over at either end.

Seven machine-made glass marbles found in the Dining Room can be classified as "Patched Translucent." They have a clear body into which have been mixed translucent colors of glass, resulting in a marble with patches of translucent glass. Three have white patches, one has a brown patch, and three have both green and white patches. Two machine-made glass marbles found in the Dining Room can be classified as "Opaque Swirls." Opaque Swirls are made when two or more opaque colors of glass are swirled together in one marble. Both have a white glass body; one has a blue swirl, and the other has an orange swirl. One machinemade glass marble found in the Dining Room is made of black glass which has a patina swirl. Another machine-made glass marble, also found in the Dining Room, has the more modern "Cat's Eye" design; the glass is pale blue while the swirl appears to be white.

Six glass marbles are so patinated that their method of manufacture is not determinable. It is likely that all were handmade since none of the machine-made marbles at Sebastopol are patinated but the handmade ones are.

\section{Tea Sets}

A miniature saucer, cup, and lid were found in the Kitchen (Figure 123a). All of these pieces are made of porcelain and are white. With the exception of molding on the lid and cup, no decoration is present. These molded pieces appear to simulate the type of molding popular on ironstone, and they are similar to an advertised set in the 1902 Sears catalog (Sears, Roebuck and Co. 1902:913).

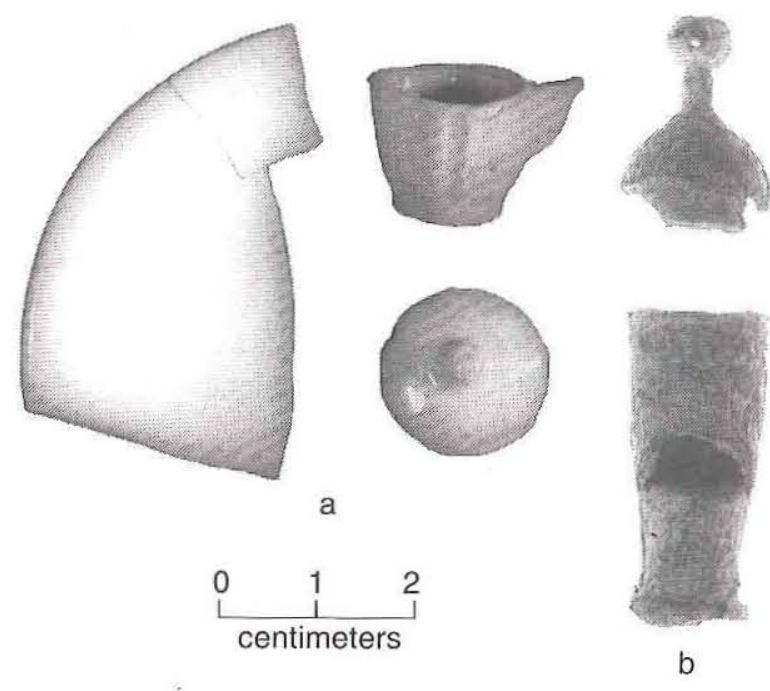

Figure 123. Toys. (a) Tea set pieces; $(b)$ tin whistle parts. 


\section{Tin Whistle}

The mouth piece and cap from a tin whistle were found in the Kitchen (Figure 123b). They are made of white metal.

\section{Wheels}

Three toy wheels, one white metal $(2.5 \mathrm{~cm}$ in diameter) and two ferrous ( 3.0 and $3.5 \mathrm{~cm}$ in diameter), were found in the Kitchen. Both of the ferrous wheels still have a shaft attached. All were molded.

\section{ACTIVITY GROUP, FARMING}

Seventy-six fragments of a curry comb were found in the Dining Room; this was an open comb made of ferrous metal. Nine fragments of leather tack were found in the Kitchen. Brass rivets and staples are on several straps of the leather. The type of tack has not been identified, but it could be a bridle or other similar item.

\section{ACTIVITY GROUP, TOBACCO RELATED}

Two articulating sherds of a gray-paste, earthenware pipe bowl were excavated, one from the Dining Room and one from the Kitchen. There are no identifying marks, but the $2.5-\mathrm{cm}$-diameter bowl had a raised ring just below the rim. No evidence of use is present.

\section{ACTIVITY GROUP, ALCOHOL}

\section{Beer Bottle}

Fifteen sherds of a modern amber-colored beer bottle were recovered from the Kitchen and Dining Room. On the shoulder of this bottle is the embossed phrase "NO DEPOSIT * NO RETURN." The bottle has a crown finish. The only sherd found in the Dining Room has "TO" embossed on it. This piece does not cross-mend with those from the Kitchen, but the color is consistent with the Kitchen sherds.

\section{Picnic Flasks}

The remains of two picnic flasks, which con- tained whiskey (Watson and Skrill 1971; Wilson 1981:15), were recovered from the Kitchen in 22 sherds. Each flask was mold blown in a two-piece cup-bottom mold. Both are made of colorless glass and are highly fragmented. One has an "A" embossed into its base, but this mark cannot be positively identified.

\section{Wine Bottle}

One glass sherd with an olive-colored champagne finish was excavated from the Dining Room. This type of finish was, and is, commonly used on wine or champagne bottles. Because of the thin glass, this piece is probably from a wine bottle, as the pressure from champagne required a stronger, thicker bottle.

\section{Other}

One down-tooled finish fragment made of amber-colored glass was found in the Dining Room. Wilson (1981:11) defines this as a "beer finish." Due to its shape, size, and color, it is likely that this was from an alcohol bottle, possibly beer.

\section{BONE GROUP}

Two human adult teeth were found in the excavations at Sebastopol. One lateral lower right incisor was excavated from the center of the Kitchen. It has a lingual caries which extended approximately one-third of the way up the root. It is believed that the buccal side of the enamel was broken off (Brian Shaffer, personal communication 1996). The lingual surface has a small caries at the neck of the tooth (gum line). The other tooth is a first right lower premolar with a lingual caries, which affected the enamel more than the root and would be classified as grade 2 caries (Lukacs 1989:267). A buildup of dental calculus is present on this premolar. This tooth was found in unit 5-6, near the door to the Dining Room. Because the pulp cavity is exposed on both teeth, either one may have caused an abscess or infection, but it is not possible to make this determination without the related mandible or maxilla. Both teeth are adult, but neither has a great deal of wear, indicating that the individual or individuals were not elderly.

Finding these teeth in the Kitchen suggests their extraction through home dentistry. The presence of 
the caries on the flat surfaces of the teeth, areas that were easy to clean, indicates that preventative dentistry was probably not a priority and that regular visits to the dentist were not common.

\section{UTILITIES GROUP, ELECTRICAL}

The city of Seguin granted the right-of-way for an electrical plant in 1893 and purchased the plant in 1907 (TPWD 1983:II:20). All electrically related artifacts found in the house, with the possible exception of the batteries, should postdate 1893 .

\section{Battery Components}

What appear to be one post and one end plate from a battery were found in the Kitchen (Figure $124 a)$.

\section{Connectors}

Two electrodes with connecting wires still attached were found in the Dining Room. One cuprous crimp, presumed to be an electrical connector, was also found in the Dining Room. Two brackets to connect a wire to an electrode were found in the Kitchen. The remains of what appears to be a ferrous electrical connector were found in the Dining Room fill.

\section{Graphite Electrode for an Arc Lamp}

One small (1.5 cm long) piece of what appears to be burned graphite was recovered from the

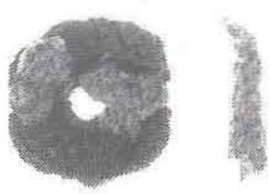

a
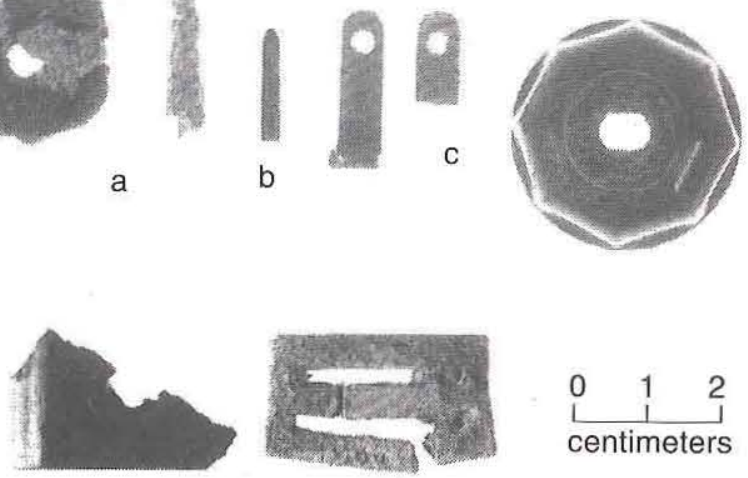

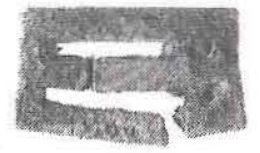

e d

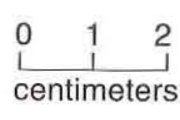

Figure 124. Electrical components. (a) Battery cap and post; (b) graphite electrode for an arc lamp; (c) electrical plug parts; $(d-e)$ possible electrical artifacts (unidentified).
Dining Room (Figure 124b). This is smaller, but is the same shape as a graphite electrode for an arc lamp shown in Woodhead et. al. (1984:81). There were a few small models of the arc lamp used in the early twentieth century, but the incandescent bulb was preferred for lighting homes (Woodhead et. al. 1984:76).

\section{Insulators}

A minimum of five glazed cylindrical insulators with a height of $3.5 \mathrm{~cm}$ and a diameter of $2.6 \mathrm{~cm}$ were found in eight sherds in the Dining Room and Kitchen. Two have an embossed " $F$ " on the interior (Figure 125a). This mark was used by the Findlay Electric Porcelain Co., Findlay, Ohio (Lehner 1988:583). At least two of these insulators from the Kitchen have black and cream-colored paint on them, indicating decor changes. One fragment of a glazed cylindrical insulator with a diameter of about $3.75 \mathrm{~cm}$ was excavated from the Dining Room. This fragment has part of a mark starting with a "D" (Figure 125b). The mark has a small portion of another symbol on the bottom, which looks like it could be "\&." This insulator may have been made by Davidson \& Stevenson Porcelain Co., East Liverpool, Ohio (Lehner 1988:583).

Two sherds of a different style of insulator were excavated from the Dining Room. This unglazed style had an oblong shape with pointed ends and holes near each end through which the insulator would have been fastened. It appears that two insulators of this style would have been used back to back, since two half-cylinder holes at the ends of the back of the insulator look like the perforations through which the wires would have run (Figure 125c). The large insulator fragment is embossed with "MACOMB," meaning that it was made by the Illinois Electric Porcelain Co., Macomb, Illinois (Lehner 1988:585).

\section{Light Bulb Parts}

What appears to be the aluminum base of a light bulb was excavated from Room 7.

\section{Plug Components}

Two cuprous tines from an electrical plug were found in the Dining Room; a 

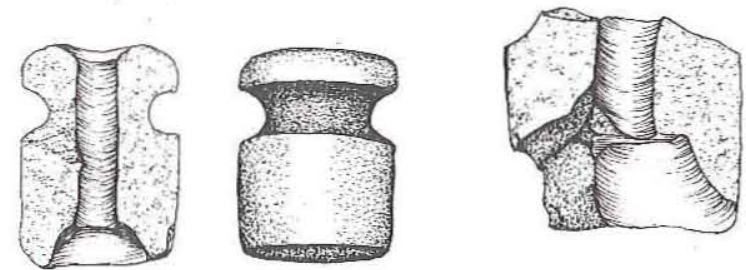

a
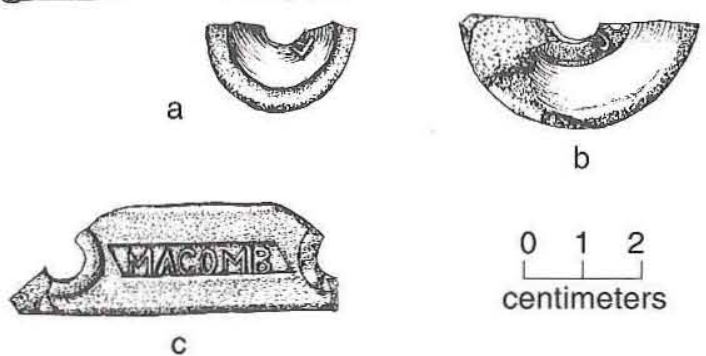

Figure 125. Electrical insulators. (a) Findlay Electric Porcelain Co., Findlay, Ohio; (b) possibly made by Davidson \& Stevenson Porcelain Co., East Liverpool, Ohio; (c) Illinois Electric Porcelain Co., Macomḅ, Illinois.

Bakelite plug casing was excavated from the Dining Room (Figure 124c).

\section{Wire Insulation}

Four pieces of plastic wire insulation are from the Dining Room. One piece has "HATFIELD" written on it.

\section{Other Electrical}

One unidentified Bakelite object, which has the appearance of an electrical insulator or possibly a plug part, was found in the Dining Room (Figure 124d). This piece has "MADE IN U.S.A." embossed on it. One unidentified lead object may be an electrical component of some sort (Figure 124e) or may have served some other function.

\section{UTILITIES GROUP, PLUMIBING}

The Seguin Water and Ice Company was established in 1886 as the city's water works system (TPWD 1983:II:20). Any plumbing fixtures or plumbing-related hardware is apt to postdate 1886 . Prior to this date, the cistern probably was the water supply for the house. It is not known if a pump was plumbed into the house from the cistern.

\section{Escutcheon}

One modern aluminum escutcheon was exca-

vated from the Dining Room. It would have been used on a bath fixture such as a shower head or handle (Figure 126a).

\section{Handle}

One brass tee handle from a square-headed faucet came from the Kitchen (Figure 126b).

\section{Hose Coupling}

One brass female hose coupling was found in the Dining Room (Figure 126c).

\section{Other}

One artifact that appears to be part of a valve came from the Kitchen.

\section{OTHER GROUP, MISCELLANEOUS}

This "Miscellaneous" class includes those artifacts that have been identified but that could fit into a number of groups. Unidentified artifacts are discussed under a separate heading following this section.

\section{Aluminum}

One piece of aluminum edging was found in Room 7. Two fragments of aluminum bottle seals which would have held caps in place were found in the Kitchen.

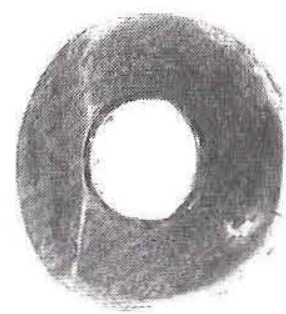

a

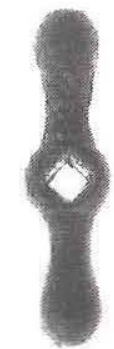

b

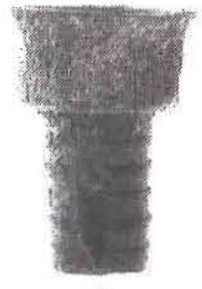

C

$$
\begin{array}{lll}
0 & 1 & 2 \\
& 1 & \rfloor \\
\text { centimeters }
\end{array}
$$

Figure 126. Plumbing-related artifacts. (a) Escutcheon; (b) tee handle; (c) female hose coupling. 


\section{Bottle Caps}

Seventeen crown caps are represented by 24 fragments, 2 of which were found in the Dining Room. The others were found in the Kitchen. All are made of ferrous metal. The crown cap was patented in the United States in 1892 by William Painter. This type of bottle cap "proved to be the ideal single-use closure for carbonated beverages" (Jones and Sullivan 1989:163).

An internal disk of natural cork was found in only one of the crown caps from the Kitchen; this cap is likely the oldest in the collection (Bender 1986:24; Jones and Sullivan 1989:163). One composition-cork crown cap liner was found in the Kitchen, and one cap was found in the Dining Room with a composition cork liner still in place; these postdate 1908 (Bender 1986:24). Two caps are lined with aluminum foil disks, and another is lined with a cardboard and aluminum liner. Spot liners of aluminum were used after 1916 (Bender 1986:24). Four others are lined with an unidentified substance. A lone foil cap liner was also found in the Kitchen.

Crown caps were initially made with 20 to 22 corrugations. In the $1920 \mathrm{~s}$, the system became standardized with 21 (Bender 1986:24). Of all of the caps found at Sebastopol, on only one are the corrugations countable; the rest are too corroded. On this one cap, there are 21 corrugations, making the dating of the cap impossible from this attribute. The height of crown caps changed in 1956 from an average of .263 inch to .228 inch (Bender 1986:25). At Sebastopol, the caps are too corroded to measure with this kind of accuracy, but there is a tendency for the caps to divide into one or two size categories, one that groups around .345 inch and the other that groups around .300 inch. The cap with the natural cork liner is in the taller group.

Two screw-on ferrous metal caps were found in the Kitchen. These caps are 2.75 and $1.75 \mathrm{~cm}$ in diameter. Three other ferrous metal caps, one a slip-on lid of $3.75 \mathrm{~cm}$ diameter and two too corroded to determine the type of fastener, were also found in the Kitchen.

\section{Bottles}

The bottles included here are those that could be positively identified as bottle glass but for which the shape and/or function of the bottle could not be positively identified. This class includes bottles with no embossing, bottles with shapes used for many different liquids, unidentified bottles, and glass sherds that do not indicate the precise shape of the bottle.

One particular bottle shape was found more often than any other in the Sebastopol deposits. This style is a paneled bottle with a patent lip and ball neck (Figure 127a) and a body cross section that is rectangular with flat chamfers. All bottles of this type at Sebastopol were made of colorless glass. Three sizes of this bottle were found. The largest is $14.8 \mathrm{~cm}$ tall, $5.0 \mathrm{~cm}$ wide, and $2.8 \mathrm{~cm}$ deep from front to back. Three of these large bottles are represented by two complete bottles and one neck and finish. The middle size of this bottle style is $13.5 \mathrm{~cm}$ tall, $4.6 \mathrm{~cm}$ wide, and $2.5 \mathrm{~cm}$ deep; only one bottle of this size was found. The smallest size of this style is $11.4 \mathrm{~cm}$ tall, $4.0 \mathrm{~cm}$ wide, and $2.1 \mathrm{~cm}$ deep. Three of this size are represented by one complete bottle and two broken bodies. One of these bodies has an embossed design on the front and side panels (Figure 127b). All of these bottles were mold blown in a three-piece cup-bottom mold and have applied finishes, dating the bottles from sometime after 1850 to the early twentieth century (Jones and Sullivan 1989:28, 39). This bottle style is known to have contained hair tonic restorer (Sears, Roebuck and Co. 1902:460), dentifrice (Wilson 1981:80), prescriptions (Munsey 1970:179), and sewing machine oil (see Activities Group, Sewing).

Two bottles, square in cross section and with prescription finishes, were found in the Kitchen (Figure 127c). One bottle, found in nine sherds, stands $10.7 \mathrm{~cm}$ tall and is $3.5 \mathrm{~cm}$ square; the other bottle stands $8.6 \mathrm{~cm}$ tall and is $2.8 \mathrm{~cm}$ square. The corners are chamfered, and the vessels are made of colorless glass. These bottles were mold blown in three-piece cup-bottom molds and had hand-applied finishes. This shape of bottle is known to have contained medicine (Wilson 1981:51), shoe dressing (Wilson 1981:93), and dandruff tonic and hair dressing (Sears, Roebuck and Co. 1902:462).

A small paneled bottle with a patent lip was found in eight fragments in the Kitchen (Figure $127 d$ ). Its contents are unknown. The bottle stood over $8 \mathrm{~cm}$ tall with a width of approximately $3 \mathrm{~cm}$ and a depth of about $1.7 \mathrm{~cm}$; the base is not present. This bottle has mold seams which continue part-way up the neck and a finish which was applied by hand with a finishing tool. 

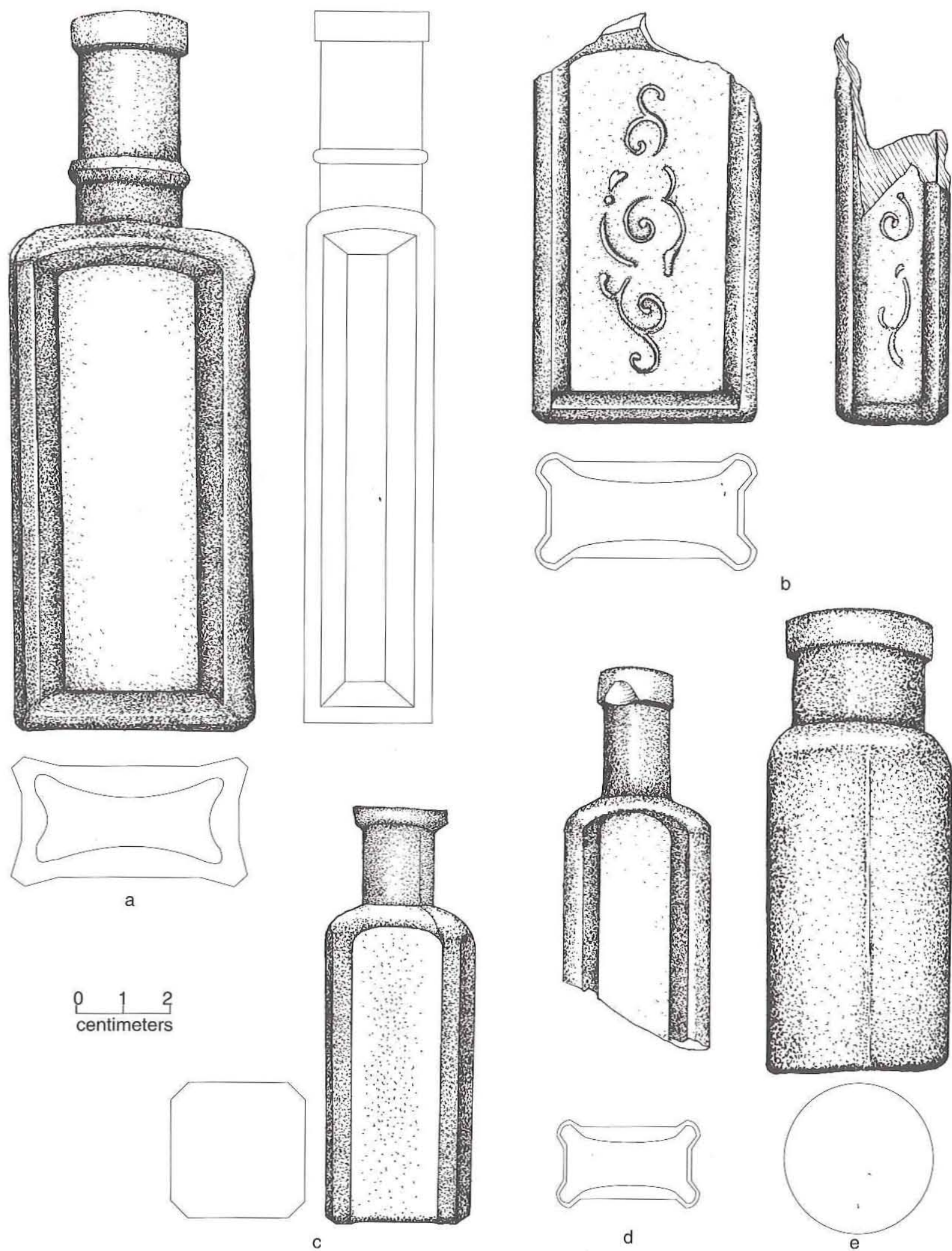

Figure 127. Miscellaneous bottles. (a) Paneled bottle with patent lip and ball neck; $(b)$ design embossed on small paneled bottle; $(c)$ square bottle with prescription finish; $(d)$ small paneled bottle; $(e)$ unidentified bottle. 
The bottom half of a bottle with a Philadelphia oval cross section was excavated from the Kitchen in 11 fragments. It was mold blown in a threepiece cup-bottom mold and was made of colorless glass. This bottle was approximately $6.5 \mathrm{~cm}$ wide and $3.5 \mathrm{~cm}$ from front to back.

The bottom half of a bottle was found in four fragments in the Kitchen. It has a cross section that is rectangular with flat chamfers and one rounded side. This bottle was mold blown in a three-piece post-bottom mold and was made of colorless glass. This vessel is approximately $4.2 \mathrm{~cm}$ wide and $2.7 \mathrm{~cm}$ front to back. The base is embossed with "McC." "McC" was a mark used by William McCully of Pittsburgh, Pennsylvania, from 1832 to ca. 1886 (Toulouse 1971:351).

A body sherd from a bottle was found in the Dining Room. This bottle was round in cross section and had a panel molded into its side. The bottle was made of colorless glass in a three-piece cup-bottom mold and is $3.2 \mathrm{~cm}$ in diameter.

A complete bottle was found in the Kitchen. It is round in cross section with a wide mouth, short neck, and patent lip (Figure 127e). The bottle is made of pale blue glass, stands $7.4 \mathrm{~cm}$ tall, and has a diameter of $3.2 \mathrm{~cm}$.

A neck and finish were found in the Kitchen. The neck is $3.5 \mathrm{~cm}$ long, and the finish is what Jones and Sullivan (1989:92) define as "flattened side." This style of finish is seen on many different products including olive oil (Watson and Dwyer 1977:248), bluing (Wilson 1981:91), sauce (Wilson 1981:84), toilet water (Wilson 1981:71), and medicines (Wilson 1981:54).

A small bottle base fragment made of light blue glass with a pontil mark was found in the Kitchen (Figure 128). The pontil mark and the uneven nature of the bottle shape indicate that this bottle was mouth blown.

A small bottle with a threaded finish was found in the Kitchen (Figure 129). The bottle is round in cross section and has a wide mouth. Standing $5.2 \mathrm{~cm}$ tall, this bottle has a body diameter of $3.5 \mathrm{~cm}$ and a bore diameter of $2.2 \mathrm{~cm}$. On its base is embossed " 841 " over " 1. ." Three threads are present on the finish, but the body mold seams do not extend onto the finish. It is unclear how the finish was made, but the rest of the body appears to have been hand blown into a three-piece cup-bottom mold.

Four bottle body fragments with vertical lines

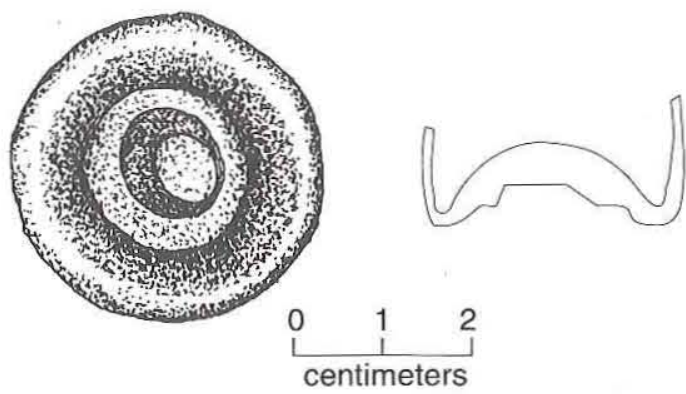

Figure 128. Mouth-blown bottle base showing pontil mark.

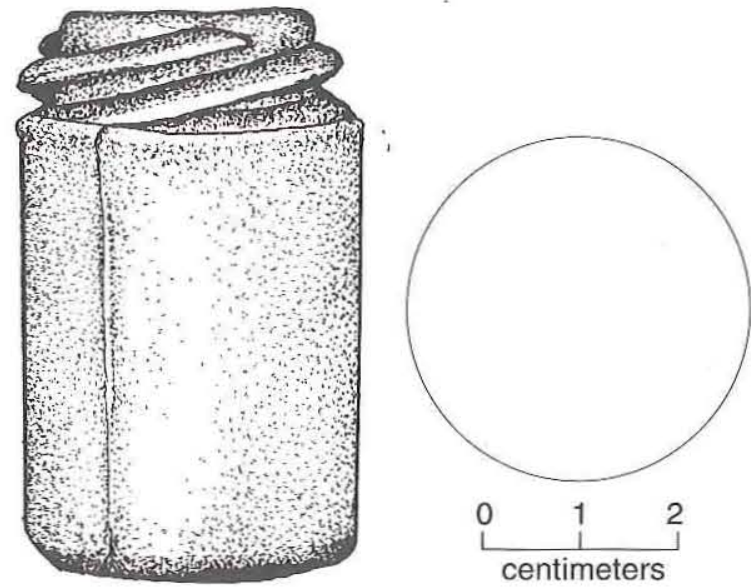

Figure 129. Threaded-finish bottle.

running in a stripe around the body were found in the Dining Room. This bottle was made of colorless glass and was paneled. Mold seams are visible on at least one of these body sherds, but bottle shape cannot be determined. A base sherd found in the Kitchen looks like it may be from a similar bottle. It has the same vertical lines running around the body at the base, and an Owen's scar is visible on the base. The Owen's automated machine was developed in 1903 and was used until the late 1940s (Jones and Sullivan 1989:39). Another basal sherd with an Owen's scar and a body sherd were found in the Dining Room. A bottle body sherd from the Kitchen shows a distinct "ghost seam," a seam that indicates machine manufacture. One basal sherd shows the seam of a two-piece mold. This bottle was round in cross section with a diameter of about $6 \mathrm{~cm}$. The glass is pale green.

A bottle shoulder sherd from the Kitchen is 
made of pale green glass and has the characteristic mold seams of a three-piece Rickett's-style mold. The Rickett's mold created the body in a one-piece mold and the shoulder and neck in two other parts. The seams from this mold include a seam running lengthwise around the shoulder and two seams running up the neck from the shoulder seam on opposite sides of the bottle. This style of mold was used from the 1820 s to the late nineteenth century, although use in some smaller bottle types continued into the 1920s (Jones and Sullivan 1989:30). The sherd found at this site is of the size to suggest a larger, pre-twentieth-century bottle. Two other bottle shoulder sherds were found in the Kitchen.

One piece of milk glass is from the Dining Room. This piece appears to be a basal sherd from a jar, likely a toiletry or cosmetic bottle. One bottle finish, made of dark green glass and with a rounded lip, was found in the Kitchen. This type of top can be found on alcohol or soda bottles.

Twenty-one other bottle body sherds (11 colorless and 10 aqua) were excavated from the Kitchen, and two aqua-colored sherds came from the Dining Room. The shapes of the bottles, beyond flat or curved, could not be determined.

\section{Brass Bells}

A minimum of four round brass bells was recovered. Three were found in the Dining Room, and one in the Kitchen. These bells are approximately $1.3 \mathrm{~cm}$ in diameter and $1.1 \mathrm{~cm}$ tall and were made in two parts which were crimped together.

\section{Brass Caps}

Three conical brass caps were found in the Kitchen. These caps would have been mounted onto rods of some sort. One of the caps has a flared rim with a hole through which a nail would have secured it.

\section{Bushing}

One threaded lead bushing was found in the Dining Room fireplace. Its inner diameter is $1.3 \mathrm{~cm}$.

\section{Caps}

Three ferrous metal objects that look like caps with a rounded top were found in the Kitchen.

\section{Chain}

Seven fragments of a brass chain were excavated from the Kitchen.

\section{Christmas Ornament Hanger}

A brass hanger from a Christmas ornament was found in the Kitchen. The plate is $1.7 \mathrm{~cm}$ in diameter.

\section{Colored Eggshells}

Twenty-one fragments of colored eggshell were found in the Kitchen. These are likely from the Easter tradition of coloring eggs. These eggshells suggest a Christian household which celebrated Easter with their children, which supports the oral traditions of the family.

\section{Corks}

Cork has been used as a sealing material at least since the sixteenth or seventeenth century (Jones and Sullivan 1989:149). One cylindrical cork which had been removed with a corkscrew, probably from a wine bottle, was excavated from the Dining Room. Four wide, flat corks (three from the Kitchen and one from the Dining Room) were found, the largest having a diameter of $3.25 \mathrm{~cm}$. These would have been used to seal large-mouthed vessels such as pickle or mustard bottles.

Eight tapered corks, likely used to seal pharmaceutical or condiment bottles, were excavated. Five of these were found in the Kitchen, two were found in the Dining Room, and one is of unknown provenience. One of these tapered corks is extremely small, being $4 \times 4 \mathrm{~mm}$. The largest tapered cork is $2.5 \times 2.1 \mathrm{~cm}$. The shapes of six cork fragments are not recognizable.

\section{Cotter Pins}

Two cuprous cotter pins were excavated from the Kitchen.

\section{Ferrule}

A ferrule is a "ring put around the end of a post, cane, etc., to prevent splitting" (Random House 1978:330). Two brass ferrules were excavated in 
the Kitchen. One is a short cylinder $(1 \mathrm{~cm}$ long and $1.4 \mathrm{~cm}$ in diameter), open at one end with an oblong hole in the other. The other ferrule $(1.2 \mathrm{~cm}$ long and $1.7 \mathrm{~cm}$ in diameter) is open at one end and at the other end has an inner-rolled rim.

\section{Ferrous Strapping}

Nine fragments of ferrous strapping were recovered.

\section{Ferrous Tubing}

Two fragments of ferrous pipe or tubing were excavated from the Dining Room, and one was found in the Kitchen. The two fragments from the Dining Room have a diameter of around $1.8 \mathrm{~cm}$; the one from the Kitchen is smaller, with a diameter of $1.0 \mathrm{~cm}$

\section{Glass Stoppers}

Three stoppers made of glass were excavated from the Kitchen. One has the finial, which is decorated with elevated irregular circles and has a ridge running along the top; the shank is ground and unthreaded. At the shank's widest point, the diameter is $9 \mathrm{~mm}$. The finial from the second stopper has broken off, but the shank is threaded and ground. The third stopper is missing its finial and has an unground, unthreaded shank.

\section{Miniature Golf Club}

One miniature bone golf club, $10.2 \mathrm{~cm}$ long, was found in the Kitchen. It is broken off at the handle, but looks like it was part of a trophy or a similar item. On one side of the shaft is embossed "ON THE LINKS"; the other side reads "E. DUPONT \& Co" (Figure 130a).

\section{Grommet}

One cuprous grommet was found in the Dining Room. It has an inner diameter of $0.9 \mathrm{~cm}$.

\section{Hook}

One brass hook was found in the Kitchen. It is $5.0 \mathrm{~cm}$ long and has two rivets which would have attached it to another object. The hook is slightly

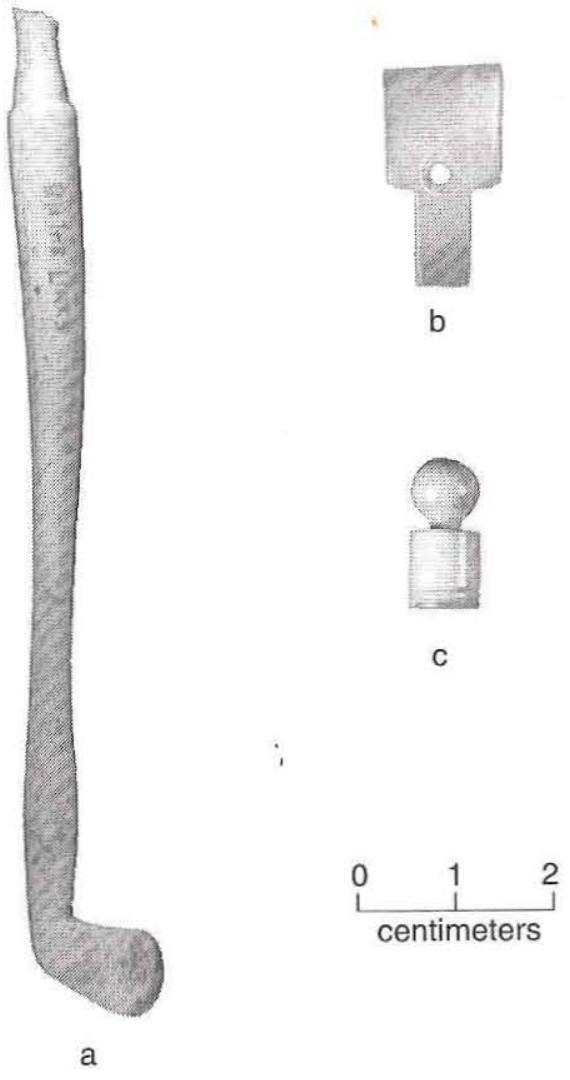

Figure 130. Miscellaneous. (a) Miniature bone golf club; $(b)$ shell inlay; $(c)$ wooden cap.

lopsided and looks like it may have been made from another object.

\section{Rivets and Burrs}

Three rivets and two burrs were found in the Kitchen and Dining Room. All are brass. The rivets are small, all being around $0.75 \mathrm{~cm}$ long, and the burrs are both less than $1 \mathrm{~cm}$ in diameter.

\section{Rubber Stopper}

One rubber stopper was excavated from the Kitchen. It is tapered with a length of $2.75 \mathrm{~cm}$ and a diameter of $1.25 \mathrm{~cm}$ at its top.

\section{Rubber Tubing}

Two pieces of rubber tube were found in the Kitchen, and one came from the Dining Room. One of the pieces from the Kitchen is hardened and fragile, the other is still soft and resembles wire 
insulation, particularly since it has been split from end to end. Both the hard rubber tube and the soft one are about $0.7 \mathrm{~cm}$ in diameter. The piece of rubber from the Dining Room is oval in cross section with a width of $0.4 \mathrm{~cm}$, a depth of $0.2 \mathrm{~cm}$, and a length of $5.5 \mathrm{~cm}$. This piece of tubing could also have been some sort of wire insulation.

\section{Seals for Bottles}

A lead seal with a lion embossed on it was found in the Kitchen. The maker of the product is not readable, but the words "OXFORD" and "LONDON" are clearly visible. This seal is corroded and very fragile. Another lead seal from the Dining Room has writing on it. The writing is not complete, but what is visible is ". . . R N.Y. U.S.A." with stars following the letters, indicating an American source, possibly New York. A thick lead bottle seal, which may have been the top of a cork, is embossed with ". . . RODS POWDER." This seal was found in the Dining Room. A seal with an incised pull-tab was found in the Kitchen. This seal is aluminum and has no embossing. Six fragments of four lead foil seals were also excavated, five from the Kitchen and one from the Dining Room. An aluminum cap seal, the kind that would have wrapped around the mouth of a bottle to hold a stopper or seal in place, was found in two pieces in the Kitchen. This one appears to be from a milk bottle or other similarly shaped bottle.

\section{Shell Inlay}

One shell inlay was found in the Dining Room fireplace. The inlay has a hole drilled into it through which it would have been nailed (Figure $130 \mathrm{~b}$ ). This piece could have been applied to any number of objects to provide decoration. One side of the inlay is flat, the other is curved at the edges.

\section{Washers}

Three washers were excavated from the Kitchen and one from the Dining Room. Two are made of ferrous metal, one is of brass, and the fourth appears to be plated. The brass washer has a rim around the opening and appears to have had a cloth gasket.

\section{Wooden Cap}

One polished and carved wooden cap or finial was found in the Dining Room. This piece is shaped with a wooden cylinder under a wooden sphere (Figure 130c).

\section{Wooden Pins or Dowels}

One large wooden dowel was found in the Dining Room. It is broken, but was longer than $8.5 \mathrm{~cm}$. The shaft diameter is about $1.3 \mathrm{~cm}$, and the pointed head has a widest diameter of $1.8 \mathrm{~cm}$. Insects have eaten into this wood, leaving the piece fragile. This dowel could have been used in house or furniture construction. One smaller wooden dowel was found in the Kitchen. This is a plain straight dowel with no head. The length of this piece is $3 \mathrm{~cm}$, and the diameter is about $0.7 \mathrm{~cm}$. Two fragments of at least one wooden peg were found in the Dining Room. The shape of this peg is reminiscent of a horseshoe nail, with a large, oval head and a smaller shaft.

\section{OTHER GROUP, UNIDENTIFIED}

This class includes those artifacts that are potentially identifiable but that have not yet been identified. They are categorized by material.

\section{Ceramics}

Included here are ceramic sherds from unidentified vessels. These sherds are generally small, but because they have a specific decoration type diagnostic of the earlier occupations, they are described in this section. Others are over the $4 \mathrm{~cm}$ minimum size but are undecorated or are not vessel specific.

\section{Undecorated}

Nine white earthenware body sherds (seven of which cross-mend) were excavated from the Kitchen, and one came from the Dining Room. One undecorated white earthenware rim sherd was found in the Dining Room. This sherd appears to be from a large serving dish or platter. One large white earthenware handle fragment was found in Room 7. One sherd of gray-bodied earthenware was excavated from the Kitchen. This piece is unglazed and very porous. Two orange-bodied fragments were excavated from the Kitchen as well. This piece is very fine and may have been a lid or a small shallow dish. One sherd of earthenware with a partial maker's mark was excavated in the Kitchen. It 
appears to be from a flat-bottomed vessel. The mark is from W. S. George Pottery in Canonsburg, Pennsylvania, and dates ca. 1920 (DeBolt 1988:33).

Three undecorated porcelain sherds were excavated from the Kitchen. Two pieces are only slightly translucent and fluoresce under a black light. These may be early true ironstone. One sherd of molded porcelain from a hollowware vessel was found in the Kitchen. The pattern on this piece incorporates large molded leaves up the side of the vessel.

\section{Painted}

Two sherds of hard-paste porcelain were excavated: one in the Kitchen and one in the Dining Room. Both were painted underglaze in blue patterns. One is very small and thin, the other is thicker.

\section{Annular}

One body sherd from an annular vessel was found in the Kitchen. This piece had a white base color with at least two blue stripes. Two other annular sherds were excavated from the Kitchen. These small body sherds are decorated mostly in blue, but a small amount of brown can be seen on the tip of one.

\section{Sponge Stamped}

Two sherds with sponge-stamped red flowers were found, one in the Kitchen and the other in Room 7. This type of flower was quite common on sponge-stamped wares (Robacker and Robacker 1978:76, top photo). The piece found in Room 7 shows at least two green strips decorating the vessel.

\section{Molded and Glazed}

Fifteen sherds of a large majolica hollowware vessel were found in the Kitchen. The piece has a mustard-colored glaze on the exterior, with a basketweave molding (Figure 131). Just visible are long purple and green leaves hanging over the basket weave. The interior of the vessel is purple. A raised diamond-shaped registration mark is on the base of the vessel. No marks are visible within the registration mark. Registration marks of this shape were used in Great Britain between 1842 and 1883 (Godden 1991:526).
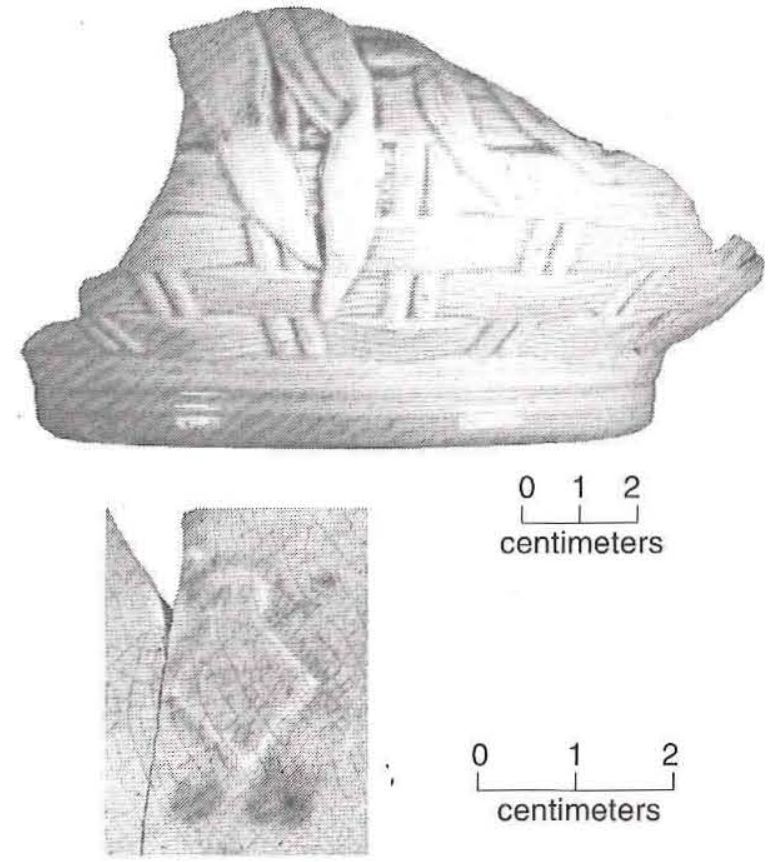

Figure 131. Majolica hollowware vessel and registration mark.

\section{Molded, Gilded, and Enameled}

One rim sherd from the Dining Room is molded around the rim and into the body. Gilding decorates the molding, and green enamel decorates the interior.

\section{Decaled}

A rim sherd from an earthenware bowl, saucer, or soup plate with a gold decal was found in the Kitchen. The decoration probably dates to the Art Nouveau period, ca. 1890 s to 1910 (Majewski 1994b). One sherd with a floral decal is encrusted with cement or plaster and cannot be identified. This piece is from the Kitchen.

\section{Luster}

One piece of luster-decorated red earthenware was excavated from the Dining Room. This piece has a blue slip, which reaches up to within $1.3 \mathrm{~cm}$ of the rim on the exterior, and a white slip extending to the rim on the interior. The gold luster was applied over both the blue and white slips, down $5 \mathrm{~mm}$ from the rim on the inside, and in an unrecognizable pattern on the exterior. 


\section{Transfer Printed and Luster}

Three cross-mending sherds from the Dining Room, are printed in teal green, orange, and salmon. The small portion of the design present includes double bands bordering an Art Nouveau-style floral motif and a band of fine vertical lines above stylized four-petaled rosettes.

\section{Cuprous Metal}

A cuprous object, possibly a spoke nipple for a bicycle, was found in the Kitchen. It is small and cylindrical with a small threaded projection coming out one end and a threaded socket in the other.

Six cuprous metal rings were recovered: three from the Kitchen, two from the Dining Room, and one from Room 7. One cuprous object shaped like a "C," which looks like a baby's bracelet, was found in the Kitchen. A cuprous artifact that looks like the handle from a toy pail was found in Room 7. A small cuprous clip of unknown function was found in the Kitchen. A cuprous object looking like one half of a very small handle and shaped somewhat like a question mark was found in the Kitchen. Three other cuprous objects that should be identifiable but that have not been located in the literature were also found.

\section{Felt}

Five unidentified felt fragments were found in the Dining Room, and one was found in the Kitchen.

\section{Ferrous Metal}

Ferrous metal items from Sebastopol are very corroded and in most cases unidentifiable to form or function. Twenty cast iron fragments may have been stove parts, but due to their condition are not identifiable. Two iron disks, both with a diameter of around $3.5 \mathrm{~cm}$, were found, one in the Kitchen and the other in the Dining Room. One barbed piece of ferrous metal was found in the Kitchen. Five fragments of flat narrow iron were found in the Kitchen. These look like strapping, but are too thick. One fragment has a cuprous piece attached to it. Thirteen other ferrous fragments were found: 10 in the Kitchen, 1 in Room 7, and 2 in the Dining Room; these pieces may be identifiable.

\section{Glass}

Glass is included in this section if it has an interesting characteristic such as shape or color, but is not identifiable to function.

One colorless glass fragment, which fluoresces yellow under ultraviolet light, was found in the Kitchen. This piece is round in cross section and has a hole in its center. This configuration suggests use as a knob.

A milk glass object was recovered from the Kitchen. This piece is egg shaped and has been damaged on one end where a post or other part may have broken off. This appears to have been a stopper for a cruet or possibly a knob from a lid.

Two colorless rim sherds were found in the Kitchen. This vessel appears to have been made with a cracked-off rim, indicating that it was not used as tableware since the edges are rough. The shape of the sherds do not indicate the shape of the vessel. Ten translucent blue glass sherds were recovered from the Kitchen. The object from which they came is not known. One pressed milk glass sherd was found in the Dining Room. Again, the shape of the sherd does not indicate the shape of the vessel from which it came. One milk glass sherd from a bottle neck or similar shape was found in the Dining Room. One translucent blue-purple glass sherd and one blue sherd from pressed-glass objects were found in the Kitchen. Three pieces of thin, blue glass were excavated, two from the Kitchen and one from Room 7. These pieces appear to be from light bulbs, lamp chimneys, or other such thinwalled objects. One glass fragment from what appears to be a glass tube was found in the Kitchen. The piece is made of colorless, thin glass. One glass rim sherd with pink flashing was found in the Kitchen. This piece is scalloped and may have come from a vase, spoon holder, or other such vessel. One aqua-colored rim sherd, possibly from a canning jar, was found in the Kitchen. One large colorless glass sherd from the Kitchen has pointed beads of glass on its border (either the rim or base). The vessel was round and had sloping sides. Eleven sherds of colorless glass from an oddly. shaped vessel were found in the Kitchen; this vessel resembles a large flattened doorknob with a rounded face opposing a face in which the glass emerges from the face. This vessel is not identified.

Two sherds of the Daisy and Button pattern were found in the Kitchen (Figure 132). The Daisy 


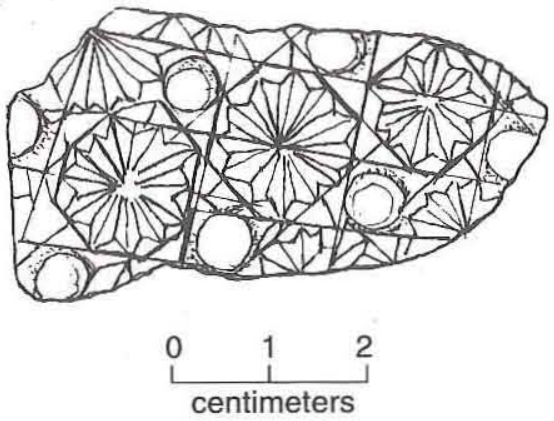

Figure 132. Pressed glass Daisy and Button pattern.

and Button pattern was one of the most popular pressed-glass patterns ever made. Daisy and Button was made as early as 1875 and was in continuous production for more than three decades (Jenks and Luna 1990:149; Jenks et al. 1993:74). Both pieces fluoresce yellow under ultraviolet light, possibly indicating uranium in the glass. The type of vessel represented by these sherds is not identifiable.

One pressed-glass rim sherd designed to imitate cut glass was found in the Kitchen. The edge of the vessel would have had a scalloped appearance.

Nine sherds of cut lead glass were found in the Kitchen. These fragments represent a minimum of two vessels. Three of the sherds represent two different patterns; the other six sherds could belong to either pattern but do not cross mend with either. The edges of these pieces would have had a scalloped and ruffled look. Both vessels are bowls or a similar type of vessel.

Three other glass objects were found in the Dining Room and the Kitchen. These are rounded disks with one curved side and one flat side (Figure 133). Two have an indentation in the center. These may have been glass heads of buttons called "Coronets," which have a glass body and a metal shank (Luscomb 1992:81).
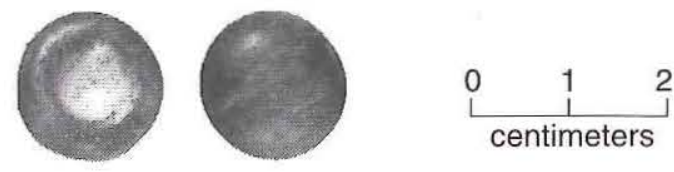

Figure 133. Unknown glass object, possible button body.

\section{Lead and Lead Alloys}

Four unidentified lead artifacts were found, one in the Dining Room and three in the Kitchen. One of these is circular with threads on its interior, one is a circle, one looks like a deteriorated grommet, and one is a solid rectangular object with three incised lines.

\section{Leather}

Twelve unidentified leather fragments were found in the Kitchen, and one came from the Dining Room. These are different from the shoe leather in that they have no sewing holes or recognizable shape.

\section{White Metal}

One white metal object was found in the Kitchen. It is shaped somewhat like a snowflake and has molded round depressions decorating it. Some of the depressions are colored pink (Figure 134). A disk of cardboard covered in white metal was found in the Kitchen.

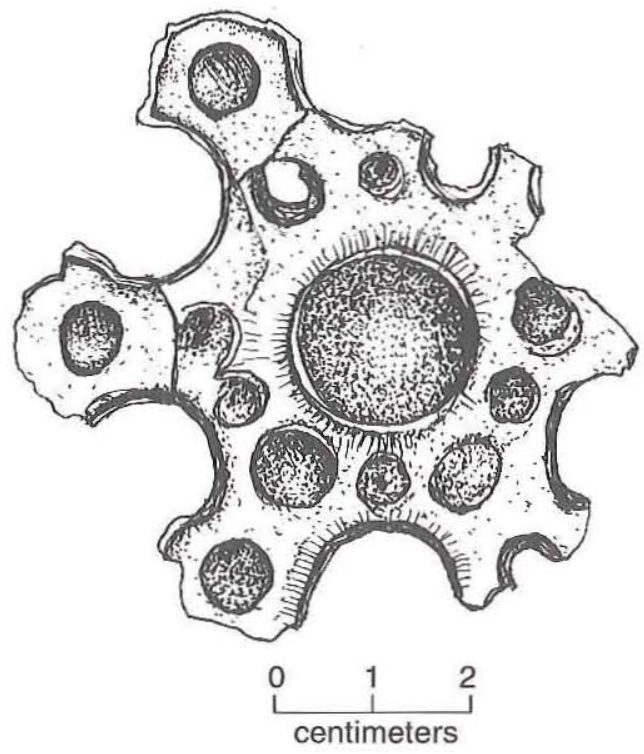

Figure 134. White metal artifact.

\section{Other}

One ring of unidentifiable material was found in the Dining Room. This ring was $0.4 \mathrm{~cm}$ thick and approximately $1.2 \mathrm{~cm}$ in diameter and had a hole in the center. The material is almost rubberlike. 


\section{SUMIMARY AND CONCLUSIONS}

This report was designed to summarize the nine excavation seasons at Sebastopol between 1978 and 1988 , to provide historical and architectural background for the site, and to analyze selected artifacts from the site. A primary objective, accomplished in Chapters 5 and 6 , is to provide a catalog of diagnostic artifacts found at the site and representative of artifacts available in Central Texas during the life span of the house. The artifact sample chosen for inclusion in the catalog consists of all pre-1910 ceramic sets found across the site as well as a selection of the most diagnostic artifact groups from the Dining Room, the Kitchen, and Room 7. The pre-1910 ceramic sets were chosen as most representative of the early Zorn period of the house (18741910) and also include the LeGette/Young period (1854-1874). The analyses of selected artifacts from the Dining Room, the Kitchen, and Room 7 provide insights into the activities in the house, these presumably being the most actively used and least disturbed rooms in the lower floor. Another objective of this report is to summarize the artifact data from all excavation areas across the site. These data, provided in Appendix A, will aid future researchers wishing to make intersite comparisons. Of 106,586 artifacts recovered by TPWD, 4,071 are discussed in this report.

\section{STATISTICAL SUMMARIES}

The following statistical summaries and comparisons only apply to those artifacts selected for study from the Dining Room, the Kitchen, and Room 7. The classification system used by TPWD was based on that created by Roderick Sprague (1981). Through several historical excavations and analyses, TPWD expanded on the system outlined by
Sprague and created a very detailed organization system for nineteenth- and twentieth-century historical artifacts. The report presented here was organized in a manner different than the TPWD classification (see Appendix A); and this necessitated the separation and regrouping of some artifacts for the two systems to be directly comparable. For example, in the TPWD classification, no alcohol bottles were identified separate from other bottle glass, while during the writing of this report, 39 fragments of alcohol bottles were analyzed. Also in this research, two human teeth were found and classified in the "bone" group. There is no category that accounted for these teeth in the TPWD classification. In summarizing the TPWD classification, the "other" group was used to absorb all unidentified artifacts as well as those that were not analyzed and those that did not fit easily into any other categories. This included the large group of faunal remains as well as smaller groups of artifacts such as candy wrappers, matchsticks, and washers, making this group very large. Aside from some problems such as these, the comparison provides the reader with an estimation of the percentage of each artifact group analyzed.

Of the 106,586 artifacts summarized in the TPWD classification, 41,065 (38.5 percent) were found in the Dining Room, the Kitchen, and Room 7. Exactly 3,592 of these were analyzed, constituting 8.7 percent of the assemblage from these rooms and 3.4 percent of the entire assemblage (Table 7). If artifacts classified as "other" and "architecture" are not considered, the number of artifacts found in the Dining Room, the Kitchen, and Room 7 is reduced to 10,085 , meaning that 35.6 percent of the assemblage was analyzed. Much of the unanalyzed part of the assemblage consists of materials such as 
TABLE 7

SUMMARY OF ARTIFACTS FROM THE KITCHEN, DINING ROOM, AND ROOM 7

\begin{tabular}{|c|c|c|c|}
\hline \multicolumn{2}{|c|}{ TPWD Classification } & \multicolumn{2}{|c|}{ This Analysis } \\
\hline Group and Class & No. of Artifacts & No. of Artifacts & Percent Analyzed \\
\hline $\begin{array}{l}\text { Food Group } \\
\text { 1. Storage } \\
\text { 2. Preparation } \\
\text { 3. Service } \\
\text { Subtotals: }\end{array}$ & $\begin{array}{r}- \\
- \\
6,507\end{array}$ & $\begin{array}{r}212 \\
20 \\
1,338 \\
1,570\end{array}$ & $\begin{array}{l}- \\
- \\
\overline{24.1}\end{array}$ \\
\hline $\begin{array}{l}\text { Furniture and Fixtures Group } \\
\text { 1. Furniture Hardware } \\
\text { 2. Lamps } \\
\text { 3. Fixtures } \\
\text { 4. Other } \\
\text { Subtotals: }\end{array}$ & $\begin{array}{r}1 \\
966 \\
46 \\
34 \\
1,047\end{array}$ & $\begin{array}{r}7 \\
46 \\
19 \\
7 \\
79\end{array}$ & $\begin{array}{l}- \\
- \\
- \\
- \\
7.5\end{array}$ \\
\hline $\begin{array}{l}\text { Personal Group } \\
\text { 1. Clothing } \\
\text { 2. Clothing Accessories } \\
\text { 3. Jewelry } \\
\text { 4. Toiletry } \\
\text { 5. School/Stationery Supplies } \\
\text { 6. Other } \\
\text { Subtotals: }\end{array}$ & $\begin{array}{r}575 \\
122 \\
36 \\
36 \\
231 \\
36 \\
1,036\end{array}$ & $\begin{array}{r}480 \\
109 \\
35 \\
39 \\
119 \\
\frac{28}{810}\end{array}$ & $\begin{array}{c}- \\
- \\
- \\
- \\
- \\
- \\
78.2\end{array}$ \\
\hline Pharmaceutical Bottles & 0 & 30 & N/A \\
\hline $\begin{array}{l}\text { Activity Group } \\
\text { 1. Sewing } \\
\text { 2. Guns and Ammunition } \\
\text { 3. Fishing } \\
\text { 4. Household } \\
\text { 5. Toys } \\
\text { 6. Farming } \\
\text { Subtotals: }\end{array}$ & $\begin{array}{r}1,045 \\
209 \\
2 \\
5 \\
105 \\
33 \\
1,399\end{array}$ & $\begin{array}{r}25 \\
195 \\
1 \\
16 \\
128 \\
87 \\
452\end{array}$ & $\begin{array}{l}- \\
- \\
- \\
- \\
- \\
- \\
32.3\end{array}$ \\
\hline $\begin{array}{l}\text { Recreation Group } \\
\text { 1. Tobacco } \\
\text { 2. Alcohol } \\
\text { Subtotals: }\end{array}$ & $\begin{array}{r}24 \\
\frac{0}{24}\end{array}$ & $\begin{array}{r}2 \\
\frac{39}{41}\end{array}$ & $\begin{array}{c}- \\
- \\
170.8\end{array}$ \\
\hline Bone & 0 & 2 & N/A \\
\hline $\begin{array}{l}\text { Utilities Group } \\
\text { 1. Electrical } \\
\text { 2. Plumbing } \\
\text { Subtotals: }\end{array}$ & $\begin{array}{r}68 \\
\frac{4}{72}\end{array}$ & $\begin{array}{r}29 \\
\frac{7}{36}\end{array}$ & $\begin{array}{c}- \\
- \\
50.0\end{array}$ \\
\hline $\begin{array}{l}\text { Other } \\
\text { 1. Miscellaneous } \\
\text { 2. Unidentified } \\
\text { Subtotals: }\end{array}$ & $\begin{array}{r}- \\
18,058\end{array}$ & $\begin{array}{l}359 \\
213 \\
572\end{array}$ & $\begin{array}{l}- \\
- \\
3.2\end{array}$ \\
\hline Architecture Group & 12,922 & - & 0 \\
\hline GRAND TOTALS: & 41,065 & 3,592 & 8.7 \\
\hline
\end{tabular}


unidentified glass sherds, undecorated lamp chimney glass, straight pins, and faunal remains.

By far the largest group of artifacts found in the Dining Room, the Kitchen, and Room 7 was the "food" group (see Table 7), with a total of 6,507 artifacts excavated. About one-quarter of these food-related artifacts $(n=1,570)$ are analyzed here; of this total, 535 artifacts are associated with ceramic sets. The percentage of analyzed food-related artifacts is low (24.1 percent) because in the TPWD classification all bottle glass was grouped together; thus, all alcohol, food, pharmaceutical, and unidentified glass which was not necessarily related to food was counted together. This is not comparable to the analysis conducted for this report where alcohol, pharmaceutical, and food bottles are separated into different groups. When collapsing the TPWD classification for comparisons, all of the unidentified glass had to be included in the "food" group since it was counted simply as "glass" in the kitchen group of the TPWD classification. The TPWD classification system allows for alcohol and pharmaceutical bottles to be counted separately, but these bottles were not identified in the original cataloging of the artifacts. In the present classification system, miscellaneous bottle glass was not analyzed unless it was of a certain size, and then, if it could not be identified to use, it was included in the "other" group.

The next largest group of analyzed artifacts is the "personal" group. A total of 1,036 "personal" items were excavated from the three rooms, and 810 (78.2 percent) are analyzed here. The size of this group is due partly to the number of buttons found at the site. Of the 810 artifacts analyzed from this group, 589 are clothing or clothing accessories. Over 300 of these are buttons. This large number of buttons suggests that something other than normal household activities related to buttons, such as sewing or mending clothes for profit, occurred in the finished lower-floor rooms. It has been rumored that two of the Zorn sisters sewed for a department store (Brandimarte 1986:20). Although there is no oral documentation of where this work occurred, the large number of buttons may indicate that these activities were carried out in the house.

The third largest group (excluding the "other" group) analyzed is the "activity" group, with gunrelated artifacts and toys being most frequent. In total, 452 activity-related artifacts are analyzed here out of 1,399 counted in the TPWD classification
(32.3 percent). Nearly all of the unanalyzed materials are straight pins, 962 of which are listed in the TPWD classification. The guns and ammunition class totals 195 artifacts, containing 135 pieces of lead shot and 21 percussion caps. The 128 toy fragments analyzed in this report represent the many children who lived in the house. Toys representative of both girls and boys are present. Porcelain dolls indicate a certain level of wealth, while only one agate marble indicates that the fanciest marbles were not bought. From the toys alone, one can estimate that the family was not poor, but they were not at the very top of the income scale either.

After the "activity" group, in order from largest to smallest, are the "furniture and fixture" group; the "recreation" group; the "utilities" group; the "pharmaceutical bottles" group; and the "bone" group. The analyzed "furniture and fixtures" group consists of 79 artifacts, representing 7.5 percent of the 1,047 artifacts recorded in the TPWD classification. Almost all of the unanalyzed materials are sherds of undecorated lamp chimney glass, with 914 sherds recorded by TPWD. Pharmaceutical bottles and alcohol bottles were included in the "kitchen" (food) group of the TPWD classification, and therefore the "pharmaceutical bottles" and "recreation" groups used in this analysis have no comparable categories in the TPWD classification. Fifty percent of the "utilities" artifacts found in the house are analyzed in this report.

\section{COMPARATIVE ROOM USE}

With the exception of the "utilities" and "activity" groups, all analyzed groups are larger for the Kitchen than for the Dining Room or Room 7 (Table 8). From the Kitchen, 2,646 artifacts are analyzed; 810 artifacts from the Dining Room are analyzed; and 89 artifacts are analyzed from Room 7. Because the artifacts most diagnostic of everyday activities were analyzed, rather than nondiagnostic and architectural materials, these totals generally indicate that more activities concerning these artifacts occurred in the Kitchen than in the other two rooms, or that the other rooms were cleaned out more than the Kitchen when renovations began. The latter explanation is less likely since there is evidence, in cross-mending sherds from the cistern, that the Kitchen was cleaned out at least to some extent.

The food group shows the largest discrepancy between the rooms, with 1,473 artifacts in the 
TABLE 8

DISTRIBUTION OF ARTIFACTS IN THE KITCHEN, DINING ROOM, AND ROOM 7

\begin{tabular}{|c|c|c|c|c|c|}
\hline Group and Class & Kitchen & Dining Room & Room 7 & Unknown* & Totals \\
\hline $\begin{array}{l}\text { Food Group } \\
\text { 1. Storage } \\
\text { 2. Preparation } \\
\text { 3. Service } \\
\text { Subtotals: }\end{array}$ & $\begin{array}{r}195 \\
19 \\
1,259 \\
1,473\end{array}$ & $\begin{array}{r}17 \\
1 \\
\frac{48}{66} \\
\end{array}$ & $\begin{array}{l}0 \\
0 \\
\frac{5}{5}\end{array}$ & $\begin{array}{r}0 \\
0 \\
\frac{26}{26} \\
\end{array}$ & $\begin{array}{r}212 \\
20 \\
1,338 \\
1,570\end{array}$ \\
\hline $\begin{array}{l}\text { Furniture and Fixtures Group } \\
\text { 1. Furniture Hardware } \\
\text { 2. Lamps } \\
\text { 3. Fixtures } \\
\text { 4. Other } \\
\text { Subtotals: }\end{array}$ & $\begin{array}{r}6 \\
45 \\
15 \\
3 \\
69\end{array}$ & $\begin{array}{r}1 \\
1 \\
4 \\
4 \\
10\end{array}$ & $\begin{array}{l}0 \\
0 \\
0 \\
\underline{0}\end{array}$ & $\begin{array}{l}0 \\
0 \\
0 \\
\underline{0} \\
0\end{array}$ & $\begin{array}{r}7 \\
46 \\
19 \\
7 \\
79\end{array}$ \\
\hline $\begin{array}{l}\text { Personal Group } \\
\text { 1. Clothing } \\
\text { 2. Clothing Accessories } \\
\text { 3. Jewelry } \\
\text { 4. Toiletry } \\
\text { 5. School/Stationery Supplies } \\
\text { 6. Other } \\
\text { Subtotals: }\end{array}$ & $\begin{array}{r}265 \\
10 \\
29 \\
18 \\
74 \\
\frac{25}{421}\end{array}$ & $\begin{array}{r}174 \\
97 \\
4 \\
17 \\
41 \\
\frac{3}{336}\end{array}$ & $\begin{array}{r}36 \\
2 \\
2 \\
3 \\
4 \\
\frac{0}{47}\end{array}$ & $\begin{array}{l}5 \\
0 \\
0 \\
1 \\
0 \\
\frac{0}{6}\end{array}$ & $\begin{array}{r}480 \\
109 \\
35 \\
39 \\
119 \\
28 \\
810\end{array}$ \\
\hline Pharmaceutical Bottles & 27 & 3 & 0 & 0 & 30 \\
\hline $\begin{array}{l}\text { Activity Group } \\
\text { 1. Sewing } \\
\text { 2. Guns and Ammunition } \\
\text { 3. Fishing } \\
\text { 4. Household } \\
\text { 5. Toys } \\
\text { 6. Farming } \\
\text { Subtotals: }\end{array}$ & $\begin{array}{r}8 \\
56 \\
0 \\
0 \\
83 \\
\frac{11}{158}\end{array}$ & $\begin{array}{r}16 \\
115 \\
0 \\
14 \\
43 \\
76 \\
264\end{array}$ & $\begin{array}{r}0 \\
24 \\
1 \\
2 \\
2 \\
0 \\
29\end{array}$ & $\begin{array}{l}1 \\
0 \\
0 \\
0 \\
0 \\
0 \\
1\end{array}$ & $\begin{array}{r}25 \\
195 \\
1 \\
16 \\
128 \\
\frac{87}{452}\end{array}$ \\
\hline $\begin{array}{l}\text { Recreation Group } \\
\text { 1. Tobacco } \\
\text { 2. Alcohol } \\
\text { Subtotals: }\end{array}$ & $\begin{array}{r}1 \\
\frac{37}{38}\end{array}$ & $\begin{array}{l}1 \\
\frac{2}{3}\end{array}$ & $\begin{array}{l}0 \\
\underline{0} \\
0\end{array}$ & $\begin{array}{l}0 \\
\underline{0} \\
0\end{array}$ & $\begin{array}{r}2 \\
\frac{39}{41}\end{array}$ \\
\hline Bone & 2 & 0 & 0 & 0 & 2 \\
\hline $\begin{array}{l}\text { Utilities Group } \\
\text { 1. Electrical } \\
\text { 2. Plumbing } \\
\text { Subtotals: }\end{array}$ & $\begin{array}{l}9 \\
2 \\
11\end{array}$ & $\begin{array}{r}19 \\
\frac{5}{24}\end{array}$ & $\begin{array}{l}1 \\
\frac{0}{1}\end{array}$ & $\begin{array}{l}0 \\
\underline{0} \\
0\end{array}$ & $\begin{array}{r}29 \\
\frac{7}{36}\end{array}$ \\
\hline $\begin{array}{l}\text { Other } \\
\text { 1. Miscellaneous } \\
\text { 2. Unidentified } \\
\text { Subtotals: }\end{array}$ & $\begin{array}{l}292 \\
\frac{155}{447}\end{array}$ & $\begin{array}{r}52 \\
52 \\
104\end{array}$ & $\begin{array}{l}1 \\
\frac{6}{7}\end{array}$ & $\begin{array}{r}14 \\
\frac{0}{14}\end{array}$ & $\begin{array}{l}359 \\
213 \\
572\end{array}$ \\
\hline GRAND TOTALS: & 2,646 & 810 & 89 & 47 & 3,592 \\
\hline
\end{tabular}

*Includes artifacts boxed with materials from the three rooms but not labeled as to provenience. 
Kitchen, 66 in the Dining Room, and 5 in Room 7. The large number in the Kitchen indicates at least two things. First, 525 of the 687 sherds from the ceramic sets are from the Kitchen. This suggests that the ceramics may have been dumped in this room after use. Sherds were found in the cistern that cross-mend to some of those in the Kitchen, indicating that garbage from the Kitchen was possibly dumped in the cistern during the restoration by the Seguin Conservation Society in the 1960s. Mrs. Mary Ibarra, a worker for the Zorns and then a resident with her family renting Sebastopol, recognized some of the excavated ceramics as sets that Mrs. Zorn had given to her. Mrs. Ibarra claimed that when she and her family moved out, they left those ceramics in the house with the intention of coming to pick them up, but that they never did (Ibarra 1981). It is possible that the house was ransacked prior to takeover by the Seguin Conservation Society in 1961 and that it was at that earlier time that the floor was damaged and the ceramics broken and deposited. The large number of "food"related artifacts in the Kitchen also indicates that a larger proportion of the food storage,

preparation, and service items were stored, used, or cleaned in the Kitchen than in the other two rooms.

A general trend throughout the house is the low quantity of "recreation" group artifacts, or those related to the use of alcohol and tobacco. The remains of one pipe and five alcohol bottles were found. Of the 39 alcohol bottle fragments, only 2 are from the Dining Room, with the others coming from the Kitchen. Oral histories record that Joseph Zorn Jr. did not drink alcohol (Tegener 1981b), and although dinner parties were common at the house, it appears that little alcohol was served. With the exception of several modern cigarette butts (which are not included in this analysis), only two sherds of one ceramic pipe were found, which indicates a lack of tobacco smoking.

Within the personal group, the school/stationery supplies class is larger in the Kitchen (74 artifacts) than in the Dining Room (41 artifacts) or Room 7 (4 artifacts). This may indicate that home schooling or homework activities were carried out primarily in the Kitchen. On a general level, the presence of these artifacts indicates the focus on education in the Zorn household. Joseph Zorn Jr. was a supporter of the school system, serving as a trustee for the school board from 1891 to 1909 . These school supplies alone do not indicate the extent of Zorn's involvement in the school system, but they support this knowledge and indicate that the Zorns were as concerned about education on a private level as Joseph Zorn was publicly.

\section{TRADE SOURCES}

At Sebastopol, imported ceramics were preferred over American ones, whether due to availability or personal taste. This is not surprising for the mid-nineteenth-century occupations, but by the turn of the century and later, American goods generally became more popular in U.S. households (Majewski 1994a:4; Majewski and O'Brien 1987:127). Only one set from the site is identifiable as American made; this is a heavy, refined earthenware set made in 1892. It appears to have been a poorer quality set used on a daily basis by the family (as attested to by Hazel Tegener in the oral histories). One other American maker's mark was found on an earthenware sherd. This was sourced to the W. S. George Pottery in Canonsburg, Pennsylvania, and dates to ca. 1920. Other American ceramics may have been present but unmarked. The representation of 11 Staffordshire potters in the refined earthenware collections reflects their dominance over the market in the United States (Majewski 1994a:4). At least five of these potters, who produced some of the ironstone found at the site, were in business only before 1870 . Other countries of origin for ceramics in this collection are Japan, Germany, France, and Austria.

Other indicators for countries of manufacture come from varying material types and show trade with many areas of the eastern United States and Europe. Evidence from bottle seals indicates trade with companies in London, Louisiana, Pittsburgh, and Seguin. One identifiable spoon was made in Sheffield, England. Medicine bottles are embossed with names from St. Louis and Seguin. One gunflint is believed to be from France, while all the sourceable cartridges are from Connecticut. Also from America are all of the ceramic insulators which were sourced to Ohio and Illinois. Lacking in the deposits at Sebastopol are any artifacts from the western United States. This is not too surprising, since trade networks tended to move east to west, with the major access routes to Texas through the Gulf Coast. 


\section{STYLE}

The styles of decoration for the ceramic sets reflect the most popular styles of their times. Molded ironstone reflects the preference for the Greek Revival style of the 1840 s to 1860 s, with simple yet bold designs (a trait also seen in the architecture of the house). The Japanese influence seen during the aesthetic movement (most popular during the late 1870 s and through the 1880 s) is seen in the pseudo-Japanese Grass and Flowers decal design of Set $\mathrm{C}$; the sprays of stylized flowers and grass placed asymmetrically were common during the aesthetic movement (Majewski 1994a:5). This set dates from 1879 to 1900 , fitting in nicely with the period of the style's highest popularity. The date range for the set also fits into the most popular period for decal decoration on porcelain (1880 to 1920) (Majewski and O'Brien 1987:147).

Set $\mathrm{I}$, the Phoenix Pattern, is marked "Made in Japan"; this pattern has been made for over 100 years (Banks 1983:149). This set proves a problem in dating. Since the term "Made in" was required after 1887 for imports to Britain (Kovel and Kovel 1986:231), this set could fit into the aesthetic movement period. Unfortunately, the same source states that the earliest use of the word "Japan" in any mark is 1921 (Kovel and Kovel 1986:229). No other sources have been found to refute this later date. But if this later date is wrong and the 1887 date is closer to the date of manufacture of this set, it could also fit into the pre-1900 period.

\section{SOCIOECONOMIC STATUS}

The study of artifacts from an archeological site is just one way to examine socioeconomic status. Many authors have determined that an individual's occupation is the best indicator of socioeconomic status (Spencer-Wood 1987:323). The analysis of artifacts together with a knowledge of family members' occupations (and therefore community standing) should provide a reasonable determination of status for a household.

In analyzing artifacts for an archeological investigation, the researcher asks why an artifact is at the site, how it got there, and why another artifact was not chosen instead. An artifact with an implicit function may have been brought to the site to be used in a completely different manner. For instance, a plate which would usually be used to serve dinner may be at a site as a display item.
The possible reasons for any artifact being at a site are plentiful, but also important are the reasons for an artifact not being at a site, or the limitations of the occupants to acquire certain artifacts.

The first limitation to consider is that of availability. If a site is too far from a port city, certain items will not be available. The next limitation is how affordable an item was for the family, or how much available money they had to spend on it. Beyond the factor of availability, affordability is the best indication of socioeconomic standing. To do this type of economic study, it is best to do between-site comparisons and not to look at one site alone. In the case of Sebastopol, no other house sites in the area are available for comparison, so an overview of one site will have to suffice.

Joseph Zorn Jr. and his family had the most influence on the Sebastopol building and its grounds, being the sole occupants of the house from 1874 until the 1940s when they started renting out rooms. Throughout that time, Joseph Zorn Jr. provided the major income for the household. He started out as a businessman running a store in Seguin, a public and visible role in the community. He married a local woman, and together they had six children. Although he declared bankruptcy in 1876, by 1888 Zorn was again a businessman with a substantial amount of merchandise. In 1890, Zorn was elected mayor. This position is one of high status in a small town, holding a significant amount of influence and visibility in the community. Zorn later ran the telephone company, and he always remained active in the community. Even if the absolute wealth of the family is questionable during different periods of time, their standing as a visible and influential family in the town of Seguin is not.

A public lifestyle accompanies the role of mayor. Any politician is required to socialize and entertain to maintain his position. Since Zorn was mayor for 20 years, he undoubtedly socialized and entertained on a regular basis in his house. This is attested to in the oral histories of his granddaughter (see Chapter 1). The entertainment of important guests and the need to display wealth should be reflected in the relative cost of certain items in this assemblage such as tea sets, dinner sets, decorative household items, and jewelry.

\section{Tea Sets}

Tea sets were used for formal tea parties or afternoon gatherings. A tea set advertised in the 
Sears, Roebuck and Co. catalog from 1897 is shown having either 44 or 56 pieces, including 12 tea plates, 12 teacups, 12 tea saucers, a teapot, a cream pitcher, a slop bowl, 2 cake plates, and 1 sugar bowl (the larger set had 12 sauce plates added for an additional 85 cents). A tea set was nearly as expensive as a small dinner set and could have as many pieces (Sears, Roebuck and Co. 1897:678682). The tea set would have been an important status item since it was displayed to visitors (Spencer-Wood 1987:325).

Most of the sets found at Sebastopol could have been tea sets originally. Because only parts of the sets were found, it is sometimes difficult to determine which were tea sets and which were dinner sets. Set A, "cherry blossom and clamshell," with only saucers and teacups is considered a tea set. Set D, "rose decal," is also considered a tea set since cups, saucers, small plates, and one small bowl were found. Set E, the double swagged ironstone set of three cups, also could have been a tea set. The Phoenix pattern of Set I is represented only by small bowls, cups, and saucers and could have been used for teas. Set $\mathrm{J}$, the Rosaline pattern from Alfred Meakin, was also likely a tea set since only cups and saucers were found. It is also possible that Set N, the refined earthenware saucers from Alcock \& Co., was part of a tea set. Of these proposed tea sets, three have makers' marks.

Set D was probably made by Carl Krister of Waldenburg, Silesia, Germany, after 1891 (Godden 1991:11). This is a well-made set with a traditional polychrome floral decal and gilding. Majewski (1994b) states that by the late 1800 s, polychrome decals were used mostly on high-cost wares from Germany and France. One comment can be made comparing British refined earthenware to European bone china based on the Sears, Roebuck and Co. 1897 catalog. In this volume, a 56-piece tea set made of refined earthenware (semiporcelain) by Alfred Meakin was priced at $\$ 7.05$ (this was the most expensive set in the catalog made from this material). A 56-piece (bone) china tea set made by Charles Field Haviland of Limoges, France, on the other hand, cost $\$ 14.65$; this price is more than double that of the refined earthenware set (Sears, Roebuck and Co. 1897:680). This advertised set is similar to Set D in that it is decorated with a spray of pink roses (not specifying transfer print or decal) and has fluted edges and gold trim. This is the only type out of 12 advertised dinner sets that is bone china and not British semiporcelain. Set D with the rose decal was, therefore, a fancy and expensive tea set. Five years later, in the 1902 Sears, Roebuck and Co. catalog, tea sets are no longer advertised, but a 100-piece bone china dinner set from France is still nearly twice the cost of the most expensive British semiporcelain.

Extrapolating from this, Set A was also likely an expensive set. It was made of bone china, was gilded and molded, and was decorated with a decal. It likely dates from around the same period or slightly earlier due to its decoration of a monochrome decal with atomized colors added.

The Japanese-made set was probably not as expensive as the rose decal because it is transfer printed. Due to the difficulty in dating these pieces, however, this set is of little use in this discussion.

The Rosaline pattern from Alfred Meakin, most likely dating 1891 to 1899 , would have been comparable in price to the British semiporcelain mentioned above from the Sears catalog. This set was probably worth about half that of the rose decal set and would have been used on a more regular basis for less-fancy afternoon teas.

The Zorns used both expensive and inexpensive teaware, but the bone china sets indicate a level of socioeconomic display suited to their public role. Entertaining the upper class was one of their duties.

\section{Dinner Sets}

It has been established that European bone china dinner sets were worth a great deal more than British semiporcelain sets. The 1902 Sears, Roebuck and Co. catalog advertised several American-made, 100-piece, semiporcelain dinner sets which ranged in price from $\$ 4.98$ to $\$ 8.58$. Only three 100 -piece British-made sets of refined earthenware (semiporcelain) were advertised, and they were priced from $\$ 11.28$ to $\$ 11.75$. A French set made of bone china was priced at \$19.95. An American-made dinner set of refined earthenware, then, could cost as little as one-quarter that of a European bone china set.

The one American-made dinner set found at the site was made by Burroughs and Mountford Co. of Trenton, New Jersey, in 1892. Of all the sets recorded at the site, this one has the largest variety and the largest number of vessels represented $(n=$ 19). This set was also remembered by Hazel Tegener as the one used regularly by the family for meals. The glaze of this set is delaminating and 
peeling off in many places. Used on a daily basis, this set of dishes would not have been presented to guests when they visited the house, and therefore would not have been a status item.

On the other hand, Set $\mathrm{C}$, a bone china set represented by 10 pieces including dinner plates, would probably have been a dinner set reserved for company. This was a monochrome decaled ware which was filled in with hand-painted colors. This set was likely made by R. Delinieres \& Co. of Limoges, France, dates from 1879 to 1891 , and would have been worth more than the American set. This set lacks molding and gilding, but this is likely due to the style of the time rather than lower value.

A large quantity of molded ironstone was found which generally dates from the 1840 s to the 1860 s. According to Miller's CC value index (Miller 1991:22), this ironstone is anywhere from third least expensive out of seven (in 1846) to the most valuable ware $(1858,1868,1871,1874$, and 1880). This indicates that these pieces were fairly common and somewhat valuable.

Like the tea sets, the dinner sets identified here indicate separate, more-expensive tablewares used for entertaining, at least in the decades bordering 1900 . The need to display status is apparent through these pieces.

\section{Decorative Household Items}

Few specifically decorative items were found. These include the remains of five plates and six ceramic sherds representing three artifacts. The Timor pattern plate has evidence of being displayed on a plate rail or other hard surface since the paint on its lower rim is worn. This piece dates from 1870 to 1880 and is a monochrome blue transfer print with polychrome enamel over the top. Several sherds from a calendar plate were also recovered. This type of plate was manufactured with the intent of primarily being decorative and perhaps subsequently being utilitarian. No use wear indicating a utilitarian function is found on any of the decorative plates. All of the decorative plates except the calendar and Timor plates (which are made of earthenware) are made of bone china.

\section{Jewelry}

Jewelry is not common on archeological sites since these items were carefully curated by their owners. Thus, Sebastopol is unusual because of the presence of several different pieces of jewelry. Some of these pieces are gold or gold plated and therefore would have been fairly expensive. Two gold-plated cuff links and two gold-plated earrings were found; also found were two buttons that appear to be gold plated.

These personal decorative items are reflections of status display as much as, if not more than, the household decorations. Jewelry was not confined to the house, but could be worn on special occasions inside or outside the house. Thus even if social occasions were not held in the house and the house was not set up for a display of wealth, a person could still show status by buying personal decorations.

Finding expensive goods in a house suggests a certain level of wealth. However, other evidence can contradict such an interpretation. In this case, there is evidence for money-saving and moneymaking ventures in the household. The presence of so much shot and many unfired shotgun shells, as described in detail previously in this report, is evidence that shotgun shell reloading occurred in the house. This was a fairly common practice when loaded shotgun shells were not available or when money needed to be saved. The presence of over 300 buttons is evidence of some sewing activity other than simple repairs. As previously mentioned, it is possible and likely that members of the household participated in some kind of professional sewing activity, either sewing clothes for sale privately or doing so for a department store. In either case, this was an activity that would have supplemented the income of the household.

\section{CONCLUSION}

In 1976, TPWD purchased what is now Sebastopol State Historical Park in Seguin, Texas. The park is an 1850 s limecrete residential house known historically as Sebastopol. The Seguin Conservation Society, which had purchased the house and renovated it in 1961, sold the house and property to the state. In their work restoring the house, TPWD brought in archeologists to investigate those deposits that would be disturbed. Nine archeological seasons ensued over the next 10 years, with the main goals being to excavate those deposits that would be destroyed and to aid in data collection for the restoration. During the excavations, over 
106,000 artifacts were collected and consequently curated. This report summarizes the excavation seasons and provides an analysis of part of the artifact collection.

Sebastopol was originally built between 1854 and 1856 by Joshua Young. His sister, Catherine LeGette, bought the house from her brother in 1857 and lived there with her eight children until 1874, when Joseph Zorn Jr. bought the house and land. Zorn, a businessman in Seguin and the mayor from 1890 to 1910 , and his wife raised their six children in the house. Members of the family continued to live there into the early 1950 s, when the house was rented out. The property was sold in 1961 by Hazel Tegener, Joseph Zorn Jr.'s oldest granddaughter. Little is known of the domestic life at Sebastopol historically, but interviews with many of Zorn's grandchildren and friends of the family have expanded our knowledge of activities there. Of particular importance were the interviews conducted with Hazel Tegener, who lived at the house from 1898 to 1908 and who provided many details of family life at the house during this period.

Slave labor is believed to have been used in the construction of the house, and black laborers and house servants worked for the Zorns for many years. Some of the black workers lived on the property, while others came in from a local black neighborhood. One artifact, a black frozen Charlie doll, may be an indication of black children at the site, but the oral histories provide more information about the African Americans at the site than does the archeology.

The architecture of Sebastopol proved to have a fascinating history, and one that could not have been fully understood without the archeological investigations. The house is constructed of limecrete - an early form of concrete made of lime, water, and gravel-which was related to the tabby used in southern coastal areas. Structures made of limecrete were poured into molds in subsequent layers. Because of the numbers of buildings made with this material in Seguin during the 1840 s and 1850 s and the fact that Sebastopol is one of the last standing structures made of limecrete, analysis of the architecture was a vital component of the research.

Aside from learning about the make-up and use of limecrete, unique facts about the house itself were learned through the archeology. It is theorized that the house originally had a different orientation, with what is now the back intended to be used as the front facade. This theory is substantiated by the occurrence of a limecrete pier outside the Dining Room door and a filled-in door above. It seems that either a portico or a full-length porch which would have been supported by this pier was intended for this facade but was abandoned during construction. Also filled-in either during construction or shortly thereafter were doors into the south lowerfloor rooms and the walkways that led to them. The archeology revealed that these doors were indeed used for a period of time since there are compacted areas in the floors adjacent to them. The presence of these doors indicates that the lower-floor rooms were intended to be used for purposes other than storage, possibly for guests, slave quarters, or a work area. There is also firm evidence in the form of historic photographs from the 1930s that the house was not always painted white, contradicting the oral histories of the family. Red- or brickcolored ashlar etching in the plaster of the north end and sides of the house were once part of the building's appearance. Although not investigated, it is likely that a separate kitchen building was either planned or built. This was a standard practice of the antebellum period.

The deposits at Sebastopol were most likely disturbed when the renovations of 1961 occurred. A general trend of three stratigraphic layers within the house can been seen, though. These strata include the lowest layer of construction debris, a middle layer of habitation debris, and an upper layer of restoration debris. The exterior deposits showed evidence of a 4-ft-wide walkway dug into the bedrock on either side of the house and extending around to the front of the building. Within the fill of the walkway was evidence of a narrow trench beside the wall, possibly dug to check the wall integrity, and a buttress at the southeast corner of the house supporting that section of the wall. The excavations revealed a 15 -ft-deep cistern which was never made water tight and therefore never used except as a dumping area.

Some of the materials recovered during the archeological excavations are analyzed in this report, focusing on those parts of the collectionspecifically the pre-1910 ceramic sets and all diagnostic artifacts from the Kitchen, Dining Room, and Room 7-that have the greatest potential to contribute useful information about the residents, especially the Zorns. When originally collected, the artifacts were organized by a functional classification 
system developed by Roderick Sprague in the 1970s (Sprague 1981). This system was felt to be limiting in its scope, so a different method of classification, loosely based on South's (1977) pattern recognition classifications, was developed. For comparisons, the Sprague codes were broken down into categories compatible with those used in this analysis. The beginning of this chapter pulls together information from this analysis and makes interpretations based on it. Included is a statistical summary showing the predominance of artifacts in the "food" group, followed by the "personal," "activity," "furniture and fixtures," "recreation," "utilities," "pharmaceutical bottles," and "bone" groups. The Kitchen had the largest concentration of artifacts, even with the ceramic set data removed, and this is believed to indicate more activities in this area that in the other two rooms.

The artifacts also provide an idea of the extent of trade into the area. Items from local merchants, the eastern United States, Europe, and Asia were all identified at Sebastopol. Missing are artifacts from the western United States.

To some extent, the styles of the times can be seen in the archeological record. This is tied closely to the socioeconomic status of the family as revealed in part by the tea sets, dinner sets, decorative household items, and jewelry found there. It is believed that the Zorns, who declared bankruptcy at least once, were a reasonably affluent family during Zorn's time as mayor. Together with the architectural, archival, and informant data, the archeological analysis provides a sound basis for adding to the interpretation of Sebastopol State Historical Park. 


\section{REFERENCES CITED}

Adams, Jane Ford

1967 A Complete Classification of Black Glass Buttons. The National Button Society.

Adams, William H., and Linda P. Gaw

1977 A Model for Determining Time Lag of Ceramic Artifacts. Northwest Anthropological Research Notes 11(2):218-231.

Albert, Lillian Smith, and Jane Ford Adams

1970 Essential Data Concerning China Buttons. The National Button Society of America.

Anderson, Adrienne

1968 The Archaeology of Mass-Produced Footwear. Historical Archaeology 2:56-65.

Arthur May Directory Co.

1896 Homeseeker's Guide to Seguin and Guadalupe County. Arthur May Directory Co., Dallas.

Banks, Cynthia

1983 Brazos Santiago Depot and Fort Polk, Cameron County, Texas: Contexts of the Sites and Analysis of the Ceramics from 1967 and 1980 Investigations. Master's thesis, Department of Anthropology, The University of Texas at Austin.

Barber, John L.

1987 The Rimfire Cartridge of the United States \& Canada: An Illustrated History of its Manufacturers and Their Products. Armory Publications, Tacoma, Washington.

Barlow, Raymond, and Joan E. Kaiser

1987 A Guide to Sandwich Glass: Witch Balls, Containers and Toys. Schiffer Publishing, West Chester, Pennsylvania.

Barnes, Frank C.

1993 Cartridges of the World. DBI Books Inc., Northfield, Illinois.
Bender, Nathan E.

1986 Early 20th Century Commercial Closures. Paper presented at the annual meeting of the Society for Historical Archaeology, Sacramento, California.

Brandimarte, Cynthia

1986 Sebastopol Archeology Report. Ms. on file, Texas Parks and Wildlife Department, Austin.

Brewer, Mary

1996 Collector's Guide to Rockingham, the Enduring Ware: Identification \& Values. Collector Books, Paducah, Kentucky.

Brown, Dorothy Foster

1942 Button Parade. Wallace-Homestead Co., Des Moines, Iowa.

Calhoun County Historical Survey Committee

1974 Indianola Scrapbook. Calhoun County Historical Survey Committee, Port Lavaca, Texas.

Claassen, Cheryl

1994 Washboards, Pigtoes, and Muckets: Historic Musseling in the Mississippi Watershed. Historical Archaeology 28(2).

Coleman, D. S., E. A., and E. J.

1968 The Collector's Encyclopedia of Dolls. Crown Publishers, New York.

Copeland, Richard

1982 Blue and White Transfer-printed Pottery. Shire Album 97. Shire Publications Ltd., Princes Risborough, Buckinghamshire, Great Britain.

Cushion, J. P., and W. B. Honey

1980 Handbook of Pottery and Porcelain Marks. Faber and Faber, London.

DeBolt, C. Gerald

1988 The Dictionary of American Pottery Marks, 
Whiteware and Porcelain. Charles E. Tuttle Company, Rutland, Vermont.

Denker, Ellen, and Bert Denker

1982 The Main Street Pocket Guide to North American Pottery and Porcelain. The Main Street Press, Pittstown, New Jersey.

Fike, Richard E.

1987 The Bottle Book: A Comprehensive Guide to Historic, Embossed Medicine Bottles. Gibbs M. Smith, Inc., Salt Lake City.

Fitzsimon, Laurence J.

1938 History of Seguin. C. H. Jackson Directory Co., San Antonio.

Flayderman, Norm

1980 Flayderman's Guide to Antique American Firearms ... and their values. DBI Books, Inc., Northfield, Illinois.

Foulke, Jan

1995 Insider's Guide to China Doll Collecting. Hobby House Press, Inc., Grantsville, Maryland.

Friedel, Robert

1983 Pioneer Plastic: The Making and Selling of Celluloid. University of Wisconsin Press.

1995 Crazy About Rubber. American Inventions. Barnes and Noble Inc., Hong Kong.

Galveston City Directory, 1875-1876

Gere, Charlotte

1993 Jewelry. In The Collectors' Encyclopedia of Antiques. Edited by Phoebe Phillips. Bloomsbury Books, London.

Gibson, Michael

1993 Lustreware. Shire Album 290. Shire Publications Ltd., Princes Risborough, Buckinghamshire, Great Britain.

Godden, Geoffrey

1991 Encyclopedia of British Pottery and Porcelain Marks. Crown Publishers, New York.

1992 Godden's Guide to English Porcelain. Wallace-Homestead Book Co., Radnor, Pennsylvania.

Green, Michael

1982 Interview with Michael Green, February 17, 1982, Austin, Texas, by Cynthia Brandimarte. On file with the Cultural Resources Program, Texas Parks and Wildlife Department, Austin.
Griffiths, Dorothy M.

1978 Use-Marks on Historic Ceramics: A Preliminary Study. Historical Archaeology 12:68-81.

Grist, Everett

1993 Big Book of Marbles. Collector Books, Paducah, Kentucky.

Guadalupe County, Texas

Deed Records

District Court Records

Marriage Records

Probate Records

Tax Records

Guadalupe Times (Seguin)

Hauser, Vincent

1980 A Survey of the Technologies Contributing to the Concrete Era of Seguin, Texas in the Midnineteenth Century. Master's thesis, The University of Texas at Austin.

Historic American Buildings Survey (HABS)

1934 Sketches and photographs of the Sebastopol house made during this survey.

Hourart, Victor

1977 Buttons: A Collector's Guide. Methuen Publications, Ontario.

Howard, Hugh

1989 How Old is This House? Noonday Press, New York.

Hughes, G. B.

1961 English and Scottish Earthenwares, 1660-1860. Abby Fine Arts, London.

Ibarra, Mary

1981 Interview with Mary Ibarra, February 10, 1981, Seguin, Texas, by Cynthia Brandimarte. On file with the Cultural Resources Program, Texas Parks and Wildlife Department, Austin.

Ing, J. David, and John Hart

1987 Archeological Excavations at Fanthorp Inn State Historic Site (4lGM79), Grimes County, Texas: Spring and Fall 1982. Texas Parks and Wildlife Department, Historic Sites and Restoration Branch, Austin, Texas.

Jenks, Bill, and Jerry Luna

1990 Early American Pattern Glass 1850-1910. Wallace-Homestead Book Company, Radnor, Pennsylvania. 
Jenks, Biil, Jerry Luna, and Darryl Reilly

1993 Identifying Pattern Glass Reproductions. Wallace-Homestead Book Company, Radnor, Pennsylvania.

Jennings, Jan, and Herbert Gottfried

1993 American Vernacular Interior Architecture 1870-1940. Iowa State University Press, Ames, Iowa.

Jones, Olive, and Catherine Sullivan

1989 The Parks Canada Glass Glossary for the Description of Containers, Tableware, Flat Glass, and Closures. National Historic Parks and Sites Branch, Canadian Parks Service, Ottawa.

Jordan, Terry G.

1978 Texas Log Buildings: A Folk Architecture. University of Texas Press, Austin.

Kelso, Margaret F.

1971 A Classification of Pearl and Shell'Buttons. The National Button Society.

Kenmotsu, Nancy

1991 Gunflints: A Study. In Approaches to Material Culture Research for Historical Archaeologists, edited by George L. Miller, Olive R. Jones, Lester A. Ross, and Teresita Majewski, pp. 197-222. The Society for Historical Archaeology.

Ketchum, William C.

1987 American Country Pottery: Yellowware and Spongeware. Alfred A. Knopf, New York.

Kidd, Kenneth E., and Martha Ann Kidd

1970 A Classification System for Glass Beads for the Use of Field Archaeologists. Canadian Historic Sites: Occasional Papers in Archaeology and History, No. 1. National Historic Sites Service, National and Historic Parks Branch, Department of Indian Affairs and Northern Development, Ottawa, Ontario.

Kinney, John M. (compiler)

1977 Index to Applications for Texas Confederate Pensions. Texas State Library, Austin.

Kovel, Ralph, and Terry Kovel

1986 Kovels' New Dictionary of Marks. Crown Publishers, Inc., New York.

Lamm, Ruth, Beatrice Lorah, Lester Lorah and Helen W. Schuler

1970 Guidelines for Collecting China Buttons. The National Button Society of America.
Lardner, Dionysius (editor)

1832 A Treatise on the Progressive Improvement and Present State of the Manufacture of Porcelain and Glass. Longeman, Rees, Orme, Brown, and Green and John Taylor, London. Reprinted 1972 by Noyes Press, Park Ridge, New Jersey.

LeGette Family Papers

Wood Collection, Seguin Conservation Society.

Lehner, Lois

1988 Lehner's Encyclopedia of U.S. Marks on Pottery, Porcelain and Clay. Collector Books, Paducah, Kentucky.

Lord, Francis A.

1995 Civil War Collector's Encyclopedia, Volume IV. Blue and Grey Press, Edison, New Jersey.

Lukacs, John R.

1989 Dental Paleopathology: Methods for Reconstructing Dietary Patterns. In Reconstruction of Life from the Skeleton, edited by Mahmet Yasar Iscan and Kenneth A. R. Kennedy, pp. 261286. Alan R. Liss, Inc., New York.

Luscomb, Sally C.

1992 The Collector's Encyclopedia of Buttons. Schiffer Publishing, Ltd., West Chester, Pennsylvania.

Mace, Henry O.

1991 Collector's Guide to Victoriana. WallaceHomestead Book Co., Radnor, Pennsylvania.

Majewski, Teresita

1994a The Recognition of Style in Late 19th-century Ceramics: Implications for Archaeological Interpretations. Paper presented at the 1994 Conference on Historical and Underwater Archaeology, Vancouver, British Columbia.

1994b Workshop on Late 19th- and Early 20thCentury Ceramics. Society for Historical Archaeology annual meeting, Vancouver, British Columbia.

Majewski, Teresita, and Michael J. O'Brien

1987 The Use and Misuse of Nineteenth-Century English and American Ceramics in Archaeological Analysis. In Advances in Archaeological Method and Theory, Vol 11, edited by Michael B. Schiffer, pp. 97-209. Academic Press, New York.

Maxson, Peter

1978 Sebastapol Historical Narrative. Draft report on file with the Cultural Resources Program, Texas Parks and Wildlife Department, Austin. 
McAlesier, Virginia, and Lee McAlester

1990 A Field Guide to American Houses. Alfred A. Knopf, New York.

Miller, George

1991 A Revised Set of CC Index Values for Classification and Economic Scaling of English Ceramics from 1787 to 1880 . Historical Archaeology 25(1):1-25.

M'Kee and Brothers

1981 M'Kee Victorian Glass: Five Complete Glass Catalogs from 1859/60 to 1871. Dover Publications, Inc., New York.

Moellering, Arwerd Max

1938 History of Guadalupe County, Texas. Master's thesis, The University of Texas at Austin.

Montgomery Ward and Co.

1895 Catalogue and Buyer's Guide No. 57 Spring and Summer. Unabridged facsimile reprint, 1969. Dover Publications, Inc., New York.

Munsey, Cecil

1970 The Illustrated Guide to Collecting Bottles. Hawthorn Books, Inc., New York.

O'Bannon, Patrick William

1983 Technological Change in the Pacific Coast Canned Salmon Industry, 1864-1924. Ph.D Dissertation, University of California, San Diego.

Olsen, Stanley J.

1963 Dating Early Plain Buttons by Their Form. American Antiquity 28(4):551-554.

Orser, Charles E. Jr., and David W. Babson

1990 Tabasco Brand Pepper Sauce Bottles from Avery Island, Louisiana. Historical Archaeology 24(3):107-114.

Pollan, Sandra D., W. Sue Gross, Amy C. Earls, Johnney T. Pollan Jr., and James L. Smith

1996 Nineteenth-Century Transfer-Printed Ceramics from the Townsite of Old Velasco (41BO125), Brazoria County, Texas: An Illustrated Catalogue. Prewitt and Associates, Inc., Austin, Texas.

Pool, Juliann C.

1991 An Overview of Nineteenth and Twentieth Century Buttons. Research Notes, Historic Sites and Materials, Number 1. Texas Parks and Wildlife Department, Austin, Texas.
Randall, Mark E.

1979 Marbles as Historical Artifacts. Marble Collectors Society of America. Trumbull, Connecticut.

Random House

1978 The Random House Dictionary. Ballantine Books, New York.

Richardson, Rupert Norval, Ernest Wallace, and Adrian N. Anderson

1981 Texas: The Lone Star State. Prentice-Hall, Inc., Englewood Cliffs, New Jersey.

Ritchie, Neville, and Stuart Bedford

1985 An Analysis of the Metal Containers from Chinese Sites in the Cromwell Area, Central Otago, New Zealand. New Zealand Journal of Archaeology 7:95-115.

Robacker, Earl F., and Ada 'F. Robacker

1978 Spatterware and Sponge: Hardy Perennials of Ceramics. A. S. Barnes and Company, South Brunswick, New Jersey.

Roberson, Wayne R.

1974 The Carrington-Covert House: Archeological Investigation of a 19th-Century Residence in Austin, Texas. Texas Historical Commission, Austin, Texas.

Rock, James T.

1981 Tin Cans Notes and Comments. Klamath National Forest, Region 5, Department of Agriculture, U.S. Forest Service.

1984 Cans in the Countryside. Historical Archaeology 18(2):97-111.

Russell and Erwin

1865 Illustrated Catalogue of American Hardware of the Russell and Erwin Manufacturing Company. Unabridged reprint in 1980. The Association for Preservation Technology, U.S.A.

Ryan, Helen L.

1986 A Complete Classification of Clear and Colored Glass Buttons. The National Button Society.

Sauer, Sandra R.

1995 The O'Keefe Ranch: An Archaeological Perspective. Unpublished Master's thesis, Simon Fraser University, Burnaby, British Columbia.

Sanborn Fire Insurance Maps

1930 Seguin, Texas 
Schiff, Stefen $\mathrm{O}$.

1979 Buttons: Art in Miniature. Miller Publisherd, Berkeley, CA.

Sears, Roebuck and Co., Inc.

1897 Catalogue No. 104, edited by Fred L. Israel. Reprinted in 1993 by Chelsea House Publishers, New York.

1902 Catalogue No. 111. Reprinted in 1993 by Gramercy Books, New York.

1908 Catalogue No. 117, edited by Joseph J. Scroeder, Jr. Reprinted in 1971 by Digest Books, Inc., Northbrook, Illinois.

1909 Catalogue No. 118. Reprinted in 1979 by Ventura Books, Inc., New York.

Seguin Enterprise

Seguin Mercury

Seguin Times

Silverthorne, Elizabeth

1986 Plantation Life in Texas. Number One of The Clayton Wheat Williams Texas Life Series. Texas A\&M University Press, College Station, Texas.

Snyder, Jeffrey B., and Leslie Bockol

1994 Majolica: American and European Wares. Schiffer Publishing, Ltd, Atglen, Pennsylvania.

South, Stanley

1964 Analysis of the Buttons from Brunswick Town and Fort Fisher. Florida Anthropologist 17(2):113-133.

1977 Method and Theory in Historical Archeology. Academic Press, New York.

Southern Confederacy (Seguin)

Spector, Janet D.

1976 The Interpretive Potential of Glass Trade Beads in Historic Archaeology. Historical Archaeology 10:17-27.

Spencer-Wood, Suzanne M.

1987 Miller's Indices and Consumer-Choice Profiles: Status-Related Behaviors and White Ceramics. In Consumer Choice in Historical Archaeology, edited by Suzanne M. Spencer-Wood, pp. 321-359. Plenum Press, New York.
Sprague, Roderick

1981 A Functional Classification for Artifacts from 19th and 20th Century Historical Sites. North American Archaeologist 2(3).

1985 Glass Trade Beads: A Progress Report. Historical Archaeology 19(2):87-105.

Storm, J. M.

1976 Bead and Button Analysis. In Kanaka Village/ Vancouver Barracks, by David H. Chance and Jennifer V. Chance, pp. 106-132. Reports in Highway Archaeology No. 3. Office of Public Archaeology Institute for Environmental Studies, University of Washington. Seattle, Washington.

Taylor, Lonn, and David B. Warren

1975 Texas Furniture: The Cabinetmakers and Their Work, 1840-1880. University of Texas Press, Austin.

Taylor, S.

1950 China and Other Dinnerware. Fairchild, New York.

Tegener, Hazel

1981a Interview with Hazel Tegener, February 12, 1981, San Antonio, Texas, by Cynthia Brandimarte. On file with the Cultural Resources Program, Texas Parks and Wildlife Department, Austin.

1981b Interview with Hazel Tegener, February 26, 1981, San Antonio, Texas, by Cynthia Brandimarte. On file with the Cultural Resources Program, Texas Parks and Wildlife Department, Austin.

1981c Interview with Hazel Tegener, March 10, 1981, Seguin, Texas, by Cynthia Brandimarte. On file with the Cultural Resources Program, Texas Parks and Wildlife Department, Austin.

Texas Parks and Wildlife Department

1983 Preservation Plan and Program for Sebastopol State Historic Structure Seguin, Texas. 2 vols. Texas Parks and Wildlife Department, Historic Sites and Restoration Branch, Austin.

1986 Sebastopol State Historic Structure Restoration and Development Plans. Texas Parks and Wildlife Department, Historic Sites and Restoration Branch, Austin.

Texas State Troops Muster Rolls, Texas State Archives 
Tosa, Marco

1987 Classic Dolls. Abbeville Press, New York.

Toulouse, Julian H.

1970 High on the Hawg or How the Western Miner lived, as Told by Bottles He Left Behind. Historical Archaeology 4:59-69.

1971 Bottle Makers and Their Marks. Thomas Nelson, Inc, New York.

Traister, John E.

1994 Antique Guns: The Collector's Guide. Stoeger Publishing Company.

U.S. Bureau of the Census

1840 New Orleans Parish, Louisiana

1850a Gasconade County, Missouri

$1850 \mathrm{~b}$ Guadalupe County, Texas

1850c New Orleans Parish, Louisiana

1860a Gasconade County, Missouri

1860 b Guadalupe County, Texas

1870 Guadalupe County, Texas

1880a Gasconade County, Missouri

$1880 \mathrm{~b}$ Guadalupe County, Texas

Vinson, Carlos

1968 Collecting Shotshells. Gun Digest 22:91-97.

Vose, Ruth Hurst

1989 The Antique Collector's Guides: Glass. Crescent Books, New York.

War of the Rebellion

$1880+$ Government Printing Office, Washington, D.C.

Watson and Dwyer Publishing Ltd.

1977 The Autumn and Winter Catalogue 1910-1911 of the Hudson's Bay Company. Saults and Pollard, Ltd., Winnipeg, Manitoba.

Watson, George, and Robert Skrill

1971 Western Canadian Bottle Collecting. Hume Compton, Nanaimo, B.C.

Webb, Walter Prescott, and H. Bailey Carroll (editors) 1952 The Handbook of Texas. 2 vols. Texas State Historical Association, Austin.

Western Texian, The (Seguin)

Wetherbee, Jean

1985 A Second Look at White Ironstone. WallaceHomestead Book Company, Lombard, Illinois.

White, Gifford

1979 Texas Scholastics 1854-55. Texas State Library, Austin.
White, John R.

1978 Bottle Nomenclature: A Glossary of Landmark Terminology for the Archaeologist. Historical Archaeology 12:58-67.

White, Henry P., and Burton D. Munhall

1977 Cartridge Headstamp Guide. H. P. White Laboratory, Inc., Bel Air, Maryland.

Williams, Petra

1987 Staffordshire Romantic Transfer Patterns. Fountain House East, Jeffersontown, Kentucky.

1995 Flow Blue China: An Aid to Identification. Rev. ed. Fountain House East, Jeffersontown, Kentucky.

Williams, Petra, and Marguerite R. Weber

1986 Staffordshire II Romantic Transfer Patterns. Fountain House East, Jeffersontown, Kentucky.

Wilson, Rex

1981 Bottles on the Western Frontier. University of Arizona Press.

Witthoft, John

1966 A History of Gunflints. Pennsylvania Archaeologist 36(1-2):12-49.

Woodhead, Eileen

1987 Trademarks on Base-Metal Tableware. National Historic Sites, Parks Service, Environment Canada.

Woodhead, E. I, C. Sullivan, and G. Gusset

1984 Lighting Devices in the National Reference Collection, Parks Canada. National Historic Parks and Sites, Canadian Parks Service, Ottawa.

Wright, Marcus J. (compiler)

1965 Texas in the War, 1861-1865. Hill Junior College Press, Hillsboro, Texas.

Wyman, Colin

1980 The Early Techniques of Transfer Printing. English Ceramic Circle Transactions Vol. 10 (Parts 4 and 5).

Yeoman, R. S.

1976 A Guide Book of United States Coins. Western Publishing Company, Inc., Racine, Wisconsin

Zorn, Joseph A.

1981 Interview with Joseph A. Zorn, February 5, 1981, Seguin, Texas, by Cynthia Brandimarte. On file with the Cultural Resources Program, Texas Parks and Wildlife Department, Austin. 
Zorn, Joseph N.

1981 Interview with Joseph N. Zorn, February 25, 1981, San Antonio, Texas, by Cynthia Brandimarte. On file with the Cultural Resources Program, Texas Parks and Wildlife Department, Austin.

Zorn, Thomas

1981 Interview with Thomas Zorn, July 1, 1981,
Waco, Texas, by Cynthia Brandimarte. On file with the Cultural Resources Program, Texas Parks and Wildlife Department, Austin.

Zorn, William

1981 Interview with William Zorn, February 17, 1981, Del Rio, Texas, by Cynthia Brandimarte. On file with the Cultural Resources Program, Texas Parks and Wildlife Department, Austin. 

APPENDIX A: The TPWD Classification of All Artifacts from Sebastopol 



\begin{tabular}{|c|c|c|c|c|c|c|c|c|c|c|c|c|c|c|}
\hline & Kitchen & $\begin{array}{l}\text { Dining } \\
\text { Room }\end{array}$ & $\begin{array}{c}\text { Room } \\
1\end{array}$ & $\begin{array}{c}\text { Room } \\
2\end{array}$ & $\begin{array}{c}\text { Room } \\
3\end{array}$ & $\begin{array}{c}\text { Room } \\
4\end{array}$ & \begin{tabular}{|c|} 
Room \\
7
\end{tabular} & $\begin{array}{c}\text { Room } \\
8\end{array}$ & $\begin{array}{c}\text { Room } \\
9\end{array}$ & $\begin{array}{c}\text { Room } \\
10\end{array}$ & $\begin{array}{l}\text { Exterior } \\
\text { Walls }\end{array}$ & Misc. & Cistern & Totals \\
\hline 1. Personal Items & & & & & & & & & & & & & & \\
\hline A. Clothing & & & & & & & & & & & & & & \\
\hline 1. Fasteners & & & & & & & & & & & & & & \\
\hline a. zipper & & & & & & & & 1 & & & 2 & & 4 & 7 \\
\hline b. suspender loop & 1 & & & & & & & & & & & & 2 & 3 \\
\hline c. snap/rivet & 7 & 2 & 1 & & & & & 2 & 4 & & 6 & & 22 & 44 \\
\hline d. grommet & 15 & 10 & & & 1 & 1 & 1 & 5 & 1 & & 9 & & 20 & 63 \\
\hline e. stud & 7 & & & & & & 1 & & 1 & & 3 & & & 12 \\
\hline f. buckle & 1 & 2 & & & & & 2 & 1 & 1 & & 5 & & 14 & 26 \\
\hline g. collar and cuff studs & 2 & 1 & & & & & & & & & & & 4 & 7 \\
\hline h. misc. & 5 & 3 & & & & & & 1 & & & 3 & & 2 & 14 \\
\hline 2. Buttons & & 1 & & & & & & & & & & & & 1 \\
\hline a. ferrous & 34 & 16 & & & & & 2 & 4 & 3 & & 10 & & 16 & 85 \\
\hline b. cuprous - brass & 9 & 7 & & 1 & & & & & 1 & & & & 2 & 20 \\
\hline c. white metal & 2 & & & & & & & & & & & & & 2 \\
\hline d. china & 68 & 35 & & 2 & & & 7 & 8 & 6 & & 12 & & 6 & 144 \\
\hline e. glass & 16 & 5 & & & & & & 1 & & & & & 5 & 27 \\
\hline f. bone & 16 & 4 & 2 & & & & 1 & 9 & 2 & & 3 & & 3 & 40 \\
\hline g. shell/mother of pearl & 94 & 33 & 3 & 3 & & & 9 & 12 & 8 & & 39 & & 29 & 230 \\
\hline h. hard rubber & 2 & 1 & & & & & & & 1 & & 2 & & & 6 \\
\hline i. plastic & 7 & 4 & 1 & 1 & & & 2 & 3 & 5 & & 8 & & 10 & 41 \\
\hline j. composition & 7 & 1 & & & & & & & & & 2 & & & 10 \\
\hline k. misc. & 5 & 2 & & & & & & 2 & & & 4 & & 4 & 17 \\
\hline 4. Fabric & & & & & & & & & & & & & & \\
\hline a. unidentified & 4 & 72 & 1 & & & & 6 & 12 & 9 & & 8 & 1 & 10 & 123 \\
\hline 6. Clothing & & & & & & & & & & & & & & \\
\hline a. fabric & & 1 & & & & & & & & & & & & 1 \\
\hline 7. Undergarments & & & & & & & & & & & & & & \\
\hline b. hardware & 2 & & & & & & & & & & & & & 2 \\
\hline c. misc. & 1 & 1 & & & & & & & & & 1 & & 1 & 4 \\
\hline 8. Accessories & & & & & & & & & & & & & & \\
\hline a. purse & 2 & 1 & & 1 & & & & & & & & & 1 & 5 \\
\hline d. misc. & 7 & 4 & & & & & & & & & 1 & & 3 & 15 \\
\hline 9. Notions & & & & & & & & & & & & & & \\
\hline a. safety pin & & 5 & & & & & & & 2 & & 10 & & 12 & 29 \\
\hline b. hook and eye & 2 & 3 & & & & & & 2 & & & 1 & & & 8 \\
\hline 1. hook only & 6 & 14 & & 1 & & & 1 & & 2 & & 2 & & & 26 \\
\hline 2: eye only & & 7 & & 1 & & & & & & & 3 & & 1 & 12 \\
\hline B. Footwear & & & & & & & & & & & & & & \\
\hline 1. Grommet & 1 & & & & & & & & & & & & & 1 \\
\hline 2. Shoe Parts & & & & & & & & & & & & & 1 & 1 \\
\hline
\end{tabular}




\begin{tabular}{|c|c|c|c|c|c|c|c|c|c|c|c|c|c|c|}
\hline & Kitchen & $\begin{array}{l}\text { Dining } \\
\text { Room }\end{array}$ & $\begin{array}{c}\text { Room } \\
1 \\
\end{array}$ & \begin{tabular}{c|} 
Room \\
2 \\
\end{tabular} & $\begin{array}{c}\text { Room } \\
3 \\
\end{array}$ & $\begin{array}{c}\text { Room } \\
4 \\
\end{array}$ & \begin{tabular}{|c|} 
Room \\
7 \\
\end{tabular} & $\begin{array}{c}\text { Room } \\
8 \\
\end{array}$ & $\begin{array}{c}\text { Room } \\
9\end{array}$ & $\begin{array}{c}\text { Room } \\
10 \\
\end{array}$ & $\begin{array}{c}\text { Exterior } \\
\text { Walls }\end{array}$ & Misc. & Cistern & Totals \\
\hline \multicolumn{15}{|l|}{ a. upper } \\
\hline 1. leather & & & & & & & & & & & & & 7 & 7 \\
\hline b. sole & & & & & & & & 1 & & & & & 1 & 2 \\
\hline 1. leather & & & & & & & & 1 & & & & & & 1 \\
\hline 3. vinyl, plastic, or rubber & & & & & & & & & & & & & 2 & 2 \\
\hline c. heel & 2 & & & & & & & 1 & & & & & & 3 \\
\hline 1. leather & & 1 & & & & & & & 1 & & 1 & 1 & 1 & 5 \\
\hline 3. vinyl & 1 & & & & & & & & & & & & & 1 \\
\hline d. misc. & 2 & & & & & & & & & & & & 2 & 4 \\
\hline 4. Laces & & & & & & & & & & & & & & \\
\hline a. tips & 3 & 2 & & & & & & & & & & & & 5 \\
\hline 6. Misc. & & 3 & & & & & & & & & & & 1 & 4 \\
\hline C. Adornment & & & & & & & & & & & & & & \\
\hline 1. Jewelry & & & & & & & & & & & & & & \\
\hline a. ring & & & & & & & & & & & & & 3 & 3 \\
\hline b. tie tack & 1 & & & & & & & & & & & & & 1 \\
\hline c. misc. & 19 & & & 4 & & & & & 1 & & 14 & 1 & 17 & 56 \\
\hline 2. Beads & & & & & & & & & & & & & & \\
\hline a. glass & 25 & 79 & & & & & 2 & 6 & 2 & & 12 & & & 126 \\
\hline b. misc. & 5 & 11 & & 4 & & & & 11 & 1 & & 11 & & 8 & 51 \\
\hline 3. Misc. & & 5 & & & & & & & & & & & 1 & 6 \\
\hline D. Body Ritual & & & & & & & & & & & & & & \\
\hline 1. Teeth & & & & & & & & & & & & & & \\
\hline b. toothpaste/powder container & & & & & & & & & & & & & 4 & 4 \\
\hline e. misc. & & & & & & & & & & & 1 & & & 1 \\
\hline 2. Hair & & & & & & & & & & & & & & \\
\hline b. comb (pocket style) & 13 & 16 & & 1 & 1 & 2 & 2 & 7 & 15 & & 11 & 1 & 3 & 72 \\
\hline c. accessories & 1 & & & & & & & 2 & 3 & & 4 & 1 & 3 & 14 \\
\hline d. grooming & & & & & & & & 7 & & & 11 & & 2 & 20 \\
\hline e. misc. & & & 2 & & & & & 5 & 2 & & & & 1 & 10 \\
\hline 3. Body & & & & & & & &. & & & & & & \\
\hline a. grooming & & & & & & & & & & & & & & \\
\hline 1. supplies & & & & & & & & & 1 & & & & 1 & 2 \\
\hline 2. tools and hardware & 3 & & & & & & & & 8 & & & & 2 & 13 \\
\hline 4. Cosmetic & & & & & & & & & & & & & & \\
\hline a. makeup & & & & & & & & & & & & & 4 & 4 \\
\hline b. tools & & & & & & & & & & & & & 1 & 1 \\
\hline c. misc. & 1 & & & & & & & & & & & & 4 & 5 \\
\hline E. Medical & & & & & & & & & & & & & & \\
\hline 1. Bottles & & & & & & & & & & & & & 9 & 9 \\
\hline 2. Eyeglasses & 2 & 1 & & & & & & & & & 1 & & 3 & 7 \\
\hline
\end{tabular}




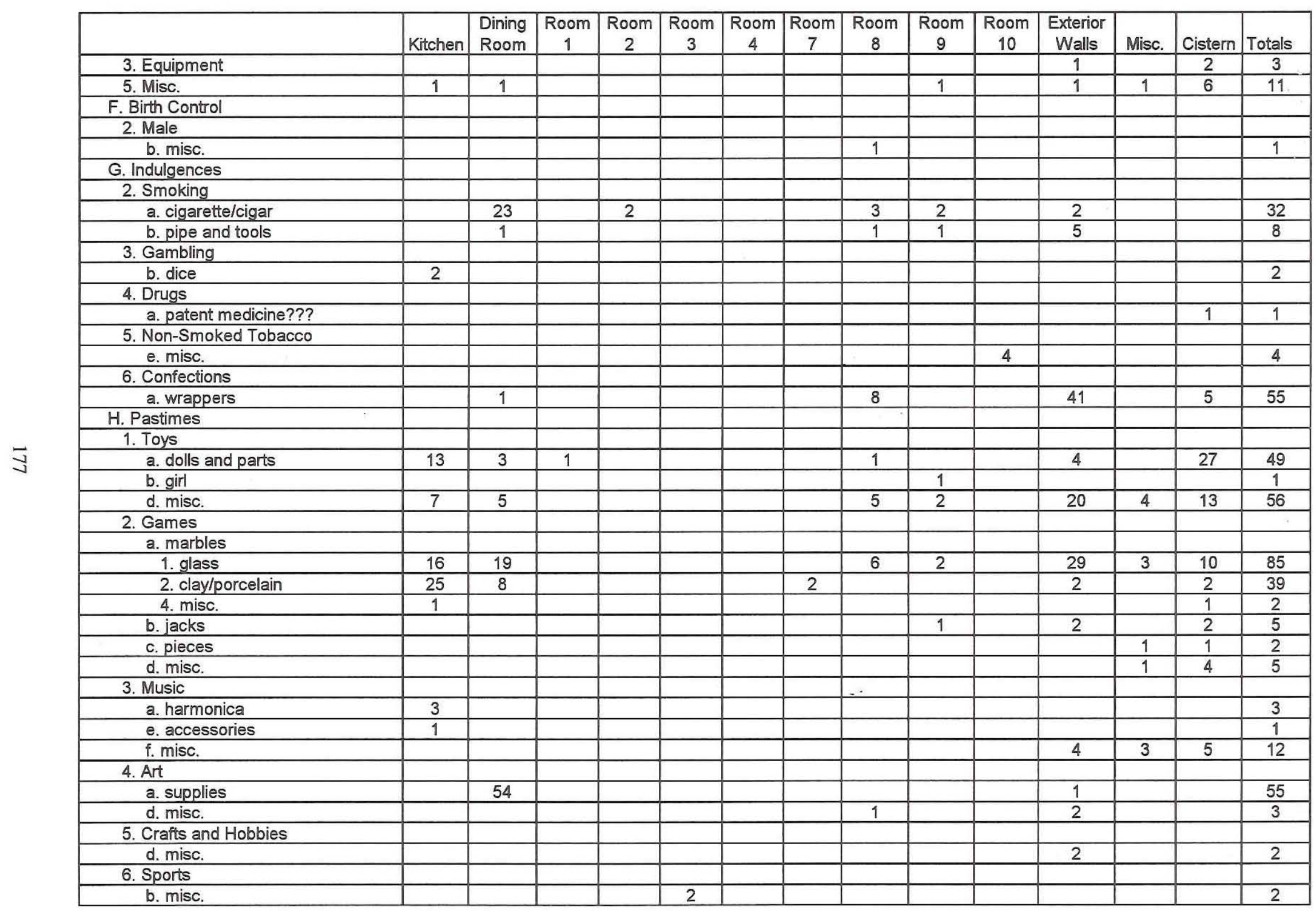




\begin{tabular}{|c|c|c|c|c|c|c|c|c|c|c|c|c|c|c|}
\hline & Kitchen & $\begin{array}{l}\text { Dining } \\
\text { Room }\end{array}$ & \begin{tabular}{|c|} 
Room \\
1 \\
\end{tabular} & \begin{tabular}{|c|} 
Room \\
2 \\
\end{tabular} & \begin{tabular}{|c|} 
Room \\
3 \\
\end{tabular} & \begin{tabular}{|c|} 
Room \\
4 \\
\end{tabular} & \begin{tabular}{|c|} 
Room \\
7 \\
\end{tabular} & $\begin{array}{c}\text { Room } \\
8 \\
\end{array}$ & $\begin{array}{c}\text { Room } \\
9\end{array}$ & \begin{tabular}{|c|} 
Room \\
10
\end{tabular} & \begin{tabular}{|c|} 
Exterior \\
Walls
\end{tabular} & Misc. & Cistern & Totals \\
\hline I. Ritual & & & & & & & & & & & & & & \\
\hline 1. Religious & & & & & & & & & & & & & & - \\
\hline b. rosary & 5 & & & & & & & & & & & & & 5 \\
\hline J. Pocket Tools and Accessories & & & & & & & & & & & & & & \\
\hline 1. Keys & & & & & & & & & & & & & & \\
\hline b. skeleton & & & & & & & & & & & 2 & & & 2 \\
\hline e. misc. & & & & & & & & & 1 & & 2 & & 1 & 4 \\
\hline 2. Knife & & & & & & & & & & & & & & \\
\hline a. pocket & & & 1 & & & & & & & & 1 & & 1 & 3 \\
\hline 4. Charms/Good luck pieces & & & & & & & & & & & & & & \\
\hline a. special coins & & & & & & & & 1 & & & & & & 1 \\
\hline d. misc. & 1 & & & & & & & & 2 & & & & 1 & 4 \\
\hline 5. Watch & & & & & & & & & & & 2 & & 2 & 4 \\
\hline K. Infant Care & & & & & & & & & & & & & & \\
\hline 1. Feeding & & & & & & & & & & & & & & \\
\hline a. bottle/nipple & & & & & & & & & 1 & & & & & 1 \\
\hline 4. Care & & & & & & & & & & & & & & \\
\hline b. ointment tubes & & & & $=$ & & & & & & & & & 5 & 5 \\
\hline L. Luggage & & & & & & & & & & & & & & \\
\hline 1. Suitcase & & & & & & & & & & & & & & \\
\hline a. hardware & & & & & & & & & & & & & 1 & 1 \\
\hline 2. Domestic Items & & & & & & & & & & & & & & \\
\hline A. Furnishings & & & & & & & & & & & & & & \\
\hline 1. Furniture & & & & & & & & & & & & & & \\
\hline a. hardware & & & & & & & 1 & 1 & 1 & & 1 & & 14. & 18 \\
\hline b. object & & & & & & & & & 1 & & 3 & & & 4 \\
\hline 2. DraperyMindow Coverings & & & & & & & & & & & & & & \\
\hline b. hardware & & 1 & & & & & & & 1 & & 3 & 2 & 3 & 10 \\
\hline 3. Decorative & & & & & & & & & & & & & & \\
\hline a. knickknacks & & 1 & & & & & & & & & & & & 1 \\
\hline d. misc. & 8 & & & & & & 24 & .1 & 2 & & 51 & & 7 & 93 \\
\hline 4. Wall/Ceiling Coverings & & & & & & & & & & & & & & \\
\hline a. wallpaper & 1 & & & & & & & 1 & 6 & & & & 2 & 10 \\
\hline B. Housewares and Appliances & & & & & & & & & & & & & & \\
\hline 1. Culinary & & & & & & & & & & & & & & \\
\hline a. ceramic & & 2 & & & & & & & & & & & & 2 \\
\hline 1. stoneware & 14 & 8 & & 1 & & 1 & & 2 & 11 & & 34 & & 208 & 279 \\
\hline 2. misc. & 1 & & & & & & & & & & & & 4 & 5 \\
\hline b. glass & 2202 & 1283 & 64 & 347 & 122 & 42 & 18 & 1107 & 1032 & 1 & 3153 & 78 & 3573 & 13022 \\
\hline c. utensils & 2 & 3 & & & & & & & & & 2 & & 11 & 18 \\
\hline d. cookware & 1 & 5 & & & & & & & 36 & & 7 & & 46 & 95 \\
\hline
\end{tabular}




\begin{tabular}{|c|c|c|c|c|c|c|c|c|c|c|c|c|c|c|}
\hline . & Kitchen & $\begin{array}{l}\text { Dining } \\
\text { Room }\end{array}$ & $\begin{array}{c}\text { Room } \\
1 \\
\end{array}$ & $\begin{array}{c}\text { Room } \\
2\end{array}$ & $\begin{array}{c}\text { Room } \\
3\end{array}$ & $\begin{array}{c}\text { Room } \\
4\end{array}$ & \begin{tabular}{|c|} 
Room \\
7
\end{tabular} & $\begin{array}{c}\text { Room } \\
8\end{array}$ & $\begin{array}{c}\text { Room } \\
9\end{array}$ & $\begin{array}{c}\text { Room } \\
10\end{array}$ & $\begin{array}{c}\text { Exterior } \\
\text { Walls }\end{array}$ & Misc. & Cistern & Totals \\
\hline e. tin cans, can key, etc. & 1070 & 28 & 8 & 2 & & & & 9 & 243 & & 25 & 54 & 653 & 2092 \\
\hline f. stove & & & & & & & & & & & 1 & 1 & 5 & 7 \\
\hline g. refrigerator & & & & & & & & & & & & & 1 & 1 \\
\hline h. misc. & 3 & 2 & & & & & & & & & 6 & & 3 & 14 \\
\hline 2. Gustatory & & & & & & & & & & & & & & \\
\hline a. ceramic & & 3 & & & & & & & & & & & & 3 \\
\hline 1. earthenware & 524 & 105 & & 78 & 8 & 5 & 12 & 281 & 214 & & 562 & 13 & 760 & 2562 \\
\hline 2. porcelain & 782 & 137 & & 3 & 2 & & 9 & 21 & 40 & & 138 & 7 & 516 & 1655 \\
\hline 3. misc. & 209 & 2 & & 14 & & & & 5 & 4 & & 56 & & 90 & 380 \\
\hline b. glass (tablewares) & & 7 & & & & & & & 2 & & & & & 9 \\
\hline c. utensils & 6 & & & & & & & 2 & & & 6 & & 3 & 17 \\
\hline d. serving dishes & & & & & & & & & & & 3 & & 1 & 4 \\
\hline e. condiments & 3 & & & & & & & & & & 3 & & 1 & 7 \\
\hline f. drinks & 43 & 4 & & & & & & 4 & 7 & 1 & 117 & 9 & 59 & 244 \\
\hline g. misc. & 6 & 13 & & & & & & 1 & & & 26 & 1 & 28 & 75 \\
\hline 3. Portable Illumination & & & & & & & & & & & & & & \\
\hline a. lamp or parts & & & & & & & & & & & & & & \\
\hline 1. chimney glass & 738 & 212 & & 17 & 1 & 9 & 10 & 17 & 141 & & 342 & & 450 & 1937 \\
\hline 2. parts & 6 & & 13 & & & & & 17 & 369 & & 3 & & 12 & 420 \\
\hline d. matches & 79 & 93 & 8 & 1 & 1 & & & & 6 & & & & & 188 \\
\hline e. batteries & 1 & 3 & & & & & & & & & & & 10 & 14 \\
\hline 8. Home Education & & & & & & & & & & & & & & \\
\hline a. pencil, slate pencil & 66 & 30 & & 2 & & & & 9 & 12 & & 30 & & 37 & 186 \\
\hline b. pens and parts & 7 & 6 & & & & & & 1 & 1 & & 6 & 1 & 2 & 24 \\
\hline c. slate board/fragments & 12 & 44 & & 1 & & & 1 & 7 & 1 & & 10 & & 4 & 80 \\
\hline d. desk accessories & 1 & & & 1 & & & & & & & 2 & & & 4 \\
\hline e. clock & & & & & & & & & & & & & 5 & 5 \\
\hline h. ink/bottles & & & & & & & & & & & & & 2 & 2 \\
\hline i. misc. & 3 & 7 & & & & & & 2 & 4 & & 9 & & 17 & 42 \\
\hline C. Cleaning and Maintenance & & & & & & & & & & & & & & \\
\hline 1. Cleaning & & & & & & & & & & & & & & \\
\hline a. chemicals & & & & & & & & & & & & & 1 & 1 \\
\hline b. tools & & & & & & & & & 1 & & & & 5 & 6 \\
\hline c. misc. & & & & & & & & & & & 1 & & & 1 \\
\hline 2. Household Maintenance & & & & & & & & & & & & & & \\
\hline c. misc. & & 1 & & & & & & & & & 1 & & 6 & 8 \\
\hline 3. Laundry & & & & & & & & & & & & & & \\
\hline b. clothespin & & & & & & & & 1 & 3 & & 8 & 2 & 12 & 26 \\
\hline c. washboard & & & & & & & & & & & & & 97 & 97 \\
\hline d. misc. & & & & & & & & & & & 1 & & 4 & 5 \\
\hline 4. Sewing & & & & & & & & & & & & & & \\
\hline
\end{tabular}




\begin{tabular}{|c|c|c|c|c|c|c|c|c|c|c|c|c|c|c|}
\hline & Kitchen & $\begin{array}{l}\text { Dining } \\
\text { Room }\end{array}$ & \begin{tabular}{|c|} 
Room \\
1 \\
\end{tabular} & \begin{tabular}{|c|} 
Room \\
2 \\
\end{tabular} & \begin{tabular}{|c|} 
Room \\
3 \\
\end{tabular} & \begin{tabular}{|c|} 
Room \\
4
\end{tabular} & \begin{tabular}{|c|} 
Room \\
7
\end{tabular} & $\begin{array}{c}\text { Room } \\
8 \\
\end{array}$ & $\begin{array}{c}\text { Room } \\
9 \\
\end{array}$ & \begin{tabular}{|c|}
$\begin{array}{c}\text { Room } \\
10\end{array}$ \\
\end{tabular} & \begin{tabular}{|c|}
$\begin{array}{c}\text { Exterior } \\
\text { Walls }\end{array}$ \\
\end{tabular} & Misc. & Cistern & Totals \\
\hline a. pins (straight) & 421 & 536 & 3 & 9 & & 1 & 5 & 81 & 31 & & 16 & 1 & 11 & 1115 \\
\hline b. needles & & & & & & & & & & & 1 & & & 1 \\
\hline c. scissors & & & & & & & & & & & & & 2 & 2 \\
\hline d. thimble & 1 & 2 & & & & & & & & & 1 & & 1 & 5 \\
\hline e. machine (parts) & 1 & & & & & & & & & & & & & 1 \\
\hline f. misc. & 9 & 65 & & 1 & & & & 2 & & & 1 & & 1 & 79 \\
\hline 5. Pest Control & & & & & & & & & & & & & & \\
\hline a. mousetrap & & & & & & & & & & & & & 1 & 1 \\
\hline 6. Yard Maintenance & & & & & & & & & & & & & & \\
\hline a. tools & & & & & & & & & & & & & & \\
\hline 1. rake & & & & & & & & & & & & & 1 & 1 \\
\hline 2. hoe & & & & & & & & & & & & & 1 & 1 \\
\hline 3. shovel & & & & & & & & & & & & & 1 & 1 \\
\hline 7. water hose & 2 & & & & & & & & 1 & & & 1 & 20 & 24 \\
\hline 8. axe & & & & & & & & & & & 1 & & & 1 \\
\hline b. flower pot & & & & & & & & & 17 & & 64 & 3 & 127 & 211 \\
\hline c. misc. & & & & & & & & & & & & & 2 & 2 \\
\hline 3. Architecture & & & & & & & & & & & & & & \\
\hline B. Construction & & & & & & & & & & & & & & \\
\hline 1. Materials & & & & & & & & & & & & & & \\
\hline a. wood & 65 & 93 & 5 & 4 & & & 8 & 20 & 75 & & 75 & 13 & & 358 \\
\hline b. window glass & 2497 & 988 & 39 & 931 & 198 & 67 & 408 & 1418 & 1025 & 2 & 3666 & 17 & 3105 & 14361 \\
\hline c. paint & 1 & 10 & & 1 & 1 & & & 15 & 39 & & 30 & & 13 & 110 \\
\hline d. cement, mortar, plaster, rock & 341 & 1903 & 4 & 56 & 6 & 1 & 33 & 147 & 151 & & 1131 & 67 & 143 & 4109 \\
\hline e. shingles & & 4 & & & & & & 1 & 5 & 2 & 30 & & 31 & 73 \\
\hline f. adobe & & 13 & & & & & & & & & & & 3 & 16 \\
\hline g. brick & 27 & 947 & 2 & 2 & 7 & 3 & 1 & 72 & 22 & & 317 & 22 & 61 & 1483 \\
\hline h. misc. & 107 & 113 & 16 & 88 & & 27 & 2 & 106 & 126 & & 260 & 2 & 81 & 928 \\
\hline 2. Hardware & & & & & & & & & & & & & & \\
\hline a. nails & 826 & 540 & & 180 & 57 & 24 & 17 & 67 & 53 & & 123 & & 286 & 2173 \\
\hline 1. cut & 849 & 1070 & 28 & 901 & 11 & 52 & 80 & 1155 & 1981 & & 3631 & 40 & 801 & 10599 \\
\hline 2. wire & 1045 & 543 & 13 & 259 & 6 & 80 & 11 & 663 & 559 & & 1950 & 48 & 936 & 6113 \\
\hline 3. forged & 6 & & & 1 & & & & & & & 6 & 1 & 1 & 15 \\
\hline b. screws & 1 & 10 & & 2 & & & & 6 & 2 & & 14 & & 11 & 46 \\
\hline 1. wood & 7 & 1 & 1 & 10 & & 1 & 3 & 4 & 5 & & 62 & 2 & 18 & 114 \\
\hline c. door hardware & & & & & & & & & & & & & & \\
\hline 1. hinge & 1 & & & & & & & & & & 9 & & 18 & 28 \\
\hline 2. knob & 1 & & & & & & & & 1 & & 1 & 1 & & 4 \\
\hline 3. lock & 1 & 8 & & 1 & & & & & & & & 1 & 2 & 13 \\
\hline 4. escutcheon & 1 & & & & & & & 1 & & & & 1 & 1 & 4 \\
\hline 5. misc. & 2 & & & & & & & & & & 14 & & 2 & 18 \\
\hline
\end{tabular}




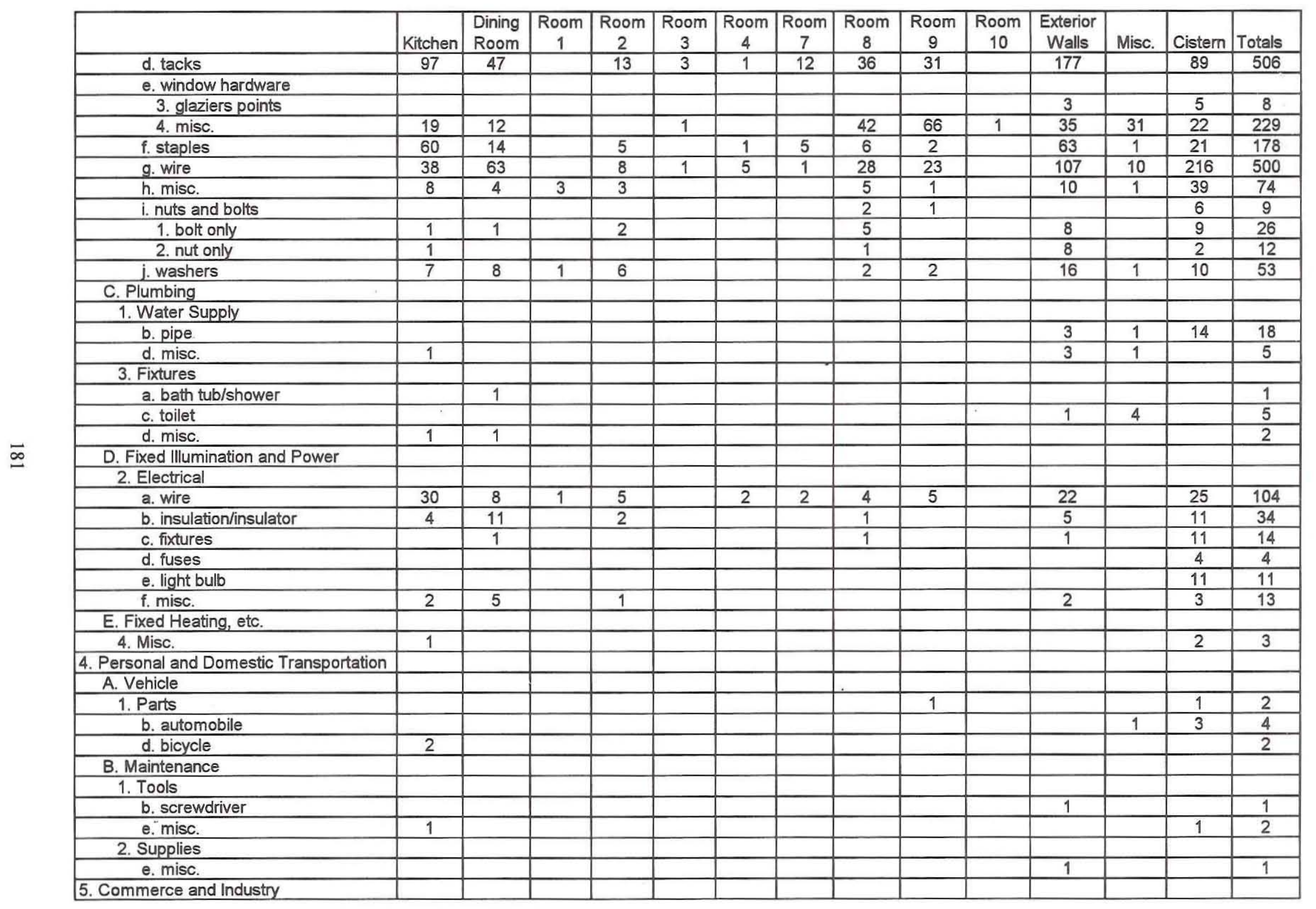




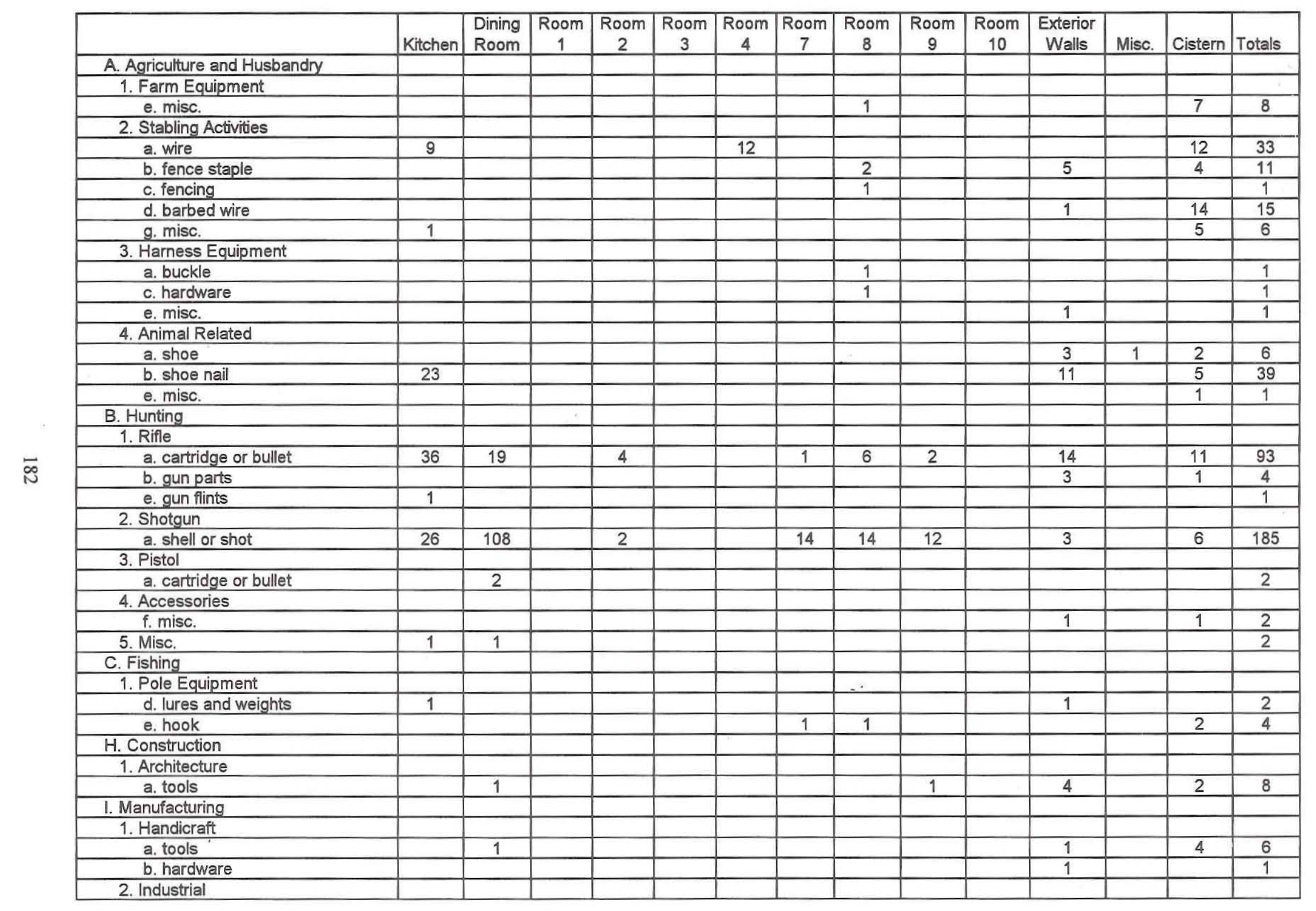




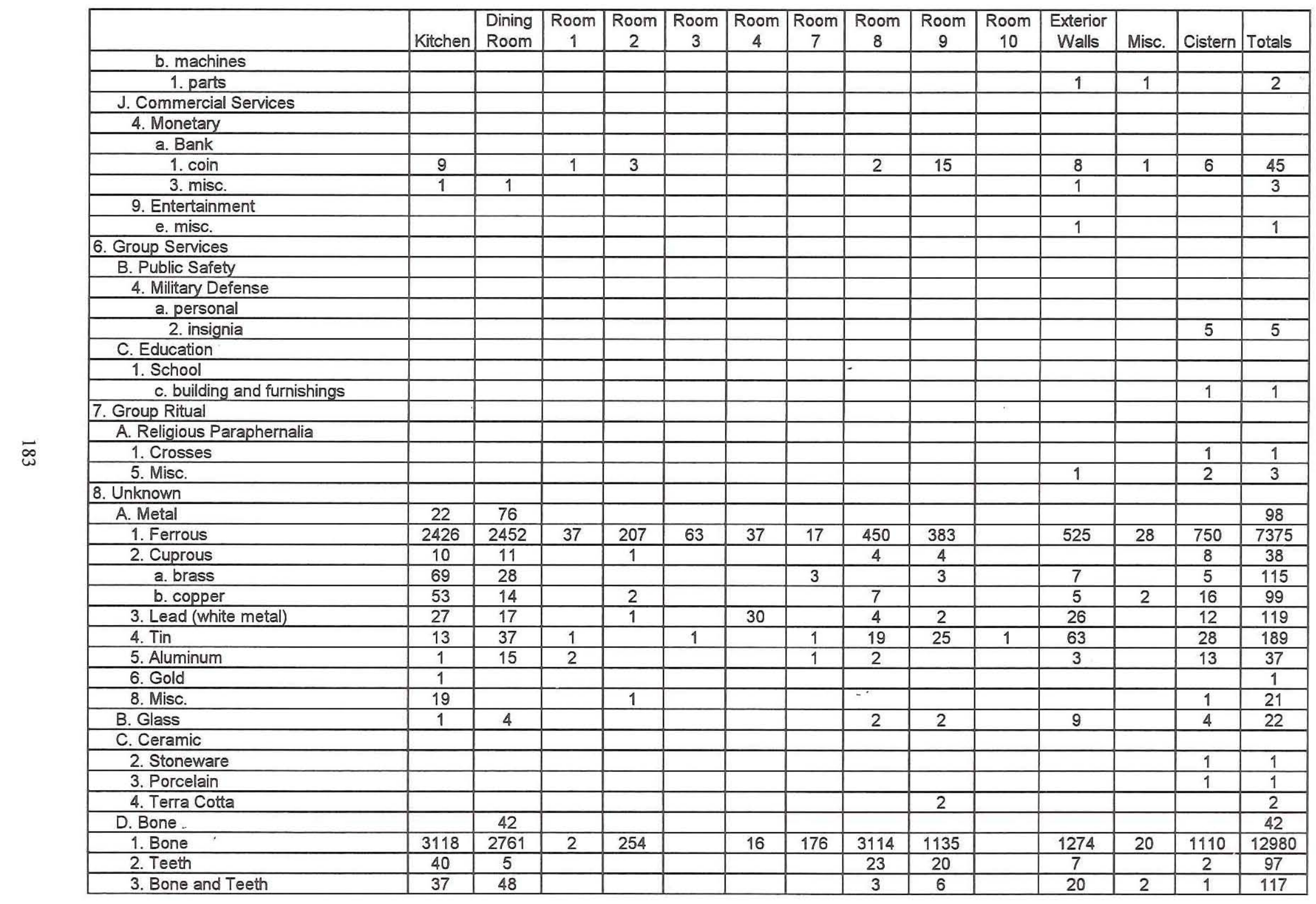




\begin{tabular}{|c|c|c|c|c|c|c|c|c|c|c|c|c|c|c|}
\hline & Kitchen & $\begin{array}{l}\text { Dining } \\
\text { Room }\end{array}$ & $\begin{array}{c}\text { Room } \\
1\end{array}$ & $\begin{array}{c}\text { Room } \\
2\end{array}$ & $\begin{array}{c}\text { Room } \\
3\end{array}$ & $\begin{array}{c}\text { Room } \\
4\end{array}$ & \begin{tabular}{|c|} 
Room \\
7
\end{tabular} & \begin{tabular}{c|} 
Room \\
8
\end{tabular} & $\begin{array}{c}\text { Room } \\
9\end{array}$ & $\begin{array}{c}\text { Room } \\
10\end{array}$ & $\begin{array}{l}\text { Exterior } \\
\text { Walls }\end{array}$ & Misc. & Cistern & Totals \\
\hline 4. Artifact & 10 & 7 & & & & & & 4 & & & 8 & & 1 & 30 \\
\hline 5. Misc. & 58 & 15 & & & & & 13 & 119 & & & & & 1 & 206 \\
\hline E. Ethnographic & & 1 & & & & & & & & & & & & 1 \\
\hline 1. Seeds & 132 & 618 & 3 & 7 & & & 1 & 141 & 92 & & 11 & 2 & 73 & 1080 \\
\hline 2. Egg Shell & 879 & 771 & 9 & 25 & 25 & 7 & 10 & 1511 & 1123 & & 42 & & 28 & 4430 \\
\hline 3. Fiber Matter & 10 & 19 & & 1 & & 1 & & 3 & 2 & & & 1 & & 37 \\
\hline 4. Shell/Mother of Pearl & 31 & 71 & & 3 & & & 1 & 57 & 17 & & 126 & & 19 & 325 \\
\hline 5. Leather & 22 & 4 & & 2 & & 11 & & & 1 & & 4 & & 17 & 61 \\
\hline 6. Wood & 291 & 2365 & 25 & 159 & 10 & 38 & 39 & 555 & 2745 & & 38 & 13 & 196 & 6903 \\
\hline 7. Soil & & & & & & & & & & & & & & \\
\hline a. sample & 1 & 146 & & 1 & & & & 29 & 7 & & 7 & 2 & & 200 \\
\hline b. burned clay & & & & & & & & & & & 2 & & & 2 \\
\hline 8. Misc. & & 92 & & 13 & & & & 1 & 7 & & 5 & 3 & 8 & 129 \\
\hline 9. Paper & 23 & 328 & 3 & & & & & 98 & 7 & 1 & 2 & 1 & 10 & 473 \\
\hline F. Lithics & & & & & & & & & & & & & & \\
\hline 1. Cultural & & & & & & & & & & & & & & \\
\hline a. tools and cores & & & & & & & & & & & & 1 & 2 & 3 \\
\hline 1. chipped stone & & & & & & & & & 1 & & & & & 1 \\
\hline 2. ground/pecked stone & & & & & & & & & & & 1 & & 1 & 2 \\
\hline b. debitage & & 15 & & 3 & 2 & & & 12 & 9 & & 24 & 1 & 4 & 70 \\
\hline c. burned rock & & 3 & & 2 & & & & 1 & 1 & & & & & 7 \\
\hline d. slate & & 1 & & & & & & & & & 4 & & & 5 \\
\hline 2. Rock & 23 & 181 & 169 & 12 & 9 & 3 & & 68 & 138 & & 123 & 4 & 9 & 739 \\
\hline 3. Fossil & & & & & & & & & & & 1 & & & 1 \\
\hline G. Plastic and Rubber & & & & & & & & & & & & & & \\
\hline 1. Plastic & 10 & 66 & & 12 & & 1 & 4 & 36 & 57 & & 160 & 5 & 101 & 452 \\
\hline 2. Rubber & 26 & 22 & & 1 & & & & 1 & 10 & & 37 & 3 & 21 & 121 \\
\hline H. Unknown & 8 & 6 & & & & & & 1 & & & 5 & & 2 & 22 \\
\hline otals & 20218 & 19864 & 473 & 3695 & 539 & 480 & 983 & 11805 & 12286 & 13 & 19831 & 572 & 15717 & 106586 \\
\hline
\end{tabular}


APPENDIX B: Artifacts on Display at Sebastopol 
Because these artifacts are on display at Sebastopol, they were not available for analysis for this report. The following list was prepared from a catalog provided by TPWD.

Cup with "Remember Me" enameled

Hand-painted fruit bowl with KPM mark*

White plate with gold rim and pink flowers; M.Z. Austria mark*

Alfred Meakin cup with brown transfer and hand-painted detail*

Alfred Meakin saucer with brown transfer and hand-painted detail*

Window glass with "Louis LeGette" incised on it

"Rogers Bros." fork

“1847 Rogers Bros.” spoon

Porcelain toy dish

Child's toy pitcher

Porcelain doll

Toy stoneware bottle, handle missing

Toy milk bottle*

"Eastman/Royal/Perfume" bottle

"Singer MFG Co. NY" bottle*

"P.C. Serger PkC/Prescription Department/Seguin, TEX." bottle

Slate pencil

4 marbles

Buttons (bone, shell, abalone, china, cuprous (2), hard rubber, glass, composition with lady's face, composition with wolf's head with gold flecks

Collar studs (china collar stud; brass, gold-plated stud with shell)

*Artifact is mentioned in text. 



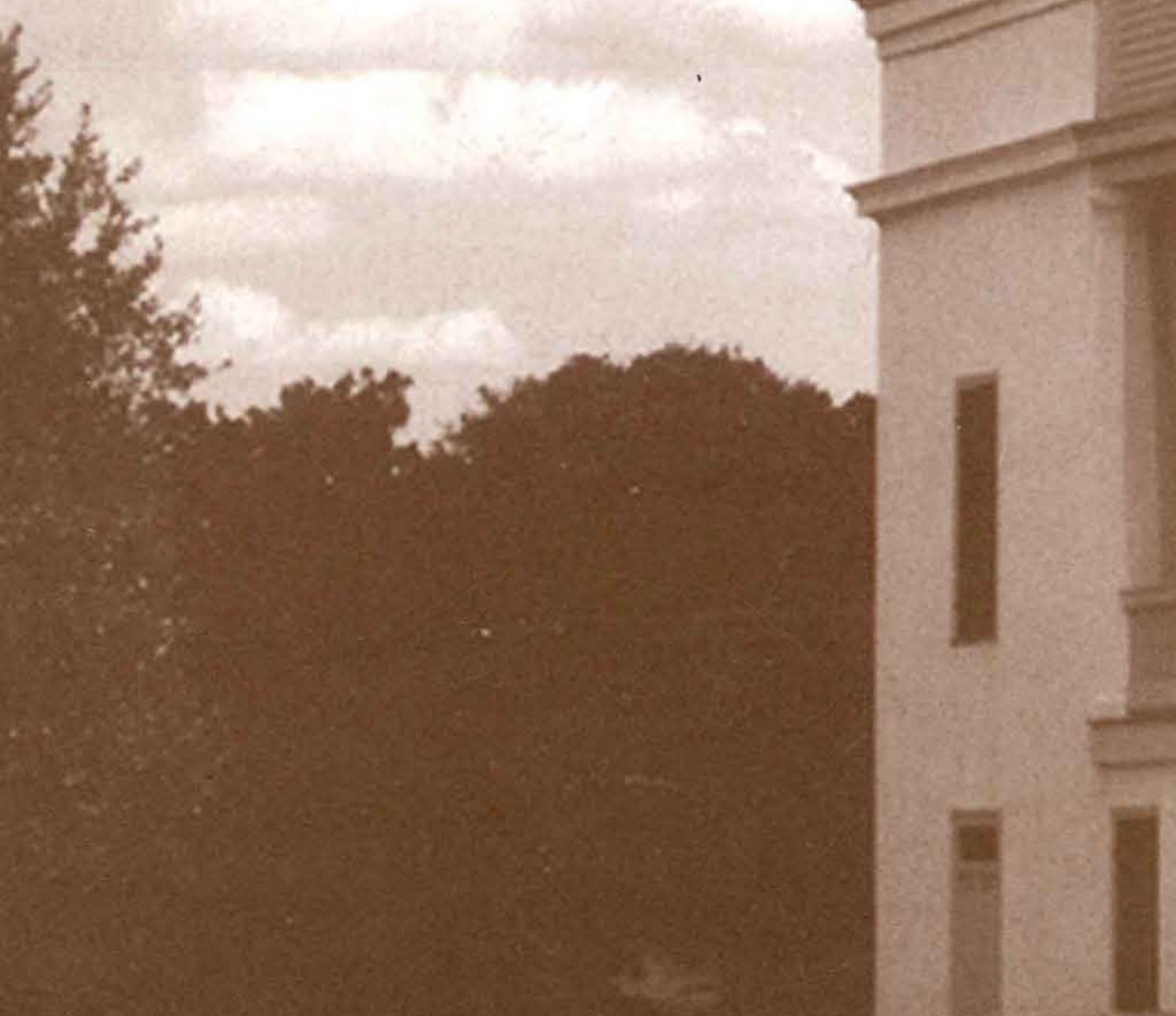